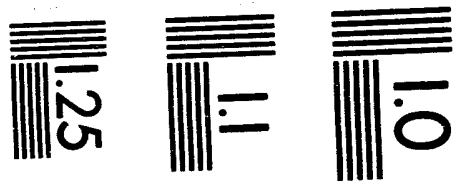

$$
\begin{aligned}
& \text { E e renuter } \\
& \text { III }
\end{aligned}
$$

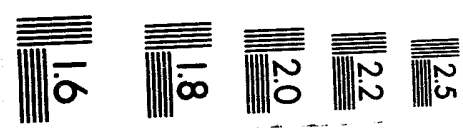



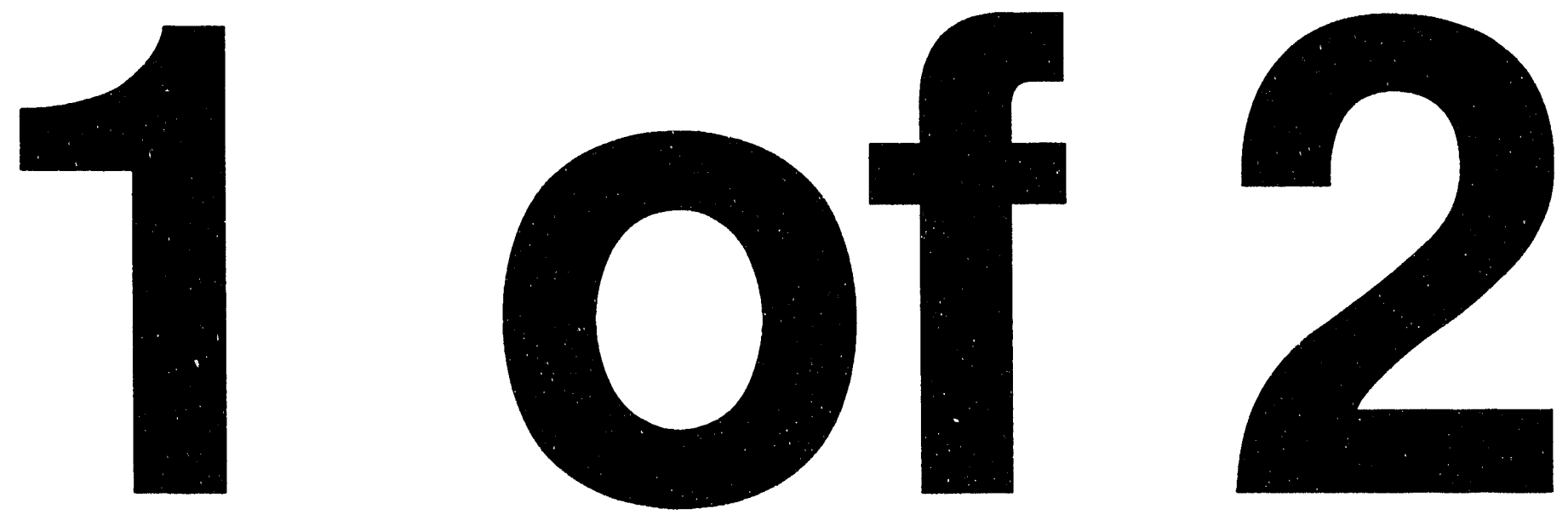


\section{Petroleum
April 1994}

$\sigma$

Supply
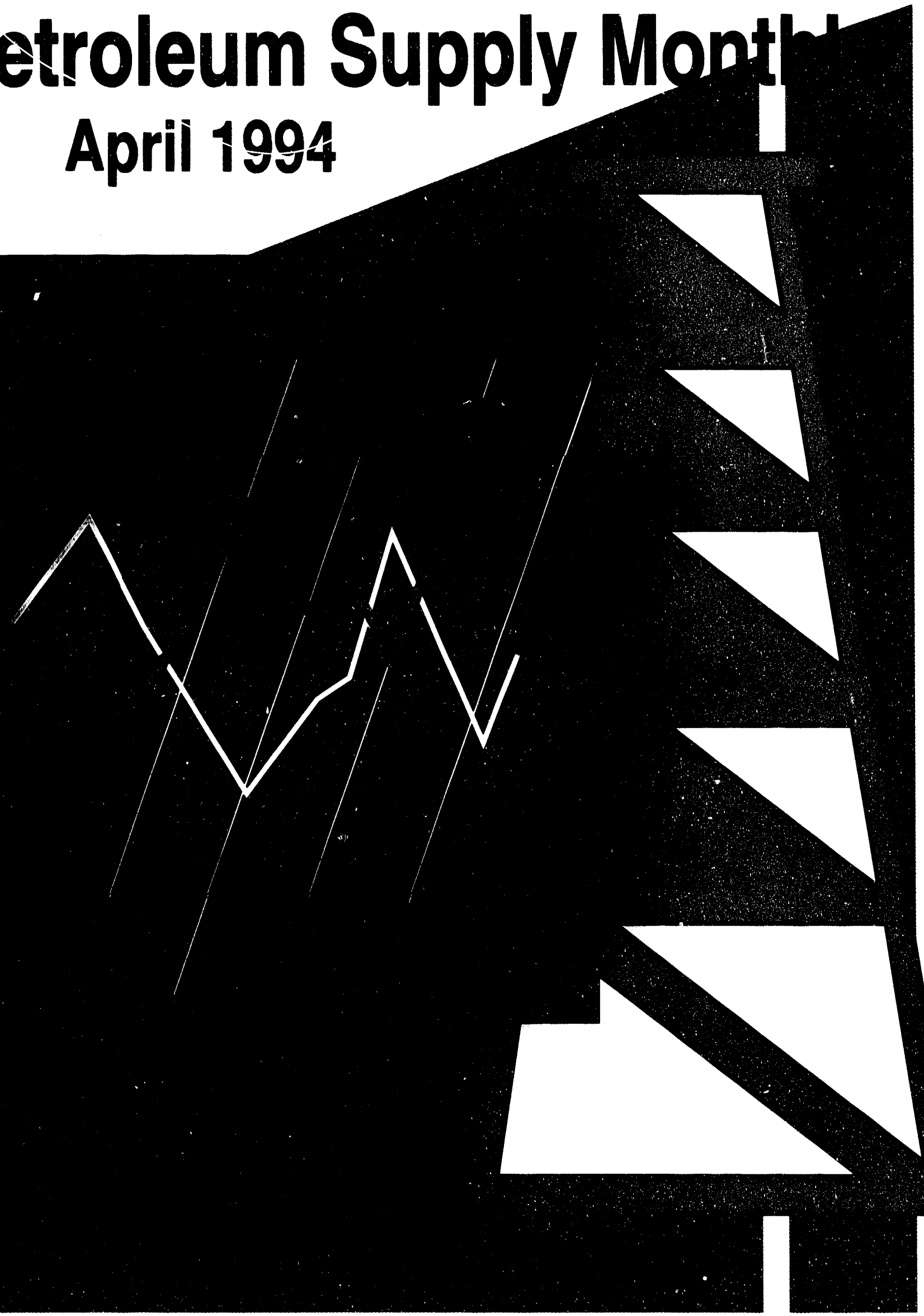
This publication and other Energy Information Administration (EIA) publications may be purchased from the Superintendent of Documents, U.S. Government Printing Office.

\section{All telephone orders should be directed to:}

\author{
U.S. Government Printing Office \\ McPherson Square Bookstore \\ 1510 H Street N.W. \\ Washington, DC 20005 \\ (202) 653-2050
}

FAX (202) 376-50155

9:00 a.m. to 4:30 p.m., casiern time, M-F
Superintendent of Documents

U.S. Government Printing Office

Washington, DC 20402

(202) 783-3238

FAX (202) 512-2233

8:00 a.m. to 4:30 p.m., eastern time, M-F

\section{All mail orders should be directed to:}

U.S. Government Printing Office

P.O. Box 371954

Pittsburgh, PA 15250-7954

Complimentary subscriptions and single issues are available to certain groups of subscribers, such as public and academic libraries, Federal, State, local, and foreign governments, and the media. For further information, and for answers to questions on energy statistics, please contact EIA's National Energy Information Center. Address, telephone numbers, and hours appear below.

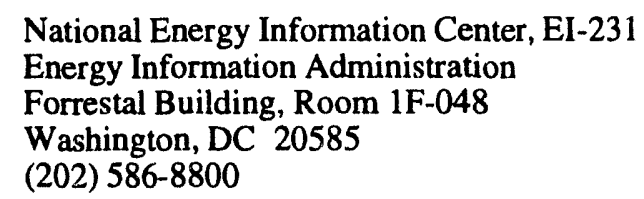

TTY: For people who are deaf or hard of hearing: (2.02) 586-1181

9:00 a.m. to 5:00 p.m., eastern time, M-F

We thank the following for the use of their photographs and illustrations in this report.

Cities Service Co., page xxi (courtesy of the American Petroleum Institute).

Standard Oil Co., page 1 (courtesy of the American Petroleum Institute).

Phillips 66 Co., page 33 (courtesy of Phillips 66 Company).

Texaco Inc., page 109 (courtesy of Texaco Inc.).

Standard Oil Co., page 113 (courtesy of the American Petroleum Institute).

Texaco Inc., page 127 (courtesy of the American Petroleum Institute).

American Petroleum Institute, page 133 (courtesy of the American Petroleum Institute).

Atlantic Richfield Co., page 139 (courtesy of the American Petroleum Institute).

Released for printing: May 4, 1994

The Petroleum Supply Monthly (ISSN 0733-0553) is published monthly by the Energy Information Administration, 1000 Independence Avenue, SW, Washington, DC 20585 , and sells for $\$ 80.00$ per year (price is subject to change without advance notice). Second-class postage paid at Washington, DC 20066-9998, and at additional mailing offices. POSTMASTER: Send address changes to Petroleum Supply Monthly, Energy Information Administration, EI-231, 1000 Independence Avenue, SW, Washington, DC 20585. 
DOE/EIA-0109 (94/04)

Distribution Category UC-950

\title{
Petroleum Supply Monthly
}

\section{April 1994}

\author{
Energy Information Administration \\ Office of Oil and Gas \\ U.S. Department of Energy \\ Washington, DC 20585
}

This report was prepared by the Energy Information Administration, the independent statistical and analytical agency within the Department of Energy. The information contained herein should not be construed as advocating or reflecting any policy position of the Department of Energy or any other organization. 


\section{Data Available Electronically}

Data from the Weekly Petroleum Status Report, Winter Fuels Report, and the Petroleum Supply Monthly publications as well as data from other sources are available electronically on the Energy Information Administration's Electronic Publication Bulletin (EPUB) Board, and the Comprehensive Oil and Gas Information Source (COGIS). The schedule for data release is as follows:

\begin{tabular}{|c|c|c|}
\hline Publications/Sources & Platform & Information \\
\hline \multicolumn{3}{|l|}{ Weekly Petroleum Status Report } \\
\hline Wednesday 9:00 a.m. (weekly) & EPUB & $\begin{array}{l}\text { Table } 1 \text { (U.S. Balance Sheet) and } \\
\text { Data Log (Table } 14 \text { plus } 4 \text {-week averages) }\end{array}$ \\
\hline $\begin{array}{l}\text { Wednesday 5:00 p.m. } \\
\text { 6th-12th (monthly) }\end{array}$ & EPUB & Table H1 (Petroleum Supply Summary) \\
\hline Thursday by Noon (weekly) & COGIS & $\begin{array}{l}\text { Table } 1 \text { (U.S. Balance Sheet) and } \\
\text { Table } 14 \text { (Most recent } 5 \text {-weeks) }\end{array}$ \\
\hline $\begin{array}{l}\text { Thursday by Noon } \\
\text { 7th-13th (monthly) }\end{array}$ & COGIS & Table H1 (Petroleum Supply Summary) \\
\hline \multicolumn{3}{|c|}{ Winter Fuels Report (October through March) } \\
\hline Wednesday 5:00 p.m. (weekly) & EPUB & Propane highlights \\
\hline Thursday 5:00 p.m. (weekly) & EPUB & All tables and highlights \\
\hline Friday by Noon (weekly) & COGIS & All tables and highlights \\
\hline \multicolumn{3}{|c|}{ Propane Data (April through September) } \\
\hline $\begin{array}{l}\text { Second Wednesday of the } \\
\text { month }(5: 00 \text { p.m.) }\end{array}$ & EPUB & Propane Stocks \\
\hline \multicolumn{3}{|l|}{ Petroleum Supply Monthly } \\
\hline 23rd-26th (monthly) & EPUB & $\begin{array}{l}\text { Table H1 (Petroleum Supply Summary) and } \\
\text { Detailed Statistics Tables 4, 26, 35, 51, and } 52\end{array}$ \\
\hline 23rd-26th (monthly) & COGIS & $\begin{array}{l}\text { Table H1 (Petroleum Supply Summary), and } \\
\text { all Summary Statistics and Detailed Statistics Tables }\end{array}$ \\
\hline \multicolumn{3}{|l|}{ Oxygenate Data } \\
\hline $\begin{array}{l}15 \text { working days after the } \\
\text { report month }\end{array}$ & EPUB & $\begin{array}{l}\text { Table D1 (Fuel Ethanol Production/Stocks) and } \\
\text { Table D2 (MTBE Production/Stocks) }\end{array}$ \\
\hline \multicolumn{3}{|l|}{ Imports Data } \\
\hline 23rd-26th (monthly) & EPUB & $\begin{array}{l}\text { Import data by company from the Form EIA-814, } \\
\text { "Monthly Imports Report" }\end{array}$ \\
\hline
\end{tabular}




\section{Electronic Publishing System (EPUB) \\ User Instructions}

EPUB is an electronic publishing system maintained by the Energy Information Administration of the U.S. Department of Energy. EPUB allows the general public to electronically access selected energy data from many of EIA's statistical reports. The system is a menu-driven, bulletin board type system with extensive online help capabilities that can be accessed free of charge 24 hours a day by using a terminal or PC with an asynchronous modem. (EPUB will be taken down briefly at midnight for backup.)

\section{CONFIGURING YOUR PC SOFTWARE}

PC users must provide the following information to their communications software in order to successfully access the EPUB system. Consult your communications software documentation for information on how to correctly configure your software.

Communication Parameters:

BAUD RATE: 300 - 2400 bps

DATA BITS: 8

STOP BITS: 1

PARITY: NONE

DUPLEX: FULL

TERMINAL TYPE: examples: ANSI, ANSI-BBS, VT100

\section{ACCESS PHONE NUMBER}

Once your communications software and/or hardware has been configured, you can access EPUB by dialing (202) 586-2557.

\section{USING EPUB}

When a connection to the system has been made, some users may find that the menu-driven instructions and the online help capabilities will provide enough information to effectively use EPUB. If needed, more extensive information may be found in the EPUB Users Guide, which is available online from the EPUB system or from:

National Energy Information Center, EI-231

Energy Information Administration

Forrestal Building, Room 1F-048

Washington, DC 20585

(202) $586-8800$

Hours: 9:00 a.m. to 5:00 p.m. Eastern Time, Monday through Friday

Telecommunications device for the hearing-impaired only:

(202) 586-1181. Hours: 9:00 a.m. to 5:00 p.m. Eastern Time, Monday through Friday

\section{EPUB ASSISTANCE}

For communications or technical assistance, call (202) 586-8959, 8:00 a.m. to 5:00 p.m. Eastern Time, Monday through Friday.

For questions about the content of EPUB reports, call (202) 586-8800, 9:00 a.m. to 5:00 p.m. Eastern Time, Monday through Friday.

\section{EPUB PROVIDES STATISTICAL INFORMATION, AS WELL AS DATA FROM THE FOLLOWING EIA PUBLICATIONS:}

Heating fuel data, (April through September) updated the 2nd week of the month

Oxygenate data, updated approximately 15 working days after the end of the report month

Weekly Petroleum Status Report, updated on Wednesdays (Thursday in event of a holiday) at 9:00 a.m.

Petroleum Supply Monthly, updated between the 23rd and 26th of the month

Petroleum Marketing Monthly, updated on the 20th of the month

Winter Fuels Report, propane inventory data updated Wednesdays at 5:00 p.m. All other data updated on Thursdays (Friday in event of a holiday) at 5:00 p.m. (October through March)

Natural Gas Monthly, updated on the 20th of the month

Weekly Coal Production, updated on Fridays at 5:00 p.m.

Quarterly Coal Report, updated 60 days after the end of the quarter

Electric Power Monthly, updated on the 1st of the month

Monthly Energy Review, updated the last week of the month

Short Term Energy Outlook, updated 60 days after the end of the quarter 


\title{
Comprehensive Oil and Gas Information Source
}

The Comprehensive Oil and Gas Information Source (COGIS) is a project recently developed by the Energy Information Administration (EIA), in cooperation with the U.S. Department of Commerce in an effort to provide more timely information to its customers. COGIS offers the latest oil and gas data published by the EIA. Selected data series from the Petroleum Supply Monthly, the Petroleum Marketing Monthly, the Natural Gas Monthly, the Monthly Energy Reveiw, the Weekly Petroleum Status Report, the Short Term Energy Outlook, and the Winter Fuels Report are available. In addition, COGIS offers timely analysis of major oil and gas trends, and weekly and monthly highlights of oil and gas activity.

Anyone with a workstation connected to an Internet node, or with a personal computer and modem, can have immediate access to oil and gas industry information.

For information, call ElA's National Energy Information Center, (202) 586-8800. To open an account, call the U.S. Department of Commerce, Office of Business Analysis, (202) 482-1986.

Current fee schedule is listed below.

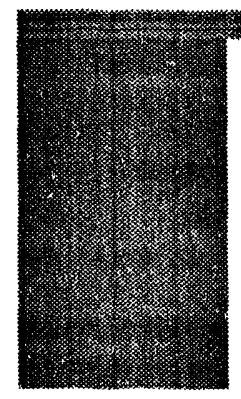

.

\author{
Charge \\ Annual Fee \\ Connect Charge Credit \\ Connect Charges (per minute based on \\ eastern time) \\ Weekdays: 8:00 a.m. - noon \\ Noon - 6:00 p.m. \\ 6:00 p.m. - 8:00 a.m.
}

(Also weekends and holidays)

Means Used to Access the EBB

\begin{tabular}{ccc}
\hline Up to 2400 Baud & 9600 Baud & Internet (telnet only) \\
$\$ 45.00$ & $\$ 45.00$ & $\$ 45.00$ \\
$\$ 20.00$ & $\$ 20.00$ & $\$ 20.00$
\end{tabular}

$\$ 0.20$

$\$ 0.40$

$\$ 0.25$

$\$ 0.40$

$\$ 0.15$

$\$ 0.10$

$\$ 0.25$

$\$ 0.05$

$\$ 0.10$

Annual Flat Fee Option (cannot use account between 8:00 a.m. and noon)

Maximum 1 hour per day

Maximum 4 hours per day 


\section{Contacts}

The Petroleum Supply Monthly is prepared by the Petroleum Supply Division of the Office of Oil and Gas, Energy Information Administration, under the direction of Charles C. Heath (202) 586-6860.

Questions and comments concerning the contents of the Petroleum Supply Monthly may be referred to Ronald W. O'Neill (202) 586-9884, Chief of the Industry Analysis Branch, or the following specialists:

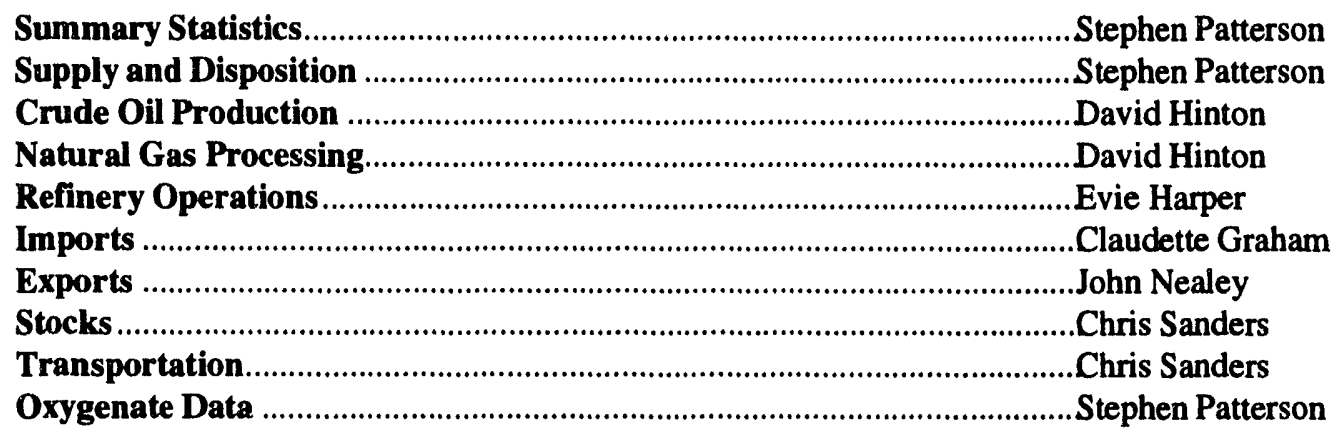

(202) 586-5994

(202) 586-5994

(202) 586-2990

(202) 586-2990

(202) 586-5786

(202) 586-9649

(202) 586-9670

(202) 586-8995

(202) 586-8995

(202) 586-5994

Additional information on all energy statistics available from the Energy Information Administration may be obtained from the National Energy Information Center (202) 586-8800. 


\section{Preface}

The Petroleum Supply Monthly (PSM) is one of a family of four publications produced by the Petroleum Supply Division within the Energy Information Administration (EIA) reflecting different levels of data timeliness and completeness. The other publications are the Weekly Petroleum Status Report (WPSR), the Winter Fuels Report, and the Petroleum Supply Annual (PSA).

Data presented in the PSM describe the supply and disposition of petroleum products in the United States and major U.S. geographic regions. The data series describe production, imports and exports, inter-Petroleum Administration for Defense (PAD) District movements, and inventories by the primary suppliers of petroleum products in the United States (50 States and the District of Columbia). The reporting universe includes those petroleum sectors in primary supply. Included are: petroleum refiners, motor gasoline blenders, operators of natural gas processing plants and fractionators, inter-PAD transporters, importers, and major inventory holders of petioleum products and crude oil. When aggregated, the data reported by these sectors approximately represent the consumption of petroleum products in the United States.

Data presented in the PSM are divided into two sections: Summary Statistics and Detailed Statistics.

\section{Summary Statistics}

The tables and figures in the Summary Statistics section of the PSM present a time series of selected petroleum data on a U.S. level. Most time series include preliminary estimates for one month based on the Weekly Petroleum Supply Reporting System; statistics based on the most recent data from the Monthly Petroleum Supply Reporting System (MPSRS); and statistics published in prior issues of the PSM and PSA.

\section{Detailed Statistics}

The Detailed Statistics tables of the PSM present statistics for the most current month available as well as vear-to-date. In most cases, the statistics are presented for several geographic areas - - the United States (50 States and the District of Columbia), five PAD Districts, and 12 Refining Districts. At the U.S. and PAD District level, the total volume and the daily rate of activities are presented. The statistics are developed from monthly survey forms submitted by respondents to the EIA and from data provided from other sources.

\section{Appendices}

Four appendices are provided to assist in understanding and interpreting the data presented in this publication. They are:

- Appendix A (District Descriptions and Maps) - Geographic aggregations of the 50 States and the District of Columbia into Refining Districts which make up the PAD Districts.

- Appendix B (Detailed Statistics Explanatory Notes) - Information describing data collection, sources, estimation methodology, data quality control procedures, modifications to reporting requirements and interpretation of tables.

- Appendix C (Impact of Resubmissions) - Information on revisions to published statistics caused by resubmission of respondent survey forms.

- Appendix D (EIA-819M, Monthly Oxygenate Telephone Report) - Preliminary information on production and stocks of fuel ethanol and methyl tertiary butyl ether (MTBE) by PAD District. Data are collected from a sample of respondents reporting on the MPSRS surveys. Data are also published in the WPSR and are available electronically approximately 15 working days after the end of the month.

Industry terminology and product definitions are listed alphabetically in the Glossary. Final statistics for the data series published in the PSM, as well as additional data from the annual refinery and oxygenate capacity surveys are published in the PSA. The PSA is published approximately five months after the end of the report year. 


\section{Contents}

Feature Article.

Tables

\section{Summary Statistics}

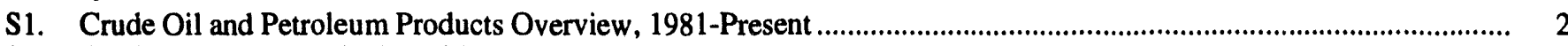

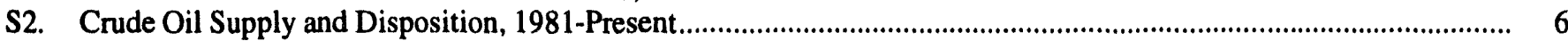

S3. Crude Oil and Petroleum Product Imports, 1981-Present ................................................................................. 8

S4. Finished Motor Gasoline Supply and Disposition, 1981-Present .............................................................................. 17

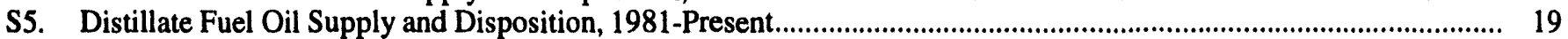

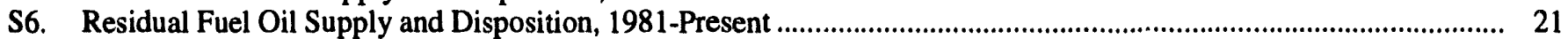

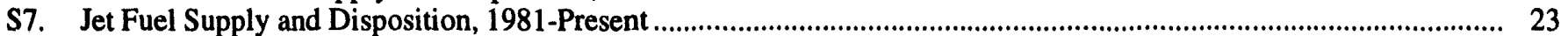

S8. Propane/Propylene Supply and Disposition, 1981-Present .................................................................................. 25

S9. Liquefied Petroleum Gases Supply and Disposition, 1981-Present ..................................................................... 27

S10. Other Petroleum Products Supply and Disposition, 1981-Present..................................................................... 28

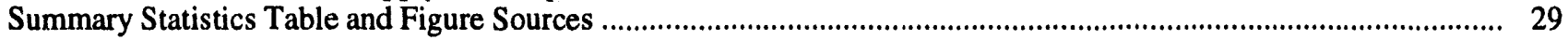

Summary Statistics Explanatory Notes .............................................................................................................

\section{Detailed Statistics}

\section{National Statistics}

1. U.S. Petroleum Balance

2. U.S. Supply, Disposition, and Ending Stocks of Crude Oil and Petroleum Products ................................................. 36

3. U.S. Year-to-Date Supply, Disposition, and Ending Stocks of Crude Oil and Petroleum Products ............................. 37

4. U.S. Daily Average Supply and Disposition of Crude Oil and Petroleum Products ....................................................... 38

5. U.S. Year-to-Date Daily Average Supply and Disposition of Crude Oil and Petroleum Products.

Supply and Disposition of Crude Oil and Petroleum Products

6. NA.D District!

7. Year-to-Date PAD District I .....

8. Daily Average PAD District I.

9. Year-to-Date Daily Average PAD District I

10. PAD District II

11. Year-to-Date PAD District II

12. Daily Average PAD District II

13. Year-to-Date Daily Average PAD District II

14. PAD District III.

15. Year-to-Date PAD District III ...

16. Daily Average PAD District III.

17. Year-to-Date Daily Average PAD District III.

18. PAD District IV.

19. Year-to-Date PAD District IV

20. Daily Average PAD District IV....

21. Year-to-Date Daily Average PAD District IV .

22. PAD District $V$...

23. Year-to-Date PAD District V...

24. Daily Average PAD District $V$...

25. Year-to-Date Daily Average PAD District V

Production of Crude Oil

26. Production of Crude Oil by PAD District and State

Natural Gas Processing

27. Natural Gas Plant Net Production and Stocks of Petroleum Products by PAD and Refining Districts

\section{Refinery Operations}

28. Refinery Input of Crude Oil and Petroleum Products by PAD and Refining Districts

29. Refinery Net Production of Finished Petroleum Products by PAD and Refining Districts ....................................... 64

30. Refinery Stocks of Crude Oil and Petroleum Products by PAD and Refining Districts ......................................... 66

31. Percent Refinery Yield of Petroleum Products by PAD and Refining Districts ....................................................... 68 


\section{Imports of Crude Oil and Petroleum Products}

State of Entry

32. Imports of Residual Fuel Oil by Sulfur Content

\section{PAD District}

33. Imports of Crude Oil and Petroleum Products

34. Year-to-Date Imports of Crude Oil and Petroleum Products

\section{Country of Origin}

35. United States.

36. PAD District I.

37. PAD District II

38. PAD District III

39. PAD Districts IV and V

40. Year-to-Date United States

41. Year-to-Date PAD District I

42. Year-to-Date PAD District II

43. Year-to-Date PAD District III

44. Year-to-Date PAD Districts IV and V

\section{Exports of Crude Oil and Petroleum Products}

45. Exports of Crude Oil and Petroleum Products by PAD District.

46. Year-to-Date Exports of Crude Oil and Petroleum Products by PAD District

47. Exports of Crude Oil and Petroleum Products by Destination ....

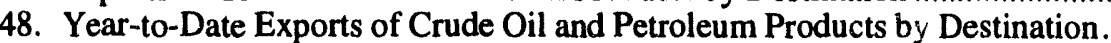

\section{Net Imports}

49. Net Imports of Crude Oil and Petroleum Products into the United States by Country

50. Year-to-Date Net Imports of Crude Oil and Petroleum Products into the United States by Country

Stocks

51. Stocks of Crude Oil and Petroleum Products by PAD District

52. Refinery, Bulk Terminal, and Natural Gas Plant Stocks of Selected Petroleum Products by PAD District and State

\section{Movements of Crude Oil and Petroleum Products}

53. Movements of Crude Oil and Petroleum Products by Pipeline, Tanker, and Barge Between PAD Districts

54. Movements of Crude Oil and Petroleum Products by Pipeline Between PAD Districts .

55. Movements of Crude Oil and Petroleum Products by Tanker and Barge Between

PAD Districts

56. Net Movements of Crude Oil and Petroleum Products by Pipeline, Tanker, and Barge

Between PAD Districts

\section{Illustrations}

S1. Petroleum Overview, February 1993-Present.

S2. Petroleum Products Supplied, February 1993-Present

S3. Crude Oil Supply and Disposition, February 1993-Present

S4. Crude Oil Ending Stocks, February 1993-Present

S5. Finished Motor Gasoline Supply and Disposition, February 1993-Present

S6. Motor Gasoline Ending Stocks, February 1993-Present

S7. Distillate Fuel Oil Supply and Disposition, February 1993-Present

S8. Distillate Fuel Oil Ending Stocks, February 1993-Present...

S9. Residual Fuel Oil Supply and Disposition, February 1993-Present

S10. Residual Fuel Oil Ending Stocks, February 1993-Present

S11. Jet Fuel Supply and Disposition, February 1993-Present.

S12. Jet Fuel Ending Stocks, February 1993-Present

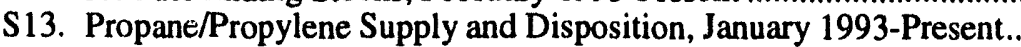

S14. Propane/Propylene Ending Stocks, January 1993-Present

S15. Liquefied Petroleum Gases Supply and Disposition, January 1993-Present

S16. Liquefied Petroleum Gases Ending Stocks, January 1993-Present.

\section{Appendices}

A. District Descriptions and Maps

B. Detailed Statistics Explanatory Notes.

C. Impact of Resubmissions on Major Series, 1993.

D. EIA-819M, Monthly Oxygenate Telephone Report.

\section{Glossary}

Definitions of Petroleum Products and Other Terms 


\section{Articles}

Feature articles on energy-related subjects are frequently included in this publication. The following articles have appeared in previous issues.

Trends in Petroleum Product Consumption

January 1986

Western Countries Lead U.S. Petroleum Import Sources

January 1986

U.S. Petroleum Exports Show Slight Upturn

January 1986

Motor Gasoline Trends

February 1986

Oil Imports from Saudi Arabia

February 1986

Refinery Capacity Trends and Outlook

March 1986

Timeliness and Accuracy of Petroleum Supply Data

April 1986

Midyear Petroleum Review

May 1986

Winter 1986-1987 Distillate Fuel Outlook

July 1986

Recent Trends for Middle Distillates

Comparison of Independent Statistics on Petroleum Supply

U.S. Petroleum Developments: 1986

July 1986

U.S. Petroleum Imports, 1986 Regional Highlights

September 1986

November 1986

Leading Petroleum Importers, 1986

U.S. Exports of Petroleum Products Reach Record High

Trends in Petroleum Product Consumption

Refinery Capacity: 1987

December 1986

December 1986

December 1986

Motor Gasoline Outlook for Summer 1987

February 1987

March 1987

March 1987

Motor Gasoline Trends Through 1986

March 1987

Timeliness and Accuracy of Petroleum Supply Data

April 1987

Midyear Petroleum Review

May 1987

Petroleum Heating Fuels

July 1987

Distillate Fuel Oil Outlook for Winter 1987/1988

July 1987

Petroleum Exports

August 1987

EIA Releases Annual Reserves Summary

August 1987

Comparisons of Independent Statistics on Petroleum Supply

The Northeast-Distillate Fuel Oil Supply

U.S. Petroleum Developments: 1987

September 1987

U.S. Petroleum Import/Export Trends Through 1987

November 1987

Motor Gasoline Trends Through 1987

December 1987

January 1988

Distillate Fuel Oil Outlook: Winter 1988/1989

February 1988

July 1988

Comparison of Independent Statistics on Petroleum Supply

U.S. Petroleum Developments: 1988

September 1988

U.S. Petroleum Trade Trends: 1988

December 1988

Timeliness and Accuracy of Petroleum Supply Data

January 1989

Distillate Fuel Oil Outlook: Winter 1989/1990

Comparisons of Independent Statistics on Petroleum Supply

U.S. Petroleum Developments: 1989.

U.S. Petroleum Trade Trends: 1989

July 1989

July 1989

September 1989

December 1989

Motor Gasoline Outlook: 1990

Timeliness and Accuracy of Petroleum Supply Data

January 1990

February 1990

April 1990

Heating Fuel Outlook: Winter 1990-91

Comparisons of Independent Statistics on Petroleum Supply

U.S. Petroleum Developments: 1990

July 1990

U.S. Petroleum Trade 1990

September 1990

Effects of the Clean Air Act's Highway Diesel Fuel Oil Provisions

February 1991

March 1991

June 1991

Timeliness and Accuracy of Petroleum Supply Data.

June 1991

Regulation of Underground Petroleum Storage

Alternative Transportation Fuels

U.S. Petroleum Developments: 1991

February 1992

Comparisons of Independent Statistics on Petroleum Supply

March 1992 


\section{Articles (Continued)}

U.S. Petroleum Trade, 1991

April 1992

Timeliness and Accuracy of Petroleum Supply Data

September 1992

Three Dimensional Seismology-A New Perspective

December 1992

Summer 1993 Motor Gasoline Outlook

April 1993

Comparisons of Independent Statistics on Petroleum Supply

May 1993

Drilling Sideways

June 1993

The Economics of the Clean Air Act Amendments of 1990

July 1993

Accuracy of Petroleum Supply Data

August 1993

Distillate Fuel Oil Outlook for Winter 1993-1994

October 1993

Propane Outlook for Winter 1993-1994

October 1993

Strategic Shipping Lanes January 1994 


\section{Feature Article}

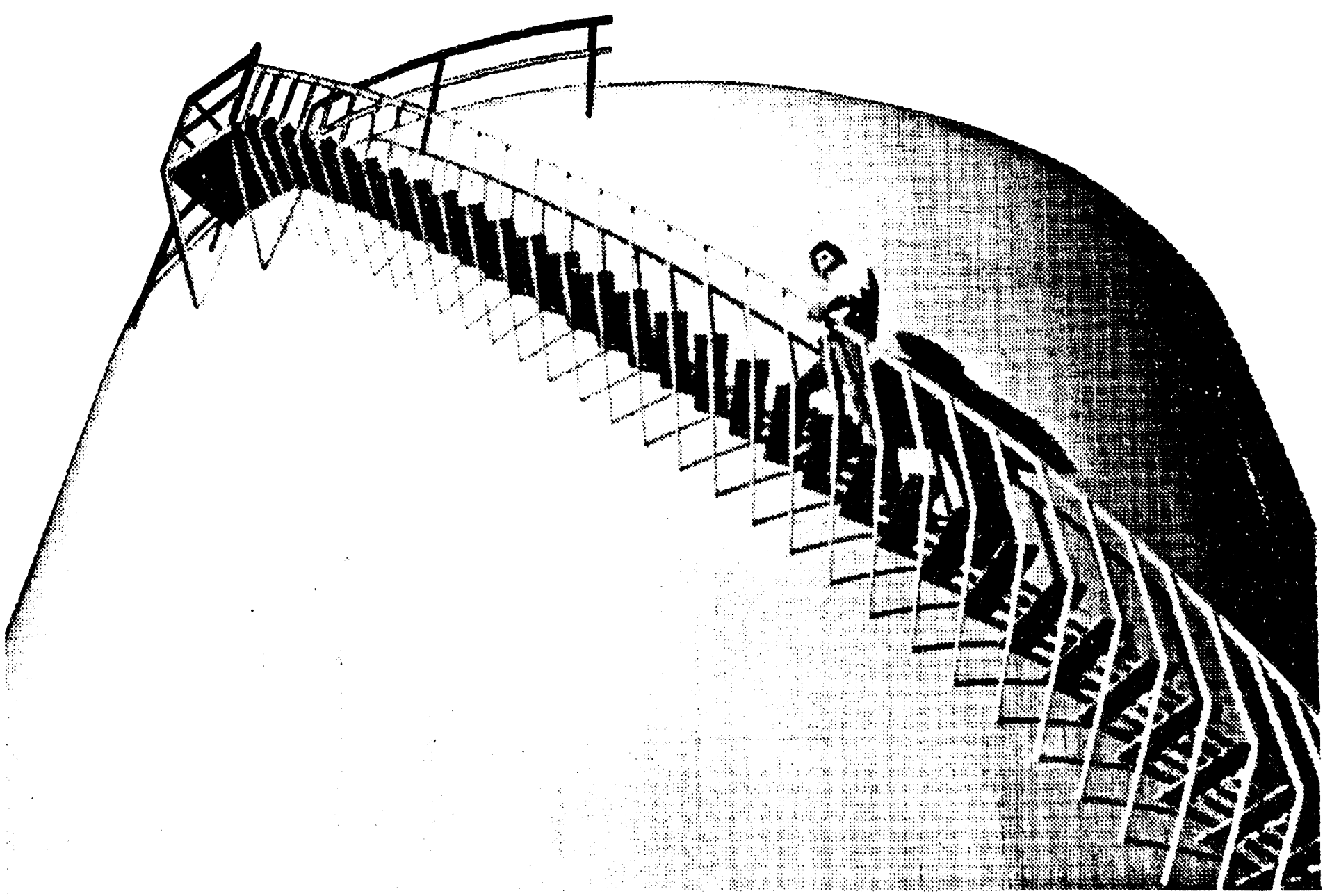




\title{
Summer 1994 Motor Gasoline Outlook
}

\author{
by Charles Dale and Robert Schmer
}

Continued improvement in the economy along with steady growth in employment and income are expected to result in increased highway travel. The Energy Information Administration's (EIA) Short-Term Energy Outlook (STEO) Mid-World Oil Price Case forecasts about 1.6 percent growth in gasoline demand this summer (April 1 - September 1) over last. This article uses the STEO Mid-World Price Case as its starting point and considers three other scenarios to test unexpected yet feasible price and stock patterns in response to changes in underlying economic conditions. The analysis concludes that adequate supplies of motor gasoline exist under all scenarios considered, with only modest price increases foreseen.

The first scenario which might have the most significant impact on motor gasoline prices assumes a $\$ 3.00$ per barrel rise in the price of crude oil if, for example, the Organization of Petroleum Exporting Countries were to agree to limit production. The effect of this crude price increase on retail gasoline markets is expected to be an approximate 3-cent per gallon rise in the first month, increasing to 6 cents in the second and following months. Such an increase in retail gasoline prices beyond the base case seasonal increment would have only a small impact on gasoline demand, decreasing average demand by only 15 thousand barrels per day during the driving season.
The second scenario considers a 2-percent demand increase, which is similar to last year's experience which would be met solely through increased refinery production and stock withdrawals. Refinery utilization is expected to increase by about 1 percentage point during the months of July through September to meet part of the increased demand. The balance of the increase would result in end-of-month August stocks dropping to a low level of 198 million barrels. Under this scenario, a 1-cent per gallon additional increase in the retail price of gasoline would be expected during the second half of the driving season.

The third scenario differs from the second only in that the 2-percent demand surge is met solely through incremental imports. Historically, incremental imports from Europe tend to occur when gasoline spot prices in New York Harbor exceed those in Rotterdam by 5 cents per gallon or more. Given such a price spread, imports would begin increasing in July and continue at an increased level through September, adding a premium to retail prices of about 5 cents per gallon (or the cost of incremental imports) during the late summer months

Table FE1 contains historical and STEO Mid-World Oil Price values for the key variables considered in the analysis. Values for the three alternative cases considered are shown in Table FE2.

Table FE1. Motor Gasoline Demand and Supply Factors, Summers (April 1 - September 30) 1991 - 1994

\begin{tabular}{|c|c|c|c|c|}
\hline \multirow[b]{2}{*}{ Factor } & \multicolumn{3}{|c|}{ History } & \multirow{2}{*}{$\begin{array}{c}\text { STEO } \\
\text { Mid Case } \\
\text { Summer } \\
1994\end{array}$} \\
\hline & $\begin{array}{c}\text { Summer } \\
1991\end{array}$ & $\begin{array}{c}\text { Summer } \\
1992\end{array}$ & $\begin{array}{c}\text { Summer } \\
1993\end{array}$ & \\
\hline Gross Domestic Product Growth Rate (percent per year) & 1.4 & 1.8 & 2.8 & 3.2 \\
\hline Disposable Personal Income (billions of $\$ 1987$ ) & $\$ 3,509$ & $\$ 3,579$ & $\$ 3,699$ & $\$ 3,820$ \\
\hline Vehicle Miles Traveled (million miles per day) & 6,220 & 6,453 & 6,618 & 6,787 \\
\hline Vehicle Fuel Efficiency (index) & 20.10 & 20.78 & 20.60 & 20.81 \\
\hline Summer Demand (million barrels per day) & 7.37 & 7.40 & 7.65 & 7.77 \\
\hline Total Production (million barrels per day) & 7.12 & 7.05 & 7.37 & 7.51 \\
\hline Net Imports (million barrels per day) & 0.29 & 0.27 & 0.19 & 0.21 \\
\hline Stcck Change (million barrels per day) & +0.04 & -0.08 & -0.11 & -0.04 \\
\hline Stock Levels, begin/end (million barrels) & $210 / 216$ & 220/206 & 227/207 & $214 / 206$ \\
\hline Refinery Operable Utilization Rate (percent) & 88.0 & 89.6 & 93.2 & 93.7 \\
\hline Price of Imported Crude Oil (avg. per barrel) & $\$ 18.34$ & $\$ 19.04$ & $\$ 16.63$ & $\$ 13.75$ \\
\hline Federal Tax Rate (avg. per gallon) & $\$ 0.14$ & $\$ 0.14$ & $\$ 0.14$ & $\$ 0.18$ \\
\hline Retail Gasoline Price (avg. per gallon) & $\$ 1.19$ & $\$ 1.21$ & $\$ 1.17$ & $\$ 1.17$ \\
\hline
\end{tabular}

Source: Short-Term Energy Outlook, Petroleum Supply Monthly/Petroleum Supply Annual, Petroleum Marketing Monthly/Petroleum Marketing Annual.

Unics othervise referenced, data in this article are taken from the following. Weekly Petroleum Status Report, DOEEIIA-0208(March

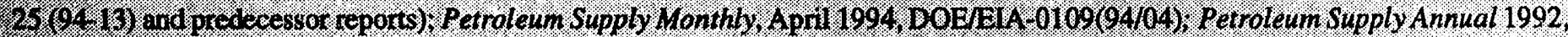
DOEIEIA-0340. Volumes 1 and 2 and predecessor reports; Petroleun Marketing Monthly, March 1994, DOEIEIA-0380(94/03); 51,or. Trm Energy Outlook. DOEIEIA-0202(94/20) and predecessor reports. All data through 1992 are considered final and are not subject to firther revision. 


\section{Current Situation}

The U.S. economy is expected to continue the higher rate of recovery which began in the second half of 1992 . Real gross domestic product (GDP) is projected to grow by 3.2 percent and real disposable income is expected to increase by 3.3 percent compared to last summer.

The most important determinants of gasoline demand are vehicle miles traveled and fuel efficiency. Vehicle miles traveled by all vehicles is projected by STEO to be about 2.6 percent higher this summer, while vehicle efficiency growth rates continue to decrease. As recently as 1989 , vehicle efficiency improved about 3 percent annually, but by 1990 growth had fallen to nearly 1 percent. Current fuel efficiency growth rate projections of about 1.5 percent reflect the dwindling number of older, less fuel-eficient vehicles remaining to be retired.

Falling crude oil prices, especially in the second half of 1993, resulted in high refinery runs and high product stock levels. This in turn led to falling gasoline prices, which helped to stimulate gasoline demand. The U.S. average retail price of gasoline began 1993 at $\$ 1.18$ per gallon, reaching a peak of $\$ 1.19$ per gallon in October before falling and ending the year at $\$ 1.14$ per gallon. The low end-of-year price occurred in spite of a 4.3-cent per gallon gasoline tax increase that took effect on October 1, 1993, attempts by OPEC to maintain production quotas in the second half of the year, and motor gasoline oxygenate requirements in the Fall of 1993.

Operable refinery capacity of about 15.1 million barrels per day has been essentially unchanged since January 1, 1993. During June and July 1993 gross inputs to atmospheric crude oil distillation units exceeded 95 percent of operable capacity in order to meet the summer demand for gasoline. High capacity utilization rates are expected again this summer as stocks are

Figure FE1. World Crude Oll Price

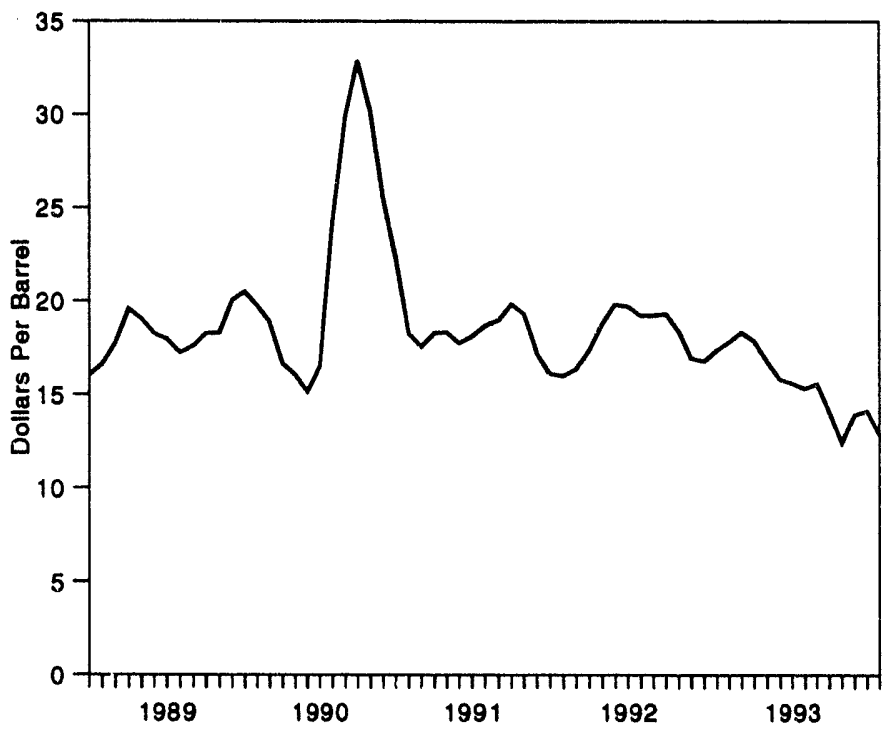

Source: Energy Information Administration, Weekly Petroleum Status Report, various issues, 1994. lower than last April and demand is expected to be 1.6 percent higher for the summer of 1994.

Net imports of motor gasoline have been going down in recent years while exports have been going up. Net imports of motor gasoline averaged over 4 percent of product supplied annually between 1986 and 1990, but dropped to under 3 percent during 1991 and 1992 and to 1.9 percent during 1993. Net imports may go even lower during 1994 due to low crude oil acquisition costs. The outlook for continued low crude oil prices would tend to encourage high refinery runs, reducing the requirement for motor gasoline imports.

Current stock patterns reflect the need to make changes in response to seasonal regulation shifts. Stocks of oxygenated gasoline have dropped rapidly since the winter program ended in most States on February 28, 1994. Preliminary statistics from the Weekly Petroleum Status Report indicate that March 31, 1994 stocks of oxygenated gasoline will be less than 10 million barrels which compares to early June 1993 inventories. Stocks of motor gasoline are expected to fall in August as the low-RVP summer gasolines will be replaced by the increased supplies of oxygenated gasolines to meet the winter requirements during September and October. August inventories of motor gasoline were the lowest monthly level for both 1992 and 1993 at 201 million barrels and 200 million barrels respectively.

\section{STEO Mid-World Oil Price Case}

The Mid World Oil Price Case presented in EIA's second quarter STEO for the second and third quarters of 1994 underlies our analysis. Table FE1 compares this case to the historical values for key economic and market variables during the driving seasons of April through September 1991-1993.

Figure FE2. Average Retail Gasoline Prices

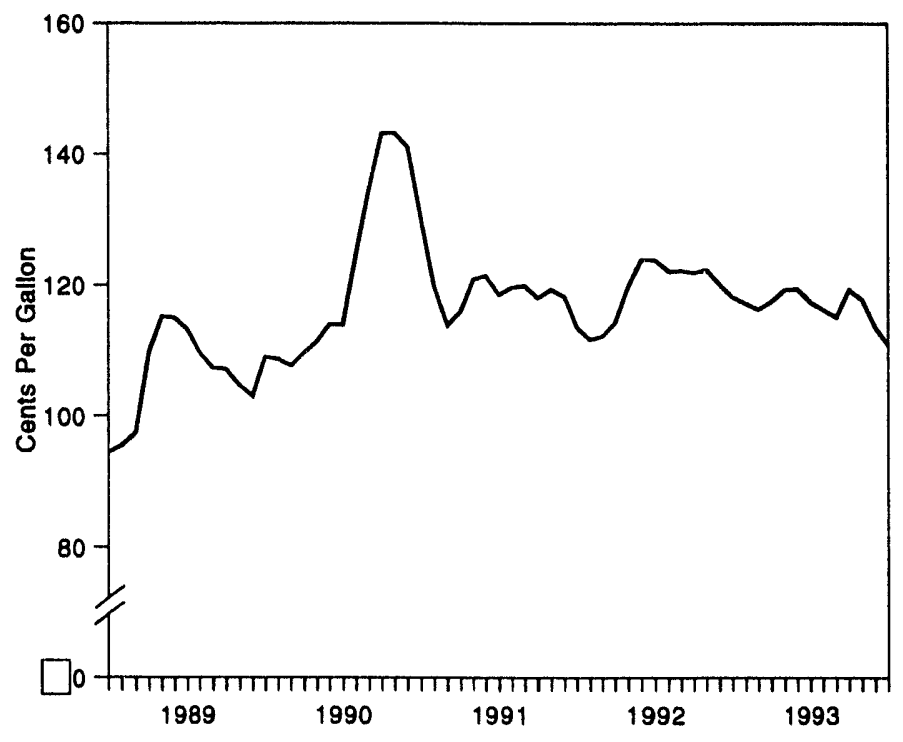

Source: Bureau of Labor Statistics, Retail Motor Gasoline Prices. 
The STEO mid-price case estimates that the demand for motor gasoline over the summer, expressed as product supplied, could increase 1.6 percent from 1993, from 7.65 to 7.77 million barrels per day, a somewhat smaller increase from the previous year's growth rate of 3.4 percent. The projected demand growth reflects an improving economy, as Gross Domestic Product during the summer is projected to rise from 2.8 percent to 3.2 percent on an annual basis.

The increased gasoline demand could be met by increased domestic production, as net imports of gasoline are projected to increase from an average of 186,000 barrels per day during the Summer of 1993 to about 210,000 barrels per day in Summer 1994. Refinery output of motor gasoline could rise to 7.29 million barrels per day in 1994, a 0.8 percent increase over the 1993 level of 7.23 million barrels per day. Gasoline stocks and blending components (except oxygenates) are projected to end the season at 206 million barrels on September 30, 1994, close to the 207 million barrels ending level of September 1993. (Contrary to the forecasted stock build, data for the first two weeks in April show primary stocks declining a further 3.5 million barrels. Even though preliminary data show refinery production and product imporis to be rising faster than expected, the second quarter stock build may be delayed, which could result in end of June primary stock levels 2 to 3 million barrels lower than forecasted.)

Refinery capacity utilization rates are projected to be 94 percent of operable capacity through most of the spring and summer. This projected figure is similar to that which occurred during the 1993 driving season, when the capacity utilization rate peaked at 95.3 percent during June and July, and no large scale disruptions occurred.

The STEO mid-price case estimates that the world crude oil price could be $\$ 13.50$ per barrel early in the season and rise to $\$ 14$ per barrel in July, about \$3.00 per barrel lower than in Summer 1993. The failure of OPEC in November 1993 and again in March 1994 to agree on a strategy to push oil prices higher could potentially cause oil prices to remain low throughout 1994. Retail gasoline prices at the pump could average $\$ 1.17$ per gallon, the same level as a year earlier, as relatively weak crude oil prices offset the stronger economy and higher gasoline taxes.

To examine the critical assumptions in the STEO mid-price case, three scenarios were created to determine the sensitivity of retail prices and primary stock levels to changes in those assumptions. The scenarios were developed using EIA's Motor Gasoline Market Model (MGMM). ${ }^{1}$ Table FE2 summarizes the results in the scenarios and shows the resulting impact on gasoline stocks and retail prices forecast in the STEO mid-price case. The monthly estimates for stocks and retail prices are shown in Figures FE3 and FE4, and are described below. The results indicate that even unforeseen developments should not result in major disruptions in gasoline supplies or prices in 1994.

\section{Scenario 1: Crude Oil Price Spike}

This scenario differs from the STEO mid-price case by examining the impact of a $\$ 3.00$-per-barrel increase in the price of imported crude oil in April and May. This increase could arise from a number of unforseen events which raise the possibility of tighter world crude supplies. One such possibility is that OPEC would agree on a credible production limiting agreement during its June 1994 meeting. This would cause world oil markets to react by temporarily bidding up crude oil prices; probable overproduction by members of the cartel would then return prices to recent historical levels for the remainder of the summer driving season. In this scenario, actual world supply is not altered, and ciude oil prices would begin to retreat after a few months, followed by longer term adjustments in stocks and retail prices.

The $\$ 3.00$ per barrel crude price increase would have an immediate effect on refining margins, given that crude oil accounts for most of the marginal cost of motor gasoline production. This would result in an immediate effect on wholesale market prices in response to the higher refinery cost and spot market uncertainties. Whereas crude oil prices would increase by approximately 7.1 cents per gallon in April, the retail price of gasoline would increase

${ }^{1}$ Energy Information Administration, Motor Gasoline Market Model Documentation Report, DOE/EIA-M054 (Washington, D.C., September 1993).

Table FE2. Motor Gasoline Demand and Supply Factors - Alternative Projections (April 1 - September 30)

\begin{tabular}{|c|c|c|c|c|}
\hline \multirow[b]{3}{*}{ Factor } & \multirow{3}{*}{$\begin{array}{c}\text { STEO } \\
\text { Mid Case }\end{array}$} & \multicolumn{3}{|c|}{ Scenarios } \\
\hline & & \multirow{2}{*}{$\begin{array}{l}\text { Crude OII } \\
\text { Spike (\$3) }\end{array}$} & \multicolumn{2}{|c|}{ Demand } \\
\hline & & & Production High & Imports High \\
\hline Gross Domestic Product Growth Rate (percent per year) & 3.2 & 3.2 & 3.2 & 3.2 \\
\hline Summer Demand (million barrels per day) & 7.77 & 7.75 & 7.84 & 7.83 \\
\hline Total Production (million barrels per day) & 7.51 & 7.51 & 7.55 & 7.51 \\
\hline Net Imports (million barrels per day) & 0.21 & 0.21 & 0.21 & 0.27 \\
\hline Stock Change (million barrels per day) & -0.04 & -0.03 & -0.08 & -0.04 \\
\hline Stock Levels, begin/end (million barrels) & $214 / 206$ & $214 / 209$ & $214 / 199$ & $214 / 206$ \\
\hline Refinery Operable Utilization Rate (percent) & 93.7 & 93.7 & 94.4 & 93.7 \\
\hline Price of Imported Crude Oil (avg. per barrel) & $\$ 13.75$ & $\$ 14.75$ & $\$ 13.75$ & $\$ 13.75$ \\
\hline Retail Gasoline Price (avg. per gallon) & $\$ 1.17$ & $\$ 1.19$ & $\$ 1.17$ & $\$ 1.19$ \\
\hline
\end{tabular}

Source: Short-Term Energy Outiook, Petroleum Supply Monthly/Petroleum Supply Annual, Petroleum Marketing Monthly/Petroleum MarketingAnnual. 
by only 6 cents during the month due to seasonal factors and increased refiner cost. Apart from seasonal factors, the effect of the crude price increase on retail gasoline markets is expected to be only 3 cents per gallon in the first month, increasing to 6 cents in the second month; although the motor gasoline price would not immediately rise by the full extent of the increased refinery cost, it would likely remain elevated for several months after crude oil prices returned to previous levels.

It is estimated that retail gasoline prices would have only a small effect on gasoline demand, decreasing average demand by only 15 thousand barrels per day during the driving season. The resulting lower stock withdrawals would leave end-of-September stocks at a level of 2.6 million barrels higher than the STEO case.

\section{High Demand, With Alternative Supply Responses}

Scenarios 2 and 3 examine the impact of a 2-percent increase in motor gasoline demand during the last 3 months of the summer driving season, over the STEO mid-price case. As in the previous scenario, this could occur for several reasons. One possibility is a surge in driving during the summer months, combined with little improvement in automobile efficiency. This increased driving could occur because of pent up consumer demand for vacations and increased economic activity due to the expected rapid economic upturn. This is not unlike what happened during the 1993 driving season when demand rose sharply during the late summer due to an expanding economy. The two scenarios differ in the manner in which the supply system responds -- scenario 2 relies on increased refinery production and incremental stock withdrawals, while scenario 3 relies solely on incremental imports. Each of these extremes is unlikely, as an unexpected surge in demand would probably be met through some combination of incremental supplies, including a short-term increase in refinery production, as well as additional imports. Nonetheless, these two scenarios illustrate the substantial flexibility in the supply system and provide for a range of gasoline stock levels and retail prices.

\section{Scenario 2. High Demand, Met Through Increased Refinery Production}

In this scenario, high demand during the months of July through September results in stock withdrawals larger than anticipated in the STEO mid-price case, given no change in the level of imports. Utilization of operable refinery capacity is allowed to increase by 1 percentage point during this period (1.3 percentage points in July) to help meet the excess demand. To meet the large excess of demand over supply, end-of-month August stocks fall to a low level of 198 million barrels. (Stocks dropped close to that level in August 1993, with no price response). The retail price of gasoline is projected to increase gradually, eventually reaching a 1.0 cent per gallon premium in September, with only a small dampening effect on gasoline demand. For the entire 6-month period, retail prices would average only $1 / 3$ of a cent higher than the STEO mid-price case. It is important to note that the forecasted prices do not take into account (and thus understate any current or subsequent price increases) any cost of restocking the low primary inventory levels estimated for this scenario.

\section{Scenario 3. High Demand, Met Through Increased Imports}

This scenario modifies the STEO case by assuming a demand increase of 2 percent larger than expected, with end-of-month stocks held to be the same level as the STEO mid-price case and the demand shortfall made up entirely by imports, which would likely come from Western Europe. These incremental motor gasoline imports are known to be sensitive to short-term price fluctuations. Large volumes of such shipments have historically come from the Amsterdam-Rotterdam-Antwerp region of Northwest Europe, but for those shipments to take place, the variable costs of transportation must be covered. Historically, incremental imports have occurred when gasoline spot prices in New York Harbor show a differential of at least 5-cents per gallon over those in Rotterdam. Since European economies are likely to remain sluggish relative to the U.S. economy, as well as having apparent surplus gasoline inventories (as evidenced by current levels of exports to the U.S.), it is assumed that a relatively small spread of $5-7$ cents per gallon would be sufficient to induce the required incremental imports into the U.S. It is further assumed that half of the original spot spread required to sustain the incremental imports is passed to the retail market in the first month, with the remainder during the second and subsequent months. Under these assumptions, imports would begin increasing in July and continue at a high level through September. The net effect on retail prices would be about 5 cents per gallon during the late summer months.

\section{Figure FE3. Motor Gasoline Outlook: Prices 1994}

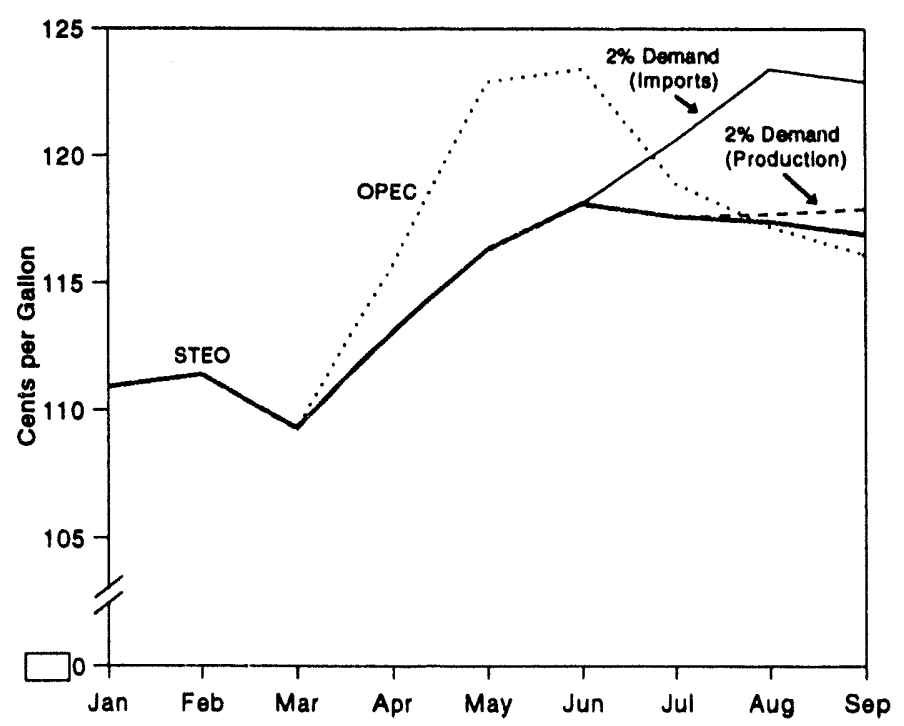

Source: Energy Information Administration, estimates derived from regression analysis and Short-Term Energy Outlook, Second Quarter, 


\section{Conclusions}

The scenario analysis using the EIA Motor Gasoline Market Model (MGMM) shows that gasoline supplies are ample to cover major contingencies such as price spikes caused by OPEC agreements or by increased demand caused by a rapidly improving economy. This analysis shows that even a $\$ 3.00$ per barrel spike (scenario 1) in the price of oil could be absorbed with a 6-cent per gallon rise in the price of gasoline over the STEO projection.

Higher demand could cause retail prices to be 4.4 to 6 cents per gallon higher by September than the STEO estimates, but incremental demand could easily be met through either increased production or increased imports (scenarios 2 and 3 ).
Figure FE4. Motor Gasoline Outlook: Stocks 1994

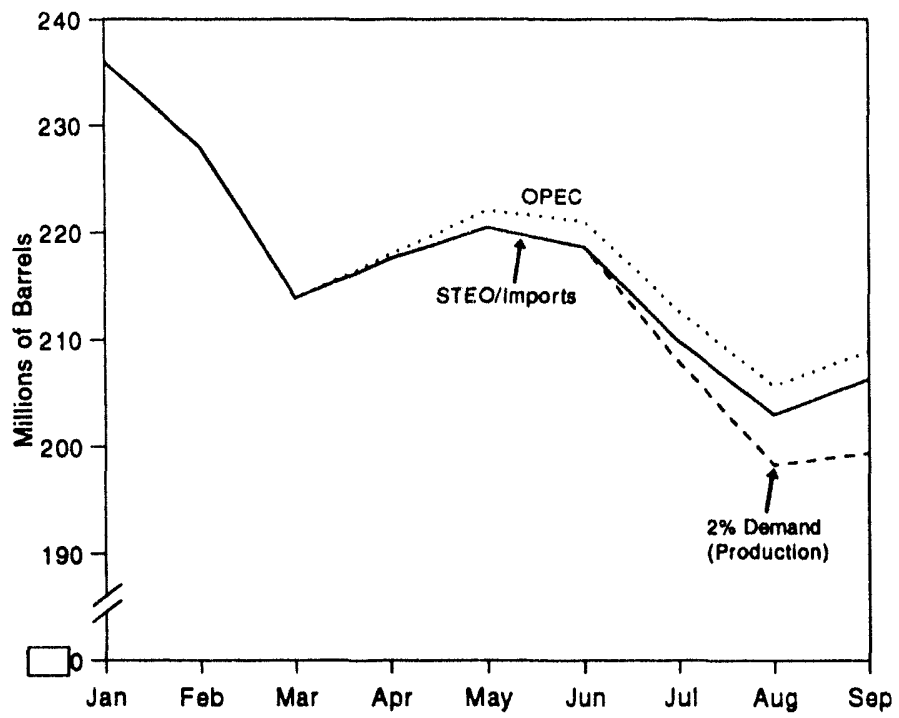

Source: Energy Information Administration, estimates derived from regression analysis and Short-Term Energy Outlook, Second Quarter, 1994.

\section{Demand For Oxygenates and Oxygenated Gasoline}

\section{Demand}

The demand for oxygenates and oxygenated gasoline was slightly less last season than for the previous, initial, oxygenated gasoline season. One of the causes of the decline was that the Hartford, CT, Syracuse, NY, Cleveland OH areas, and areas in Alaska where oxygenated fuels were required last year, did not participate this year. Their nonparticipation resulted in a decline of about 145,000 barrels per day of required oxygenated gasoline. Meanwhile, overall demand for gasoline was up about 1.6 percent in the Fourth Quarter of 1993 over the fourth quarter of 1992, adding about 35,000 barrels per day of oxygenated gasoline demand. Thus, net oxygenated gasoline requirements were down about 110,000 barrels per day ( 5 percent). Ethanol usage was affected more by the nonparticipation of the Cleveland and Syracuse areas, while Methyl Tertiary Butyl Ether (MTBE) usage was primarily affected by the nonparticipation of Hartford.

\section{Supply}

The supply situation for oxygenates also showed some changes in 1993 from 1992, primarily with respect to MTBE supply. While demand for oxygenated gasoline was slightly less in the most recent oxygenated season than the first one, MTBE production capacity continued to increase. The results are shown in Figures FE5 and FE6. Comparing the Fourth Quarter of 1993 with the same period of the previous year, production was up over 25,000 barrels per day while the rate of stock drawdown decreased by 30-40,000 barrels per day. Partly in response to the surplus oxygenates last year, the total U.S. MTBE stock level at the end of September 1993 was 15,510 thousand barrels compared to 22,635 thousand barrels the previous year. However, the lower beginning stock level for the most recent oxygenated fuel season did not pose a problem because of the higher production levels.

\section{Oxygenate Prices}

MTBE spot prices since the beginning of April 1993 are shown in Figure FE7. During this period, MTBE prices were primarily determined by MTBE's value as a high octane blending component. The value of gasoline blending components move up and down with the price of gasoline, which in turn moves with the price of crude. The price pattern shown in Figure FE7 mirrors the pattern of crude oil prices. 


\section{Oxygenated Gasoline Price}

EIA surveys the price of gasoline at retail outlets. To gauge the impact of meeting oxygenated gasoline standards, the relative prices of stations in PADD I nonattainment areas are compared to prices in PADD I attainment areas. Before the oxygenated gasoline season began, average prices at nonattainment areas were about 1.5 cents per gallon under those in attainment areas of PADD I. But in November, December, and January, when oxygenated gasolines were being sold in nonattainment areas, the nonattainment prices exceeded the attainment area prices by 2.5 cents per gallon. Thus, the impact on retail gasoline prices in PADD I was a net increase of about 4.0 cents per gallon for oxygenated versus conventional gasoline. Given the low price of crude oil and the marginal cost of making oxygenated gasoline, most refiners were again able to pass through their incremental costs to consumers.

\section{Production Capacity}

United States MTBE production capacity was expected to top 200,000 barrels per day on January 1, 1994. Future growth in MTBE capacity may be slower than previously expected, because MTBE prices have been weaker than expected the past two years. A number of proposed MTBE facilities have already been canceled.

Figure FE6. MTBE Monthly Stock Change

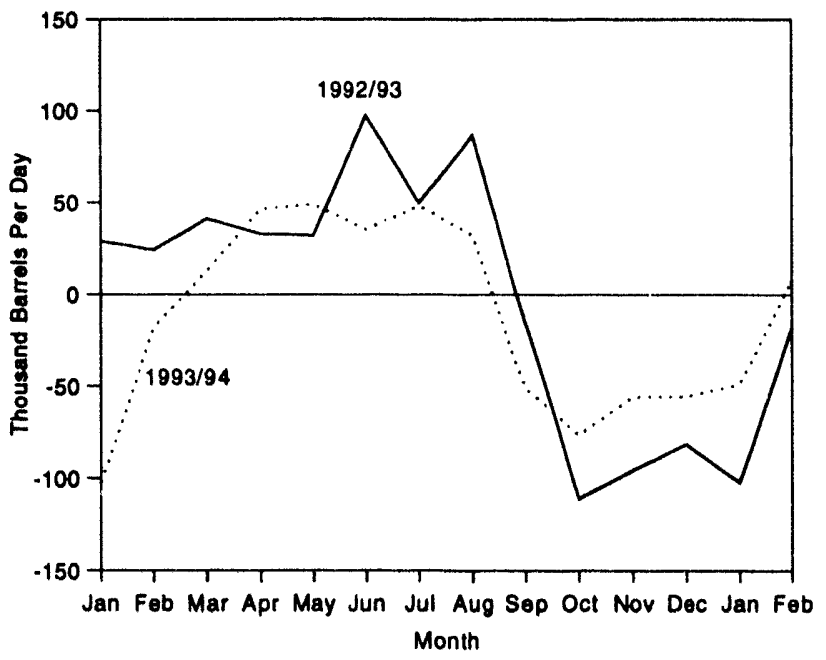

Source: Energy Information Administration, Weekly Petroleum Status Report, Week Ending March 18, 1994, Table B3.

Figure FE5. U.S. MTBE Production

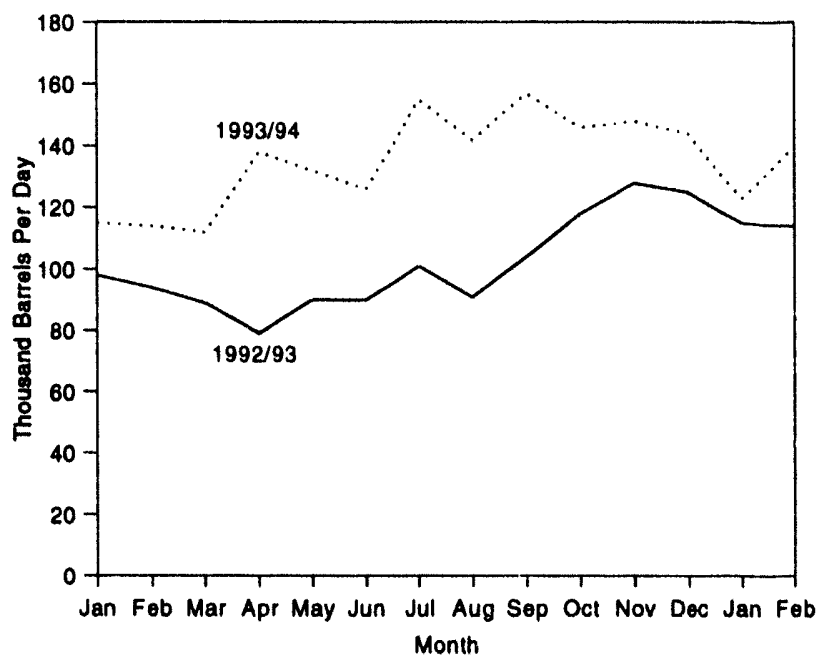

Source: Energy Information Administration, Weekly Petroleum Status Report, Week Ending March 18, 1994, Table B3.

Figure FE7. MTBE Spot Prices U.S. Gulf Coast (1993/94 Weekly Data)

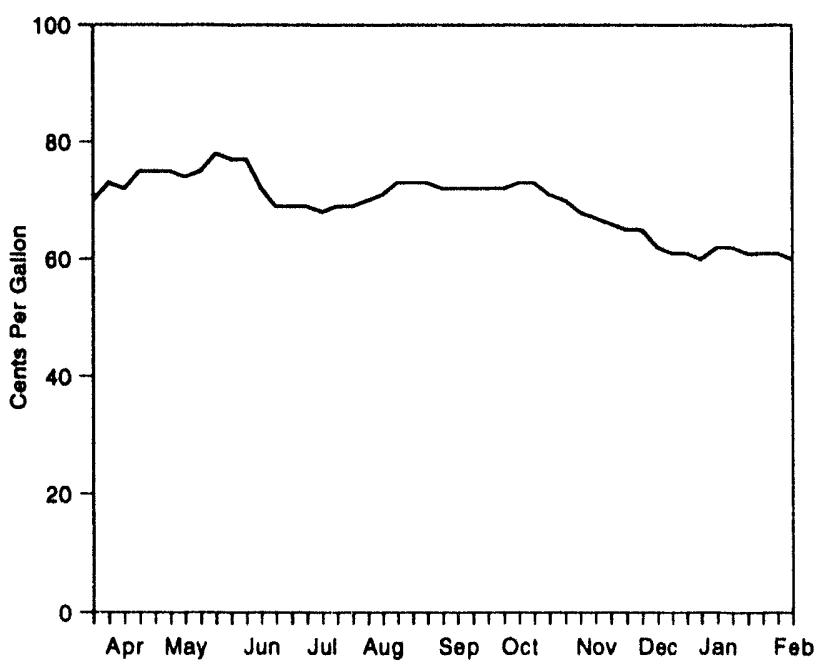

Source: Octane Week, various issues, 1994. 


\section{Highlights}

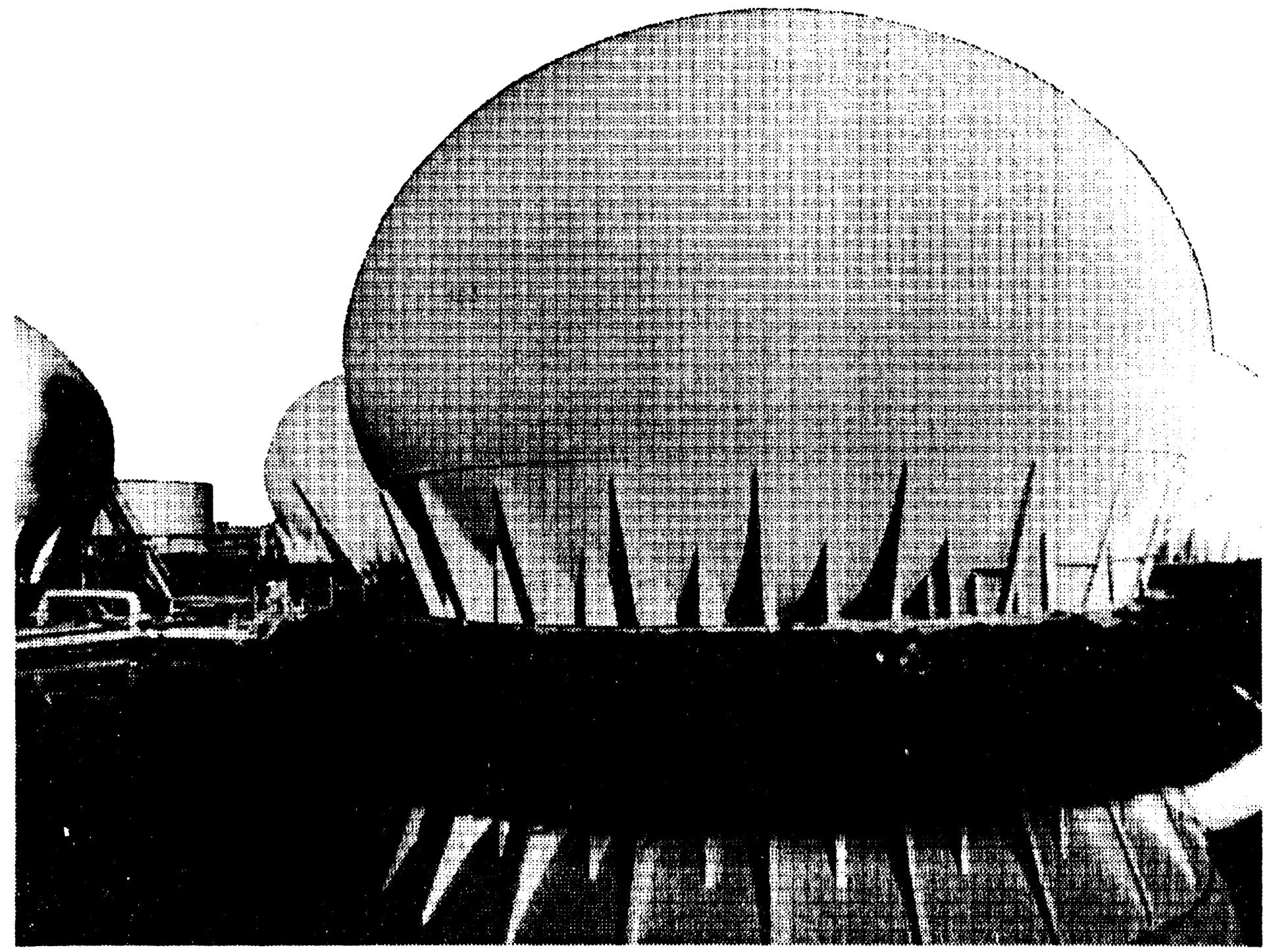

Spherical tanks are used to store liquefied petroleum gases under pressure. 


\section{Highlights}

Total demand for petroleum products (measured as products supplied) averaged 17.7 million barrels per day during March $1994^{1}$, essentially unchanged from a year earlier. The severe winter weather ended, and March temperatures across the United States averaged 7 percent warmer than during the same period last year and 11 percent warmer than normal ${ }^{2}$. Economic activity was mixed as consumer prices rose slightly, but were offset by an increase in retail sales ${ }^{3}$.

Other March 1994 highlights include the following:

- Motor gasoline imports reach their highest lev:l for March since 1989, as retail prices were low and demand was strong for this time of the year. Stocks were abnormally low, dropping to their lowest level in 3 years.

- Distillate fuel oil production, imports, and stocks were the highest for March in years, and demand remained strong.

- Kerosene-type jet fuel demand was at an all-time high for March and end-of-March stocks were the lowest in 10 years, due to continued cold-weather blending of jet fuel into diesel fuel oil.

- U.S. inventories of propane finished the 1994 winter heating season (March 31) at an estimated 24.0 million barrels ${ }^{4}$.

- Domestic crude oil production declined to its lowest level for March in 36 years.

- Petroleum refiners performing scheduled maintenance and turnaround activities contributed significantly to the drop in refinery operating utilization rate; its lowest March level since 1991.

\section{Motor Gasoline}

Demand for motor gasoline at 7.4 million barrels per day was nearly 2 percent higher than in February 1994 and at the same level as March 1993. Imports averaged about 0.4 million barrels per day, bolstered by shipments of surplus European motor gasoline ${ }^{5}$. Reportedly, the increased gasoline shipments caused temporary bottlenecks at New York Harbor because of limited storage facilities. End-of-March stocks totaled 176 million barrels, the lowest since 1991 and well below the seasonal range.

\section{Distillate Fuel Oil}

Despite the warm temperatures across large regions of the country during most of March, demand for distillate fuel oil remained strong and reached 3.3 million barrels per day. Production of 3.1 million barrels per day was the highest for March since 1977, and imports reached 0.3 million barrels per day. This was the highest March level for distillate imports since 1989. Inventories of 99 million barrels were at the highest for March since 1987. Low-sulfur stocks increased slightly to 50 million barrels, nearly 51 percent of the total.

\section{Kerosene-Type Jet Fuel}

Continued diesel fuel blending helped to sustain kerosene-type jet fuel's unusually high demand level of 1.4 million barrels per day, a record high for March. Inventories plunged to 35 million barrels, the lowest March level since 1984. Refinery production of kerosene-type jet fuel averaged 1.3 million barrels per day during March, essentially unchanged from a year earlier.

\section{Propane}

U.S. inventories of propane finished the 1994 winter heating season (March 31) at an estimated 24.0 million barrels. Despite the record first quarter 1994 stock draw, inventories were 10 percent higher than the level reported for the same period last year. See "Propane Supply Review, 1993-1994 Winter Heating Season," page xxiv for additional information.

\section{Crude Oil}

Crude oil production continued to decline to 6.7 million barrels per day, the lowest March level since 1958. Crude oil imports at 6.4 million barrels per day were high for this time of year, but 2 percent lower than in March 1993.

\section{Refinery Operations}

Operating utilization rates reached a 3-year low for March at 88 percent, as petroleum refiners removed major processing units from operations for scheduled maintenance and production turnaround activities. Crude oil inputs to atmospheric crude oil distillation units decreased to 12.8 million barrels per day, the lowest level for any month since February 1992.

\footnotetext{
'March 1994 data are monthly-from-weekly estimates based on the Energy Information Administration's Weekly Petroleum Supply Reporting System.

${ }^{2}$ Based on national population-weighted average heating degree-day data, National Oceanic and Atmospheric Administration, Climate Analysis Center, "Heating Degree Day Data Monthly Summary, Monthly Data for Mar 1994."

"Consumer Prices Increased 0.3\% During March," The Wall Street Journal, April 14, 1994, pp. A2 and A6.

"Propane data taken from Energy Information Administration Monthly Petroleum Supply Reporting System and Form EIA-807, "Propane Telephone Survey."

s"Europe Targets U.S. For North Sea Crude And Surplus Gasoline," The Oil Daily, April 8, 1994, pp. 1 and 4.
} 

(Million Barrels per Day, Except Where Noted)

\begin{tabular}{|c|c|c|c|c|c|c|}
\hline \multirow{2}{*}{ Category } & \multicolumn{3}{|c|}{1994} & \multirow{2}{*}{$\frac{1803}{\text { Mareh }}$} & \multicolumn{2}{|c|}{ January - March } \\
\hline & March & Fobruary & Difterence ${ }^{a}$ & & 1004 & 1993 \\
\hline 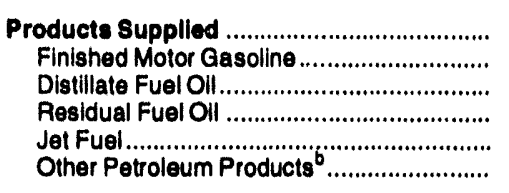 & $\begin{array}{l}E_{17.7} \\
E_{7.4} \\
E_{3.3} \\
E_{1.1} \\
E_{1.5} \\
E_{4.4}\end{array}$ & $\begin{array}{r}18.3 \\
7.3 \\
3.6 \\
1.5 \\
1.5 \\
4.5\end{array}$ & $\begin{array}{r}E_{-}-0.6 \\
E_{0.1} \\
E_{-0.3} \\
E_{-0.4} \\
E_{(8)}(8) \\
E_{(8)}\end{array}$ & $\begin{array}{r}17.7 \\
7.4 \\
3.4 \\
1.1 \\
1.5 \\
4.3\end{array}$ & $\begin{array}{r}E_{18.0} \\
E_{7.2} \\
E_{3.5} \\
E_{1.3} \\
E_{1.5} \\
E_{4.5}\end{array}$ & $\begin{array}{r}17.1 \\
7.1 \\
3.3 \\
1.1 \\
1.5 \\
4.2\end{array}$ \\
\hline Crude Oll Inputs & $E_{12.8}$ & 13.1 & $\mathrm{E}_{-0.3}$ & 13.2 & $E_{13.1}$ & 13.1 \\
\hline 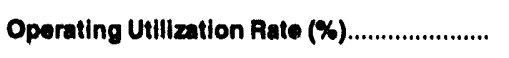 & $E_{88.0}$ & 89.8 & $E_{-1.8}$ & 90.8 & $E_{89.8}$ & 89.6 \\
\hline 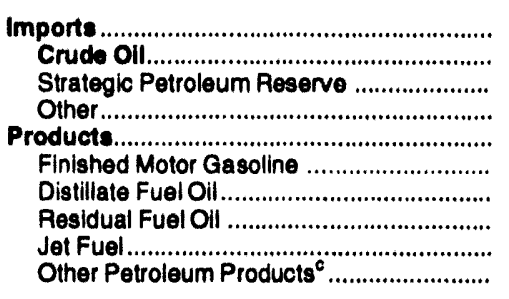 & $\begin{array}{l}E_{8.4} \\
E_{6.4} \\
E_{0.1} \\
E_{6.3} \\
E_{2.0} \\
E_{0.4} \\
E_{0.3} \\
E_{0.4} \\
E_{0.1} \\
\varepsilon_{0.8}\end{array}$ & $\begin{array}{l}8.5 \\
6.3 \\
0.0 \\
6.3 \\
2.2 \\
0.3 \\
0.3 \\
0.6 \\
0.1 \\
0.9\end{array}$ & $\begin{array}{l}E-0.1 \\
E_{0.1} \\
E_{0.1} \\
E_{(8)} \\
E_{-0.2} \\
E_{0.1} \\
E_{(8)}(8) \\
E_{-0.2} \\
E_{-0.1}(8) \\
E_{-0.1}\end{array}$ & $\begin{array}{l}8.3 \\
6.5 \\
(8) \\
6.5 \\
1.8 \\
0.2 \\
0.2 \\
0.4 \\
0.1 \\
0.9\end{array}$ & $\begin{array}{l}E_{8.3} \\
E_{6.2} \\
E_{(8)} \\
E_{6.2} \\
E_{2.1} \\
E_{0.3} \\
E_{0.2} \\
E_{0.5} \\
E_{0.1} \\
E_{0.9}\end{array}$ & $\begin{array}{r}8.1 \\
6.3 \\
(8) \\
6.3 \\
1.8 \\
0.2 \\
0.2 \\
0.4 \\
0.1 \\
0.9\end{array}$ \\
\hline 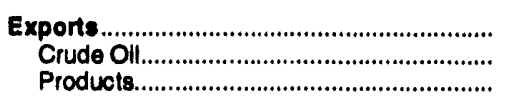 & $\begin{array}{l}E_{0.9} \\
E_{0.1} \\
E_{0.8}\end{array}$ & $\begin{array}{l}0.9 \\
0.1 \\
0.8\end{array}$ & $\begin{array}{l}E(8) \\
E_{(g)} \\
E_{(s)}\end{array}$ & $\begin{array}{l}1.0 \\
0.1 \\
0.8\end{array}$ & $\begin{array}{l}\varepsilon_{0.9} \\
\varepsilon_{0.1} \\
\varepsilon_{0.8}\end{array}$ & $\begin{array}{l}1.0 \\
0.1 \\
0.9\end{array}$ \\
\hline Total Not Imports & $E_{7.5}$ & 7.6 & E.0.1 & 7.4 & 5.4 & 7.0 \\
\hline 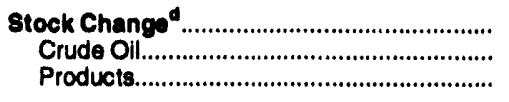 & $\begin{aligned} E_{-0.8} \\
E_{0.2} \\
E_{-1.0}\end{aligned}$ & $\begin{array}{l}-1.4 \\
-0.2 \\
-1.2\end{array}$ & $\begin{array}{l}E 0.6 \\
E 0.4 \\
E 0.2\end{array}$ & $\begin{array}{r}-0.4 \\
0.2 \\
-0.6\end{array}$ & $\begin{array}{l}E_{-1.0} \\
E_{-1.0}(8)\end{array}$ & $\begin{array}{r}-0.1 \\
0.2 \\
-0.3\end{array}$ \\
\hline 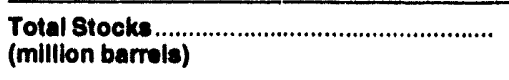 & $E_{1581}$ & 1581 & $E_{1}$ & 1584 & - & - \\
\hline 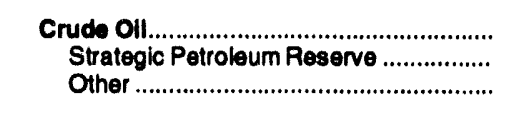 & $\begin{array}{l}E_{926} \\
E_{589} \\
E_{337}\end{array}$ & $\begin{array}{l}917 \\
587 \\
330\end{array}$ & $\begin{array}{l}E_{9} \\
E_{2} \\
E_{7}\end{array}$ & $\begin{array}{l}915 \\
578 \\
337\end{array}$ & $\overline{-}$ & $\overline{-}$ \\
\hline 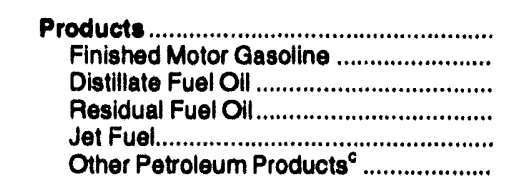 & $\begin{array}{r}E_{655} \\
E_{176} \\
E_{99} \\
E_{41} \\
E_{37} \\
E_{302}\end{array}$ & $\begin{array}{r}663 \\
187 \\
104 \\
39 \\
40 \\
293\end{array}$ & $\begin{array}{r}E_{-8} \\
E_{-10} \\
E_{-5} \\
E_{1} \\
E_{-3} \\
E_{9}\end{array}$ & $\begin{array}{r}669 \\
187 \\
97 \\
41 \\
41 \\
302\end{array}$ & 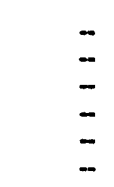 & 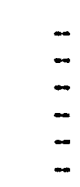 \\
\hline
\end{tabular}

- Difference is equal to volume for current month minus volume for previous month.

- Includes crude oll product supplied, natural gas liquids, liquefled refinery gases (LAG's), other liquids, and all finiahad petroleum products except finished motor gasoline, distillate fuel oil, residual fuel oil, jet fuel, and liquefied petroloum gases.

c Includes natural gas liquids, liquefied refinery gases (LRG's), other liquids, and all finished petroleum products except motor gasoline, jet fuel, distillate fuel oll, and residual fuel oll.

A negative number indicates a decrease in stocks and a positive number indicates an increase.

(8) = Less than 0.05 million barrels per day, or less than 0.05 percent, or less than 0.5 million barrele.

E=Estimated.

Note: Totals may not equal sum of components due to independent rounding.

Source: Energy Information Administration, appropriate issues of the Petroloum Supply Monthy and the Weakly Petroleum Status Report.

Data for the current month are preliminary estimates, based on weekly submissions. For an explanation of estimation methodology and accuracy, see Appendix A of Weekly Petroleum Status Report and the article, "Accuracy of Petroleum Supply Data", published in the August 1993, Petroleum Supply Monthly. 
Table H2. U.S. Refinery Inputs, Capacities and Utilization Rates: 1993-1994

(Thousand Barrels per Day, Except Where Noted)

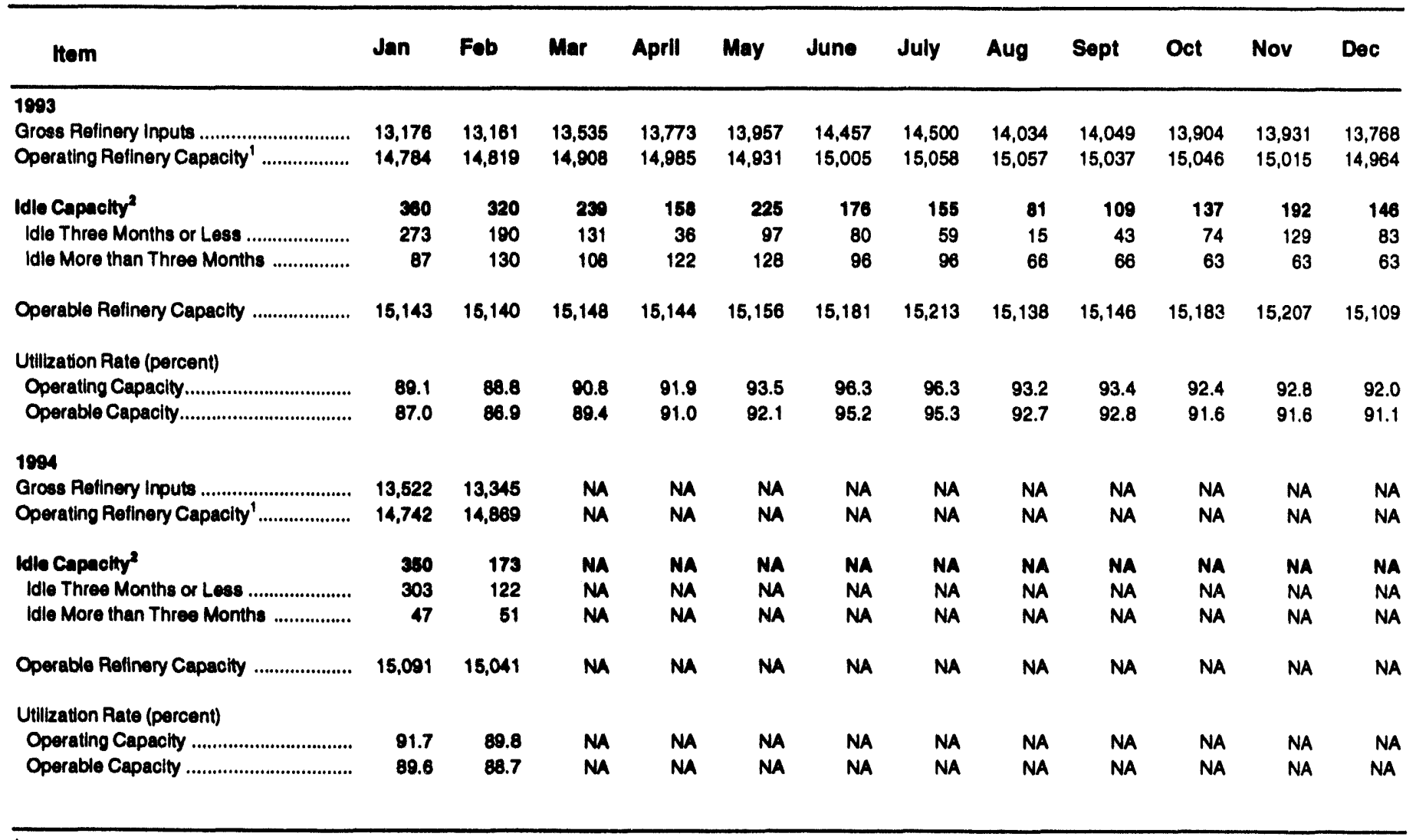

\footnotetext{
${ }^{1}$ Operating capacity equals the coperable capacity lees the totaridie capacity.

${ }^{2}$ Idle capacity is the component of operable cepacity that th not in cperation and not under active repair, but is capable of being placed in operation within 30 days; and capacity not in operation but is under ecthe repair that can be completed within 90 days.

NA = Not Available.

Sources: Energy Information Administration, Petroloum Supply Monthly, 1993 data lesue, Table 28; Petroloum Supply Annual, Volumo 2, 1992, Table 16; Form ElA-810, "Monthly Retinery Report."
} 


\section{Propane Supply Review, 1993-1994 Winter Heating Season}

On April 7, 1994, the Energy Information Administration (EIA) issued its last Winter Fuels Report and Weekly Propane Watch and ended its collection of propane inventories on a weekly basis for the 1993-1994 winter heating season. From April through September 1994, the EIA will publish monthly propane inventory data in the Weekly Petroleum Status Report and the Petroleum Supply Monthly.

Highlights of the 1993-1994 winter heating season included:

- Rebounding from an all-time low reached at the end of last year's heating season (March 31, 1993), U.S. stocks of propane were replenished at a record pace to an above average level of 61.3 million barrels by the start of the 1993-1994 heating season (September 30, 1993). This also marked the highest pre-heating season level of propane inventories since 1988.

- The first half of the 1993-1994 winter heating season (October through December) saw fairly strong demand for propane, due in part to weather that was slightly colder than normal during December 1993. However, agricultural sector demand for propane for crop drying was significantly below the record level set during the fall of 1992. During the fourth quarter 1992, 13 million barrels of propane were withdrawn from storage in the Midwest, the major crop drying region in the Nation. This compares with only 3.7 million barrels withdrawn from Midwest storage during the same period in 1993.

- The second half of the 1993-1994 winter heating season (January through March) set a record stock draw of over 27 million barrels, surpassing the old record of nearly 26 million barrels set during the same period in 1977.

- Despite the record first quarter 1994 stock draw, U.S. inventories of propane did not breach last year's record low level of 21.8 million barrels. U.S. propane stocks finished the 1994 heating season at an estimated 24.0 million barrels.

- U.S. and regional inventories of propane remained within or above their average ranges of the last 3 years during the first taalf of the 1993-1994 heating season. However, during the second half, propane stocks fell below their respective avc $=5 \approx=5$. Moreover, Gulf Coast inventories fell to 11.1 million barrels, their lowest level in nearly a quarter-century.

- Although January and February winter storms and record cold temperatures over portions of the Midwest and East Coast caused numerous supply and distribution problems, propane markets continued to function without any major disruptions.

- Despite the heavy draw on propane inventories during the second half of the 1993-1994 heating season, propane spot prices ${ }^{6}$ remained relatively stable with no apparent price spikes being reported anywhere in the Nation.

${ }^{6}$ Spot prices are the most widely-watched prices for propane in the United States and are considered representative of transactions at the major distribution hubs of Mont Belvieu, Texas, and Conway, Kansas. 

Table S1. Crude Oil and Petroleum Products Overview, 1981 - Present (Thousand Barrels per Day, Except Where Noted)

\begin{tabular}{|c|c|c|c|c|c|c|c|c|}
\hline \multirow{2}{*}{\multicolumn{2}{|c|}{ Year/Month }} & \multicolumn{3}{|c|}{ Field Production } & \multicolumn{2}{|c|}{ Stock Change ${ }^{a}$} & \multirow[b]{2}{*}{$\begin{array}{l}\text { Petroleum } \\
\text { Products } \\
\text { Supplied }\end{array}$} & \multirow{2}{*}{$\begin{array}{c}\text { Ending } \\
\text { Stocks } \\
\text { (Million Barrels) } \\
\text { Crude Oll and }^{\text {Cotroleum }} \\
\text { Products } \\
\text { Prom }\end{array}$} \\
\hline & & $\begin{array}{c}\text { Total } \\
\text { Domestic }\end{array}$ & $\begin{array}{c}\text { Crude } \\
\text { Oll }\end{array}$ & $\begin{array}{l}\text { Natural } \\
\text { Gas Plant } \\
\text { Llquids }\end{array}$ & $\begin{array}{c}\text { Crugde } \\
\text { Oild }^{d}\end{array}$ & $\begin{array}{l}\text { Petroleum } \\
\text { Products }\end{array}$ & & \\
\hline $\begin{array}{l}1981 \\
1982 \\
1983 \\
1984 \\
1985 \\
1986 \\
1987 \\
1988 \\
1989 \\
1990 \\
1991\end{array}$ & 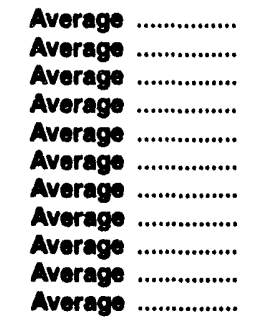 & $\begin{array}{r}10,230 \\
10,252 \\
10,299 \\
10,554 \\
10,636 \\
10,289 \\
10,008 \\
9,818 \\
9,219 \\
8,994 \\
9,168\end{array}$ & $\begin{array}{l}8,572 \\
8,649 \\
8,688 \\
8,879 \\
8,971 \\
8,680 \\
8,349 \\
8,140 \\
7,613 \\
7,355 \\
7,417\end{array}$ & $\begin{array}{l}1,609 \\
1,550 \\
1,559 \\
1,630 \\
1,609 \\
1,551 \\
1,595 \\
1,625 \\
1,546 \\
1,559 \\
1,659\end{array}$ & $\begin{array}{r}9290 \\
136 \\
9214 \\
199 \\
50 \\
78 \\
128 \\
1 \\
86 \\
-35 \\
-42\end{array}$ & $\begin{array}{r}g-130 \\
-283 \\
g-234 \\
81 \\
-153 \\
124 \\
-87 \\
-29 \\
-129 \\
142 \\
32\end{array}$ & $\begin{array}{l}16,058 \\
15,296 \\
15,231 \\
15,726 \\
15,726 \\
16,281 \\
16,665 \\
17,283 \\
17,325 \\
16,988 \\
16,714\end{array}$ & $\begin{array}{r}1,484 \\
91,430 \\
1,454 \\
1,556 \\
1,519 \\
1,593 \\
1,607 \\
1,597 \\
1,581 \\
1,621 \\
1,617\end{array}$ \\
\hline \multicolumn{2}{|c|}{ 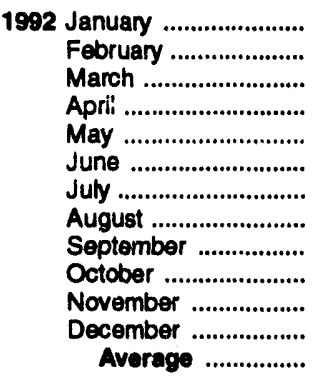 } & $\begin{array}{l}9,176 \\
9,175 \\
9,123 \\
9,072 \\
8,949 \\
8,968 \\
8,961 \\
8,678 \\
8,843 \\
9,025 \\
8,975 \\
9,019 \\
8,996\end{array}$ & $\begin{array}{l}7,361 \\
7,389 \\
7,348 \\
7,290 \\
7,169 \\
7,167 \\
7,131 \\
6,922 \\
7,030 \\
7,126 \\
7,024 \\
7,103 \\
7,171\end{array}$ & $\begin{array}{l}1,688 \\
1,696 \\
1,694 \\
1,693 \\
1,695 \\
1,701 \\
1,683 \\
1,638 \\
1,660 \\
1,722 \\
1,754 \\
1,744 \\
1,697\end{array}$ & $\begin{array}{r}540 \\
171 \\
-250 \\
315 \\
-144 \\
-581 \\
244 \\
-124 \\
-160 \\
411 \\
-227 \\
-212 \\
-1\end{array}$ & $\begin{array}{r}-757 \\
-951 \\
-291 \\
92 \\
770 \\
604 \\
290 \\
161 \\
653 \\
-258 \\
77 \\
-1,203 \\
-68\end{array}$ & $\begin{array}{l}17,012 \\
16,893 \\
16,825 \\
16,764 \\
16,485 \\
16,978 \\
17,143 \\
16,929 \\
16,876 \\
17,448 \\
17,091 \\
17,928 \\
17,033\end{array}$ & $\begin{array}{r}1,610 \\
1,588 \\
1,571 \\
1,583 \\
1,602 \\
1,603 \\
1,620 \\
1,621 \\
1,636 \\
1,640 \\
1,636 \\
1,592 \\
-\end{array}$ \\
\hline \multicolumn{2}{|c|}{ 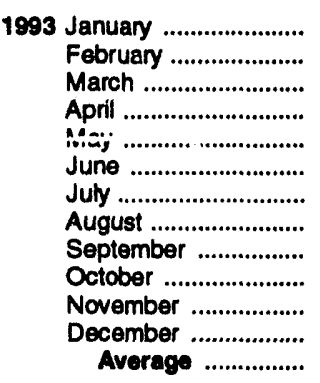 } & $\begin{array}{l}E_{9,257} \\
E_{8,948} \\
E_{9,009} \\
E_{8,904} \\
E_{8,775} \\
E_{8,697} \\
E_{8,599} \\
E_{8,691} \\
E_{8,670} \\
E_{8,847} \\
E_{8,823} \\
E_{8,696} \\
E_{8,826}\end{array}$ & $\begin{array}{l}E_{7,008} \\
E_{6,957} \\
E_{6,976} \\
E_{6,897} \\
E_{6,833} \\
E_{6,756} \\
E_{6,654} \\
E_{6,732} \\
E_{6,711} \\
E_{6,816} \\
E_{6,888} \\
E_{6,838} \\
E_{6,838}\end{array}$ & $\begin{array}{l}1,728 \\
1,761 \\
1,799 \\
1,790 \\
1,719 \\
1,738 \\
1,723 \\
1,732 \\
1,717 \\
1,765 \\
1,674 \\
1,607 \\
1,729\end{array}$ & $\begin{array}{r}264 \\
219 \\
246 \\
537 \\
133 \\
-15 \\
41 \\
-524 \\
-439 \\
333 \\
2.1 \\
-58 \\
81\end{array}$ & $\begin{array}{r}g_{370} \\
-799 \\
-619 \\
388 \\
897 \\
586 \\
542 \\
386 \\
7 \\
420 \\
-286 \\
-1,158 \\
67\end{array}$ & $\begin{array}{l}16,320 \\
17,397 \\
17,688 \\
16,673 \\
16,340 \\
17,032 \\
17,208 \\
17,176 \\
17,709 \\
17,230 \\
17,688 \\
17,887 \\
17,193\end{array}$ & $\begin{array}{r}91,611 \\
1,595 \\
1,584 \\
1,611 \\
1,542 \\
1,660 \\
1,678 \\
1,674 \\
1,661 \\
1,685 \\
1,684 \\
1,646 \\
-.\end{array}$ \\
\hline \multicolumn{2}{|c|}{$\begin{array}{l}1994 \text { January ..................... } \\
\text { February ..................... } \\
\text { March" ....................... } \\
\text { 3-Mo. Average .......... }\end{array}$} & $\begin{array}{r}E_{8,674} \\
\operatorname{RE}_{8,586} \\
E_{8,549} \\
E_{8,604}\end{array}$ & $\begin{array}{l}\text { E }_{6,777} \\
\text { RE } 6,745 \\
\text { PE } 6,682 \\
\text { PE } 6,735\end{array}$ & $\begin{array}{l}1,619 \\
R_{1,642} \\
E_{1,611} \\
E_{1,623}\end{array}$ & $\begin{array}{r}R_{-164}^{-16} \\
E_{231} \\
E_{23}\end{array}$ & $\begin{array}{r}-831 \\
R_{-1,225} \\
E_{-996} \\
E_{-1,010}\end{array}$ & $\begin{array}{l}17,924 \\
R_{18,302} \\
E_{17,667} \\
E_{17,953}\end{array}$ & $\begin{array}{r}1,620 \\
R_{1,581}^{1,581} \\
.-\end{array}$ \\
\hline \multicolumn{2}{|c|}{$\begin{array}{l}1993 \text { 3-Mo. Average ........... } \\
1992 \text { 3-Mo. Average .......... }\end{array}$} & $\begin{array}{r}E_{9,075} \\
9,157\end{array}$ & $\begin{array}{r}E_{6,981} \\
7,365\end{array}$ & $\begin{array}{l}1,763 \\
1,693\end{array}$ & $\begin{array}{l}244 \\
153\end{array}$ & $\begin{array}{l}-334 \\
-660\end{array}$ & $\begin{array}{l}17,126 \\
16,910\end{array}$ & $=$ \\
\hline
\end{tabular}

a A negative number indicates a decrease in stocks and a positive number indicates an increase.

Stocks are totals as of end of period.

c Includes crude oll, natural gas plant liquids, and other liquids. Beginning in 1993, fuel ethanol blended into finished motor gasoline and oxygenate production from merchant MTBE plants are also included.

d Includes stocks located in the Strategic Petroleum Reserve.

- Includes crude oil for storage in the Strategic Petroleum Reserve.

Net Imports equal Imports minus Exports.

g In January 1981 and 1983, numerous respondents were added to surveys affecting stocks reported and stock change calculations. Stock changes are calculated using new basis stock levels. Bulk terminal and pipeline stocks of oxygenates were added beginning in January 1993 . See Summary Statistics Explanatory Note 4.

Footnotes continued on following page. 
Table S1. Crude Oil and Petroleum Products Overview, 1981 - Present (Continued) (Thousand Barrels per Day, Except Where Noted)

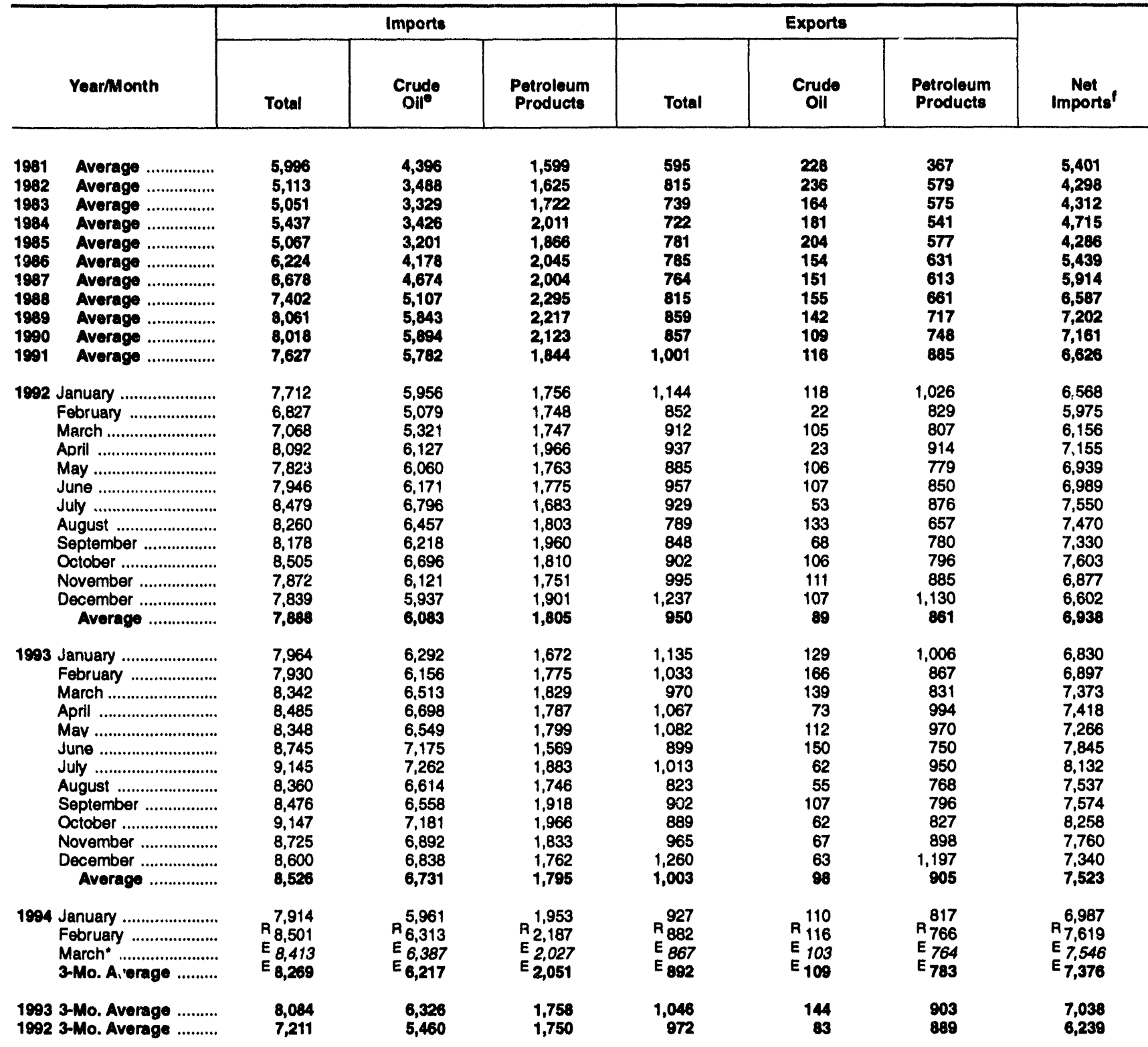

Footnotes continued.

$R=$ Revised data. $E=$ Estimated. $P E=$ Preliminary estimate. $R E=$ Revised estimate.

- See Summary Statistics Explanatory Note 1.

Notes: - Crude oil includes lease condensate. - Italics denote estimates based upon preliminary data. - Geographic coverage is the 50 States and the District of Columbia. - Totals may not equal sum of components due to independent rounding.

Source: See Summary Statistics Table and Figure Sources. 
Figure S1. Petroleum Overview, February 1993 - Present

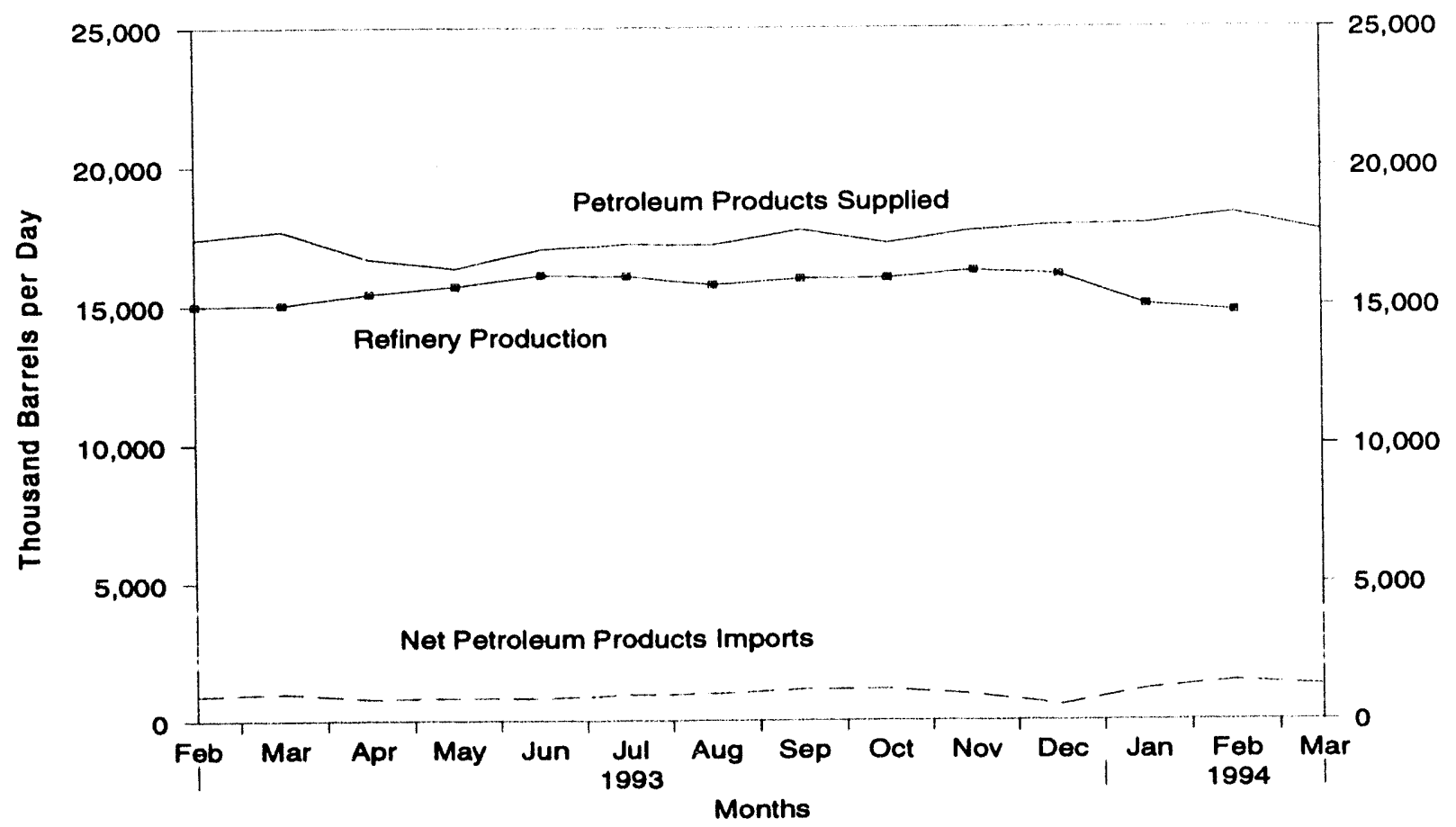

Source: Energy Information Administration, Petroleum Supply Monthly, Table S1. See Summary Statistics Table and Figure Sources.

Figure S2. Petroleum Products Supplied, February 1993 - Present

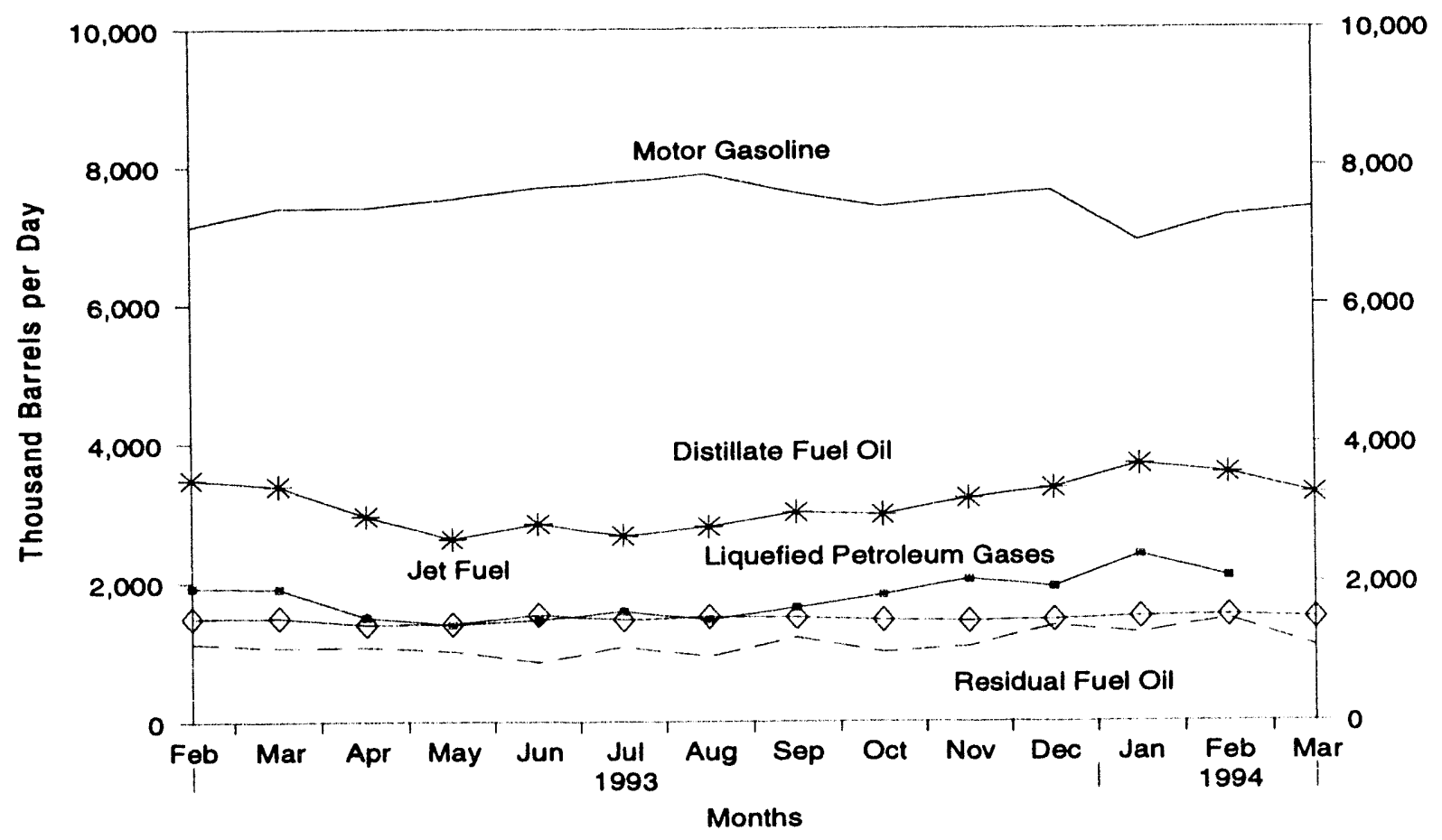

Source: Energy Information Administration, Petroleum Supply Monthly, Tables S4-S7, and S9. See Summary Statistics Table and Figure Sources. 
Figure S3. Crude Oil Supply and Disposition, February 1993 - Present

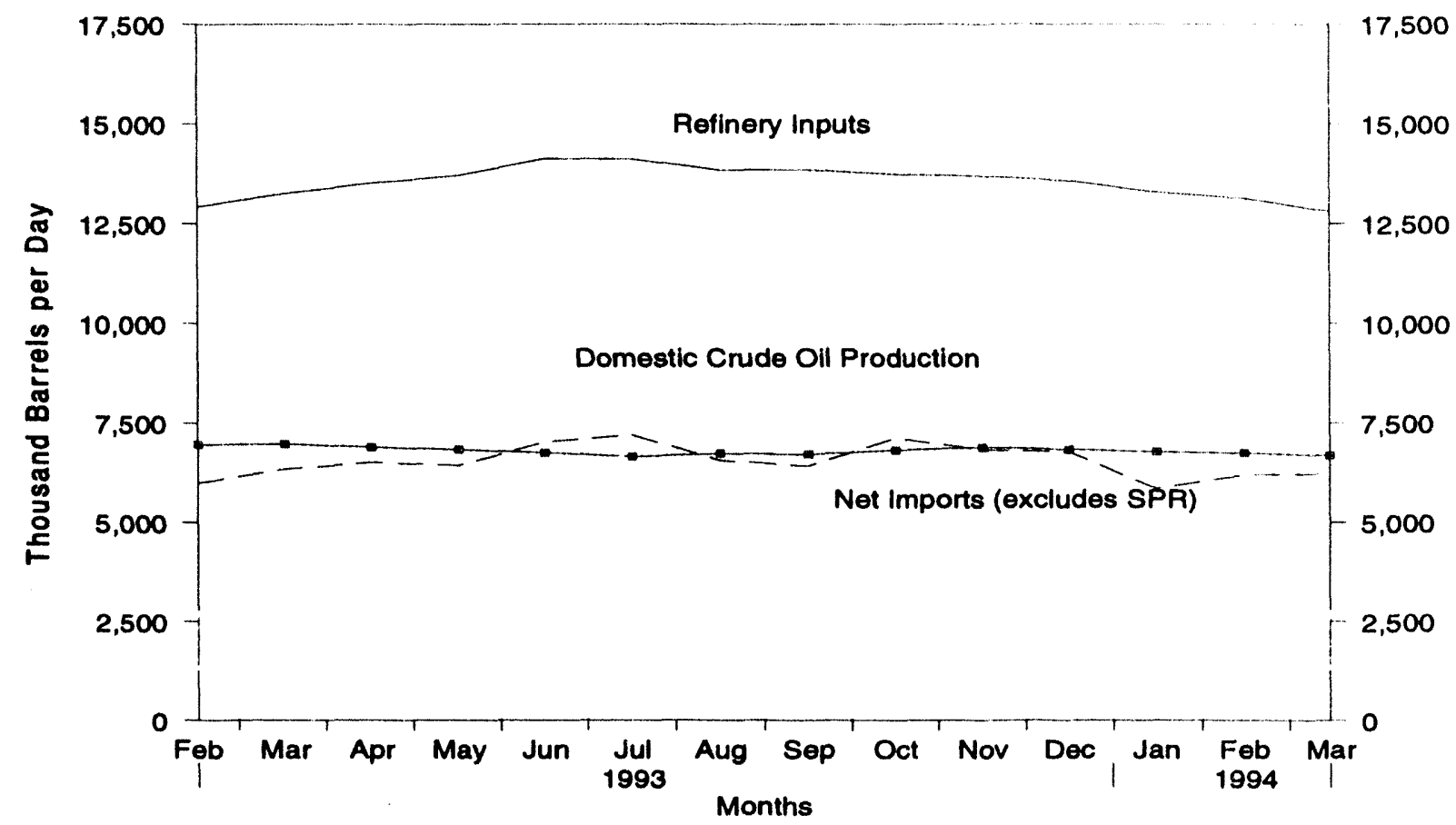

Source: Energy Information Administration, Petroleum Supply Monthly, Table S2. See Summary Statistics Table and Figure Sources.

Figure S4. Crude Oil Ending Stocks ${ }^{1}$, February 1993 - Present

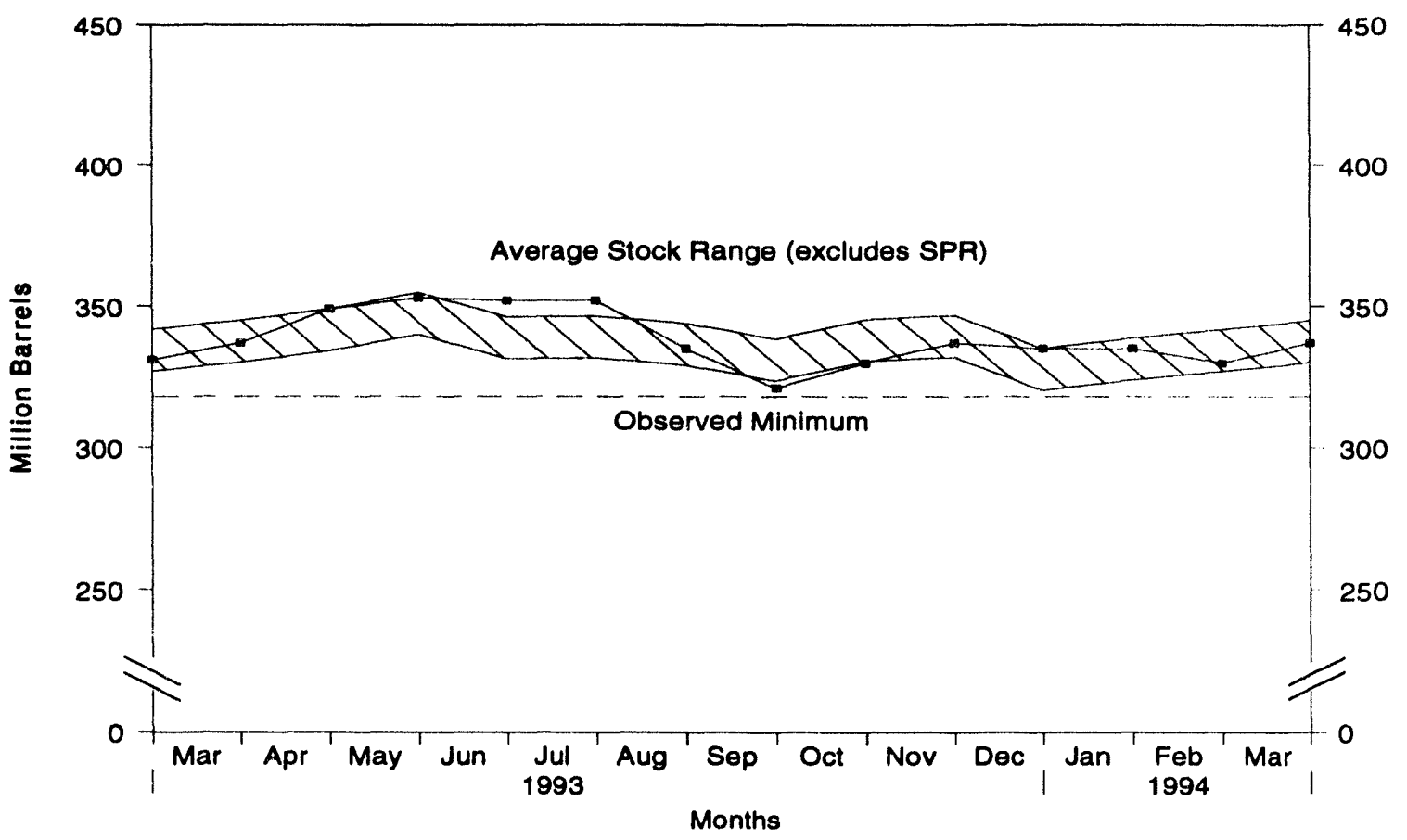

'Excludes stocks held in the Strategic Petroleum Reserve (SPR).

Note: The Observed Minimum for crude oil stocks in the last 36-month period was 318.1 million barrels, occurring in December 1992.

Source: Energy Information Administration, Petroleum Supply Monthly, Table S2. See Summary Statistics Table and Figure Sources. 
Table S2. Crude Oil Supply and Disposition, 1981 - Present (Thousand Barrels per Day, Except Where Noted)

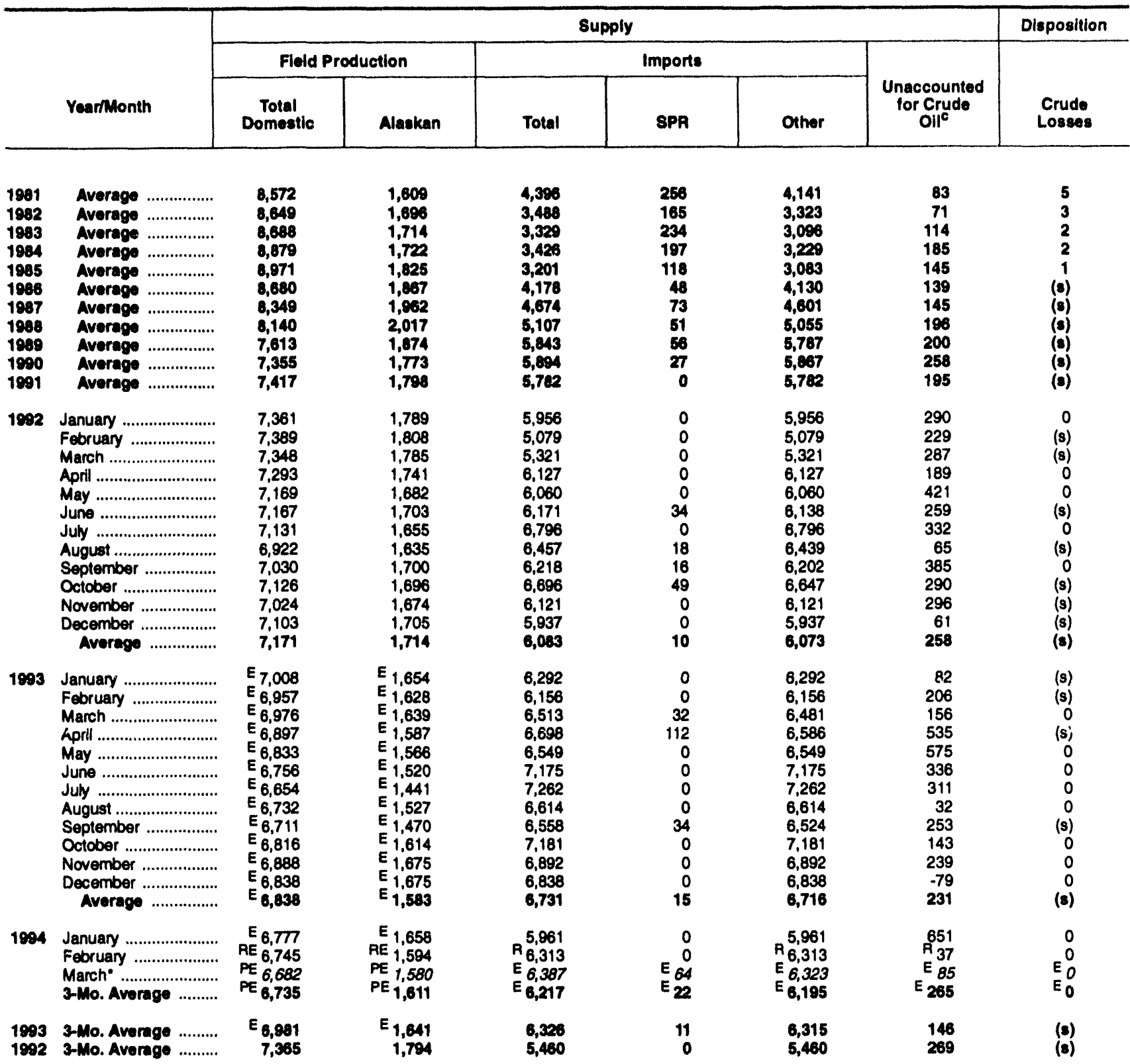

a Stocks are totais as of end of period.

A negative number indicates a decrease in stocks and a positive number indicates an increase.

c Unaccounted for crude oil represents the difference between the supply and disposition of crude oil. Preliminary estimates of crude oil imports at the National level have historically understated final values by approximately 50 thousand barrels per day. This causes the preliminary values of unaccounted for crude oil to overstate the final values by the same amount.

d Previously published as crude used directly.

- Stock changes are calculated using new basis stock levels. See Summary Statistics Explanatory Note 4.

Footnotes continued on following page. 
Table S2. Crude Oll Supply and Disposition, 1981 - Present (Continued) (Thousand Barrels per Day, Except Where Noted)

\begin{tabular}{|c|c|c|c|c|c|c|c|c|c|}
\hline \multirow{3}{*}{\multicolumn{2}{|c|}{ Yearfionth }} & \multicolumn{5}{|c|}{ Diepostion } & \multicolumn{3}{|c|}{ Ending Stocks" (Million Barrels) } \\
\hline & & \multicolumn{2}{|c|}{ Stock Chengeb } & \multirow[b]{2}{*}{$\begin{array}{l}\text { Rofinery } \\
\text { Inputs }\end{array}$} & \multirow[b]{2}{*}{ Exporte } & \multirow[b]{2}{*}{$\begin{array}{l}\text { Product } \\
\text { Bupplisd }\end{array}$} & \multirow[b]{2}{*}{ Total } & \multirow[b]{2}{*}{ 8PR } & \multirow[b]{2}{*}{$\begin{array}{l}\text { Othor } \\
\text { Primary }\end{array}$} \\
\hline & & 8PR & Other & & & & & & \\
\hline 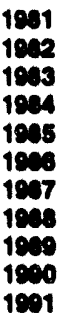 & 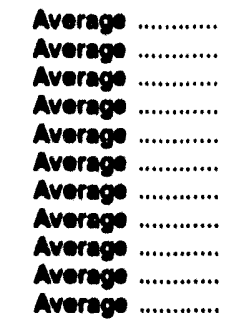 & $\begin{array}{r}385 \\
174 \\
234 \\
195 \\
117 \\
50 \\
80 \\
52 \\
58 \\
18 \\
47\end{array}$ & $\begin{array}{r}-40 \\
-39 \\
20 \\
4 \\
-87 \\
28 \\
40 \\
-81 \\
30 \\
-81 \\
5\end{array}$ & $\begin{array}{l}12,470 \\
11,774 \\
11,095 \\
12,044 \\
12,002 \\
12,716 \\
12,094 \\
13,210 \\
13,401 \\
13,400 \\
13,301\end{array}$ & $\begin{array}{l}228 \\
200 \\
184 \\
181 \\
204 \\
154 \\
181 \\
185 \\
142 \\
100 \\
116\end{array}$ & $\begin{array}{r}d c 8 \\
d 80 \\
6 \\
64 \\
60 \\
40 \\
34 \\
40 \\
20 \\
24 \\
10\end{array}$ & 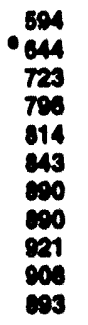 & $\begin{array}{l}230 \\
204 \\
370 \\
451 \\
493 \\
512 \\
541 \\
600 \\
600 \\
800 \\
600\end{array}$ & $\begin{array}{r}303 \\
350 \\
344 \\
345 \\
321 \\
331 \\
349 \\
330 \\
341 \\
323 \\
325\end{array}$ \\
\hline 1902 & 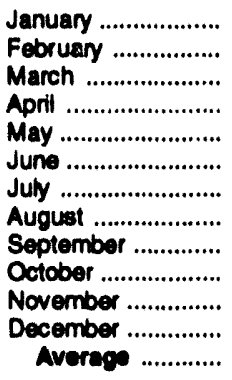 & $\begin{array}{r}(8) \\
0 \\
(8) \\
0 \\
(8) \\
34 \\
(8) \\
20 \\
43 \\
69 \\
15 \\
22 \\
17\end{array}$ & $\begin{array}{r}540 \\
171 \\
-250 \\
315 \\
-145 \\
-615 \\
244 \\
-144 \\
-204 \\
342 \\
-243 \\
-234 \\
-18\end{array}$ & $\begin{array}{l}12,923 \\
12,488 \\
13,083 \\
13,260 \\
13,679 \\
14,059 \\
13,953 \\
13,426 \\
13,714 \\
13,584 \\
13,547 \\
13,194 \\
13,411\end{array}$ & $\begin{array}{r}118 \\
22 \\
105 \\
23 \\
23 \\
108 \\
107 \\
53 \\
133 \\
68 \\
108 \\
111 \\
107 \\
0\end{array}$ & $\begin{array}{r}28 \\
17 \\
18 \\
11 \\
10 \\
12 \\
9 \\
8 \\
11 \\
10 \\
10 \\
12 \\
13\end{array}$ & $\begin{array}{r}910 \\
915 \\
807 \\
917 \\
912 \\
895 \\
802 \\
898 \\
893 \\
906 \\
899 \\
893 \\
-\end{array}$ & $\begin{array}{r}\mathbf{5 6 9} \\
\mathbf{5 6 9} \\
\mathbf{5 6 9} \\
\mathbf{5 6 9} \\
\mathbf{5 6 9} \\
\mathbf{5 7 0} \\
\mathbf{5 7 0} \\
\mathbf{5 7 0} \\
\mathbf{5 7 1} \\
\mathbf{5 7 4} \\
\mathbf{5 7 4} \\
\mathbf{5 7 5} \\
-\end{array}$ & $\begin{array}{r}341 \\
346 \\
339 \\
348 \\
344 \\
325 \\
333 \\
328 \\
322 \\
333 \\
325 \\
318 \\
-\end{array}$ \\
\hline 1003 & 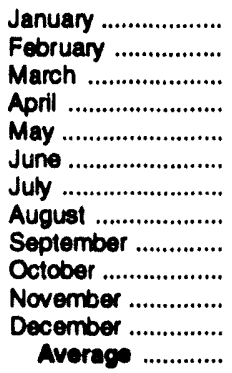 & $\begin{array}{r}19 \\
18 \\
58 \\
136 \\
13 \\
21 \\
19 \\
24 \\
52 \\
19 \\
18 \\
9 \\
34\end{array}$ & $\begin{array}{r}245 \\
202 \\
188 \\
401 \\
120 \\
-37 \\
22 \\
-548 \\
-491 \\
314 \\
233 \\
-67 \\
47\end{array}$ & $\begin{array}{l}12,890 \\
12,923 \\
13,249 \\
13,512 \\
13,701 \\
14,125 \\
14,114 \\
13,839 \\
13,845 \\
13,733 \\
13,689 \\
13,571 \\
13,610\end{array}$ & $\begin{array}{r}129 \\
168 \\
139 \\
73 \\
112 \\
150 \\
62 \\
55 \\
107 \\
62 \\
67 \\
63 \\
89\end{array}$ & $\begin{array}{r}10 \\
10 \\
11 \\
9 \\
10 \\
8 \\
9 \\
8 \\
9 \\
12 \\
13 \\
21 \\
11\end{array}$ & $\begin{array}{l}901 \\
907 \\
915 \\
931 \\
935 \\
935 \\
938 \\
920 \\
906 \\
917 \\
924 \\
922 \\
-\end{array}$ & $\begin{array}{r}\mathbf{5 7 5} \\
\mathbf{5 7 6} \\
\mathbf{5 7 8} \\
\mathbf{5 8 2} \\
\mathbf{5 8 2} \\
\mathbf{5 8 3} \\
\mathbf{5 8 3} \\
\mathbf{5 8 4} \\
\mathbf{5 8 6} \\
\mathbf{5 8 6} \\
\mathbf{5 8 7} \\
\mathbf{5 8 7} \\
-\end{array}$ & $\begin{array}{r}326 \\
331 \\
337 \\
349 \\
353 \\
352 \\
352 \\
335 \\
321 \\
330 \\
337 \\
335 \\
-\end{array}$ \\
\hline 1994 & $\begin{array}{l}\text { January .................. } \\
\text { February .................. } \\
\text { March" ................. } \\
\text { 3-Mo. Aworage ...... }\end{array}$ & $\begin{array}{l}(8) \\
E_{23}^{(8)}\end{array}$ & $\begin{array}{r}-19 \\
E_{-164} \\
E_{(8)}(68\end{array}$ & $\begin{array}{l}13,285 \\
A_{13,132} \\
E_{12,806} \\
E_{13,072}\end{array}$ & $\begin{array}{l}A_{110}^{110} \\
E_{103} \\
E_{100}\end{array}$ & $\begin{array}{l}R_{12}^{10} \\
E_{19} \\
E_{14}\end{array}$ & $\begin{array}{r}922 \\
R_{917} \\
E_{926} \\
-\end{array}$ & $\begin{array}{r}587 \\
587 \\
589 \\
-\end{array}$ & $\begin{array}{r}335 \\
330 \\
E_{337} \\
-\end{array}$ \\
\hline $\begin{array}{l}1903 \\
1992\end{array}$ & $\begin{array}{l}\text { 3-Mo. Awarge ...... } \\
\text { 3-Mo. Average ...... }\end{array}$ & 32 & $\begin{array}{l}212 \\
153\end{array}$ & $\begin{array}{l}13,055 \\
12,035\end{array}$ & $\begin{array}{r}144 \\
83\end{array}$ & $\begin{array}{l}10 \\
20\end{array}$ & $\underline{-}$ & - & $\ddot{-}$ \\
\hline
\end{tabular}

Footnotes continued.

$R=$ Revised data. $(s)=$ Less than 500 barrels per day. $E=$ Estimated. PE $=$ Preliminary estimate. RE = Revised estimate.

$S P R=$ Strategic Petroleum Reserve.

- See Summary Statistics Explanatory Note 1.

Notes: - Crude oll includes lease condensate. - Italics denote estimates based upon preliminary data. - Geographic coverage is the 50 States and the District of Columbia. - Totals may not equal sum of components due to independent rounding.

Source: See Summary Statistics Table and Figure Sources. 
Table S3. Crude Oll and Potroleum Product Imports, 1981 - Present (Thousand Barrels per Day)

\begin{tabular}{|c|c|c|c|c|c|c|c|c|c|}
\hline & \multirow{3}{*}{ Yearmonth } & \multicolumn{8}{|c|}{ Imports from Arab-OPEC Sources } \\
\hline & & \multicolumn{2}{|c|}{ Alepria } & \multicolumn{2}{|c|}{ Inq } & \multicolumn{2}{|c|}{ Kuwaltb } & \multicolumn{2}{|c|}{ Libya } \\
\hline & & Total & Crude OII & Total & Crude Oll & Total & Crude Oil & Total & Crude Oll \\
\hline $\begin{array}{l}1081 \\
1982 \\
1983 \\
1994 \\
1898 \\
1098 \\
1987 \\
1098 \\
1090 \\
1090 \\
1001\end{array}$ & 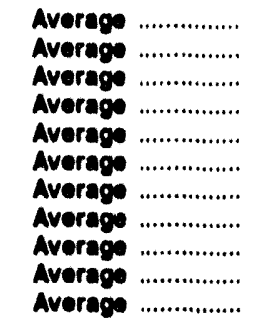 & $\begin{array}{l}311 \\
170 \\
240 \\
323 \\
107 \\
271 \\
205 \\
300 \\
209 \\
200 \\
243\end{array}$ & $\begin{array}{r}281 \\
90 \\
178 \\
104 \\
94 \\
78 \\
115 \\
88 \\
60 \\
63 \\
44\end{array}$ & $\begin{array}{r}(6) \\
3 \\
10 \\
12 \\
46 \\
81 \\
63 \\
345 \\
449 \\
518 \\
0\end{array}$ & $\begin{array}{r}0 \\
3 \\
10 \\
12 \\
46 \\
81 \\
82 \\
343 \\
441 \\
814 \\
0\end{array}$ & $\begin{array}{r}0 \\
5 \\
14 \\
38 \\
21 \\
68 \\
84 \\
92 \\
157 \\
80 \\
6\end{array}$ & $\begin{array}{r}0 \\
2 \\
7 \\
24 \\
4 \\
28 \\
70 \\
80 \\
158 \\
79 \\
6\end{array}$ & $\begin{array}{r}319 \\
26 \\
0 \\
1 \\
4 \\
0 \\
0 \\
0 \\
0 \\
0 \\
0\end{array}$ & $\begin{array}{r}317 \\
23 \\
0 \\
0 \\
0 \\
0 \\
0 \\
0 \\
0 \\
0 \\
0\end{array}$ \\
\hline 1992 & 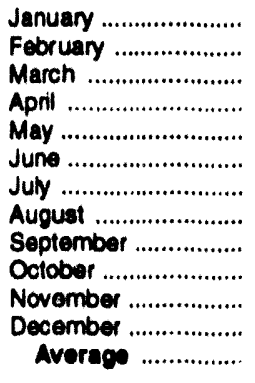 & $\begin{array}{l}208 \\
218 \\
215 \\
162 \\
202 \\
144 \\
179 \\
261 \\
184 \\
188 \\
171 \\
203 \\
198\end{array}$ & $\begin{array}{r}37 \\
57 \\
37 \\
19 \\
7 \\
12 \\
37 \\
45 \\
19 \\
8 \\
0 \\
9 \\
24\end{array}$ & $\begin{array}{l}0 \\
0 \\
0 \\
0 \\
0 \\
0 \\
0 \\
0 \\
0 \\
0 \\
0 \\
0 \\
0\end{array}$ & $\begin{array}{l}0 \\
0 \\
0 \\
0 \\
0 \\
0 \\
0 \\
0 \\
0 \\
0 \\
0 \\
0 \\
0\end{array}$ & $\begin{array}{r}0 \\
0 \\
0 \\
0 \\
0 \\
0 \\
58 \\
66 \\
70 \\
137 \\
117 \\
165 \\
51\end{array}$ & $\begin{array}{r}0 \\
0 \\
0 \\
0 \\
0 \\
0 \\
23 \\
33 \\
33 \\
109 \\
117 \\
149 \\
30\end{array}$ & $\begin{array}{l}0 \\
0 \\
0 \\
0 \\
0 \\
0 \\
0 \\
0 \\
0 \\
0 \\
0 \\
0 \\
0\end{array}$ & $\begin{array}{l}0 \\
0 \\
0 \\
0 \\
0 \\
0 \\
0 \\
0 \\
0 \\
0 \\
0 \\
0 \\
0\end{array}$ \\
\hline 1093 & 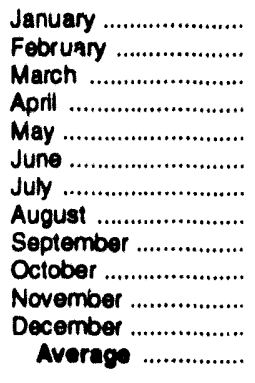 & $\begin{array}{l}153 \\
256 \\
185 \\
274 \\
226 \\
169 \\
246 \\
241 \\
192 \\
317 \\
217 \\
189 \\
220\end{array}$ & $\begin{array}{r}28 \\
0 \\
7 \\
26 \\
3 \\
32 \\
6 \\
28 \\
0 \\
80 \\
47 \\
25 \\
24\end{array}$ & $\begin{array}{l}0 \\
0 \\
0 \\
0 \\
0 \\
0 \\
0 \\
0 \\
0 \\
0 \\
0 \\
0 \\
0\end{array}$ & $\begin{array}{l}0 \\
0 \\
0 \\
0 \\
0 \\
0 \\
0 \\
0 \\
0 \\
0 \\
0 \\
0 \\
0\end{array}$ & $\begin{array}{l}144 \\
251 \\
316 \\
262 \\
222 \\
235 \\
368 \\
467 \\
445 \\
530 \\
486 \\
484 \\
352\end{array}$ & $\begin{array}{l}129 \\
229 \\
300 \\
262 \\
222 \\
235 \\
362 \\
451 \\
431 \\
526 \\
470 \\
484 \\
343\end{array}$ & $\begin{array}{l}0 \\
0 \\
0 \\
0 \\
0 \\
0 \\
0 \\
0 \\
0 \\
0 \\
0 \\
0 \\
0\end{array}$ & $\begin{array}{l}0 \\
0 \\
0 \\
0 \\
0 \\
0 \\
0 \\
0 \\
0 \\
0 \\
0 \\
0 \\
0\end{array}$ \\
\hline 1994 & $\begin{array}{l}\text { January .................. } \\
\text { February ................... } \\
\text { 2-Mo. Avernge ......... }\end{array}$ & $\begin{array}{l}233 \\
226 \\
230\end{array}$ & $\begin{array}{l}35 \\
20 \\
28\end{array}$ & $\begin{array}{l}0 \\
0 \\
0\end{array}$ & $\begin{array}{l}0 \\
0 \\
0\end{array}$ & $\begin{array}{l}309 \\
423 \\
333\end{array}$ & $\begin{array}{l}309 \\
423 \\
333\end{array}$ & $\begin{array}{l}0 \\
0 \\
0\end{array}$ & $\begin{array}{l}0 \\
0 \\
0\end{array}$ \\
\hline $\begin{array}{l}1903 \\
1902\end{array}$ & $\begin{array}{l}\text { 2-Mo. Avernge ......... } \\
\text { 2-Mo. Avernge ......... }\end{array}$ & $\begin{array}{l}202 \\
212\end{array}$ & $\begin{array}{l}15 \\
47\end{array}$ & $\begin{array}{l}0 \\
0\end{array}$ & $\begin{array}{l}0 \\
0\end{array}$ & $\begin{array}{r}195 \\
0\end{array}$ & $\begin{array}{r}178 \\
0\end{array}$ & $\begin{array}{l}0 \\
0\end{array}$ & $\begin{array}{l}0 \\
0\end{array}$ \\
\hline
\end{tabular}

See footnotes at end of table. 
Table S3. Crude Oll and Petroleum Product Imports, 1981 - Present (Continued) (Thousand Barrels per Day)

\begin{tabular}{|c|c|c|c|c|c|c|c|c|c|}
\hline & \multirow{3}{*}{ Yoarmonth } & \multicolumn{8}{|c|}{ Importe trom Arab-OPEC sources } \\
\hline & & \multicolumn{2}{|c|}{ onine } & \multicolumn{2}{|c|}{$\begin{array}{l}\text { saudl } \\
\text { Anplin }\end{array}$} & \multicolumn{2}{|c|}{$\begin{array}{c}\text { United } \\
\text { Arab } \\
\text { Emirnien }\end{array}$} & \multicolumn{2}{|c|}{$\begin{array}{l}\text { Total } \\
\text { Arab } \\
\text { opere }\end{array}$} \\
\hline & & Totel & Crude oll & Total & Crude Oll & Total & Crude oll & Total & Crude Oll \\
\hline 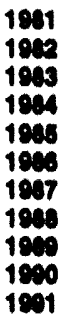 & 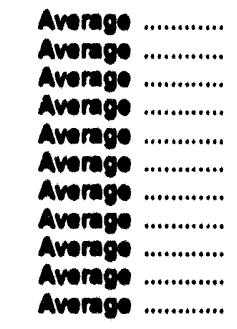 & $\begin{array}{r}7 \\
7 \\
(0) \\
8 \\
(0) \\
13 \\
0 \\
0 \\
2 \\
4 \\
0\end{array}$ & $\begin{array}{r}7 \\
7 \\
0 \\
4 \\
0 \\
12 \\
0 \\
0 \\
2 \\
4 \\
0\end{array}$ & $\begin{array}{r}1,129 \\
882 \\
337 \\
328 \\
169 \\
645 \\
781 \\
1,073 \\
1,204 \\
1,390 \\
1,000\end{array}$ & $\begin{array}{r}1,112 \\
830 \\
321 \\
300 \\
132 \\
618 \\
942 \\
911 \\
1,116 \\
1,198 \\
1,708\end{array}$ & $\begin{array}{r}81 \\
92 \\
30 \\
117 \\
45 \\
44 \\
61 \\
24 \\
29 \\
17 \\
3\end{array}$ & $\begin{array}{l}7 \\
81 \\
18 \\
00 \\
38 \\
30 \\
83 \\
20 \\
21 \\
0 \\
2\end{array}$ & $\begin{array}{r}1,048 \\
894 \\
830 \\
819 \\
472 \\
1,102 \\
1,274 \\
1,030 \\
2,130 \\
2,244 \\
2,044\end{array}$ & $\begin{array}{r}1,774 \\
736 \\
633 \\
634 \\
300 \\
884 \\
808 \\
1,418 \\
1,794 \\
1,094 \\
1,784\end{array}$ \\
\hline 189 & 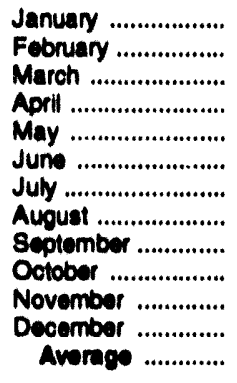 & $\begin{array}{l}0 \\
0 \\
0 \\
0 \\
0 \\
0 \\
8 \\
0 \\
0 \\
0 \\
0 \\
0 \\
1\end{array}$ & $\begin{array}{l}0 \\
0 \\
0 \\
0 \\
0 \\
0 \\
0 \\
0 \\
0 \\
0 \\
0 \\
0 \\
0\end{array}$ & $\begin{array}{l}2,017 \\
1,776 \\
1,707 \\
1,734 \\
1,784 \\
1,744 \\
1,713 \\
1,604 \\
1,603 \\
1,803 \\
1,608 \\
1,793 \\
1,720\end{array}$ & $\begin{array}{l}1,800 \\
1,687 \\
1,868 \\
1,524 \\
1.684 \\
1,610 \\
1,690 \\
1,473 \\
1,477 \\
1,462 \\
1.640 \\
1.726 \\
1,607\end{array}$ & $\begin{array}{r}18 \\
0 \\
0 \\
0 \\
0 \\
0 \\
0 \\
7 \\
0 \\
4 \\
17 \\
28 \\
6\end{array}$ & $\begin{array}{l}0 \\
0 \\
0 \\
0 \\
0 \\
0 \\
0 \\
0 \\
0 \\
0 \\
0 \\
0 \\
0\end{array}$ & $\begin{array}{l}2,241 \\
1,995 \\
1,922 \\
1,916 \\
1,968 \\
1,888 \\
1,958 \\
1,929 \\
1,847 \\
1,920 \\
1,913 \\
2,188 \\
1,974\end{array}$ & $\begin{array}{l}1,037 \\
1,745 \\
1,608 \\
1,543 \\
1,591 \\
1,621 \\
1,689 \\
1,651 \\
1,529 \\
1,699 \\
1,667 \\
1,882 \\
1,600\end{array}$ \\
\hline 1928 & 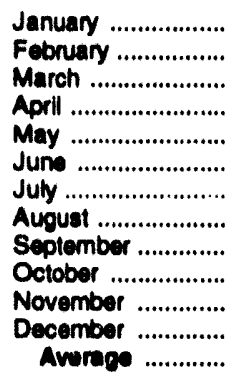 & $\begin{array}{l}0 \\
0 \\
0 \\
0 \\
0 \\
0 \\
0 \\
0 \\
0 \\
0 \\
0 \\
0 \\
1\end{array}$ & $\begin{array}{l}0 \\
0 \\
0 \\
0 \\
0 \\
0 \\
0 \\
0 \\
0 \\
0 \\
0 \\
0 \\
0\end{array}$ & $\begin{array}{l}1,687 \\
1,628 \\
1,479 \\
1,608 \\
1,524 \\
1,623 \\
1,270 \\
1,151 \\
1,329 \\
1,115 \\
1,281 \\
1,330 \\
1,401\end{array}$ & $\begin{array}{l}1,571 \\
1,460 \\
1,349 \\
1,478 \\
1,361 \\
1,398 \\
1,171 \\
1,036 \\
1,181 \\
089 \\
1,162 \\
1,205 \\
1,277\end{array}$ & $\begin{array}{r}0 \\
0 \\
0 \\
17 \\
59 \\
68 \\
19 \\
0 \\
0 \\
0 \\
1 \\
0 \\
14\end{array}$ & $\begin{array}{r}0 \\
0 \\
0 \\
17 \\
50 \\
68 \\
0 \\
0 \\
0 \\
0 \\
0 \\
0 \\
12\end{array}$ & $\begin{array}{l}1,984 \\
2,133 \\
1,987 \\
2,161 \\
2,034 \\
1,993 \\
1,004 \\
1,859 \\
1,968 \\
1,961 \\
1,984 \\
1,983 \\
1,004\end{array}$ & $\begin{array}{l}1,728 \\
1,709 \\
1,656 \\
1,783 \\
1,046 \\
1,729 \\
1,538 \\
1,515 \\
1,612 \\
1,574 \\
1,668 \\
1,713 \\
1,685\end{array}$ \\
\hline 104 & $\begin{array}{l}\text { January ................. } \\
\text { Fobruary ................ } \\
\text { 2-Mo. Aver... ...... }\end{array}$ & $\begin{array}{l}0 \\
0 \\
0\end{array}$ & $\begin{array}{l}0 \\
0 \\
0\end{array}$ & $\begin{array}{l}1,320 \\
1,071 \\
1,209\end{array}$ & $\begin{array}{l}1,175 \\
1,023 \\
1,103\end{array}$ & $\begin{array}{l}0 \\
0 \\
0\end{array}$ & $\begin{array}{l}0 \\
0 \\
0\end{array}$ & $\begin{array}{l}1,863 \\
1,719 \\
1,705\end{array}$ & $\begin{array}{l}1,520 \\
1,467 \\
1,404\end{array}$ \\
\hline $\begin{array}{l}1938 \\
192\end{array}$ & $\begin{array}{l}\text { 2-Mo. Awerego ...... } \\
\text { 2-Mo. Awerves ...... }\end{array}$ & $\begin{array}{l}0 \\
0\end{array}$ & $\begin{array}{l}0 \\
0\end{array}$ & $\begin{array}{l}1,080 \\
1,001\end{array}$ & $\begin{array}{l}1,620 \\
1,797\end{array}$ & $\begin{array}{l}0 \\
0\end{array}$ & $\begin{array}{l}0 \\
0\end{array}$ & $\begin{array}{l}2,085 \\
2,122\end{array}$ & $\begin{array}{l}1,710 \\
1,844\end{array}$ \\
\hline
\end{tabular}

See footnotes at end of table. 
Table S3. Crude Oll and Potroleum Product Imports, 1981 - Present (Continued) (Thousand Barrels per Day)

\begin{tabular}{|c|c|c|c|c|c|c|c|c|c|}
\hline & \multirow{3}{*}{ YearMmonth } & \multicolumn{8}{|c|}{ Imports from Other-OPEC souross } \\
\hline & & \multicolumn{2}{|c|}{ Eoundoro } & \multicolumn{2}{|c|}{ Cabon } & \multicolumn{2}{|c|}{ Indonesia } & \multicolumn{2}{|c|}{ Iran } \\
\hline & & Total & Crude OII & Total & Crude OII & Total & Crude Oll & Total & Crude OII \\
\hline 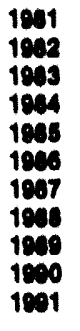 & 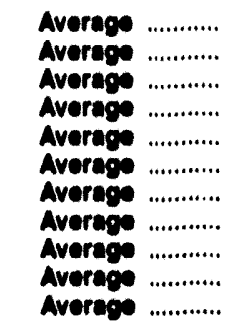 & $\begin{array}{l}40 \\
42 \\
61 \\
88 \\
67 \\
77 \\
29 \\
47 \\
69 \\
49 \\
63\end{array}$ & $\begin{array}{l}38 \\
32 \\
80 \\
17 \\
80 \\
64 \\
23 \\
33 \\
60 \\
30 \\
33\end{array}$ & $\begin{array}{l}35 \\
40 \\
80 \\
80 \\
82 \\
20 \\
38 \\
16 \\
80 \\
44 \\
44\end{array}$ & $\begin{array}{l}35 \\
40 \\
50 \\
57 \\
51 \\
28 \\
35 \\
15 \\
49 \\
44 \\
44\end{array}$ & $\begin{array}{l}366 \\
248 \\
338 \\
343 \\
314 \\
318 \\
208 \\
205 \\
183 \\
114 \\
111\end{array}$ & 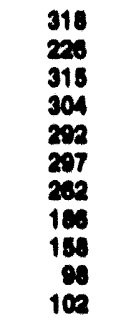 & $\begin{array}{r}0 \\
36 \\
48 \\
10 \\
27 \\
10 \\
18 \\
1(5) \\
0 \\
0 \\
32\end{array}$ & $\begin{array}{r}0 \\
38 \\
48 \\
10 \\
27 \\
19 \\
90 \\
1(0) \\
0 \\
0 \\
32\end{array}$ \\
\hline 1002 & 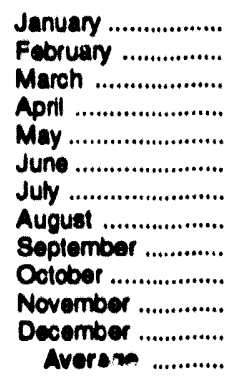 & $\begin{array}{c}56 \\
61 \\
26 \\
63 \\
51 \\
105 \\
111 \\
90 \\
97 \\
42 \\
53 \\
24 \\
68\end{array}$ & $\begin{array}{r}56 \\
48 \\
26 \\
46 \\
51 \\
101 \\
111 \\
93 \\
97 \\
36 \\
53 \\
24 \\
62\end{array}$ & $\begin{array}{r}91 \\
105 \\
25 \\
186 \\
136 \\
129 \\
143 \\
108 \\
165 \\
167 \\
114 \\
120 \\
124\end{array}$ & $\begin{array}{r}91 \\
105 \\
25 \\
186 \\
135 \\
129 \\
143 \\
108 \\
158 \\
167 \\
114 \\
120 \\
123\end{array}$ & $\begin{array}{r}125 \\
39 \\
85 \\
54 \\
155 \\
109 \\
65 \\
91 \\
57 \\
54 \\
36 \\
60 \\
78\end{array}$ & $\begin{array}{r}117 \\
39 \\
83 \\
49 \\
133 \\
102 \\
65 \\
88 \\
38 \\
43 \\
23 \\
60 \\
70\end{array}$ & $\begin{array}{l}0 \\
0 \\
0 \\
0 \\
0 \\
0 \\
0 \\
0 \\
0 \\
0 \\
0 \\
0 \\
0\end{array}$ & $\begin{array}{l}0 \\
0 \\
0 \\
0 \\
0 \\
0 \\
0 \\
0 \\
0 \\
0 \\
0 \\
0 \\
0\end{array}$ \\
\hline 1003 & 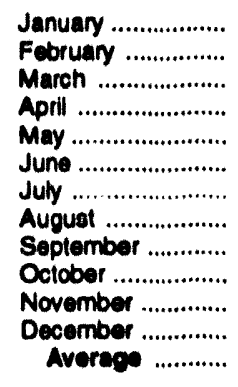 & $\begin{array}{r}76 \\
14 \\
89 \\
74 \\
56 \\
75 \\
85 \\
121 \\
49 \\
146 \\
115 \\
84 \\
80\end{array}$ & $\begin{array}{r}70 \\
14 \\
59 \\
62 \\
50 \\
75 \\
85 \\
121 \\
49 \\
135 \\
106 \\
84 \\
77\end{array}$ & $\begin{array}{r}90 \\
86 \\
126 \\
127 \\
169 \\
107 \\
168 \\
152 \\
211 \\
242 \\
143 \\
191 \\
152\end{array}$ & $\begin{array}{r}89 \\
88 \\
123 \\
127 \\
169 \\
107 \\
166 \\
152 \\
211 \\
242 \\
136 \\
191 \\
161\end{array}$ & $\begin{array}{r}37 \\
52 \\
67 \\
76 \\
82 \\
97 \\
55 \\
95 \\
51 \\
131 \\
74 \\
158 \\
81\end{array}$ & $\begin{array}{r}37 \\
51 \\
64 \\
76 \\
62 \\
67 \\
55 \\
80 \\
40 \\
82 \\
34 \\
114 \\
65\end{array}$ & $\begin{array}{l}0 \\
0 \\
0 \\
0 \\
0 \\
0 \\
0 \\
0 \\
0 \\
0 \\
0 \\
0 \\
0\end{array}$ & $\begin{array}{l}0 \\
0 \\
0 \\
0 \\
0 \\
0 \\
0 \\
0 \\
0 \\
0 \\
0 \\
0 \\
0\end{array}$ \\
\hline 1804 & $\begin{array}{l}\text { January ................. } \\
\text { February ............. } \\
\text { 2-Mo. Avorigge ..... }\end{array}$ & $\begin{array}{l}\text { (c) } \\
\text { (c) } \\
\text { (c) }\end{array}$ & $\begin{array}{l}\text { (c) } \\
\text { (c) } \\
\text { (c) }\end{array}$ & $\begin{array}{l}144 \\
212 \\
176\end{array}$ & $\begin{array}{l}144 \\
208 \\
174\end{array}$ & $\begin{array}{l}140 \\
103 \\
122\end{array}$ & $\begin{array}{l}81 \\
59 \\
71\end{array}$ & $\begin{array}{l}0 \\
0 \\
0\end{array}$ & $\begin{array}{l}0 \\
0 \\
0\end{array}$ \\
\hline $\begin{array}{l}1003 \\
1002\end{array}$ & $\begin{array}{l}\text { 2-1.0. Avonge ..... } \\
\text { 2-Mo. Averigge ..... }\end{array}$ & $\begin{array}{l}47 \\
80\end{array}$ & $\begin{array}{l}43 \\
82\end{array}$ & $\begin{array}{l}9 \\
97\end{array}$ & $\begin{array}{l}86 \\
97\end{array}$ & 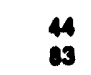 & 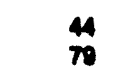 & $\begin{array}{l}0 \\
0\end{array}$ & $\begin{array}{l}0 \\
0\end{array}$ \\
\hline
\end{tabular}

See tootnotes at end of table. 
Table S3. Crude Oll and Petroleum Product Imports, 1981 - Present (Continued) (Thousand Barrels per Day)

\begin{tabular}{|c|c|c|c|c|c|c|c|c|c|}
\hline & \multirow{3}{*}{ Yoarmonth } & \multicolumn{6}{|c|}{ Imports trom Other-OPEC sources } & \multirow{2}{*}{\multicolumn{2}{|c|}{$\begin{array}{c}\text { Total } \\
\text { opfece,d }\end{array}$}} \\
\hline & & \multicolumn{2}{|c|}{ Nonde } & \multicolumn{2}{|c|}{ Yonswuln } & \multicolumn{2}{|c|}{$\begin{array}{l}\text { Total } \\
\text { Othor } \\
\text { Oeteo }\end{array}$} & & \\
\hline & & Total & Crude OII & Total & Crude OII & Total & Crude OII & Total & Crude Oll \\
\hline 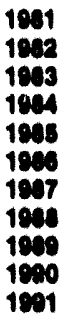 & 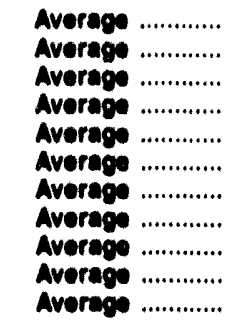 & $\begin{array}{l}620 \\
514 \\
302 \\
216 \\
203 \\
40 \\
035 \\
610 \\
818 \\
000 \\
703\end{array}$ & $\begin{array}{l}611 \\
610 \\
301 \\
207 \\
200 \\
497 \\
620 \\
607 \\
600 \\
794 \\
603\end{array}$ & $\begin{array}{l}400 \\
412 \\
420 \\
640 \\
605 \\
705 \\
604 \\
704 \\
673 \\
1,026 \\
1,085\end{array}$ & $\begin{array}{l}147 \\
156 \\
164 \\
258 \\
305 \\
416 \\
498 \\
490 \\
498 \\
645 \\
695\end{array}$ & $\begin{array}{l}1,470 \\
1,201 \\
1,231 \\
1,230 \\
1,368 \\
1,074 \\
1,707 \\
1,091 \\
2,010 \\
2,080 \\
2,020\end{array}$ & $\begin{array}{r}1,140 \\
909 \\
94 \\
070 \\
1,012 \\
1,280 \\
1,438 \\
1,201 \\
1,802 \\
1,680 \\
1,620\end{array}$ & $\begin{array}{l}3,323 \\
2,140 \\
1,892 \\
2,040 \\
1,830 \\
2,837 \\
3,000 \\
3,820 \\
4,140 \\
4,200 \\
4,092\end{array}$ & $\begin{array}{l}2,922 \\
1,734 \\
1,477 \\
1,812 \\
1,312 \\
2,113 \\
2,400 \\
2,690 \\
3,376 \\
3,814 \\
3,377\end{array}$ \\
\hline 1902 & 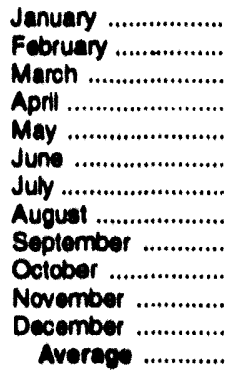 & $\begin{array}{l}583 \\
322 \\
441 \\
793 \\
773 \\
740 \\
900 \\
815 \\
774 \\
827 \\
628 \\
549 \\
601\end{array}$ & $\begin{array}{l}688 \\
303 \\
409 \\
789 \\
773 \\
740 \\
883 \\
795 \\
784 \\
813 \\
609 \\
632 \\
698\end{array}$ & $\begin{array}{l}1,110 \\
1,028 \\
1,108 \\
1,079 \\
1,038 \\
1,059 \\
1,163 \\
1,102 \\
1,333 \\
1,497 \\
1,343 \\
1,164 \\
1,170\end{array}$ & $\begin{array}{r}787 \\
655 \\
793 \\
722 \\
745 \\
738 \\
912 \\
841 \\
953 \\
1,073 \\
921 \\
763 \\
909\end{array}$ & $\begin{array}{l}1,984 \\
1,655 \\
1,684 \\
2,169 \\
2,162 \\
2,141 \\
2,382 \\
2,216 \\
2,426 \\
2,587 \\
2,173 \\
1,917 \\
2,117\end{array}$ & $\begin{array}{l}1,617 \\
1,180 \\
1,338 \\
1,791 \\
1,837 \\
1,800 \\
2,114 \\
1,022 \\
2,001 \\
2,133 \\
1,719 \\
1,499 \\
1,740\end{array}$ & $\begin{array}{l}4,224 \\
3,649 \\
3,600 \\
4,006 \\
4,118 \\
4,029 \\
4,339 \\
4,144 \\
4,274 \\
4,507 \\
4,086 \\
4,108 \\
4,002\end{array}$ & $\begin{array}{l}3,854 \\
2,896 \\
2,941 \\
3,334 \\
3,428 \\
3,430 \\
3,772 \\
3,473 \\
3,631 \\
3,732 \\
3,376 \\
3,381 \\
3,406\end{array}$ \\
\hline 1903 & 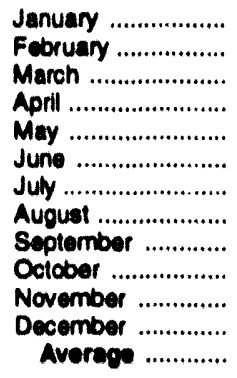 & $\begin{array}{l}729 \\
927 \\
928 \\
892 \\
741 \\
848 \\
893 \\
582 \\
514 \\
603 \\
636 \\
598 \\
739\end{array}$ & $\begin{array}{l}729 \\
913 \\
892 \\
871 \\
723 \\
827 \\
888 \\
549 \\
496 \\
693 \\
612 \\
869 \\
720\end{array}$ & $\begin{array}{l}1,385 \\
1,290 \\
1,208 \\
1,297 \\
1,226 \\
1,277 \\
1,384 \\
1,375 \\
1,243 \\
1,267 \\
1,267 \\
1,205 \\
1,298\end{array}$ & $\begin{array}{r}1,038 \\
925 \\
817 \\
1,008 \\
954 \\
992 \\
1,068 \\
1,135 \\
1,033 \\
903 \\
1,073 \\
052 \\
090\end{array}$ & $\begin{array}{l}2,317 \\
2,372 \\
2,388 \\
2,468 \\
2,275 \\
2,403 \\
2,685 \\
2,305 \\
2,087 \\
2,388 \\
2,234 \\
2,236 \\
2,337\end{array}$ & $\begin{array}{l}1,982 \\
1,990 \\
1,965 \\
2,141 \\
1,984 \\
2,087 \\
2,282 \\
2,037 \\
1,828 \\
2,045 \\
1,892 \\
1,910 \\
2,012\end{array}$ & $\begin{array}{l}4,301 \\
4,508 \\
4,376 \\
4,627 \\
4,308 \\
4,396 \\
4,489 \\
4,164 \\
4,033 \\
4,360 \\
4,219 \\
4,218 \\
4,331\end{array}$ & $\begin{array}{l}3,690 \\
3,699 \\
3,611 \\
3,924 \\
3,630 \\
3,798 \\
3,800 \\
3,562 \\
3,440 \\
3,618 \\
3,630 \\
3,624 \\
3,667\end{array}$ \\
\hline $19 \times 4$ & $\begin{array}{l}\text { January ................. } \\
\text { February ................ } \\
\text { 2-Mo. Ayor. ....... }\end{array}$ & $\begin{array}{l}310 \\
576 \\
485\end{array}$ & $\begin{array}{l}274 \\
657 \\
400\end{array}$ & $\begin{array}{l}1,185 \\
1,204 \\
1,104\end{array}$ & $\begin{array}{l}801 \\
048 \\
08\end{array}$ & $\begin{array}{l}1,780 \\
2,004 \\
1,000\end{array}$ & $\begin{array}{l}1,400 \\
1,770 \\
1,570\end{array}$ & $\begin{array}{l}3,643 \\
3,814 \\
3,724\end{array}$ & $\begin{array}{l}2,920 \\
3,237 \\
3,070\end{array}$ \\
\hline $\begin{array}{l}1908 \\
1902\end{array}$ & $\begin{array}{l}\text { 2-Mo. Awernge ...... } \\
\text { 2-Mo. Avernge ...... }\end{array}$ & $\frac{123}{402}$ & $\begin{array}{l}919 \\
450\end{array}$ & $\begin{array}{l}1,340 \\
1,076\end{array}$ & $\underset{m}{m}$ & $\begin{array}{l}2,343 \\
1,776\end{array}$ & $\begin{array}{l}1,075 \\
1,301\end{array}$ & $\begin{array}{l}4,300 \\
3,000\end{array}$ & $\begin{array}{l}3,604 \\
3,2 \times 6\end{array}$ \\
\hline
\end{tabular}

See tootnotes at end of table. 
Table 53. Crude Oll and Petroleum Product Imports, 1981 - Present (Continued) (Thousand Barrels per Day)

\begin{tabular}{|c|c|c|c|c|c|c|c|c|c|c|c|c|c|}
\hline & \multirow{3}{*}{ Yearkionth } & \multicolumn{12}{|c|}{ Imports from Non-OPEC sources } \\
\hline & & \multicolumn{2}{|c|}{ Anpoln } & \multicolumn{2}{|c|}{ Auntralln } & \multicolumn{2}{|c|}{$\begin{array}{l}\text { Bahama } \\
\text { Inlende }\end{array}$} & \multicolumn{2}{|c|}{ Arall. } & \multicolumn{2}{|c|}{ Cenen } & \multicolumn{2}{|c|}{$\begin{array}{l}\text { China } \\
\text { People's } \\
\text { Bapuble }\end{array}$} \\
\hline & & Total & Crude OII & Total & Crude OII & Total & Crude oll & Total & Crude OII & Total & Crude Oll & Total & Crude OII \\
\hline 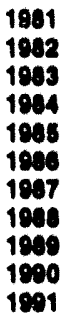 & 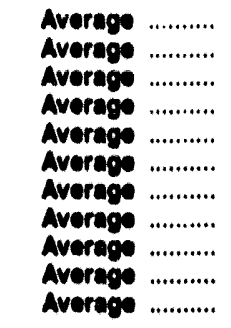 & $\begin{array}{r}40 \\
44 \\
70 \\
00 \\
110 \\
112 \\
192 \\
212 \\
294 \\
207 \\
284\end{array}$ & $\begin{array}{r}48 \\
42 \\
71 \\
85 \\
104 \\
100 \\
180 \\
203 \\
270 \\
2 \times 3 \\
284\end{array}$ & $\begin{array}{l}6 \\
5 \\
4 \\
38 \\
37 \\
41 \\
8 \\
4 \\
39 \\
83 \\
24\end{array}$ & $\begin{array}{r}0 \\
(0) \\
0 \\
25 \\
21 \\
30 \\
49 \\
89 \\
31 \\
47 \\
21\end{array}$ & $\begin{array}{r}74 \\
65 \\
128 \\
89 \\
40 \\
37 \\
37 \\
37 \\
34 \\
37 \\
35\end{array}$ & $\begin{array}{l}0 \\
0 \\
0 \\
0 \\
0 \\
0 \\
0 \\
0 \\
0 \\
0 \\
0\end{array}$ & $\begin{array}{l}23 \\
47 \\
41 \\
60 \\
81 \\
80 \\
84 \\
98 \\
62 \\
49 \\
22\end{array}$ & $\begin{array}{r}14 \\
10 \\
2 \\
(0) \\
0 \\
0 \\
0 \\
0 \\
0 \\
0 \\
0\end{array}$ & $\begin{array}{r}447 \\
482 \\
547 \\
630 \\
770 \\
807 \\
948 \\
900 \\
931 \\
934 \\
1,033\end{array}$ & $\begin{array}{l}104 \\
214 \\
274 \\
341 \\
468 \\
570 \\
608 \\
601 \\
630 \\
643 \\
743\end{array}$ & $\begin{array}{l}18 \\
40 \\
34 \\
40 \\
39 \\
90 \\
02 \\
08 \\
80 \\
00 \\
91\end{array}$ & $\begin{array}{r}0 \\
8 \\
6 \\
16 \\
35 \\
68 \\
63 \\
82 \\
70 \\
77 \\
87\end{array}$ \\
\hline 1902 & 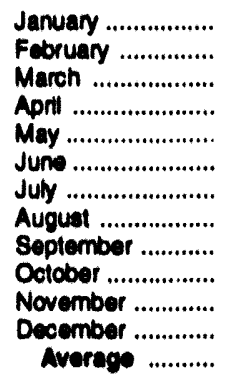 & $\begin{array}{l}380 \\
246 \\
339 \\
381 \\
264 \\
286 \\
443 \\
335 \\
248 \\
395 \\
458 \\
279 \\
335\end{array}$ & $\begin{array}{l}380 \\
246 \\
339 \\
381 \\
264 \\
286 \\
443 \\
323 \\
248 \\
395 \\
488 \\
279 \\
385\end{array}$ & $\begin{array}{r}11 \\
10 \\
0 \\
39 \\
0 \\
21 \\
20 \\
21 \\
0 \\
11 \\
53 \\
38 \\
19\end{array}$ & $\begin{array}{r}11 \\
10 \\
0 \\
22 \\
0 \\
21 \\
20 \\
21 \\
0 \\
11 \\
49 \\
38 \\
17\end{array}$ & $\begin{array}{r}63 \\
47 \\
76 \\
67 \\
46 \\
57 \\
22 \\
8 \\
8 \\
1 \\
20 \\
19 \\
30\end{array}$ & $\begin{array}{l}0 \\
0 \\
0 \\
0 \\
0 \\
0 \\
0 \\
0 \\
0 \\
0 \\
0 \\
0 \\
0\end{array}$ & $\begin{array}{l}18 \\
12 \\
(8) \\
17 \\
18 \\
28 \\
25 \\
10 \\
21 \\
10 \\
32 \\
50 \\
20\end{array}$ & $\begin{array}{l}0 \\
0 \\
0 \\
0 \\
0 \\
0 \\
0 \\
0 \\
0 \\
0 \\
0 \\
0 \\
0\end{array}$ & $\begin{array}{r}1,045 \\
1,147 \\
1,100 \\
1,121 \\
1,013 \\
970 \\
1,044 \\
1,038 \\
1,131 \\
1,063 \\
1,037 \\
1,122 \\
1,009\end{array}$ & $\begin{array}{l}786 \\
834 \\
832 \\
835 \\
779 \\
736 \\
788 \\
762 \\
839 \\
761 \\
784 \\
816 \\
797\end{array}$ & $\begin{array}{r}144 \\
80 \\
75 \\
86 \\
129 \\
110 \\
68 \\
66 \\
80 \\
61 \\
86 \\
97 \\
90\end{array}$ & $\begin{array}{r}144 \\
69 \\
76 \\
69 \\
114 \\
95 \\
64 \\
68 \\
75 \\
61 \\
86 \\
90 \\
84\end{array}$ \\
\hline 1003 & 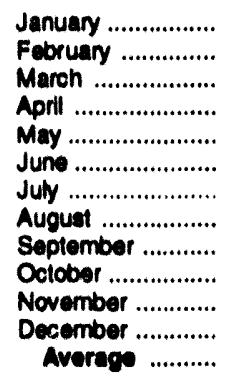 & $\begin{array}{l}384 \\
348 \\
409 \\
322 \\
287 \\
209 \\
386 \\
258 \\
282 \\
440 \\
283 \\
379 \\
330\end{array}$ & $\begin{array}{l}354 \\
348 \\
408 \\
322 \\
287 \\
209 \\
386 \\
258 \\
282 \\
440 \\
283 \\
379 \\
330\end{array}$ & $\begin{array}{r}0 \\
0 \\
0 \\
0 \\
13 \\
34 \\
40 \\
33 \\
0 \\
53 \\
0 \\
53 \\
10\end{array}$ & $\begin{array}{r}0 \\
0 \\
0 \\
0 \\
13 \\
34 \\
40 \\
27 \\
0 \\
47 \\
0 \\
53 \\
10\end{array}$ & $\begin{array}{r}18 \\
19 \\
30 \\
16 \\
6 \\
7 \\
31 \\
37 \\
27 \\
42 \\
26 \\
23 \\
24\end{array}$ & $\begin{array}{l}0 \\
0 \\
0 \\
0 \\
0 \\
0 \\
0 \\
0 \\
0 \\
0 \\
0 \\
0 \\
0\end{array}$ & $\begin{array}{r}3 \\
22 \\
27 \\
56 \\
41 \\
19 \\
48 \\
32 \\
59 \\
15 \\
51 \\
10 \\
32\end{array}$ & $\begin{array}{l}0 \\
0 \\
0 \\
0 \\
0 \\
0 \\
0 \\
0 \\
0 \\
0 \\
0 \\
0 \\
0\end{array}$ & $\begin{array}{l}1,034 \\
1,084 \\
1,065 \\
1,032 \\
1,118 \\
1,111 \\
1,247 \\
1,237 \\
1,309 \\
1,367 \\
1,231 \\
1,254 \\
1,175\end{array}$ & $\begin{array}{r}778 \\
782 \\
814 \\
783 \\
874 \\
910 \\
991 \\
966 \\
1,018 \\
1,030 \\
917 \\
984 \\
903\end{array}$ & $\begin{array}{r}60 \\
44 \\
79 \\
0 \\
40 \\
48 \\
24 \\
38 \\
91 \\
61 \\
68 \\
61 \\
51\end{array}$ & $\begin{array}{r}60 \\
44 \\
73 \\
0 \\
40 \\
46 \\
24 \\
38 \\
89 \\
61 \\
68 \\
61 \\
50\end{array}$ \\
\hline 1904 & $\begin{array}{l}\text { January ................ } \\
\text { February ............. } \\
\text { 2-1wo. Average .... }\end{array}$ & $\begin{array}{l}338 \\
295 \\
317\end{array}$ & $\begin{array}{l}338 \\
202 \\
311\end{array}$ & $\begin{array}{r}12 \\
0 \\
6\end{array}$ & $\begin{array}{l}0 \\
0 \\
0\end{array}$ & $\begin{array}{l}28 \\
79 \\
52\end{array}$ & $\begin{array}{l}0 \\
0 \\
0\end{array}$ & $\begin{array}{l}11 \\
12 \\
11\end{array}$ & $\begin{array}{l}0 \\
0 \\
0\end{array}$ & $\begin{array}{l}1,234 \\
1,364 \\
1,296\end{array}$ & $\begin{array}{l}905 \\
994 \\
947\end{array}$ & $\begin{array}{l}81 \\
44 \\
44\end{array}$ & $\begin{array}{l}78 \\
44 \\
62\end{array}$ \\
\hline $\begin{array}{l}1903 \\
1002\end{array}$ & $\begin{array}{l}\text { 2-110. Averges .... } \\
2 \text {.110. Averges .... }\end{array}$ & $\begin{array}{l}351 \\
308\end{array}$ & $\begin{array}{l}381 \\
308\end{array}$ & $\begin{array}{r}0 \\
10\end{array}$ & $\begin{array}{r}0 \\
10\end{array}$ & $\begin{array}{l}18 \\
88\end{array}$ & $\begin{array}{l}\mathbf{0} \\
\mathbf{0}\end{array}$ & $\begin{array}{l}12 \\
18\end{array}$ & $\begin{array}{l}0 \\
0\end{array}$ & $\begin{array}{l}1,058 \\
1,005\end{array}$ & $\begin{array}{l}780 \\
800\end{array}$ & $\begin{array}{r}83 \\
113\end{array}$ & $\begin{array}{r}63 \\
100\end{array}$ \\
\hline
\end{tabular}

See footnotes at end of table. 
Table 53. Crude Oll and Petroleum Product Imports, 1981 - Present (Continued) (Thousand Barrels per Day)

\begin{tabular}{|c|c|c|c|c|c|c|c|c|c|c|c|c|c|}
\hline & \multirow{3}{*}{ Yearmionth } & \multicolumn{12}{|c|}{ Imports from Non-OPEC sources } \\
\hline & & \multicolumn{2}{|c|}{ Colombia } & \multicolumn{2}{|c|}{ Eoundore } & \multicolumn{2}{|c|}{ Maty } & \multicolumn{2}{|c|}{ Malayola } & \multicolumn{2}{|c|}{ Moxico } & \multicolumn{2}{|c|}{ Netherlands } \\
\hline & & Total & Cruste OII & Total & Crude oll & Total & Crude OII & Total & Cructs OII & Total & Crude OII & Totnt & Crude OII \\
\hline 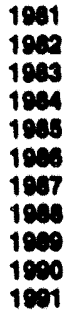 & 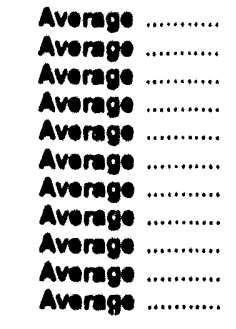 & $\begin{array}{r}1 \\
8 \\
10 \\
6 \\
23 \\
97 \\
148 \\
134 \\
172 \\
182 \\
183\end{array}$ & $\begin{array}{r}0 \\
0 \\
0 \\
0 \\
0 \\
57 \\
118 \\
108 \\
130 \\
140 \\
123\end{array}$ & $\begin{array}{l}- \\
- \\
- \\
- \\
- \\
- \\
-\end{array}$ & $\begin{array}{l}- \\
- \\
- \\
- \\
- \\
- \\
-\end{array}$ & $\begin{array}{l}11 \\
18 \\
18 \\
48 \\
60 \\
76 \\
84 \\
88 \\
34 \\
8 \\
47\end{array}$ & $\begin{array}{l}0 \\
(0) \\
(0) \\
(0) \\
(0) \\
0 \\
1 \\
8 \\
3 \\
2 \\
3\end{array}$ & $\begin{array}{r}39 \\
20 \\
4 \\
1 \\
3 \\
12 \\
13 \\
10 \\
39 \\
41 \\
24\end{array}$ & $\begin{array}{r}33 \\
10 \\
3 \\
0 \\
1 \\
11 \\
12 \\
10 \\
30 \\
40 \\
24\end{array}$ & $\begin{array}{l}520 \\
685 \\
820 \\
748 \\
816 \\
690 \\
655 \\
747 \\
767 \\
755 \\
807\end{array}$ & $\begin{array}{l}460 \\
648 \\
768 \\
650 \\
715 \\
621 \\
602 \\
674 \\
716 \\
600 \\
780\end{array}$ & $\begin{array}{l}30 \\
35 \\
85 \\
65 \\
88 \\
54 \\
60 \\
61 \\
49 \\
58 \\
20\end{array}$ & $\begin{array}{c}(0) \\
(0) \\
3 \\
3 \\
0 \\
0 \\
0 \\
0 \\
0 \\
0 \\
0\end{array}$ \\
\hline 1000 & 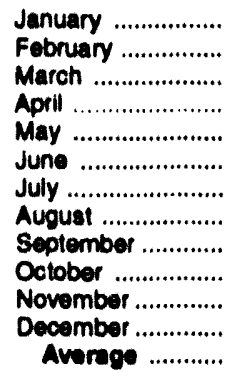 & $\begin{array}{r}158 \\
114 \\
101 \\
150 \\
57 \\
135 \\
103 \\
156 \\
190 \\
153 \\
127 \\
66 \\
128\end{array}$ & $\begin{array}{r}111 \\
92 \\
74 \\
129 \\
46 \\
114 \\
83 \\
142 \\
179 \\
132 \\
84 \\
34 \\
102\end{array}$ & $\begin{array}{l}- \\
\overline{-} \\
\overline{-} \\
\overline{-} \\
\overline{-} \\
- \\
-\end{array}$ & $\begin{array}{l}- \\
\overline{-} \\
\overline{-} \\
\overline{-} \\
\overline{-} \\
\overline{-}\end{array}$ & $\begin{array}{l}51 \\
48 \\
44 \\
75 \\
57 \\
69 \\
36 \\
94 \\
81 \\
37 \\
33 \\
37 \\
55\end{array}$ & $\begin{array}{l}0 \\
0 \\
0 \\
0 \\
0 \\
0 \\
0 \\
0 \\
0 \\
0 \\
0 \\
0 \\
0\end{array}$ & $\begin{array}{r}0 \\
0 \\
0 \\
0 \\
6 \\
8 \\
40 \\
22 \\
17 \\
17 \\
8 \\
4 \\
10\end{array}$ & $\begin{array}{r}0 \\
0 \\
0 \\
0 \\
5 \\
8 \\
40 \\
22 \\
17 \\
17 \\
8 \\
4 \\
10\end{array}$ & $\begin{array}{l}764 \\
838 \\
846 \\
857 \\
788 \\
805 \\
830 \\
857 \\
755 \\
829 \\
762 \\
930 \\
830\end{array}$ & $\begin{array}{l}721 \\
807 \\
809 \\
795 \\
784 \\
883 \\
788 \\
780 \\
720 \\
783 \\
700 \\
889 \\
787\end{array}$ & $\begin{array}{r}31 \\
9 \\
34 \\
8 \\
27 \\
25 \\
21 \\
45 \\
39 \\
18 \\
26 \\
33 \\
20\end{array}$ & $\begin{array}{l}0 \\
0 \\
0 \\
0 \\
0 \\
0 \\
0 \\
0 \\
0 \\
0 \\
0 \\
0 \\
0\end{array}$ \\
\hline 1993 & 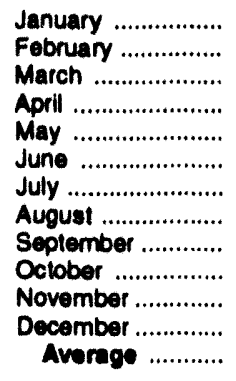 & $\begin{array}{l}188 \\
148 \\
161 \\
152 \\
147 \\
176 \\
204 \\
124 \\
224 \\
192 \\
153 \\
125 \\
168\end{array}$ & $\begin{array}{r}167 \\
137 \\
129 \\
138 \\
90 \\
143 \\
184 \\
101 \\
170 \\
182 \\
143 \\
85 \\
139\end{array}$ & $\begin{array}{l}- \\
\bar{z} \\
\overline{-} \\
\bar{z} \\
\overline{-} \\
\overline{-} \\
\overline{-}\end{array}$ & $\begin{array}{l}- \\
\overline{-} \\
\bar{z} \\
\overline{-} \\
\overline{-} \\
\overline{-} \\
-\end{array}$ & $\begin{array}{r}48 \\
34 \\
43 \\
14 \\
18 \\
22 \\
25 \\
50 \\
32 \\
30 \\
25 \\
0 \\
24\end{array}$ & $\begin{array}{l}0 \\
0 \\
0 \\
0 \\
0 \\
0 \\
0 \\
0 \\
0 \\
0 \\
0 \\
0 \\
0\end{array}$ & $\begin{array}{r}0 \\
0 \\
11 \\
8 \\
21 \\
0 \\
11 \\
14 \\
28 \\
10 \\
0 \\
28 \\
11\end{array}$ & $\begin{array}{r}0 \\
0 \\
10 \\
8 \\
10 \\
0 \\
11 \\
14 \\
28 \\
10 \\
0 \\
28 \\
10\end{array}$ & $\begin{array}{r}858 \\
807 \\
861 \\
844 \\
907 \\
995 \\
943 \\
862 \\
929 \\
1,013 \\
1,100 \\
909 \\
919\end{array}$ & $\begin{array}{r}820 \\
748 \\
815 \\
818 \\
846 \\
977 \\
878 \\
809 \\
867 \\
951 \\
1,025 \\
837 \\
848\end{array}$ & $\begin{array}{r}11 \\
18 \\
11 \\
0 \\
10 \\
10 \\
20 \\
17 \\
22 \\
0 \\
18) \\
6 \\
10\end{array}$ & $\begin{array}{l}0 \\
0 \\
0 \\
0 \\
0 \\
0 \\
0 \\
0 \\
0 \\
0 \\
0 \\
0 \\
0\end{array}$ \\
\hline 189 & $\begin{array}{l}\text { January ................ } \\
\text { Fobruary ............... } \\
\text { 2-Mo. Averag ...... }\end{array}$ & $\begin{array}{l}182 \\
184 \\
183\end{array}$ & $\begin{array}{l}149 \\
131 \\
141\end{array}$ & $\begin{array}{r}128 \\
88 \\
113\end{array}$ & $\begin{array}{r}128 \\
98 \\
113\end{array}$ & $\begin{array}{r}8 \\
35 \\
20\end{array}$ & $\begin{array}{l}0 \\
0 \\
0\end{array}$ & $\begin{array}{l}11 \\
19 \\
18\end{array}$ & $\begin{array}{r}0 \\
15 \\
7\end{array}$ & $\begin{array}{l}971 \\
967 \\
900\end{array}$ & $\begin{array}{l}945 \\
926 \\
935\end{array}$ & $\begin{array}{l}35 \\
43 \\
30\end{array}$ & $\begin{array}{l}0 \\
0 \\
0\end{array}$ \\
\hline $\begin{array}{l}1003 \\
1902\end{array}$ & $\begin{array}{l}\text { 2-Mo. Average ..... } \\
\text { 2-Mo. Average ..... }\end{array}$ & $\begin{array}{l}169 \\
133\end{array}$ & $\begin{array}{l}153 \\
102\end{array}$ & 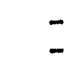 & - & $\begin{array}{l}42 \\
60\end{array}$ & $\begin{array}{l}0 \\
0\end{array}$ & $\begin{array}{l}0 \\
0\end{array}$ & $\begin{array}{l}0 \\
0\end{array}$ & $\begin{array}{l}834 \\
800\end{array}$ & $\begin{array}{l}763 \\
763\end{array}$ & $\begin{array}{l}14 \\
20\end{array}$ & $\begin{array}{l}0 \\
0\end{array}$ \\
\hline
\end{tabular}

See footnotes at end of table. 
Table 53. Crude Oll and Petroleum Product Imports, 1981 - Present (Continued) (Thousand Barrels per Day)

\begin{tabular}{|c|c|c|c|c|c|c|c|c|c|c|c|c|c|}
\hline & \multirow{3}{*}{ Yearkonth } & \multicolumn{12}{|c|}{ Importe from Non-OPEC sources" } \\
\hline & & \multicolumn{2}{|c|}{$\begin{array}{l}\text { Nothertanda } \\
\text { Antillin }\end{array}$} & \multicolumn{2}{|c|}{ Mopinx } & \multicolumn{2}{|c|}{$\begin{array}{l}\text { Puerto } \\
\text { Place }\end{array}$} & \multicolumn{2}{|c|}{ Aunge } & \multicolumn{2}{|c|}{ spin } & \multicolumn{2}{|c|}{$\begin{array}{l}\text { Trinidad } \\
\text { and } \\
\text { Tobnoe }\end{array}$} \\
\hline & & Total & Crude oll & Total & Crude oll & Total & Crude OII & Total & Crude OII & Total & Crude OII & Total & Crude oll \\
\hline 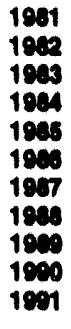 & 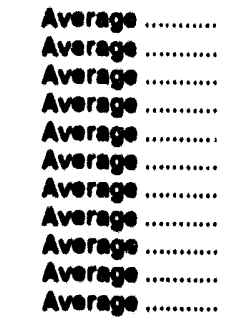 & $\begin{array}{r}197 \\
178 \\
189 \\
188 \\
40 \\
28 \\
29 \\
35 \\
42 \\
31 \\
81\end{array}$ & $\begin{array}{l}0 \\
0 \\
0 \\
0 \\
0 \\
0 \\
0 \\
0 \\
0 \\
0 \\
0\end{array}$ & $\begin{array}{r}119 \\
102 \\
60 \\
114 \\
32 \\
60 \\
60 \\
67 \\
130 \\
102 \\
02\end{array}$ & $\begin{array}{r}114 \\
102 \\
65 \\
112 \\
31 \\
83 \\
70 \\
62 \\
127 \\
80 \\
74\end{array}$ & $\begin{array}{l}62 \\
80 \\
40 \\
42 \\
28 \\
21 \\
21 \\
22 \\
32 \\
32 \\
27\end{array}$ & $\begin{array}{l}0 \\
0 \\
0 \\
0 \\
0 \\
0 \\
0 \\
0 \\
0 \\
0 \\
0\end{array}$ & $\begin{array}{r}5 \\
1 \\
1 \\
13 \\
8 \\
18 \\
11 \\
29 \\
48 \\
45 \\
29\end{array}$ & $\begin{array}{r}(3) \\
0 \\
(0) \\
(0) \\
(0) \\
(0) \\
0 \\
0 \\
0 \\
1 \\
1\end{array}$ & $\begin{array}{l}1 \\
3 \\
2 \\
11 \\
29 \\
63 \\
58 \\
68 \\
67 \\
47 \\
33\end{array}$ & $\begin{array}{l}(0) \\
(0) \\
(0) \\
0 \\
1 \\
0 \\
0 \\
0 \\
0 \\
0 \\
0\end{array}$ & $\begin{array}{r}133 \\
112 \\
86 \\
84 \\
113 \\
125 \\
108 \\
97 \\
84 \\
86 \\
88\end{array}$ & $\begin{array}{r}102 \\
92 \\
83 \\
97 \\
98 \\
93 \\
75 \\
71 \\
73 \\
78 \\
72\end{array}$ \\
\hline 1902 & 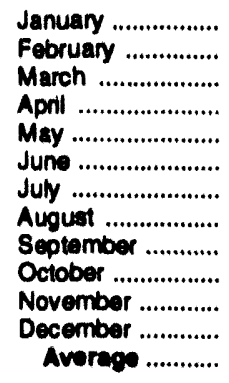 & $\begin{array}{l}40 \\
82 \\
49 \\
73 \\
59 \\
63 \\
49 \\
65 \\
60 \\
60 \\
56 \\
80 \\
65\end{array}$ & $\begin{array}{l}0 \\
0 \\
0 \\
0 \\
0 \\
0 \\
0 \\
0 \\
0 \\
0 \\
0 \\
0 \\
0\end{array}$ & $\begin{array}{r}26 \\
11 \\
11 \\
155 \\
210 \\
234 \\
186 \\
142 \\
103 \\
190 \\
111 \\
140 \\
127\end{array}$ & $\begin{array}{r}17 \\
0 \\
0 \\
147 \\
200 \\
225 \\
179 \\
134 \\
102 \\
177 \\
104 \\
133 \\
119\end{array}$ & $\begin{array}{l}32 \\
23 \\
18 \\
14 \\
22 \\
36 \\
11 \\
38 \\
37 \\
29 \\
26 \\
28 \\
29\end{array}$ & $\begin{array}{l}0 \\
0 \\
0 \\
0 \\
0 \\
0 \\
0 \\
0 \\
0 \\
0 \\
0 \\
0 \\
0\end{array}$ & $\begin{array}{r}17 \\
3 \\
0 \\
0 \\
0 \\
0 \\
72 \\
62 \\
53 \\
0 \\
0 \\
0 \\
18\end{array}$ & $\begin{array}{r}0 \\
0 \\
0 \\
0 \\
0 \\
0 \\
32 \\
31 \\
0 \\
0 \\
0 \\
0 \\
5\end{array}$ & $\begin{array}{l}35 \\
16 \\
37 \\
35 \\
30 \\
46 \\
18 \\
29 \\
56 \\
32 \\
36 \\
17 \\
32\end{array}$ & $\begin{array}{l}0 \\
0 \\
0 \\
0 \\
0 \\
0 \\
0 \\
0 \\
0 \\
0 \\
0 \\
0 \\
0\end{array}$ & $\begin{array}{r}108 \\
109 \\
105 \\
79 \\
69 \\
84 \\
103 \\
106 \\
84 \\
108 \\
85 \\
91 \\
85\end{array}$ & $\begin{array}{l}79 \\
76 \\
85 \\
75 \\
54 \\
74 \\
78 \\
54 \\
56 \\
71 \\
62 \\
71 \\
70\end{array}$ \\
\hline 1903 & 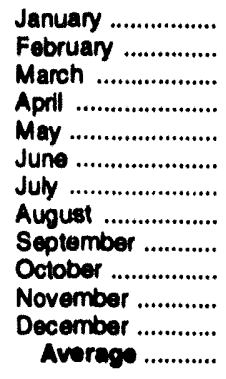 & $\begin{array}{r}73 \\
80 \\
61 \\
86 \\
77 \\
55 \\
52 \\
52 \\
97 \\
111 \\
83 \\
107 \\
76\end{array}$ & $\begin{array}{l}0 \\
0 \\
0 \\
0 \\
0 \\
0 \\
0 \\
0 \\
0 \\
0 \\
0 \\
0 \\
0\end{array}$ & $\begin{array}{r}70 \\
62 \\
122 \\
109 \\
65 \\
160 \\
215 \\
180 \\
113 \\
115 \\
162 \\
108 \\
124\end{array}$ & $\begin{array}{r}70 \\
61 \\
115 \\
109 \\
65 \\
160 \\
215 \\
161 \\
113 \\
93 \\
155 \\
101 \\
119\end{array}$ & $\begin{array}{l}37 \\
21 \\
26 \\
18 \\
38 \\
29 \\
49 \\
30 \\
28 \\
30 \\
23 \\
14 \\
20\end{array}$ & $\begin{array}{l}0 \\
0 \\
0 \\
0 \\
0 \\
0 \\
0 \\
0 \\
0 \\
0 \\
0 \\
0 \\
0\end{array}$ & $\begin{array}{r}0 \\
0 \\
0 \\
16 \\
32 \\
59 \\
157 \\
26 \\
57 \\
176 \\
56 \\
38 \\
52\end{array}$ & $\begin{array}{r}0 \\
0 \\
0 \\
16 \\
32 \\
34 \\
134 \\
0 \\
29 \\
123 \\
32 \\
0 \\
34\end{array}$ & $\begin{array}{l}44 \\
25 \\
21 \\
61 \\
34 \\
20 \\
41 \\
37 \\
54 \\
33 \\
30 \\
42 \\
37\end{array}$ & $\begin{array}{l}0 \\
0 \\
0 \\
0 \\
0 \\
0 \\
0 \\
0 \\
0 \\
0 \\
0 \\
0 \\
0\end{array}$ & $\begin{array}{r}59 \\
72 \\
92 \\
78 \\
61 \\
77 \\
82 \\
50 \\
70 \\
69 \\
66 \\
103 \\
73\end{array}$ & $\begin{array}{l}48 \\
58 \\
71 \\
55 \\
51 \\
55 \\
53 \\
37 \\
55 \\
54 \\
55 \\
71 \\
55\end{array}$ \\
\hline 1004 & $\begin{array}{l}\text { January ................ } \\
\text { February .............. } \\
\text { 2-Mo. Average .... }\end{array}$ & $\begin{array}{r}162 \\
119 \\
142\end{array}$ & $\begin{array}{l}0 \\
0 \\
0\end{array}$ & $\begin{array}{l}101 \\
199 \\
147\end{array}$ & $\begin{array}{r}96 \\
166 \\
129\end{array}$ & $\begin{array}{r}20 \\
11 \\
16\end{array}$ & $\begin{array}{l}0 \\
0 \\
0\end{array}$ & $\begin{array}{l}11 \\
14 \\
12\end{array}$ & $\begin{array}{l}0 \\
0 \\
0\end{array}$ & $\begin{array}{l}26 \\
31 \\
28\end{array}$ & $\begin{array}{l}0 \\
0 \\
0\end{array}$ & $\begin{array}{l}79 \\
92 \\
85\end{array}$ & $\begin{array}{l}60 \\
80 \\
70\end{array}$ \\
\hline $\begin{array}{l}1903 \\
1092\end{array}$ & $\begin{array}{l}\text { 2-Mo. Average .... } \\
\text { 2-Mo. Average .... }\end{array}$ & $\begin{array}{l}76 \\
60\end{array}$ & $\begin{array}{l}0 \\
0\end{array}$ & $\begin{array}{l}60 \\
18\end{array}$ & $\begin{array}{r}68 \\
9\end{array}$ & $\begin{array}{l}30 \\
28\end{array}$ & $\begin{array}{l}0 \\
0\end{array}$ & $\begin{array}{r}0 \\
10\end{array}$ & $\begin{array}{l}0 \\
0\end{array}$ & $\begin{array}{l}35 \\
26\end{array}$ & $\begin{array}{l}0 \\
0\end{array}$ & $\begin{array}{r}85 \\
100\end{array}$ & $\begin{array}{l}53 \\
78\end{array}$ \\
\hline
\end{tabular}

See footnotes at end of table. 
Table S3. Crude Oil and Petroleum Product Imports, 1981 - Present (Continued) (Thousand Barrels per Day)

\begin{tabular}{|c|c|c|c|c|c|c|c|c|c|c|c|}
\hline & \multirow{3}{*}{ Yearkinonth } & \multicolumn{8}{|c|}{ Imports from Non-OPEC sources" } & & \\
\hline & & \multicolumn{2}{|c|}{$\begin{array}{l}\text { United } \\
\text { Kingdem }\end{array}$} & \multicolumn{2}{|c|}{$\begin{array}{l}\text { Virgin } \\
\text { Inlunde }\end{array}$} & \multicolumn{2}{|c|}{$\begin{array}{l}\text { Other } \\
\text { Non: } \\
\text { opse }\end{array}$} & \multicolumn{2}{|c|}{$\begin{array}{l}\text { Total } \\
\text { Non- } \\
\text { Opgé }\end{array}$} & \multicolumn{2}{|c|}{$\begin{array}{c}\text { Total } \\
\text { Importa }\end{array}$} \\
\hline & & Total & Crude OII & Total & Crude OII & Total & Crude OII & Total & Crude Oll & Total & Crude oll \\
\hline $\begin{array}{l}1991 \\
1992 \\
1993 \\
1984 \\
1995 \\
1908 \\
1997 \\
1998 \\
1909 \\
1900 \\
1901\end{array}$ & 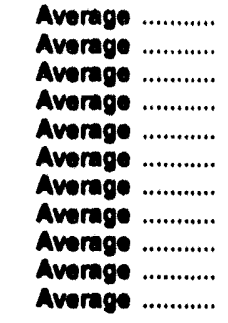 & $\begin{array}{l}375 \\
456 \\
382 \\
402 \\
310 \\
350 \\
352 \\
315 \\
215 \\
189 \\
138\end{array}$ & $\begin{array}{l}369 \\
441 \\
365 \\
378 \\
278 \\
317 \\
304 \\
254 \\
160 \\
155 \\
108\end{array}$ & $\begin{array}{l}327 \\
316 \\
282 \\
294 \\
247 \\
244 \\
272 \\
242 \\
321 \\
282 \\
243\end{array}$ & $\begin{array}{l}0 \\
0 \\
0 \\
0 \\
0 \\
0 \\
0 \\
0 \\
0 \\
0 \\
0\end{array}$ & $\begin{array}{l}238 \\
308 \\
378 \\
411 \\
384 \\
420 \\
450 \\
487 \\
467 \\
417 \\
202\end{array}$ & $\begin{array}{l}163 \\
174 \\
215 \\
210 \\
137 \\
144 \\
189 \\
198 \\
197 \\
180 \\
137\end{array}$ & $\begin{array}{l}2,672 \\
2,908 \\
3,189 \\
3,389 \\
3,237 \\
3,387 \\
3,617 \\
3,082 \\
3,921 \\
3,721 \\
3,538\end{array}$ & $\begin{array}{l}1,474 \\
1,784 \\
1,853 \\
1,914 \\
1,898 \\
2,005 \\
2,274 \\
2,411 \\
2,407 \\
2,381 \\
2,405\end{array}$ & $\begin{array}{l}5,998 \\
8,113 \\
8,081 \\
8,437 \\
8,007 \\
8,224 \\
8,078 \\
7,402 \\
8,081 \\
8,018 \\
7,027\end{array}$ & $\begin{array}{l}4,300 \\
3,488 \\
3,320 \\
3,420 \\
3,201 \\
4,178 \\
4,074 \\
8,107 \\
8,043 \\
5,094 \\
5,702\end{array}$ \\
\hline $1 \operatorname{sen}$ & 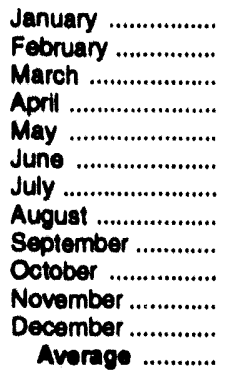 & $\begin{array}{r}129 \\
63 \\
79 \\
157 \\
198 \\
248 \\
354 \\
295 \\
341 \\
411 \\
336 \\
148 \\
230\end{array}$ & $\begin{array}{r}115 \\
0 \\
52 \\
128 \\
180 \\
206 \\
337 \\
282 \\
291 \\
411 \\
285 \\
110 \\
200\end{array}$ & $\begin{array}{l}250 \\
222 \\
202 \\
234 \\
246 \\
266 \\
280 \\
263 \\
217 \\
254 \\
274 \\
273 \\
249\end{array}$ & $\begin{array}{l}0 \\
0 \\
0 \\
0 \\
0 \\
0 \\
0 \\
0 \\
0 \\
0 \\
0 \\
0 \\
0\end{array}$ & $\begin{array}{l}208 \\
196 \\
345 \\
458 \\
467 \\
297 \\
415 \\
464 \\
382 \\
279 \\
219 \\
283 \\
335\end{array}$ & $\begin{array}{r}59 \\
50 \\
114 \\
212 \\
225 \\
95 \\
152 \\
357 \\
160 \\
144 \\
124 \\
92 \\
149\end{array}$ & $\begin{array}{l}3,488 \\
3,278 \\
3,462 \\
4,007 \\
3,705 \\
3,917 \\
4,140 \\
4,116 \\
3,904 \\
3,988 \\
3,786 \\
3,734 \\
3,793\end{array}$ & $\begin{array}{l}2,402 \\
2,184 \\
2,380 \\
2,793 \\
2,633 \\
2,741 \\
3,024 \\
2,984 \\
2,687 \\
2,964 \\
2,745 \\
2,556 \\
2,678\end{array}$ & $\begin{array}{l}7,712 \\
6,827 \\
7,068 \\
8,092 \\
7,823 \\
7,946 \\
8,479 \\
8,260 \\
8,178 \\
8,505 \\
7,872 \\
7,839 \\
7,889\end{array}$ & $\begin{array}{l}\mathbf{5 , 9 5 6} \\
\mathbf{5 , 0 7 9} \\
\mathbf{5 , 3 2 1} \\
6,127 \\
\mathbf{6 , 0 6 0} \\
6,171 \\
6,796 \\
6,457 \\
6,218 \\
6,686 \\
6,121 \\
5,937 \\
6,003\end{array}$ \\
\hline 1093 & 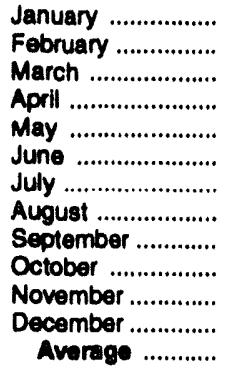 & $\begin{array}{l}228 \\
173 \\
315 \\
348 \\
486 \\
458 \\
292 \\
343 \\
286 \\
352 \\
351 \\
432 \\
340\end{array}$ & $\begin{array}{l}201 \\
127 \\
281 \\
281 \\
458 \\
408 \\
247 \\
323 \\
217 \\
338 \\
340 \\
403 \\
303\end{array}$ & $\begin{array}{l}252 \\
244 \\
244 \\
245 \\
279 \\
290 \\
202 \\
258 \\
184 \\
236 \\
330 \\
288 \\
254\end{array}$ & $\begin{array}{l}0 \\
0 \\
0 \\
0 \\
0 \\
0 \\
0 \\
0 \\
0 \\
0 \\
0 \\
0 \\
0\end{array}$ & $\begin{array}{l}325 \\
223 \\
390 \\
455 \\
356 \\
570 \\
585 \\
520 \\
551 \\
453 \\
468 \\
402 \\
443\end{array}$ & $\begin{array}{l}104 \\
151 \\
188 \\
243 \\
162 \\
405 \\
299 \\
329 \\
251 \\
233 \\
248 \\
231 \\
238\end{array}$ & $\begin{array}{l}3,663 \\
3,425 \\
3,967 \\
3,859 \\
4,039 \\
4,349 \\
4,658 \\
4,196 \\
4,444 \\
4,798 \\
4,506 \\
4,382 \\
4,198\end{array}$ & $\begin{array}{l}2,602 \\
2,457 \\
2,903 \\
2,774 \\
2,919 \\
3,380 \\
3,461 \\
3,082 \\
3,118 \\
3,582 \\
3,262 \\
3,214 \\
3,094\end{array}$ & $\begin{array}{l}7,864 \\
7,830 \\
8,342 \\
8,485 \\
0,346 \\
8,745 \\
9,145 \\
8,360 \\
8,476 \\
9,147 \\
8,725 \\
8,600 \\
8,524\end{array}$ & $\begin{array}{l}6,292 \\
6,156 \\
6,513 \\
6,698 \\
0,548 \\
7,175 \\
7,262 \\
6,614 \\
6,558 \\
7,181 \\
6,892 \\
6,838 \\
6,731\end{array}$ \\
\hline 1904 & $\begin{array}{l}\text { January ............... } \\
\text { February ............... } \\
\text { 2-No. Averag ..... }\end{array}$ & $\begin{array}{l}205 \\
290 \\
246\end{array}$ & $\begin{array}{l}161 \\
232 \\
195\end{array}$ & $\begin{array}{l}276 \\
351 \\
312\end{array}$ & $\begin{array}{l}0 \\
0 \\
0\end{array}$ & $\begin{array}{l}353 \\
441 \\
305\end{array}$ & $\begin{array}{r}181 \\
111 \\
146\end{array}$ & $\begin{array}{l}4,271 \\
4,687 \\
4,460\end{array}$ & $\begin{array}{l}3,041 \\
3,077 \\
3,088\end{array}$ & $\begin{array}{l}7,914 \\
8,501 \\
8,193\end{array}$ & $\begin{array}{l}5,961 \\
6,313 \\
6,128\end{array}$ \\
\hline $\begin{array}{l}1903 \\
1902\end{array}$ & $\begin{array}{l}\text { 2-Mo. Average ..... } \\
\text { 2-Mo. Average ..... }\end{array}$ & $\begin{array}{r}202 \\
97\end{array}$ & $\begin{array}{r}168 \\
59\end{array}$ & $\begin{array}{l}248 \\
237\end{array}$ & $\begin{array}{l}0 \\
0\end{array}$ & $\begin{array}{l}277 \\
202\end{array}$ & $\begin{array}{r}128 \\
55\end{array}$ & $\begin{array}{l}3,680 \\
3,380\end{array}$ & $\begin{array}{l}2,533 \\
2,207\end{array}$ & $\begin{array}{l}7,948 \\
7,284\end{array}$ & $\begin{array}{l}6,227 \\
5,532\end{array}$ \\
\hline
\end{tabular}

\footnotetext{
Includes petroleum imported into the United States indirectly from members of the Organization of Petroleum Exporting Countries (OPEC) primarily from Caribbean and West Eurcpean areas as petroleum products that were refined from crude oll produced by OPEC.

Imports from the Neutral Zone between Kuwait and Saudi Arabla are included in imports from Saudi Arabla.

' On December 31, 1992, Ecuador withdrew as a member of OPEC. As of January 1, 1994, imports of petroleum from Ecuador appear under imports from Non-OPEC Sources.

Excludes petroleum imported into the United States indirectly trom members of the Organization of Petroleum Exporting Countries (OPEC), primarily trom Caribbean and West European areas, as petroleum products that were refined from crude oll produced by OPEC.

Imports from other States in the former U.S.S.R. may be included in imports from Russia for the years 1981 through 1992.

A small amount of Iranian crude oll entered the United States in January 1988 from the Virgin Isiands. This oil originated in Iran and was exported to the Virgin Islands prior to the signing of Executive Order 12613 on October 29, 1987.

(s) = Less than 500 barrels per day.

Notes: - Geographic coverage is the 50 States and the District of Columbia. - Totals may not equal sum of components due to independent rounding Source: See Summary Statistics Table and Figure Sources.
} 
Figure S5. Finished Motor Gasoline Supply and Disposition, February 1993 - Present

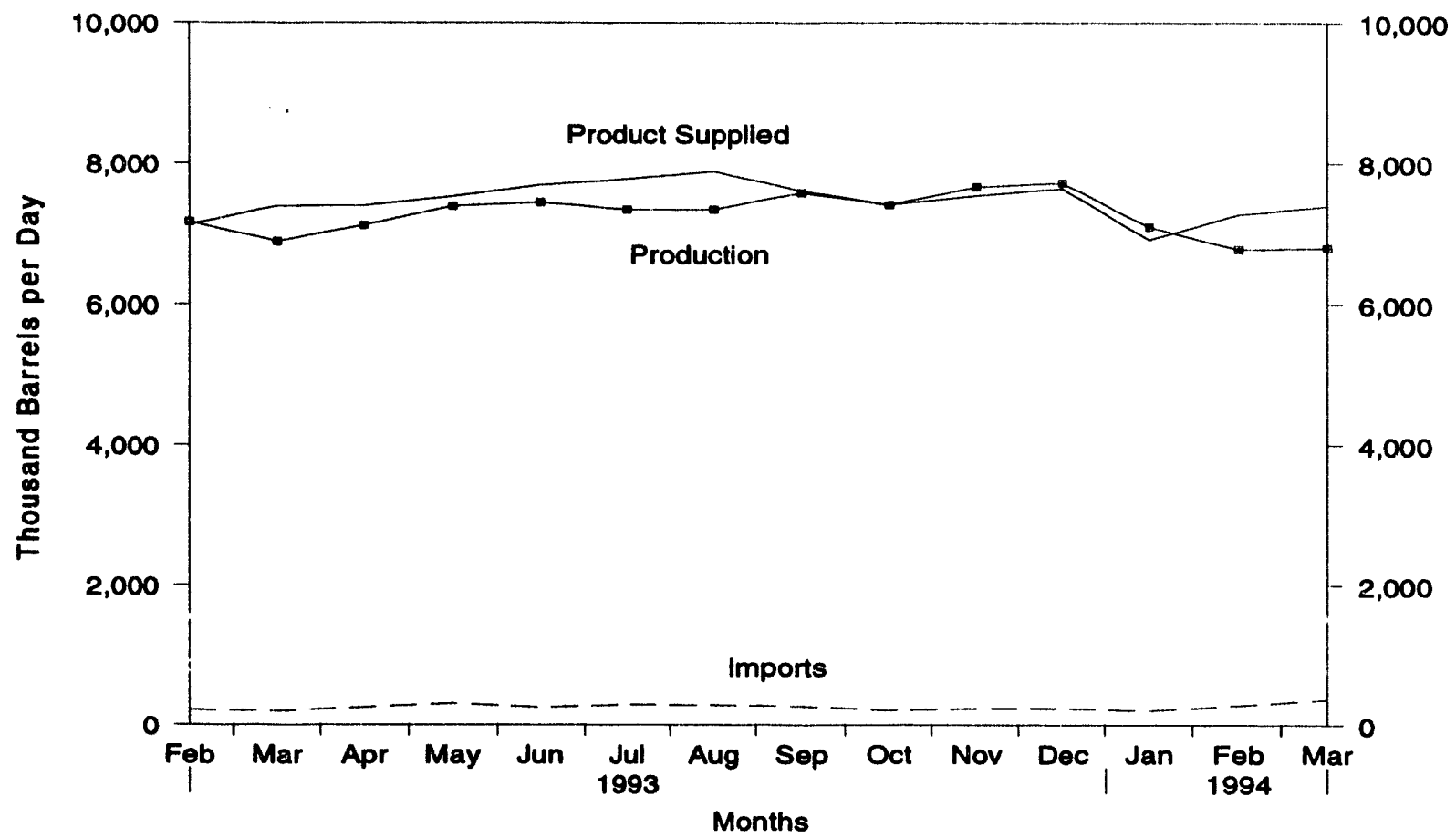

Source: Energy Information Administration, Petroleum Supply Monthly, Table S4. See Summary Statistics Table and Figure Sources.

Figure S6. Motor Gasoline Ending Stocks, February 1993 - Present

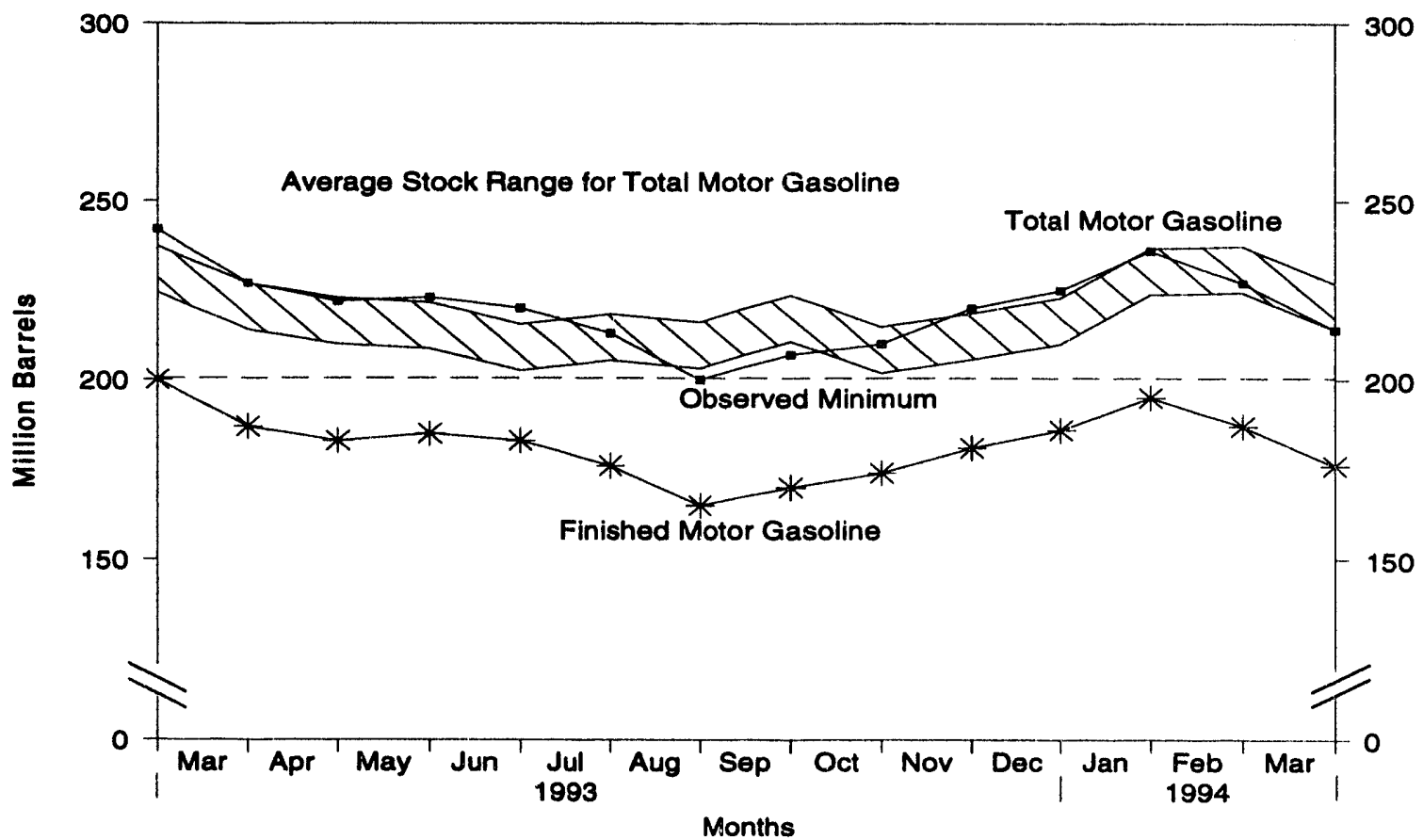

Note: - Total motor gasoline includes motor gasoline blending components and finished motor gasoline. - The Observed Minimum for total motor gasoline stocks in the last 36-month period was 200.5 million barrels, occurring in August 1993.

Source: Energy Information Administration, Petroleum Supply Monthly, Table S4. See Summary Statistics Table and Figure Sources. 
Table S4. Finished Motor Gasoline Supply and Disposition, 1981 - Present (Thousand Barrels per Day, Except Where Noted)

\begin{tabular}{|c|c|c|c|c|c|c|c|c|c|}
\hline & \multirow{3}{*}{ Year/Month } & \multicolumn{2}{|c|}{ Supply } & \multicolumn{3}{|c|}{ Disposition } & \multirow{2}{*}{\multicolumn{2}{|c|}{$\begin{array}{l}\text { Ending Stocks } \\
\text { (Million Barrels) }\end{array}$}} & \multirow{3}{*}{$\begin{array}{c}\begin{array}{c}\text { Ending Stocks } \\
\text { (Million Barrels) }\end{array} \\
\text { Oxygenates }\end{array}$} \\
\hline & & \multirow{2}{*}{$\begin{array}{c}\text { Total } \\
\text { Production }\end{array}$} & \multirow[b]{2}{*}{ Imports ${ }^{c}$} & \multirow{2}{*}{$\begin{array}{c}\text { Stock } \\
\text { Change } \\
\text { c,d }\end{array}$} & \multirow[b]{2}{*}{ Exports } & \multirow{2}{*}{$\begin{array}{l}\text { Product } \\
\text { Supplied }\end{array}$} & & & \\
\hline & & & & & & & Total $^{\circ}$ & Finished & \\
\hline $\begin{array}{l}1981 \\
1982 \\
1983 \\
1984 \\
1985 \\
1986 \\
1987 \\
1988 \\
1989 \\
1980 \\
1991\end{array}$ & $\begin{array}{l}\text { Average ............. } \\
\text { Average .............. } \\
\text { Average ............ } \\
\text { Average .............. } \\
\text { Average ............. } \\
\text { Average } \\
\text { Average } \\
\text { Average }\end{array}$ & $\begin{array}{l}6,405 \\
6,338 \\
6,340 \\
6,453 \\
6,419 \\
6,752 \\
6,841 \\
6,956 \\
6,963 \\
6,959 \\
6,975\end{array}$ & $\begin{array}{l}157 \\
197 \\
247 \\
299 \\
381 \\
326 \\
384 \\
405 \\
369 \\
342 \\
297\end{array}$ & $\begin{array}{r}1-28 \\
-25 \\
-45 \\
54 \\
-41 \\
11 \\
-15 \\
3 \\
-35 \\
10 \\
3\end{array}$ & $\begin{array}{r}2 \\
20 \\
10 \\
6 \\
10 \\
33 \\
35 \\
22 \\
39 \\
55 \\
82\end{array}$ & $\begin{array}{l}6,588 \\
6,539 \\
6,622 \\
6,693 \\
6,831 \\
7,034 \\
7,206 \\
7,336 \\
7,328 \\
7,235 \\
7,188\end{array}$ & $\begin{array}{r}253 \\
235 \\
222 \\
243 \\
223 \\
233 \\
226 \\
228 \\
213 \\
220 \\
219\end{array}$ & $\begin{array}{l}203 \\
194 \\
186 \\
205 \\
190 \\
194 \\
189 \\
190 \\
177 \\
181 \\
182\end{array}$ & $\begin{array}{l}- \\
- \\
- \\
- \\
- \\
- \\
-\end{array}$ \\
\hline 1992 & 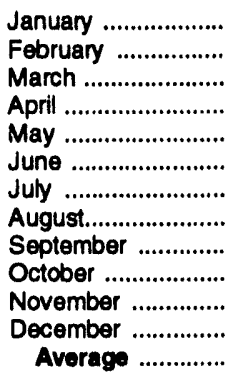 & $\begin{array}{l}7,013 \\
6,726 \\
6,683 \\
6,954 \\
7,092 \\
7,198 \\
7,195 \\
6,817 \\
7,071 \\
7,198 \\
7,323 \\
7,411 \\
7,058\end{array}$ & $\begin{array}{l}246 \\
275 \\
247 \\
428 \\
392 \\
424 \\
303 \\
240 \\
418 \\
193 \\
170 \\
202 \\
294\end{array}$ & $\begin{array}{r}304 \\
-22 \\
-278 \\
54 \\
74 \\
76 \\
-249 \\
-446 \\
60 \\
-41 \\
318 \\
32 \\
-11\end{array}$ & $\begin{array}{r}87 \\
59 \\
71 \\
90 \\
82 \\
86 \\
108 \\
123 \\
85 \\
94 \\
74 \\
184 \\
96\end{array}$ & $\begin{array}{l}6,869 \\
6,963 \\
7,137 \\
7,238 \\
7,328 \\
7,460 \\
7,639 \\
7,380 \\
7,344 \\
7,338 \\
7,102 \\
7,396 \\
7,268\end{array}$ & $\begin{array}{r}229 \\
230 \\
220 \\
218 \\
220 \\
225 \\
215 \\
201 \\
206 \\
204 \\
214 \\
216 \\
-\end{array}$ & $\begin{array}{r}191 \\
191 \\
182 \\
183 \\
186 \\
188 \\
180 \\
167 \\
168 \\
167 \\
177 \\
178 \\
-\end{array}$ & $\begin{array}{l}- \\
- \\
- \\
- \\
- \\
- \\
- \\
- \\
- \\
-\end{array}$ \\
\hline 1993 & 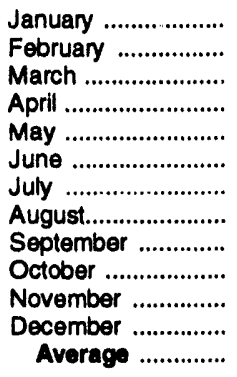 & $\begin{array}{l}7,254 \\
7,172 \\
6,897 \\
7,123 \\
7,394 \\
7,447 \\
7,344 \\
7,344 \\
7,583 \\
7,409 \\
7,664 \\
7,722 \\
7,363\end{array}$ & $\begin{array}{l}204 \\
216 \\
198 \\
253 \\
308 \\
251 \\
292 \\
283 \\
269 \\
210 \\
237 \\
238 \\
247\end{array}$ & $\begin{array}{r}571 \\
160 \\
-411 \\
-137 \\
80 \\
-75 \\
-242 \\
-336 \\
154 \\
127 \\
237 \\
152 \\
22\end{array}$ & $\begin{array}{r}142 \\
99 \\
109 \\
111 \\
90 \\
81 \\
100 \\
77 \\
85 \\
80 \\
123 \\
165 \\
105\end{array}$ & $\begin{array}{l}6,746 \\
7,129 \\
7,397 \\
7,401 \\
7,551 \\
7,692 \\
7,777 \\
7,885 \\
7,612 \\
7,411 \\
7,541 \\
7,643 \\
7,483\end{array}$ & $\begin{array}{r}237 \\
242 \\
227 \\
222 \\
223 \\
220 \\
213 \\
200 \\
207 \\
210 \\
220 \\
225 \\
-\end{array}$ & $\begin{array}{r}195 \\
200 \\
187 \\
183 \\
185 \\
183 \\
176 \\
165 \\
170 \\
174 \\
181 \\
186 \\
-\end{array}$ & $\begin{array}{l}14 \\
13 \\
14 \\
15 \\
17 \\
18 \\
20 \\
21 \\
20 \\
17 \\
15 \\
13 \\
-\end{array}$ \\
\hline 1994 & $\begin{array}{l}\text { January .................. } \\
\text { February .................. } \\
\text { March" ................. } \\
\text { 3-Mo. Average ....... }\end{array}$ & $\begin{array}{l}7,098 \\
R_{6,780} \\
E_{6,799} \\
E_{6,896}\end{array}$ & $\begin{array}{l}R_{281}^{206} \\
E_{364} \\
E_{284}\end{array}$ & $\begin{array}{l}291 \\
R-288 \\
E-334 \\
E-105\end{array}$ & $\begin{array}{r}R_{77}^{97} \\
E_{105} \\
E_{93}\end{array}$ & $\begin{array}{l}R_{7,916}^{6} \\
E_{7,272} \\
E_{7,392}\end{array}$ & $\begin{array}{r}236 \\
R_{227}^{214} \\
-\end{array}$ & $\begin{array}{r}195 \\
187 \\
176 \\
-\end{array}$ & $\begin{array}{r}11 \\
11 \\
\text { NA } \\
-\end{array}$ \\
\hline $\begin{array}{l}1993 \\
1992\end{array}$ & $\begin{array}{l}\text { 3-Mo. Average ...... } \\
\text { 3-Mo. Average ...... }\end{array}$ & $\begin{array}{l}7,106 \\
6,809\end{array}$ & $\begin{array}{l}206 \\
256\end{array}$ & $\begin{array}{r}105 \\
2\end{array}$ & $\begin{array}{r}117 \\
73\end{array}$ & $\begin{array}{l}7,089 \\
6,990\end{array}$ & $\overline{-}$ & $\overline{-}$ & $\overline{-}$ \\
\hline
\end{tabular}

\footnotetext{
a Stocks are totals as of end of period.

b Beginning in 1993, motor gasoline production and product supplied inciudes blending of fuel ethanol and an adjustment to correct for the imbalance of motor gasoline blending components.

c Beginning in 1981, excludes blending components.

d A negative number indicates a decrease in stocks and a positive number indicates an increase.

- Includes motor gasoline blending components but excludes stocks of oxygenates.

I In January 1981 and 1983, numerous respondents were added to surveys affecting stocks reported and stock change calculations. Stock changes are calculated using new basis stock levels. See Summary Statistics Explanatory Note 4.

$\mathrm{R}=$ Revised data. $E=$ Estimated. $\mathrm{NA}=$ Not Available.

- See Summary Statistics Explanatory Note 1.

Notes: - Italics denote estimates based upon preliminary data. - Geographic coverage is the 50 States and the District of Columbia. - Totals may not equal sum of components due to independent rounding.

Source: See Summary Statistics Table and Figure Sources.
} 
Figure S7. Distillate Fuel Oil Supply and Disposition, February 1993 - Present

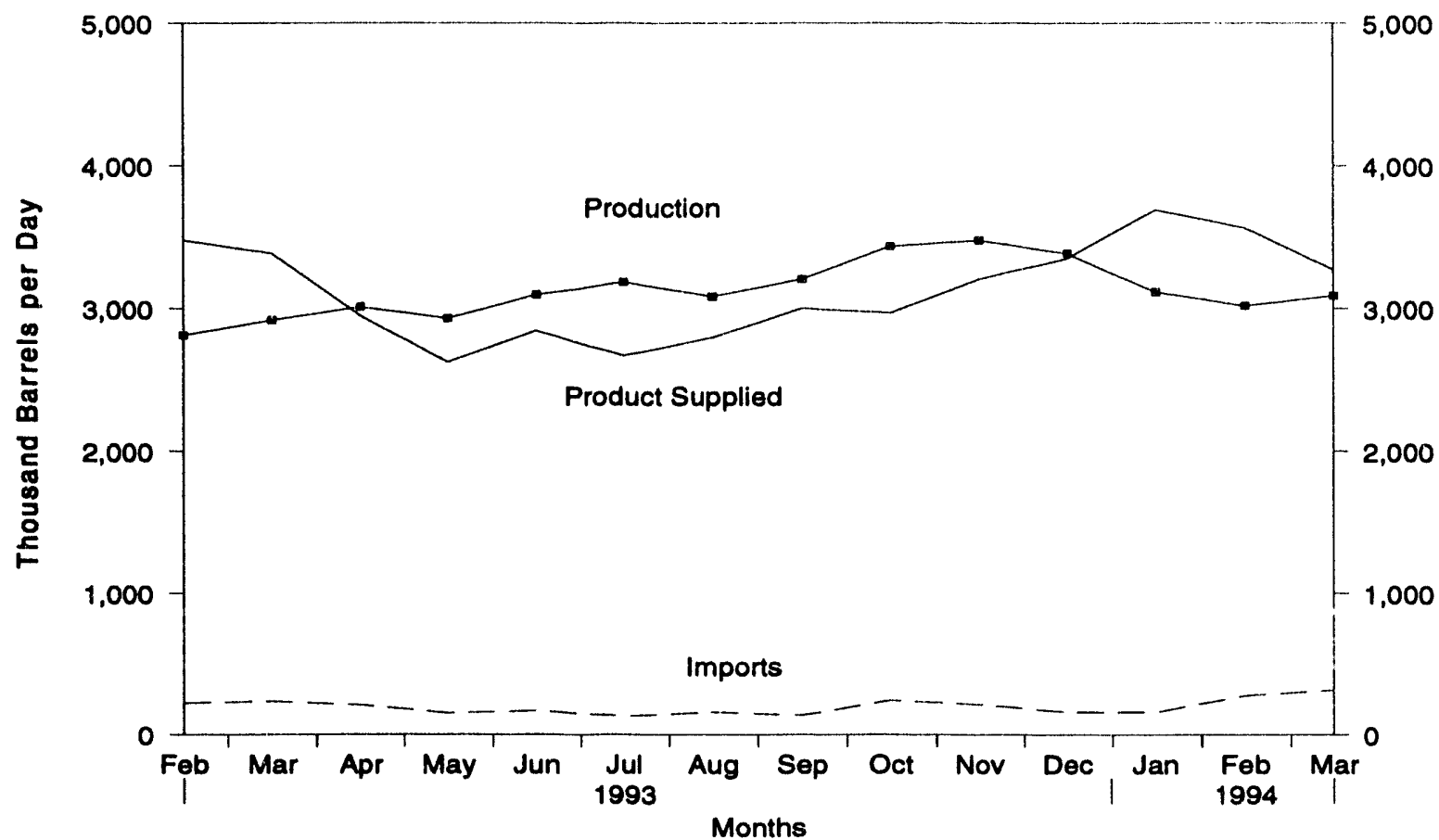

Source: Energy Information Administration, Petroleum Supply Monthly, Table S5. See Summary Statistics Table and Figure Sources.

Figure S8. Distillate Fuel Oll Ending Stocks, February 1993 - Present

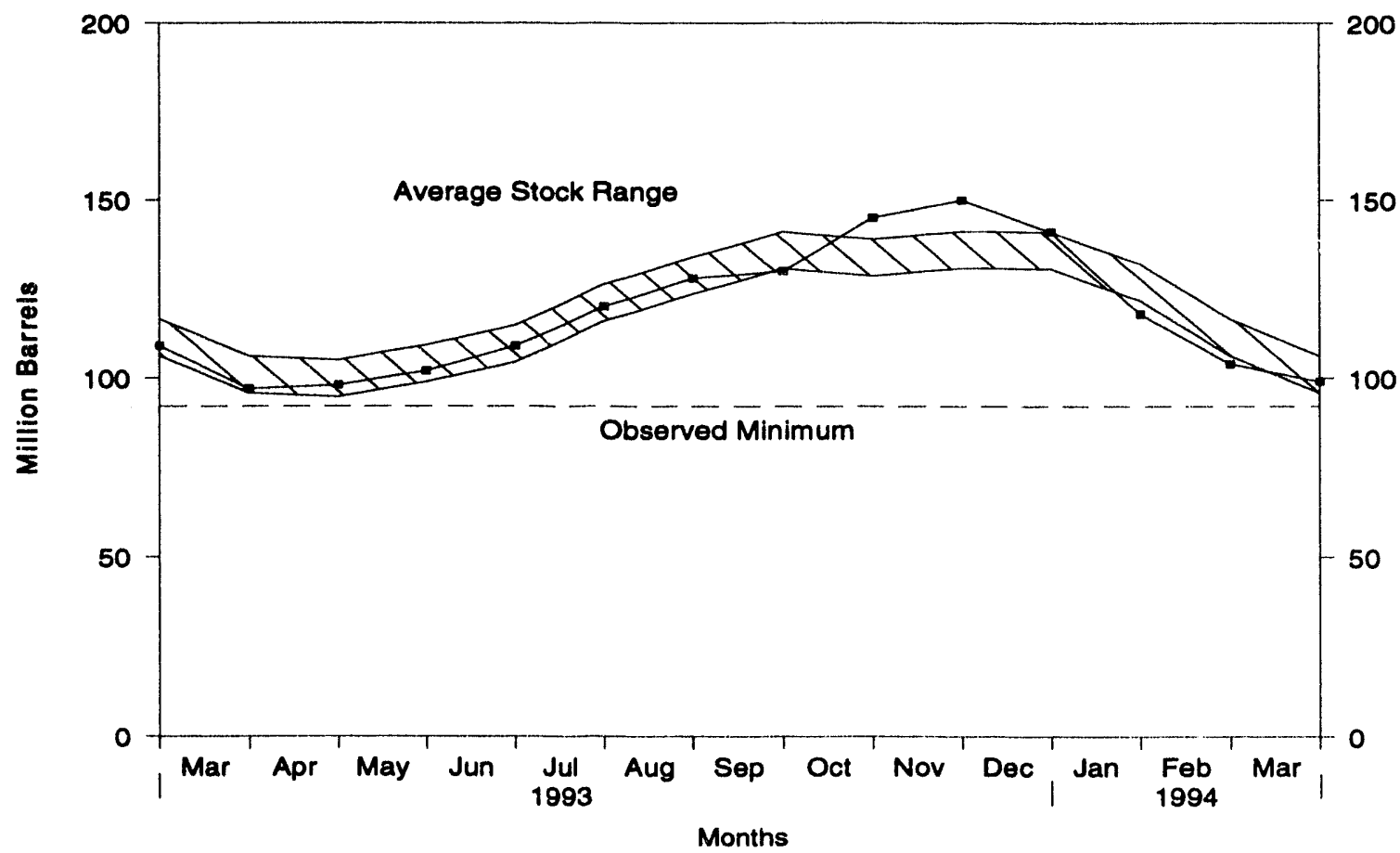

Note: The Observed Minimum for distillate fuel oil stocks in the last 36-month period was 92.1 million barrels, occurring in April 1992.

Source: Energy Information Administration, Petroleum Supply Monthly, Table S5. See Summary Statistics Table and Figure Sources. 
Table S5. Distillate Fuel Oil Supply and Disposition, 1981 - Present (Thousand Barrels per Day, Except Where Noted)

\begin{tabular}{|c|c|c|c|c|c|c|c|c|c|}
\hline & \multirow{3}{*}{ Year/Month } & \multicolumn{2}{|c|}{ Supply } & \multicolumn{3}{|c|}{ Disposition } & \multirow{2}{*}{\multicolumn{3}{|c|}{$\begin{array}{l}\text { Ending Stocks" } \\
\text { (Million Barrels) }\end{array}$}} \\
\hline & & \multirow[b]{2}{*}{$\begin{array}{c}\text { Total } \\
\text { Production }\end{array}$} & \multirow[b]{2}{*}{ Imports } & \multirow[b]{2}{*}{$\begin{array}{l}\text { Stock } \\
\text { Change }\end{array}$} & \multirow[b]{2}{*}{ Exports } & \multirow[b]{2}{*}{$\begin{array}{l}\text { Product } \\
\text { Supplied }\end{array}$} & & & \\
\hline & & & & & & & Total & $\begin{array}{l}0.05 \% \text { Sulfur } \\
\text { and Under }\end{array}$ & $\begin{array}{l}\text { Greater than } \\
0.05 \% \text { Sulfur }\end{array}$ \\
\hline $\begin{array}{l}1981 \\
1982 \\
1983 \\
1984 \\
1985 \\
1986 \\
1987 \\
1988 \\
1989 \\
1980 \\
1991\end{array}$ & 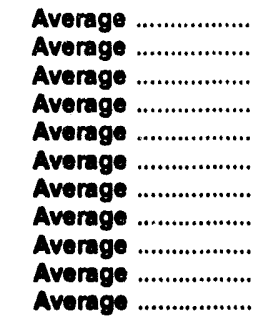 & $\begin{array}{l}2,613 \\
2,606 \\
2,456 \\
2,681 \\
2,687 \\
2,798 \\
2,731 \\
2,859 \\
2,899 \\
2,925 \\
2,962 \\
\end{array}$ & $\begin{array}{r}173 \\
93 \\
174 \\
272 \\
200 \\
247 \\
255 \\
302 \\
306 \\
278 \\
205\end{array}$ & $\begin{array}{r}d-38 \\
-35 \\
d-124 \\
57 \\
-48 \\
31 \\
-56 \\
-30 \\
-49 \\
73 \\
31\end{array}$ & $\begin{array}{r}5 \\
74 \\
64 \\
51 \\
67 \\
100 \\
66 \\
69 \\
97 \\
109 \\
215\end{array}$ & $\begin{array}{l}2,829 \\
2,671 \\
2,690 \\
2,845 \\
2,868 \\
2,914 \\
2,976 \\
3,122 \\
3,157 \\
3,021 \\
2,921\end{array}$ & $\begin{array}{r}192 \\
d 179 \\
140 \\
161 \\
144 \\
155 \\
134 \\
124 \\
108 \\
132 \\
144\end{array}$ & $\begin{array}{l}- \\
- \\
- \\
- \\
- \\
- \\
-\end{array}$ & $\begin{array}{l}- \\
- \\
- \\
- \\
- \\
- \\
- \\
-\end{array}$ \\
\hline 1992 & 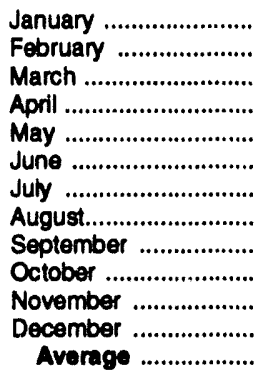 & $\begin{array}{l}2,818 \\
2,661 \\
2,749 \\
2,930 \\
2,933 \\
2,995 \\
3,067 \\
2,865 \\
2,983 \\
3,251 \\
3,240 \\
3,179 \\
2,974\end{array}$ & $\begin{array}{l}232 \\
217 \\
238 \\
202 \\
179 \\
157 \\
172 \\
229 \\
237 \\
263 \\
236 \\
229 \\
216\end{array}$ & $\begin{array}{r}-541 \\
-619 \\
-358 \\
-185 \\
139 \\
268 \\
328 \\
262 \\
168 \\
290 \\
316 \\
-183 \\
-8\end{array}$ & $\begin{array}{l}360 \\
278 \\
138 \\
278 \\
222 \\
205 \\
201 \\
127 \\
145 \\
169 \\
230 \\
276 \\
219\end{array}$ & $\begin{array}{l}3,231 \\
3,219 \\
3,207 \\
3,039 \\
2,753 \\
2,679 \\
2,710 \\
2,705 \\
2,908 \\
3,056 \\
2,929 \\
3,316 \\
2,979\end{array}$ & $\begin{array}{r}127 \\
109 \\
98 \\
92 \\
96 \\
104 \\
115 \\
123 \\
128 \\
137 \\
146 \\
141 \\
-\end{array}$ & $\begin{array}{l}- \\
- \\
- \\
- \\
- \\
\overline{-} \\
- \\
-\end{array}$ & $\begin{array}{l}- \\
- \\
- \\
\overline{-} \\
\overline{-} \\
\overline{-} \\
\overline{-}\end{array}$ \\
\hline 1993 & 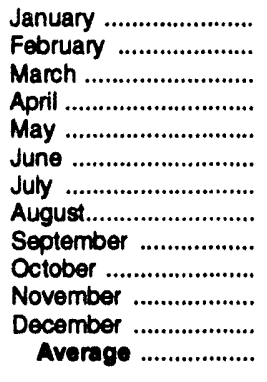 & $\begin{array}{l}2,909 \\
2,813 \\
2,918 \\
3,010 \\
2,930 \\
3,095 \\
3,185 \\
3,084 \\
3,206 \\
3,435 \\
3,478 \\
3,385 \\
3,123\end{array}$ & $\begin{array}{l}182 \\
224 \\
235 \\
209 \\
153 \\
168 \\
130 \\
159 \\
137 \\
242 \\
214 \\
160 \\
184\end{array}$ & $\begin{array}{r}-336 \\
-742 \\
-386 \\
30 \\
104 \\
263 \\
348 \\
249 \\
80 \\
467 \\
156 \\
-266 \\
2\end{array}$ & $\begin{array}{l}287 \\
301 \\
154 \\
241 \\
355 \\
158 \\
298 \\
197 \\
262 \\
241 \\
330 \\
460 \\
274\end{array}$ & $\begin{array}{l}3,141 \\
3,478 \\
3,386 \\
2,949 \\
2,624 \\
2,843 \\
2,669 \\
2,797 \\
3,001 \\
2,968 \\
3,206 \\
3,351 \\
3,031\end{array}$ & $\begin{array}{r}130 \\
109 \\
97 \\
98 \\
102 \\
109 \\
120 \\
128 \\
130 \\
145 \\
150 \\
141 \\
-\end{array}$ & $\begin{array}{l}22 \\
16 \\
12 \\
13 \\
14 \\
17 \\
23 \\
45 \\
47 \\
55 \\
64 \\
63 \\
-\end{array}$ & $\begin{array}{r}108 \\
94 \\
85 \\
86 \\
87 \\
92 \\
97 \\
83 \\
84 \\
90 \\
85 \\
79 \\
-\end{array}$ \\
\hline 1904 & $\begin{array}{l}\text { January ....................... } \\
\text { February ....................... } \\
\text { March" ....................... } \\
\text { 3-Mo. Average ........... }\end{array}$ & $\begin{array}{l}3,117 \\
R_{3,019} \\
E_{3,090} \\
E_{3,077}\end{array}$ & $\begin{array}{l}160 \\
A_{276} \\
E_{315} \\
E_{249}\end{array}$ & $\begin{array}{r}R_{-746}^{-505} \\
E_{-29} \\
E_{-424}\end{array}$ & $\begin{array}{l}332 \\
R_{235} \\
E_{161} \\
E_{243}\end{array}$ & $\begin{array}{l}3,692 \\
R_{3,565} \\
E_{3,272} \\
E_{3,508}\end{array}$ & $\begin{array}{r}118 \\
P_{104} \\
E_{99}\end{array}$ & $\begin{array}{r}56 \\
E_{50}^{49} \\
-\end{array}$ & $\begin{array}{r}R_{55}^{62} \\
E_{49} \\
-\end{array}$ \\
\hline $\begin{array}{l}1993 \\
1992\end{array}$ & $\begin{array}{l}\text { 3-Mo. Average ........... } \\
\text { 3-Mo. Average .......... }\end{array}$ & $\begin{array}{l}2,883 \\
2,744\end{array}$ & $\begin{array}{l}213 \\
229\end{array}$ & $\begin{array}{l}-480 \\
-504\end{array}$ & $\begin{array}{l}245 \\
258\end{array}$ & $\begin{array}{l}3,330 \\
3,219\end{array}$ & $\overline{-}$ & $\overline{-}$ & - \\
\hline
\end{tabular}

a Excludes 10,000 barrels per day in 1981 and 1982. previously published as crude used directly.

b Stocks are totals as of end of period.

c A negative number indicates a decrease in stocks and a positive number indicates an increase.

d In January 1981 and 1983, numerous respondents were added to surveys affecting stocks reported and stock change calculations. Stock changes are calculated using new stock basis stock levels. See Summary Statistics Explanatory Note 4.

$R=$ Revised data. $E=$ Estimated.

- See Summary Statistics Explanatory Note 1.

Notes: - Italics denote estimates based upon preliminary data. - Geographic coverage is the 50 States and the District of Columbia. - Totals may not equal sum of components due to independent rounding.

Source: See Summary Statistics Table and Figure Sources. 


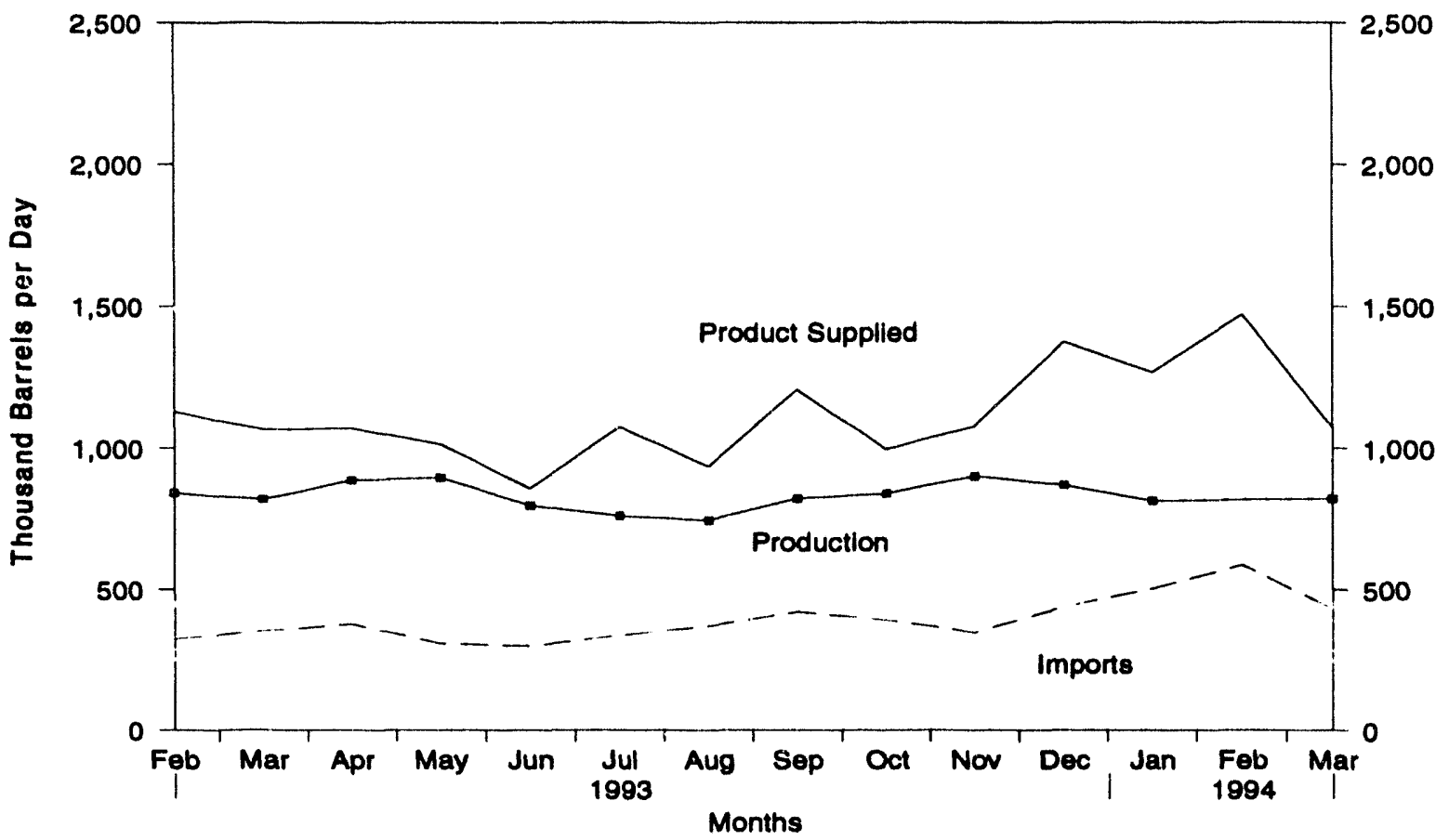

Source: Energy Information Administration, Petroleum Supply Monthly, Table S6. See Summary Statistics Table and Figure Sources.

Figure S10. Residual Fuel Oil Ending Stocks, February 1993 - Present

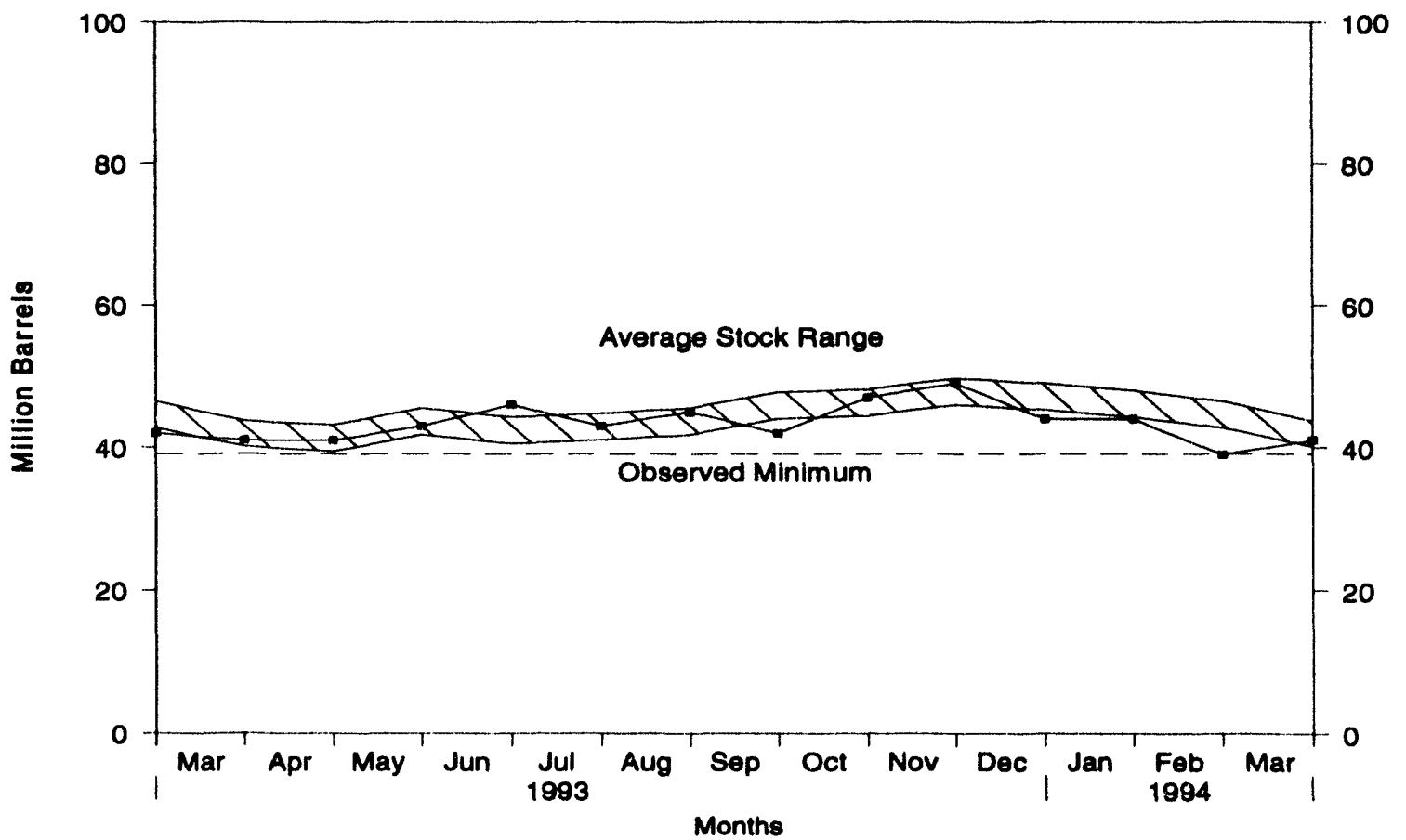

Note: The Observed Minimum for residual fuel oil stocks in the last 36-month period was 39.1 million barrels, occurring in April 1992.

Source: Energy Information Administration, Petroleum Supply Monthly, Table S6. See Summary Statistics Table and Figure Sources. 
Table S6. Residual Fuel Oil Supply and Disposition, 1981 - Present

(Thousand Barrels per Day, Except Where Noted)

\begin{tabular}{|c|c|c|c|c|c|c|c|}
\hline \multirow{2}{*}{\multicolumn{2}{|c|}{ Year/Month }} & \multicolumn{2}{|c|}{ Supply } & \multicolumn{3}{|c|}{ Disposttion } & \multirow[b]{2}{*}{$\begin{array}{c}\text { Ending } \\
\text { Stocke } \\
\text { (Million Barrelo) }\end{array}$} \\
\hline & & $\begin{array}{c}\text { Total } \\
\text { Production }\end{array}$ & Imports & $\begin{array}{l}\text { Stock } \\
\text { Changob }\end{array}$ & Exports & $\begin{array}{l}\text { Product } \\
\text { Supplled }\end{array}$ & \\
\hline $\begin{array}{l}1981 \\
1882 \\
1983 \\
1984 \\
1905 \\
1983 \\
1997 \\
1808 \\
1989 \\
1900 \\
1901\end{array}$ & 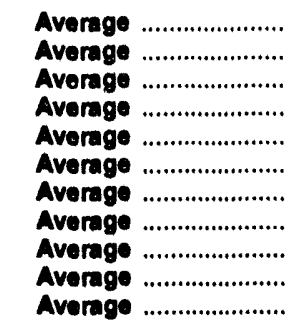 & $\begin{array}{r}1,321 \\
1,070 \\
852 \\
891 \\
882 \\
889 \\
885 \\
926 \\
954 \\
950 \\
934\end{array}$ & $\begin{array}{l}800 \\
776 \\
699 \\
681 \\
510 \\
669 \\
565 \\
644 \\
629 \\
504 \\
453\end{array}$ & $\begin{array}{r}d-37 \\
-32 \\
d-55 \\
12 \\
-7 \\
-8 \\
(0) \\
-8 \\
-2 \\
13 \\
4\end{array}$ & $\begin{array}{l}118 \\
209 \\
185 \\
190 \\
197 \\
147 \\
186 \\
200 \\
215 \\
211 \\
220\end{array}$ & $\begin{array}{l}2,088 \\
1,716 \\
1,421 \\
1,369 \\
1,202 \\
1,418 \\
1,264 \\
1,378 \\
1,370 \\
1,229 \\
1,158\end{array}$ & $\begin{array}{r}78 \\
d 66 \\
49 \\
53 \\
50 \\
47 \\
47 \\
45 \\
44 \\
49 \\
50\end{array}$ \\
\hline 1992 & 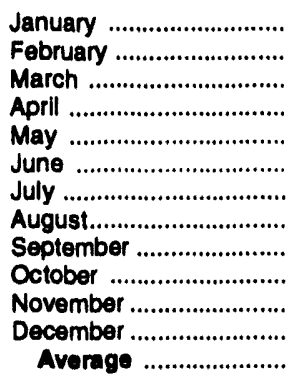 & $\begin{array}{l}965 \\
957 \\
990 \\
900 \\
964 \\
894 \\
838 \\
815 \\
810 \\
818 \\
895 \\
862 \\
892\end{array}$ & $\begin{array}{l}364 \\
498 \\
397 \\
342 \\
328 \\
334 \\
280 \\
347 \\
349 \\
376 \\
411 \\
481 \\
375\end{array}$ & $\begin{array}{r}-144 \\
-55 \\
-77 \\
-78 \\
67 \\
-11 \\
-37 \\
125 \\
123 \\
-72 \\
49 \\
-127 \\
-20\end{array}$ & $\begin{array}{r}184 \\
176 \\
310 \\
265 \\
207 \\
230 \\
169 \\
96 \\
149 \\
156 \\
216 \\
158 \\
193\end{array}$ & $\begin{array}{r}1,289 \\
1,334 \\
1,154 \\
1,055 \\
1,019 \\
1,009 \\
986 \\
941 \\
887 \\
1,110 \\
1,041 \\
1,312 \\
1,004\end{array}$ & $\begin{array}{l}45 \\
44 \\
41 \\
39 \\
41 \\
41 \\
40 \\
44 \\
47 \\
45 \\
47 \\
43 \\
-\end{array}$ \\
\hline 1003 & 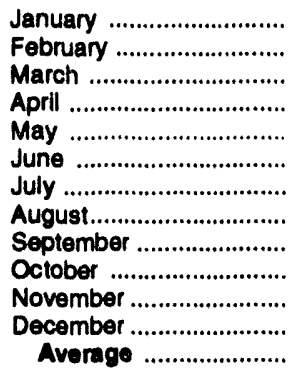 & $\begin{array}{l}820 \\
841 \\
819 \\
887 \\
896 \\
797 \\
760 \\
745 \\
822 \\
839 \\
901 \\
869 \\
833\end{array}$ & $\begin{array}{l}383 \\
325 \\
352 \\
377 \\
308 \\
299 \\
337 \\
370 \\
420 \\
391 \\
347 \\
439 \\
363\end{array}$ & $\begin{array}{r}49 \\
-75 \\
-46 \\
24 \\
53 \\
92 \\
-101 \\
61 \\
-73 \\
141 \\
85 \\
-164 \\
4\end{array}$ & $\begin{array}{r}133 \\
113 \\
152 \\
169 \\
137 \\
147 \\
122 \\
120 \\
110 \\
94 \\
86 \\
98 \\
123\end{array}$ & $\begin{array}{r}1,020 \\
1,128 \\
1,065 \\
1,070 \\
1,014 \\
857 \\
1,075 \\
935 \\
1,205 \\
995 \\
1,077 \\
1,375 \\
1,068\end{array}$ & $\begin{array}{l}44 \\
42 \\
41 \\
41 \\
43 \\
46 \\
43 \\
45 \\
42 \\
47 \\
49 \\
44 \\
-\end{array}$ \\
\hline 1904 & 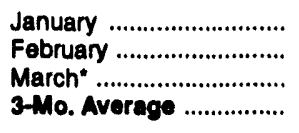 & $\begin{array}{l}813 \\
E_{859} \\
E_{822} \\
E_{830}\end{array}$ & $\begin{array}{l}503 \\
R 586 \\
E_{432} \\
E_{504}\end{array}$ & $\begin{array}{r}-16 \\
R-152 \\
E-26 \\
E-44\end{array}$ & $\begin{array}{r}64 \\
E_{127} \\
E_{154} \\
E_{115}\end{array}$ & $\begin{array}{l}1,267 \\
E_{1,470} \\
E_{1,074} \\
1,263\end{array}$ & $\begin{array}{r}44 \\
R_{39} \\
-\end{array}$ \\
\hline $\begin{array}{l}1893 \\
1892\end{array}$ & $\begin{array}{l}\text { 3-Mo. Average ................ } \\
\text { 3-Mo. Average .............. }\end{array}$ & $\begin{array}{l}826 \\
971\end{array}$ & $\begin{array}{l}354 \\
418\end{array}$ & $\begin{array}{l}-22 \\
-93\end{array}$ & $\begin{array}{l}133 \\
224\end{array}$ & $\begin{array}{l}1,069 \\
1,257\end{array}$ & $\overline{-}$ \\
\hline
\end{tabular}

a Excludes 48,000 barrels per day in 1981 and 1982 previously published as crude used directly.

b A negative number indicates a decrease in stocks and a positive number indicates an increase.

C Stocks are totals as of end of period.

d In January 1981 and 1983 , numerous respondents were added to surveys affecting stocks reported and stock change calculations. Stock changes are calculated using new basis stock levels. See Summary Statistics Explanatory Note 4.

$R=$ Revised data. (s) = Less than 500 barrels per day. $E=$ Estimated.

- See Summary Statistics Explanatory Note 1.

Notes: - Italics denote estimates based upon preliminary data. - Geographic coverage is the 50 States and the District of Columbla. $\bullet$ Totals may not equal sum of components due to independent rounding.

Source: See Summary Statistics Table and Figure Sources. 
Figuro S11. Jot Fuol Supply and Dlsposition, February 1993 - Present

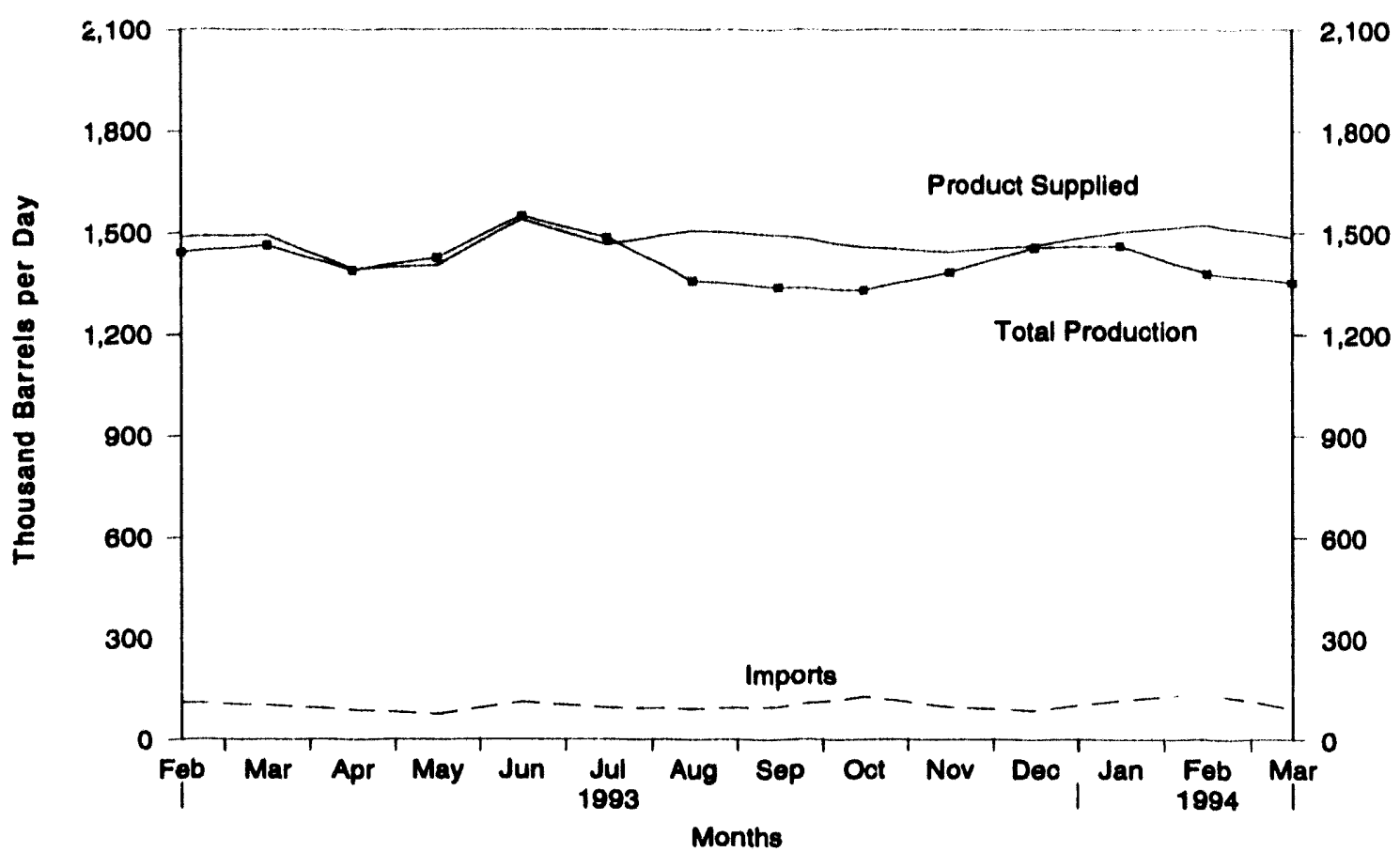

Source: Energy Information Administration, Petroleum Supply Monthly, Table S7. See Summary Statistics Table and Figure Sources.

Figure S12. Jet Fuel Ending Stocks, Fobruary 1993 - Present

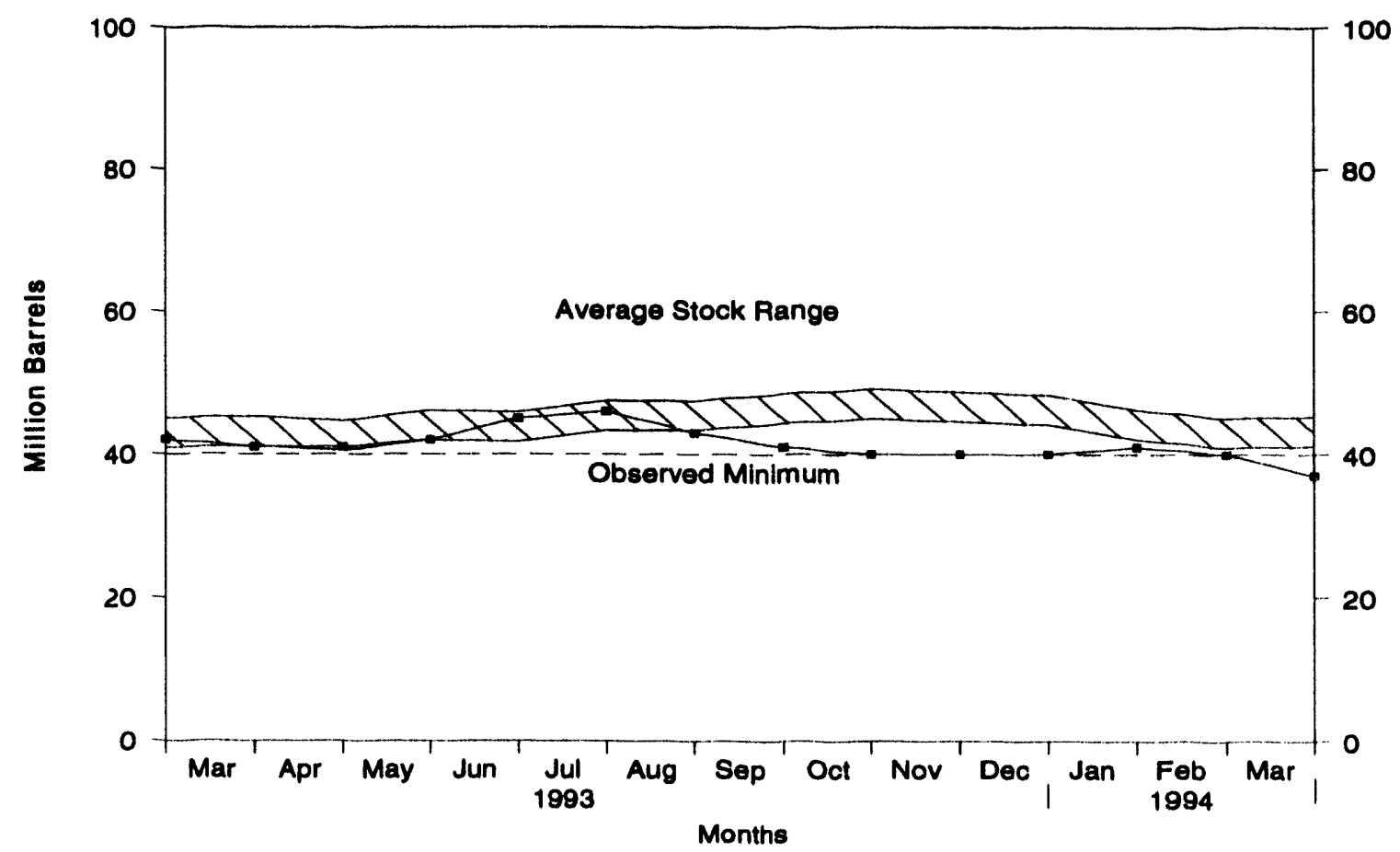

Note: The Observed Minimum for total jet fuel stocks in the last 36-month period was 40.2 million barrels, occurring in February 1994.

Source: Energy Information Administration, Petroleum Supply Monthly, Table S7. See Summany Statistics Table and Figure Sources. 
Table S7. Jet Fuel Supply and Dleposition, 1981 - Present

(Thousand Barrels per Day, Except Where Noted)

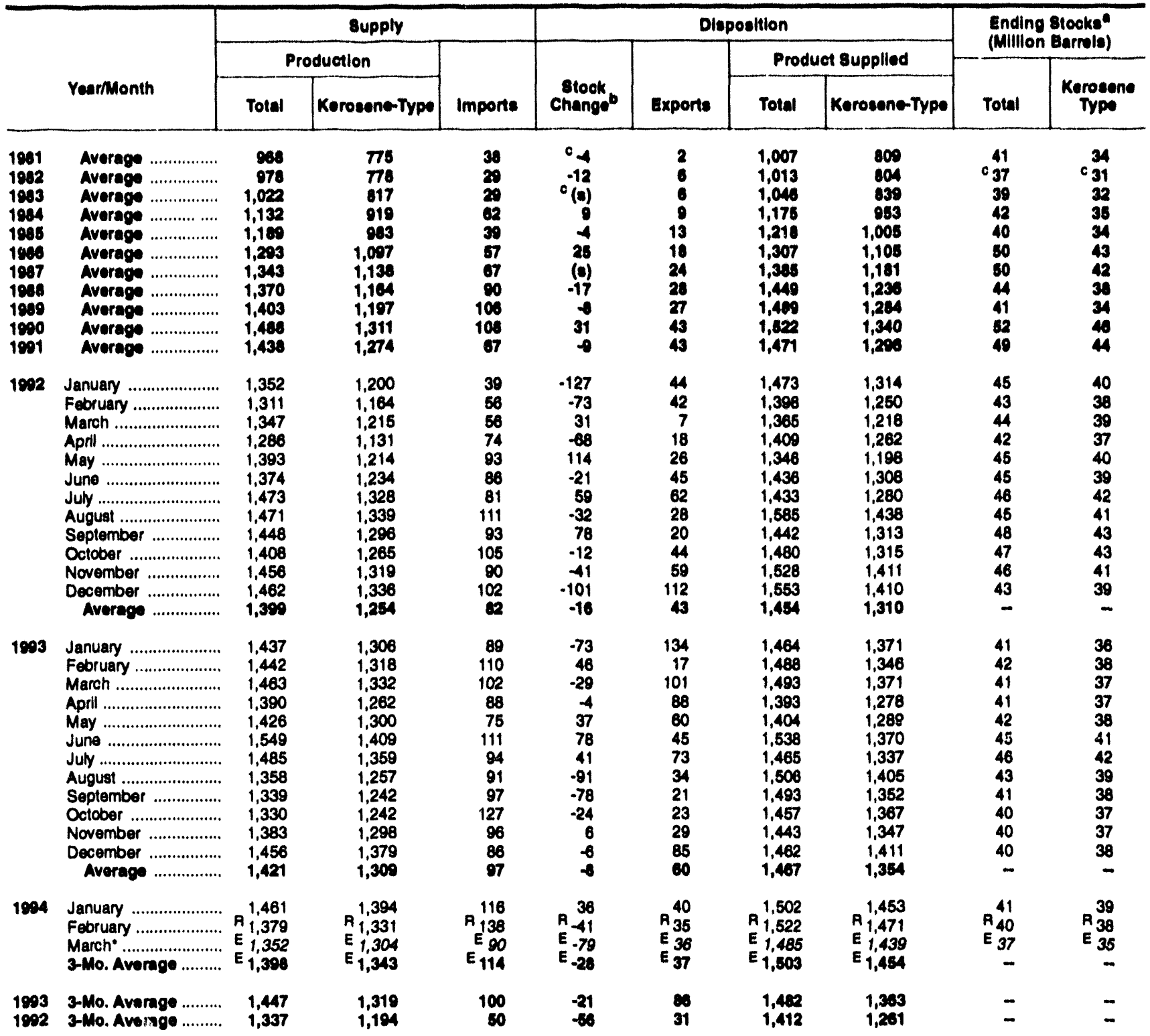

a Stocks are totals as of end of period.

b A negative number indicates a decrease in stocks and a positive number indicates an increase.

c In January 1981, 1983, and 1984, a new stock basis was established affecting stocks repc. ted and stock change calculations. Stock changes are calculated using new basis stock levels. See Summary Statistics Explanatory Note 4.

$R=$ Pevised data. (s) = Less than 500 barrels per day. Ex Estimated.

- See Summary Statistics Explanatory Note 1.

Notes: - Italics denote estimates based upon preliminary data. Geographic coverage is the 50 States and the District of Columbia. - Totals may not equal sum of components due to independent rounding.

Source: See Summary Statistics Table and Figure Sources. 
Figure 813. Propane/Propylene Supply and Dlaposttion, January 1993 - Present

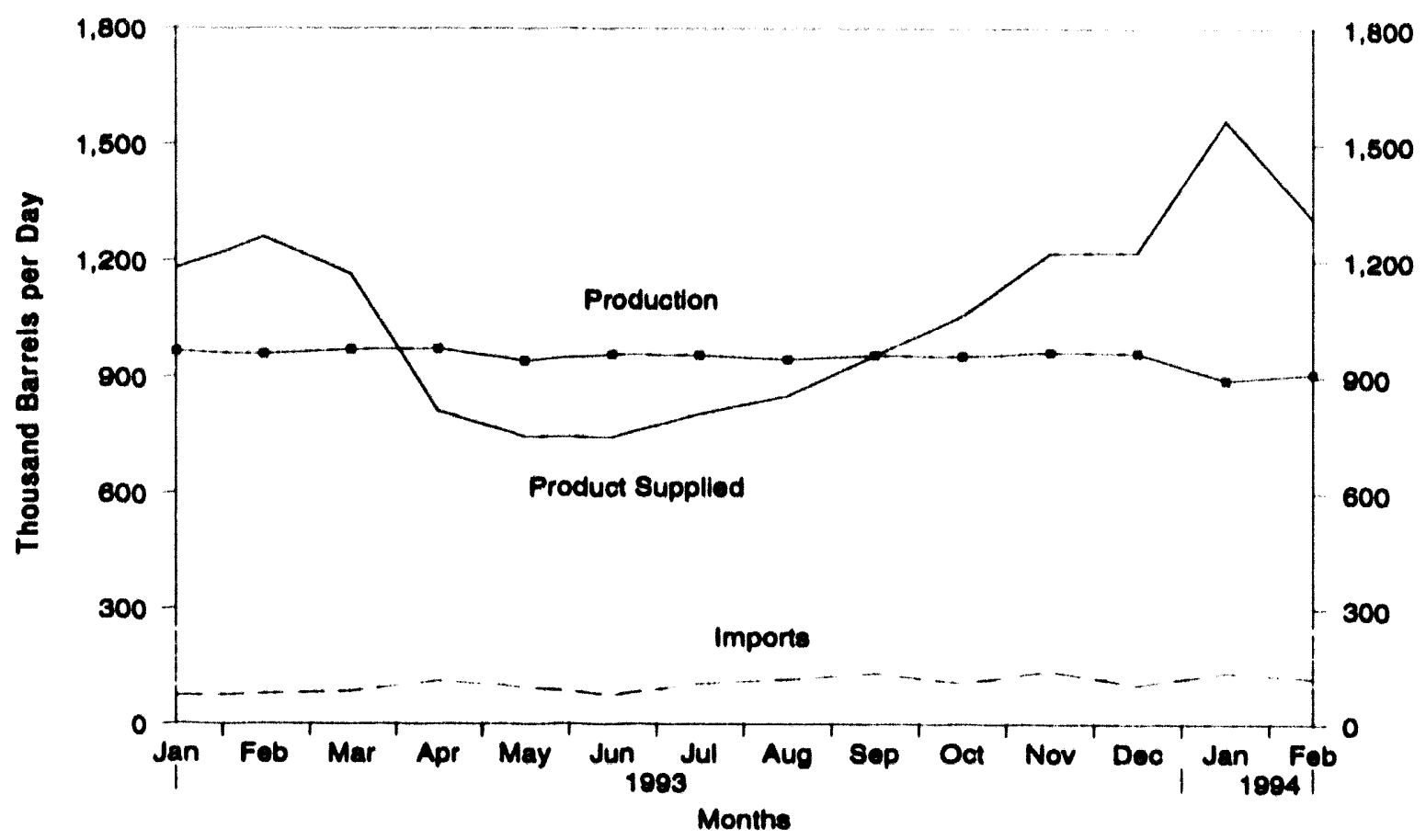

Source: Energy Information Adminibtration, Potroleum Supply Monthly, Table S8. See Summary Statistios Table and Figure Sources.

Figure S14. Propam/Propylene Ending Stocks, January 1993 - Present

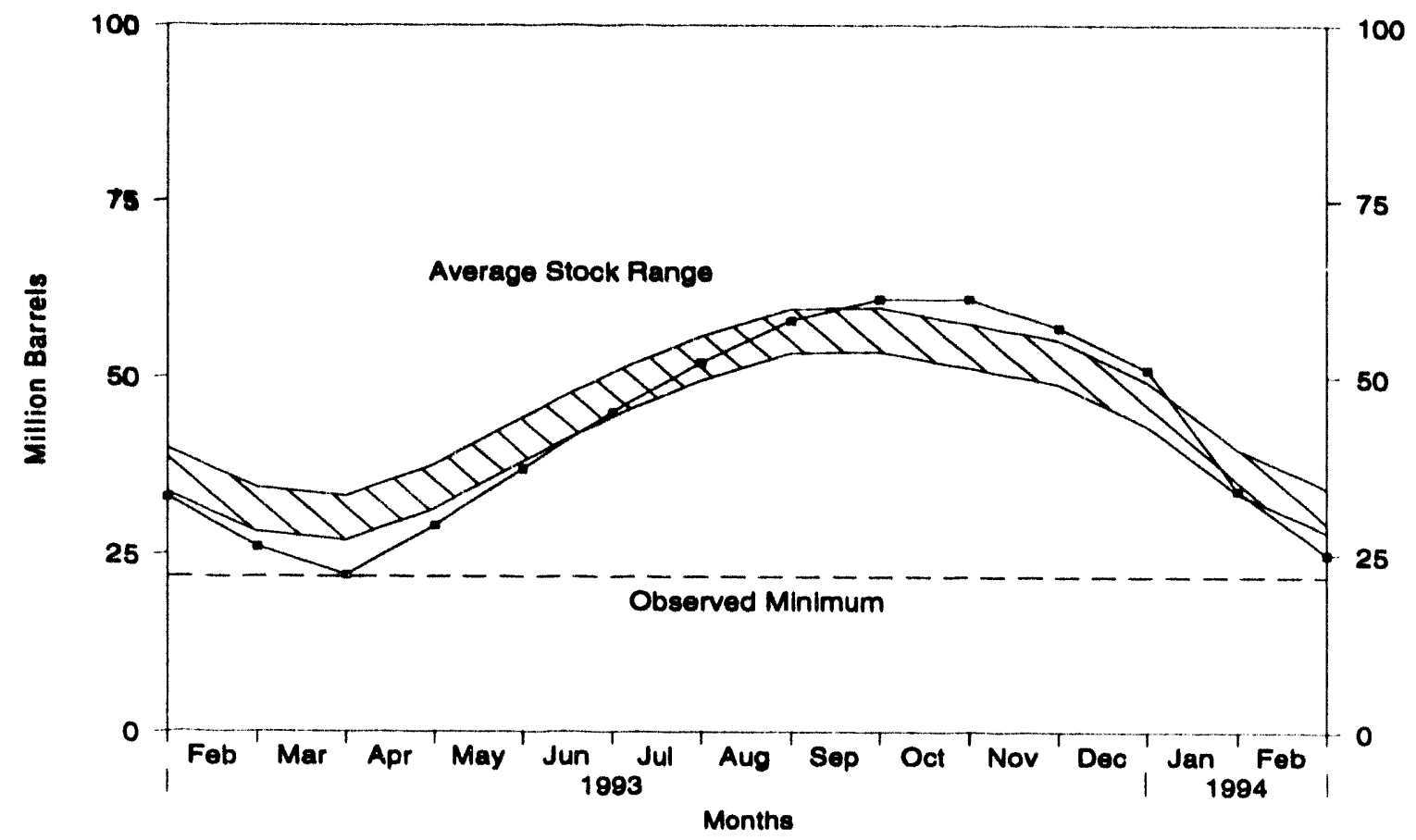

Note: The Observed Minimum for propane stocks in the last 36 month period was 21.8 million barrels, occurring in March 1993.

Source: Energy Information Administration, Petroleum Supply Monthly, Tablo S8. See Summary Statistics Table and Figure Sources. 
Table 88. Propane/Propylene Supply and Diepositlon, 1981 - Prosent (Thousand Barrels per Day, Except Where Noted)

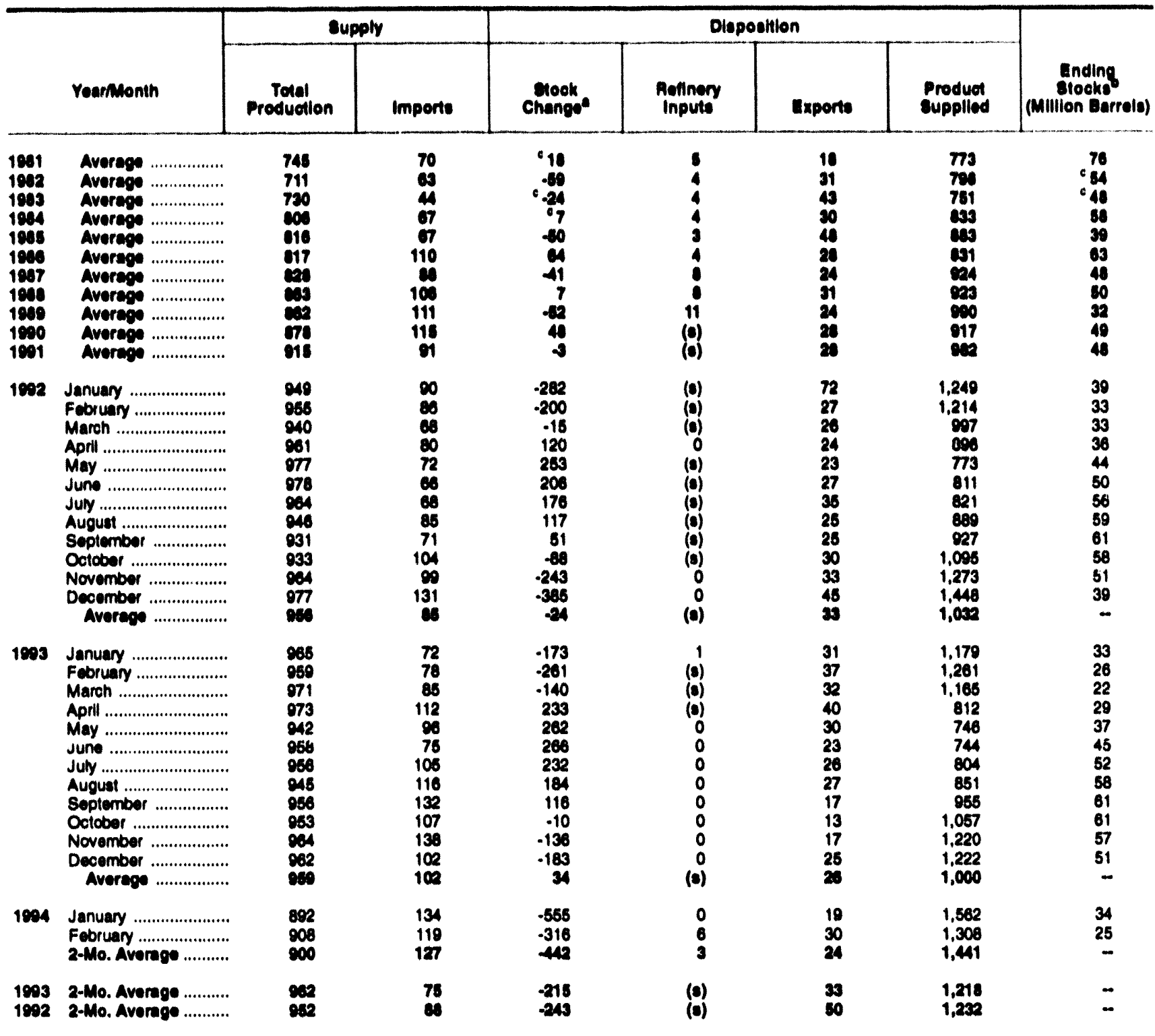

- A negative number indicates a decrease in stocks and positive number Indicates an increase.

- Stocks are totals as of end of period.

c In January 1981, 1883, and 1884, a new stock basis was established affecting stocks reported and stock change calculations. Stock changes ars calculated using now basis stock levels. See Summary Statistics Explanatory Note 4.

$(8)=$ Less than 500 barrels per day.

Notes: - Geographic coverage is the 50 States and the District of Columbia. - Totals may not equal sum of components due to independent rounding.

Source: See Summary Statistics Table and Figure Sources. 
Figure 815. Llquofled Potroloum Gases 8upply and Disposition, January 1993 - Present

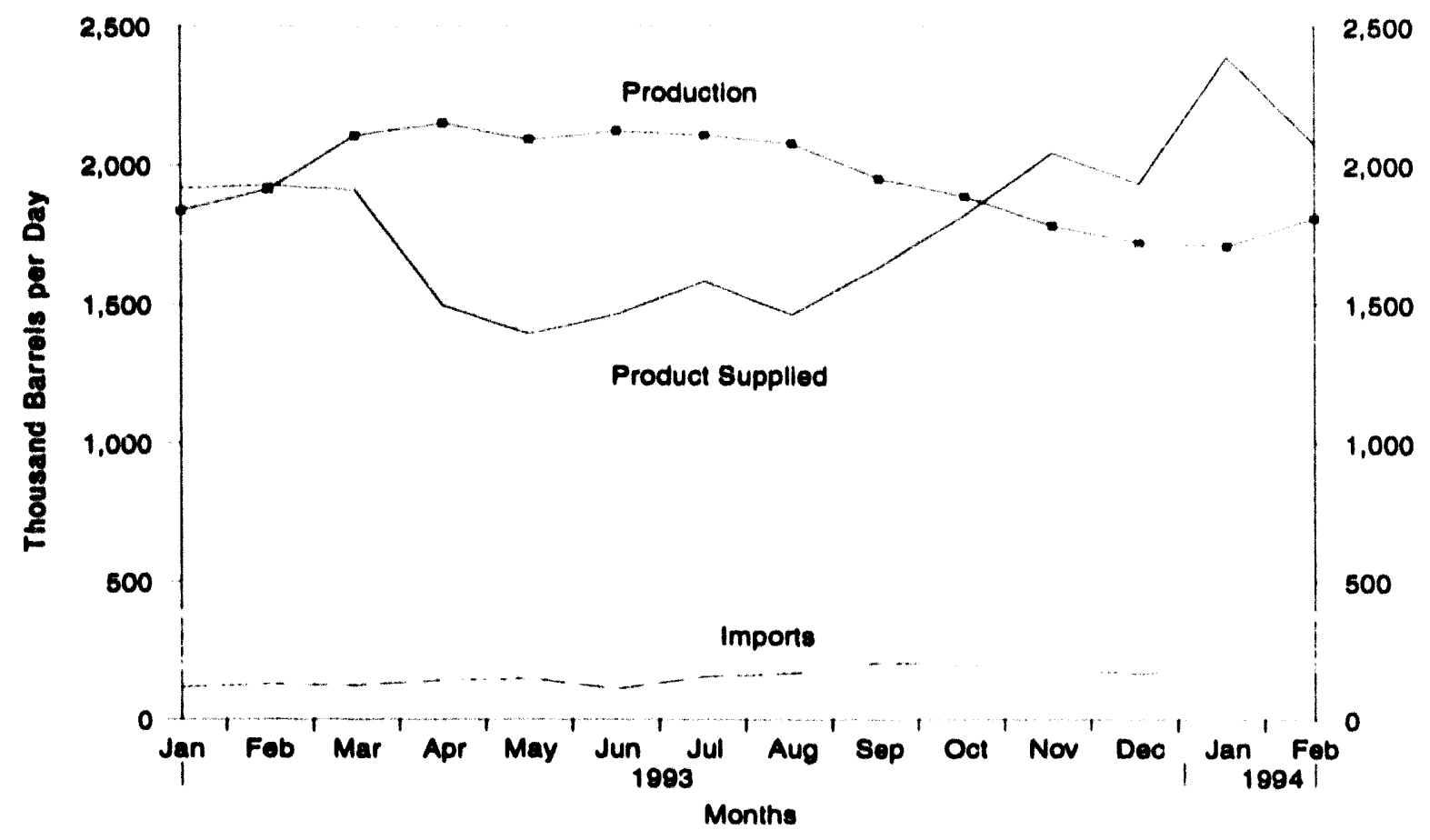

Source: Energy Intormation Administration, Potroloum Supply Monthy, Table S9. See Summary Statiatice Table and Figure Sources.

Figure 816. Llquofied Potroloum Gases Ending Stocks, January 1993 - Present

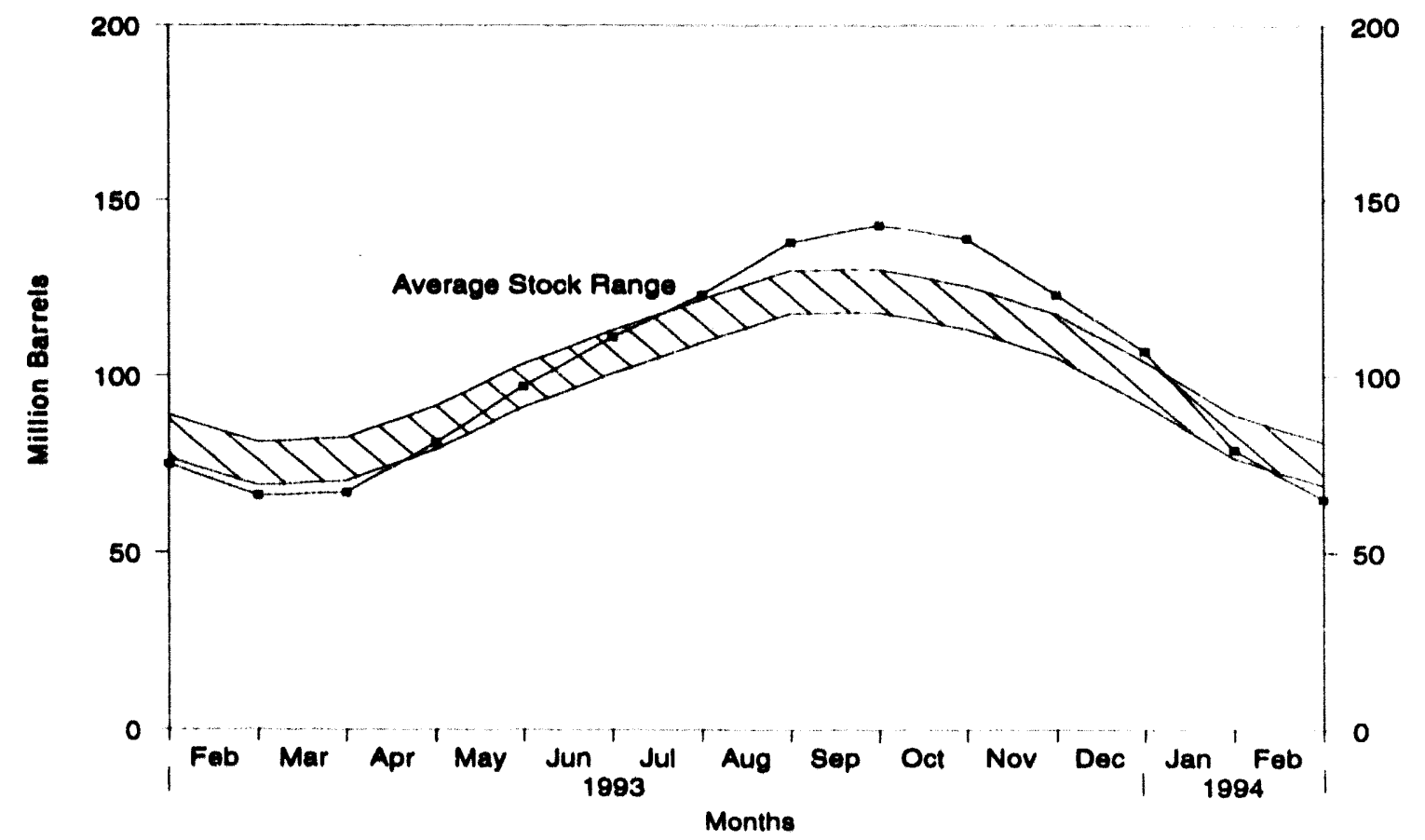

Source: Energy Information Administration, Petroloum Supply Monthly, Table S9. See Summary Statistlics Table and Figure Sources. 
Table 89. Llquefled Potroleum Gases Supply and Disposttion, 1981 - Present (Thousand Barrels per Day, Except Where Noted)

\begin{tabular}{|c|c|c|c|c|c|c|c|c|}
\hline \multirow{2}{*}{\multicolumn{2}{|c|}{ Yoarmonth }} & \multicolumn{2}{|c|}{ supply } & \multicolumn{4}{|c|}{ Dispostition } & \multirow{2}{*}{$\begin{array}{c}\text { Ending } \\
\text { stooks } \\
\text { (Millon Barrolo) }\end{array}$} \\
\hline & & $\begin{array}{c}\text { Totel } \\
\text { Production }\end{array}$ & Imports & $\begin{array}{l}\text { stook } \\
\text { Chango }\end{array}$ & $\begin{array}{l}\text { Rofinery } \\
\text { Inputs }\end{array}$ & Exports & $\begin{array}{l}\text { Product } \\
\text { supplied }\end{array}$ & \\
\hline 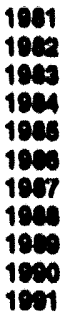 & 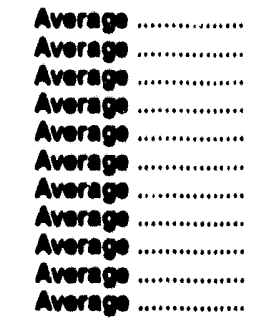 & $\begin{array}{l}1,671 \\
1,829 \\
1,048 \\
1,607 \\
1,704 \\
1,608 \\
1,748 \\
1,017 \\
1,701 \\
1,749 \\
1,071\end{array}$ & $\begin{array}{l}244 \\
206 \\
100 \\
198 \\
187 \\
242 \\
180 \\
200 \\
101 \\
108 \\
147\end{array}$ & $\begin{array}{r}18 \\
-111 \\
6.4 \\
6.19 \\
-78 \\
00 \\
-18 \\
1 \\
47 \\
48 \\
-18\end{array}$ & $\begin{array}{l}209 \\
300 \\
233 \\
201 \\
304 \\
302 \\
304 \\
201 \\
318 \\
203 \\
304\end{array}$ & $\begin{array}{l}42 \\
68 \\
73 \\
48 \\
62 \\
42 \\
38 \\
49 \\
38 \\
40 \\
41\end{array}$ & $\begin{array}{l}1,498 \\
1,409 \\
1,809 \\
1,672 \\
1,690 \\
1,512 \\
1,612 \\
1,696 \\
1,688 \\
1,858 \\
1,608\end{array}$ & $\begin{array}{r}138 \\
\circ 94 \\
\times 101 \\
101 \\
74 \\
103 \\
97 \\
97 \\
80 \\
98 \\
92\end{array}$ \\
\hline 100 & 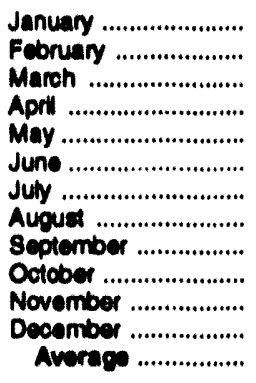 & $\begin{array}{l}1,820 \\
1,917 \\
2,033 \\
2,102 \\
2,108 \\
2,102 \\
2,090 \\
2,016 \\
1,886 \\
1,802 \\
1,884 \\
1,849 \\
1,072\end{array}$ & $\begin{array}{r}142 \\
126 \\
97 \\
127 \\
108 \\
104 \\
108 \\
148 \\
114 \\
171 \\
148 \\
178 \\
131\end{array}$ & $\begin{array}{r}-452 \\
-365 \\
163 \\
401 \\
489 \\
334 \\
345 \\
369 \\
37 \\
-242 \\
-541 \\
-660 \\
-10\end{array}$ & $\begin{array}{l}384 \\
326 \\
247 \\
233 \\
245 \\
257 \\
255 \\
233 \\
299 \\
369 \\
403 \\
453 \\
300\end{array}$ & $\begin{array}{l}80 \\
33 \\
43 \\
45 \\
44 \\
59 \\
52 \\
55 \\
45 \\
39 \\
43 \\
49 \\
49\end{array}$ & $\begin{array}{l}1,950 \\
2,051 \\
1,687 \\
1,549 \\
1,433 \\
1,556 \\
1,544 \\
1,507 \\
1,620 \\
1,898 \\
2,097 \\
2,184 \\
1,785\end{array}$ & $\begin{array}{r}78 \\
68 \\
72 \\
84 \\
100 \\
110 \\
120 \\
132 \\
133 \\
125 \\
109 \\
89 \\
-\end{array}$ \\
\hline 1000 & 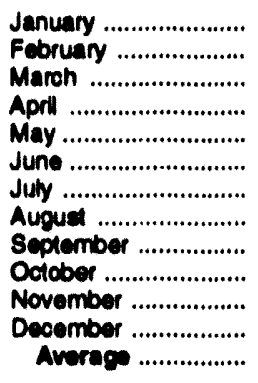 & $\begin{array}{l}1,037 \\
1,012 \\
2,108 \\
2,151 \\
2,091 \\
2,122 \\
2,108 \\
2,078 \\
1,95 ? \\
1,87 \\
1,11 \\
1,721 \\
1,979\end{array}$ & $\begin{array}{l}117 \\
128 \\
123 \\
142 \\
148 \\
111 \\
155 \\
167 \\
206 \\
195 \\
180 \\
166 \\
153\end{array}$ & $\begin{array}{r}-441 \\
-310 \\
9 \\
466 \\
538 \\
469 \\
380 \\
475 \\
188 \\
-129 \\
-580 \\
-518 \\
40\end{array}$ & $\begin{array}{l}440 \\
367 \\
263 \\
263 \\
258 \\
260 \\
246 \\
263 \\
304 \\
372 \\
458 \\
432 \\
327\end{array}$ & $\begin{array}{l}39 \\
55 \\
47 \\
69 \\
50 \\
41 \\
54 \\
45 \\
35 \\
21 \\
21 \\
40 \\
43\end{array}$ & $\begin{array}{l}1,917 \\
1,928 \\
1,910 \\
1,495 \\
1,393 \\
1,463 \\
1,583 \\
1,462 \\
1,632 \\
1,819 \\
2,042 \\
1,933 \\
1,714\end{array}$ & $\begin{array}{r}76 \\
66 \\
67 \\
81 \\
97 \\
111 \\
123 \\
138 \\
143 \\
139 \\
123 \\
107 \\
-\end{array}$ \\
\hline 1904 & $\begin{array}{l}\text { January ..................... } \\
\text { Februany ................... } \\
\text { 2-No. Averwoe ......... }\end{array}$ & $\begin{array}{l}1,710 \\
1,809 \\
1,757\end{array}$ & $\begin{array}{l}187 \\
182 \\
188\end{array}$ & $\begin{array}{l}-902 \\
-474 \\
-999\end{array}$ & $\begin{array}{l}381 \\
343 \\
3.3\end{array}$ & $\begin{array}{l}28 \\
44 \\
36\end{array}$ & $\begin{array}{l}2,390 \\
2,077 \\
2,242\end{array}$ & $\begin{array}{r}79 \\
65 \\
-\end{array}$ \\
\hline $\begin{array}{l}1993 \\
1902\end{array}$ & $\begin{array}{l}\text { 2-Mo. Averege ......... } \\
\text { 2-Mo. Averege ......... }\end{array}$ & $\begin{array}{l}1,073 \\
1,807\end{array}$ & $\begin{array}{l}122 \\
134\end{array}$ & $\begin{array}{l}-379 \\
-410\end{array}$ & $\begin{array}{l}405 \\
356\end{array}$ & $\begin{array}{l}46 \\
57\end{array}$ & $\begin{array}{l}1,020 \\
1,000\end{array}$ & - \\
\hline
\end{tabular}

\footnotetext{
- A negative number indicates a decrease in stocks and a positive number indicates an increase.
}

b Stocks are totals as of end of period.

- In January 1981, 1983, and 1884, a new stock basis was eatablished affecting stooks reported and stock change calculations. Stock changes are cakulated using new basis stock lovels. See Summan Statistics Explanatory Note 4.

Notes: - Liquefied petroleum gases includes ethane/ethylene, propane/propylene, normal butane/butylene, and lsobutane/sobutylene. - Beginning in January 1884, unirectlonated stream, is reported by individual product. • Geographic coverage is the 50 States and the District of Columbla. - Totals may not equal sum of component due to independent rounding.

Source: See Summary Statiatics Table and Figure Sources. 
Table 810. Other Petroleum Products Supply and Disposition, 1981 - Present (Thousand Barrels per Day, Except Where Noted)

\begin{tabular}{|c|c|c|c|c|c|c|c|c|}
\hline & \multirow[b]{2}{*}{ Voar/Month } & \multicolumn{2}{|c|}{ Supply } & \multicolumn{4}{|c|}{ Disposition } & \multirow[b]{2}{*}{$\begin{array}{c}\text { Ending } \\
\text { Stocks } \\
\text { (Mililon Barrols) }\end{array}$} \\
\hline & & $\begin{array}{c}\text { Total } \\
\text { Production }\end{array}$ & Imports & $\begin{array}{l}\text { Stock } \\
\text { Change }\end{array}$ & $\begin{array}{l}\text { Aoflnery } \\
\text { Inputs }\end{array}$ & Exports & $\begin{array}{l}\text { Products } \\
\text { supplled }\end{array}$ & \\
\hline $\begin{array}{l}1981 \\
1982 \\
1983 \\
1984 \\
1985 \\
1986 \\
1987 \\
1988 \\
1989 \\
1900 \\
1991\end{array}$ & 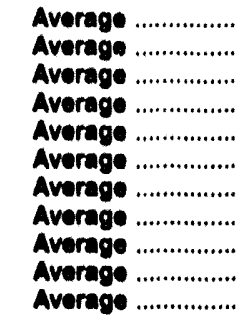 & $\begin{array}{l}2,771 \\
2,475 \\
2,437 \\
2,800 \\
2,832 \\
2,704 \\
2,737 \\
2,773 \\
2,771 \\
2,842 \\
2,020\end{array}$ & $\begin{array}{l}188 \\
305 \\
392 \\
803 \\
850 \\
604 \\
543 \\
648 \\
627 \\
705 \\
675\end{array}$ & $\begin{array}{r}c-42 \\
-68 \\
c-6 \\
c .32 \\
22 \\
-15 \\
-1 \\
22 \\
12 \\
-32 \\
18\end{array}$ & $\begin{array}{l}723 \\
787 \\
712 \\
791 \\
886 \\
888 \\
829 \\
799 \\
797 \\
897 \\
930\end{array}$ & $\begin{array}{l}197 \\
205 \\
238 \\
236 \\
227 \\
291 \\
294 \\
294 \\
305 \\
209 \\
277\end{array}$ & $\begin{array}{l}2,081 \\
1,856 \\
1,877 \\
2,007 \\
1,947 \\
2,045 \\
2,187 \\
2,303 \\
2,285 \\
2,402 \\
2,289\end{array}$ & $\begin{array}{l}241 \\
c 216 \\
c 217 \\
198 \\
206 \\
201 \\
200 \\
208 \\
213 \\
201 \\
208\end{array}$ \\
\hline 192 & 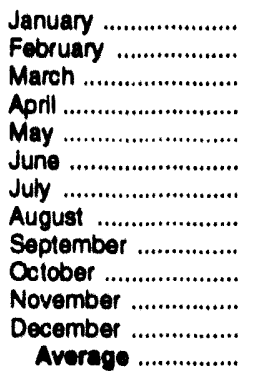 & $\begin{array}{l}2,702 \\
2,642 \\
2,752 \\
2,900 \\
2,929 \\
3,126 \\
3,207 \\
3,068 \\
3,114 \\
2,923 \\
2,915 \\
2,853 \\
2,828\end{array}$ & $\begin{array}{l}734 \\
575 \\
713 \\
793 \\
685 \\
669 \\
740 \\
729 \\
748 \\
701 \\
697 \\
711 \\
707\end{array}$ & $\begin{array}{r}203 \\
183 \\
238 \\
-31 \\
-113 \\
-42 \\
-156 \\
-116 \\
188 \\
.182 \\
-24 \\
-165 \\
-3\end{array}$ & $\begin{array}{r}787 \\
883 \\
730 \\
1,043 \\
910 \\
787 \\
996 \\
884 \\
675 \\
964 \\
989 \\
1,223 \\
908\end{array}$ & $\begin{array}{l}272 \\
240 \\
239 \\
217 \\
199 \\
225 \\
284 \\
227 \\
336 \\
295 \\
264 \\
352 \\
283\end{array}$ & $\begin{array}{l}2,175 \\
1,911 \\
2,258 \\
2,464 \\
2,598 \\
2,826 \\
2,822 \\
2,802 \\
2,663 \\
2,557 \\
2,383 \\
2,154 \\
2,470\end{array}$ & $\begin{array}{r}214 \\
219 \\
227 \\
226 \\
222 \\
221 \\
216 \\
212 \\
218 \\
212 \\
212 \\
207 \\
-\end{array}$ \\
\hline 1993 & 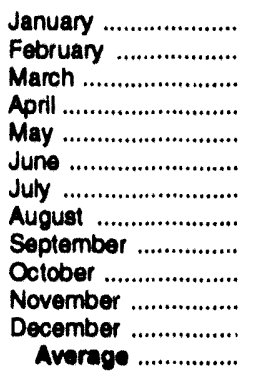 & $\begin{array}{l}3,026 \\
2,815 \\
2,866 \\
2,862 \\
2,899 \\
3,022 \\
3,116 \\
3,094 \\
3,016 \\
3,108 \\
2,978 \\
2,810 \\
2,969\end{array}$ & $\begin{array}{l}698 \\
773 \\
818 \\
719 \\
808 \\
630 \\
875 \\
676 \\
789 \\
802 \\
760 \\
674 \\
782\end{array}$ & $\begin{array}{r}{ }^{c} 600 \\
122 \\
243 \\
9 \\
85 \\
-240 \\
116 \\
27 \\
-265 \\
-164 \\
-210 \\
-356 \\
-2\end{array}$ & $\begin{array}{r}829 \\
949 \\
747 \\
900 \\
979 \\
981 \\
945 \\
865 \\
1,031 \\
1,138 \\
1,274 \\
1,389 \\
1,002\end{array}$ & $\begin{array}{l}271 \\
282 \\
269 \\
315 \\
278 \\
278 \\
302 \\
295 \\
282 \\
369 \\
309 \\
349 \\
300\end{array}$ & $\begin{array}{l}2,023 \\
2,235 \\
2,425 \\
2,357 \\
2,364 \\
2,632 \\
2,628 \\
2,583 \\
2,757 \\
2,567 \\
2,365 \\
2,101 \\
2,420\end{array}$ & $\begin{array}{r}225 \\
228 \\
236 \\
236 \\
239 \\
231 \\
235 \\
236 \\
228 \\
223 \\
217 \\
205 \\
-\end{array}$ \\
\hline 1994 & $\begin{array}{l}\text { January ................... } \\
\text { February .................. } \\
\text { 2-No. Average ........ }\end{array}$ & $\begin{array}{l}2,719 \\
2,779 \\
2,748\end{array}$ & $\begin{array}{l}780 \\
725 \\
754\end{array}$ & $\begin{array}{l}507 \\
236 \\
378\end{array}$ & $\begin{array}{l}590 \\
638 \\
613\end{array}$ & $\begin{array}{l}256 \\
248 \\
252\end{array}$ & $\begin{array}{l}2,147 \\
2,383 \\
2,259\end{array}$ & $\begin{array}{r}221 \\
228 \\
-\end{array}$ \\
\hline $\begin{array}{l}1993 \\
1992\end{array}$ & $\begin{array}{l}\text { 2-Mo. Average ........ } \\
\text { 2-Mo. Average ........ }\end{array}$ & $\begin{array}{l}2,028 \\
2,073\end{array}$ & $\begin{array}{l}733 \\
657\end{array}$ & $\begin{array}{l}373 \\
193\end{array}$ & $\begin{array}{l}888 \\
833\end{array}$ & $\begin{array}{l}277 \\
256\end{array}$ & $\begin{array}{l}2,123 \\
2,047\end{array}$ & - \\
\hline
\end{tabular}

A Anegative number indicates a decrease in stocks and a positive number indicates an increase.

Stocks are totals as of end of period.

c In January 1981, 1983, and 1984, a new stock basis was established affecting stocks reported and stock change calculations. Stock changes are calculated using new basis stock levels. Bulk terminal and pipeline slocks of oxygenates were added beginning in January 1993 . See Summary Statistics Explanatory Note 4.

Notes: - Other petroleum products includes pentanes plus, other hydrocarbons and oxygenates, unfinished oils, gasoline blending components and all finished petroleum products except finished motor gasoline, distillate fuel oll, residual fuel oll, jet fuel, and liquefied petroleum gases. - Geographic coverage is the 50 States and the District of Columbia. - Totals may not equal sum of components due to independent rounding.

Source: See Summary Statistics Table and Figure Sources. 


\section{Summary Statistics Table and Figure Sources}

Information about petroleum supply and disposition at the National level are presented in the Summary Statistics tables. Industry terminology and product definitions are listed alphabetically in the Glossary.

The data presented in these tables are from several sources and represent different levels of timeliness and data finality.

- U.S. Department of Energy, Energy Information Administration (EIA), Petroleum Supply Annual (1981 through 1992).

- EIA, Petroleum Supply Monthly (January 1993 through February 1994).
- EIA, Weekly Petroleum Supply Reporting System (except domestic crude oil production) (March 1994). A more detailed explanation is provided in Summary Statistics Explanatory Note 1.

- Domestic crude oil production estimate is based on historical statistics from State conservation agencies and the Minerals Management Service of the U.S. Department of the Interior. (January 1993 through March 1994). Refer to Summary Statistics Explanatory Note 2 for a more detailed explanation. 


\section{Summary Statistics Explanatory Notes}

The following explanatory notes are provided to assist in understanding and interpreting the data presented in the Summary Statistics section of this publication.

\section{Note 1. Preliminary Monthly Statistics Derivation}

Data collected from the Weekly Petroleum Supply Reporting System (WPSRS) are used to develop estimates of the most current monthly quantities. The forms that comprise the WPSRS are:

$\begin{array}{ll}\text { Eorm Number } & \text { Name } \\ \text { EIA-800 } & \text { "Weekly Refinery Report" } \\ \text { EIA-801 } & \text { "Weekly Bulk Terminal Report" } \\ \text { EIA-802 } & \text { "Weekly Product Pipeline Report" } \\ \text { EIA-803 } & \text { "Weekly Crude Oil Stocks Report" } \\ \text { EIA-804 } & \text { "Weekly Imports Report" }\end{array}$

A sample of all petroleum companies report weekly data to the Energy Information Administration (EIA) on crude oil and petroleum pruducts stocks, refinery inputs and production, and crude oil and petroleum product imports. The sample of companies that report weekly is selected from the universe of companies that report on the comparable monthly surveys.

The sampling procedure used for the weekly system is the cut-off method. In the cut-off method, companies are ranked from largest to smallest on the basis of the quantities reported during a 12-month period. Companies are chosen for the sample beginning with the largest companies with additional companies added until the total sample coverage represents a minimum of 90 percent of each item by geographic region being measured. All monthly-from-weekly estimates are shown in italics.

In calculating monthly estimates based upon weekly submissions, an interpolation process is used to make the weekly figures comparable to the monthly. The interpolation process is designed to resolve the timing differences between the weekly and the monthly systems -- the time-of-day of reporting periods and the day-of-month of reporting periods. The end of the weekly reporting period (exactly 1 week long) is 7 a.m. Friday. The end of the monthly reporting period (one calendar month long) is 12 midnight on the last day of the month. To resolve the difference in the time-of-day of the weekly and monthly reporting periods, it is assumed that there is no activity during the period 12 midnight Thursday through 7 a.m. Friday. Thus, for the purposes of interpolation, the weekly system reporting period is assumed to end at 12 midnight on Thursday. The resolution of the day-of-month differences depends on whether the series is a cumulative one (such as production and imports) or a value at a fixed point-in-time (i.e., stocks).

For cumulative items (all items except stocks) the following method is used to calculate a monthly-from-weekly figure for a given month. First, a weight is assigned to each week in the month based on the number of days in that week that are in the month. (All intermediate weeks in a month will have a weight of seven; the beginning and ending weeks in the month may have a weight of less than seven, according to the number of days of the week that are in the month.) The weight for each week is then multiplied by the average daily volume for that week. To arrive at the monthly-from-weekly figure, a sum is taken of these weighted weekly volumes. The daily average for the monthly-from-weekly figure is calculated by dividing the total monthly-from-weekly figure by the number of days in the month.

Stock figures are not cumulative but represent inventories as of the last day of the reporting period. When the reporting week does not coincide with the end of a reporting month, an interpolation is necessary to derive a monthly-from-weekly figure for end-of-month stocks.

To derive the monthly-from-weekly stock figures, the two weekly reports that bracket the end of the month are used. Average daily stock change and the number of interpolated days are determined. The average daily stock change is defined as one-seventh of the difference between the stock level at the end of the last full week of the month and the stock level at the end of the week containing the last day of the month. The number of interpolation days is defined as the number of days between the end of the preceding weekly reporting period (midnight Thursday) and the end of the monthly reporting period. The end-of-month stock levels are then estimated as the sum of (a) the stock level reported the last full week of the month, plus (b) the number of interpolation days multiplied by the average daily stock change for the week.

The monthly-from-weekly exports data are derived from the most recent data published in the Weekly Petroleum Status Report. Beginning with statistics for the first week ending in October 1991, weekly estimates of exports are forecast using an autoregressive integrated moving-average (ARIMA) procedure. The ARIMA procedure models a value as a linear combination of its own past values and present and past values of other related time series. The most recent 5 years of 
past data are used to obtain the forecast. In addition, for the major products and crude oil, 5 years of related price data are used. The price data include some U.S. and some foreign series.

\section{Note 2. Domestic Crude Oil Production}

The Energy Information Administration (EIA) collects monthly crude oil production data on an ongoing basis. Data on crude oil production for States are reported to the EIA by State govermment agencies. Data on crude oil production for Federal offshore areas are reported to the EIA by the Minerals Management Service of the U.S. Department of the Interior and the Conservation Committee of California Oil Producers.

Currently, all except four crude oil producing States (Michigan, New York, Ohio, and Pennsylvania) report production on a monthly basis. These four States report crude oil production on an annual basis. Estimates of monthly crude oil production for these four States are made by the EIA using data reported on Form EIA-182, "Domestic Crude Oil First Purchase Report." After the end of each calendar year, the monthly crude oil production estimates are updated using annual reports from various State agencies, the Minerals Management Service, and the Conservation Committee of California Oil Producers. The final estimate is published in the Petroleum Supply Annual. There is a time lag of approximately 4 months between the end of the production month and the time when most monthly State crude oil production data become available.

In order to present more timely crude oil production estimates, the EIA prepares an original, forecast estimate on the first day of the production month (indicated with a "PE"). Approximately 45 days later, this original estimate of monthly crude oil production is replaced by State-level interim estimates (indicated with an "RE"). The State-level interim estimates are based on: (a) data reported by the States (e.g., production data for Alaska are typically reported to the EIA before the interim estimate is made); (b) first purchase data reported on Form EIA-182, "Domestic Crude Oil First Purchase Report;" (c) exponential or hyperbolic curve fitted projections based on recent State data; or (d) constant level projections based on the average production rate during a recent time period.

\section{Note 3. Figures}

Figures associated with the Summary Statistics tables are provided which depict the balance between supply, disposition, and ending stocks for various commodities.

The national inventory (stocks) graphs (Figures S4, S6, S8, $\mathrm{S} 10, \mathrm{~S} 12, \mathrm{~S} 14$, and S16) for crude oil, finished motor gasoline, distillate fuel oil, residual fuel oil, jet fuel, propane/propylene, and liquefied petroleum gases, in this publication include features to assist in comparing current inventory levels with past inventory levels and observed minimum operating levels. These features are described below.

The graphs displaying inventory levels provide the reader with actual inventory data compared to an average range from the most recent 3-year period running from January through December or from July through June. The ranges are updated every 6 months in April and October. The 3-year period is adjusted by dropping the oldest 6 months and including the most recent 6 months. The ranges also reflect seasonal variation determined from a 7 -year period. The seasonal factors, which determine the shape of the upper and lower curves, are updated annually in October, using the most recent year's final monthly data.

The monthly seasonal factors are estimated by means of a seasonal adjustment technique developed at the U.S. Bureau of the Census (Census X-11). The seasonal factors are assumed to be stable (i.e., unchanging from year to year) and additive (i.e., the series is deseasonalized by subtracting the seasonal factor for the appropriate month from the reported inventory levels). The intent of deseasonalization is to remove only variation from the data. Thus, a deseasonalized series would contain the same trends, cyclical components, and irregularities as the original data.

After seasonal factors are derived, data from the most recent 3-year period (January through December or July through June) are deseasonalized. The average of the deseasonalized 36-month series determines the midpoint of the deseasonalized average band. The standard deviation of the deseasonalized 36 months is calculated adjusting for extreme data points. The upper curve of the average range is defined as the average plus the seasonal factors plus the standard deviation. The lower curve is defined as the average plus the seasonal factors minus the standard deviation. Thus, the width of the average range is twice the standard deviation.

The lines labeled "observed mininium" are the lowest inventory level observed during the most recent 36-month period as published in the Petroleum Supply Monthly.

\section{Note 4. Frames Maintenance}

In January 1981 and 1983, numerous respondents were added to bulk terminal and pipeline surveys affecting subsequent stocks reported and stock change calculations. Using the expanded coverage (new basis), the end-of-year stocks, in million barrels, would have been as listed below.

- Crude Oil: 1982-645 (Total) and 351 (Other Primary). 
- Crude Oil and Petroleum Products: 1980-1,425; and 1982-1,461.

- Motor Gasoline: 1980-263 (Total) and 214 (Finished); 1982-244 (Total) and 202 (Finished).

- Distillate Fuel Oil: 1980-205; and 1982-186.

- Residual Fuel Oil: 1980-91; and 1982-69.

- Jet Fuel: 1980-42 (Total) and 36 (Kerosene-type); and 1982-39 (Total) and 32 (Kerosene-type).

- Propane/Propylene: 1980-69; and 1982-57.

- Liquefied Petroleum Gases: 1980-128; and 1982-102.

- Other Petroleum Products: 1980-207; and 1982-219.

Stock change calculations beginning in 1981 and 1983 were made using new basis stock levels.

Stocks of Alaskan crude oil in-transit were included for the first time in January 1981. The major impact of this change is on the reporting of stock change calculations. Using the expanded coverage (new basis), 1980 end-of-year crude oil stocks would have been 488 million barrels (Total) and 380 million barrels (Other Primary).

Beginning with January 1984, natural gas liquids supply and aisposition data were coilected on a component basis rather than a product basis. This change affected stocks reported and stock change calculations. Under the new basis, end-of-year 1983 stocks would have been:

- Propane/Propylene: 1983-j5.

- Liquefied Petroleum Gases: 1983-108.

- Other Petroleum Products: 1983-210.

In response to changes in the Clean Air Act Amendments of 1990 requiring that all gasoline sold in carbon monoxide nonattainment areas have an oxygen content of 2.7 percent (by weight) during winter months, the Energy Information Administration (EIA) conducted a frame identifier survey in 1991 of companies that produce, blend, store, or import oxygenates. The purpose of this survey was to (1) identify all U.S. producers, blenders, storers, and importers of oxygenates; and (2) collect supply and blending data for 1990 and end of 1990 inventory data on those oxygenates blended into motor gasoline. A summary of the results from the identification survey were published in the Weekly Petrolcum: Status Report dated February 12, 1992 and in the February 1992 issue of the Petroleum Supply Monthly.

In order to continue to provide relevant information about U.S. and regional gasoline supply, the EIA conducted a second frame identifier survey of these companies during 1992. As a result, a number of respondents were added to the monthly surveys effective in January 1993: 19 blenders, 25 stock holders, and 8 importers. This change did not affect stocks repurteci and therefore did nor cause a new basis stocik level to be calculated. 


\section{Detailed Statistics}

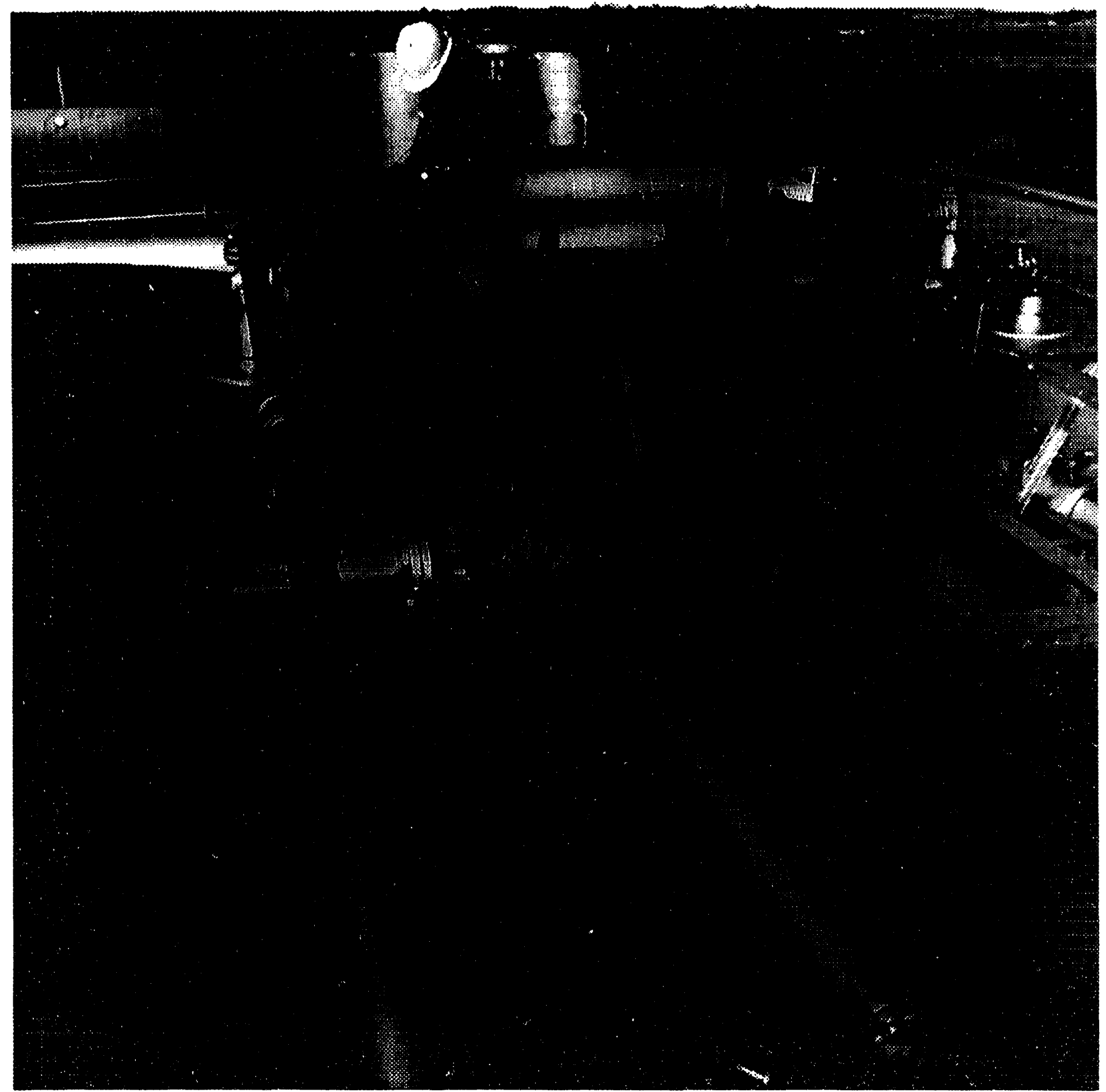




\begin{tabular}{|c|c|c|c|c|c|}
\hline \multirow{2}{*}{\multicolumn{2}{|c|}{ Commodity }} & \multicolumn{2}{|c|}{ Current Month } & \multicolumn{2}{|c|}{ Year to Date } \\
\hline & & $\begin{array}{l}\text { Thousand } \\
\text { Barrels. }\end{array}$ & $\begin{array}{l}\text { Thousand Barrole } \\
\text { per Day }\end{array}$ & $\begin{array}{l}\text { Thousand } \\
\text { Barrels }\end{array}$ & $\begin{array}{c}\text { Thousand Barrels } \\
\text { per Day }\end{array}$ \\
\hline $\begin{array}{l}(1) \\
(2) \\
(3)\end{array}$ & 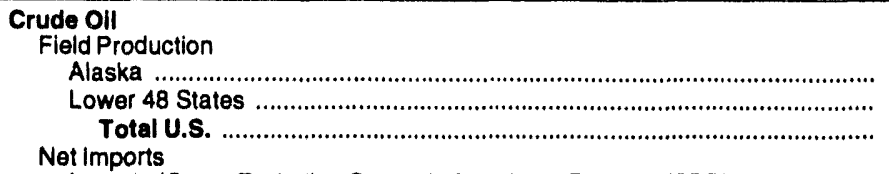 & $\begin{array}{r}E_{44,633} \\
E_{144,240} \\
E_{188,873}\end{array}$ & $\begin{array}{l}E_{1,594} \\
E_{\mathbf{5}, 151} \\
E_{\mathbf{6 , 7 4 5}}\end{array}$ & $\begin{array}{r}E_{96,020} \\
E_{302,945} \\
E_{398,965}\end{array}$ & $\begin{array}{l}E_{1,627} \\
E_{5,135} \\
E_{\mathbf{6 , 7 6 2}}\end{array}$ \\
\hline $\begin{array}{l}(4) \\
(5) \\
(6) \\
(7)\end{array}$ & 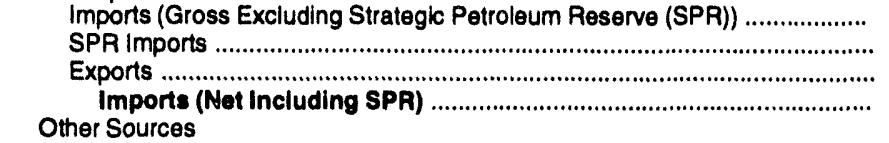 & $\begin{array}{r}176,774 \\
0 \\
3,244 \\
173,530\end{array}$ & $\begin{array}{r}6,313 \\
0 \\
116 \\
6,197\end{array}$ & $\begin{array}{r}361,566 \\
0 \\
6,645 \\
354,921\end{array}$ & $\begin{array}{r}6,128 \\
0 \\
113 \\
6,016\end{array}$ \\
\hline $\begin{array}{r}(8) \\
(9) \\
(10) \\
(11) \\
(12) \\
(13)\end{array}$ & 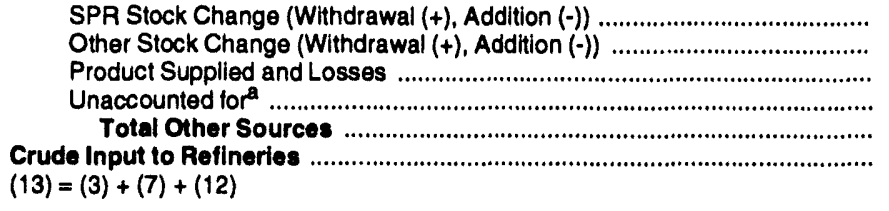 & $\begin{array}{r}-1 \\
4,601 \\
-336 \\
1,023 \\
5,287 \\
367,690\end{array}$ & $\begin{array}{r}(s) \\
164 \\
-12 \\
37 \\
189 \\
13,132\end{array}$ & $\begin{array}{r}-113 \\
5,197 \\
-647 \\
21,189 \\
25,626 \\
779,512\end{array}$ & $\begin{array}{r}-2 \\
88 \\
-11 \\
359 \\
434 \\
13,212\end{array}$ \\
\hline $\begin{array}{l}(14) \\
(15) \\
(16) \\
(17)\end{array}$ & 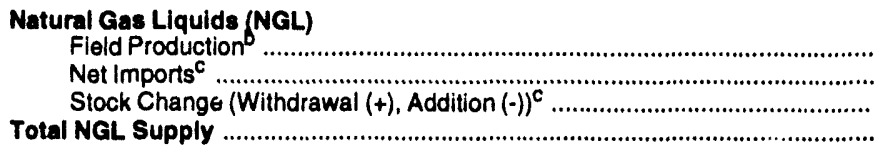 & $\begin{array}{r}47,713 \\
1,170 \\
1,149 \\
50,032\end{array}$ & $\begin{array}{r}1,704 \\
42 \\
41 \\
1,787\end{array}$ & $\begin{array}{r}101,669 \\
2,538 \\
2,312 \\
106,519\end{array}$ & $\begin{array}{r}1,723 \\
43 \\
39 \\
1,805\end{array}$ \\
\hline & $\begin{array}{l}\text { Other Llquids } \\
\text { Untinished Oils and Gasoline Blending Components, Total }\end{array}$ & & & & \\
\hline $\begin{array}{l}(18) \\
(19) \\
(20) \\
(21) \\
(22) \\
(23)\end{array}$ & 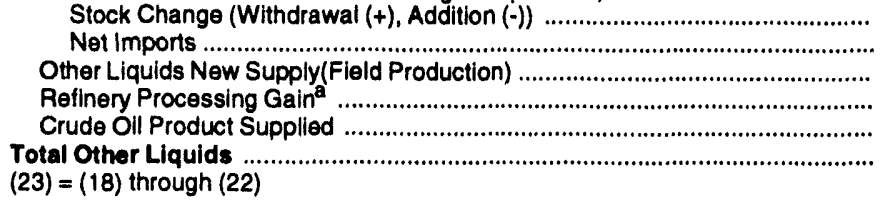 & $\begin{array}{r}-1,826 \\
13,187 \\
3,818 \\
18,782 \\
336 \\
34,297\end{array}$ & $\begin{array}{r}-65 \\
471 \\
136 \\
671 \\
12 \\
1,225\end{array}$ & $\begin{array}{r}14,555 \\
29,412 \\
8,671 \\
42,519 \\
647 \\
66,694\end{array}$ & $\begin{array}{r}-247 \\
499 \\
147 \\
721 \\
11 \\
1,130\end{array}$ \\
\hline (24) & $\begin{array}{l}\text { Total Production of Products } \\
(24)=(13)+(17)+(23)\end{array}$ & 452,019 & 16,144 & 952,725 & 16,146 \\
\hline $\begin{array}{l}(25) \\
(26) \\
(27)\end{array}$ & $\begin{array}{l}\text { Not Imports of Refined Products } \\
\text { Imports (Gross) } \\
\text { Exports }\end{array}$ & $\begin{array}{l}46,504 \\
21,058 \\
25,446\end{array}$ & $\begin{array}{r}1,661 \\
752 \\
909\end{array}$ & $\begin{array}{l}89,270 \\
46,203 \\
43,087\end{array}$ & $\begin{array}{r}1,513 \\
783 \\
730\end{array}$ \\
\hline (28) & $\begin{array}{l}\text { Total New Supply of Products } \\
(28)=(24)+(27)\end{array}$ & 477,465 & 17,052 & 995,791 & 16,878 \\
\hline (29) & 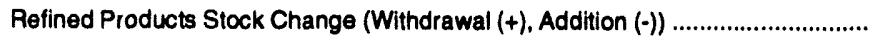 & 34,978 & 1,249 & 72,292 & 1,225 \\
\hline (30) & $\begin{array}{l}\text { Total Petroleum Products Supplied for Domestic Use } \\
(30)=(28)+(29)\end{array}$ & 512,443 & 18,302 & $1,068,083$ & 18,103 \\
\hline $\begin{array}{l}(31) \\
(32) \\
(33) \\
(34) \\
(35) \\
(36) \\
(37) \\
(38)\end{array}$ & 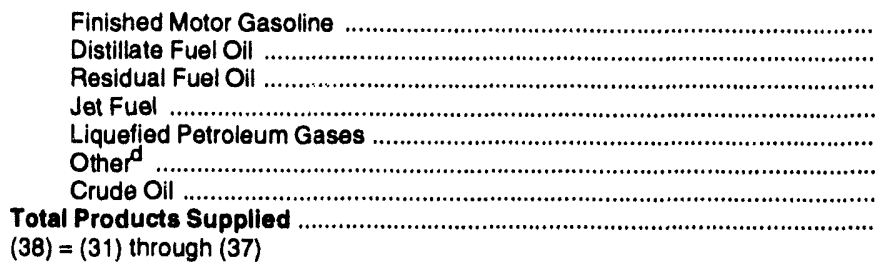 & $\begin{array}{r}203,617 \\
99,819 \\
41,152 \\
42,629 \\
58,166 \\
66,724 \\
336 \\
512,443\end{array}$ & $\begin{array}{r}7,272 \\
3,565 \\
1,470 \\
1,522 \\
2,077 \\
2,383 \\
12 \\
18,302\end{array}$ & $\begin{array}{r}418,026 \\
214,283 \\
80,415 \\
89,184 \\
132,253 \\
133,274 \\
647 \\
1,068,083\end{array}$ & $\begin{array}{r}7,085 \\
3,632 \\
1,363 \\
1,512 \\
2,242 \\
2,259 \\
11 \\
18,103\end{array}$ \\
\hline $\begin{array}{l}(39) \\
(40) \\
(41) \\
(42) \\
(43) \\
(44) \\
(45) \\
(46) \\
(47)\end{array}$ & $\begin{array}{l}\text { Ending Stocks, All Olls } \\
\text { Crude Oil (Excluding SPR) } \\
\text { Strategic Petroleum Reserve } \\
\text { Finished Motor Gasoline } \\
\text { Distillate Fuel Oil } \\
\text { Residual Fuel Oil } \\
\text { Jet Fuel } \\
\text { Liquefied Petroleum Gases } \\
\text { Other } \\
\text { Total Stocks } \\
\text { (47) }=\text { (39) through (46) }\end{array}$ & $\begin{array}{r}330,161 \\
587,193 \\
186,603 \\
103,985 \\
39,440 \\
40,155 \\
65,407 \\
227,781 \\
1,580,725\end{array}$ & $\begin{array}{l}- \\
- \\
- \\
- \\
- \\
- \\
-\end{array}$ & $\begin{array}{r}330,161 \\
587,193 \\
186,603 \\
103,985 \\
39,440 \\
40,155 \\
65,407 \\
227,781 \\
1,580,725\end{array}$ & $\begin{array}{l}- \\
- \\
- \\
- \\
- \\
-\end{array}$ \\
\hline
\end{tabular}

a Unaccounted for crude oil represents the difference between the supply and disposition of crude oil. Refinery processing gain represents the volumetric amount by which total output is greater than input for a given period of time. Preliminary estimates of crude oll imports at the National level have historically understated final values by approximately 50 thousand barrels per day. This causes the preliminary values of unaccounted for crude oil to overstate the final values by the same amount.

Includes fuel ethanol blended into finished motor gasoline.

c Includes products in the pentanes plus category only.

d Includes pentanes plus, other liquids, and all tinished petroleum products except finished motor gasoline, distillate fuel oil, residual fuel oil, jet fuel, and liquefied petroleum gases.

$E=$ Estimated.

Note: Totals may not equal sum of components due to independent rounding.

Sources: - Energy Information Administration (EIA), Monthly Petroleum Supply Reporting System. - Domestic crude oll production estimates based on historical statistics from State conservation agencies and the Minerals Management Service of the U.S. Department of the Interlor. - Export data from the Bureau of the Census and Form EIA-B10, "Monthly Refinery Report." 
Table 2. U.S. Supply, Disposition, and Ending Stocks of Crude Oil and Petroleum Products, February 1994

(Thousand Barrels)

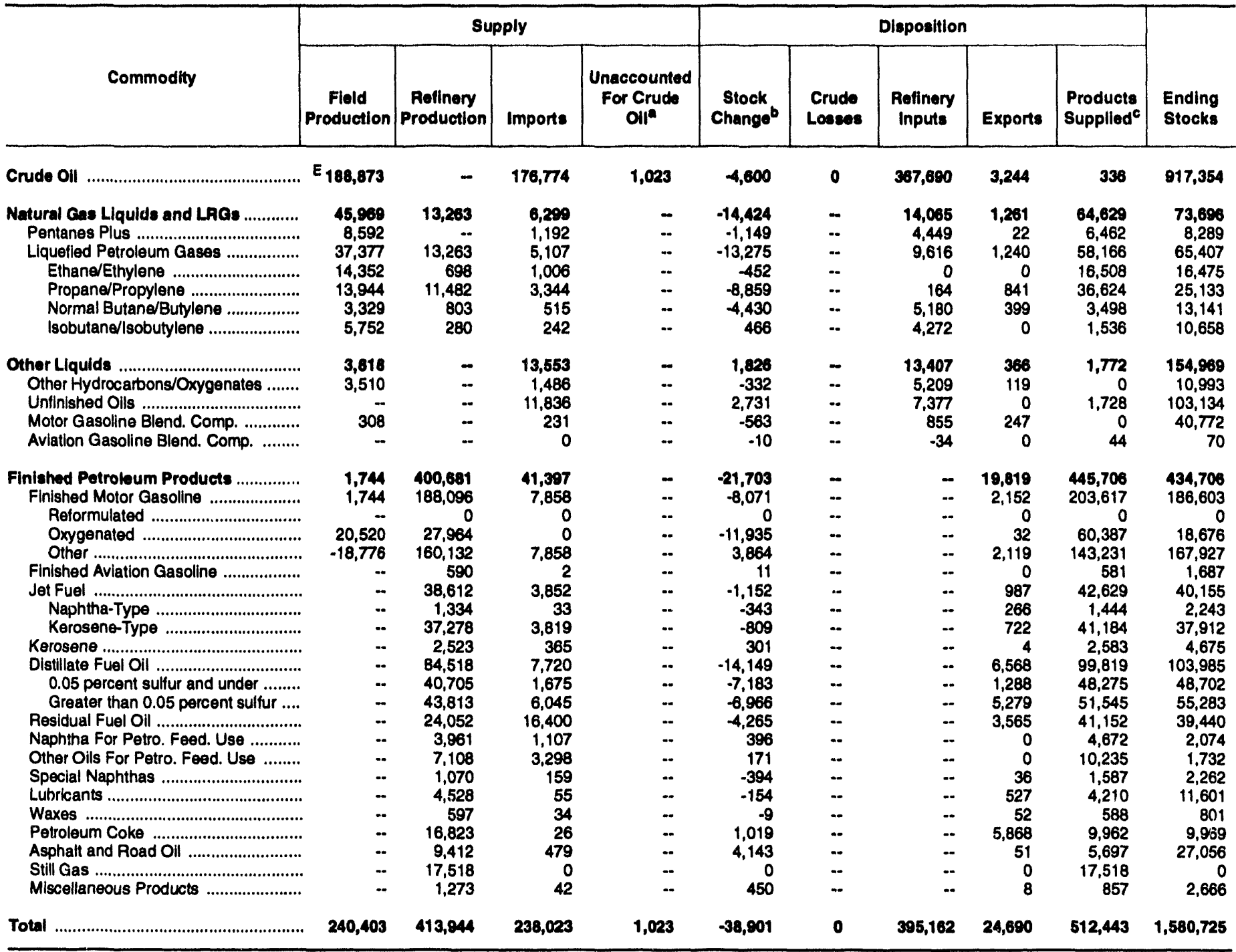

a Unaccounted for crude oil represents the difference between the supply and disposition of crude oll. Preliminary estimates of crude oll imports at the National level have historically understated final values by approximately 50,000 barrels per day. This causes the preliminary values of unaccounted for crude oil to overstate the final values by the same amount.

A negative number indicates a decrease in stocks and a positive number indicates an increase in stocks.

c Products supplied is equal to field production, plus refinery production, plus imports, plus unaccounted for crude oil, minus stock change, minus crude losses, minus retinery inputs, minus exports.

(s) $=$ Less than 500 barrols.

$E=$ Estimated.

LRG = Liquefied Refinery Gas.

Note: Totals may not equal sum of components due to independent rounding.

Sources: - Energy Information Administration (EIA) Forms EIA-810, "Monthly Refinery Report," EIA-811, "Monthly Bulk Terminal Report," ElA-812, "Monthly Product Pipeline Report," EIA-813, "Monthly Crude Oll Report," EIA-814, "Monthly Imports Report," ElA-816, "Monthly Natural Gas Liquids Report," EIA-817, "Monthly Tanker and Barge Movement Report," and EIA-B19M, "Monthly Oxygenate Telephone Report." - Domestic crude oll production estimates based on historical statistics from State conservation agencies and the Minerals Management Service of the U.S. Department of the Interior. • Export data from the Bureau of the Census and Form EIA-810, "Monthly Refinery Report." 
Table 3. U.S. Year-to-Date Supply, Disposition, and Ending Stocks of Crude OII and Petroleum Products, January-February 1994

(Thousand Barrels)

\begin{tabular}{|c|c|c|c|c|c|c|c|c|c|c|}
\hline \multirow[b]{2}{*}{ Commodity } & \multicolumn{4}{|c|}{ Supply } & \multicolumn{5}{|c|}{ Disposttion } & \multirow[b]{2}{*}{$\begin{array}{l}\text { Ending } \\
\text { Stocks }\end{array}$} \\
\hline & $\begin{array}{c}\text { Fleld } \\
\text { Production }\end{array}$ & $\begin{array}{l}\text {, Rofinery } \\
\text { Production }\end{array}$ & Imports & $\begin{array}{c}\text { Unaceounted } \\
\text { For Crude } \\
\text { OIf }^{\mathbf{m}}\end{array}$ & $\begin{array}{c}\text { stook } \\
\text { Changob }\end{array}$ & $\begin{array}{l}\text { Crude } \\
\text { Loeses }\end{array}$ & $\begin{array}{l}\text { Rofinery } \\
\text { Inputs }\end{array}$ & Exports & $\begin{array}{l}\text { Products } \\
\text { Supplied }\end{array}$ & \\
\hline 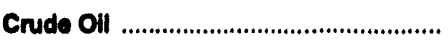 & E $\mathbf{3 0 9 , 9 3 8}$ & - & 381,566 & 21,180 & $-5,094$ & 0 & 779,512 & 6,645 & 647 & 917,354 \\
\hline $\begin{array}{l}\text { Natural Oas Llquids and LRGs ............ } \\
\text { Pentanes Plus ................................... } \\
\text { Llquefled Petroleum Gases .............. } \\
\text { Ethane/Ethylene ............................. } \\
\text { Propane/Propylene ...................... } \\
\text { Normal Butane/Butylene ............... } \\
\text { Isobutane/lsobutylene ................... }\end{array}$ & $\begin{array}{r}\mathbf{9 6 , 1 6 8} \\
18,015 \\
78,153 \\
29,824 \\
29,203 \\
7,306 \\
11,820\end{array}$ & $\begin{array}{r}25,506 \\
\cdots \\
25,506 \\
1,559 \\
23,872 \\
-546 \\
621\end{array}$ & $\begin{array}{r}13,499 \\
2,581 \\
10,918 \\
1,601 \\
7,513 \\
1,469 \\
335\end{array}$ & $\begin{array}{l}\ddot{-} \\
\ddot{-} \\
\ddot{-} \\
\ddot{-} \\
\cdots\end{array}$ & $\begin{array}{r}-43,535 \\
-2,312 \\
-41,223 \\
-3,755 \\
-26,064 \\
-11,825 \\
421\end{array}$ & $\begin{array}{l}- \\
-. \\
\cdots \\
-. \\
-. \\
-\end{array}$ & $\begin{array}{r}30,927 \\
9,492 \\
21,435 \\
0 \\
164 \\
12,103 \\
9,168\end{array}$ & $\begin{array}{r}2,155 \\
43 \\
2,112 \\
0 \\
1,442 \\
669 \\
0\end{array}$ & $\begin{array}{r}145,626 \\
13,373 \\
132,253 \\
36,739 \\
85,046 \\
7,282 \\
3,187\end{array}$ & $\begin{array}{r}73,688 \\
8,289 \\
65,407 \\
16,475 \\
25,133 \\
13,141 \\
10,658\end{array}$ \\
\hline $\begin{array}{l}\text { Other Liquids ............................... } \\
\text { Other Hydrocarbons/Oxygenates ....... } \\
\text { Unflnished Olls ............................... } \\
\text { Motor Gasoline Blend. Comp. ............ } \\
\text { Aviation Gasoline Blend. Comp. ........ }\end{array}$ & $\begin{array}{r}8,671 \\
9,451 \\
-780 \\
--\end{array}$ & $\begin{array}{l}- \\
\cdots \\
\cdots \\
\cdots\end{array}$ & $\begin{array}{r}29,945 \\
2,325 \\
27,193 \\
427 \\
0\end{array}$ & $\begin{array}{l}- \\
\ddot{-} \\
\ddot{-} \\
\ddot{-}\end{array}$ & $\begin{array}{r}14,565 \\
-1,548 \\
14,714 \\
1,397 \\
-8\end{array}$ & $\begin{array}{l}- \\
\ddot{-} \\
\ddot{-} \\
-\end{array}$ & $\begin{array}{r}28,648 \\
13,039 \\
15,643 \\
-1,998 \\
-36\end{array}$ & $\begin{array}{r}533 \\
285 \\
0 \\
248 \\
0\end{array}$ & $\begin{array}{r}-3,120 \\
0 \\
-3,164 \\
0 \\
44\end{array}$ & $\begin{array}{r}154,989 \\
10,993 \\
103,134 \\
40,772 \\
70\end{array}$ \\
\hline 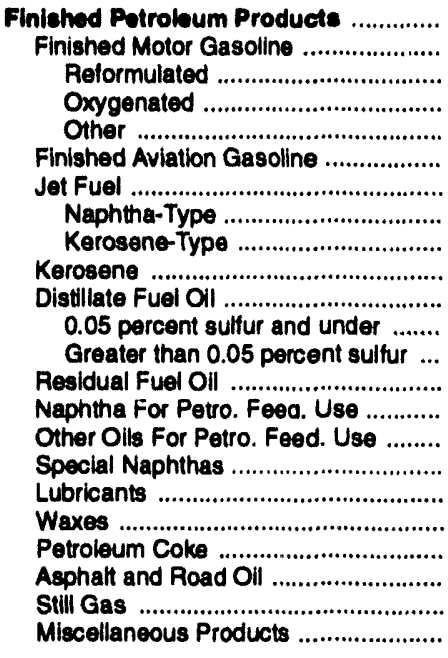 & 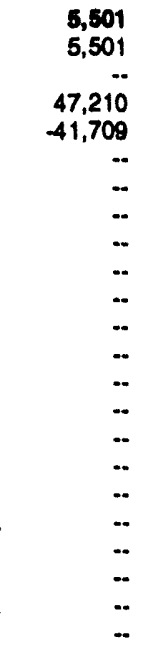 & $\begin{array}{r}854,100 \\
404,379 \\
0 \\
76,226 \\
328,153 \\
1,021 \\
83,904 \\
3,402 \\
80,502 \\
5,768 \\
181,155 \\
85,083 \\
96,072 \\
49,240 \\
8,002 \\
13,762 \\
2,665 \\
9,414 \\
1,144 \\
35,945 \\
17,882 \\
37,129 \\
2,690\end{array}$ & $\begin{array}{r}78,352 \\
14,254 \\
0 \\
0 \\
14,254 \\
8 \\
7,460 \\
386 \\
7,074 \\
462 \\
12,694 \\
3,125 \\
9,569 \\
31,983 \\
2,397 \\
7,123 \\
372 \\
94 \\
71 \\
138 \\
1,248 \\
0 \\
48\end{array}$ & 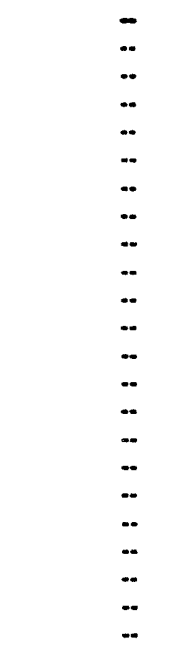 & $\begin{array}{r}-31,090 \\
847 \\
0 \\
-15,257 \\
16,204 \\
-124 \\
-51 \\
-114 \\
63 \\
588 \\
-37,283 \\
-14,049 \\
-23,234 \\
-4,756 \\
209 \\
367 \\
-254 \\
-201 \\
-51 \\
1,458 \\
8,005 \\
0 \\
87\end{array}$ & $\begin{array}{l}-. \\
-. \\
-. \\
-. \\
-. \\
-. \\
-. \\
-. \\
-. \\
-- \\
-- \\
-. \\
-- \\
-. \\
-. \\
- \\
-. \\
-\end{array}$ & 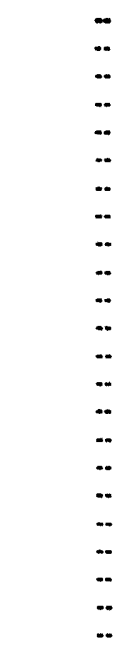 & $\begin{array}{r}44,002 \\
5,161 \\
0 \\
144 \\
5,017 \\
0 \\
2,231 \\
948 \\
1,283 \\
52 \\
16,849 \\
4,410 \\
12,439 \\
5,564 \\
0 \\
0 \\
82 \\
1,067 \\
111 \\
12,879 \\
82 \\
0 \\
15\end{array}$ & $\begin{array}{r}924,030 \\
418,026 \\
0 \\
138,549 \\
279,477 \\
1,153 \\
89,184 \\
2,954 \\
86,230 \\
5,590 \\
214,283 \\
97,847 \\
116,436 \\
80,415 \\
10,190 \\
20,528 \\
3,209 \\
8,642 \\
1,155 \\
21,746 \\
11,043 \\
37,129 \\
2,636\end{array}$ & $\begin{array}{r}434,706 \\
186,603 \\
0 \\
18,676 \\
167,927 \\
1,687 \\
40,155 \\
2,243 \\
37,912 \\
4,675 \\
103,985 \\
48,702 \\
55,283 \\
39,440 \\
2,074 \\
1,732 \\
2,262 \\
11,601 \\
801 \\
9,969 \\
27,056 \\
0 \\
2,666\end{array}$ \\
\hline Total & 509,305 & 879,606 & 493,302 & 21,180 & $-85,133$ & $\mathbf{0}$ & 837,087 & 53,425 & $1,088,083$ & $1,580,725$ \\
\hline
\end{tabular}

- Unaccounted for crucle oll represents the difference between the supply and disposition of crude oil. Preliminary estimates of crude oil imports at the National level have historicalty understated final values by approximately 50,000 barrels per day. This causes the preliminary values of unaccounted for crude oil to overstate the

final values by the same amount.

A negative number indicates a decrease in stocks and a positive number indicates an increase in stocks.

c Products supplied is equal to field production, plus refinery production, plus imports, plus unaccounted lor crude oil, minus stock change, minus crude losses, minus refinery inputs, minus exports.

(s) = Less than 500 barrels.

$E=$ Estimated.

LRG = Llquefied Refinery Gas.

Note: Totals may not equal sum of components due to independent rounding.

Sources: - Energy Information Administration (EIA) Forms EIA-810, "Monthly Refinery Report," EIA-811, "Monthly Bulk Terminal Report," ElA-812, "Monthly Product Pipeline Report," ElA-813, "Monthly Crude Oll Report," EIA-814, "Monthly imports Report," ElA-816, "Monthly Natural Gas Liquids Report," ElA-817, "Monthly Tanker and Barge Movement Report," and EIA-819M, "Monthly Oxygenate Telephone Report." - Domestic crude oil production estimates based on historical statistics from State conservation agencies and the Minerais Management Service of the U.S. Department of the Interior. • Export data from the Bureau of the Census and Form EIA-810, "Monthly Refinery Report." 
Table 4. U.S. Dally Average Supply and Dispostion of Crude Oll and Petroleum Products, February 1994

(Thousand Barrels per Day)

\begin{tabular}{|c|c|c|c|c|c|c|c|c|c|}
\hline \multirow[b]{2}{*}{ Commodity } & \multicolumn{4}{|c|}{ supply } & \multicolumn{5}{|c|}{ Dlepostilon } \\
\hline & \begin{tabular}{|c|} 
Fiold \\
Production
\end{tabular} & $\begin{array}{c}\text { Ruflnory } \\
\text { Production }\end{array}$ & Imports & $\begin{array}{c}\text { Unaccounted } \\
\text { For Crude } \\
\text { Olf }\end{array}$ & $\begin{array}{l}\text { stook } \\
\text { Changeb }\end{array}$ & $\begin{array}{l}\text { Crude } \\
\text { Lonnes }\end{array}$ & $\begin{array}{l}\text { Refinery } \\
\text { Inputs }\end{array}$ & Exports & $\begin{array}{l}\text { Producte } \\
\text { supplied }\end{array}$ \\
\hline 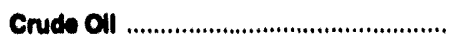 & $E_{0,746}$ & - & 6,313 & 37 & -184 & $\mathbf{0}$ & 13,132 & 116 & 12 \\
\hline 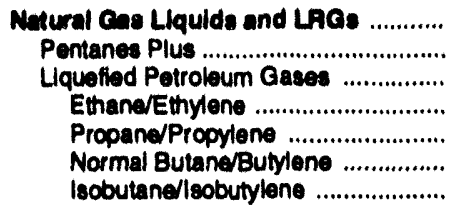 & $\begin{array}{r}1,942 \\
307 \\
1,335 \\
513 \\
498 \\
119 \\
205\end{array}$ & $\begin{array}{r}474 \\
474 \\
25 \\
410 \\
29 \\
10\end{array}$ & $\begin{array}{r}225 \\
43 \\
182 \\
36 \\
119 \\
18 \\
9\end{array}$ & $\begin{array}{l}\ddot{-} \\
\ddot{-} \\
\ddot{-}\end{array}$ & $\begin{array}{r}-816 \\
-41 \\
-474 \\
-16 \\
.316 \\
.158 \\
17\end{array}$ & $\begin{array}{l}\ddot{-} \\
\ddot{-} \\
\ddot{-} \\
\ddot{-}\end{array}$ & $\begin{array}{r}502 \\
159 \\
343 \\
0 \\
6 \\
185 \\
153\end{array}$ & $\begin{array}{r}45 \\
1 \\
44 \\
0 \\
30 \\
14 \\
0\end{array}$ & $\begin{array}{r}2,308 \\
231 \\
2,077 \\
590 \\
1,308 \\
125 \\
55\end{array}$ \\
\hline $\begin{array}{l}\text { Other Liquide } \\
\text { Other Hydrocaitoons........................... } \\
\text { Unflinighed Olls .................................... } \\
\text { Motor Gasoline Blend. Comp. ........... } \\
\text { Aviation Gasoline Blend. Comp. ........ }\end{array}$ & $\begin{array}{r}133 \\
125 \\
11 \\
-\end{array}$ & $\begin{array}{l}- \\
\ddot{-} \\
\ddot{-}\end{array}$ & $\begin{array}{r}494 \\
53 \\
423 \\
8 \\
0\end{array}$ & $\begin{array}{l}- \\
- \\
-\end{array}$ & $\begin{array}{r}68 \\
-12 \\
98 \\
-20 \\
(8)\end{array}$ & $\begin{array}{l}- \\
\ddot{-} \\
\ddot{-}\end{array}$ & $\begin{array}{r}479 \\
186 \\
263 \\
31 \\
-1\end{array}$ & $\begin{array}{r}13 \\
4 \\
0 \\
9 \\
0\end{array}$ & $\begin{array}{r}63 \\
0 \\
62 \\
0 \\
2\end{array}$ \\
\hline 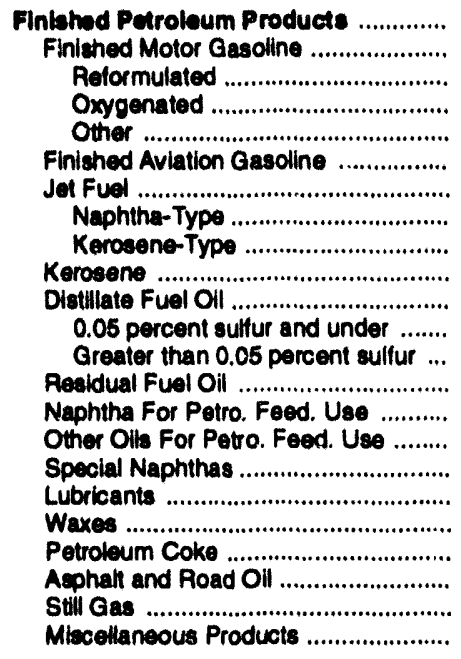 & $\begin{array}{r}62 \\
62 \\
733 \\
67 \\
- \\
- \\
- \\
- \\
- \\
- \\
- \\
- \\
- \\
- \\
-\end{array}$ & $\begin{array}{r}14,310 \\
6,718 \\
0 \\
909 \\
5,719 \\
21 \\
1,379 \\
48 \\
1,331 \\
90 \\
3,019 \\
1,454 \\
1,565 \\
859 \\
141 \\
254 \\
38 \\
162 \\
21 \\
601 \\
336 \\
626 \\
45\end{array}$ & $\begin{array}{r}1,478 \\
281 \\
0 \\
0 \\
281 \\
(8) \\
138 \\
1 \\
136 \\
13 \\
278 \\
60 \\
216 \\
586 \\
40 \\
118 \\
6 \\
2 \\
1 \\
1 \\
17 \\
0 \\
2\end{array}$ & $\begin{array}{l}- \\
- \\
- \\
- \\
- \\
- \\
- \\
- \\
- \\
- \\
- \\
- \\
- \\
- \\
- \\
-\end{array}$ & $\begin{array}{r}-75 \\
-288 \\
0 \\
-426 \\
138 \\
(8) \\
-41 \\
-12 \\
-28 \\
11 \\
-505 \\
-257 \\
-249 \\
-152 \\
14 \\
6 \\
-14 \\
-6 \\
(8) \\
36 \\
148 \\
0 \\
16\end{array}$ & $\begin{array}{l}- \\
. \\
- \\
\ldots \\
. . \\
-. \\
- \\
- \\
- \\
- \\
- \\
- \\
- \\
- \\
-. \\
-. \\
- \\
-\end{array}$ & $\begin{array}{l}- \\
- \\
- \\
- \\
- \\
- \\
- \\
- \\
- \\
- \\
- \\
- \\
- \\
- \\
- \\
- \\
- \\
- \\
-\end{array}$ & $\begin{array}{r}708 \\
77 \\
0 \\
1 \\
76 \\
0 \\
35 \\
9 \\
26 \\
(8) \\
235 \\
46 \\
189 \\
127 \\
0 \\
0 \\
1 \\
19 \\
2 \\
210 \\
2 \\
0 \\
(8)\end{array}$ & $\begin{array}{r}15,918 \\
7,272 \\
0 \\
2,157 \\
5,115 \\
21 \\
1,522 \\
52 \\
1,471 \\
92 \\
3,565 \\
1,724 \\
1,841 \\
1,470 \\
167 \\
366 \\
57 \\
150 \\
21 \\
356 \\
203 \\
626 \\
31\end{array}$ \\
\hline 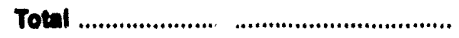 & 8,586 & 14,704 & Q,501 & 37 & $-1,399$ & 0 & 14,113 & 882 & 18,302 \\
\hline
\end{tabular}

- Unaccounted for crude oll represents the difference between the supply and disposition of crude oll. Prellminary estimates of crude oll imports at the National level have historically understated final values by approximately 50,000 barrels per day. This causes the preliminary values of unaccounted for crude oll to overstate the final values by the same amount.

- A negative number indicates a decrease in stocks and a positive number indicates an increase in stocks.

c Products supplied is equal to fleld production, plus refinery production, plus imports, plus unaccounted for crude oil, minus stock change, minus crude losses, minus refinery inputs, minus exports.

$(8)=$ Less than 500 barrols per day.

E = Estimated.

LRG = Llquefied Refinery Gas.

Note: Totals may not equal sum of components due to independent rounding

Sources: - Energy Information Administration (ElA) Forms EIA-810, "Monthly Refinery Report, EIA-811, "Monthly Bulk Terminal Report," EIA-812, "Monthly Product Pipeline Report," ElA-813, "Monthly Crude Oll Repont," ElA-814, "Monthly Imports Repont," ElA-816, "Monthly Natural Gas Liquids Repor," EIA-817, "Monthly Tanker and Barge Movement Report," and ElA-819M, "Monthly Oxygenate Telephone Report". Domestic crude oll producthw estimates based on historical statstics from State conservation agencies and the Minerals Management Service of the U.S. Department of the interior. Export data from the Bureau of the Census and Form ElA-810, "Monthly Refinery Report." 
Table 5. U.S. Year-to-Date Daily Average Supply and Dieposition of Crude Oll and Potroleum Products, January-Fobruary 1994 (Thousand Barrels per Day)

\begin{tabular}{|c|c|c|c|c|c|c|c|c|c|}
\hline \multirow[b]{2}{*}{ Commodty } & \multicolumn{4}{|c|}{ supply } & \multicolumn{5}{|c|}{ Diepostition } \\
\hline & $\begin{array}{c}\text { Fleld } \\
\text { Production }\end{array}$ & $\begin{array}{c}\text { Rofinory } \\
\text { Preduction }\end{array}$ & Imports & $\begin{array}{c}\text { Uneooounted } \\
\text { Por Crude } \\
\text { Oll }\end{array}$ & $\begin{array}{l}\text { slock } \\
\text { Change" }\end{array}$ & $\begin{array}{l}\text { Crude } \\
\text { Loesees }\end{array}$ & $\begin{array}{c}\text { Rofinery } \\
\text { Inpute }\end{array}$ & Exponts & $\begin{array}{l}\text { Products } \\
\text { Supplied }\end{array}$ \\
\hline 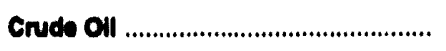 & E 6,702 & - & 0,120 & 349 & -4 & $\mathbf{0}$ & 13,212 & 113 & 11 \\
\hline 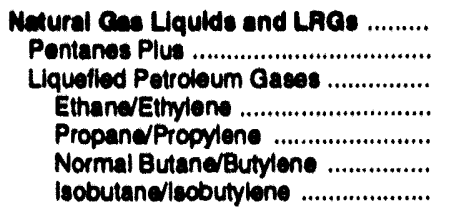 & $\begin{array}{r}1,930 \\
308 \\
1,325 \\
508 \\
495 \\
124 \\
200\end{array}$ & $\begin{array}{r}482 \\
432 \\
26 \\
405 \\
-9 \\
11\end{array}$ & $\begin{array}{r}29 \\
44 \\
186 \\
27 \\
127 \\
28 \\
6\end{array}$ & $\begin{array}{l}- \\
\ddot{*} \\
\ldots \\
. \\
.\end{array}$ & $\begin{array}{r}-730 \\
-30 \\
690 \\
64 \\
-442 \\
-200 \\
7\end{array}$ & 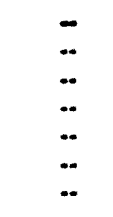 & $\begin{array}{r}824 \\
161 \\
363 \\
0 \\
3 \\
205 \\
155\end{array}$ & $\begin{array}{r}37 \\
1 \\
36 \\
0 \\
24 \\
11 \\
0\end{array}$ & $\begin{array}{r}2,468 \\
227 \\
2,242 \\
623 \\
1,441 \\
123 \\
54\end{array}$ \\
\hline $\begin{array}{l}\text { Other Lquids .................................... } \\
\text { Other Hydrocarbona Oxygenates ..... } \\
\text { Unilinished Oils ................................... } \\
\text { Motor Gacollne Biend. Comp. ........... } \\
\text { Aviation Gasoline Blend. Comp. ....... }\end{array}$ & $\begin{array}{r}147 \\
160 \\
.13 \\
-.\end{array}$ & $\begin{array}{l}\ddot{-} \\
\ddot{*} \\
\ddot{*}\end{array}$ & $\begin{array}{r}105 \\
30 \\
481 \\
7 \\
0\end{array}$ & $\begin{array}{l}- \\
\ldots \\
\ldots\end{array}$ & $\begin{array}{r}247 \\
-28 \\
240 \\
24 \\
(8)\end{array}$ & 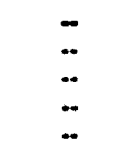 & $\begin{array}{r}482 \\
221 \\
285 \\
-34 \\
.1\end{array}$ & $\begin{array}{l}9 \\
5 \\
0 \\
4 \\
0\end{array}$ & $\begin{array}{r}-63 \\
0 \\
-54 \\
0 \\
1\end{array}$ \\
\hline 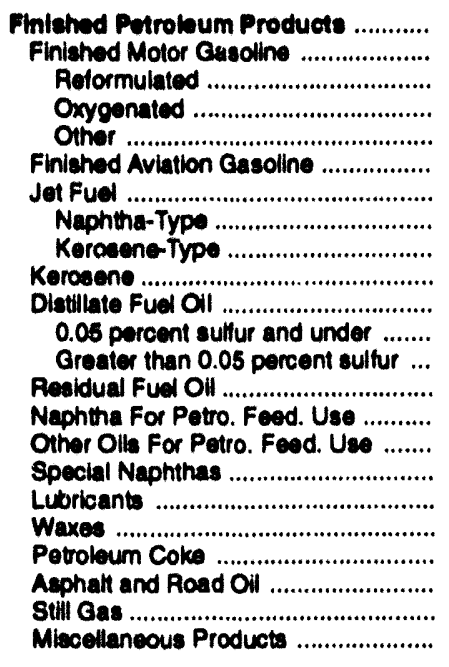 & 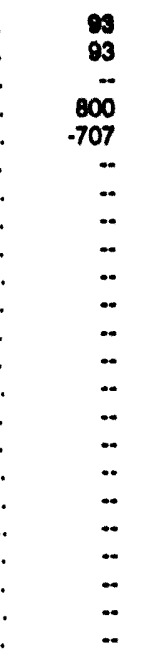 & $\begin{array}{r}14,478 \\
6,884 \\
0 \\
1,292 \\
6,602 \\
17 \\
1,422 \\
58 \\
1,384 \\
80 \\
3,070 \\
1,442 \\
1,628 \\
835 \\
136 \\
233 \\
45 \\
160 \\
19 \\
609 \\
303 \\
629 \\
46\end{array}$ & $\begin{array}{r}1.208 \\
242 \\
0 \\
0 \\
242 \\
(0) \\
126 \\
7 \\
120 \\
8 \\
215 \\
63 \\
162 \\
542 \\
41 \\
121 \\
6 \\
2 \\
1 \\
2 \\
21 \\
0 \\
1\end{array}$ & 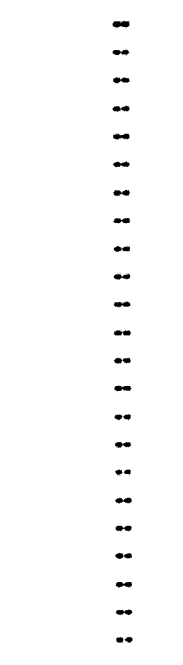 & $\begin{array}{r}-27 \\
16 \\
0 \\
-260 \\
275 \\
-2 \\
-1 \\
-2 \\
1 \\
10 \\
-632 \\
-238 \\
-304 \\
-81 \\
4 \\
6 \\
-4 \\
-3 \\
-1 \\
25 \\
136 \\
0 \\
1\end{array}$ & 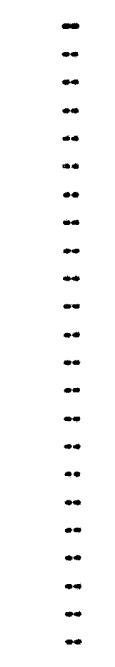 & 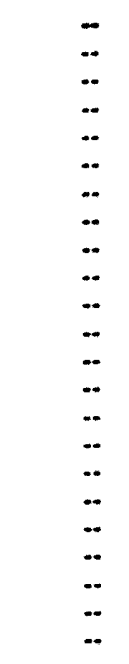 & $\begin{array}{r}747 \\
87 \\
0 \\
2 \\
85 \\
0 \\
38 \\
16 \\
22 \\
1 \\
286 \\
75 \\
211 \\
84 \\
0 \\
0 \\
1 \\
18 \\
2 \\
218 \\
1 \\
0 \\
(8)\end{array}$ & $\begin{array}{r}15,677 \\
7,085 \\
0 \\
2,348 \\
4,737 \\
20 \\
1,512 \\
50 \\
1,462 \\
95 \\
3,632 \\
1,658 \\
1,973 \\
1,363 \\
173 \\
348 \\
54 \\
146 \\
20 \\
369 \\
187 \\
629 \\
45\end{array}$ \\
\hline 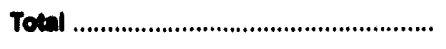 & 8,080 & 14,919 & 0,193 & 300 & $-1,104$ & $\mathbf{0}$ & 14,198 & $\operatorname{sos}$ & 18,103 \\
\hline
\end{tabular}

- Uneccounted for crude oll represents the difflorence between the supply and diepoeition of erude oll. Prellminary eatimates of crude oll imports at the National level have historlcally understated tinal values by approximaley 50,000 barrele per dey. This causes the preltminary values of unaccounted for crude oll to overstate the final values by the same amount.

- A negative number indicates a decrease in etocks and a poeltwe number indicates an increase in stocks.

- Products supplied ls equal to field production, plus refinery production, plus imports, plus unaccounted for crude oll, minus stock change, minus crude loseses, minus refinery inputs, minus exports.

(s) = Less than 500 barrels per day.

E = Estimated.

LRQ = Llquelled Refinery Gas.

Note: Totals may not equal sum of components due to indepondent rounding.

Sources: - Energy Intormation Administration (EIA) Forms ElA-810, "Monthly Refinery Repon," ElA-811, "Monthly Bulk Torminal Report," ElA-812, 'Monthly Product Pipeline Repon,' ElA-813, 'Monthly Crude Oll Report," ElA-814, "Monthly imports Report," ElA-816, "Monthly Natural Gas Liquids Report," ElA-817. "Monthly Tanker and Barge Movement Report," and ELA-819M, 'Monthly Oxygenale Telephone Report'. - Domestic crude oil production estimates based on historical statistics from State conservation agencies and the Minerals Management Service of the U.S. Department of the Interior. • Export data from the Bureau of the Census and Form EIA-810, "Monthly Refinery Repont." 
Table 6. PAD District —Supply, Disposition, and Ending Stocks of Crude Oll and Petroleum Products, February 1994

(Thousand Barrels)

\begin{tabular}{|c|c|c|c|c|c|c|c|c|c|c|c|}
\hline \multirow[b]{2}{*}{ Commodity } & \multicolumn{5}{|c|}{ supply } & \multicolumn{5}{|c|}{ Disposition } & \multirow[b]{2}{*}{$\begin{array}{l}\text { Ending } \\
\text { eleake }\end{array}$} \\
\hline & $\begin{array}{c}\text { Pleld } \\
\text { Proxduction }\end{array}$ & $\begin{array}{c}\text { Rofinery } \\
\text { Production }\end{array}$ & $\begin{array}{c}\text { Imports by } \\
\text { PAD } \\
\text { Diatriet } \\
\text { olented }\end{array}$ & $\begin{array}{l}\text { Unac- } \\
\text { oounted } \\
\text { For } \\
\text { Crude } 01^{b}\end{array}$ & $\begin{array}{c}\text { Net } \\
\text { Anedinte }\end{array}$ & $\left.\begin{array}{c}\text { Stook } \\
\text { Chnnme }\end{array}\right]$ & $\begin{array}{l}\text { Crude } \\
\text { hosere }\end{array}$ & $\begin{array}{c}\text { Rofinery } \\
\text { Inpits }\end{array}$ & Exporte & $\begin{array}{l}\text { Producte } \\
\text { Supelind }\end{array}$ & \\
\hline 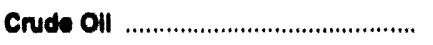 & $E_{003}$ & $\infty$ & 30,493 & 707 & 10 & 2,470 & $\mathbf{0}$ & 38,520 & 2 & 0 & 18,297 \\
\hline 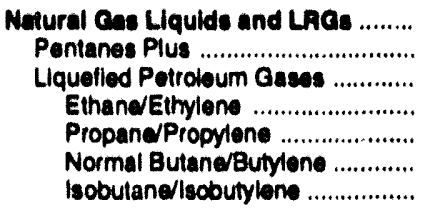 & $\begin{array}{r}72 \\
75 \\
684 \\
230 \\
292 \\
99 \\
33\end{array}$ & $\begin{array}{r}1,042 \\
\ldots \\
1,042 \\
0 \\
1,236 \\
-224 \\
30\end{array}$ & $\begin{array}{r}1,833 \\
0 \\
1,533 \\
0 \\
1,518 \\
15 \\
0\end{array}$ & 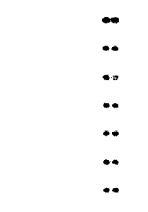 & $\begin{array}{r}4,212 \\
0 \\
4,212 \\
0 \\
4,212 \\
0 \\
0\end{array}$ & $\begin{array}{r}118 \\
.79 \\
197 \\
0 \\
355 \\
.189 \\
31\end{array}$ & $\begin{array}{l}\ddot{.} \\
\ddot{.} \\
\ddot{.} \\
\ddot{.} \\
\ddot{*}\end{array}$ & $\begin{array}{r}393 \\
76 \\
317 \\
0 \\
0 \\
240 \\
77\end{array}$ & $\begin{array}{r}27 \\
1 \\
26 \\
0 \\
20 \\
5 \\
0\end{array}$ & $\begin{array}{r}6,970 \\
77 \\
6,901 \\
230 \\
6,883 \\
-168 \\
45\end{array}$ & $\begin{array}{r}3,240 \\
106 \\
3,075 \\
0 \\
2,237 \\
700 \\
138\end{array}$ \\
\hline $\begin{array}{l}\text { Other Liquids ................................. } \\
\text { Other HydrocarbonarOxygenates .... } \\
\text { Unifinished Olls ................................ } \\
\text { Motor Gasoline Blend. Comp. ......... } \\
\text { Aviation Gasc."ne Blend. Comp. .... }\end{array}$ & $\begin{array}{r}1,000 \\
1,161 \\
.03 \\
. .\end{array}$ & $\ddot{-}$ & $\begin{array}{r}5,698 \\
568 \\
5,115 \\
184 \\
0\end{array}$ & $\begin{array}{l}\ddot{ } \\
\ddot{.} \\
\ddot{.} \\
\ddot{ }\end{array}$ & $\begin{array}{r}271 \\
0 \\
286 \\
-15 \\
0\end{array}$ & $\begin{array}{r}207 \\
225 \\
18 \\
-408 \\
-42\end{array}$ & 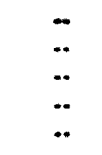 & $\begin{array}{r}6,139 \\
1,502 \\
4,154 \\
484 \\
-1\end{array}$ & $\begin{array}{r}1 \\
(8) \\
0 \\
(8) \\
0\end{array}$ & $\begin{array}{r}1,272 \\
0 \\
1,229 \\
0 \\
43\end{array}$ & $\begin{array}{r}15,979 \\
1,288 \\
9,650 \\
5,126 \\
16\end{array}$ \\
\hline 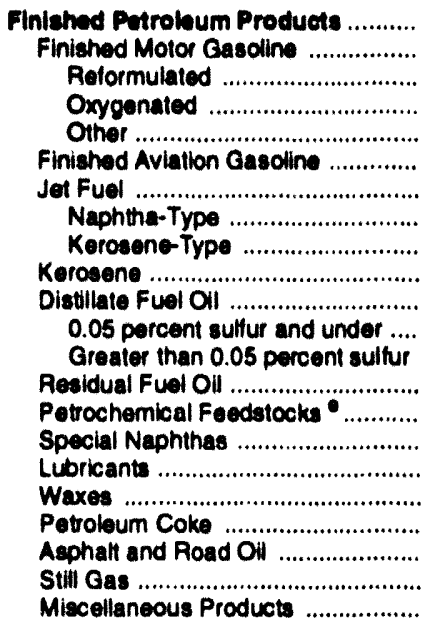 & 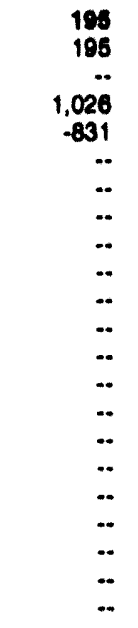 & $\begin{array}{r}4,002 \\
21,631 \\
0 \\
8,058 \\
13,575 \\
-1 \\
2,321 \\
0 \\
2,321 \\
212 \\
11,866 \\
3,652 \\
8,214 \\
4,201 \\
398 \\
16 \\
503 \\
142 \\
1,411 \\
1,424 \\
1,908 \\
62\end{array}$ & $\begin{array}{r}38,702 \\
7,760 \\
0 \\
0 \\
7,768 \\
0 \\
3,784 \\
0 \\
3,784 \\
280 \\
7,367 \\
1,496 \\
5,862 \\
15,756 \\
195 \\
44 \\
37 \\
20 \\
0 \\
459 \\
0 \\
2\end{array}$ & 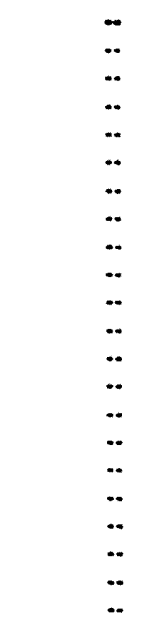 & $\begin{array}{r}71,179 \\
37,132 \\
0 \\
9,862 \\
27,270 \\
44 \\
11,419 \\
51 \\
11,368 \\
343 \\
21,350 \\
6,314 \\
15,036 \\
321 \\
-9 \\
39 \\
357 \\
0 \\
0 \\
148 \\
0 \\
35\end{array}$ & $\begin{array}{r}-8,080 \\
-1,922 \\
0 \\
-4,767 \\
2,845 \\
-157 \\
1,855 \\
-52 \\
1,907 \\
292 \\
-6,481 \\
-2,227 \\
-4,254 \\
-743 \\
-9 \\
10 \\
149 \\
0 \\
-63 \\
1,085 \\
0 \\
124\end{array}$ & 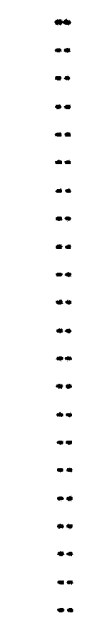 & 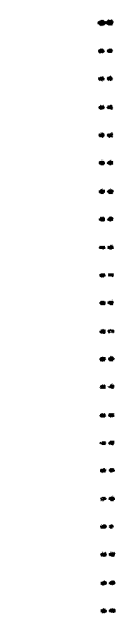 & $\begin{array}{r}670 \\
15 \\
0 \\
15 \\
(8) \\
0 \\
1 \\
(8) \\
(8) \\
1 \\
63 \\
14 \\
49 \\
260 \\
0 \\
7 \\
94 \\
9 \\
218 \\
3 \\
0 \\
5\end{array}$ & $\begin{array}{r}168,362 \\
68,633 \\
0 \\
23,686 \\
44,937 \\
200 \\
15,668 \\
103 \\
15,568 \\
542 \\
46,991 \\
13,674 \\
33,317 \\
20,761 \\
593 \\
82 \\
654 \\
153 \\
1,256 \\
943 \\
1,908 \\
-30\end{array}$ & $\begin{array}{r}129,604 \\
56,902 \\
0 \\
9,802 \\
47,490 \\
420 \\
10,043 \\
225 \\
9,818 \\
1,802 \\
35,086 \\
11,028 \\
24,029 \\
14,075 \\
249 \\
130 \\
2,729 \\
158 \\
1,061 \\
5,389 \\
0 \\
5525\end{array}$ \\
\hline 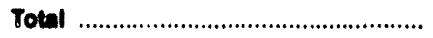 & 2,700 & 47,134 & 92,893 & 707 & 75,681 & $-3,479$ & $\mathbf{0}$ & 45,052 & 705 & 160,602 & 104,044 \\
\hline
\end{tabular}

Represents the PAD Diatict in which the material entered the United States and not necessarily where the crude ofl or product is processed and/or consumed.

- Unaccounted for crude oll represents the difference between the supply and disposition of crude oll.

c A negative number indicates a decrease in atocks and a poest tve number indicates an increase in stocks.

d Products supplied is equal to field production, plus refinery production, plus imports, plus unaccounted lor crude oll, plus net receipts, minus stock change, minus crude losses, minus relinery inputs, minus exports.

- includes naphtha less than $401^{\circ} \mathrm{F}$ endpoint and other olls equal to or greater than $401^{\circ} \mathrm{F}$ endpoint.

(s) = Less than 500 barrels.

$E=$ Estimated.

LRG $=$ Liquetied Retinery Gas.

Note: Totals may not equal sum of components due to independent rounding

Sources: - Energy Information Administration (EIA) Forms ElA-810, "Monthly Refinery Report," ElA-811. "Monthly Bulk Terminal Report," EIA-812, "Monthly Product Pipeline Report," ElA-813, "Monthly Crude Oil Report," ElA-814, "Monthly Imports Report," EIA-816. "Monthly Natural Gas Liquids Report," ElA-817, "Monthly Tanker and Barge Movement Repon," and EIA-818M, "Monthly Oxyoenate Telephone Report". - Domestic crude oll production estimates based on historical statistics trom State coneervation agencies and the Minerala Management Service of the U.S. Department of the Interior. - Export data from the Bureau of the Census and Form ElA-810, "Moninly Refinery Report." 
Table 7. PAD Diatrict —Yoar-to-Date Supply, Dispositlon, and Ending Stocks of Crude Oll and Potroloum Products, January-Fobruary 1984 (Thousand Barrels)

\begin{tabular}{|c|c|c|c|c|c|c|c|c|c|c|c|}
\hline \multirow[b]{2}{*}{ Commedity } & \multicolumn{5}{|c|}{ supply } & \multicolumn{5}{|c|}{ Diepostilon } & \multirow[b]{2}{*}{$\begin{array}{l}\text { Endling } \\
\text { Slocks }\end{array}$} \\
\hline & $\begin{array}{l}\text { Fiold } \\
\text { Production }\end{array}$ & $\begin{array}{l}\text { Rownery } \\
\text { Produetlon }\end{array}$ & $\begin{array}{c}\text { Importe by } \\
\text { PAD } \\
\text { Dicterlet } \\
\text { of entige }\end{array}$ & $\begin{array}{l}\text { Unao- } \\
\text { counted } \\
\text { For } \\
\text { crudiegle }\end{array}$ & $\begin{array}{c}\mathrm{Nex} \\
\text { Reniot }\end{array}$ & $\begin{array}{c}\text { stook } \\
\text { Chinne }\end{array}$ & $\begin{array}{l}\text { Crude } \\
\text { Loenes }\end{array}$ & $\begin{array}{l}\text { Rofinery } \\
\text { lnoute }\end{array}$ & Exooth & $\begin{array}{l}\text { Products } \\
\text { supolled }\end{array}$ & \\
\hline 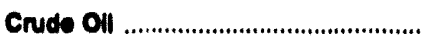 & $E_{1,818}$ & - & 72,194 & 4,470 & 70 & 977 & $\mathbf{0}$ & 77,319 & 2 & 0 & 16,297 \\
\hline 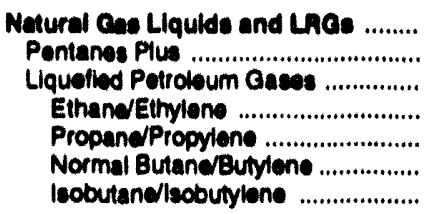 & $\begin{array}{r}1,408 \\
180 \\
1,318 \\
477 \\
676 \\
201 \\
62\end{array}$ & $\begin{array}{r}1,706 \\
1.76 \\
0 \\
2,389 \\
.577 \\
.23\end{array}$ & $\begin{array}{r}2,998 \\
0 \\
2,896 \\
0 \\
2,897 \\
78 \\
0\end{array}$ & $\begin{array}{l}\ddot{ } \\
\cdots \\
\cdots \\
\ddot{*} \\
\cdots\end{array}$ & $\begin{array}{r}9,205 \\
0 \\
9,208 \\
0 \\
0,165 \\
50 \\
0\end{array}$ & $\begin{array}{r}-2,259 \\
-123 \\
-2,129 \\
0 \\
-1,413 \\
-744 \\
28\end{array}$ & 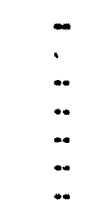 & $\begin{array}{r}670 \\
128 \\
550 \\
0 \\
0 \\
412 \\
138\end{array}$ & $\begin{array}{r}48 \\
5 \\
43 \\
0 \\
37 \\
6 \\
0\end{array}$ & $\begin{array}{r}16,927 \\
140 \\
16,787 \\
477 \\
16,359 \\
78 \\
.127\end{array}$ & $\begin{array}{r}3,240 \\
165 \\
3,075 \\
0 \\
2,237 \\
700 \\
138\end{array}$ \\
\hline 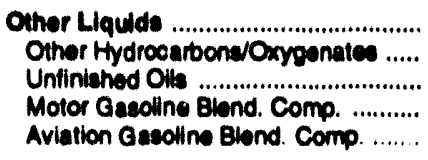 & $\begin{array}{r}2,309 \\
2,213 \\
\ddot{04} \\
\cdots\end{array}$ & $\begin{array}{l}\ddot{-} \\
\ddot{-} \\
\ddot{-}\end{array}$ & $\begin{array}{r}10.021 \\
813 \\
0.484 \\
331 \\
0\end{array}$ & $\begin{array}{l}\ddot{ } \\
\ddot{*} \\
\ddot{*}\end{array}$ & $\begin{array}{r}610 \\
0 \\
634 \\
-24 \\
0\end{array}$ & $\begin{array}{r}-171 \\
-272 \\
813 \\
-486 \\
-26\end{array}$ & $\begin{array}{l}\cdots \\
\cdots \\
\cdots \\
\cdots\end{array}$ & $\begin{array}{r}13,000 \\
3,297 \\
8,924 \\
886 \\
.17\end{array}$ & $\begin{array}{l}1 \\
1 \\
0 \\
1 \\
0\end{array}$ & $\begin{array}{r}624 \\
0 \\
581 \\
0 \\
43\end{array}$ & $\begin{array}{r}15,979 \\
1,288 \\
9,550 \\
5,125 \\
16\end{array}$ \\
\hline 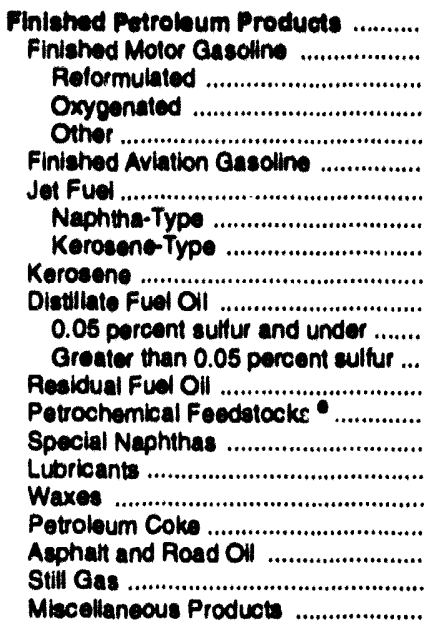 & $\begin{array}{r}149 \\
142 \\
. . \\
2,381 \\
.2,218 \\
. . \\
. . \\
. . \\
. . \\
. . \\
. . \\
. . \\
. . \\
. . \\
. . \\
. . \\
. . \\
.\end{array}$ & $\begin{array}{r}83,894 \\
4,986 \\
0 \\
17,689 \\
27,417 \\
24 \\
4,653 \\
28 \\
4,625 \\
399 \\
23,688 \\
6,722 \\
16,840 \\
8,696 \\
810 \\
36 \\
1,014 \\
244 \\
3,099 \\
2,380 \\
3,877 \\
120\end{array}$ & $\begin{array}{r}94,727 \\
13,936 \\
0 \\
0 \\
13,986 \\
0 \\
7,323 \\
320 \\
7,003 \\
328 \\
11,098 \\
2,746 \\
9,252 \\
29,333 \\
462 \\
108 \\
64 \\
47 \\
0 \\
1,106 \\
0 \\
4\end{array}$ & 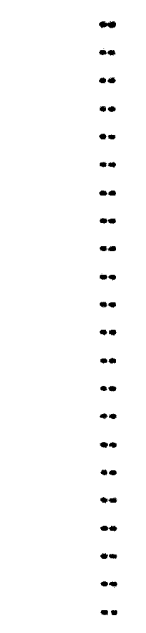 & $\begin{array}{r}147,700 \\
78,771 \\
0 \\
19,590 \\
69,175 \\
72 \\
22,685 \\
171 \\
22,494 \\
575 \\
43,679 \\
16,170 \\
27,500 \\
585 \\
-9 \\
140 \\
860 \\
2 \\
0 \\
258 \\
0 \\
102\end{array}$ & $\begin{array}{r}-29,693 \\
-2,714 \\
0 \\
-6,085 \\
3,341 \\
-193 \\
1,109 \\
-46 \\
1,165 \\
209 \\
-26,789 \\
-8,937 \\
\cdot 17,862 \\
-2,215 \\
-26 \\
-92 \\
34 \\
-3 \\
150 \\
1,872 \\
0 \\
65\end{array}$ & 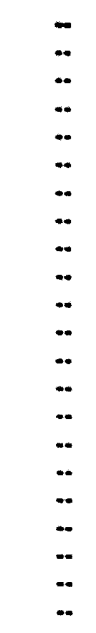 & 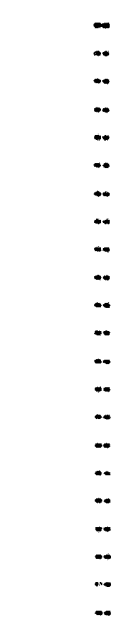 & $\begin{array}{r}2,215 \\
38 \\
0 \\
38 \\
(5) \\
0 \\
45 \\
1 \\
44 \\
2 \\
1,147 \\
66 \\
1,092 \\
338 \\
0 \\
13 \\
230 \\
26 \\
359 \\
5 \\
0 \\
11\end{array}$ & $\begin{array}{r}332,002 \\
140,511 \\
0 \\
45,513 \\
94,998 \\
289 \\
33,487 \\
564 \\
32,923 \\
1,090 \\
104,887 \\
34,519 \\
70,367 \\
40,490 \\
1,279 \\
361 \\
1,674 \\
270 \\
2,590 \\
1,847 \\
3,877 \\
150\end{array}$ & $\begin{array}{r}129,568 \\
56,992 \\
0 \\
9,502 \\
47,490 \\
420 \\
10,043 \\
225 \\
9,818 \\
1,862 \\
35,955 \\
11,026 \\
24,929 \\
14.075 \\
249 \\
130 \\
2,729 \\
158 \\
1,061 \\
5,369 \\
0 \\
525\end{array}$ \\
\hline Total & 8,460 & 98,000 & 180,514 & 4,470 & 187,509 & $-30,030$ & $\mathbf{0}$ & 91,007 & 2,208 & 350,353 & 164,084 \\
\hline
\end{tabular}

- Represents the PAD District in which the material entered the United Stutes and not necesearily where the crude oll or product is processed and/or consumed.

b Unaccounted for crude oll represents the difference between the supply and disposition of crude oll.

c A necattve number indicates a decreace in stocks and a positive number indicates an increase in stocks.

d Products suppiled is equal to fleld production, plus relinery production, plus imports, plus unaccounted lor cri de oll, plus net receipts, minus stock change, minus crude losese, minus refinery inputs, minus exports.

- Includes naphtha lese than $401^{\circ} \mathrm{F}$ endpoint and other olle equal to or greater than $401^{\circ} \mathrm{F}$ endpoint.

(s) = Lese than 500 barrele.

E Estimated.

LRG = Llquetied Refinery Gas.

Note: Totals may not equal sum of components due to independent rounding

Sources: - Energy Intormation Administration (EIA) Forme EM-810, 'Monthy Refinery Repont," EIA-811, "Monthly Bulk Terminal Report," EIA-812, "Monthly Product Pipeline Report," ELA-813, "Monthy Crude Oil Report," ElA-814, "Monthly Imports Report, ElA-816, "Monthly Natural Gas Liquids Report," ElA-817, "Monthly Tanker and Barge Movement Report," and ELA-819M, "Monthly Oxygenate Telephone Report". - Domestic crude oll production estimates based on historical statistics Irom State conservation agencies and the Minerals Management Service of the U.S. Department of the Interior. Export data trom the Bureau of the Census and Form EIA-810, "Monthly Refinery Report." 
Table 8. PAD District —Dally Average Supply and Disposition of Crude Oll and Petroleum Products, Fobruary 1994 (Thousand Barrels per Day)

\begin{tabular}{|c|c|c|c|c|c|c|c|c|c|c|}
\hline \multirow[b]{2}{*}{ Commodty } & \multicolumn{5}{|c|}{ supply } & \multicolumn{5}{|c|}{ Dleposition } \\
\hline & $\begin{array}{l}\text { Fibld } \\
\text { eroduction }\end{array}$ & $\begin{array}{c}\text { Poflinory } \\
\text { Productlon }\end{array}$ & $\begin{array}{c}\text { Imports by } \\
\text { Pad } \\
\text { Dlotitet } \\
\text { of inted }\end{array}$ & $\begin{array}{l}\text { Unao- } \\
\text { oounted } \\
\text { For } \\
\text { crudtolle }\end{array}$ & $\begin{array}{c}\text { Net } \\
\text { Amatoln }\end{array}$ & $\begin{array}{c}\text { stock } \\
\text { Chntroe }\end{array}$ & $\begin{array}{l}\text { Crude } \\
\text { lorine }\end{array}$ & $\begin{array}{c}\text { Rofinery } \\
\text { Inoute }\end{array}$ & Exports & $\begin{array}{l}\text { Products } \\
\text { surelled }\end{array}$ \\
\hline Crude Oll & E 20 & - & 1,400 & 25 & 1 & 88 & 0 & 1,370 & (a) & 0 \\
\hline 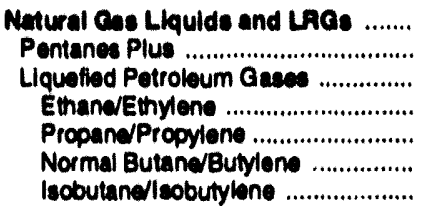 & $\begin{array}{r}20 \\
3 \\
23 \\
8 \\
10 \\
4 \\
1\end{array}$ & $\begin{array}{r}37 \\
37 \\
0 \\
44 \\
-8 \\
1\end{array}$ & $\begin{array}{r}55 \\
0 \\
55 \\
0 \\
54 \\
1 \\
0\end{array}$ & $\begin{array}{l}- \\
\ddot{m} \\
\ddot{m}\end{array}$ & $\begin{array}{r}150 \\
0 \\
150 \\
0 \\
150 \\
0 \\
0\end{array}$ & $\begin{array}{r}4 \\
-3 \\
7 \\
0 \\
13 \\
-7 \\
1\end{array}$ & $\begin{array}{l}\ddot{-} \\
\ddot{-} \\
\ddot{-}\end{array}$ & $\begin{array}{r}14 \\
3 \\
11 \\
0 \\
0 \\
9 \\
3\end{array}$ & $\begin{array}{r}1 \\
(s) \\
1 \\
0 \\
1 \\
(s) \\
0\end{array}$ & $\begin{array}{r}249 \\
3 \\
246 \\
8 \\
246 \\
-6 \\
-2\end{array}$ \\
\hline 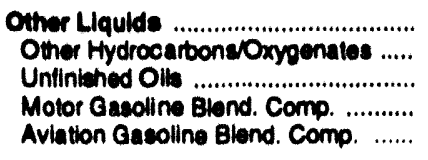 & $\begin{array}{l}30 \\
41 \\
-3\end{array}$ & $\begin{array}{l}- \\
- \\
- \\
-\end{array}$ & $\begin{array}{r}200 \\
20 \\
183 \\
7 \\
0\end{array}$ & $\begin{array}{l}- \\
- \\
-\end{array}$ & $\begin{array}{r}10 \\
0 \\
10 \\
.1 \\
0\end{array}$ & $\begin{array}{r}-7 \\
8 \\
1 \\
-15 \\
-2\end{array}$ & $\begin{array}{l}- \\
-\end{array}$ & $\begin{array}{r}219 \\
54 \\
148 \\
17 \\
(8)\end{array}$ & $\begin{array}{r}(8) \\
(8) \\
0 \\
(s) \\
0\end{array}$ & $\begin{array}{r}45 \\
0 \\
44 \\
0 \\
2\end{array}$ \\
\hline 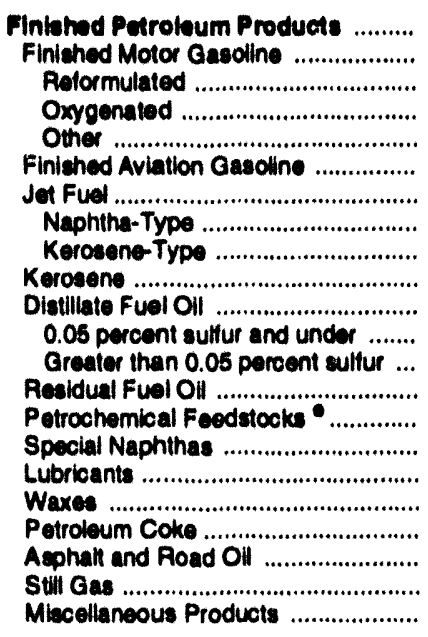 & $\begin{array}{r}7 \\
7 \\
37 \\
-30 \\
= \\
= \\
= \\
= \\
- \\
- \\
- \\
- \\
- \\
- \\
-\end{array}$ & $\begin{array}{r}1,846 \\
773 \\
0 \\
288 \\
485 \\
(0) \\
83 \\
0 \\
83 \\
8 \\
424 \\
130 \\
293 \\
150 \\
14 \\
1 \\
18 \\
5 \\
50 \\
51 \\
68 \\
2\end{array}$ & $\begin{array}{r}1,276 \\
277 \\
0 \\
0 \\
277 \\
0 \\
135 \\
0 \\
135 \\
10 \\
263 \\
53 \\
209 \\
563 \\
7 \\
2 \\
1 \\
1 \\
0 \\
16 \\
0 \\
(8)\end{array}$ & $\begin{array}{l}- \\
- \\
= \\
- \\
- \\
- \\
- \\
- \\
- \\
- \\
- \\
- \\
-\end{array}$ & $\begin{array}{r}2,542 \\
1,328 \\
0 \\
352 \\
974 \\
2 \\
408 \\
2 \\
406 \\
12 \\
763 \\
226 \\
537 \\
11 \\
(8) \\
1 \\
13 \\
0 \\
0 \\
5 \\
0 \\
1\end{array}$ & $\begin{array}{r}-209 \\
-69 \\
0 \\
.170 \\
102 \\
-6 \\
66 \\
-2 \\
68 \\
10 \\
-231 \\
-80 \\
-152 \\
-27 \\
(8) \\
(8) \\
5 \\
0 \\
-2 \\
39 \\
0 \\
4\end{array}$ & $\begin{array}{l}- \\
= \\
= \\
- \\
- \\
= \\
- \\
- \\
- \\
- \\
- \\
- \\
- \\
-\end{array}$ & 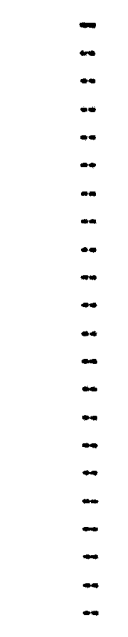 & $\begin{array}{r}24 \\
1 \\
0 \\
1 \\
(8) \\
0 \\
(8) \\
(8) \\
(8) \\
(8) \\
2 \\
(8) \\
2 \\
9 \\
0 \\
(8) \\
3 \\
(8) \\
8 \\
(8) \\
0 \\
(8)\end{array}$ & $\begin{array}{r}5,685 \\
2,451 \\
0 \\
846 \\
1,605 \\
7 \\
560 \\
4 \\
556 \\
19 \\
1,678 \\
488 \\
1,190 \\
741 \\
21 \\
3 \\
23 \\
5 \\
45 \\
34 \\
68 \\
-1\end{array}$ \\
\hline , & 100 & 1,643 & 2,840 & 28 & 2,703 & -124 & 0 & 1,600 & 25 & 5,950 \\
\hline
\end{tabular}

- Represents the PAD District in which the material entered the United States and not necessarily where the crude oll or product is processed andyor consumed.

b Unsccounted for crude oll represents the difference between the supply and disposition of crude oil.

c A negative number indicates a decrease in atocks and a poaltive number indicates an increase in stocks.

d Products supplied is equal to fleld production, plus relinery production, plus imports, plus unaccounted tor crude oll, plus net receipls, minus stock change, minus crude loseses, minus refinery inouts, minus exports.

- Includes naphtha less than $401^{\circ} \mathrm{F}$ endpoint and other olls equal to or greater than $401^{\circ} \mathrm{F}$ endpoint.

(s) = Lees than 500 barrets per day.

$E=$ Estimated.

$L R Q=$ Liquelled Relinery Gas.

Note: Totals may not equal sum of components due to independent rounding.

Sources: - Energy Intormation Administration (EIA) Forms EIA-810, "Monthly Refinery Report," ElA-811, "Monthly Bulk Terminal Report," EIA-812, "Monthly Product Pipeline Report, ElA-813, "Monthly Crude Oil Report," ElA-814, "Monthly Imports Report," ElA-816, "Monthly Natural Gas Liquids Report," EIA-817, "Monthly Tanker and Barge Movement Report," and ELA-819M, "Monthly Oxygenate Telephone Report". - Domestic crude oll production estimates based on historical statiatios from State conservation agencies and the Minerals Management Service of the U.S Department of the Interior. - Export data from the Bureau of the Census and Form ElA-810, "Monthly Refinery Report." 
Table 9. PAD District —Year-to-Date Dally Average Supply and Disposition of Crude Oll and Petroleum Products, January-Fobruary 1994

(Thousand Barrels per Day)

\begin{tabular}{|c|c|c|c|c|c|c|c|c|c|c|}
\hline \multirow[b]{2}{*}{ Commodity } & \multicolumn{5}{|c|}{ 8upply } & \multicolumn{5}{|c|}{ Disposition } \\
\hline & $\begin{array}{c}\text { Flold } \\
\text { Production }\end{array}$ & $\begin{array}{c}\text { Rofinery } \\
\text { Production }\end{array}$ & $\begin{array}{c}\text { Imports by } \\
\text { PAD } \\
\text { Dietriet } \\
\text { of Entore }\end{array}$ & $\begin{array}{l}\text { Unao- } \\
\text { counted } \\
\text { For } \\
\text { Crucheoll }\end{array}$ & $\begin{array}{c}\text { Not } \\
\text { Becelote }\end{array}$ & $\begin{array}{c}\text { Stook } \\
\text { Channe }\end{array}$ & $\begin{array}{l}\text { Crude } \\
\text { Lerese }\end{array}$ & $\begin{array}{c}\text { Pofinery } \\
\text { Inpute }\end{array}$ & Exporte & $\begin{array}{l}\text { Products } \\
\text { Supplled }\end{array}$ \\
\hline 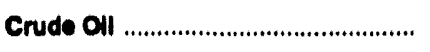 & $E_{26}$ & - & 1,224 & 70 & 1 & 17 & 0 & 1,310 & (s) & 0 \\
\hline 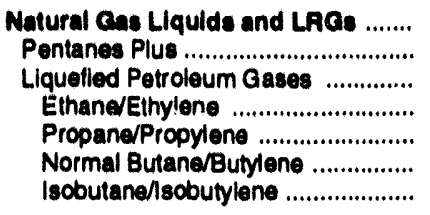 & $\begin{array}{r}25 \\
3 \\
22 \\
8 \\
10 \\
3 \\
1\end{array}$ & $\begin{array}{r}30 \\
\ddot{30} \\
0 \\
40 \\
-10 \\
\text { (s) }\end{array}$ & $\begin{array}{r}50 \\
0 \\
50 \\
0 \\
49 \\
1 \\
0\end{array}$ & $\begin{array}{l}\ddot{-} \\
\ddot{-} \\
\ddot{-} \\
\ddot{-}\end{array}$ & $\begin{array}{r}156 \\
0 \\
156 \\
0 \\
155 \\
1 \\
0\end{array}$ & $\begin{array}{r}-38 \\
-2 \\
-36 \\
0 \\
-24 \\
-13 \\
(8)\end{array}$ & 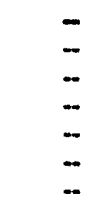 & $\begin{array}{r}11 \\
2 \\
9 \\
0 \\
0 \\
7 \\
2\end{array}$ & $\begin{array}{r}1 \\
\text { (s) } \\
1 \\
0 \\
1 \\
(8) \\
0\end{array}$ & $\begin{array}{r}287 \\
2 \\
285 \\
8 \\
277 \\
1 \\
-2\end{array}$ \\
\hline $\begin{array}{l}\text { Other Liquilds } \\
\text { Other Hydrocarbons/Oxygenates ..... } \\
\text { Unitinished Olls .............................. } \\
\text { Motor Gasoline Blend. Comp. .......... } \\
\text { Aviation Gasoline Blend. Comp. ...... }\end{array}$ & $\frac{39}{38}$ & $\begin{array}{l}\ddot{-} \\
\ddot{-} \\
\ddot{-}\end{array}$ & $\begin{array}{r}180 \\
14 \\
161 \\
6 \\
0\end{array}$ & $\begin{array}{l}\overline{-} \\
\ddot{-}\end{array}$ & $\begin{array}{r}10 \\
0 \\
11 \\
(8) \\
0\end{array}$ & $\begin{array}{l}-3 \\
-5 \\
10 \\
-8 \\
(8)\end{array}$ & $\begin{array}{l}\overline{-} \\
\overline{-}\end{array}$ & $\begin{array}{r}222 \\
56 \\
151 \\
15 \\
(s)\end{array}$ & $\begin{array}{r}(\mathbf{l}) \\
(8) \\
0 \\
(\mathbf{s}) \\
0\end{array}$ & $\begin{array}{r}11 \\
0 \\
10 \\
0 \\
1\end{array}$ \\
\hline 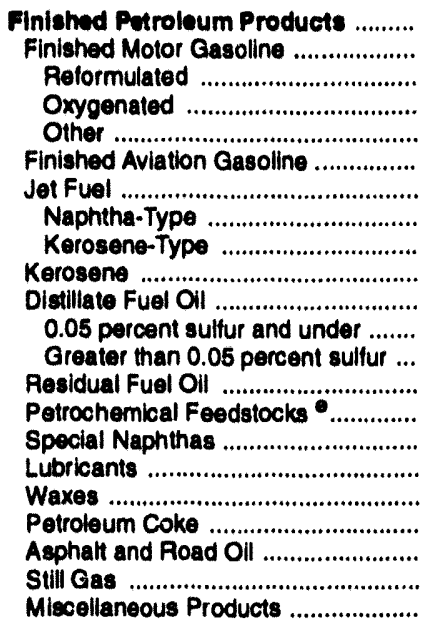 & $\begin{array}{r}2 \\
2 \\
40 \\
-38 \\
= \\
= \\
= \\
= \\
= \\
= \\
= \\
= \\
= \\
=\end{array}$ & $\begin{array}{r}1,591 \\
762 \\
0 \\
297 \\
465 \\
(8) \\
79 \\
(8) \\
78 \\
7 \\
399 \\
114 \\
286 \\
147 \\
14 \\
1 \\
17 \\
4 \\
53 \\
40 \\
66 \\
2\end{array}$ & $\begin{array}{r}1,097 \\
237 \\
0 \\
0 \\
237 \\
0 \\
124 \\
5 \\
119 \\
6 \\
203 \\
47 \\
157 \\
497 \\
8 \\
2 \\
1 \\
1 \\
0 \\
19 \\
0 \\
(8)\end{array}$ & $\begin{array}{l}= \\
= \\
= \\
= \\
= \\
= \\
= \\
= \\
= \\
= \\
= \\
= \\
=\end{array}$ & $\begin{array}{r}2,503 \\
1,335 \\
0 \\
332 \\
1,003 \\
1 \\
384 \\
3 \\
381 \\
10 \\
740 \\
274 \\
466 \\
10 \\
(8) \\
2 \\
15 \\
(8) \\
0 \\
4 \\
0 \\
2\end{array}$ & $\begin{array}{r}-465 \\
-46 \\
0 \\
-103 \\
57 \\
-3 \\
19 \\
-1 \\
20 \\
4 \\
-454 \\
-151 \\
-303 \\
-38 \\
(8) \\
-2 \\
1 \\
(8) \\
3 \\
32 \\
0 \\
1\end{array}$ & 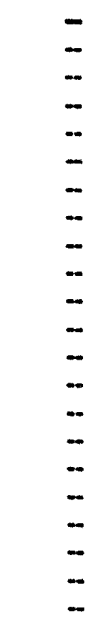 & 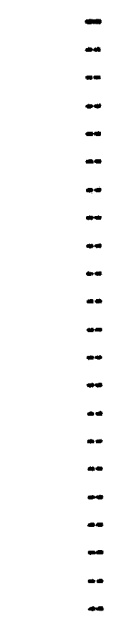 & $\begin{array}{r}38 \\
1 \\
0 \\
1 \\
(9) \\
0 \\
1 \\
(s) \\
1 \\
(9) \\
19 \\
1 \\
19 \\
6 \\
0 \\
(8) \\
4 \\
(8) \\
6 \\
(8) \\
0 \\
\text { (s) }\end{array}$ & $\begin{array}{r}5,641 \\
2,382 \\
0 \\
771 \\
1,610 \\
5 \\
568 \\
10 \\
558 \\
18 \\
1,778 \\
585 \\
1,193 \\
686 \\
22 \\
6 \\
28 \\
5 \\
54 \\
31 \\
66 \\
3\end{array}$ \\
\hline Total & 93 & 1,621 & 2,551 & 76 & $\mathbf{2 , 6 7 1}$ & -600 & $\mathbf{0}$ & 1,544 & 38 & 5,936 \\
\hline
\end{tabular}

a Represents the PAD District in which the material entered the United States and nol necessarily where the crude oll or product is processed and/or consumed.

b Unaccounted for crude oll represents the difference between the supply and disposition of crude oil.

c A negative number indicates a decrease in stocks and a positive number indicates an increase in stocks.

d Products supplied is equal to field production, plus refinery production, plus imports, plus unaccounted for crude oll, plus net receipts, minus stock change, minus crude losses, minus refinery inputs, minus exports.

- Includes naphtha less than $401^{\circ} \mathrm{F}$ endpoint and other oils equal to or greater than $401^{\circ} \mathrm{F}$ endpoint.

(8) = Less than 500 barrels per day.

$E=$ Estimated.

LRQ = Liquefied Refinery Gas.

Note: Totals may not equal sum of components due to independent rounding.

Sources: - Energy Information Administration (EIA) Forms EIA-810, "Monthly Refinery Report," ElA-811, "Monthly Bulk Terminal Report." ElA-812, "Monthly Product Plpeline Report," EIA-813, "Monthly Crude Oil Report," EIA-814, "Monthly Imports Report," EIA-816, "Monthly Natural Gas Liquids Report," ElA-817, "Monthly Tanker and Barge Movement Report," and ElA-819M, "Monthly Oxygenate Telephone Report". - Domestic crude oll productlon estimates based on historical statistics from State conservation agencies and the Minerals Management Service of the U.S. Department of the Interior. - Export data from the Bureau of the Census and Form EIA-810, "Monthly Refinery Report." 
Table 10. PAD District II-Supply, Disposition, and Ending Stocks of Crude Oll and Petroleum Products, February 1994

(Thousand Barrels)

\begin{tabular}{|c|c|c|c|c|c|c|c|c|c|c|c|}
\hline \multirow[b]{2}{*}{ Commodity } & \multicolumn{5}{|c|}{ 8upply } & \multicolumn{5}{|c|}{ Disposition } & \multirow[b]{2}{*}{$\begin{array}{l}\text { Ending } \\
\text { Etocke }\end{array}$} \\
\hline & $\begin{array}{c}\text { Fiold } \\
\text { Producton }\end{array}$ & $\begin{array}{c}\text { Rollnory } \\
\text { Productlon }\end{array}$ & $\begin{array}{c}\text { Imports by } \\
\text { PAD } \\
\text { Dietriot } \\
\text { ol Entin? }\end{array}$ & $\begin{array}{l}\text { Unac- } \\
\text { oounted } \\
\text { For } \\
\text { Crude } 0 \|^{b}\end{array}$ & $\begin{array}{c}\text { Not } \\
\text { Recelple }\end{array}$ & $\left.\begin{array}{c}\text { Stook } \\
\text { Chmnge }\end{array}\right]$ & $\begin{array}{l}\text { Crude } \\
\text { Lense }\end{array}$ & $\begin{array}{c}\text { Rofinory } \\
\text { Inpute }\end{array}$ & Exponte & $\begin{array}{l}\text { Products } \\
\text { Eugolledt }\end{array}$ & \\
\hline 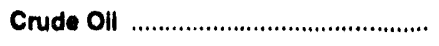 & $E_{16,201}$ & $\cdots$ & 20,239 & 1,376 & 48,287 & $-2,509$ & 0 & 80,780 & 0 & 0 & 78.430 \\
\hline 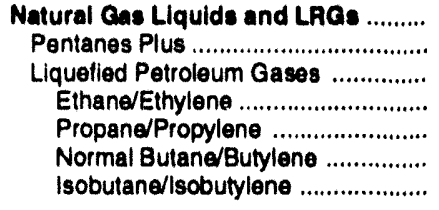 & $\begin{array}{r}6,389 \\
1,255 \\
7,114 \\
2,210 \\
3,217 \\
1,024 \\
663\end{array}$ & $\begin{array}{r}2,584 \\
-. \\
2,564 \\
0 \\
2,814 \\
-273 \\
23\end{array}$ & $\begin{array}{r}2,883 \\
34 \\
2,849 \\
866 \\
1,659 \\
185 \\
139\end{array}$ & 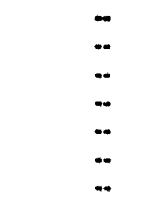 & $\begin{array}{r}4,138 \\
651 \\
3,487 \\
-283 \\
2,820 \\
380 \\
570\end{array}$ & $\begin{array}{r}-5,875 \\
-401 \\
-5,474 \\
85 \\
-4,187 \\
-1,582 \\
210\end{array}$ & $\begin{array}{l}\cdots \\
\cdots \\
\cdots \\
\cdots \\
\cdots \\
\cdots\end{array}$ & $\begin{array}{r}3,000 \\
1,167 \\
2,733 \\
0 \\
164 \\
1,496 \\
1,073\end{array}$ & $\begin{array}{r}147 \\
17 \\
130 \\
0 \\
63 \\
67 \\
0\end{array}$ & $\begin{array}{r}19,782 \\
1,157 \\
18,625 \\
2,708 \\
14,470 \\
1,335 \\
112\end{array}$ & $\begin{array}{r}22,331 \\
3,157 \\
19,174 \\
4,181 \\
8,692 \\
3,408 \\
2,893\end{array}$ \\
\hline $\begin{array}{l}\text { Other Llquids ................................... } \\
\text { Other Hydrocarbons/Oxygenates ..... } \\
\text { Unfinished Olis .................................... } \\
\text { Motor Gasoline Blend. Comp. ........... } \\
\text { Aviation Gasoline Blend. Comp. ....... }\end{array}$ & $\begin{array}{r}-248 \\
311 \\
- \\
-559 \\
\ldots\end{array}$ & 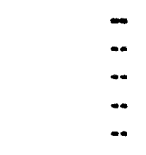 & $\begin{array}{r}27 \\
0 \\
26 \\
1 \\
0\end{array}$ & $\begin{array}{l}\ddot{-} \\
\ddot{-} \\
\ddot{-}\end{array}$ & $\begin{array}{r}1,028 \\
0 \\
142 \\
884 \\
0\end{array}$ & $\begin{array}{r}1,132 \\
3 \\
422 \\
707 \\
0\end{array}$ & $\begin{array}{l}\ddot{-} \\
\ddot{*} \\
\cdots \\
\cdots\end{array}$ & $\begin{array}{r}470 \\
308 \\
562 \\
-381 \\
0\end{array}$ & $\begin{array}{l}(8) \\
(s) \\
0 \\
0 \\
0\end{array}$ & $\begin{array}{r}-808 \\
0 \\
-808 \\
0 \\
0\end{array}$ & $\begin{array}{r}25,026 \\
1,072 \\
15,614 \\
9,139 \\
0\end{array}$ \\
\hline 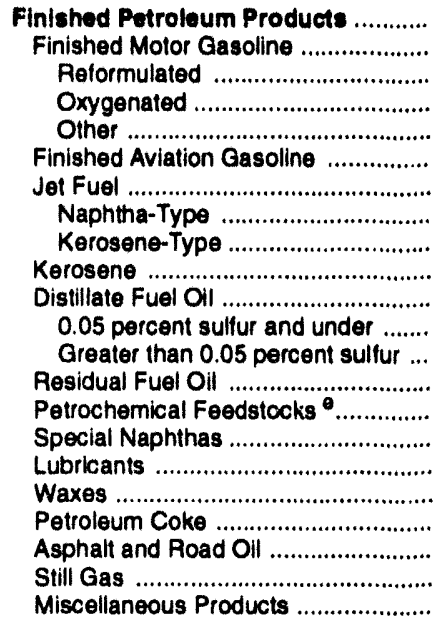 & $\begin{array}{r}2,119 \\
2,119 \\
\ldots \\
15,595 \\
-13,477 \\
\ldots \\
\ldots \\
\ldots \\
\cdots \\
\cdots \\
\cdots \\
\ldots \\
\cdots \\
\ldots \\
\cdots \\
\cdots \\
\cdots \\
\cdots \\
\cdots \\
\cdots \\
\cdots \\
\cdots\end{array}$ & $\begin{array}{r}92,142 \\
47,706 \\
0 \\
3,834 \\
43,872 \\
67 \\
6,267 \\
298 \\
5,969 \\
1,338 \\
20,424 \\
10,112 \\
10,312 \\
2,441 \\
1,077 \\
358 \\
555 \\
56 \\
3,640 \\
4,109 \\
3,793 \\
311\end{array}$ & $\begin{array}{r}47 \\
64 \\
0 \\
0 \\
64 \\
2 \\
33 \\
33 \\
0 \\
0 \\
244 \\
151 \\
93 \\
16 \\
19 \\
68 \\
18 \\
7 \\
0 \\
0 \\
0 \\
6\end{array}$ & 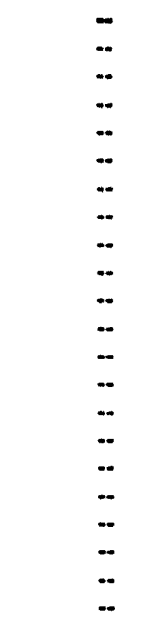 & $\begin{array}{r}15,387 \\
10,530 \\
0 \\
-224 \\
10,754 \\
80 \\
2,220 \\
173 \\
2,047 \\
117 \\
2,555 \\
1,482 \\
1,073 \\
-499 \\
9 \\
107 \\
219 \\
0 \\
0 \\
41 \\
0 \\
8\end{array}$ & $\begin{array}{r}-1,597 \\
-1,744 \\
0 \\
-10 \\
-1,734 \\
39 \\
350 \\
-116 \\
466 \\
313 \\
-2,852 \\
-2,933 \\
81 \\
-82 \\
27 \\
-99 \\
-87 \\
0 \\
324 \\
2,211 \\
0 \\
3\end{array}$ & 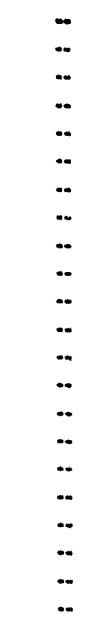 & $\begin{array}{l}. \\
. . \\
. . \\
. . \\
. . \\
. . \\
. . \\
. . \\
. . \\
. . \\
\ldots \\
. . \\
. . \\
. . \\
. . \\
. . \\
. . \\
. . \\
.\end{array}$ & $\begin{array}{r}288 \\
14 \\
0 \\
5 \\
8 \\
0 \\
21 \\
0 \\
21 \\
0 \\
87 \\
1 \\
86 \\
40 \\
0 \\
10 \\
32 \\
3 \\
43 \\
18 \\
0 \\
1\end{array}$ & $\begin{array}{r}111,493 \\
62,149 \\
0 \\
0 \\
19,210 \\
42,939 \\
110 \\
8,149 \\
620 \\
7,529 \\
1,142 \\
25,988 \\
14,677 \\
11,311 \\
2,000 \\
1,078 \\
622 \\
847 \\
60 \\
3,273 \\
1,921 \\
3,793 \\
3321\end{array}$ & $\begin{array}{r}109,121 \\
50,167 \\
0 \\
1,168 \\
48,999 \\
368 \\
8,057 \\
729 \\
7,328 \\
1,352 \\
28,800 \\
17,125 \\
11,675 \\
2,877 \\
207 \\
363 \\
1,630 \\
107 \\
2,247 \\
12,698 \\
0 \\
250\end{array}$ \\
\hline 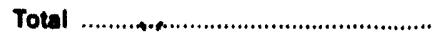 & 26,531 & 94,708 & 23,625 & 1,375 & 68,838 & $-8,939$ & 0 & 91,169 & 416 & 130,430 & 232,707 \\
\hline
\end{tabular}

a Represents the PAD District in which the material entered the United States and not necessarily where the crude oll or product is processed and/or consumed.

b Unaccounted for crude oll represents the difference between the supply and disposition of crude oil.

c A negative number indicates a decrease in stocks and a positive number indicates an increase in stocks.

d Products supplied is equal to field production, plus refinery production, plus imports, plus unaccounted tor crude oll, plus net recelpts, minus stock change, minus crude losses, minus refinery inputs, minus exports.

- Includes naphtha less than $401^{\circ} \mathrm{F}$ endpoint and other oils equal to or greater than $401^{\circ} \mathrm{F}$ endpoint.

(s) $=$ Less than 500 barrels.

$E=$ Estimated.

$\mathrm{LRG}=$ Liquefied Refinery Gas.

Note: Totals may not equal sum of components due to independent rounding.

Sources: - Energy Information Administration (EIA) Forms ElA-810, "Monthly Refinery Report," EIA-811, "Monthly Bulk Terminal Report," EIA-812, "Monthly Product Pipeline Report," ElA-813, "Monthly Crude Oil Report," EIA-814, "Monthly Imports Report," ElA-816, "Monthly Natural Gas Liquids Report," ElA-817, "Monthly Tanker and Barge Movement Report," and EIA-819M. "Monthly Oxygenate Telephone Report". - Domestic crude oil production estimates based on historical statistics trom State conservation agencies and the Minerals Management Service of the U.S. Department of the Interior. - Export data from the Bureau of the Census and Form ElA-810, "Monthly Refinery Report." 
Table 11. PAD District I-Year-to-Date Supply, Disposition, and Ending Stocks of Crude Oil and Petroleum Products, January-February 1994

(Thousand Barrels)

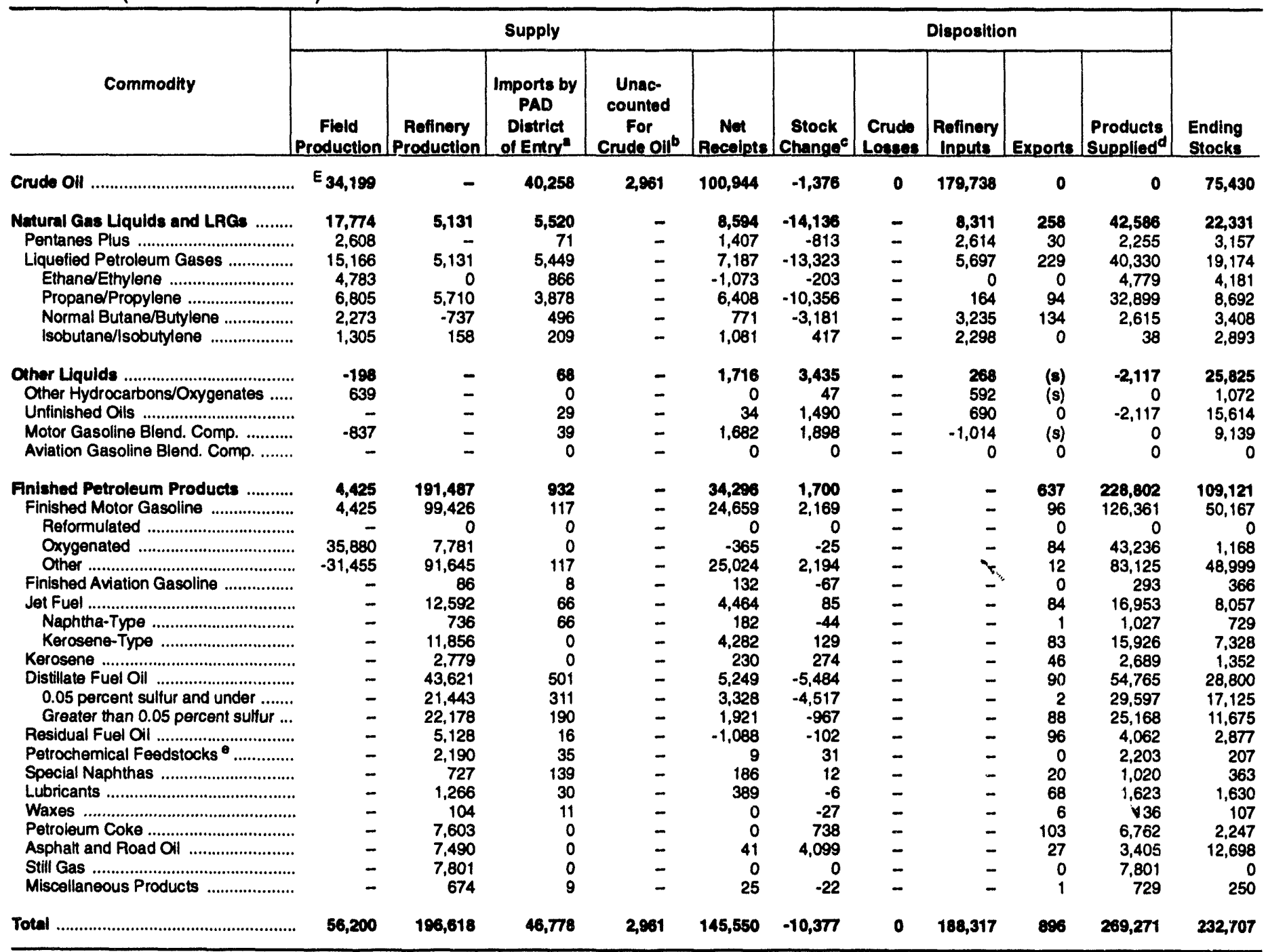

Represents the PAD District in which the material entered the United States and not necessarily where the crude oll or product is processed and/or consumed.

b Unaccounted for crude oil represents the difference between the supply and disposition of crude oil.

c A negative number indicates a decrease in stocks and a positive number indicates an increase in stocks.

d Products supplied is equal to field production, plus refinery production, plus imports, plus unaccounted for crude oil, plus net receipts, minus stock change, minus crude losses, rninus refinery inputs, minus exports.

includes naphtha less than $401^{\circ} \mathrm{F}$ endpoint and other oils equal to or greater than $401^{\circ} \mathrm{F}$ endpoint.

(s) = Less than 500 barrels.

$E=$ Estimated.

LRG = Liquefied Refinery Gas.

Note: Totals may not equal sum of components due to independent rounding

Sources: - Energy Information Administration (ElA) Forms ElA-810, "Monthly Refinery Report," EIA-811, "Monthly Bulk Terminal Report," EIA-812, "Monthly Product Pipeline Report," ElA-813, "Monthly Crude Oil Report," EIA-814, "Monthly Imports Report," EIA-816, "Monthly Natural Gas Liquids Report," ElA-817, "Monthly Tanker and Barge Movement Report," and ElA-819M, "Monthly Oxygenate Telephone Report". - Domestic crude oil production estimates based on historical statistics from State conservation agencies and the Minerals Management Service of the U.S. Department of the Interior. - Export data from the Bureau of the Census and Form ElA-810, "Monthly Refinery Report." 
Table 12. PAD District II-Daily Average Supply and Disposition of Crude Oil and Petroleum Products, February 1994

(Thousand Barrels per Day)

\begin{tabular}{|c|c|c|c|c|c|c|c|c|c|c|}
\hline \multirow[b]{2}{*}{ Commodity } & \multicolumn{5}{|c|}{ Supply } & \multicolumn{5}{|c|}{ Disposition } \\
\hline & $\begin{array}{c}\text { Field } \\
\text { Production }\end{array}$ & $\begin{array}{c}\text { Pofinery } \\
\text { Production }\end{array}$ & $\begin{array}{c}\text { Imports by } \\
\text { PAD } \\
\text { District } \\
\text { of Entro }\end{array}$ & $\begin{array}{c}\text { Unac- } \\
\text { counted } \\
\text { For } \\
\text { Cruch } \mathbf{O I I}^{\mathrm{b}}\end{array}$ & $\begin{array}{c}\text { Not } \\
\text { Recelote }\end{array}$ & $\begin{array}{c}\text { Stock } \\
\text { Changec }\end{array}$ & $\begin{array}{l}\text { Crude } \\
\text { Losese }\end{array}$ & $\begin{array}{c}\text { Rotinery } \\
\text { Inputs }\end{array}$ & Exports & $\begin{array}{l}\text { Products } \\
\text { Supolled }\end{array}$ \\
\hline 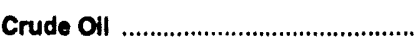 & $E_{582}$ & - & 723 & 49 & 1,653 & 93 & $\mathbf{0}$ & 3,100 & 0 & $\mathbf{0}$ \\
\hline $\begin{array}{l}\text { Natural Gas Llquids and LRGs ........ } \\
\text { Pentanes Plus ................................. } \\
\text { Liquefied Petroleum Gases .............. } \\
\text { Ethane/Ethylene ........................... } \\
\text { Propane/Propylene ..................... } \\
\text { Normal Butane/Butylene ............... } \\
\text { Isobutane/lsobutylene ................. }\end{array}$ & $\begin{array}{r}299 \\
45 \\
254 \\
79 \\
115 \\
37 \\
24\end{array}$ & $\begin{array}{r}92 \\
- \\
92 \\
0 \\
101 \\
-10 \\
1\end{array}$ & $\begin{array}{r}103 \\
1 \\
102 \\
31 \\
59 \\
7 \\
5\end{array}$ & $\begin{array}{l}\overline{-} \\
\overline{-} \\
\overline{-} \\
\overline{-}\end{array}$ & $\begin{array}{r}148 \\
23 \\
125 \\
-10 \\
101 \\
14 \\
20\end{array}$ & $\begin{array}{r}-210 \\
-14 \\
-196 \\
3 \\
-150 \\
-57 \\
8\end{array}$ & $\begin{array}{l}- \\
- \\
- \\
- \\
-\end{array}$ & $\begin{array}{r}139 \\
42 \\
98 \\
0 \\
6 \\
53 \\
38\end{array}$ & $\begin{array}{l}5 \\
1 \\
5 \\
0 \\
2 \\
2 \\
0\end{array}$ & $\begin{array}{r}707 \\
41 \\
665 \\
97 \\
517 \\
48 \\
4\end{array}$ \\
\hline $\begin{array}{l}\text { Other Liquids .................................. } \\
\text { Other Hydrocartions/Oxygenates .... } \\
\text { Untinished Oils ................................... } \\
\text { Motor Gasoline Blend. Comp. ........... } \\
\text { Aviation Gasoline Blend. Comp. ...... }\end{array}$ & $\begin{array}{r}-9 \\
11 \\
-20 \\
-\end{array}$ & $\begin{array}{l}- \\
- \\
-\end{array}$ & $\begin{array}{r}1 \\
0 \\
1 \\
(s) \\
0\end{array}$ & $\begin{array}{l}- \\
- \\
-\end{array}$ & $\begin{array}{r}37 \\
0 \\
5 \\
32 \\
0\end{array}$ & $\begin{array}{r}40 \\
(8) \\
15 \\
25 \\
0\end{array}$ & $\begin{array}{l}- \\
- \\
-\end{array}$ & $\begin{array}{r}17 \\
11 \\
20 \\
-14 \\
0\end{array}$ & $\begin{array}{l}(8) \\
(s) \\
0 \\
0 \\
0\end{array}$ & $\begin{array}{r}-29 \\
0 \\
-29 \\
0 \\
0\end{array}$ \\
\hline 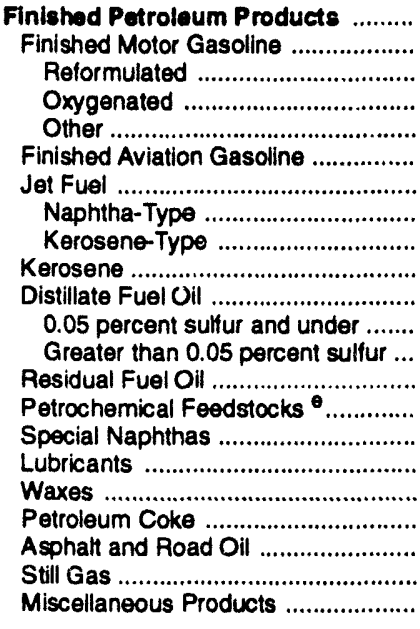 & $\begin{array}{r}76 \\
76 \\
557 \\
481 \\
- \\
- \\
- \\
- \\
- \\
- \\
- \\
- \\
- \\
- \\
- \\
-\end{array}$ & $\begin{array}{r}3,291 \\
1,704 \\
0 \\
137 \\
1,567 \\
2 \\
224 \\
11 \\
213 \\
48 \\
729 \\
361 \\
368 \\
87 \\
38 \\
13 \\
20 \\
2 \\
130 \\
147 \\
135 \\
11\end{array}$ & $\begin{array}{r}17 \\
2 \\
0 \\
0 \\
2 \\
(s) \\
1 \\
1 \\
0 \\
0 \\
9 \\
5 \\
3 \\
1 \\
1 \\
2 \\
1 \\
(s) \\
0 \\
0 \\
0 \\
(s)\end{array}$ & $\begin{array}{l}- \\
- \\
- \\
- \\
- \\
- \\
- \\
- \\
- \\
- \\
- \\
- \\
- \\
- \\
- \\
- \\
-\end{array}$ & $\begin{array}{r}550 \\
376 \\
0 \\
-8 \\
384 \\
3 \\
79 \\
6 \\
73 \\
4 \\
91 \\
53 \\
38 \\
-18 \\
(8) \\
4 \\
8 \\
0 \\
0 \\
1 \\
0 \\
(s)\end{array}$ & $\begin{array}{r}-57 \\
-62 \\
0 \\
(s) \\
-62 \\
1 \\
13 \\
-4 \\
17 \\
11 \\
-102 \\
-105 \\
3 \\
-3 \\
1 \\
-4 \\
-3 \\
0 \\
12 \\
79 \\
0 \\
(s)\end{array}$ & $\begin{array}{l}- \\
- \\
- \\
- \\
- \\
- \\
- \\
- \\
- \\
- \\
- \\
- \\
- \\
- \\
- \\
- \\
- \\
-\end{array}$ & $\begin{array}{l}- \\
- \\
- \\
- \\
- \\
- \\
- \\
- \\
- \\
- \\
- \\
- \\
- \\
- \\
- \\
- \\
- \\
- \\
-\end{array}$ & $\begin{array}{r}10 \\
(s) \\
0 \\
(8) \\
(s) \\
0 \\
1 \\
0 \\
1 \\
0 \\
3 \\
(s) \\
3 \\
1 \\
0 \\
(s) \\
1 \\
\text { (s) } \\
2 \\
1 \\
0 \\
\text { (s) }\end{array}$ & $\begin{array}{r}3,960 \\
2,220 \\
0 \\
686 \\
1,534 \\
4 \\
291 \\
22 \\
269 \\
41 \\
928 \\
524 \\
404 \\
71 \\
39 \\
22 \\
30 \\
2 \\
117 \\
69 \\
135 \\
11\end{array}$ \\
\hline Total & 848 & 3,382 & 844 & 49 & 2,387 & -319 & $\mathbf{0}$ & 3,256 & 15 & 4,658 \\
\hline
\end{tabular}

Represents the PAD District in which the material entered the United States and not necessarly where the crude oil or product is processed andror consumed.

b Unaccounted for crude oil represents the difference between the supply and disposition of crude oil.

c A negative number indicates a decrease in stocks ind a positive number indicates an increase in stocks.

d Products supplied is equal to field production, plus refinery production, plus imports, plus unaccounted for crude oil, plus net receipts, minus stock change, minus crude losses, minus refinery inputs, minus exports.

$\theta$ Includes naphtha less than $401^{\circ} \mathrm{F}$ endpoint and other oils equal to or greater than $401^{\circ} \mathrm{F}$ endpoint.

(s) = Less than 500 barrels per day.

$E=$ Estimated.

LRG = Liquefied Retinery Gas.

Note: Totals may not equal sum of components due to independent rounding.

Sources: - Energy Information Administration (EIA) Forms ElA-810, "Monthly Refinery Report," EIA-811, "Monthly Bulk Terminal Report," EIA-812, "Monthly Product Pipeline Report," EIA-813, "Monthly Crude Oil Report," ElA-814, "Monthly Imports Report," ElA-816, "Monthly Natural Gas Liquids Report," EIA-817, "Monthly Tanker and Barge Movement Report," and EIA-819M, "Monthly Oxygenate Telephone Report". - Domestic crude oil production estimates based on historical statistics from State conservation agencies and the Minerals Management Service of the U.S. Department of the Interior. - Export data trom the Bureau of the Census and Form ElA-810, "Monthly Refinery Report." 
Table 13. PAD District II-Year-to-Date Daily Average Supply and Disposition of Crude Oil and Petroleum Products, January-February 1994

(Thousand Barrels per Day)

\begin{tabular}{|c|c|c|c|c|c|c|c|c|c|c|}
\hline \multirow[b]{2}{*}{ Commodity } & \multicolumn{5}{|c|}{ Supply } & \multicolumn{5}{|c|}{ Disposition } \\
\hline & $\begin{array}{c}\text { Field } \\
\text { Production }\end{array}$ & $\begin{array}{c}\text { Rollnary } \\
\text { Production }\end{array}$ & $\begin{array}{l}\text { Imports by } \\
\text { PAD } \\
\text { District } \\
\text { of Entre }\end{array}$ & $\begin{array}{l}\text { Unac- } \\
\text { counted } \\
\text { For } \\
\text { Crude } \mathrm{OII}^{\mathrm{b}}\end{array}$ & $\begin{array}{c}\text { Not } \\
\text { Receipts } \\
\end{array}$ & $\begin{array}{c}\text { Stock } \\
\text { Changec }\end{array}$ & $\begin{array}{l}\text { Crude } \\
\text { Losses } \\
\end{array}$ & $\begin{array}{c}\text { Refinery } \\
\text { Inputs }\end{array}$ & Exports & $\begin{array}{l}\text { Products } \\
\text { Supplied }\end{array}$ \\
\hline 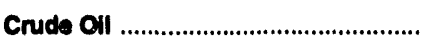 & $E_{\mathbf{5 8 0}}$ & - & 682 & 50 & 1,711 & -23 & $\mathbf{0}$ & 3,046 & 0 & 0 \\
\hline $\begin{array}{l}\text { Natural Cas Liquids and LRGs ......... } \\
\text { Pentanes Plus .................................. } \\
\text { Llquelied Petroleum Gases .............. } \\
\text { Ethane/Ethylene ........................... } \\
\text { Propane/Propylene ....................... } \\
\text { Normal Butane/Butylene ............... } \\
\text { Isobutane/lsobutylene .................... }\end{array}$ & $\begin{array}{r}301 \\
44 \\
257 \\
81 \\
115 \\
39 \\
22\end{array}$ & $\begin{array}{r}87 \\
- \\
87 \\
0 \\
97 \\
-12 \\
3\end{array}$ & $\begin{array}{r}94 \\
1 \\
92 \\
15 \\
66 \\
8 \\
4\end{array}$ & $\begin{array}{l}- \\
- \\
- \\
-\end{array}$ & $\begin{array}{r}146 \\
24 \\
122 \\
-18 \\
109 \\
13 \\
18\end{array}$ & $\begin{array}{r}-240 \\
-14 \\
-226 \\
-3 \\
-176 \\
-54 \\
7\end{array}$ & $\begin{array}{l}- \\
\ddot{-} \\
- \\
- \\
-\end{array}$ & $\begin{array}{r}141 \\
44 \\
97 \\
0 \\
3 \\
55 \\
39\end{array}$ & $\begin{array}{l}4 \\
1 \\
4 \\
0 \\
2 \\
2 \\
0\end{array}$ & $\begin{array}{r}722 \\
38 \\
684 \\
81 \\
558 \\
44 \\
1\end{array}$ \\
\hline $\begin{array}{l}\text { Other Liquids ................................ } \\
\text { Other Hydrocarbons/Oxygenates ...... } \\
\text { Unfinished Olls ................................. } \\
\text { Motor Gasoline Blend. Comp. ........... } \\
\text { Aviation Gasoline Blend. Comp. ....... }\end{array}$ & $\begin{array}{r}-3 \\
11 \\
-14 \\
-\end{array}$ & $\begin{array}{l}- \\
- \\
-\end{array}$ & $\begin{array}{r}1 \\
0 \\
(s) \\
1 \\
0\end{array}$ & $\begin{array}{l}- \\
- \\
-\end{array}$ & $\begin{array}{r}29 \\
0 \\
1 \\
29 \\
0\end{array}$ & $\begin{array}{r}58 \\
1 \\
25 \\
32 \\
0\end{array}$ & $\begin{array}{l}- \\
- \\
- \\
-\end{array}$ & $\begin{array}{r}5 \\
10 \\
12 \\
-17 \\
0\end{array}$ & $\begin{array}{r}\text { (s) } \\
(s) \\
0 \\
(s) \\
0\end{array}$ & $\begin{array}{r}-36 \\
0 \\
-36 \\
0 \\
0\end{array}$ \\
\hline 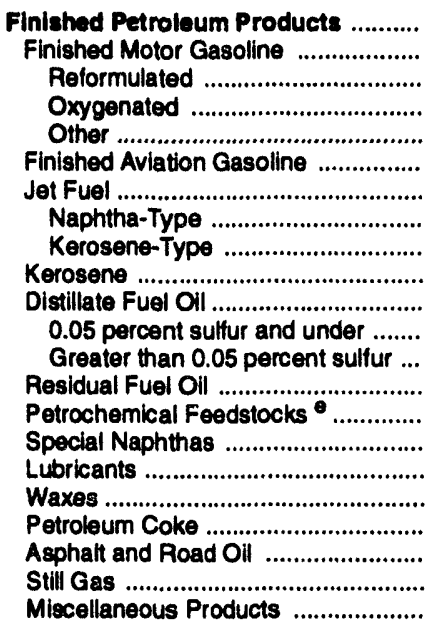 & $\begin{array}{r}75 \\
75 \\
- \\
608 \\
-533 \\
- \\
- \\
- \\
- \\
- \\
- \\
- \\
- \\
- \\
- \\
- \\
- \\
-\end{array}$ & $\begin{array}{r}3,246 \\
1,685 \\
0 \\
132 \\
1,553 \\
1 \\
213 \\
12 \\
201 \\
47 \\
739 \\
363 \\
376 \\
87 \\
37 \\
12 \\
21 \\
2 \\
129 \\
127 \\
132 \\
11\end{array}$ & $\begin{array}{r}16 \\
2 \\
0 \\
0 \\
2 \\
(s) \\
1 \\
1 \\
0 \\
0 \\
8 \\
5 \\
3 \\
\text { (s) } \\
1 \\
2 \\
1 \\
(s) \\
0 \\
0 \\
0 \\
(s)\end{array}$ & $\begin{array}{l}- \\
- \\
- \\
- \\
- \\
- \\
- \\
- \\
- \\
- \\
- \\
- \\
- \\
- \\
- \\
- \\
- \\
-\end{array}$ & $\begin{array}{r}581 \\
418 \\
0 \\
-6 \\
424 \\
2 \\
76 \\
3 \\
73 \\
4 \\
89 \\
56 \\
33 \\
-18 \\
(s) \\
3 \\
7 \\
0 \\
0 \\
1 \\
0 \\
(s)\end{array}$ & $\begin{array}{r}29 \\
37 \\
0 \\
(s) \\
37 \\
-1 \\
1 \\
-1 \\
2 \\
5 \\
-93 \\
-77 \\
-16 \\
-2 \\
1 \\
(s) \\
(s) \\
(s) \\
13 \\
69 \\
0 \\
(s)\end{array}$ & $\begin{array}{l}- \\
- \\
- \\
- \\
- \\
- \\
- \\
- \\
- \\
- \\
- \\
- \\
- \\
- \\
- \\
- \\
- \\
-\end{array}$ & $\begin{array}{l}- \\
-- \\
-. \\
-- \\
-- \\
-- \\
-- \\
-- \\
-- \\
-- \\
-- \\
-- \\
- \\
-- \\
- \\
- \\
- \\
-\end{array}$ & $\begin{array}{r}11 \\
2 \\
0 \\
1 \\
(s) \\
0 \\
1 \\
(s) \\
1 \\
1 \\
2 \\
(s) \\
1 \\
2 \\
0 \\
(s) \\
1 \\
(s) \\
2 \\
(s) \\
0 \\
(s)\end{array}$ & $\begin{array}{r}3,878 \\
2,142 \\
0 \\
733 \\
1,409 \\
5 \\
287 \\
17 \\
270 \\
46 \\
928 \\
502 \\
427 \\
69 \\
37 \\
17 \\
28 \\
2 \\
115 \\
58 \\
132 \\
12\end{array}$ \\
\hline Total & 953 & 3,333 & 793 & 50 & 2,467 & -176 & 0 & 3,192 & 15 & 4,564 \\
\hline
\end{tabular}

Represents the PAD District in which the material entered the United States and not necessarily where the crude oil or product is processed and/or consumed.

b Unaccounted for crude oil represents the difference between the supply and disposition of crude oil.

c A negative number indicates a decrease in stocks and a positive number indicates an increase in stocks.

d Products supplied is equal to field production, plus refinery production, plus imports, plus unaccounted for crude oll, plus net receipts, minus stock change, minus crude losses, minus refinery inputs, minus exports.

- Inctudes naphtha less than $401^{\circ} \mathrm{F}$ endpoint and other olls equal to or greater than $401^{\circ} \mathrm{F}$ endpoint.

(s) = Less than 500 barrels per day.

$E=$ Estimated.

LRG = Liquefied Refinery Gas.

Note: Totals may not equal sum of components due to independent rounding.

Sources: - Energy Information Administration (ElA) Forms ElA-810, "Monthly Refinery Report," ElA-811, "Monthly Bulk Terminal Report," EIA-812, "Monthly Product Pipeline Report," ElA-813, "Monthly Crude Oil Report," ElA-814, "Monthly Imports Report," EIA-816, "Monthly Natural Gas Liquids Report," EIA-817, "Monthly Tanker and Barge Movement Report," and EIA-819M, "Monthly Oxygenate Telephone Report". - Domestic crude oll production estimates based on historical statistics from State conservation agencies and the Minerals Management Service of the U.S. Department of the Interior. • Export data from the Bureau of the Census and Form EIA-810, "Monthly Refinery Report." 
Table 14. PAD District III-Supply, Disposition, and Ending Stocks of Crude Oil and Petroleum Products, February 1994

(Thousand Barrels)

\begin{tabular}{|c|c|c|c|c|c|c|c|c|c|c|c|}
\hline \multirow[b]{2}{*}{ Commodity } & \multicolumn{5}{|c|}{ Supply } & \multicolumn{5}{|c|}{ Disposition } & \multirow[b]{2}{*}{$\begin{array}{l}\text { Ending } \\
\text { Stocks }\end{array}$} \\
\hline & $\begin{array}{c}\text { Fiald } \\
\text { Production }\end{array}$ & $\begin{array}{c}\text { Rofinery } \\
\text { Production }\end{array}$ & $\begin{array}{c}\text { Imports by } \\
\text { PAD } \\
\text { District } \\
\text { of Entry }\end{array}$ & $\begin{array}{l}\text { Unac- } \\
\text { counted } \\
\text { For } \\
\text { Crude } \text { Oll }^{b}\end{array}$ & $\begin{array}{c}\text { Net } \\
\text { Recelpts }\end{array}$ & $\begin{array}{c}\text { Stock } \\
\text { Changec }\end{array}$ & $\begin{array}{c}\text { Crude } \\
\text { Losegs }\end{array}$ & $\begin{array}{c}\text { Refinery } \\
\text { Inputs }\end{array}$ & Exports & $\begin{array}{l}\text { Products } \\
\text { Supplled }\end{array}$ & \\
\hline 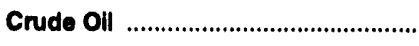 & $E_{88,752}$ & - & 107,400 & $-1,107$ & $-33,747$ & $-4,684$ & 0 & 165,977 & 5 & 0 & 741,913 \\
\hline 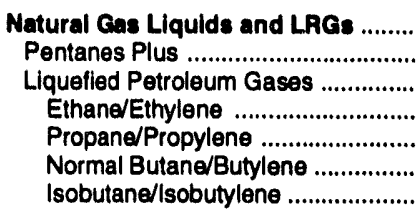 & $\begin{array}{r}30,694 \\
5,060 \\
25,634 \\
11,151 \\
9,025 \\
1,079 \\
4,379\end{array}$ & $\begin{array}{r}7,745 \\
7,- \\
7,745 \\
698 \\
6,139 \\
829 \\
79\end{array}$ & $\begin{array}{r}1,127 \\
811 \\
316 \\
0 \\
0 \\
232 \\
84\end{array}$ & $\begin{array}{l}- \\
-- \\
-. \\
-- \\
-- \\
--\end{array}$ & $\begin{array}{r}-6,343 \\
-385 \\
-5,958 \\
1,125 \\
-6,532 \\
-135 \\
-416\end{array}$ & $\begin{array}{r}-8,050 \\
-674 \\
-7,376 \\
-539 \\
-4,656 \\
-2,408 \\
227\end{array}$ & $\begin{array}{l}-- \\
-- \\
-- \\
-- \\
-- \\
--\end{array}$ & $\begin{array}{r}6,734 \\
2,012 \\
4,722 \\
0 \\
0 \\
2,309 \\
2,413\end{array}$ & $\begin{array}{r}925 \\
0 \\
925 \\
0 \\
736 \\
189 \\
0\end{array}$ & $\begin{array}{r}33,614 \\
4,148 \\
29,466 \\
13,513 \\
12,552 \\
1,915 \\
1,486\end{array}$ & $\begin{array}{r}44,922 \\
4,738 \\
40,184 \\
12,109 \\
13,229 \\
7,914 \\
6,932\end{array}$ \\
\hline $\begin{array}{l}\text { Other Llquids .................................. } \\
\text { Other Hydrocarbons/Oxygenates .... } \\
\text { Unfinished Oils ................................... } \\
\text { Motor Gasoline Blend. Comp. ........... } \\
\text { Aviation Gasoline Blend. Comp. ...... }\end{array}$ & $\begin{array}{r}2,456 \\
1,946 \\
\ldots \\
510 \\
\end{array}$ & $\begin{array}{l}- \\
- \\
- \\
-\end{array}$ & $\begin{array}{r}6,630 \\
149 \\
6,435 \\
46 \\
0\end{array}$ & $\begin{array}{l}- \\
-- \\
\cdots \\
--\end{array}$ & $\begin{array}{r}-1,297 \\
0 \\
-428 \\
-869 \\
0\end{array}$ & $\begin{array}{r}886 \\
323 \\
1,012 \\
-471 \\
22\end{array}$ & $\begin{array}{l}- \\
-- \\
-- \\
--\end{array}$ & $\begin{array}{r}4,892 \\
1,654 \\
3,104 \\
157 \\
-23\end{array}$ & $\begin{array}{r}119 \\
118 \\
0 \\
1 \\
0\end{array}$ & $\begin{array}{r}1,892 \\
0 \\
1,891 \\
0 \\
1\end{array}$ & $\begin{array}{r}70,758 \\
5,463 \\
49,915 \\
15,338 \\
42\end{array}$ \\
\hline 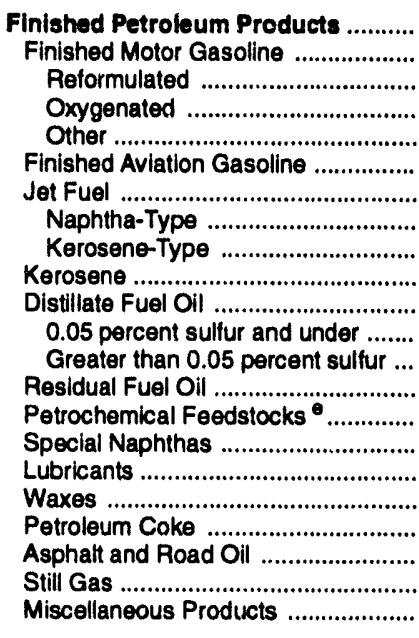 & $\begin{array}{r}-346 \\
-346 \\
. . \\
1,642 \\
-1,987 \\
. . \\
.- \\
. . \\
.- \\
. . \\
.- \\
.- \\
-. \\
. . \\
. . \\
. . \\
. . \\
. . \\
.- \\
. . \\
.-\end{array}$ & $\begin{array}{r}178,928 \\
79,714 \\
0 \\
5,893 \\
73,821 \\
389 \\
19,441 \\
729 \\
18,712 \\
860 \\
37,547 \\
17,143 \\
20,404 \\
9,641 \\
9,483 \\
656 \\
2,895 \\
316 \\
7,488 \\
2,122 \\
7,719 \\
655\end{array}$ & $\begin{array}{r}4,725 \\
0 \\
0 \\
0 \\
0 \\
0 \\
8 \\
0 \\
8 \\
85 \\
0 \\
0 \\
0 \\
359 \\
4,191 \\
45 \\
0 \\
3 \\
0 \\
0 \\
0 \\
34\end{array}$ & 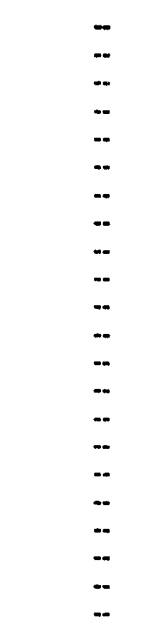 & $\begin{array}{r}-91,131 \\
-50,274 \\
0 \\
-9,657 \\
-40,617 \\
-132 \\
-14,987 \\
-156 \\
-14,831 \\
-422 \\
-24,404 \\
-8,212 \\
-16,192 \\
178 \\
0 \\
-146 \\
-712 \\
0 \\
0 \\
-189 \\
0 \\
-43\end{array}$ & $\begin{array}{r}-9,327 \\
-2,460 \\
0 \\
-1,746 \\
-714 \\
92 \\
-2,327 \\
-188 \\
-2,139 \\
-207 \\
-4,060 \\
-1,582 \\
-2,478 \\
-1,539 \\
621 \\
-294 \\
-149 \\
-1 \\
431 \\
203 \\
0 \\
363\end{array}$ & $\begin{array}{l}-. \\
-. \\
-. \\
-. \\
-. \\
-- \\
-- \\
-. \\
-. \\
-. \\
-- \\
-- \\
-- \\
-- \\
-- \\
- \\
-- \\
-- \\
-. \\
-\end{array}$ & $\begin{array}{l}-. \\
-. \\
-. \\
-. \\
-. \\
.- \\
-- \\
-. \\
-. \\
-- \\
-. \\
-- \\
-- \\
-- \\
-- \\
-- \\
-- \\
-- \\
-- \\
-- \\
--\end{array}$ & $\begin{array}{r}10,083 \\
1,836 \\
0 \\
0 \\
1,836 \\
0 \\
11 \\
0 \\
11 \\
(s) \\
2,705 \\
545 \\
2,159 \\
1,778 \\
0 \\
17 \\
316 \\
30 \\
3,371 \\
20 \\
0 \\
(\mathrm{~s})\end{array}$ & $\begin{array}{r}91,418 \\
29,718 \\
0 \\
-376 \\
30,095 \\
165 \\
6,778 \\
761 \\
6,017 \\
730 \\
14,498 \\
9,968 \\
4,531 \\
9,939 \\
13,053 \\
832 \\
2,016 \\
290 \\
3,686 \\
1,710 \\
7,719 \\
283\end{array}$ & $\begin{array}{r}124,867 \\
47,857 \\
0 \\
4,226 \\
43,631 \\
411 \\
13,473 \\
758 \\
12,715 \\
1,281 \\
25,603 \\
11,406 \\
14,197 \\
16,805 \\
3,171 \\
1,727 \\
5,537 \\
438 \\
2,699 \\
4,231 \\
0 \\
1,634\end{array}$ \\
\hline Total & 121,556 & 186,671 & 119,882 & $-1,107$ & $-132,518$ & $-21,175$ & $\mathbf{0}$ & 177,603 & 11,133 & 126,924 & 982,460 \\
\hline
\end{tabular}

Represente the PAD District in which the material entered the United States and not necessarily where the crude oll or product is processed and/or consumed.

b Unaccounted for crude oll represents the difference between the supply and disposition of crude oil.

c A negative number indicates a decrease in stocks and a positive number indicates an increase in stocks.

d Products supplied is equal to field production, plus refinery production, plus imports, plus unaccounted for crude oil, plus net receipts, minus stock change, minus crude losses, minus refinery inputs, minus exports.

- Includes naphtha less than $401^{\circ} \mathrm{F}$ endpoint and other oils equal to or greater than $401^{\circ} \mathrm{F}$ endpoint.

(s) = Less than 500 barrels.

$E$ = Estimated.

LRG = Liquefied Refinery Gas.

Note: Totals may not equal sum of components due to independent rounding.

Sources: - Energy Information Administration (EIA) Forms EIA-810, "Monthly Refinery Report, ElA-811, "Monthly Bulk Terminal Report," ElA-812 "Monthly Product Pipeline Report," ElA-813, "Monthly Crude Oil Report," EIA-814, "Monthly Imports Report," EIA-816, "Monthly Natural Gas Liquids Report," EIA-817, "Monthly Tanker and Barge Movement Report," and EIA-819M. "Monthly Oxygenate Telephone Report". - Domestic crude oll production estimates based on historical statistics from State conservation agencies and the Minerals Management Service of the U.S. Department of the Interior. - Export data from the Bureau of the Census and Form ElA-810, "Monthly Retinery Report." 
Table 15. PAD District III-Year-to-Date Supply, Disposition, and Ending Stocks of Crude Oil and Petroleum Products, January-February 1994 (Thousand Barrels)

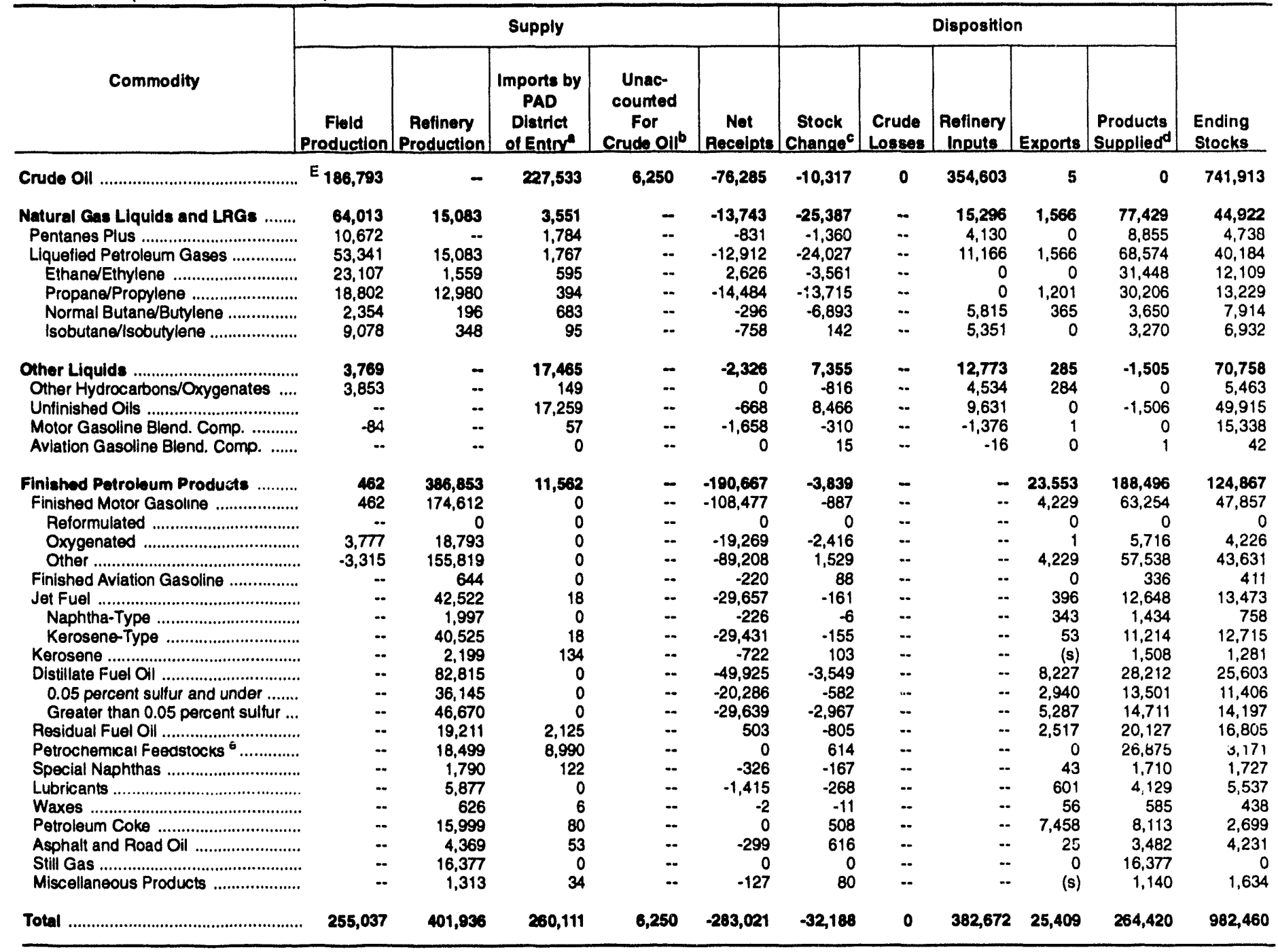

a Represents the PAD District in which the material entered the United States and not necessarily where the crude oil or product is processed and/or consumed.

b Unaccounted for crude oil represents the difference between the supply and disposition of crude oil.

c A negative number indicates a decrease in stocks and a positive number indicates an increase in stocks.

d Products supplied is equal to field production, plus refinery production, plus imports, plus unaccounted for crude oil, plus net receipts, minus stock change, minus crude losses, minus refinery inputs, minus exports.

- Includes naphtha less than $401^{\circ} \mathrm{F}$ endpoint and other olls equal to or greater than $401^{\circ} \mathrm{F}$ endpoint.

(s) = Less than 500 barrels.

$E=$ Estimated.

$L R G=$ Liquefied Refinery Gas.

Note: Totals may not equal sum of components due to independent rounding.

Sources: - Energy Information Administration (EIA) Forms ElA-810, "Monthly Refinery Report," ElA-811, "Monthly Bulk Terminal Report," ElA-812, "Monthly Product Pipeline Report," ElA-813, "Monthly Crude Oil Report," ElA-814, "Monthly Imports Report," ElA-816, "Monthly Natural Gas Liquids Report," ElA-817, "Monthly Tanker and Barge Movement Report," and ElA-819M, "Monthly Oxygenate Telephone Report". - Domestic crude oil production estimates based on historical statistics from State conservation agencies and the Minerals Management Service of the U.S. Department of the Interior. - Export data from the Bureau of the Census and Form EIA-810, "Monthly Refinery Report." 
Table 16. PAD District III-Daily Average Supply and Disposition of Crude Oil and Petroleum Products, February 1994

(Thousand Barrels per Day)

\begin{tabular}{|c|c|c|c|c|c|c|c|c|c|c|}
\hline \multirow[b]{2}{*}{ Commodity } & \multicolumn{5}{|c|}{ Supply } & \multicolumn{5}{|c|}{ Disposition } \\
\hline & $\begin{array}{c}\text { Flald } \\
\text { Production }\end{array}$ & $\begin{array}{c}\text { Rofinery } \\
\text { Production }\end{array}$ & $\begin{array}{c}\text { Imports by } \\
\text { PAD } \\
\text { District } \\
\text { of Entro }\end{array}$ & $\begin{array}{c}\text { Unac- } \\
\text { counted } \\
\text { For } \\
\text { Crude oll }\end{array}$ & $\begin{array}{c}\text { Net } \\
\text { Recelpte }\end{array}$ & $\begin{array}{c}\text { Stock } \\
\text { Chengec }\end{array}$ & $\begin{array}{l}\text { Crude } \\
\text { Lonses }\end{array}$ & $\begin{array}{c}\text { Refinery } \\
\text { Inpute }\end{array}$ & Exports & $\begin{array}{l}\text { Products } \\
\text { Supolled }\end{array}$ \\
\hline 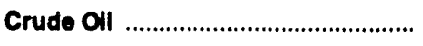 & $E_{3,170}$ & - & 3,836 & -40 & $-1,205$ & -167 & 0 & 5,928 & (s) & 0 \\
\hline 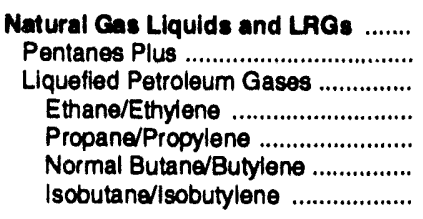 & $\begin{array}{r}1,096 \\
181 \\
916 \\
398 \\
322 \\
39 \\
156\end{array}$ & $\begin{array}{r}277 \\
- \\
277 \\
25 \\
219 \\
30 \\
3\end{array}$ & $\begin{array}{r}40 \\
29 \\
11 \\
0 \\
0 \\
8 \\
3\end{array}$ & $\begin{array}{l}- \\
- \\
- \\
- \\
-\end{array}$ & $\begin{array}{r}-227 \\
-14 \\
-213 \\
40 \\
-233 \\
-5 \\
-15\end{array}$ & $\begin{array}{r}-288 \\
-24 \\
-263 \\
-19 \\
-166 \\
-86 \\
8\end{array}$ & $\begin{array}{l}- \\
- \\
\cdots \\
- \\
- \\
-\end{array}$ & $\begin{array}{r}241 \\
72 \\
169 \\
0 \\
0 \\
82 \\
86\end{array}$ & $\begin{array}{r}33 \\
0 \\
33 \\
0 \\
26 \\
7 \\
0\end{array}$ & $\begin{array}{r}1,200 \\
148 \\
1,052 \\
483 \\
448 \\
68 \\
53\end{array}$ \\
\hline $\begin{array}{l}\text { Other Liquids .................................. } \\
\text { Other Hydrocartons/Oxygenates .... } \\
\text { Unfinished Oils .................................. } \\
\text { Motor Gasoline Blend. Comp. .......... } \\
\text { Aviation Gasoline Blend. Comp. ....... }\end{array}$ & $\begin{array}{r}88 \\
70 \\
- \\
-\end{array}$ & $\begin{array}{l}- \\
- \\
-\end{array}$ & $\begin{array}{r}237 \\
5 \\
230 \\
2 \\
0\end{array}$ & $\begin{array}{l}- \\
- \\
-\end{array}$ & $\begin{array}{r}-46 \\
0 \\
-15 \\
-31 \\
0\end{array}$ & $\begin{array}{r}32 \\
12 \\
36 \\
-17 \\
1\end{array}$ & $\begin{array}{l}- \\
- \\
-\end{array}$ & $\begin{array}{r}175 \\
59 \\
111 \\
6 \\
-1\end{array}$ & $\begin{array}{r}4 \\
4 \\
0 \\
(s) \\
0\end{array}$ & $\begin{array}{r}68 \\
0 \\
68 \\
0 \\
(s)\end{array}$ \\
\hline 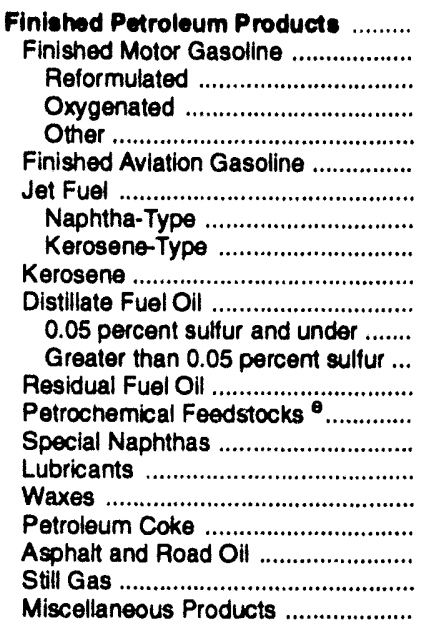 & $\begin{array}{r}-12 \\
-12 \\
- \\
59 \\
-71 \\
- \\
- \\
- \\
- \\
- \\
- \\
- \\
- \\
- \\
- \\
- \\
- \\
-\end{array}$ & $\begin{array}{r}6,390 \\
2,847 \\
0 \\
210 \\
2,636 \\
14 \\
694 \\
26 \\
668 \\
31 \\
1,341 \\
612 \\
729 \\
344 \\
339 \\
23 \\
103 \\
11 \\
267 \\
76 \\
276 \\
23\end{array}$ & $\begin{array}{r}169 \\
0 \\
0 \\
0 \\
0 \\
0 \\
(s) \\
0 \\
(8) \\
3 \\
0 \\
0 \\
0 \\
13 \\
150 \\
2 \\
0 \\
(s) \\
0 \\
0 \\
0 \\
1\end{array}$ & $\begin{array}{l}- \\
- \\
- \\
- \\
- \\
- \\
- \\
- \\
- \\
- \\
- \\
- \\
- \\
- \\
- \\
- \\
- \\
-\end{array}$ & $\begin{array}{r}-3,255 \\
-1,796 \\
0 \\
-345 \\
-1,451 \\
-5 \\
-535 \\
-6 \\
-530 \\
-15 \\
-872 \\
-293 \\
-578 \\
6 \\
0 \\
-5 \\
-25 \\
0 \\
0 \\
-7 \\
0 \\
-2\end{array}$ & $\begin{array}{r}-333 \\
-88 \\
0 \\
-62 \\
-26 \\
3 \\
-83 \\
-7 \\
-76 \\
-7 \\
-145 \\
-57 \\
-89 \\
-55 \\
22 \\
-11 \\
-5 \\
(s) \\
15 \\
7 \\
0 \\
13\end{array}$ & $\begin{array}{l}- \\
- \\
- \\
- \\
- \\
- \\
- \\
- \\
- \\
- \\
- \\
- \\
- \\
-- \\
- \\
- \\
- \\
-\end{array}$ & $\begin{array}{l}- \\
- \\
- \\
- \\
- \\
- \\
- \\
- \\
- \\
- \\
- \\
- \\
- \\
- \\
- \\
- \\
- \\
- \\
-\end{array}$ & $\begin{array}{r}360 \\
66 \\
0 \\
0 \\
66 \\
0 \\
(s) \\
0 \\
(s) \\
(s) \\
97 \\
19 \\
77 \\
63 \\
0 \\
1 \\
11 \\
1 \\
120 \\
1 \\
0 \\
(s)\end{array}$ & $\begin{array}{r}3,265 \\
1,061 \\
0 \\
-13 \\
1,075 \\
6 \\
242 \\
27 \\
215 \\
26 \\
518 \\
356 \\
162 \\
355 \\
466 \\
30 \\
72 \\
10 \\
132 \\
61 \\
276 \\
10\end{array}$ \\
\hline Total & 4,341 & 6,687 & 4,282 & -40 & $-4,733$ & -756 & 0 & 6,343 & 398 & 4,533 \\
\hline
\end{tabular}

a Represents the PAD District in which the material entered the United States and not necessarily where the crude oil or product is processed androf consumed.

b Unaccounted for crude oil represents the difference between the supply and disposition of crude oil.

c A negative number indicates a decrease in stocks and a positive number indicates an increase in stocks.

d Products supplied is equal to field production, plus refinery production, plus imports, plus unaccounted for crude oil, plus net receipts, minus stock change, minus crude losses, minus refinery inputs, minus exports.

Includes naphtha less than $401^{\circ} \mathrm{F}$ endpoint and other oils equal to or greater than $401^{\circ} \mathrm{F}$ endpoint.

(s) = Less than 500 barrels per day.

$E=$ Estimated.

$L R G=$ Liquefied Refinery Gas.

Note: Totals may not equal sum of components due to independent rounding.

Sources: - Energy Information Administration (EIA) Forms EIA-810, "Monthly Refinery Report," EIA-811, "Monthly Bulk Terminal Report," EIA-812, "Monthly Product Pipeline Report," EIA-813, "Monthly Crude Oil Report," ElA-814, "Monthly Imports Report," ElA-816, "Monthly Natural Gas Liquids Report." EIA-817, "Monthly Tanker and Earge Movement Report," and ElA-819M, "Monthly Oxygenate Telephone Report". - Domestic crude oil production estimates based on historical statistics from State conservation agencies and the Minerals Management Service of the U.S. Department of the Interior. - Export data from the Bureau of the Census and Form EIA-810, "Monthly Refinery Report." 
Table 17. PAD District II-Year-to-Date Daily Average Supply and Disposition of Crude Oll and Petroleum Products, January-February 1994

(Thousand Barrels per Day)

\begin{tabular}{|c|c|c|c|c|c|c|c|c|c|c|}
\hline \multirow[b]{2}{*}{ Commodity } & \multicolumn{5}{|c|}{ Supply } & \multicolumn{5}{|c|}{ Disposition } \\
\hline & $\begin{array}{c}\text { Field } \\
\text { Production }\end{array}$ & $\begin{array}{c}\text { Rofinery } \\
\text { Production }\end{array}$ & $\begin{array}{l}\text { Imports by } \\
\text { PAD } \\
\text { District } \\
\text { of Entre }\end{array}$ & $\begin{array}{l}\text { Unac- } \\
\text { counted } \\
\text { For } \\
\text { Crude oll }\end{array}$ & $\begin{array}{c}\text { Not } \\
\text { Receipte }\end{array}$ & $\begin{array}{c}\text { Stock } \\
\text { Changec }\end{array}$ & $\begin{array}{l}\text { Crude } \\
\text { Leseses }\end{array}$ & $\begin{array}{c}\text { Rofinery } \\
\text { Inpute }\end{array}$ & Experte & $\begin{array}{l}\text { Products } \\
\text { Supplied }\end{array}$ \\
\hline 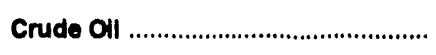 & $E_{3,166}$ & - & 3,856 & 106 & $-1,293$ & -175 & 0 & 6,010 & (s) & 0 \\
\hline 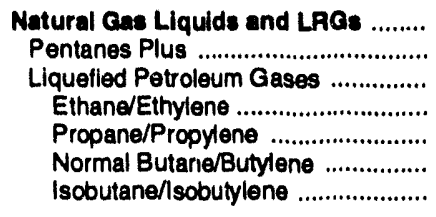 & $\begin{array}{r}1,085 \\
181 \\
904 \\
392 \\
319 \\
40 \\
154\end{array}$ & $\begin{array}{r}256 \\
25 \overline{-} \\
256 \\
26 \\
220 \\
3 \\
6\end{array}$ & $\begin{array}{r}60 \\
30 \\
30 \\
10 \\
7 \\
12 \\
2\end{array}$ & $\begin{array}{l}\ddot{-} \\
\ddot{-} \\
\ddot{-} \\
\ddot{-}\end{array}$ & $\begin{array}{r}-233 \\
-14 \\
-219 \\
45 \\
-245 \\
-5 \\
-13\end{array}$ & $\begin{array}{r}-430 \\
-23 \\
-407 \\
-60 \\
-232 \\
-117 \\
2\end{array}$ & $\begin{array}{l}\overline{-} \\
= \\
=\end{array}$ & $\begin{array}{r}259 \\
70 \\
189 \\
0 \\
0 \\
99 \\
91\end{array}$ & $\begin{array}{r}27 \\
0 \\
27 \\
0 \\
20 \\
6 \\
0\end{array}$ & $\begin{array}{r}1,312 \\
150 \\
1,162 \\
533 \\
512 \\
62 \\
55\end{array}$ \\
\hline 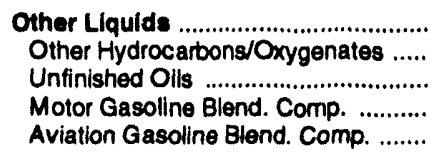 & $\begin{array}{l}64 \\
65 \\
-1 \\
-1\end{array}$ & $\begin{array}{l}\overline{-} \\
\overline{-}\end{array}$ & $\begin{array}{r}296 \\
3 \\
293 \\
1 \\
0\end{array}$ & $\begin{array}{l}\ddot{-} \\
\ddot{-} \\
\overline{-}\end{array}$ & $\begin{array}{r}-39 \\
0 \\
-11 \\
-28 \\
0\end{array}$ & $\begin{array}{r}125 \\
-14 \\
143 \\
-5 \\
(s)\end{array}$ & $\begin{array}{l}- \\
- \\
-\end{array}$ & $\begin{array}{r}216 \\
77 \\
163 \\
-23 \\
(8)\end{array}$ & $\begin{array}{r}5 \\
5 \\
0 \\
(s) \\
0\end{array}$ & $\begin{array}{r}-26 \\
0 \\
-26 \\
0 \\
(s)\end{array}$ \\
\hline 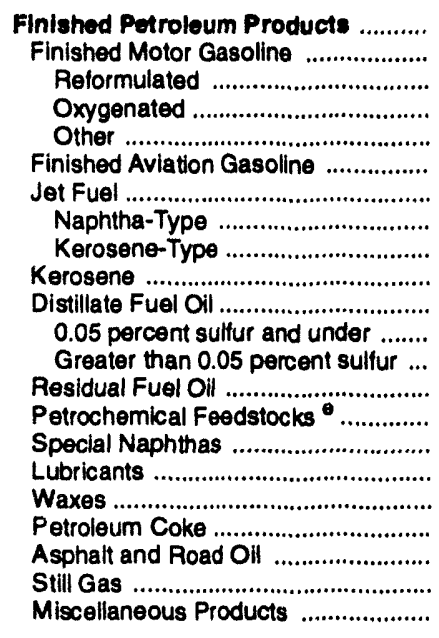 & $\begin{array}{r}8 \\
8 \\
64 \\
-56 \\
= \\
= \\
= \\
= \\
= \\
= \\
= \\
= \\
= \\
= \\
= \\
= \\
-\end{array}$ & $\begin{array}{r}6,557 \\
2,960 \\
0 \\
319 \\
2,641 \\
11 \\
721 \\
34 \\
687 \\
37 \\
1,404 \\
613 \\
791 \\
326 \\
314 \\
30 \\
100 \\
11 \\
271 \\
74 \\
278 \\
22\end{array}$ & $\begin{array}{r}196 \\
0 \\
0 \\
0 \\
0 \\
0 \\
(s) \\
0 \\
(\mathbf{s}) \\
2 \\
0 \\
0 \\
0 \\
36 \\
152 \\
2 \\
0 \\
(\mathbf{s}) \\
1 \\
1 \\
0 \\
1\end{array}$ & 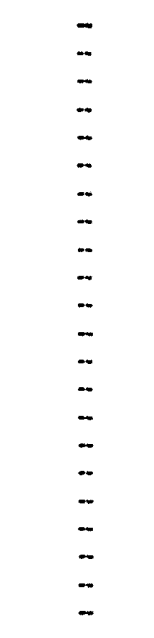 & $\begin{array}{r}-3,232 \\
-1,839 \\
0 \\
-327 \\
-1,512 \\
-4 \\
-503 \\
-4 \\
-499 \\
-12 \\
-846 \\
-344 \\
-502 \\
9 \\
0 \\
-6 \\
-24 \\
(8) \\
0 \\
-5 \\
0 \\
-2\end{array}$ & $\begin{array}{r}-65 \\
-15 \\
0 \\
-41 \\
26 \\
1 \\
-3 \\
(s) \\
-3 \\
2 \\
-60 \\
-10 \\
-50 \\
-14 \\
10 \\
-3 \\
-5 \\
(s) \\
9 \\
10 \\
0 \\
1\end{array}$ & $\begin{array}{l}- \\
- \\
= \\
= \\
= \\
= \\
= \\
= \\
= \\
= \\
- \\
- \\
- \\
= \\
= \\
-\end{array}$ & 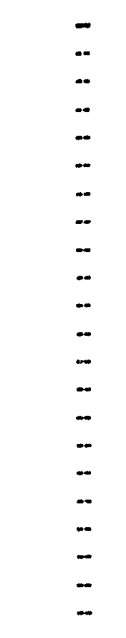 & $\begin{array}{r}399 \\
72 \\
0 \\
(s) \\
72 \\
0 \\
7 \\
6 \\
1 \\
(s) \\
139 \\
50 \\
90 \\
43 \\
0 \\
1 \\
10 \\
1 \\
126 \\
(s) \\
0 \\
(s)\end{array}$ & $\begin{array}{r}3,195 \\
1,072 \\
0 \\
97 \\
975 \\
6 \\
6 \\
214 \\
24 \\
190 \\
26 \\
478 \\
229 \\
249 \\
341 \\
456 \\
29 \\
70 \\
10 \\
138 \\
59 \\
278 \\
19\end{array}$ \\
\hline Total & 4,323 & 6,812 & 4,409 & 108 & $-4,797$ & -546 & 0 & 6,486 & 431 & 4,482 \\
\hline
\end{tabular}

a Represents the PAD District in which the material entered the United States and not necessarily where the crude oll or product is processed and/or consumed.

6 Unaccounted for crude oll represents the difference between the supply and disposition of crude oil.

c A negative number indicates a decrease in stocks and a positive number indicates an increase in stocks.

d Prodixts supplied is equal to field production, plus retinery production, plus imports, plus unaccounted tor crude oil, plus net receipts, minus stock change, minus crude losses, minus refinery inputs, minus exports.

- Includes naphtha less than $401^{\circ} \mathrm{F}$ endpoint and other olls equal to or greater than $401^{\circ} \mathrm{F}$ endpoint.

(s) = Less than 500 barrels per day.

$E=$ Estimated.

LRG = Liquefied Refinery Gas.

Note: Totals may not equal sum of components due to independent rounding.

Sources: - Energy Information Administration (EIA) Forms ElA-810, "Monthly Refinery Report," ElA-811, "Monthly Bulk Terminal Report," EIA-812, "Monthly Product Pipeline Report," EIA-813, "Monthly Crude OII Report," ElA-814, "Monthly Imports Report," ElA-816, "Monthly Natural Gas Liquids Report," EIA-817, "Monthly Tanker and Barge Movement Report," and EIA-819M. "Monthly Oxygenate Telephone Report". - Domestic crude oil production estimates based on historical statistics from State conservation agencies and the Minerals Management Service of the U.S. Department of the Interior. • Export data from the Bureau of the Census and Form EIA-810, "Monthly Refinery Report." 
Table 18. PAD District IV-Supply, Disposition, and Ending Stocks of Crude Oll and Petroleum Products, February 1994

(Thousand Barrels)

\begin{tabular}{|c|c|c|c|c|c|c|c|c|c|c|c|}
\hline \multirow[b]{2}{*}{ Commodity } & \multicolumn{5}{|c|}{ Supply } & \multicolumn{5}{|c|}{ Dispostion } & \multirow[b]{2}{*}{$\begin{array}{l}\text { Ending } \\
\text { Stoakn }\end{array}$} \\
\hline & $\begin{array}{c}\text { Field } \\
\text { Production }\end{array}$ & $\begin{array}{c}\text { Rofinory } \\
\text { Production }\end{array}$ & $\begin{array}{c}\text { Importa by } \\
\text { PAD } \\
\text { District } \\
\text { of Entre }\end{array}$ & $\begin{array}{l}\text { Unac- } \\
\text { counted } \\
\text { For } \\
\text { Crude } \\
\end{array}$ & $\begin{array}{c}\text { Not } \\
\text { Recelpts }\end{array}$ & $\begin{array}{c}\text { Btock } \\
\text { Chengec }\end{array}$ & $\begin{array}{l}\text { Crude } \\
\text { Leses }\end{array}$ & $\begin{array}{c}\text { Rofinery } \\
\text { Inputs }\end{array}$ & Expon & $\begin{array}{l}\text { Products } \\
\text { 8ypolind }\end{array}$ & \\
\hline 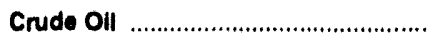 & $E_{11,463}$ & - & 2,969 & 1,404 & $-3,718$ & -305 & $\mathbf{0}$ & 12,473 & $\mathbf{0}$ & 0 & 11,086 \\
\hline 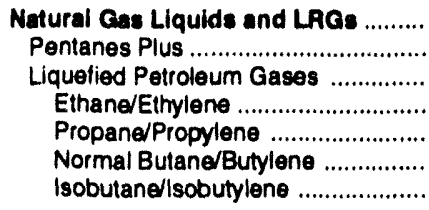 & $\begin{array}{r}3,433 \\
789 \\
2,644 \\
760 \\
1,172 \\
441 \\
271\end{array}$ & $\begin{array}{r}148 \\
148 \\
0 \\
242 \\
-109 \\
15\end{array}$ & $\begin{array}{r}594 \\
347 \\
247 \\
0 \\
161 \\
67 \\
19\end{array}$ & 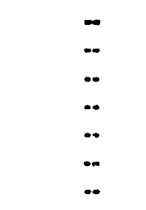 & $\begin{array}{r}-2,007 \\
-266 \\
-1,741 \\
-842 \\
-500 \\
-245 \\
-154\end{array}$ & $\begin{array}{r}-21 \\
9 \\
-30 \\
2 \\
-50 \\
0 \\
18\end{array}$ & 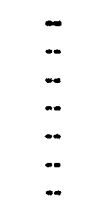 & $\begin{array}{r}530 \\
173 \\
357 \\
0 \\
0 \\
228 \\
128\end{array}$ & $\begin{array}{l}3 \\
3 \\
0 \\
0 \\
0 \\
0 \\
0\end{array}$ & $\begin{array}{r}1,688 \\
685 \\
971 \\
-84 \\
1,125 \\
-74 \\
4\end{array}$ & $\begin{array}{r}1,317 \\
179 \\
1,138 \\
185 \\
422 \\
336 \\
195\end{array}$ \\
\hline $\begin{array}{l}\text { Other Liquids .................................... } \\
\text { Other Hydrocartoons/Oxygenates ..... } \\
\text { Untinished Oils ................................... } \\
\text { Motor Gasoline Blend. Comp. .......... } \\
\text { Aviation Gasoline Blend. Comp. ........ }\end{array}$ & $\begin{array}{r}165 \\
105 \\
\cdots \\
60 \\
\cdots\end{array}$ & $\begin{array}{l}- \\
\cdots \\
-. \\
\cdots\end{array}$ & $\begin{array}{l}0 \\
0 \\
0 \\
0 \\
0\end{array}$ & $\begin{array}{l}\ddot{ } \\
\cdots \\
\cdots \\
\cdots\end{array}$ & $\begin{array}{l}0 \\
0 \\
0 \\
0 \\
0\end{array}$ & $\begin{array}{r}-67 \\
-7 \\
0 \\
-66 \\
0\end{array}$ & $\begin{array}{l}\ddot{-} \\
\ddot{-} \\
\ddot{-}\end{array}$ & $\begin{array}{r}168 \\
112 \\
-70 \\
126 \\
0\end{array}$ & $\begin{array}{l}0 \\
0 \\
0 \\
0 \\
0\end{array}$ & $\begin{array}{r}64 \\
0 \\
64 \\
0 \\
0\end{array}$ & $\begin{array}{r}5,398 \\
270 \\
2,545 \\
2,581 \\
0\end{array}$ \\
\hline 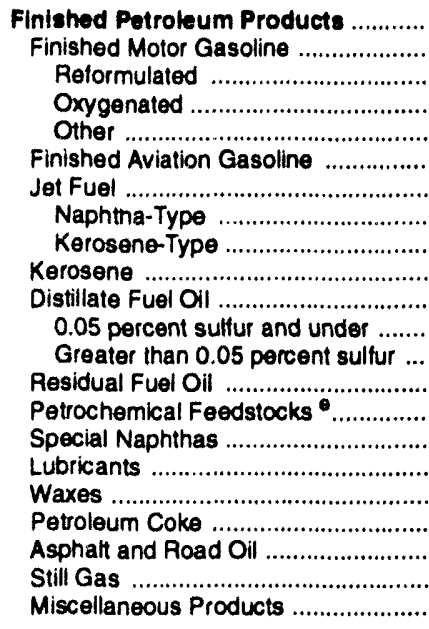 & $\begin{array}{r}-19 \\
-19 \\
. . \\
410 \\
429 \\
. . \\
. . \\
. . \\
. . \\
. . \\
. . \\
.- \\
. . \\
. . \\
. . \\
. . \\
. . \\
.- \\
. . \\
.-\end{array}$ & $\begin{array}{r}13,403 \\
6,839 \\
0 \\
346 \\
6,493 \\
2 \\
908 \\
257 \\
651 \\
102 \\
3,419 \\
2,066 \\
1,353 \\
216 \\
15 \\
0 \\
0 \\
28 \\
402 \\
836 \\
557 \\
79\end{array}$ & $\begin{array}{r}108 \\
5 \\
0 \\
0 \\
5 \\
0 \\
0 \\
0 \\
0 \\
0 \\
97 \\
27 \\
70 \\
2 \\
0 \\
0 \\
0 \\
2 \\
0 \\
0 \\
0 \\
0\end{array}$ & 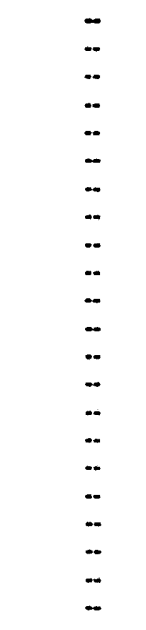 & $\begin{array}{r}1,321 \\
504 \\
0 \\
19 \\
485 \\
8 \\
857 \\
-166 \\
1,023 \\
-38 \\
-10 \\
62 \\
-72 \\
0 \\
0 \\
0 \\
0 \\
0 \\
0 \\
0 \\
0 \\
0\end{array}$ & $\begin{array}{r}936 \\
535 \\
0 \\
-427 \\
962 \\
-7 \\
-63 \\
-16 \\
-47 \\
-38 \\
58 \\
26 \\
32 \\
-50 \\
-1 \\
0 \\
0 \\
-3 \\
24 \\
478 \\
0 \\
3\end{array}$ & $\begin{array}{l}-. \\
. . \\
- \\
. . \\
. . \\
.- \\
. . \\
. . \\
. . \\
.- \\
-. \\
. . \\
-. \\
-. \\
-. \\
-. \\
. . \\
. .\end{array}$ & 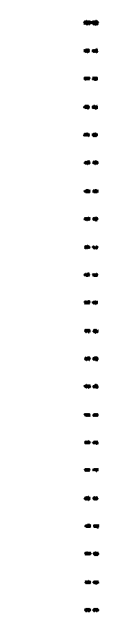 & $\begin{array}{r}18 \\
10 \\
0 \\
9 \\
1 \\
0 \\
0 \\
0 \\
0 \\
0 \\
3 \\
0 \\
3 \\
0 \\
0 \\
(8) \\
4 \\
0 \\
0 \\
1 \\
0 \\
0\end{array}$ & $\begin{array}{r}13,857 \\
6,784 \\
0 \\
1,194 \\
5,591 \\
17 \\
1,828 \\
107 \\
1,721 \\
102 \\
3,445 \\
2,129 \\
1,316 \\
268 \\
16 \\
(8) \\
-4 \\
33 \\
378 \\
357 \\
557 \\
76\end{array}$ & $\begin{array}{r}12,921 \\
5,672 \\
0 \\
381 \\
5,291 \\
49 \\
850 \\
195 \\
655 \\
113 \\
3,059 \\
1,979 \\
1,080 \\
321 \\
0 \\
1 \\
0 \\
28 \\
142 \\
2,666 \\
0 \\
20\end{array}$ \\
\hline Total & 15,042 & 13,551 & 3,650 & 1,404 & 4,404 & 483 & $\mathbf{0}$ & 13,171 & 21 & 15,577 & 30,700 \\
\hline
\end{tabular}

a Represents the PAD District in which the material entered the United States and not necessarlly where the crude oll or product is processed and/or consumed.

b Unaccounted for crude oil represents the difference between the supply and disposition of crude oll.

c. A negative number indicates a decrease in stocks and a positive number indicates an increase in stocks.

d Products supplied is equal to field production, plus refinery production, plus imports, plus unaccounted for crude oil, plus net receipts, minus stock change, minus crude losses, minus refinery inputs, minus exports.

Includes naphtha less than $401^{\circ} \mathrm{F}$ endpoint and other olls equal to or greater than $401^{\circ} \mathrm{F}$ endpoint.

(s) $=$ Less than 500 barrels.

$E=$ Estimated.

LRG = Liquefied Refinery Gas.

Note: Totals may not equal sum of components due to independent rounding.

Sources: - Energy Information Administration (ElA) Forms ElA-810, "Monthly Refinery Report," ElA-811, "Monthly Bulk Terminal Report," ElA-812, "Monthly Product Pipeline Report," ElA-813, "Monthly Crude Oil Report," EIA-814, "Monthly Imports Report," EIA-816, "Monthly Natural Gas Llquids Report," EIA-817, "Monthly Tanker and Barge Movement Repon," and EIA-819M, "Monthly Oxygenate Telephone Report. - Domestic crude oil production estimates based on historical statistics from State conservation agencies and the Minerals Management Service of the U.S. Department of the Interior. - Export data from the Bureau of the Census and Form ElA-810, "Monthly Refinery Report." 
Table 19. PAD District IV-Year-to-Date Supply, Disposition, and Ending Stocks of Crude Oll and Petroleum Products, January-February 1994 (Thousand Barrels)

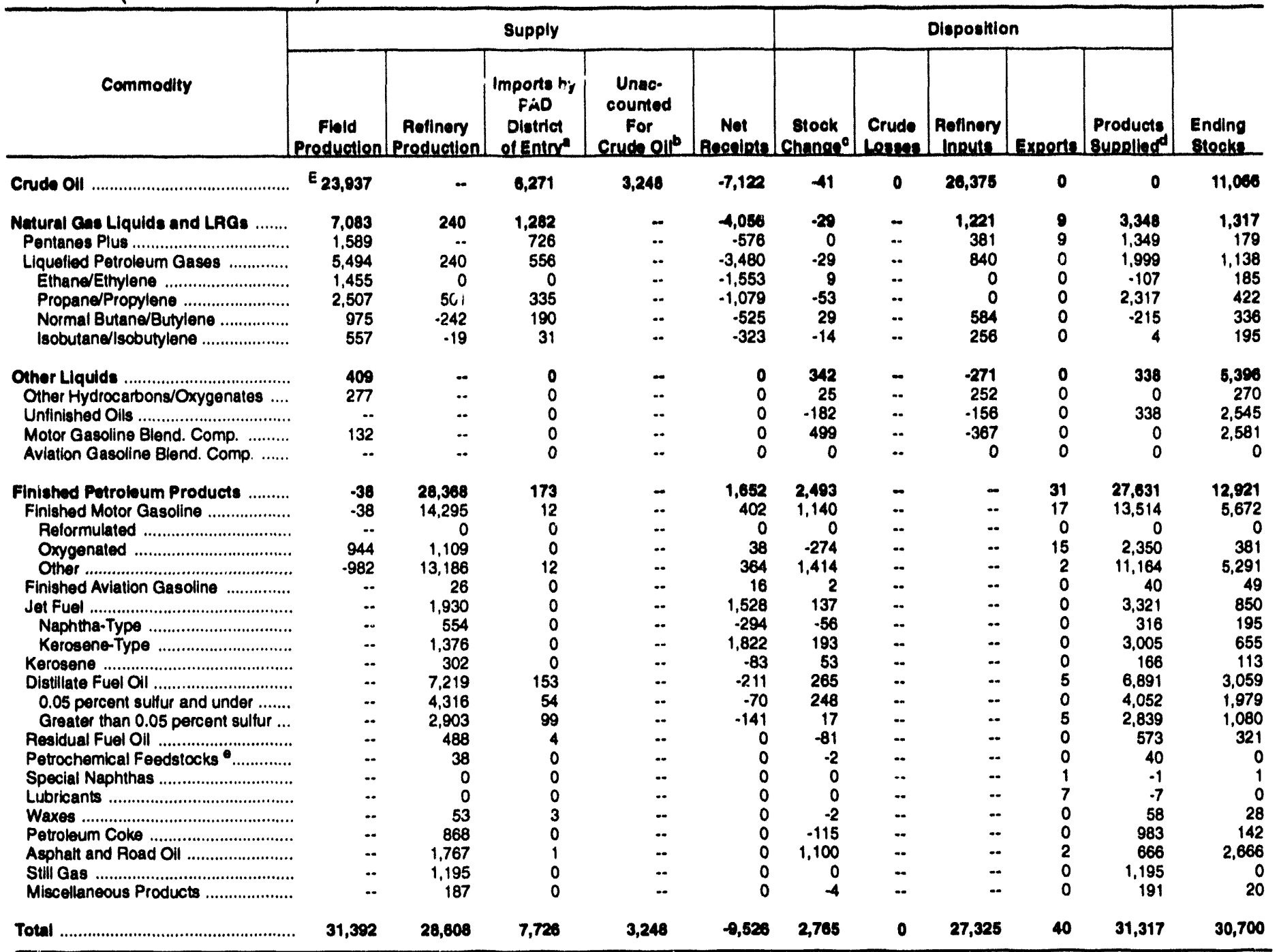

Represents the PAD District in which the material entered the United States and not necessarily where the crude oll or product is processed and/or consumed.

b Unaccounted for crude oil represents the difference between the supply and disposition of crude oll.

c A negative number indicates a decrease in stocks and a positive number indicates an increase in stocks.

d Products supplied is equal to tield production, plus refinery production, plus imports, plus unaccounted for cruce oll, plus net recelpts, minus stock change, minus crude losses, minus refinery inputs, minus exports.

Includes naphtha less than $401^{\circ} \mathrm{F}$ endpoint and other olls equal to or greater than $401^{\circ} \mathrm{F}$ endpoint.

(8) = Less than 500 barrels.

$E=$ Estimated.

LRG = Liquefied Refinery Gas.

Note: Totals may not equal sum of components due to independent rounding.

Sources: - Energy Information Administration (EIA) Forms EIA-810, "Monthly Refinery Report," ElA-811, "Monthly Bulk Terminal Report" ElA-812, "Monthly Producl Pipeline Report, "EIA-813, "Monthly Crude Oll Report," EIA-814, "Monthly Imports Report," ElA-816, "Monthly Natural Gas Liquids Report," EIA-817, "Monthly Tanker and Barge Movement Report," and EIA-819M, "Monthly Oxygenate Telephone Report". - Domestic crude oil production estimates based on historical statistics from State conservation agencies and the Minerais Management Service of the U.S. Department of the Interior. - Export data from the Bureau of the Census and Form ElA-810, "Monthly Refinery Report." 
Table 20. PAD Distriot IV-Dally Average supply and Disposition of Crude Oll and Potroloum Products, February 1994

(Thousand Barrels per Day)

\begin{tabular}{|c|c|c|c|c|c|c|c|c|c|c|}
\hline \multirow[b]{2}{*}{ Commodity } & \multicolumn{5}{|c|}{ supply } & \multicolumn{5}{|c|}{ Disposition } \\
\hline & $\begin{array}{l}\text { Fold } \\
\text { Eroduction }\end{array}$ & $\begin{array}{c}\text { Rofinem } \\
\text { Production }\end{array}$ & $\begin{array}{c}\text { Imports by } \\
\text { PAD } \\
\text { Diotriet } \\
\text { offente }\end{array}$ & $\begin{array}{l}\text { Unso- } \\
\text { couned } \\
\text { For } \\
\text { cinuchele }\end{array}$ & Net & $\begin{array}{l}\text { Elook } \\
\text { Chmane }\end{array}$ & $\begin{array}{l}\text { Crude } \\
\text { Lesten }\end{array}$ & $\begin{array}{c}\text { Aofinery } \\
\text { lnouth }\end{array}$ & Lroonte & $\begin{array}{l}\text { Products } \\
\text { supoliade }\end{array}$ \\
\hline 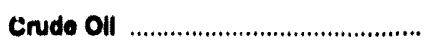 & E 400 & - & 100 & 80 & .133 & -13 & 0 & 445 & 0 & 0 \\
\hline 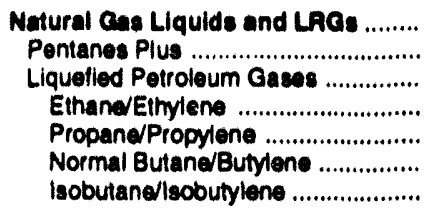 & $\begin{array}{r}123 \\
28 \\
24 \\
27 \\
42 \\
18 \\
10\end{array}$ & $\begin{array}{l}8 \\
\cdots 5 \\
0 \\
9 \\
1 \\
1\end{array}$ & $\begin{array}{r}21 \\
12 \\
0 \\
0 \\
6 \\
2 \\
1\end{array}$ & $\begin{array}{l}\ddot{.} \\
\ddot{.} \\
\ddot{.} \\
\ddot{.}\end{array}$ & $\begin{array}{r}.72 \\
.10 \\
.62 \\
.30 \\
.18 \\
.9 \\
.6\end{array}$ & $\begin{array}{l}-1 \\
(8) \\
-1 \\
(8) \\
-2 \\
0 \\
1\end{array}$ & $\begin{array}{l}\ddot{.} \\
\ddot{.} \\
\ddot{.} \\
\ddot{.} \\
\ddot{.}\end{array}$ & $\begin{array}{r}19 \\
6 \\
13 \\
0 \\
0 \\
8 \\
5\end{array}$ & $\begin{array}{l}(0) \\
(0) \\
0 \\
0 \\
0 \\
0 \\
0\end{array}$ & $\begin{array}{r}50 \\
24 \\
35 \\
-3 \\
40 \\
-3 \\
(8)\end{array}$ \\
\hline $\begin{array}{l}\text { Other Liquids } \\
\text { Other Hydrocarbons/Oxygenates ..... } \\
\text { Unfinished Oils } \\
\text { Motor Gasoline Biend. Comp............... } \\
\text { Aviation Gasoline Blend. Comp. }\end{array}$ & $\begin{array}{l}6 \\
4 \\
\ddot{2} \\
-\end{array}$ & $\begin{array}{l}\ddot{-} \\
\ddot{-} \\
\ddot{-}\end{array}$ & $\begin{array}{l}0 \\
0 \\
0 \\
0 \\
0\end{array}$ & $\begin{array}{l}\ddot{.} \\
\ddot{.} \\
\ddot{.}\end{array}$ & $\begin{array}{l}0 \\
0 \\
0 \\
0 \\
0\end{array}$ & $\begin{array}{l}-2 \\
(8) \\
(8) \\
-2 \\
0\end{array}$ & $\begin{array}{l}\ddot{.} \\
\ddot{.} \\
\ddot{.}\end{array}$ & $\begin{array}{r}6 \\
4 \\
-3 \\
5 \\
0\end{array}$ & $\begin{array}{l}0 \\
0 \\
0 \\
0 \\
0\end{array}$ & $\begin{array}{l}2 \\
0 \\
2 \\
0 \\
0\end{array}$ \\
\hline 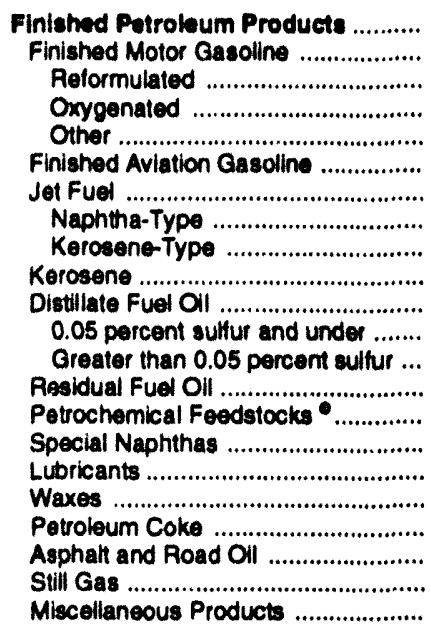 & 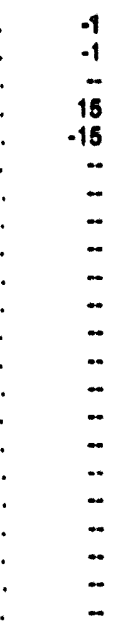 & $\begin{array}{r}470 \\
244 \\
0 \\
12 \\
232 \\
(0) \\
32 \\
9 \\
23 \\
4 \\
122 \\
74 \\
48 \\
8 \\
1 \\
0 \\
0 \\
1 \\
14 \\
30 \\
20 \\
3\end{array}$ & $\begin{array}{r}1 \\
(0) \\
0 \\
0 \\
(0) \\
0 \\
0 \\
0 \\
0 \\
0 \\
3 \\
1 \\
3 \\
(8) \\
0 \\
0 \\
0 \\
(0) \\
0 \\
0 \\
0 \\
0\end{array}$ & 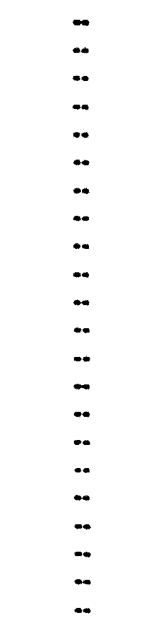 & $\begin{array}{r}17 \\
18 \\
0 \\
1 \\
17 \\
(8) \\
31 \\
6 \\
37 \\
-1 \\
10) \\
2 \\
-3 \\
0 \\
0 \\
0 \\
0 \\
0 \\
0 \\
0 \\
0 \\
0 \\
0\end{array}$ & $\begin{array}{r}33 \\
19 \\
0 \\
-15 \\
34 \\
(8) \\
-2 \\
-1 \\
-2 \\
-1 \\
2 \\
1 \\
1 \\
-2 \\
(8) \\
0 \\
0 \\
(8) \\
1 \\
17 \\
0 \\
(8)\end{array}$ & 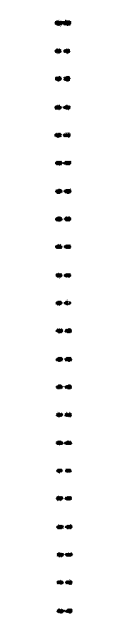 & 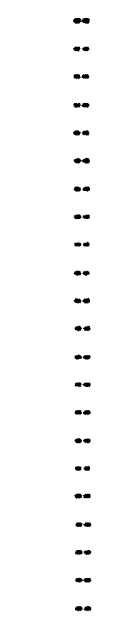 & $\begin{array}{r}1 \\
(8) \\
0 \\
(8) \\
(8) \\
0 \\
0 \\
0 \\
0 \\
0 \\
(8) \\
0 \\
(8) \\
0 \\
0 \\
(8) \\
(8) \\
0 \\
0 \\
(8) \\
0 \\
0\end{array}$ & $\begin{array}{r}495 \\
242 \\
0 \\
43 \\
200 \\
1 \\
65 \\
4 \\
61 \\
4 \\
123 \\
76 \\
47 \\
10 \\
1 \\
(8) \\
(8) \\
1 \\
14 \\
13 \\
20 \\
3\end{array}$ \\
\hline Total & 537 & 464 & 131 & 80 & -187 & 17 & $\mathbf{0}$ & 470 & 1 & 550 \\
\hline
\end{tabular}

- Represents the PAD District in which the materlal entered the United Stabes and not necessarliy where the crude ofl or product is proceseed andVor consumed.

- Unaccounted for srude oll represents the difference between the aupply and diepoedilion of crude oll.

c A negative number indicales a decrease in stocks and a poelitw number indicalos an increace in stocks.

d Products supplied is equal to field production, phus refinery production, plus imports, plus unaccounted for crude oil, plus net receipts, minus stock change, minus crude losses, minus refinery inputs, minus exports.

- Includes naphtha less than $401^{\circ} \mathrm{F}$ endpoint and other olls equal to or greater than $401^{\circ} \mathrm{F}$ endpoint.

(8) = Less than 500 barrels per day.

$E$ = Estimated

LRG = Liquefied Refinery Gas.

Note: Totals may not equal sum of components due to independent rounding

Sources: - Energy Information Administration (ELA) Forms ElA-810, "Monthly Refinery Repon," ElA-811, "Monthly Bulk Terminal Repor," EIA-812, "Monthly Product Pipeline Report," EIA-813, "Monthly Crude Oll Report," ElA-814, "Monthly Imports Report," ElA-816, "Monthly Natural Gas Liquids Report," EIA-817, "Monthly Tanker and Barge Movement Report, and ELA-819M, "Monthy Oxygenate Telephone Report". - Domestic crude oll production estimates based on historical statistics from State conservation agencies and the Minerals Management Service of the U.S. Department of the Interior. - Export data from the Bureau of the Census and Form EIA-810, "Monthiy Refinery Report" 
Table 21. PAD Dlatrict IV-Year-to-Date Dally Average supply and Disposittion of Crude OII and Petroleum Producte, January-Fobruary 1994

(Thousand Barrels per Day)

\begin{tabular}{|c|c|c|c|c|c|c|c|c|c|c|}
\hline \multirow[b]{2}{*}{ Commodity } & \multicolumn{5}{|c|}{ supply } & \multicolumn{5}{|c|}{ Dleposkion } \\
\hline & $\begin{array}{l}\text { Fiold } \\
\text { Eonduation }\end{array}$ & $\begin{array}{c}\text { Roflinary } \\
\text { emortuntion }\end{array}$ & $\begin{array}{c}\text { Imponts by } \\
\text { PAD } \\
\text { Oletrict } \\
\text { ofientice }\end{array}$ & $\begin{array}{l}\text { Uneo- } \\
\text { counted } \\
\text { For } \\
\text { Crupleate }\end{array}$ & Nor & Chook & $\begin{array}{l}\text { Cruds } \\
\text { Jerren }\end{array}$ & $\begin{array}{c}\text { Poflinery } \\
\text { Inpuite }\end{array}$ & Exponte & $\begin{array}{l}\text { Producte } \\
\text { supalinde }\end{array}$ \\
\hline 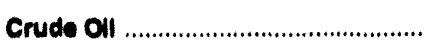 & $E_{400}$ & - & 100 & 8 & .121 & -1 & 0 & 447 & 0 & 0 \\
\hline 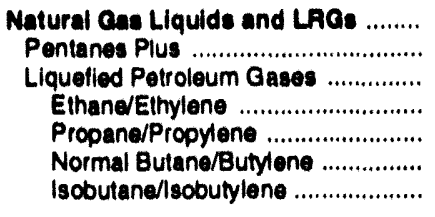 & $\begin{array}{r}120 \\
27 \\
93 \\
25 \\
42 \\
17 \\
9\end{array}$ & $\begin{array}{c}4 \\
4 \\
0 \\
8 \\
4 \\
(8)\end{array}$ & $\begin{array}{r}22 \\
12 \\
0 \\
0 \\
6 \\
3 \\
1\end{array}$ & 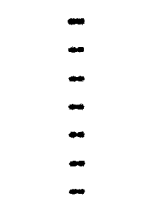 & $\begin{array}{r}.00 \\
.10 \\
.59 \\
.26 \\
.18 \\
.8 \\
.8\end{array}$ & $\begin{array}{l}\text { (o) } \\
0 \\
(8) \\
(0) \\
11 \\
(0) \\
(0)\end{array}$ & $\begin{array}{l}\ddot{-} \\
\ddot{-} \\
\ddot{-}\end{array}$ & $\begin{array}{r}21 \\
6 \\
14 \\
0 \\
0 \\
10 \\
4\end{array}$ & $\begin{array}{l}\text { (8) } \\
\text { (s) } \\
0 \\
0 \\
0 \\
0 \\
0\end{array}$ & $\begin{array}{l}57 \\
23 \\
34 \\
-2 \\
39 \\
4 \\
18\end{array}$ \\
\hline 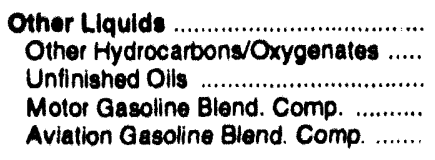 & $\begin{array}{l}7 \\
5 \\
\ddot{2} \\
-\end{array}$ & $\overline{-}$ & $\begin{array}{l}0 \\
0 \\
0 \\
0 \\
0\end{array}$ & $\overline{-}$ & $\begin{array}{l}0 \\
0 \\
0 \\
0 \\
0\end{array}$ & $\begin{array}{r}0 \\
(1) \\
-3 \\
8 \\
0\end{array}$ & $\begin{array}{l}\ddot{-} \\
\ddot{-}\end{array}$ & $\begin{array}{r}-6 \\
4 \\
-3 \\
-6 \\
0\end{array}$ & $\begin{array}{l}0 \\
0 \\
0 \\
0 \\
0\end{array}$ & $\begin{array}{l}6 \\
0 \\
6 \\
0 \\
0\end{array}$ \\
\hline 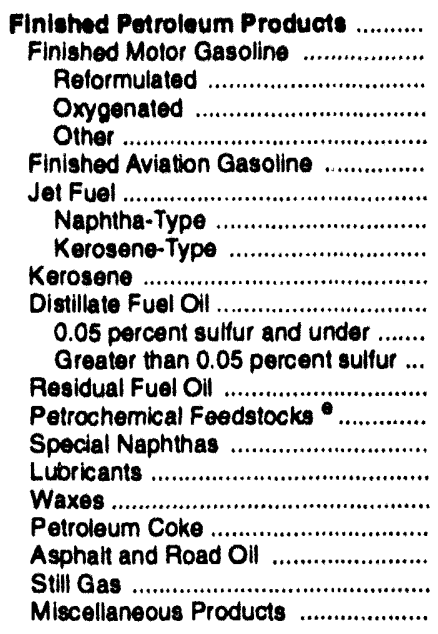 & $\begin{array}{r}1 \\
-1 \\
16 \\
17 \\
= \\
= \\
= \\
= \\
= \\
= \\
= \\
= \\
=\end{array}$ & $\begin{array}{r}461 \\
242 \\
0 \\
19 \\
223 \\
(0) \\
33 \\
9 \\
23 \\
5 \\
122 \\
73 \\
49 \\
8 \\
1 \\
0 \\
0 \\
1 \\
15 \\
30 \\
20 \\
3\end{array}$ & $\begin{array}{r}3 \\
(8) \\
0 \\
0 \\
(0) \\
0 \\
0 \\
0 \\
0 \\
0 \\
3 \\
1 \\
2 \\
(0) \\
0 \\
0 \\
0 \\
(8) \\
0 \\
(8) \\
0 \\
0\end{array}$ & 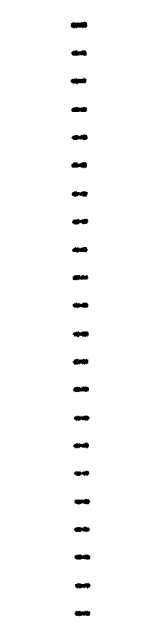 & $\begin{array}{r}20 \\
7 \\
0 \\
1 \\
6 \\
(0) \\
26 \\
-5 \\
31 \\
-1 \\
-4 \\
-1 \\
-2 \\
0 \\
0 \\
0 \\
0 \\
0 \\
0 \\
0 \\
0 \\
0\end{array}$ & $\begin{array}{r}49 \\
19 \\
0 \\
-5 \\
24 \\
(8) \\
2 \\
-1 \\
3 \\
1 \\
4 \\
4 \\
(8) \\
-1 \\
(0) \\
0 \\
0 \\
(8) \\
-2 \\
19 \\
0 \\
(8)\end{array}$ & 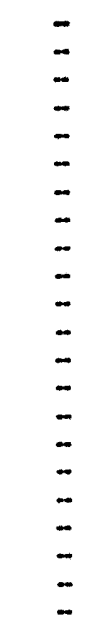 & $\begin{array}{l}- \\
- \\
- \\
- \\
- \\
- \\
- \\
= \\
= \\
- \\
- \\
- \\
- \\
- \\
- \\
-\end{array}$ & $\begin{array}{r}1 \\
(8) \\
0 \\
(8) \\
(8) \\
0 \\
0 \\
0 \\
0 \\
0 \\
(8) \\
0 \\
(8) \\
0 \\
0 \\
(8) \\
(8) \\
0 \\
0 \\
(8) \\
0 \\
0\end{array}$ & $\begin{array}{r}460 \\
229 \\
0 \\
40 \\
189 \\
1 \\
56 \\
5 \\
51 \\
3 \\
117 \\
69 \\
48 \\
10 \\
1 \\
(8) \\
(5) \\
1 \\
17 \\
11 \\
20 \\
3\end{array}$ \\
\hline Total & 532 & 405 & 131 & 95 & .101 & 47 & 0 & 403 & 1 & 531 \\
\hline
\end{tabular}

- Represents the PAD District in which the material entered the United States and not nececsarily where the crude oll or product le proceseed and/or consumed.

b Unaccounted for crude oil represents the difference between the supply and dieposition of cride oll.

- A negative number indicates a decrease in stocks and a poaltive number indicates an incroase in stocks.

d Products supplied is equal to field production, plus refinery production, plus imports, plus unacocounted for crude oil, plus net receipts, minus stock change, minus crude losses, minus refinery inputs, minus exports.

- Includes naphtha less than $401^{\circ} \mathrm{F}$ endpoint and other oils equal to or greater than $401^{\circ} \mathrm{F}$ encpoint.

(s) = Less than 500 barrels per day.

$E$ = Estimated.

LRG = Liquefied Relinery Gas.

Note: Totals may not equal sum of components due to independent rounding.

Sources: -Energy Information Administration (EIA) Forms ElA-810, "Monthily Refinery Report," ElA-811, "Monthly Bulk Terminal Report," ElA-812, "Monthly Product Pipeline Report," ElA-813, "Monthly Crude OII Report," ElA-814, "Monthly Imports Report," ElA-816, "Monthly Natural Gas Llquids Report." ElA-817, "Monthly Tanker and Barge Movement Report," and EIA-819M, "Monthly Oxygenate Telephone Reporte. - Domestic crude oil production estimates based on historical statistics from State conservation agencies and the Minerals Management Service of the U.S. Department of the Interior. - Export data from the Bureau of the Census and Form ElA-810, "Monthly Relinery Report." 
Table 22. PAD Dletrict V-Supply, Dieposttion, and Ending Stocks of Crude Oll and Potroleum Products, February 1994

(Thousand Barrels)

\begin{tabular}{|c|c|c|c|c|c|c|c|c|c|c|c|}
\hline \multirow[b]{2}{*}{ Commodlty } & \multicolumn{5}{|c|}{ Supply } & \multicolumn{5}{|c|}{ Diepostion } & \multirow[b]{2}{*}{$\begin{array}{l}\text { Ending } \\
\text { eicols? }\end{array}$} \\
\hline & $\begin{array}{l}\text { Field } \\
\text { Production }\end{array}$ & $\begin{array}{l}\text { Rolinony } \\
\text { Proxtunlon }\end{array}$ & $\begin{array}{c}\text { Importe by } \\
\text { PAD } \\
\text { Diotrlet } \\
\text { of finte }\end{array}$ & $\begin{array}{l}\text { Unsoo } \\
\text { counted } \\
\text { For } \\
\text { Conde }\end{array}$ & $\begin{array}{c}\text { Not } \\
\text { Reselos: }\end{array}$ & $\begin{array}{c}\text { Stook } \\
\text { Chnnoe }\end{array}$ & $\begin{array}{l}\text { Crude } \\
\text { Lenet }\end{array}$ & $\begin{array}{c}\text { Rofinery } \\
\text { Inpute }\end{array}$ & Expont & $\begin{array}{l}\text { Products } \\
\text { Eupolind }\end{array}$ & \\
\hline Crude Oll ............................................ & $E_{71,800}$ & - & 0,714 & $-1,348$ & $-8,041$ & 678 & 0 & 63,030 & 3,237 & 330 & 73,640 \\
\hline $\begin{array}{l}\text { Natural Cas Llquids and LACs .......... } \\
\text { Pentanes Plus ................................... } \\
\text { Liquelied Petroleum Cases .............. } \\
\text { Ethane/Ethylene ............................. } \\
\text { Propane/Propylene ..................... } \\
\text { Normal Butane/Butylene .............. } \\
\text { Isobutanelisobutylene ................... }\end{array}$ & $\begin{array}{r}2,744 \\
1,413 \\
1,331 \\
1 \\
238 \\
688 \\
408\end{array}$ & $\begin{array}{r}1,764 \\
0 \ddot{1} \\
1,764 \\
0 \\
1,081 \\
880 \\
133\end{array}$ & $\begin{array}{r}162 \\
0 \\
162 \\
140 \\
6 \\
16 \\
0\end{array}$ & $\begin{array}{l}\ddot{-} \\
\ddot{*} \\
\ddot{*} \\
\ddot{*}\end{array}$ & $\begin{array}{l}0 \\
0 \\
0 \\
0 \\
0 \\
0 \\
0\end{array}$ & $\begin{array}{r}-590 \\
-4 \\
-592 \\
0 \\
-321 \\
-251 \\
-20\end{array}$ & $\begin{array}{l}\ddot{-} \\
\ddot{.} \\
\ddot{.} \\
\ddot{.} \\
\ddot{.}\end{array}$ & $\begin{array}{r}2,800 \\
1,021 \\
1,487 \\
0 \\
0 \\
807 \\
580\end{array}$ & $\begin{array}{r}169 \\
0 \\
159 \\
0 \\
21 \\
138 \\
0\end{array}$ & $\begin{array}{r}2,590 \\
396 \\
2,203 \\
141 \\
1,595 \\
488 \\
-21\end{array}$ & $\begin{array}{r}1,006 \\
50 \\
1,836 \\
0 \\
553 \\
783 \\
500\end{array}$ \\
\hline $\begin{array}{l}\text { Other Llquids ................................... } \\
\text { Other Hydrocarbona/Oxygenates ..... } \\
\text { Unfinished Olls ................................... } \\
\text { Motor Gasoline Blend. Comp. .......... } \\
\text { Aviation Gasoline Biend. Comp. ........ }\end{array}$ & $\begin{array}{r}378 \\
-14 \\
390 \\
\cdots\end{array}$ & $\begin{array}{l}- \\
\ddot{*} \\
\ddot{*} \\
\ddot{*}\end{array}$ & $\begin{array}{r}1,081 \\
771 \\
260 \\
0 \\
0\end{array}$ & $\begin{array}{l}\ddot{-} \\
\ddot{*} \\
\ddot{*}\end{array}$ & $\begin{array}{l}0 \\
0 \\
0 \\
0 \\
0\end{array}$ & $\begin{array}{r}82 \\
-876 \\
1,273 \\
-325 \\
10\end{array}$ & $\begin{array}{l}\ddot{ } \\
\ddot{*} \\
\ddot{*}\end{array}$ & $\begin{array}{r}1,729 \\
1,633 \\
-383 \\
469 \\
.10\end{array}$ & $\begin{array}{r}246 \\
0 \\
0 \\
246 \\
0\end{array}$ & $\begin{array}{r}-650 \\
0 \\
-650 \\
0 \\
0\end{array}$ & $\begin{array}{r}37,011 \\
2,900 \\
25,510 \\
8,689 \\
12\end{array}$ \\
\hline 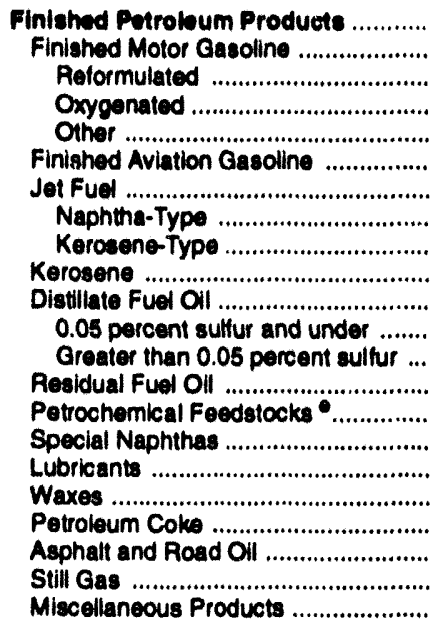 & $\begin{array}{r}208 \\
.205 \\
1,047 \\
.2,052 \\
. . \\
. . \\
. . \\
. . \\
. . \\
. . \\
. . \\
. . \\
. . \\
. . \\
.- \\
.- \\
. .\end{array}$ & $\begin{array}{r}70,118 \\
32,208 \\
0 \\
9,636 \\
22,371 \\
133 \\
9,675 \\
50 \\
9,625 \\
11 \\
11,262 \\
7,732 \\
3,530 \\
7,563 \\
88 \\
40 \\
575 \\
56 \\
3,882 \\
921 \\
3,543 \\
168\end{array}$ & $\begin{array}{r}307 \\
21 \\
0 \\
0 \\
21 \\
0 \\
27 \\
0 \\
27 \\
0 \\
22 \\
2 \\
20 \\
267 \\
0 \\
2 \\
0 \\
2 \\
26 \\
20 \\
0 \\
0\end{array}$ & $\begin{array}{l}.- \\
. . \\
\ldots \\
. . \\
- \\
- \\
- \\
- \\
- \\
- \\
- \\
- \\
- \\
- \\
- \\
-\end{array}$ & $\begin{array}{r}3,244 \\
2,108 \\
0 \\
0 \\
2,108 \\
0 \\
491 \\
98 \\
393 \\
0 \\
509 \\
354 \\
155 \\
0 \\
0 \\
0 \\
136 \\
0 \\
0 \\
0 \\
0 \\
0\end{array}$ & $\begin{array}{r}-8,886 \\
-2,480 \\
0 \\
-4,985 \\
2,505 \\
44 \\
-987 \\
29 \\
-996 \\
-59 \\
-814 \\
-467 \\
-347 \\
-1,851 \\
-71 \\
-11 \\
-67 \\
-5 \\
303 \\
166 \\
0 \\
-43\end{array}$ & 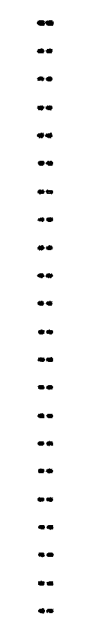 & 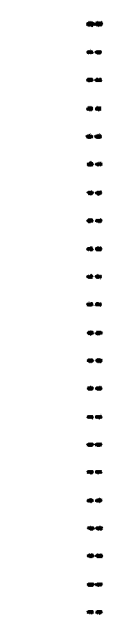 & $\begin{array}{r}r, 773 \\
277 \\
0 \\
3 \\
274 \\
0 \\
955 \\
285 \\
690 \\
3 \\
3,710 \\
728 \\
2,982 \\
1,488 \\
0 \\
2 \\
81 \\
10 \\
2,236 \\
9 \\
0 \\
1\end{array}$ & $\begin{array}{r}70,628 \\
36,333 \\
0 \\
16,663 \\
19,669 \\
89 \\
10,205 \\
-146 \\
10,351 \\
67 \\
8,897 \\
7,827 \\
1,070 \\
8,183 \\
167 \\
51 \\
697 \\
52 \\
1,369 \\
766 \\
3,543 \\
208\end{array}$ & $\begin{array}{r}58,229 \\
25,816 \\
0 \\
3,390 \\
22,516 \\
441 \\
7,732 \\
336 \\
7,396 \\
67 \\
10,568 \\
7,166 \\
3,402 \\
5,362 \\
179 \\
41 \\
1,705 \\
70 \\
3,820 \\
2,092 \\
0 \\
237\end{array}$ \\
\hline Total & $\mathbf{7 4 , 4 7 0}$ & $71,9 \times$ & 0,294 & $-1,350$ & $-8,607$ & $-6,701$ & 0 & 68,167 & 12,415 & 72,911 & 170,774 \\
\hline
\end{tabular}

a Represents the PAD Dietrict in which the material entered the Unted States and not necesearly where the crude oll or product is proceseed and/or consumed.

- Unaccounted for crude oll represents the difference between the supply and disposition of crude oll.

- A negative number indicates a decrease in stocks and a positive number indicates an increase in stocks.

d Products supplied is equal to field production, plus refinery production, plus imponts, plus unaccounted for crude oll, plus net receipts, minus stock change, minus crude losses, minus refinery inputs, minus exports.

- Includes naphtha less than $401^{\circ} \mathrm{F}$ ondpoint and other oils equal to or greater than $401^{\circ} F$ encpoint.

(s) = Less than 500 barrels.

$E=$ Estimated.

$L R G=$ Liquefied Relinery Gas.

Note: Totals may not equal sum of components due to independent rounding.

Sources: - Energy Intormation Administration (EIA) Forms ElA-810, "Monthly Refinery Report," ElA-811, "Monthly Bulk Terminal Report," ElA-812, "Monthly Product Pipeline Report," ElA-813, "Monthly Crude Oil Report," EIA-814, "Monthly Imports Report," EIA-816, "Monthly Natural Gas Liquids Repont," EIA-817, "Monthly Tanker and Barge Movement Report," and EIA-819M, "Monthly Oxygenate Telephone Report". - Domestic crude oil production estimates based on historical statistics trom State conservation agencies and the Minerals Management Service of the U.S. Department of the Interior. - Export data from the Bureau of the Census and Form ElA-810, "Monthly Refinery Report.' 
Table 23. PAD District V-Year-fo-Date Supply, Dleposition, and Ending Stocks of Crude Oll and Petroleum Producte, January-February 1994

(Thousand Barrels)

\begin{tabular}{|c|c|c|c|c|c|c|c|c|c|c|c|}
\hline \multirow[b]{2}{*}{ Commodity } & \multicolumn{5}{|c|}{ Bupply } & \multicolumn{5}{|c|}{ Diepostition } & \multirow[b]{2}{*}{$\begin{array}{l}\text { Ending } \\
\text { Slocke }\end{array}$} \\
\hline & $\begin{array}{c}\text { Fiold } \\
\text { Produotion }\end{array}$ & $\begin{array}{c}\text { Rofinery } \\
\text { Production }\end{array}$ & $\begin{array}{c}\text { Imports by } \\
\text { PAD } \\
\text { District } \\
\text { olfentoce }\end{array}$ & $\begin{array}{l}\text { Unac- } \\
\text { counted } \\
\text { For } \\
\text { crude oul }\end{array}$ & $\begin{array}{c}\text { Not } \\
\text { Anestote }\end{array}$ & $\begin{array}{c}\text { Stook } \\
\text { Chinene }\end{array}$ & $\begin{array}{l}\text { Crude } \\
\text { Learese }\end{array}$ & $\begin{array}{c}\text { Rofinery } \\
\text { Inpute }\end{array}$ & Exporte & $\begin{array}{l}\text { Product: } \\
\text { Supplled }\end{array}$ & \\
\hline 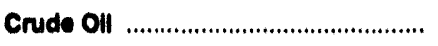 & E 182,480 & - & 15,310 & 4,260 & $-17,615$ & . 3 & 0 & 141,477 & 6,638 & 647 & 73,648 \\
\hline 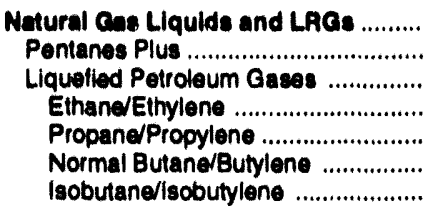 & $\begin{array}{r}5,833 \\
2,996 \\
2,837 \\
2 \\
514 \\
1,503 \\
818\end{array}$ & $\begin{array}{r}3,286 \\
3,286 \\
0 \\
2,315 \\
814 \\
157\end{array}$ & $\begin{array}{r}181 \\
0 \\
181 \\
140 \\
19 \\
22 \\
0\end{array}$ & $\begin{array}{l}\ddot{.} \\
\ddot{.} \\
\ddot{.} \\
\ddot{.} \\
\ddot{.}\end{array}$ & $\begin{array}{l}0 \\
0 \\
0 \\
0 \\
0 \\
0 \\
0\end{array}$ & $\begin{array}{r}-1,731 \\
-16 \\
-1,715 \\
0 \\
-527 \\
-1,036 \\
-152\end{array}$ & $\begin{array}{l}\ddot{.} \\
\ddot{.} \\
\ddot{.} \\
\ddot{.} \\
\ddot{.}\end{array}$ & $\begin{array}{r}5,421 \\
2,239 \\
3,182 \\
0 \\
0 \\
2.057 \\
1,125\end{array}$ & $\begin{array}{r}274 \\
(9) \\
274 \\
0 \\
110 \\
163 \\
0\end{array}$ & $\begin{array}{r}5,336 \\
773 \\
4,563 \\
142 \\
3,265 \\
1,155 \\
2\end{array}$ & $\begin{array}{r}1,886 \\
50 \\
1,836 \\
0 \\
553 \\
783 \\
500\end{array}$ \\
\hline 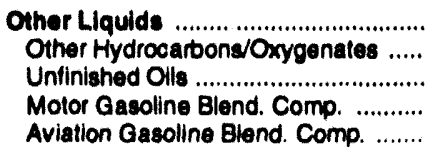 & $\begin{array}{r}2,384 \\
2,469 \\
-85 \\
-.\end{array}$ & $\begin{array}{l}\ddot{.} \\
\ddot{.} \\
\ddot{.}\end{array}$ & $\begin{array}{r}1,784 \\
1,363 \\
421 \\
0 \\
0\end{array}$ & $\begin{array}{l}\ddot{.} \\
\ddot{.} \\
\ddot{.}\end{array}$ & $\begin{array}{l}0 \\
0 \\
0 \\
0 \\
0\end{array}$ & $\begin{array}{r}3,594 \\
-532 \\
4,327 \\
-204 \\
3\end{array}$ & $\begin{array}{l}\ddot{.} \\
\ddot{.} \\
\ddot{.}\end{array}$ & $\begin{array}{r}788 \\
4,364 \\
-3,446 \\
-127 \\
-3\end{array}$ & $\begin{array}{r}246 \\
(s) \\
0 \\
246 \\
0\end{array}$ & $\begin{array}{r}-460 \\
0 \\
-460 \\
0 \\
0\end{array}$ & $\begin{array}{r}37,011 \\
2,900 \\
25,510 \\
8,589 \\
12\end{array}$ \\
\hline 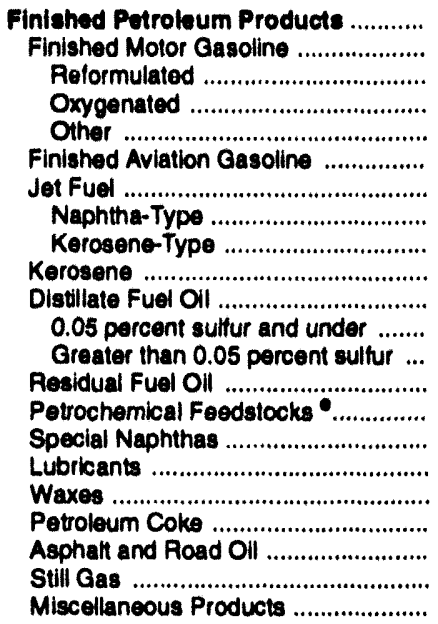 & 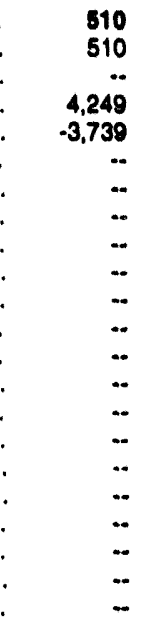 & $\begin{array}{r}153,539 \\
71,090 \\
0 \\
31,004 \\
40,086 \\
241 \\
22,207 \\
67 \\
22,120 \\
90 \\
23,932 \\
16,467 \\
7,475 \\
15.718 \\
227 \\
112 \\
1,257 \\
117 \\
8,376 \\
1,896 \\
7,879 \\
396\end{array}$ & $\begin{array}{r}950 \\
159 \\
0 \\
0 \\
159 \\
0 \\
53 \\
0 \\
53 \\
0 \\
42 \\
14 \\
28 \\
505 \\
43 \\
5 \\
0 \\
4 \\
58 \\
88 \\
0 \\
1\end{array}$ & $\begin{array}{l}\ddot{.} \\
\ddot{.} \\
\ddot{.} \\
\ddot{.} \\
\ddot{.} \\
\ddot{.} \\
\ddot{.} \\
\ddot{.} \\
\ddot{.} \\
\ddot{.} \\
\ddot{.} \\
\ddot{.} \\
.-\end{array}$ & $\begin{array}{r}7,019 \\
4,645 \\
0 \\
0 \\
4,645 \\
0 \\
0 \\
1,000 \\
167 \\
833 \\
0 \\
1,208 \\
858 \\
350 \\
0 \\
0 \\
0 \\
166 \\
0 \\
0 \\
0 \\
0 \\
0\end{array}$ & $\begin{array}{r}-2,030 \\
1,239 \\
0 \\
-6,487 \\
7,726 \\
46 \\
-1,221 \\
38 \\
-1,259 \\
-51 \\
-1,726 \\
-261 \\
-1,465 \\
-1,553 \\
-51 \\
-7 \\
39 \\
-8 \\
177 \\
318 \\
0 \\
-32\end{array}$ & $\begin{array}{l}\ddot{.} \\
\ddot{.} \\
\ddot{.} \\
\ddot{.} \\
\ddot{.} \\
\ddot{.} \\
\ddot{.} \\
\ddot{.} \\
\ddot{.} \\
\ddot{.} \\
\ddot{.} \\
\ddot{.} \\
. .\end{array}$ & $\begin{array}{l}\ddot{.} \\
. . \\
. . \\
. . \\
\ddot{.} \\
\ddot{.} \\
\ddot{.} \\
\ddot{.} \\
\ddot{.} \\
\ddot{.} \\
\ddot{.} \\
\ddot{.} \\
. .\end{array}$ & $\begin{array}{r}17,655 \\
781 \\
0 \\
7 \\
774 \\
0 \\
1,708 \\
603 \\
1,102 \\
3 \\
7,379 \\
1,412 \\
5,967 \\
2,612 \\
0 \\
6 \\
162 \\
22 \\
4,959 \\
24 \\
0 \\
2\end{array}$ & $\begin{array}{r}147,199 \\
74,384 \\
0 \\
41,733 \\
32,651 \\
195 \\
22,775 \\
-387 \\
23,163 \\
138 \\
19,529 \\
16,178 \\
3,351 \\
15,164 \\
321 \\
118 \\
1,222 \\
107 \\
3,298 \\
1,642 \\
7,879 \\
427\end{array}$ & $\begin{array}{r}58,229 \\
25,915 \\
0 \\
3,399 \\
22,516 \\
441 \\
7,732 \\
336 \\
7,396 \\
67 \\
10,568 \\
7,166 \\
3,402 \\
5,362 \\
179 \\
41 \\
1,705 \\
70 \\
3,820 \\
2,092 \\
0 \\
237\end{array}$ \\
\hline Total & 161,207 & 156,024 & 18,233 & 4,200 & $-10,596$ & 4,708 & 0 & 147,689 & 24,814 & 152,722 & 170,774 \\
\hline
\end{tabular}

- Represents the PAD District in which the material entered the United States and not necessarily where the crude oll or product le processed and/or consumed.

b Unaccounted for crude oll represents the difference between the supply and disposition of crude oll.

c A negative number indicates a decrease in stocks and a positive number indicales an increase in stocks.

- Products supplied is equal to field production, plus refinery production, plus imports, plus unaccounted for crude oil, plus net receipts, minus stock change, minus crude losses, minus refinery inputs, minus exports.

- Includes naphtha less than $401^{\circ} \mathrm{F}$ endpoint and other oils equal to or greater than $401^{\circ} \mathrm{F}$ endpoint.

(s) = Less than 500 barrels.

$E$ = Estimated.

LRG $=$ Liquefied Refinery Gas.

Note: Totals may not equal sum of components due to independent rounding.

Sources: - Energy Information Administration (EIA) Forms EIA-810, "Monthly Refinery Report," EIA-811, "Monthly Bulk Terminal Report," ElA-812, "Monthly Product Pipeline Report," ElA-813, "Monthly Crude Oil Report," EIA-814, "Monthly Imports Report," EIA-816, "Monthly Natural Gas Liquids Report," EIA-817, "Monthly Tanker and Barge Movement Repor," and EIA-819M, "Monthly Oxygenate Telephone Report". - Domestic crude oil production estimates based on historical statistics from State conservation agencles and the Minerals Management Service of the U.S. Department of the Interior. - Export data from the Bureau of the Census and Form ElA-810, "Monthly Refinery Report." 
Table 24. PAD District V - Daily Average Supply and Disposition of Crude Oll and Potroloum Products, February 1994

(Thousand Barrels per Day)

\begin{tabular}{|c|c|c|c|c|c|c|c|c|c|c|}
\hline \multirow[b]{2}{*}{ Commodlty } & \multicolumn{5}{|c|}{ 8upply } & \multicolumn{5}{|c|}{ Oleposition } \\
\hline & $\begin{array}{c}\text { Fuld } \\
\text { Production }\end{array}$ & $\begin{array}{c}\text { Rofinery } \\
\text { Produation }\end{array}$ & $\begin{array}{c}\text { Imports by } \\
\text { PAD } \\
\text { Distitot } \\
\text { offintne }\end{array}$ & $\begin{array}{l}\text { Unec- } \\
\text { counted } \\
\text { For } \\
\text { Crudinolib }\end{array}$ & $\begin{array}{c}\text { Not } \\
\text { Rincellots }\end{array}$ & $\begin{array}{c}\text { Etock } \\
\text { Chinge }\end{array}$ & $\begin{array}{l}\text { Crude } \\
\text { Lonen }\end{array}$ & $\begin{array}{c}\text { Rofinery } \\
\text { Inputh }\end{array}$ & Exponte & $\begin{array}{l}\text { Producte } \\
\text { supolled }\end{array}$ \\
\hline Crude Oll ............................................ & $E_{2,550}$ & - & 240 & 48 & -316 & 21 & 0 & 2,283 & 118 & 12 \\
\hline 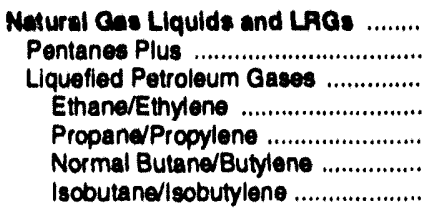 & $\begin{array}{r}98 \\
50 \\
48 \\
(8) \\
9 \\
25 \\
15\end{array}$ & $\begin{array}{r}63 \\
-63 \\
0 \\
38 \\
21 \\
5\end{array}$ & $\begin{array}{r}6 \\
0 \\
6 \\
6 \\
(8) \\
1 \\
0\end{array}$ & 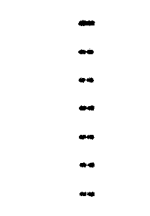 & $\begin{array}{l}0 \\
0 \\
0 \\
0 \\
0 \\
0 \\
0\end{array}$ & $\begin{array}{r}-21 \\
(8) \\
-21 \\
0 \\
-11 \\
-9 \\
-1\end{array}$ & $\begin{array}{l}- \\
\ddot{-} \\
\ddot{-} \\
\ddot{-} \\
\ddot{-}\end{array}$ & $\begin{array}{r}90 \\
36 \\
53 \\
0 \\
0 \\
32 \\
21\end{array}$ & $\begin{array}{l}6 \\
0 \\
6 \\
0 \\
1 \\
5 \\
0\end{array}$ & $\begin{array}{r}93 \\
14 \\
79 \\
5 \\
57 \\
17 \\
-1\end{array}$ \\
\hline $\begin{array}{l}\text { Other Llquids ................................... } \\
\text { Other Hydrocartoons/Oxygenates ...... } \\
\text { Unfinished Olls .................................. } \\
\text { Motor Gasoline Blend. Comp. .......... } \\
\text { Aviation Gasoline Blend. Comp. ....... }\end{array}$ & $\begin{array}{r}13 \\
-1 \\
-3 \\
14 \\
-.\end{array}$ & $\begin{array}{l}- \\
\ddot{-} \\
\ddot{-}\end{array}$ & $\begin{array}{r}37 \\
28 \\
9 \\
0 \\
0\end{array}$ & $\begin{array}{l}- \\
- \\
\cdots\end{array}$ & $\begin{array}{l}0 \\
0 \\
0 \\
0 \\
0\end{array}$ & $\begin{array}{r}3 \\
-31 \\
45 \\
-12 \\
(8)\end{array}$ & $\begin{array}{l}- \\
- \\
- \\
-\end{array}$ & $\begin{array}{r}62 \\
58 \\
-13 \\
17 \\
(8)\end{array}$ & $\begin{array}{l}9 \\
0 \\
0 \\
9 \\
0\end{array}$ & $\begin{array}{r}-23 \\
0 \\
-23 \\
0 \\
0\end{array}$ \\
\hline 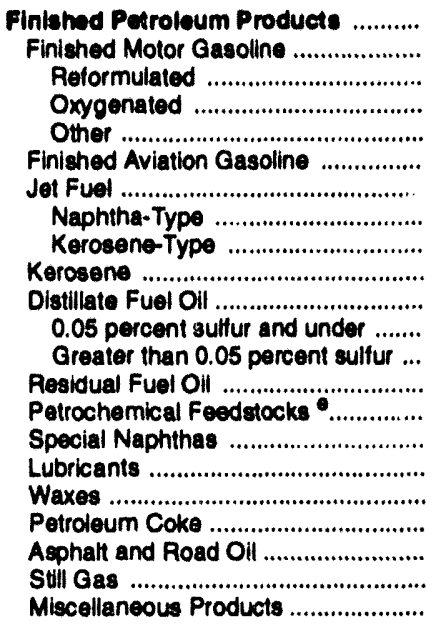 & $\begin{array}{l}-7 \\
-7 \\
-66 \\
.73 \\
- \\
- \\
- \\
- \\
- \\
- \\
- \\
- \\
- \\
- \\
- \\
- \\
-\end{array}$ & $\begin{array}{r}2,804 \\
1,150 \\
0 \\
351 \\
799 \\
5 \\
346 \\
2 \\
344 \\
(9) \\
402 \\
276 \\
126 \\
270 \\
3 \\
1 \\
21 \\
2 \\
139 \\
33 \\
127 \\
6\end{array}$ & $\begin{array}{r}14 \\
1 \\
0 \\
0 \\
1 \\
0 \\
1 \\
0 \\
1 \\
0 \\
1 \\
(8) \\
1 \\
10 \\
0 \\
(8) \\
0 \\
(8) \\
1 \\
1 \\
0 \\
0\end{array}$ & $\begin{array}{l}- \\
- \\
- \\
- \\
- \\
- \\
- \\
- \\
- \\
- \\
- \\
- \\
- \\
- \\
- \\
- \\
-\end{array}$ & $\begin{array}{r}116 \\
75 \\
0 \\
0 \\
75 \\
0 \\
18 \\
4 \\
14 \\
0 \\
18 \\
13 \\
6 \\
0 \\
0 \\
0 \\
5 \\
0 \\
0 \\
0 \\
0 \\
0\end{array}$ & $\begin{array}{r}-209 \\
-89 \\
0 \\
-178 \\
89 \\
2 \\
.35 \\
1 \\
-36 \\
-2 \\
-29 \\
-17 \\
-12 \\
-66 \\
-3 \\
(8) \\
-2 \\
(8) \\
11 \\
6 \\
0 \\
-2\end{array}$ & $\begin{array}{l}- \\
- \\
- \\
- \\
- \\
- \\
- \\
- \\
- \\
- \\
- \\
- \\
- \\
- \\
-\end{array}$ & $\begin{array}{l}- \\
- \\
- \\
- \\
- \\
- \\
- \\
- \\
- \\
- \\
- \\
- \\
- \\
- \\
- \\
- \\
- \\
- \\
-\end{array}$ & $\begin{array}{r}313 \\
10 \\
0 \\
(8) \\
10 \\
0 \\
34 \\
9 \\
25 \\
(8) \\
133 \\
26 \\
107 \\
53 \\
0 \\
(8) \\
3 \\
(8) \\
80 \\
(8) \\
0 \\
(8)\end{array}$ & $\begin{array}{r}2,522 \\
1,298 \\
0 \\
595 \\
702 \\
3 \\
364 \\
-5 \\
370 \\
2 \\
318 \\
280 \\
38 \\
292 \\
6 \\
2 \\
25 \\
2 \\
49 \\
27 \\
127 \\
7\end{array}$ \\
\hline Total & 2,680 & 2,507 & 20 & 48 & -200 & .207 & $\mathbf{0}$ & 2,435 & 143 & 2,604 \\
\hline
\end{tabular}

- Represents the PAD District in which the material entered the United States and not necessarily where the crude oll or product is processed and/or consumed.

b Unaccounted for crude oll represents the diflerence between the supply and disposition of crude oll.

- A negative number indicates a decrease in stocks and a positive number indicates an increase in stocks.

d Products supplled is equal to field production, plus refinery production, plus imports, plus unaccounted for crude oil, plus net recelpts, minus stock change, minus crude losses, minus refinery inputs, minus exports.

- Includes naphtha less than $401^{\circ} \mathrm{F}$ endpoint and other olls equal to or greater than $401^{\circ} \mathrm{F}$ endpoint.

(s) = Less than 500 barrels per day.

$E=$ Estimated.

LRG = Liquefied Refinery Gas.

Note: Totals may not equal sum of components due to independent rounding.

Sources: - Energy Intormation Administration (ElA) Forms EIA-810, "Monthly Refinery Report," EIA-811, "Monthly Bulk Terminal Report," EIA-812, "Monthly Product Pipeline Report," EIA-813, "Monthly Crude Oll Report," ElA-814, "Monthly Imports Report," ElA-816, "Monthly Natural Gas Liquids Report," EIA-817, "Monthly Tanker and Barge Movement Report," and ElA-819M, "Monthly Oxygenate Telephone Report". - Domestic crude oil production estimates based on historical statistics from State conservation agencies and the Minerals Management Service of the U.S. Departmetit of the Intertor. • Export data from the Bureau of the Census and Form EIA-810, "Monthly Relinery Report." 
Table 25. PAD District V - Year-to-Date Daily Average Supply and Disposition of Crude Oil and Petroleum Products, January-February 1994

(Thousand Barrels per Day)

\begin{tabular}{|c|c|c|c|c|c|c|c|c|c|c|}
\hline \multirow[b]{2}{*}{ Commodity } & \multicolumn{5}{|c|}{ Supply } & \multicolumn{5}{|c|}{ Disposition } \\
\hline & $\begin{array}{c}\text { Field } \\
\text { Production }\end{array}$ & $\begin{array}{c}\text { Pefinery } \\
\text { Production }\end{array}$ & $\begin{array}{l}\text { Imports by } \\
\text { PAD } \\
\text { District } \\
\text { of Entry }\end{array}$ & $\begin{array}{l}\text { Unac- } \\
\text { counted } \\
\text { For } \\
\text { Crude Oilb }\end{array}$ & $\begin{array}{c}\text { Net } \\
\text { Receipts }\end{array}$ & $\begin{array}{c}\text { Stock } \\
\text { Changec }\end{array}$ & $\begin{array}{l}\text { Crude } \\
\text { Losses }\end{array}$ & $\begin{array}{c}\text { Pefinery } \\
\text { Inputs }\end{array}$ & Exports & $\begin{array}{l}\text { Products } \\
\text { Supplledd }\end{array}$ \\
\hline 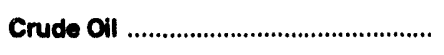 & $E_{\mathbf{2 , 5 8 4}}$ & - & 259 & 72 & -299 & 96 & 0 & 2,398 & 113 & 11 \\
\hline 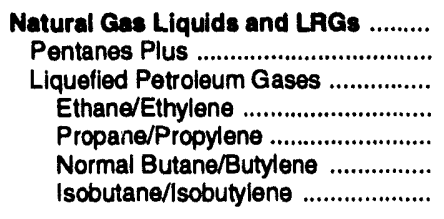 & $\begin{array}{r}99 \\
51 \\
48 \\
(s) \\
9 \\
25 \\
14\end{array}$ & $\begin{array}{r}56 \\
- \\
56 \\
0 \\
39 \\
14 \\
3\end{array}$ & $\begin{array}{r}3 \\
0 \\
3 \\
2 \\
(\mathbf{s}) \\
(\mathbf{s}) \\
0\end{array}$ & $\begin{array}{l}- \\
- \\
- \\
- \\
- \\
-\end{array}$ & $\begin{array}{l}0 \\
0 \\
0 \\
0 \\
0 \\
0 \\
0\end{array}$ & $\begin{array}{r}-29 \\
(s) \\
-29 \\
0 \\
-9 \\
-18 \\
-3\end{array}$ & $\begin{array}{l}\ddot{-} \\
- \\
\ddot{-} \\
\ddot{-} \\
-\end{array}$ & $\begin{array}{r}92 \\
38 \\
54 \\
0 \\
0 \\
35 \\
19\end{array}$ & $\begin{array}{r}5 \\
(\mathbf{s}) \\
5 \\
0 \\
2 \\
3 \\
0\end{array}$ & $\begin{array}{r}90 \\
13 \\
77 \\
2 \\
55 \\
20 \\
\text { (s) }\end{array}$ \\
\hline 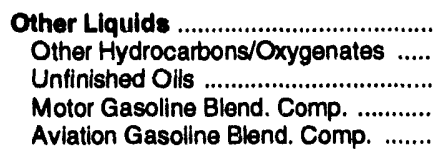 & $\begin{array}{r}40 \\
42 \\
-1 \\
-\end{array}$ & $\begin{array}{l}\overline{-} \\
\overline{-} \\
-\end{array}$ & $\begin{array}{r}30 \\
23 \\
7 \\
0 \\
0\end{array}$ & $\begin{array}{l}\ddot{-} \\
\ddot{-} \\
\ddot{-}\end{array}$ & $\begin{array}{l}0 \\
0 \\
0 \\
0 \\
0\end{array}$ & $\begin{array}{l}61 \\
-9 \\
73 \\
-3 \\
(s)\end{array}$ & $\begin{array}{l}- \\
- \\
- \\
-\end{array}$ & $\begin{array}{r}13 \\
74 \\
-58 \\
-2 \\
(s)\end{array}$ & $\begin{array}{r}4 \\
(s) \\
0 \\
4 \\
0\end{array}$ & $\begin{array}{r}-8 \\
0 \\
-8 \\
0 \\
0\end{array}$ \\
\hline 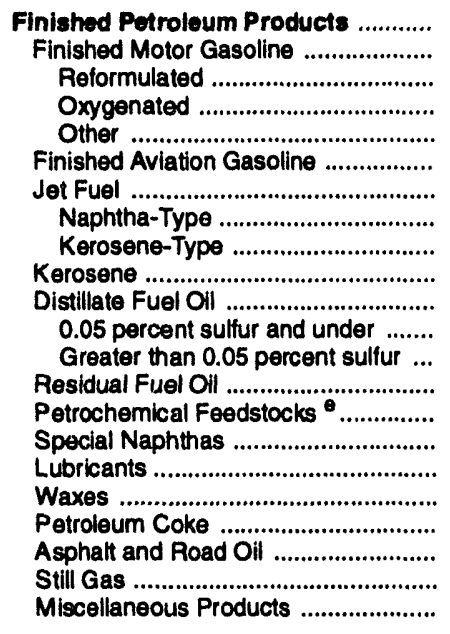 & $\begin{array}{r}9 \\
9 \\
-\overline{72} \\
-63 \\
- \\
= \\
- \\
- \\
- \\
= \\
= \\
= \\
= \\
= \\
= \\
= \\
=\end{array}$ & $\begin{array}{r}2,602 \\
1,205 \\
0 \\
525 \\
679 \\
4 \\
376 \\
1 \\
375 \\
2 \\
406 \\
279 \\
127 \\
266 \\
4 \\
2 \\
21 \\
2 \\
142 \\
32 \\
134 \\
7\end{array}$ & $\begin{array}{r}16 \\
3 \\
0 \\
0 \\
3 \\
0 \\
1 \\
0 \\
1 \\
0 \\
1 \\
(\mathbf{s}) \\
(\mathbf{s}) \\
9 \\
1 \\
\text { (s) } \\
0 \\
\text { (s) } \\
1 \\
1 \\
0 \\
\text { (s) }\end{array}$ & 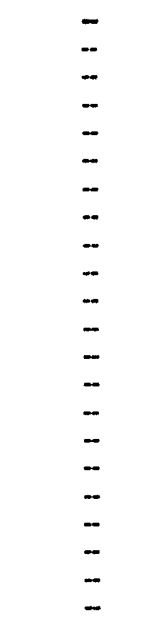 & $\begin{array}{r}119 \\
79 \\
0 \\
0 \\
79 \\
0 \\
17 \\
3 \\
14 \\
0 \\
20 \\
15 \\
6 \\
0 \\
0 \\
0 \\
3 \\
0 \\
0 \\
0 \\
0 \\
0\end{array}$ & $\begin{array}{r}-48 \\
21 \\
0 \\
-110 \\
131 \\
1 \\
-21 \\
1 \\
-21 \\
-1 \\
-29 \\
-4 \\
-25 \\
-26 \\
-1 \\
(s) \\
1 \\
(s) \\
3 \\
5 \\
0 \\
-1\end{array}$ & $\begin{array}{l}- \\
- \\
- \\
- \\
- \\
- \\
- \\
- \\
- \\
- \\
- \\
- \\
- \\
- \\
- \\
- \\
- \\
- \\
- \\
- \\
-\end{array}$ & 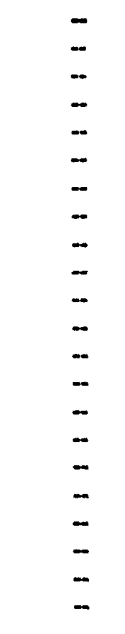 & $\begin{array}{r}299 \\
13 \\
0 \\
(s) \\
13 \\
0 \\
29 \\
10 \\
19 \\
(s) \\
125 \\
24 \\
101 \\
44 \\
0 \\
(s) \\
3 \\
(s) \\
84 \\
(s) \\
0 \\
(s)\end{array}$ & $\begin{array}{r}2,495 \\
1,261 \\
0 \\
707 \\
553 \\
3 \\
386 \\
-7 \\
393 \\
2 \\
331 \\
274 \\
57 \\
257 \\
5 \\
2 \\
21 \\
2 \\
56 \\
28 \\
134 \\
7\end{array}$ \\
\hline Total & 2,732 & 2,658 & 309 & 72 & -180 & 80 & 0 & 2,503 & 421 & 2,589 \\
\hline
\end{tabular}

a Represents the PAD District in which the material entered the United States and not necessarily where the crude oll or product is processed and/or consumed.

b Unaccounted for crude oil represents the difference between the supply and disposition of crude oil.

c A negative number indicates a decrease in stocks and a positive number indicates an increase in stocks.

d Products supplied is equal to field production, plus refinery production, plus imports, plus unaccounted for crude oll, plus net receipts, minus stock change, minus crude losses, minus refinery inputs, minus exports.

Includes naphtha less than $401^{\circ} \mathrm{F}$ endpoint and other oils equal to or greater than $401^{\circ} \mathrm{F}$ endpoint.

(s) $=$ Less than 500 barrels per day.

$E=$ Estimated.

LRG = Liquefied Refinery Gas.

Note: Totals may not equal sum of components due to independent rounding.

Sources: - Energy Information Administration (EIA) Forms EIA-810, "Monthly Refinery Report," EIA-811, "Monthly Bulk Terminal Report," EIA-812, "Monthly Product Pipeline Report," EIA-813, "Monthly Crude Oil Report," ElA-814, "Monthly Imports Report." EIA-816, "Monthly Natural Gas Liquids Report," ElA-817, "Monthly Tanker and Barge Movement Report," and EIA-819M, "Monthly Oxygenate Telephone Report". - Domestic crude oil production estimates based on historical statistics from State conservation agencies and the Minerals Management Service of the U.S. Department of the Interior. - Export data from the Bureau of the Census and Form EIA-810, "Monthly Refinery Report." 
Table 26. Production of Crude Oil by PAD District and State (Thousand Barrels)

\begin{tabular}{|c|c|c|c|c|}
\hline \multirow{2}{*}{ PAD District and Stinte } & \multicolumn{2}{|c|}{ Decembor 1983} & \multicolumn{2}{|c|}{ January-December 1993} \\
\hline & Total & $\begin{array}{c}\text { Dally } \\
\text { Average }\end{array}$ & Total & $\begin{array}{c}\text { Daily } \\
\text { Average }\end{array}$ \\
\hline $\begin{array}{l}\text { PAD District I } \\
\text { Florida } \\
\text { New York } \\
\text { Pennsylvania } \\
\text { Virginia } \\
\text { West Virginia } \\
\text { Adjustment }\end{array}$ & $\begin{array}{r}E_{834} \\
499 \\
E_{28} \\
E_{154} \\
1 \\
154 \\
-3\end{array}$ & $\begin{array}{r}E_{27} \\
16 \\
E_{1} \\
E_{5} \\
(s) \\
5 \\
(s)\end{array}$ & $\begin{array}{r}E_{9,555} \\
E_{5,521} \\
E_{351}^{\prime} \\
E_{1,940} \\
E_{8} \\
E_{2,038} \\
E_{-303}\end{array}$ & $\begin{array}{r}E_{26} \\
E_{15} \\
E_{1} \\
E_{5} \\
E_{(s)} \\
E_{6} \\
E_{-1}\end{array}$ \\
\hline 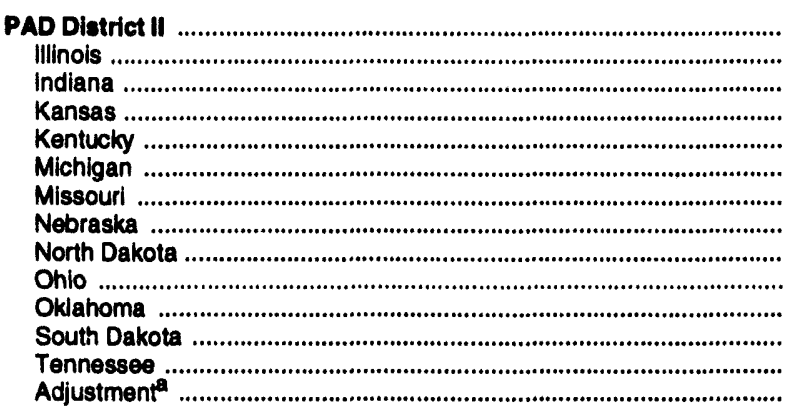 & $\begin{array}{r}18,475 \\
1,400 \\
229 \\
4,043 \\
272 \\
E_{991} \\
11 \\
384 \\
2,490 \\
=755 \\
7,680 \\
126 \\
31 \\
63\end{array}$ & $\begin{array}{r}E_{596} \\
45 \\
7 \\
130 \\
9 \\
E_{32} \\
(8) \\
12 \\
80 \\
E_{24} \\
248 \\
4 \\
1 \\
2\end{array}$ & $\begin{array}{r}E_{232,220} \\
19,050 \\
2,761 \\
49,837 \\
4,323 \\
E_{13,255} \\
E_{127} \\
4,896 \\
30,908 \\
E_{8,700} \\
95,942 \\
1,492 \\
419 \\
E_{511}\end{array}$ & $\begin{array}{r}E_{636} \\
52 \\
8 \\
137 \\
12 \\
E_{36} \\
E_{(s)} \\
13 \\
85 \\
E_{24} \\
263 \\
4 \\
1 \\
E_{1}\end{array}$ \\
\hline 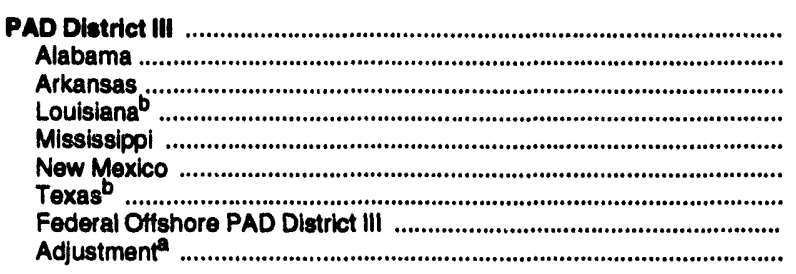 & $\begin{array}{r}E_{98,611} \\
1,610 \\
E_{782} \\
E_{11,560} \\
1,874 \\
5,977 \\
51,551 \\
25,690 \\
-432\end{array}$ & $\begin{array}{r}E_{3,181} \\
52 \\
E_{25} \\
E_{373} \\
60 \\
193 \\
1,663 \\
829 \\
-14\end{array}$ & $\begin{array}{r}E_{1,176,867} \\
18,665 \\
E_{10,032} \\
E_{137,450} \\
E_{21,725} \\
68,422 \\
E_{213,746}^{698,596} \\
E_{8,230}\end{array}$ & $\begin{array}{r}E_{3,224} \\
51 \\
E_{27} \\
E_{377} \\
E_{60} \\
187 \\
1,681 \\
E_{818} \\
E_{23}\end{array}$ \\
\hline $\begin{array}{l}\text { PAD District IV } \\
\text { Colorado } \\
\text { Montana } \\
\text { Utah } \\
\text { Wyoming } \\
\text { Adjustment }\end{array}$ & $\begin{array}{r}E_{12,570} \\
2,526 \\
1,459 \\
1,795 \\
7,301 \\
-511\end{array}$ & $\begin{array}{r}E_{81} \\
E_{85} \\
47 \\
58 \\
236 \\
-16\end{array}$ & $\begin{array}{r}E_{153,534} \\
E_{28,482} \\
E_{17,281} \\
E_{86,346}^{21,190} \\
E_{235}\end{array}$ & $\begin{array}{r}E_{421} \\
E_{78} \\
E_{47} \\
58 \\
E_{237} \\
E_{1}\end{array}$ \\
\hline 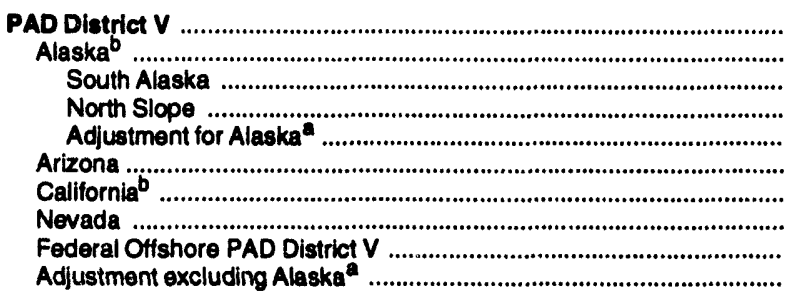 & $\begin{array}{r}E_{51,497} \\
\mathbf{5 1}_{1,936} \\
1,209 \\
50,580 \\
147 \\
6 \\
24,891 \\
123 \\
4,412 \\
130\end{array}$ & $\begin{array}{r}E 2,629 \\
1,675 \\
39 \\
1,632 \\
5 \\
(8) \\
803 \\
4 \\
142 \\
4\end{array}$ & $\begin{array}{r}E_{923,756} \\
E_{577,774} \\
13,786 \\
563,853 \\
E_{135} \\
73 \\
292,517 \\
1,861 \\
50,580 \\
\text { 948 }\end{array}$ & $\begin{array}{r}E_{2,531} \\
E_{1,583} \\
38 \\
1,545 \\
E_{(s)} \\
(s) \\
801 \\
5 \\
139 \\
E_{3}\end{array}$ \\
\hline U.S. Total ${ }^{b}$ & $E_{211,097}$ & $E_{6,838}$ & $E_{2,495,932}$ & $E_{6,838}$ \\
\hline
\end{tabular}

- These adjustments are used to reconclie the national and PAD District level sums of the State data with the independently estimated U.S. and Alaskan figures shown in the Summany Statistics portion of this issue and with the PAD District level figures published in a previous issue. Revised data at the State, PAD District, and national levels will be published without adjustments in the Petroleum Supply Annual.

Includes the following current month oftshore production (thousand barrels): Alaska: State - 7,245; California: State - 1,766; Louisiana: State -

E1,924; Texas: State -129; U.S. Total, including Federal oftahore - E41,165.

(s) = Less than 500 barrels or less than 500 barrels per day.

$E=$ Estimated.

Note: Totals may not equal sum of components due to independent rounding.

Sources: State govemment agencies, U.S. Department of the Interior, Minerals Management Service and the Conservation Committee of California Oil Producers. 
Table 27. Natural Gas Plant Net Production and Stocks of Petroleum Products by PAD and Refining Districts, February 1994

(Thousand Barrels)

\begin{tabular}{|c|c|c|c|c|c|c|c|c|c|c|}
\hline \multirow[b]{2}{*}{ Commodity } & \multicolumn{4}{|c|}{ PAD District I } & \multicolumn{6}{|c|}{ PAD District II } \\
\hline & $\begin{array}{l}\text { East } \\
\text { Coast }\end{array}$ & \multicolumn{2}{|c|}{$\begin{array}{c}\text { Appalachlan } \\
\text { No. } 1\end{array}$} & Total & Ind., III., Ky. & \multicolumn{2}{|c|}{$\begin{array}{l}\text { Minn., Wis., } \\
\text { N. Dak., S. Dak. }\end{array}$} & \multicolumn{2}{|c|}{$\begin{array}{c}\text { Okla., Kans., } \\
\text { Mo. }\end{array}$} & \multirow[t]{2}{*}{ Total } \\
\hline \multirow{3}{*}{ 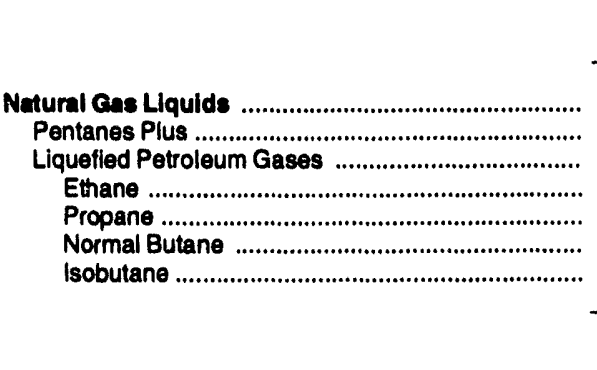 } & \multicolumn{9}{|c|}{ Net Production } & \\
\hline & $\begin{array}{r}121 \\
9 \\
112 \\
50 \\
40 \\
22 \\
0\end{array}$ & & & $\begin{array}{r}729 \\
75 \\
654 \\
230 \\
292 \\
99 \\
33\end{array}$ & $\begin{array}{r}444 \\
112 \\
332 \\
52 \\
160 \\
64 \\
56\end{array}$ & $\begin{array}{r}32 \\
8 \\
24 \\
15 \\
8\end{array}$ & & & $\begin{array}{r}7,602 \\
1,062 \\
6,540 \\
2,158 \\
2,904 \\
871 \\
607\end{array}$ & $\begin{array}{r}8,369 \\
1,255 \\
7,114 \\
2,210 \\
3,217 \\
1,024 \\
663\end{array}$ \\
\hline & \multicolumn{10}{|c|}{ Stocks } \\
\hline 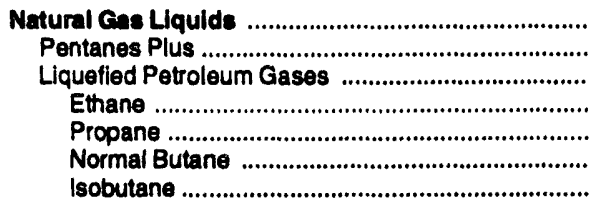 & $\begin{array}{r}26 \\
1 \\
25 \\
0 \\
20 \\
5 \\
0\end{array}$ & & & $\begin{array}{r}73 \\
12 \\
61 \\
0 \\
46 \\
9 \\
6\end{array}$ & $\begin{array}{r}114 \\
20 \\
94 \\
14 \\
43 \\
21 \\
16\end{array}$ & & & & $\begin{array}{r}2,908 \\
361 \\
2,547 \\
710 \\
1,121 \\
541 \\
175\end{array}$ & $\begin{array}{r}3,089 \\
415 \\
2,674 \\
724 \\
1,187 \\
572 \\
191\end{array}$ \\
\hline \multirow{3}{*}{ Commodity } & \multicolumn{6}{|c|}{ PAD District III } & \multirow{2}{*}{\multicolumn{2}{|c|}{$\begin{array}{c}\text { PAD Dist. } \\
\text { IV }\end{array}$}} & \multirow{2}{*}{$\begin{array}{c}\text { PAD Dist. } \\
\mathbf{y}\end{array}$} & \multirow{3}{*}{$\begin{array}{l}\text { U.S. } \\
\text { Total }\end{array}$} \\
\hline & \multirow{2}{*}{$\begin{array}{l}\text { Toxas } \\
\text { Inland }\end{array}$} & \multirow{2}{*}{$\begin{array}{l}\text { Texas } \\
\text { Gulf } \\
\text { Const }\end{array}$} & \multirow{2}{*}{$\begin{array}{l}\text { La. } \\
\text { Guif } \\
\text { Coast }\end{array}$} & \multirow{2}{*}{ N. La., } & \multirow{2}{*}{$\underset{\text { Mexico }}{\text { Now }}$} & \multirow[b]{2}{*}{ Total } & & & & \\
\hline & & & & & & & \multicolumn{2}{|c|}{ Rocky Mt. } & West Coast & \\
\hline & & & & & Net Product & & & & & \\
\hline \multirow[t]{2}{*}{ 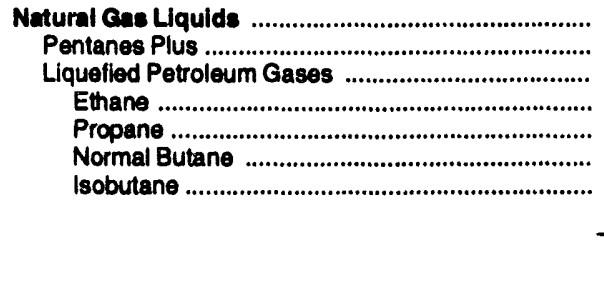 } & $\begin{array}{r}16,605 \\
2,770 \\
13,925 \\
5,929 \\
5,046 \\
2,083 \\
867\end{array}$ & $\begin{array}{r}2,935 \\
555 \\
2,380 \\
1,186 \\
753 \\
-2,137 \\
2,578\end{array}$ & $\begin{array}{r}5,800 \\
1,043 \\
4,757 \\
1,933 \\
1,666 \\
545 \\
613\end{array}$ & $\begin{array}{r}615 \\
163 \\
452 \\
94 \\
193 \\
118 \\
47\end{array}$ & $\begin{array}{r}4,649 \\
529 \\
4,120 \\
2,009 \\
1,367 \\
470 \\
274\end{array}$ & $\begin{array}{r}30,694 \\
5,060 \\
25,634 \\
11,151 \\
9,025 \\
1,079 \\
4,379\end{array}$ & $\begin{array}{r}3,4 \\
7 \\
2,6 \\
7 \\
1.1 \\
4 \\
2\end{array}$ & $\begin{array}{l}133 \\
789 \\
644 \\
760 \\
172 \\
441 \\
271\end{array}$ & $\begin{array}{r}2,744 \\
1,413 \\
1,331 \\
1 \\
238 \\
686 \\
406\end{array}$ & $\begin{array}{r}45,969 \\
8,592 \\
37,377 \\
14,352 \\
13,944 \\
3,329 \\
5,752\end{array}$ \\
\hline & \multicolumn{10}{|c|}{ Stocks } \\
\hline 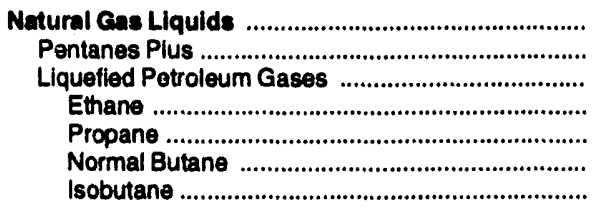 & $\begin{array}{r}415 \\
153 \\
262 \\
34 \\
167 \\
43 \\
18\end{array}$ & $\begin{array}{r}1,164 \\
371 \\
793 \\
255 \\
242 \\
154 \\
142\end{array}$ & $\begin{array}{r}1,350 \\
334 \\
1,016 \\
86 \\
503 \\
285 \\
142\end{array}$ & $\begin{array}{r}138 \\
13 \\
125 \\
97 \\
14 \\
9 \\
5\end{array}$ & $\begin{array}{r}141 \\
32 \\
109 \\
8 \\
68 \\
25 \\
8\end{array}$ & $\begin{array}{r}3,208 \\
903 \\
2,305 \\
480 \\
994 \\
516 \\
315\end{array}$ & & $\begin{array}{r}266 \\
101 \\
165 \\
2 \\
101 \\
51 \\
11\end{array}$ & $\begin{array}{r}67 \\
14 \\
53 \\
0 \\
36 \\
10 \\
7\end{array}$ & $\begin{array}{r}\mathbf{6 , 7 0 3} \\
1,445 \\
\mathbf{5 , 2 5 8} \\
1,206 \\
2,364 \\
1,158 \\
530\end{array}$ \\
\hline
\end{tabular}

Note: Refer to Appendix A for Retining District descriptions.

Source: Energy Intormation Administration (EIA) Form EIA-816, "Monthty Natural Gas Liquids Report." 
Table 28. Refinery Input of Crude Oil and Petroleum Products by PAD and Refining Districts, February 1994

(Thousand Barrels, Except Where Noted)

\begin{tabular}{|c|c|c|c|c|c|c|c|}
\hline \multirow[b]{2}{*}{ Commodity } & \multicolumn{3}{|c|}{ PAD Diatrict I } & \multicolumn{4}{|c|}{ PAD District II } \\
\hline & $\begin{array}{l}\text { East } \\
\text { Coast }\end{array}$ & $\begin{array}{c}\text { Appalachian } \\
\text { No.1 }\end{array}$ & Total & Ind., III., $\mathrm{Ky}$. & $\begin{array}{l}\text { Minn., Wis., } \\
\text { N. Dak., S. Dak. }\end{array}$ & $\begin{array}{c}\text { Okla., Kans., } \\
\text { Mo. }\end{array}$ & Total \\
\hline Crude Oll & 36,007 & 2,513 & 38,520 & 57,377 & 10,695 & 18,718 & 86,790 \\
\hline 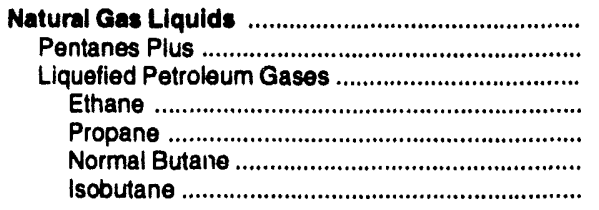 & $\begin{array}{r}393 \\
76 \\
317 \\
0 \\
0 \\
240 \\
77\end{array}$ & $\begin{array}{l}0 \\
0 \\
0 \\
0 \\
0 \\
0 \\
0\end{array}$ & $\begin{array}{r}393 \\
76 \\
317 \\
0 \\
0 \\
240 \\
77\end{array}$ & $\begin{array}{r}2,307 \\
527 \\
1,780 \\
0 \\
0 \\
1,076 \\
704\end{array}$ & $\begin{array}{r}390 \\
32 \\
358 \\
0 \\
0 \\
276 \\
82\end{array}$ & $\begin{array}{r}1,203 \\
608 \\
595 \\
0 \\
164 \\
144 \\
287\end{array}$ & $\begin{array}{r}3,900 \\
1,167 \\
2,733 \\
0 \\
164 \\
1,496 \\
1,073\end{array}$ \\
\hline $\begin{array}{l}\text { Other Lquids } \\
\text { Other Hydrocarbons/Hydrogen Oxygenates } \\
\text { Other Hydrocarbons/Hydrogen } \\
\text { Oxygenates } \\
\text { Fuel Ethanol } \\
\text { Methanol } \\
\text { MTBE } \\
\text { Other Oxygenates }\end{array}$ & $\begin{array}{r}6,019 \\
1,499 \\
85 \\
W \\
W \\
W \\
W \\
W \\
W \\
4,022 \\
499 \\
-1\end{array}$ & $\begin{array}{r}120 \\
3 \\
3 \\
W \\
W \\
W \\
W \\
W \\
W \\
132 \\
-15 \\
0\end{array}$ & $\begin{array}{r}6,139 \\
1,502 \\
88 \\
1,414 \\
W \\
W \\
1,406 \\
W \\
4,154 \\
484 \\
-1\end{array}$ & $\begin{array}{r}1,237 \\
108 \\
16 \\
92 \\
W \\
W \\
W \\
W \\
1,509 \\
-380 \\
0\end{array}$ & $\begin{array}{r}293 \\
95 \\
0 \\
95 \\
W \\
W \\
W \\
W \\
32 \\
166 \\
0\end{array}$ & $\begin{array}{r}-1,051 \\
105 \\
29 \\
76 \\
W \\
W \\
W \\
W \\
-989 \\
-167 \\
0\end{array}$ & $\begin{array}{r}479 \\
308 \\
45 \\
263 \\
179 \\
W \\
W \\
W \\
552 \\
-381 \\
0\end{array}$ \\
\hline 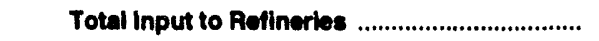 & 42,419 & 2,633 & 45,052 & 60,921 & 11,378 & 18,870 & 91,168 \\
\hline 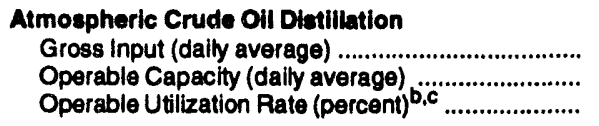 & $\begin{array}{r}1,284 \\
1,437 \\
89.4\end{array}$ & $\begin{array}{r}90 \\
97 \\
92.8\end{array}$ & $\begin{array}{r}1,375 \\
1,534 \\
89.6\end{array}$ & $\begin{array}{r}2,136 \\
2,259 \\
94.5\end{array}$ & $\begin{array}{r}382 \\
378 \\
101.0\end{array}$ & $\begin{array}{l}675 \\
677 \\
99.6\end{array}$ & $\begin{array}{r}3,192 \\
3,315 \\
96.3\end{array}$ \\
\hline 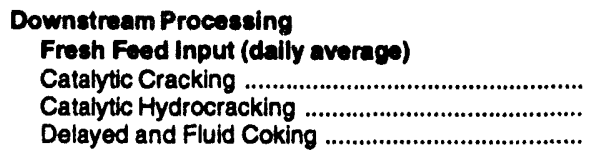 & $\begin{array}{r}590 \\
57 \\
88\end{array}$ & $\begin{array}{r}19 \\
4 \\
0\end{array}$ & $\begin{array}{r}609 \\
61 \\
88\end{array}$ & $\begin{array}{l}791 \\
119 \\
170\end{array}$ & $\begin{array}{r}123 \\
0 \\
56\end{array}$ & $\begin{array}{r}197 \\
7 \\
60\end{array}$ & $\begin{array}{r}1,110 \\
125 \\
286\end{array}$ \\
\hline $\begin{array}{l}\text { Crude Oil Qualtiles } \\
\text { Sultur Content, Weighted Average (percent) .......... } \\
\text { API Gravity, Weighted Average (degrees) .............. }\end{array}$ & $\begin{array}{r}0.84 \\
31.73\end{array}$ & $\begin{array}{r}0.90 \\
36.52\end{array}$ & $\begin{array}{r}0.84 \\
32.05\end{array}$ & $\begin{array}{r}1.05 \\
34.32\end{array}$ & $\begin{array}{r}2.00 \\
29.80\end{array}$ & $\begin{array}{r}0.71 \\
36.07\end{array}$ & $\begin{array}{r}1.09 \\
34.13\end{array}$ \\
\hline $\begin{array}{l}\text { Operable Capacity (dally average) } \\
\text { Operating } \\
\text { Idle }\end{array}$ & $\begin{array}{r}1,437 \\
1,329 \\
108\end{array}$ & $\begin{array}{r}97 \\
97 \\
0\end{array}$ & $\begin{array}{r}1,534 \\
1,426 \\
108\end{array}$ & $\begin{array}{r}2,259 \\
2,253 \\
6\end{array}$ & $\begin{array}{r}378 \\
378 \\
0\end{array}$ & $\begin{array}{r}677 \\
670 \\
8\end{array}$ & $\begin{array}{r}3,315 \\
3,301 \\
14\end{array}$ \\
\hline Alaskan Crude Oll Receipts & 0 & $\mathbf{0}$ & $\mathbf{0}$ & 1,053 & 0 & 428 & 1,481 \\
\hline
\end{tabular}

See footnotes at end of table. 
Table 28. Refinery Input of Crude Oil and Petroleum Products by PAD and Refining Districts, February 1994 (Continued)

(Thousand Barrels, Except Where Noted)

\begin{tabular}{|c|c|c|c|c|c|c|c|c|c|}
\hline \multirow[b]{2}{*}{ Commodity } & \multicolumn{6}{|c|}{ PAD District III } & \multirow{2}{*}{$\begin{array}{l}\text { PAD Dist. } \\
\text { IV } \\
\text { Rocky Mt. }\end{array}$} & \multirow{2}{*}{\begin{tabular}{|c|}
$\begin{array}{c}\text { PAD Dist. } \\
\mathbf{V}\end{array}$ \\
West Coast \\
\end{tabular}} & \multirow[b]{2}{*}{ U.S. } \\
\hline & $\begin{array}{l}\text { Texas } \\
\text { Inland }\end{array}$ & $\begin{array}{l}\text { Texas } \\
\text { Eulf } \\
\text { Coast }\end{array}$ & $\begin{array}{l}\text { La. } \\
\text { Coult } \\
\text { Coast }\end{array}$ & $\begin{array}{l}\text { N. La." } \\
\text { Ark. }\end{array}$ & $\begin{array}{c}\text { New } \\
\text { Mexleo }\end{array}$ & Total & & & \\
\hline 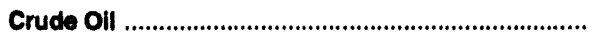 & 14,335 & 80,052 & 64,130 & 4,821 & 2,639 & 165,977 & 12,473 & 63,930 & 367,690 \\
\hline $\begin{array}{l}\text { Natural Gas Llquids } \\
\text { Pentanes Plus } \\
\text { Liquefled Petroleum Gases } \\
\text { Ethane } \\
\text { Propane } \\
\text { Normal Butane } \\
\text { Isobutane }\end{array}$ & $\begin{array}{r}953 \\
460 \\
493 \\
0 \\
0 \\
403 \\
90\end{array}$ & $\begin{array}{r}3,236 \\
1,156 \\
2,080 \\
0 \\
0 \\
846 \\
1,234\end{array}$ & $\begin{array}{r}2,100 \\
147 \\
1,953 \\
0 \\
0 \\
1,007 \\
946\end{array}$ & $\begin{array}{r}249 \\
147 \\
102 \\
0 \\
0 \\
53 \\
49\end{array}$ & $\begin{array}{r}196 \\
102 \\
94 \\
0 \\
0 \\
0 \\
94\end{array}$ & $\begin{array}{r}6,734 \\
2,012 \\
4,722 \\
0 \\
0 \\
2,309 \\
2,413\end{array}$ & $\begin{array}{r}530 \\
173 \\
357 \\
0 \\
0 \\
228 \\
129\end{array}$ & $\begin{array}{r}2,508 \\
1,021 \\
1,487 \\
0 \\
0 \\
907 \\
580\end{array}$ & $\begin{array}{r}14,065 \\
4,449 \\
9,616 \\
0 \\
164 \\
5,180 \\
4,272\end{array}$ \\
\hline 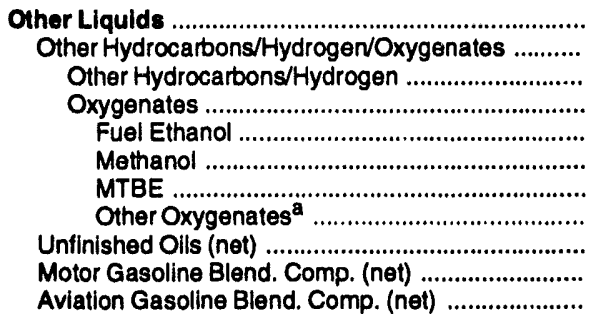 & $\begin{array}{r}-446 \\
120 \\
71 \\
49 \\
W \\
W \\
W \\
W \\
-551 \\
-15 \\
0\end{array}$ & $\begin{array}{r}6,597 \\
864 \\
119 \\
745 \\
W \\
W \\
604 \\
W \\
5,928 \\
-194 \\
-1\end{array}$ & $\begin{array}{r}-1,363 \\
653 \\
181 \\
472 \\
W \\
W \\
W \\
W \\
-2,271 \\
277 \\
-22\end{array}$ & $\begin{array}{l}6 \\
1 \\
0 \\
W \\
W \\
W \\
W \\
W \\
8 \\
-3 \\
0\end{array}$ & $\begin{array}{r}98 \\
16 \\
0 \\
W \\
W \\
W \\
W \\
W \\
-10 \\
92 \\
0\end{array}$ & $\begin{array}{r}4,892 \\
1,654 \\
371 \\
1,283 \\
W \\
W \\
1,070 \\
W \\
3,104 \\
157 \\
-23\end{array}$ & $\begin{array}{r}168 \\
112 \\
0 \\
112 \\
W \\
W \\
W \\
W \\
-70 \\
126 \\
0\end{array}$ & $\begin{array}{r}1,729 \\
1,633 \\
238 \\
1,395 \\
W \\
W \\
1,393 \\
W \\
-363 \\
469 \\
-10\end{array}$ & $\begin{array}{r}13,407 \\
5,209 \\
742 \\
4,467 \\
284 \\
34 \\
4,006 \\
143 \\
7,377 \\
855 \\
-34\end{array}$ \\
\hline 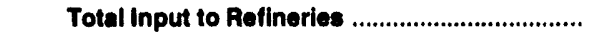 & 14,842 & 89,885 & 84,867 & 5,078 & 2,933 & 177,603 & 13,171 & 68,167 & 395,162 \\
\hline 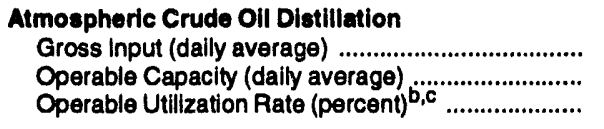 & $\begin{array}{r}514 \\
568 \\
90.5\end{array}$ & $\begin{array}{r}2,880 \\
3,226 \\
89.3\end{array}$ & $\begin{array}{r}2,342 \\
2,675 \\
87.6\end{array}$ & $\begin{array}{r}167 \\
211 \\
79.2\end{array}$ & $\begin{array}{r}94 \\
95 \\
99.6\end{array}$ & $\begin{array}{r}5,998 \\
6,774 \\
88.5\end{array}$ & $\begin{array}{r}451 \\
510 \\
88.6\end{array}$ & $\begin{array}{r}2,329 \\
2,909 \\
80.1\end{array}$ & $\begin{array}{r}13,345 \\
15,041 \\
88.7\end{array}$ \\
\hline 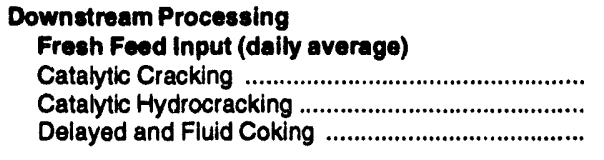 & $\begin{array}{r}166 \\
22 \\
4\end{array}$ & $\begin{array}{r}1,016 \\
159 \\
320\end{array}$ & $\begin{array}{l}741 \\
147 \\
354\end{array}$ & $\begin{array}{r}18 \\
0 \\
8\end{array}$ & $\begin{array}{r}31 \\
0 \\
0\end{array}$ & $\begin{array}{r}1,972 \\
329 \\
687\end{array}$ & $\begin{array}{r}151 \\
4 \\
38\end{array}$ & $\begin{array}{l}648 \\
394 \\
447\end{array}$ & $\begin{array}{r}4,489 \\
913 \\
1,546\end{array}$ \\
\hline $\begin{array}{l}\text { Crude Oll Qualities } \\
\text { Sulfur Content, Weighted Average (percent) ......... } \\
\text { API Gravity, Weighted Average (degrees) ............. }\end{array}$ & $\begin{array}{r}0.74 \\
39.15\end{array}$ & $\begin{array}{r}1.13 \\
32.48\end{array}$ & $\begin{array}{r}1.33 \\
30.84\end{array}$ & $\begin{array}{r}1.57 \\
31.70\end{array}$ & $\begin{array}{r}0.42 \\
40.73\end{array}$ & $\begin{array}{r}1.18 \\
32.54\end{array}$ & $\begin{array}{r}1.29 \\
33.57\end{array}$ & $\begin{array}{r}1.17 \\
25.23\end{array}$ & $\begin{array}{r}1.12 \\
31.58\end{array}$ \\
\hline $\begin{array}{l}\text { Operable Capacity (daily average) } \\
\text { Operating } \\
\text { Idle }\end{array}$ & $\begin{array}{r}858 \\
568 \\
0\end{array}$ & $\begin{array}{r}3,226 \\
3,199 \\
27\end{array}$ & $\begin{array}{r}2,675 \\
2,675 \\
0\end{array}$ & $\begin{array}{r}211 \\
211 \\
0\end{array}$ & $\begin{array}{r}95 \\
95 \\
0\end{array}$ & $\begin{array}{r}6,774 \\
6,747 \\
27\end{array}$ & $\begin{array}{r}510 \\
510 \\
0\end{array}$ & $\begin{array}{r}2,909 \\
2,885 \\
24\end{array}$ & $\begin{array}{r}15,041 \\
14,869 \\
173\end{array}$ \\
\hline 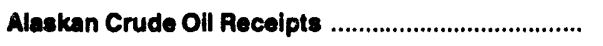 & 50 & 1,571 & 53 & $\mathbf{0}$ & $\mathbf{0}$ & 1,674 & $\mathbf{0}$ & 37,045 & 40,200 \\
\hline
\end{tabular}

a Includes ethyl tertiary butyl ether (ETBE), tertiary amyl methyl ether (TAME), tertiary butyl alcohol (TBA), and other aliphatic alcohols and ethers intended for motor gasoline blending (e.g., isopropyl ether (IPE) or n-propanol).

Represents gross input divided by operable capacity.

c See Table H2 in the Highlights Section for additional information concerning utilization rates.

$W=$ Withheld to avoid disclosure of individual company data.

Note: - Totals may not equal sum of components due to independent rounding. - Refer to Appendix A for Refining District descriptions.

Source: Energy Information Administration (EIA) Form EIA-B10, "Monthly Refinery Report." 
Table 29. Refinery Net Production of Finished Petroleum Products by PAD and Refining Districts, February 1994

(Thousand Barrels)

\begin{tabular}{|c|c|c|c|c|c|c|c|}
\hline \multirow[b]{2}{*}{ Commodity } & \multicolumn{3}{|c|}{ PAD District I } & \multicolumn{4}{|c|}{ PAD Distriet II } \\
\hline & $\begin{array}{l}\text { East } \\
\text { Coast }\end{array}$ & $\begin{array}{l}\text { Appalachian } \\
\text { No. } 1\end{array}$ & Total & Ind., III., Ky. & $\begin{array}{l}\text { Minn., Wis., } \\
\text { N. Dak., } \\
\text { S. Dak. }\end{array}$ & $\begin{array}{c}\text { Okla., Kans., } \\
\text { Mo. }\end{array}$ & Total \\
\hline $\begin{array}{l}\text { Liquefied Refinery Gases } \\
\text { Ethane/Ethylene } \\
\text { Ethane } \\
\text { Ethylene } \\
\text { Propane/Propylene } \\
\text { Propane } \\
\text { Propylene } \\
\text { Normal Butane/Butylene } \\
\text { Normal Butane } \\
\text { Butylene } \\
\text { Isobutane/lsobutylene } \\
\text { Isobutane }\end{array}$ & $\begin{array}{r}1,040 \\
0 \\
W \\
W \\
1,211 \\
W \\
W \\
-202 \\
W \\
W \\
31 \\
W \\
W \\
20,596 \\
0 \\
8,056 \\
12,540 \\
-1 \\
2,321 \\
0 \\
2,321 \\
2,338 \\
-17 \\
136 \\
11,239 \\
3,410 \\
7,829 \\
4,112 \\
689 \\
3,170 \\
253 \\
386 \\
12 \\
0 \\
278 \\
0 \\
278 \\
0 \\
1,389 \\
520 \\
869 \\
1,153 \\
1,775 \\
22 \\
0 \\
22\end{array}$ & 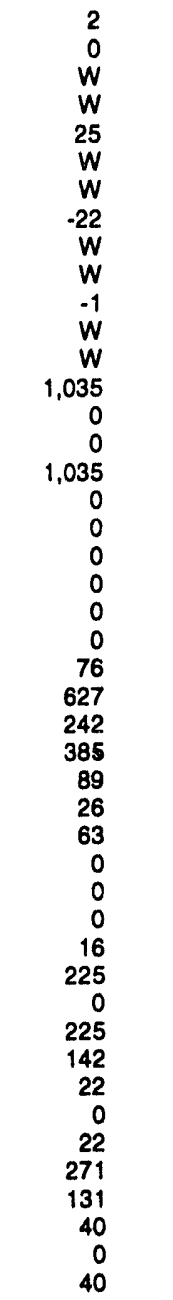 & $\begin{array}{r}1,042 \\
0 \\
W \\
W \\
1,236 \\
W \\
W \\
-224 \\
W \\
W \\
30 \\
W \\
W \\
21,631 \\
0 \\
8,056 \\
13,575 \\
-1 \\
2,321 \\
0 \\
2,321 \\
2,338 \\
-17 \\
212 \\
11,866 \\
3,652 \\
8,214 \\
4,201 \\
715 \\
3,233 \\
253 \\
386 \\
12 \\
16 \\
503 \\
0 \\
503 \\
142 \\
1,411 \\
520 \\
891 \\
1,424 \\
1,906 \\
62 \\
0 \\
62\end{array}$ & $\begin{array}{r}1,880 \\
0 \\
W \\
W \\
1,975 \\
W \\
W \\
-132 \\
W \\
W \\
37 \\
W \\
W \\
31,992 \\
0 \\
792 \\
31,200 \\
21 \\
4,098 \\
110 \\
3,988 \\
3,910 \\
78 \\
956 \\
13,022 \\
6,677 \\
6,345 \\
1,973 \\
0 \\
355 \\
1,618 \\
432 \\
602 \\
233 \\
355 \\
0 \\
355 \\
32 \\
2,339 \\
1,344 \\
995 \\
2,579 \\
2,588 \\
196 \\
0 \\
196\end{array}$ & $\begin{array}{r}271 \\
0 \\
W \\
W \\
250 \\
W \\
W \\
8 \\
W \\
W \\
13 \\
W \\
W \\
5,862 \\
0 \\
1,151 \\
4,711 \\
35 \\
896 \\
20 \\
876 \\
876 \\
0 \\
92 \\
2,633 \\
999 \\
1,634 \\
273 \\
0 \\
0 \\
273 \\
0 \\
0 \\
0 \\
0 \\
0 \\
53\end{array}$ & $\begin{array}{r}413 \\
0 \\
W \\
W \\
589 \\
W \\
W \\
-149 \\
W \\
W \\
-27 \\
W \\
W \\
9,852 \\
0 \\
1,891 \\
7,961 \\
11 \\
1,273 \\
168 \\
1,105 \\
1,087 \\
18 \\
290 \\
4,769 \\
2,436 \\
2,333 \\
195 \\
27 \\
79 \\
89 \\
12 \\
25 \\
125 \\
200 \\
0 \\
200 \\
24 \\
722 \\
480 \\
242 \\
616 \\
808 \\
62 \\
0\end{array}$ & $\begin{array}{r}2,564 \\
0 \\
W \\
W \\
2,814 \\
W \\
W \\
-273 \\
W \\
W \\
23 \\
W \\
W \\
47,706 \\
0 \\
3,834 \\
43,872 \\
67 \\
6,267 \\
298 \\
5,969 \\
5,873 \\
96 \\
1,338 \\
20,424 \\
10,112 \\
10,312 \\
2,441 \\
27 \\
434 \\
1,980 \\
450 \\
627 \\
358 \\
555 \\
0 \\
555 \\
56 \\
3,611\end{array}$ \\
\hline Total & 44,458 & 2,676 & 47,134 & 63,298 & 12,005 & 19,403 & 94,706 \\
\hline 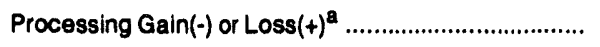 & $-2,039$ & -43 & $-2,082$ & $-2,377$ & -627 & .533 & $-3,537$ \\
\hline
\end{tabular}

See footnotes at end of table. 
Table 29. Refinery Net Production of Finished Petroleum Products by PAD and Refining Districts, February 1994 (Continued)

(Thousand Barrels)

\begin{tabular}{|c|c|c|c|c|c|c|c|c|c|}
\hline \multirow[b]{2}{*}{ Commodity } & \multicolumn{6}{|c|}{ PAD District III } & \multirow{2}{*}{\begin{tabular}{|c|}
$\begin{array}{c}\text { PAD Dist. } \\
\text { IV }\end{array}$ \\
Rocky Mt.
\end{tabular}} & \multirow{2}{*}{\begin{tabular}{|c|}
$\begin{array}{c}\text { PAD Dist. } \\
V\end{array}$ \\
West Coast
\end{tabular}} & \multirow[b]{2}{*}{$\begin{array}{l}\text { U.S. } \\
\text { Total }\end{array}$} \\
\hline & $\begin{array}{l}\text { Texas } \\
\text { Inland }\end{array}$ & $\begin{array}{c}\text { Texas } \\
\text { culf } \\
\text { Coast }\end{array}$ & $\begin{array}{l}\text { La. } \\
\text { Culf } \\
\text { Coatet }\end{array}$ & N. La." & $\begin{array}{c}\text { New } \\
\text { Mexico }\end{array}$ & Total & & & \\
\hline 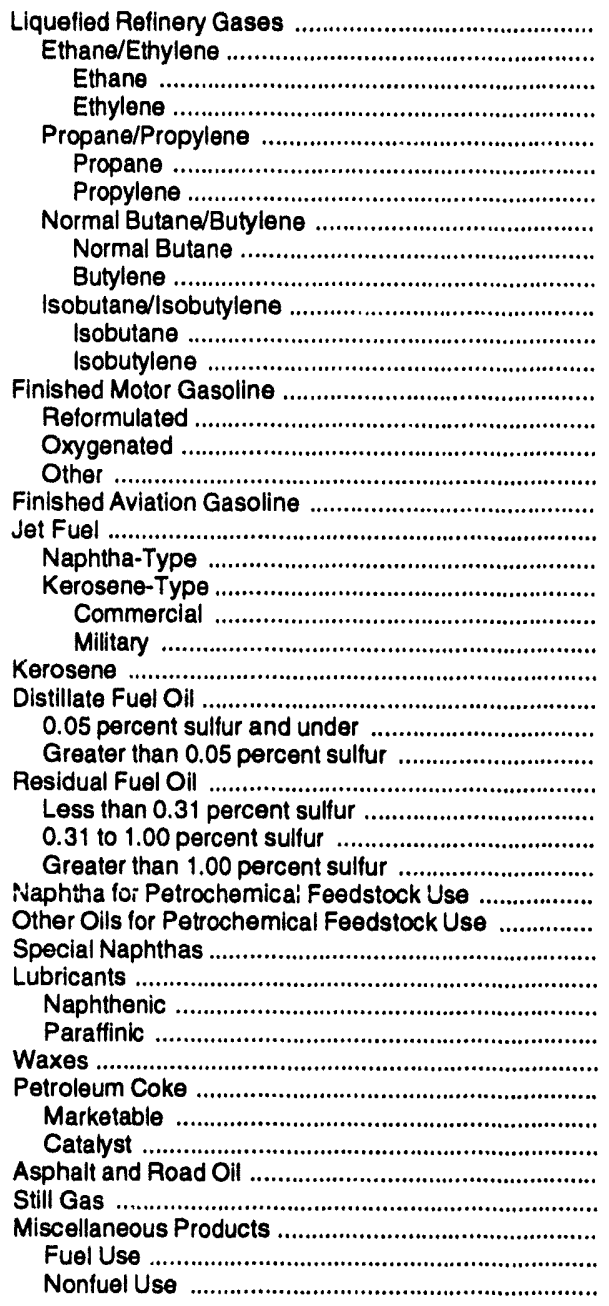 & $\begin{array}{r}488 \\
2 \\
W \\
W \\
514 \\
W \\
W \\
39 \\
W \\
W \\
-67 \\
W \\
W \\
8,340 \\
0 \\
874 \\
7,466 \\
154 \\
1,207 \\
219 \\
988 \\
852 \\
136 \\
46 \\
3,234 \\
1,580 \\
1,654 \\
352 \\
92 \\
177 \\
83 \\
8 C \\
95 \\
89 \\
W \\
W \\
W \\
8 \\
293 \\
34 \\
259 \\
236 \\
575 \\
60 \\
11 \\
49\end{array}$ & $\begin{array}{r}4,679 \\
491 \\
W \\
W \\
3,295 \\
W \\
W \\
804 \\
W \\
W \\
89 \\
W \\
W \\
39,606 \\
0 \\
2,542 \\
37,064 \\
171 \\
8,794 \\
-1 \\
8,795 \\
8,090 \\
705 \\
495 \\
17,504 \\
9,135 \\
8,369 \\
6,137 \\
461 \\
1,101 \\
4,575 \\
2,811 \\
3,686 \\
337 \\
1,713 \\
389 \\
1,324 \\
145 \\
3,559 \\
2,007 \\
1,552 \\
502 \\
4,356 \\
289 \\
0 \\
289\end{array}$ & $\begin{array}{r}2,445 \\
205 \\
W \\
W \\
2,213 \\
W \\
W \\
-21 \\
W \\
W \\
48 \\
W \\
W \\
28,638 \\
0 \\
2,335 \\
26,303 \\
64 \\
8,858 \\
365 \\
8,533 \\
8,297 \\
236 \\
300 \\
14,939 \\
4,850 \\
10,089 \\
2,851 \\
610 \\
414 \\
1,827 \\
263 \\
2,550 \\
102 \\
W \\
W \\
W \\
108 \\
3,528 \\
2,719 \\
809 \\
312 \\
2,583 \\
306 \\
119 \\
187\end{array}$ & $\begin{array}{r}89 \\
0 \\
W \\
W \\
52 \\
W \\
W \\
30 \\
W \\
W \\
7 \\
W \\
W \\
1,374 \\
0 \\
5 \\
1,369 \\
0 \\
284 \\
122 \\
162 \\
162 \\
0 \\
10 \\
1,239 \\
947 \\
292 \\
280 \\
39 \\
201 \\
40 \\
0 \\
0 \\
128 \\
W \\
W \\
W \\
55 \\
90 \\
72 \\
18 \\
923 \\
162 \\
0 \\
0 \\
0\end{array}$ & $\begin{array}{r}44 \\
0 \\
W \\
W \\
65 \\
W \\
W \\
-23 \\
W \\
W \\
2 \\
W \\
W \\
1,756 \\
0 \\
137 \\
1,619 \\
0 \\
258 \\
24 \\
234 \\
0 \\
234 \\
9 \\
631 \\
631 \\
0 \\
21 \\
0 \\
21 \\
0 \\
-2 \\
0 \\
0 \\
W \\
W \\
W \\
0 \\
18 \\
0 \\
18 \\
149 \\
43 \\
0 \\
0 \\
0\end{array}$ & $\begin{array}{r}7,745 \\
698 \\
W \\
W \\
6,139 \\
W \\
W \\
829 \\
W \\
W \\
79 \\
W \\
W \\
79,714 \\
0 \\
5,893 \\
73,821 \\
389 \\
19,441 \\
729 \\
18,712 \\
17,401 \\
1,311 \\
860 \\
37,547 \\
17,143 \\
20,404 \\
9,641 \\
1,202 \\
1,914 \\
6,525 \\
3,152 \\
6,331 \\
656 \\
2,895 \\
821 \\
2,074 \\
316 \\
7,488 \\
4,832 \\
2,656 \\
2,122 \\
7,719 \\
655 \\
130 \\
525\end{array}$ & $\begin{array}{r}148 \\
0 \\
W \\
W \\
242 \\
W \\
W \\
-109 \\
W \\
W \\
15 \\
W \\
W \\
6,839 \\
0 \\
346 \\
6,493 \\
2 \\
908 \\
257 \\
651 \\
651 \\
0 \\
102 \\
3,419 \\
2,066 \\
1,353 \\
216 \\
23 \\
42 \\
151 \\
0 \\
15 \\
0 \\
0 \\
0 \\
0 \\
28 \\
402 \\
244 \\
158 \\
836 \\
557 \\
79 \\
0 \\
79\end{array}$ & $\begin{array}{r}1,764 \\
0 \\
W \\
W \\
1,051 \\
W \\
W \\
580 \\
W \\
W \\
133 \\
W \\
W \\
32,206 \\
0 \\
9,835 \\
22,371 \\
133 \\
9,675 \\
50 \\
9,625 \\
8,487 \\
1,138 \\
11 \\
11,262 \\
7,732 \\
3,530 \\
7,553 \\
797 \\
999 \\
5,757 \\
-27 \\
123 \\
40 \\
575 \\
230 \\
345 \\
55 \\
3,882 \\
3,002 \\
880 \\
921 \\
3,543 \\
166 \\
0 \\
166\end{array}$ & $\begin{array}{r}13,263 \\
698 \\
546 \\
152 \\
11,482 \\
7,981 \\
3,501 \\
803 \\
695 \\
108 \\
280 \\
180 \\
100 \\
188,096 \\
0 \\
27,964 \\
160,132 \\
590 \\
38,612 \\
1,334 \\
37,278 \\
34,750 \\
2,528 \\
2,523 \\
84,518 \\
40,705 \\
43,813 \\
24,052 \\
2,764 \\
6,622 \\
14,666 \\
2,951 \\
7,108 \\
1,070 \\
4,528 \\
1,051 \\
3,477 \\
597 \\
16,823 \\
10,835 \\
5,988 \\
9,412 \\
17,518 \\
1,273 \\
130 \\
1,143\end{array}$ \\
\hline Total & 15,295 & 94,784 & 68,526 & 5,139 & 2,927 & 186,671 & 13,551 & 71,882 & 413,944 \\
\hline 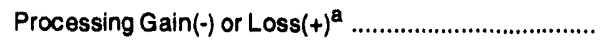 & -453 & $-4,899$ & $-3,659$ & -63 & 6 & $-9,068$ & -380 & $-3,715$ & $-18,782$ \\
\hline
\end{tabular}

a Represents the arithmetic difference between input and production.

$W=$ Withheld to avoid disclosure of individual company data.

Note: Refer to Appendix A for refining District descriptions.

Source: Energy Information Administration (EIA) Form EIA-810, "Monthly Refinery Report." 
Table 30. Refinery Stocks of Crude Oil and Petroleum Products by PAD and Refining Districts, February 1994

(Thousand Barrels)

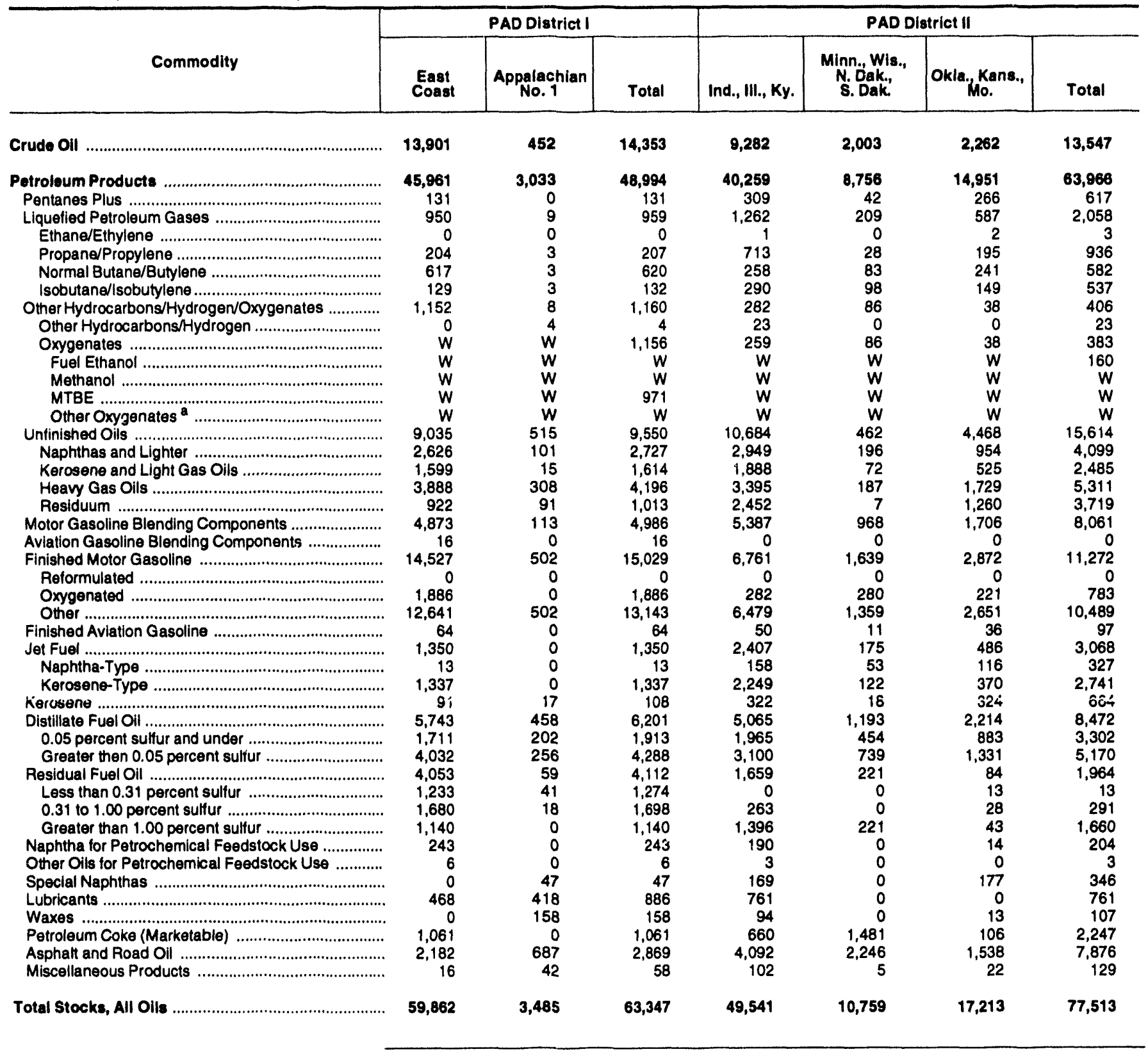

See footnotes at end of table. 
Table 30. Refinery Stocks of Crude Oil and Petroleum Products by PAD and Refining Districts, February 1994 (Continued)

(Thousand Barrels)

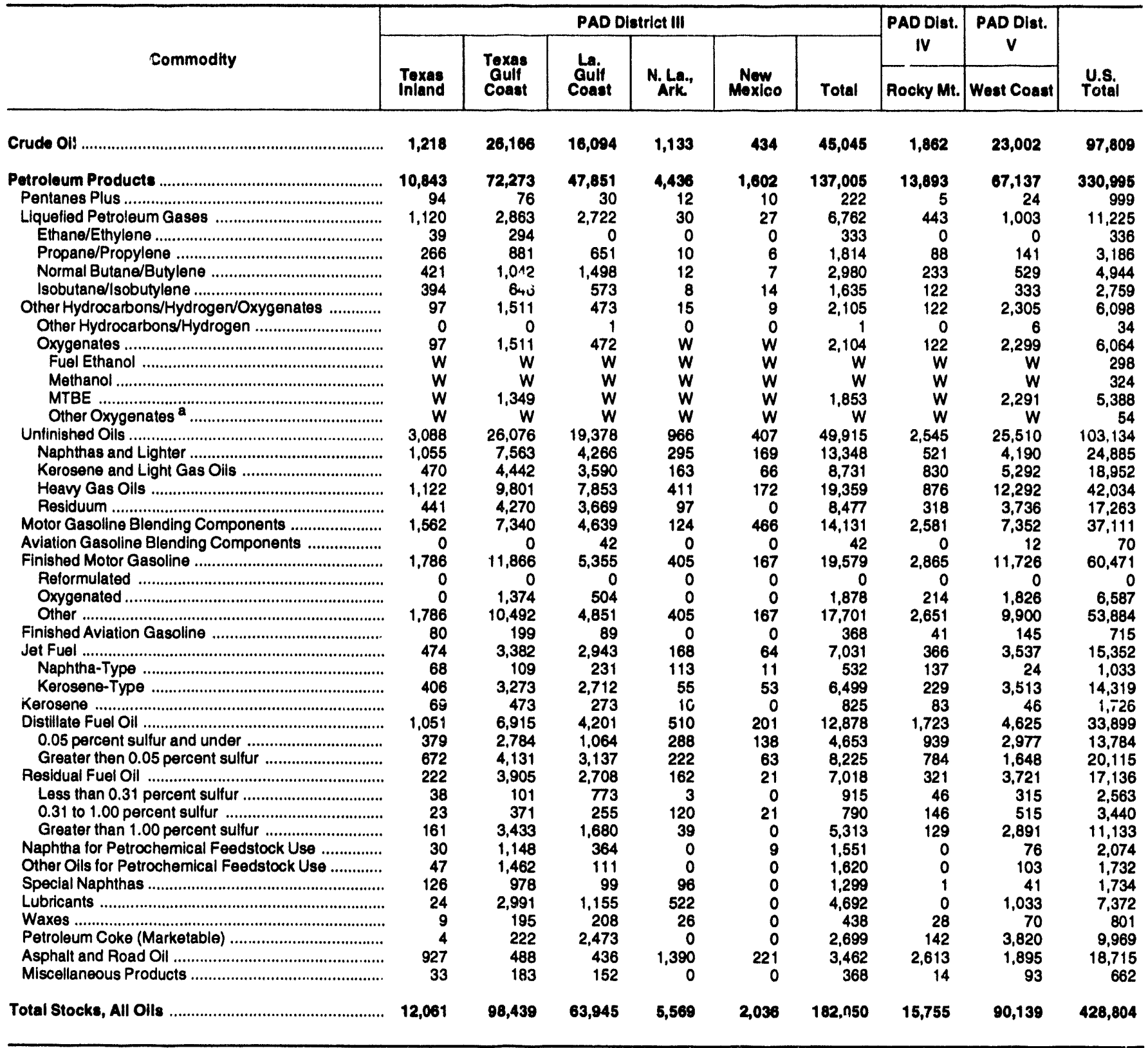

a Includes ethyl tertiary butyl ether (ETBE), tertiary amyl methyl ether (TAME), tertiary butyl alcohol (TBA), and other aliphatic alcohols and ethers intended for motor gasoline blending (e.g., isopropyl ether (IPE) or n-propanol).

$W=$ Withheld to avoid disclosure of individual company data.

Notes: - Stocks are reported as of the last day of the month. - Refer to Appendix A for Refining District descriptions.

Source: Energy Information Administration (EIA) Form EIA-810, "Monthly Refinery Report." 
Table 31. Percent Refinery Yleld of Petroleum Products by PAD and Refining Districts, ${ }^{a}$ February 1994

\begin{tabular}{|c|c|c|c|c|c|c|c|}
\hline \multirow[b]{2}{*}{ Commodity } & \multicolumn{3}{|c|}{ PAD Dlatrict I } & \multicolumn{4}{|c|}{ PAD District II } \\
\hline & $\begin{array}{l}\text { East } \\
\text { Coast }\end{array}$ & $\begin{array}{c}\text { Appalachian } \\
\text { No.1 }\end{array}$ & Total & Ind., III., Ky. & $\begin{array}{c}\text { Minn., Wia., } \\
\text { N. Dak., } \\
\text { B. Dak. }\end{array}$ & $\begin{array}{c}\text { Okla., Kans., } \\
\text { Mo. }\end{array}$ & Total \\
\hline 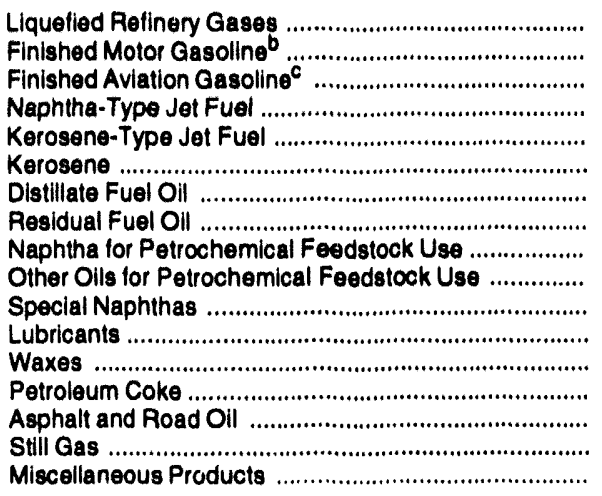 & $\begin{array}{r}2.6 \\
45.6 \\
0.0 \\
0.0 \\
5.8 \\
0.3 \\
28.1 \\
10.3 \\
1.0 \\
0.0 \\
0.0 \\
0.7 \\
0.0 \\
3.5 \\
2.9 \\
4.4 \\
0.1\end{array}$ & $\begin{array}{r}0.1 \\
39.6 \\
0.0 \\
0.0 \\
0.0 \\
2.9 \\
23.7 \\
3.4 \\
0.0 \\
0.0 \\
0.6 \\
8.5 \\
5.4 \\
0.8 \\
10.3 \\
5.0 \\
1.5\end{array}$ & $\begin{array}{r}2.4 \\
45.1 \\
0.0 \\
0.0 \\
5.4 \\
0.5 \\
27.8 \\
9.8 \\
0.9 \\
0.0 \\
0.0 \\
1.2 \\
0.3 \\
3.3 \\
3.3 \\
4.5 \\
0.2\end{array}$ & $\begin{array}{r}3.2 \\
50.9 \\
0.0 \\
0.2 \\
6.8 \\
1.6 \\
22.1 \\
3.4 \\
0.7 \\
1.0 \\
0.4 \\
0.6 \\
0.1 \\
4.0 \\
4.4 \\
4.4 \\
0.3\end{array}$ & $\begin{array}{r}2.5 \\
48.6 \\
0.3 \\
0.2 \\
8.2 \\
0.9 \\
24.6 \\
2.5 \\
0.0 \\
0.0 \\
0.0 \\
0.0 \\
0.0 \\
5.4 \\
8.5 \\
3.7 \\
0.5\end{array}$ & $\begin{array}{r}2.3 \\
49.1 \\
0.1 \\
1.0 \\
6.2 \\
1.6 \\
26.9 \\
1.1 \\
0.1 \\
0.1 \\
0.7 \\
1.1 \\
0.1 \\
4.1 \\
3.5 \\
4.6 \\
0.4\end{array}$ & $\begin{array}{r}2.9 \\
50.2 \\
0.1 \\
0.3 \\
6.8 \\
1.5 \\
23.4 \\
2.8 \\
0.5 \\
0.7 \\
0.4 \\
0.6 \\
0.1 \\
4.2 \\
4.7 \\
4.3 \\
0.4\end{array}$ \\
\hline 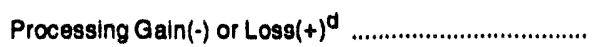 & -5.1 & $\cdot 1.6$ & -4.9 & .4 .0 & -5.9 & -3.0 & .4 .1 \\
\hline
\end{tabular}

\begin{tabular}{|c|c|c|c|c|c|c|c|c|c|}
\hline \multirow[b]{2}{*}{ Commodity } & \multicolumn{6}{|c|}{ PAD District III } & \multirow{2}{*}{\begin{tabular}{|c|}
$\begin{array}{c}\text { PAD Dist. } \\
\text { IV }\end{array}$ \\
Rocky Mt.
\end{tabular}} & \multirow{2}{*}{\begin{tabular}{|c}
$\begin{array}{c}\text { PAD Dlat. } \\
V\end{array}$ \\
West Coast
\end{tabular}} & \multirow[b]{2}{*}{$\begin{array}{l}\text { U.S. } \\
\text { Tota }\end{array}$} \\
\hline & $\begin{array}{l}\text { Texas } \\
\text { Inland }\end{array}$ & $\begin{array}{l}\text { Texas } \\
\text { Gulf } \\
\text { Cosst }\end{array}$ & $\begin{array}{l}\text { La. } \\
\text { Guif } \\
\text { Coast }\end{array}$ & N. La., & $\begin{array}{c}\text { New } \\
\text { Moxico }\end{array}$ & Total & & & \\
\hline 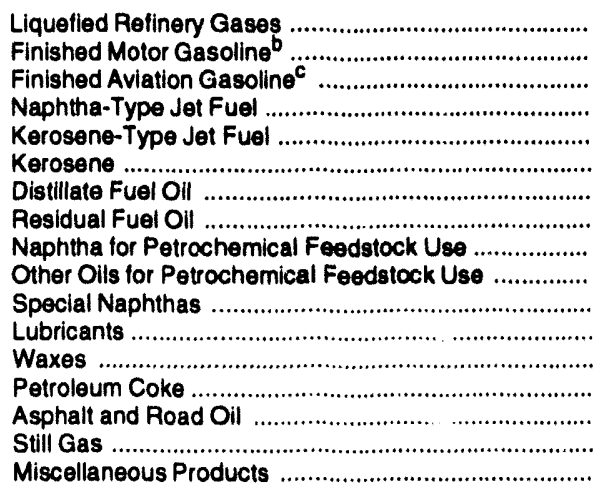 & $\begin{array}{r}3.5 \\
52.8 \\
1.1 \\
1.6 \\
7.2 \\
0.3 \\
23.5 \\
2.6 \\
0.6 \\
0.7 \\
0.7 \\
0.3 \\
0.1 \\
2.1 \\
1.7 \\
4.2 \\
0.4\end{array}$ & $\begin{array}{r}5.4 \\
41.5 \\
0.2 \\
0.0 \\
10.2 \\
0.6 \\
20.4 \\
7.1 \\
3.3 \\
4.3 \\
0.4 \\
2.0 \\
0.2 \\
4.1 \\
0.6 \\
5.1 \\
0.3\end{array}$ & $\begin{array}{r}4.0 \\
41.4 \\
0.1 \\
0.6 \\
13.8 \\
0.5 \\
24.2 \\
4.6 \\
0.4 \\
4.1 \\
0.2 \\
1.0 \\
0.2 \\
5.7 \\
0.5 \\
4.2 \\
0.5\end{array}$ & $\begin{array}{r}1.8 \\
23.3 \\
0.0 \\
2.5 \\
3.4 \\
0.2 \\
25.7 \\
5.8 \\
0.0 \\
0.0 \\
2.7 \\
10.5 \\
1.1 \\
1.9 \\
19.1 \\
3.4 \\
0.0\end{array}$ & $\begin{array}{r}1.7 \\
55.2 \\
0.0 \\
0.9 \\
8.9 \\
0.3 \\
24.0 \\
0.8 \\
-0.1 \\
0.0 \\
0.0 \\
0.0 \\
0.0 \\
0.7 \\
5.7 \\
1.6 \\
0.0\end{array}$ & $\begin{array}{r}4.6 \\
42.1 \\
0.2 \\
0.4 \\
11.1 \\
0.5 \\
22.2 \\
5.7 \\
1.9 \\
3.7 \\
0.4 \\
1.7 \\
0.2 \\
4.4 \\
1.3 \\
4.6 \\
0.4\end{array}$ & $\begin{array}{r}1.2 \\
49.0 \\
0.0 \\
2.1 \\
5.3 \\
0.8 \\
27.6 \\
1.7 \\
0.0 \\
0.1 \\
0.0 \\
0.0 \\
0.2 \\
3.2 \\
6.7 \\
4.5 \\
0.6\end{array}$ & $\begin{array}{r}2.8 \\
43.4 \\
0.2 \\
0.1 \\
15.1 \\
0.0 \\
17.7 \\
11.9 \\
0.0 \\
0.2 \\
0.1 \\
0.9 \\
0.1 \\
6.1 \\
1.5 \\
5.6 \\
0.3\end{array}$ & $\begin{array}{r}3.5 \\
44.8 \\
0.2 \\
0.4 \\
9.9 \\
0.7 \\
22.5 \\
6.4 \\
1.1 \\
1.9 \\
0.3 \\
1.2 \\
0.2 \\
4.5 \\
2.5 \\
4.7 \\
0.3\end{array}$ \\
\hline 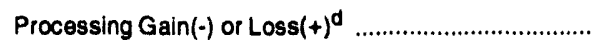 & -3.3 & -5.7 & -5.9 & -1.3 & 0.2 & -5.4 & -3.1 & -5.8 & .5 .0 \\
\hline
\end{tabular}

a Based on crude oil input and net reruns of unfinished oils.

b Based on total finished motor gasoline output minus net input of motor gasoline blending components, minus input of natural gas plant liquids, other hydrocarbons and oxygenates.

c Based on finished aviation gasoline output minus net input of aviation gasoline blending components.

d Represents the difference between input and production.

Notes: - Totals may not equal sum of components due to independent rounding. • Refer to Appendix A for Refining District descriptions.

Sources: Calculated from data on Tables 28 and 29. 
Table 32. Imports of Residual Fuel Oil by Sulfur Content and by PAD District and State of Entry, Fobruary 1994

(Thousand Barrels)

\begin{tabular}{|c|c|c|c|c|}
\hline \multirow[b]{2}{*}{ PAD District and State of Entry } & \multicolumn{4}{|c|}{ Resldual Fuel Oll } \\
\hline & $\begin{array}{l}\text { Lese than } \\
0.31 \% \\
\text { Sullur }\end{array}$ & $\begin{array}{l}0.31 \text { to } \\
1.00 \% \\
\text { Sulfur }\end{array}$ & $\begin{array}{c}\text { Oreater } \\
\text { than } 1.00 \% \\
\text { Sultur }\end{array}$ & Total \\
\hline 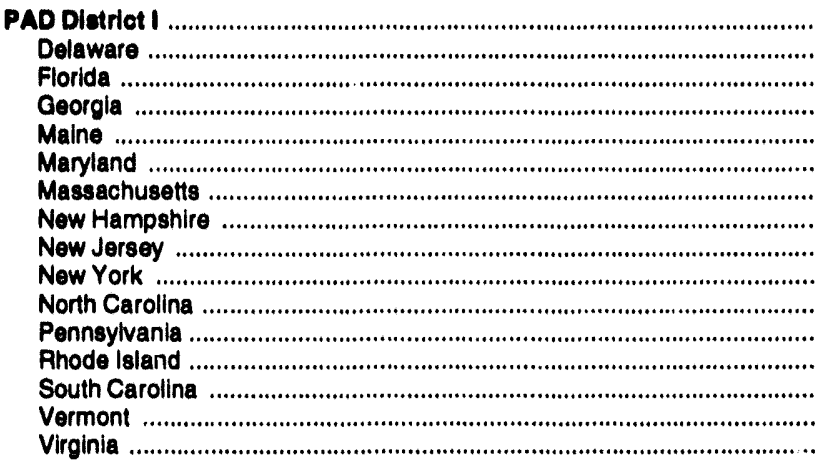 & $\begin{array}{r}4,012 \\
0 \\
0 \\
0 \\
90 \\
59 \\
170 \\
0 \\
571 \\
1,972 \\
0 \\
1,112 \\
0 \\
38 \\
0 \\
0\end{array}$ & $\begin{array}{r}4,493 \\
369 \\
61 \\
0 \\
0 \\
165 \\
1,119 \\
0 \\
272 \\
1,675 \\
0 \\
842 \\
0 \\
0 \\
0 \\
0\end{array}$ & $\begin{array}{r}7,251 \\
129 \\
885 \\
226 \\
758 \\
482 \\
528 \\
582 \\
1,350 \\
384 \\
522 \\
38 \\
100 \\
435 \\
7 \\
825\end{array}$ & $\begin{array}{r}15,756 \\
498 \\
946 \\
226 \\
848 \\
696 \\
1,817 \\
582 \\
2,193 \\
4,031 \\
522 \\
1,992 \\
100 \\
473 \\
7 \\
825\end{array}$ \\
\hline 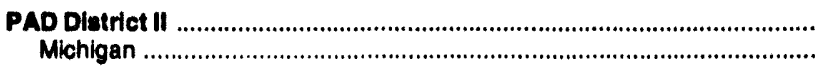 & $\begin{array}{l}18 \\
16\end{array}$ & $\begin{array}{l}0 \\
0\end{array}$ & $\begin{array}{l}0 \\
0\end{array}$ & $\begin{array}{l}16 \\
16\end{array}$ \\
\hline $\begin{array}{l}\text { PAD Distriet III } \\
\text { Loulsiana } \\
\text { Toxas }\end{array}$ & $\begin{array}{r}43 \\
0 \\
43\end{array}$ & $\begin{array}{l}0 \\
0 \\
0\end{array}$ & $\begin{array}{r}316 \\
316 \\
0\end{array}$ & $\begin{array}{r}359 \\
316 \\
43\end{array}$ \\
\hline PAD Dlatriet IV & 1 & $\begin{array}{l}1 \\
1\end{array}$ & $\begin{array}{l}0 \\
0\end{array}$ & $\begin{array}{l}2 \\
2\end{array}$ \\
\hline $\begin{array}{l}\text { PAD Dlatriet V } \\
\text { Calliornia } \\
\text { Washington }\end{array}$ & $\begin{array}{r}13 \\
0 \\
13\end{array}$ & $\begin{array}{l}0 \\
0 \\
0\end{array}$ & $\begin{array}{r}254 \\
222 \\
32\end{array}$ & $\begin{array}{r}267 \\
222 \\
45\end{array}$ \\
\hline U.8. Total & 4,085 & 4,494 & 7,821 & 16,400 \\
\hline
\end{tabular}

Source: Energy Information Administration (EIA) Form ElA-814, "Monthly Imports Report." 
Table 33. Imports of Crude Oll and Petroleum Products by PAD District, Fobruary 1994

(Thousand Barrels)

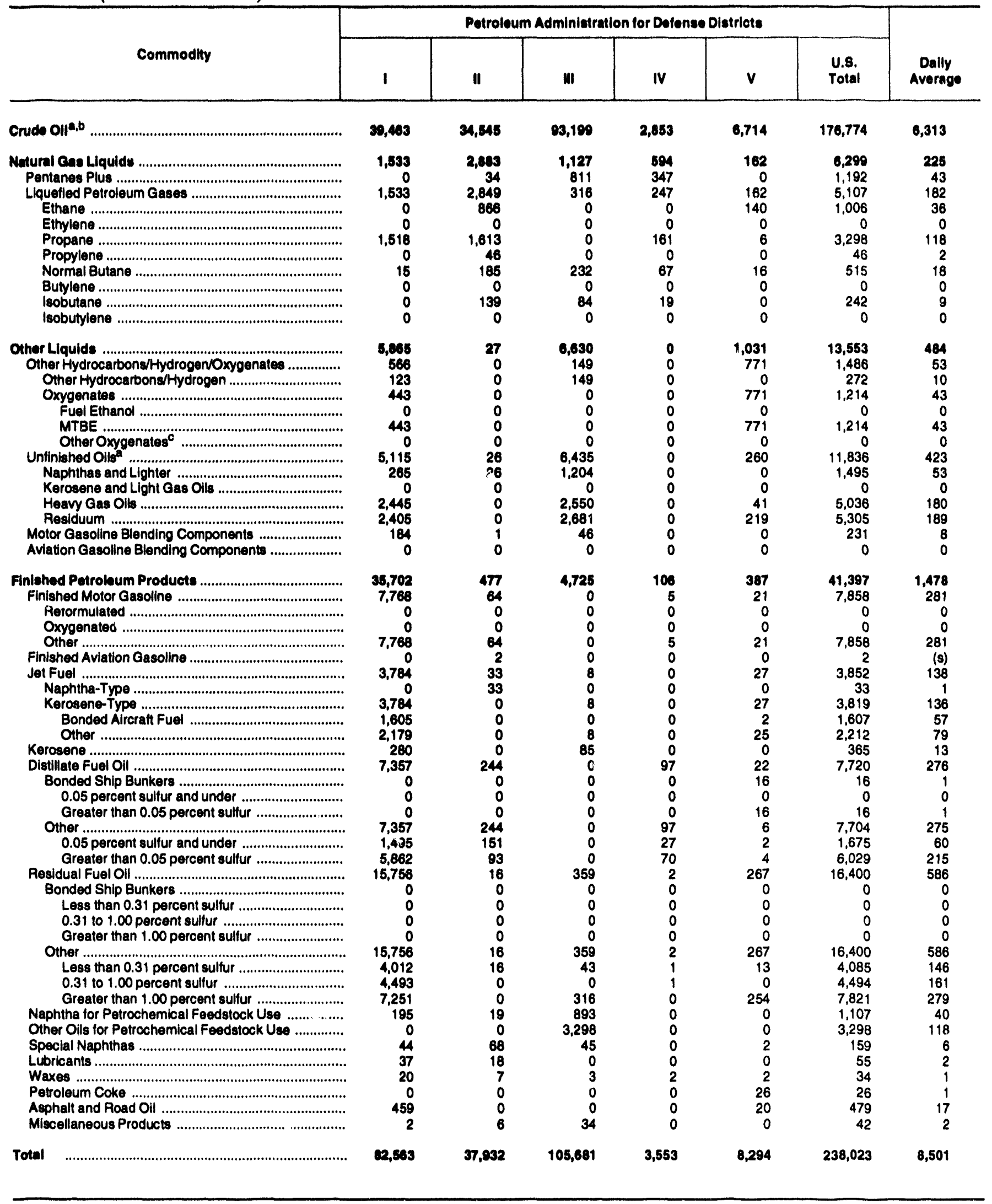

- Crude oll and unfinished oils are reported by the PAD District in which they are to be processed; all other products are reported by the PAD District of entry.

- Includes crude oil imported for storage in the Strategic Petroleum Reserve.

c Includes ethyl tertiary buty ether (ETBE), tertiary amyl methyl ether (TAME), tertiary butyl alcohol (TBA), and other aliphatic alcohols and ethers intended for motor gasoline blending (e.g., lsopropyl ether (IPE) or n-propanol).

(s) = Less than 500 barrels per day.

Note: Totals may not equal sum of components due to independent rounding.

Sources: Energy Information Administration (EIA) Form ElA-814, "Monthly Imports Report." 
Table 34. Year-to-Date Imports of Crude Oll and Potroloum Products by PAD District, January-February 1984

(Thousand Barrels)

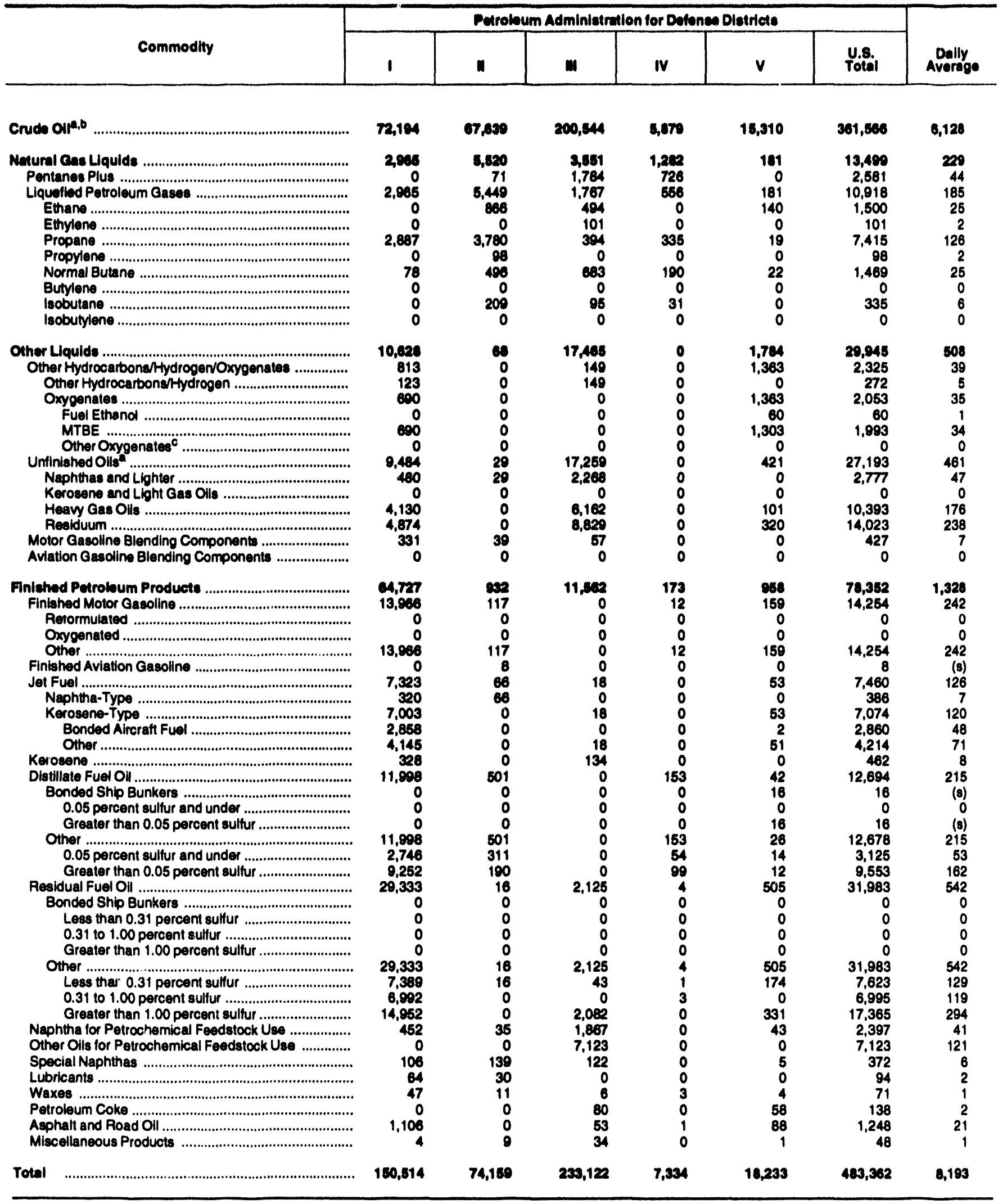

a Crude oil and unfinishat cils are reported by the PAD Dbatrict in which they are to be processed; all other products are reported by the PAD District of entry.

- Includes crude oil ir"

c Includes ethyl tertary butyl other (ETBE), tertiary amyl methyl sither (TAME), tertiary butyl alcohol (TBA), and other alphatic alcohols and ethers intended for motor gasoline blending (0.9., isopropyl ether (IPE) or n-propanol).

(s) = Less than 500 barrels per day.

Note: Totals may not equal sum of components due to independent rounding.

Source: Erergy Information Administration (EIA) Form ELA-614, "Monthly Imports Reporn." 
Table 35. Imports of Crude Oll and Petroleum Products Into the United States by Country of Origin," Fobruary 1994 (Thousand Barrels)

\begin{tabular}{|c|c|c|c|c|c|c|c|c|c|c|}
\hline Country of Origin & $\begin{array}{c}\text { Crude } \\
\text { Q11 }\end{array}$ & $\begin{array}{l}\text { Liqualled } \\
\text { Potroloum } \\
\text { enees }\end{array}$ & $\begin{array}{c}\text { Unfinishad } \\
\text { Oile }\end{array}$ & $\begin{array}{l}\text { Casoline } \\
\text { Blonding } \\
\text { Compo- } \\
\text { nente }\end{array}$ & $\begin{array}{l}\text { Finished } \\
\text { Motor } \\
\text { Casoline }\end{array}$ & Set Fuel & $\begin{array}{l}\text { Dietillate } \\
\text { Fuel OII }\end{array}$ & $\begin{array}{l}\text { Posidual } \\
\text { Fuel OII }\end{array}$ & Keroesene & $\begin{array}{l}\text { Epoolal } \\
\text { Nophthes }\end{array}$ \\
\hline 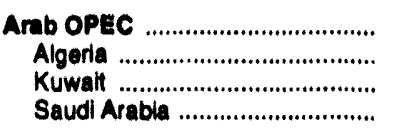 & $\begin{array}{r}41,037 \\
573 \\
11,838 \\
28,656\end{array}$ & $\begin{array}{r}198 \\
198 \\
0 \\
0\end{array}$ & $\begin{array}{r}1,482 \\
470 \\
0 \\
882\end{array}$ & $\begin{array}{l}0 \\
0 \\
0 \\
0\end{array}$ & $\begin{array}{l}0 \\
0 \\
0 \\
0\end{array}$ & $\begin{array}{r}377 \\
225 \\
0 \\
152\end{array}$ & $\begin{array}{r}198 \\
196 \\
0 \\
0\end{array}$ & $\begin{array}{r}875 \\
875 \\
0 \\
0\end{array}$ & $\begin{array}{r}228 \\
228 \\
0 \\
0\end{array}$ & $\begin{array}{l}0 \\
0 \\
0 \\
0\end{array}$ \\
\hline 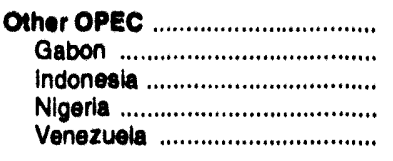 & $\begin{array}{r}49,858 \\
5,817 \\
1,650 \\
15,601 \\
26,490\end{array}$ & $\begin{array}{l}0 \\
0 \\
0 \\
0 \\
0\end{array}$ & $\begin{array}{r}809 \\
0 \\
0 \\
0 \\
889\end{array}$ & $\begin{array}{r}46 \\
0 \\
0 \\
0 \\
46\end{array}$ & $\begin{array}{r}927 \\
0 \\
0 \\
0 \\
927\end{array}$ & $\begin{array}{r}1,838 \\
0 \\
1 \\
0 \\
1,837\end{array}$ & $\begin{array}{r}1,471 \\
0 \\
0 \\
0 \\
1,471\end{array}$ & $\begin{array}{r}3,427 \\
111 \\
1,210 \\
534 \\
1,572\end{array}$ & $\begin{array}{l}0 \\
0 \\
0 \\
0 \\
0\end{array}$ & $\begin{array}{l}0 \\
0 \\
0 \\
0 \\
0\end{array}$ \\
\hline 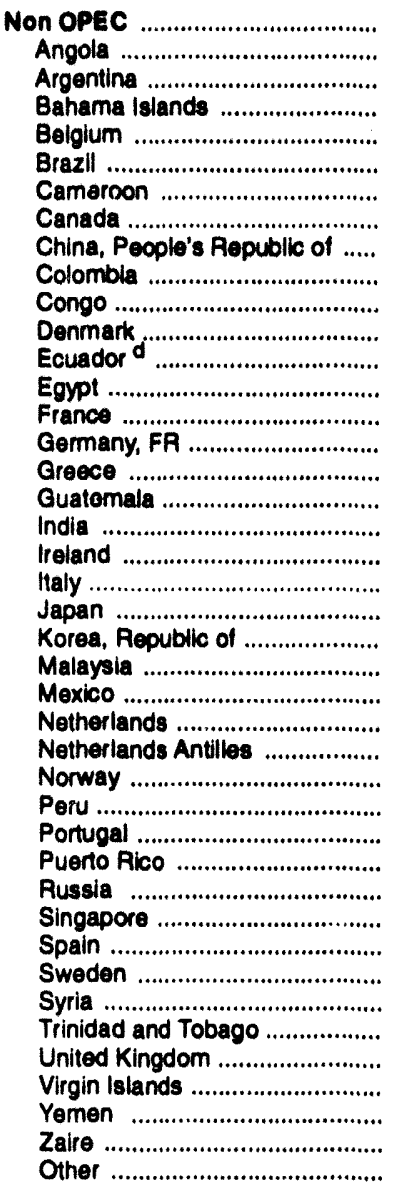 & $\begin{array}{r}86,149 \\
7,690 \\
0 \\
0 \\
0 \\
0 \\
0 \\
27,819 \\
1,243 \\
3,672 \\
530 \\
0 \\
2,697 \\
1,195 \\
0 \\
0 \\
0 \\
222 \\
0 \\
0 \\
0 \\
0 \\
0 \\
406 \\
25,919 \\
0 \\
0 \\
4,650 \\
0 \\
0 \\
0 \\
0 \\
0 \\
0 \\
0 \\
0 \\
2,250 \\
6,502 \\
0 \\
0 \\
697 \\
457\end{array}$ & $\begin{array}{r}4,909 \\
0 \\
0 \\
0 \\
0 \\
0 \\
0 \\
3,669 \\
0 \\
0 \\
0 \\
0 \\
0 \\
0 \\
17 \\
0 \\
0 \\
0 \\
0 \\
0 \\
0 \\
0 \\
0 \\
0 \\
274 \\
0 \\
25 \\
573 \\
0 \\
0 \\
0 \\
0 \\
0 \\
0 \\
0 \\
0 \\
0 \\
351 \\
0 \\
0 \\
0 \\
0\end{array}$ & $\begin{array}{r}9,498 \\
0 \\
0 \\
0 \\
516 \\
0 \\
0 \\
103 \\
0 \\
271 \\
0 \\
0 \\
0 \\
0 \\
861 \\
326 \\
0 \\
0 \\
265 \\
0 \\
0 \\
0 \\
1,319 \\
0 \\
0 \\
404 \\
1,107 \\
191 \\
142 \\
656 \\
0 \\
0 \\
460 \\
442 \\
0 \\
231 \\
0 \\
463 \\
1,442 \\
296 \\
0 \\
?\end{array}$ & $\begin{array}{r}190 \\
0 \\
0 \\
0 \\
0 \\
0 \\
0 \\
0 \\
1 \\
0 \\
0 \\
0 \\
0 \\
0 \\
0 \\
0 \\
0 \\
0 \\
0 \\
0 \\
0 \\
0 \\
0 \\
0 \\
0 \\
0 \\
0 \\
0 \\
0 \\
0 \\
0 \\
0 \\
0 \\
0 \\
0 \\
0 \\
0 \\
0 \\
0 \\
0 \\
0 \\
0 \\
0 \\
0 \\
0 \\
0 \\
0 \\
184 \\
0 \\
0 \\
0\end{array}$ & $\begin{array}{r}6,93: \\
0 \\
0 \\
0 \\
0 \\
299 \\
0 \\
1,678 \\
0 \\
0 \\
0 \\
0 \\
0 \\
0 \\
283 \\
0 \\
335 \\
0 \\
0 \\
0 \\
968 \\
0 \\
0 \\
0 \\
0 \\
0 \\
261 \\
0 \\
0 \\
0 \\
0 \\
0 \\
0 \\
0 \\
0 \\
0 \\
0 \\
4799 \\
0 \\
0 \\
258\end{array}$ & $\begin{array}{r}1,637 \\
0 \\
0 \\
0 \\
0 \\
0 \\
0 \\
110 \\
0 \\
0 \\
0 \\
0 \\
0 \\
0 \\
0 \\
0 \\
0 \\
0 \\
0 \\
0 \\
0 \\
0 \\
0 \\
0 \\
32 \\
0 \\
215 \\
0 \\
0 \\
0 \\
0 \\
0 \\
0 \\
0 \\
0 \\
0 \\
0 \\
0 \\
1,280 \\
0 \\
0 \\
0\end{array}$ & $\begin{array}{r}6,054 \\
0 \\
0 \\
0 \\
0 \\
36 \\
0 \\
2,654 \\
0 \\
0 \\
0 \\
0 \\
0 \\
0 \\
0 \\
197 \\
0 \\
0 \\
0 \\
156 \\
0 \\
0 \\
0 \\
0 \\
0 \\
0 \\
198 \\
0 \\
0 \\
0 \\
0 \\
379 \\
0 \\
0 \\
0 \\
0 \\
0 \\
0 \\
2,434 \\
0 \\
0 \\
0\end{array}$ & $\begin{array}{r}12,000 \\
357 \\
0 \\
2,207 \\
458 \\
0 \\
143 \\
524 \\
0 \\
1,217 \\
717 \\
142 \\
0 \\
0 \\
0 \\
328 \\
0 \\
0 \\
0 \\
0 \\
0 \\
0 \\
0 \\
0 \\
222 \\
433 \\
1,530 \\
156 \\
180 \\
0 \\
0 \\
0 \\
0 \\
436 \\
192 \\
0 \\
329 \\
330 \\
2,128 \\
0 \\
0 \\
69\end{array}$ & $\begin{array}{r}137 \\
0 \\
0 \\
0 \\
0 \\
0 \\
0 \\
27 \\
0 \\
0 \\
0 \\
0 \\
0 \\
0 \\
0 \\
0 \\
0 \\
0 \\
0 \\
25 \\
0 \\
0 \\
0 \\
0 \\
85 \\
0 \\
0 \\
0 \\
0 \\
0 \\
0 \\
0 \\
0 \\
0 \\
0 \\
0 \\
0 \\
0 \\
0 \\
0 \\
0 \\
0\end{array}$ & $\begin{array}{r}180 \\
0 \\
0 \\
0 \\
0 \\
0 \\
0 \\
159 \\
0 \\
0 \\
0 \\
0 \\
0 \\
0 \\
0 \\
0 \\
0 \\
0 \\
0 \\
0 \\
0 \\
0 \\
0 \\
0 \\
0 \\
0 \\
0 \\
0 \\
0 \\
0 \\
0 \\
0 \\
0 \\
0 \\
0 \\
0 \\
0 \\
0 \\
0 \\
0 \\
0 \\
0\end{array}$ \\
\hline Total & 176,774 & 5,107 & 11,830 & 231 & 7,858 & 3,652 & 7,720 & 16,400 & 385 & 180 \\
\hline 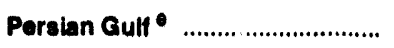 & 40,494 & 0 & 892 & $\mathbf{0}$ & 0 & 152 & 0 & 0 & 0 & 0 \\
\hline
\end{tabular}

See fooinotes at end of table. 


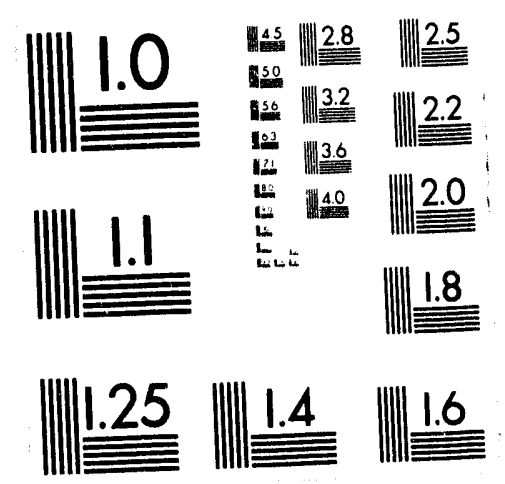



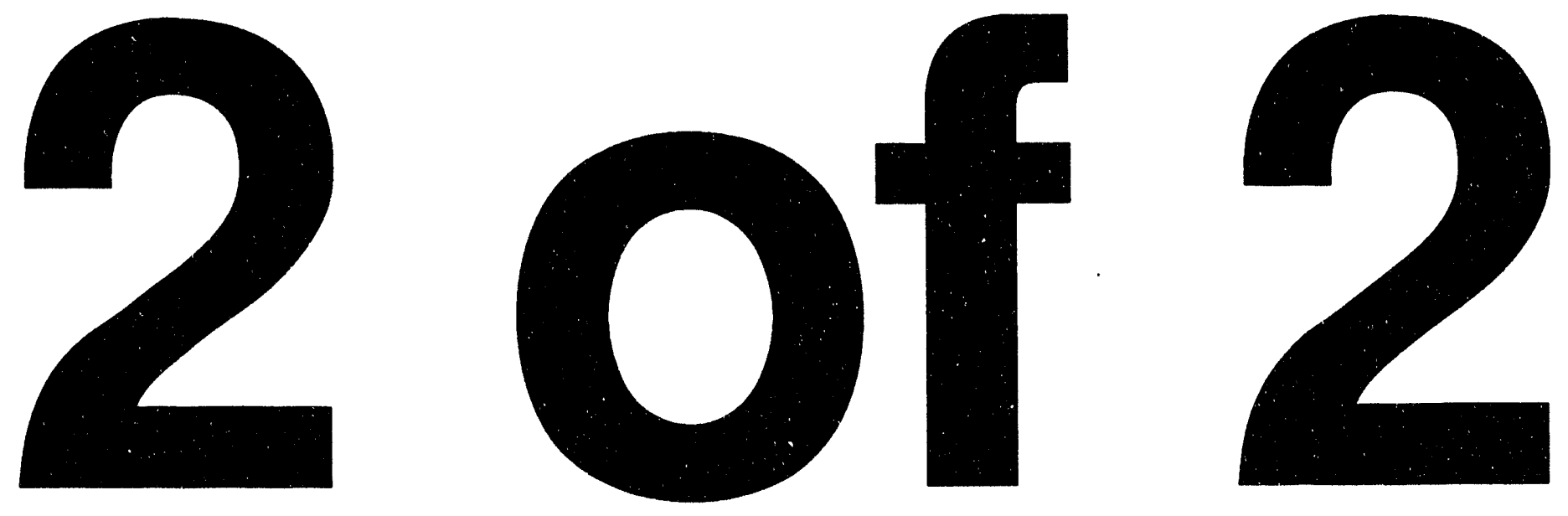
Table 35. Imports of Crude Oil and Petroleum Products into the United States by Country of Origin, ${ }^{a}$ February 1994 (Continued) (Thousand Barrels)

\begin{tabular}{|c|c|c|c|c|c|c|c|c|c|c|}
\hline \multirow[b]{2}{*}{ Country of Origin } & \multirow[b]{2}{*}{$\begin{array}{l}\text { Naphtha for } \\
\text { Petrochemical } \\
\text { Foedstock } \\
\text { Use }\end{array}$} & \multirow[b]{2}{*}{$\begin{array}{c}\text { Other Oils for } \\
\text { Petrochemical } \\
\text { Foedstock } \\
\text { Use }\end{array}$} & \multirow[b]{2}{*}{ Lubricants } & \multirow[b]{2}{*}{$\begin{array}{c}\text { Asphath and } \\
\text { Road OII }\end{array}$} & \multirow[b]{2}{*}{$\begin{array}{c}\text { Other } \\
\text { Products }\end{array}$} & \multirow[b]{2}{*}{$\begin{array}{c}\text { Total } \\
\text { Products }\end{array}$} & \multirow[b]{2}{*}{$\begin{array}{c}\text { Total } \\
\text { Crude Oil } \\
\text { and } \\
\text { Products }\end{array}$} & \multicolumn{3}{|c|}{ Daily Average } \\
\hline & & & & & & & & $\begin{array}{c}\text { Crude } \\
\text { Oll }\end{array}$ & Products & Total \\
\hline 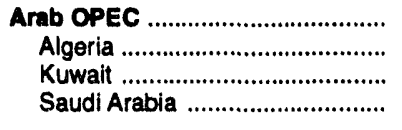 & $\begin{array}{r}95 \\
0 \\
0 \\
95\end{array}$ & $\begin{array}{r}3,038 \\
3,038 \\
0 \\
0\end{array}$ & $\begin{array}{l}0 \\
0 \\
0 \\
0\end{array}$ & $\begin{array}{l}0 \\
0 \\
0 \\
0\end{array}$ & $\begin{array}{r}618 \\
528 \\
0 \\
90\end{array}$ & $\begin{array}{r}7,076 \\
5,757 \\
0 \\
1,319\end{array}$ & $\begin{array}{r}48,143 \\
6,330 \\
11,838 \\
29,975\end{array}$ & $\begin{array}{r}1,467 \\
20 \\
423 \\
1,023\end{array}$ & $\begin{array}{r}253 \\
206 \\
0 \\
47\end{array}$ & $\begin{array}{r}1,719 \\
226 \\
423 \\
1,071\end{array}$ \\
\hline 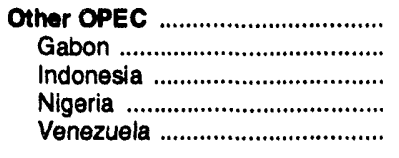 & $\begin{array}{l}0 \\
0 \\
0 \\
0 \\
0\end{array}$ & $\begin{array}{l}0 \\
0 \\
0 \\
0 \\
0\end{array}$ & $\begin{array}{l}0 \\
0 \\
0 \\
0 \\
0\end{array}$ & $\begin{array}{r}243 \\
0 \\
0 \\
0 \\
243\end{array}$ & $\begin{array}{r}245 \\
0 \\
9 \\
0 \\
236\end{array}$ & $\begin{array}{r}9,086 \\
111 \\
1,220 \\
534 \\
7,221\end{array}$ & $\begin{array}{r}58,644 \\
5,928 \\
2,870 \\
16,135 \\
33,711\end{array}$ & $\begin{array}{r}1,770 \\
208 \\
59 \\
557 \\
946\end{array}$ & $\begin{array}{r}325 \\
4 \\
44 \\
19 \\
258\end{array}$ & $\begin{array}{r}2,094 \\
212 \\
103 \\
576 \\
1,204\end{array}$ \\
\hline 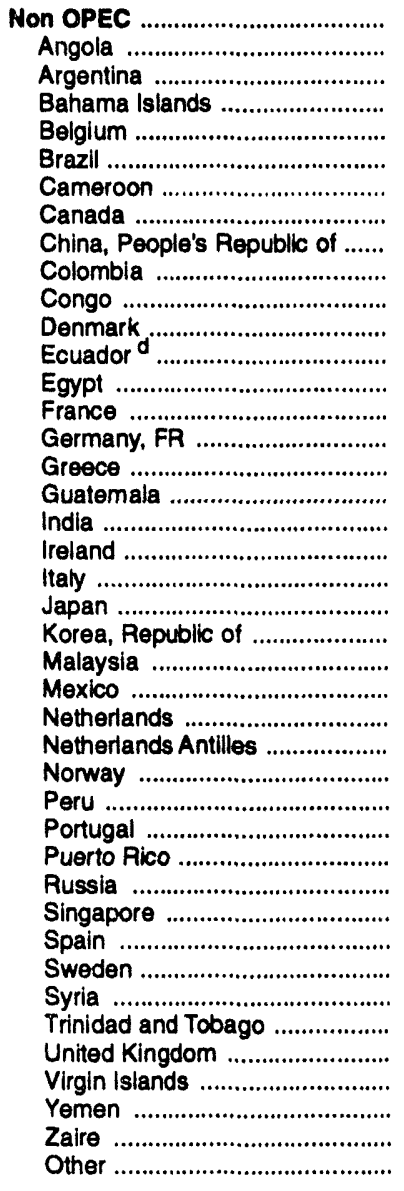 & 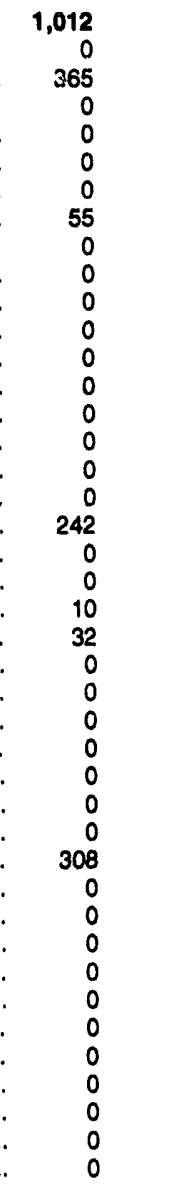 & $\begin{array}{r}260 \\
0 \\
0 \\
0 \\
0 \\
0 \\
0 \\
260 \\
0 \\
0 \\
0 \\
0 \\
0 \\
0 \\
0 \\
0 \\
0 \\
0 \\
0 \\
0 \\
0 \\
0 \\
0 \\
0 \\
0 \\
0 \\
0 \\
0 \\
0 \\
0 \\
0 \\
0 \\
0 \\
0 \\
0 \\
0 \\
0 \\
0 \\
0 \\
0 \\
0 \\
0\end{array}$ & $\begin{array}{r}\mathbf{5 5} \\
0 \\
0 \\
0 \\
0 \\
0 \\
0 \\
\mathbf{5 5} \\
0 \\
0 \\
0 \\
0 \\
0 \\
0 \\
0 \\
0 \\
0 \\
0 \\
0 \\
0 \\
0 \\
0 \\
0 \\
0 \\
0 \\
0 \\
0 \\
0 \\
0 \\
0 \\
0 \\
0 \\
0 \\
0 \\
0 \\
0 \\
0 \\
0 \\
0 \\
0 \\
0 \\
0\end{array}$ & $\begin{array}{r}236 \\
0 \\
0 \\
0 \\
0 \\
0 \\
0 \\
236 \\
0 \\
0 \\
0 \\
0 \\
0 \\
0 \\
0 \\
0 \\
0 \\
0 \\
0 \\
0 \\
0 \\
0 \\
0 \\
0 \\
0 \\
0 \\
0 \\
0 \\
0 \\
0 \\
0 \\
0 \\
0 \\
0 \\
0 \\
0 \\
0 \\
0 \\
0 \\
0 \\
0 \\
0\end{array}$ & $\begin{array}{r}1,919 \\
0 \\
0 \\
0 \\
0 \\
0 \\
0 \\
838 \\
0 \\
0 \\
0 \\
0 \\
0 \\
0 \\
0 \\
5 \\
0 \\
0 \\
0 \\
0 \\
0 \\
2 \\
25 \\
133 \\
557 \\
353 \\
0 \\
0 \\
0 \\
0 \\
0 \\
0 \\
0 \\
0 \\
0 \\
0 \\
0 \\
0 \\
0 \\
0 \\
0 \\
6\end{array}$ & $\begin{array}{r}45,087 \\
357 \\
365 \\
2,207 \\
974 \\
335 \\
143 \\
10,369 \\
0 \\
1,488 \\
717 \\
142 \\
0 \\
0 \\
1,161 \\
856 \\
335 \\
0 \\
507 \\
181 \\
968 \\
12 \\
1,376 \\
133 \\
1,170 \\
1,190 \\
3,336 \\
920 \\
322 \\
656 \\
308 \\
379 \\
460 \\
878 \\
192 \\
231 \\
329 \\
1,623 \\
9,838 \\
296 \\
0 \\
333 \\
\end{array}$ & $\begin{array}{r}131,236 \\
8,247 \\
365 \\
2,207 \\
974 \\
335 \\
143 \\
38,188 \\
1,243 \\
5,160 \\
1,247 \\
142 \\
2,697 \\
1,195 \\
1,161 \\
856 \\
335 \\
222 \\
507 \\
181 \\
968 \\
12 \\
1,376 \\
539 \\
27,089 \\
1,190 \\
3,336 \\
5,570 \\
322 \\
656 \\
308 \\
379 \\
460 \\
878 \\
192 \\
231 \\
2,579 \\
8,125 \\
9,838 \\
296 \\
697 \\
790\end{array}$ & $\begin{array}{r}3,077 \\
282 \\
0 \\
0 \\
0 \\
0 \\
0 \\
994 \\
44 \\
131 \\
19 \\
0 \\
96 \\
43 \\
0 \\
0 \\
0 \\
8 \\
0 \\
0 \\
0 \\
0 \\
0 \\
15 \\
926 \\
0 \\
0 \\
166 \\
0 \\
0 \\
0 \\
0 \\
0 \\
0 \\
0 \\
0 \\
80 \\
232 \\
0 \\
0 \\
25 \\
16\end{array}$ & $\begin{array}{r}1,610 \\
13 \\
13 \\
79 \\
35 \\
12 \\
5 \\
370 \\
0 \\
53 \\
26 \\
5 \\
0 \\
0 \\
41 \\
31 \\
12 \\
0 \\
18 \\
6 \\
35 \\
(s) \\
49 \\
5 \\
42 \\
43 \\
119 \\
33 \\
12 \\
23 \\
11 \\
14 \\
16 \\
31 \\
7 \\
8 \\
12 \\
58 \\
351 \\
11 \\
0 \\
12\end{array}$ & $\begin{array}{r}4,687 \\
295 \\
13 \\
79 \\
35 \\
12 \\
5 \\
5 \\
1,364 \\
44 \\
184 \\
45 \\
5 \\
96 \\
43 \\
43 \\
41 \\
31 \\
12 \\
8 \\
18 \\
6 \\
35 \\
(\mathbf{s}) \\
49 \\
19 \\
967 \\
43 \\
119 \\
199 \\
12 \\
23 \\
11 \\
14 \\
16 \\
31 \\
7 \\
8 \\
92 \\
290 \\
351 \\
11 \\
25 \\
28\end{array}$ \\
\hline Total & . 1,107 & 3,298 & 55 & 479 & 2,782 & 61,249 & 238,023 & 6,313 & 2,187 & 8,501 \\
\hline 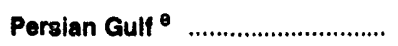 & 95 & 0 & 0 & 0 & 90 & 1,319 & 41,813 & 1,446 & 47 & 1,493 \\
\hline
\end{tabular}

\footnotetext{
a Crude oil and unfinished oils are reported by the PAD District in which they are to be processed; all other products are reported by the PAD District of entry.

b Includes crude oil imported for storage in the Strategic Petroleum Reserve.

c Includes aviation gasoline, aviation gasoline blending components, miscellaneous products, other hydrocarbons and oxygenates, pentanes plus, petroleum coke, and waxes. Sources.

On December 31, 1992, Ecuador withdrew as a mernber of OPEC. As of January 1, 1994, imports of petroleum from Ecuador appear under imports from Non-OPEC

$\theta$ Includes Bahrain, Iran, Iraq, Kuwait, Qatar, Saudi Arabla, and United Arab Emirates.

(s) $=$ Less than 500 barrels per day.

Note: Totals may not equal sum of components due to independent rounding.

Source: Energy Information Administration (EIA) Form ElA-814, "Monthly Imports Report."
} 
Table 36. PAD District $\longmapsto$ Imports of Crude Oil and Petroleum Products by Country of Origin, ${ }^{a}$ February 1994 (Thousand Barrels)

\begin{tabular}{|c|c|c|c|c|c|c|c|c|c|c|}
\hline Country of Origin & $\begin{array}{c}\text { Crude } \\
\text { Oil }^{b}\end{array}$ & $\begin{array}{c}\text { Liquefled } \\
\text { Petroleum } \\
\text { Gases } \\
\end{array}$ & $\begin{array}{c}\text { Untinished } \\
\text { Olls }\end{array}$ & $\begin{array}{l}\text { Gasoline } \\
\text { Blending } \\
\text { Compo- } \\
\text { nents } \\
\end{array}$ & $\begin{array}{l}\text { Finished } \\
\text { Motor } \\
\text { Gasoline }\end{array}$ & Jet Fuel & $\begin{array}{l}\text { Distillate } \\
\text { Fuel Oil }\end{array}$ & $\begin{array}{l}\text { Residual } \\
\text { Fuel Oil }\end{array}$ & Kerosene & $\begin{array}{c}\text { Special } \\
\text { Naphthas } \\
\end{array}$ \\
\hline 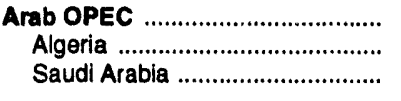 & $\begin{array}{r}4,763 \\
0 \\
4,763\end{array}$ & $\begin{array}{r}198 \\
198 \\
0\end{array}$ & $\begin{array}{r}321 \\
321 \\
0\end{array}$ & $\begin{array}{l}0 \\
0 \\
0\end{array}$ & $\begin{array}{l}0 \\
0 \\
0\end{array}$ & $\begin{array}{l}377 \\
225 \\
152\end{array}$ & $\begin{array}{r}195 \\
195 \\
0\end{array}$ & $\begin{array}{r}832 \\
832 \\
0\end{array}$ & $\begin{array}{r}228 \\
228 \\
0\end{array}$ & $\begin{array}{l}0 \\
0 \\
0\end{array}$ \\
\hline 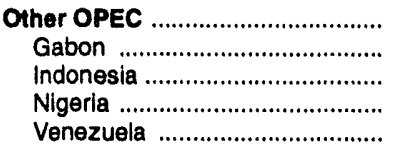 & $\begin{array}{r}18,014 \\
4,892 \\
0 \\
9,236 \\
3,886\end{array}$ & $\begin{array}{l}0 \\
0 \\
0 \\
0 \\
0\end{array}$ & $\begin{array}{l}0 \\
0 \\
0 \\
0 \\
0\end{array}$ & $\begin{array}{l}0 \\
0 \\
0 \\
0 \\
0\end{array}$ & $\begin{array}{r}927 \\
0 \\
0 \\
0 \\
927\end{array}$ & $\begin{array}{r}1,837 \\
0 \\
0 \\
0 \\
1,837\end{array}$ & $\begin{array}{r}1,471 \\
0 \\
0 \\
0 \\
1,471\end{array}$ & $\begin{array}{r}3,111 \\
111 \\
1,210 \\
534 \\
1,256\end{array}$ & $\begin{array}{l}0 \\
0 \\
0 \\
0 \\
0\end{array}$ & $\begin{array}{l}0 \\
0 \\
0 \\
0 \\
0\end{array}$ \\
\hline 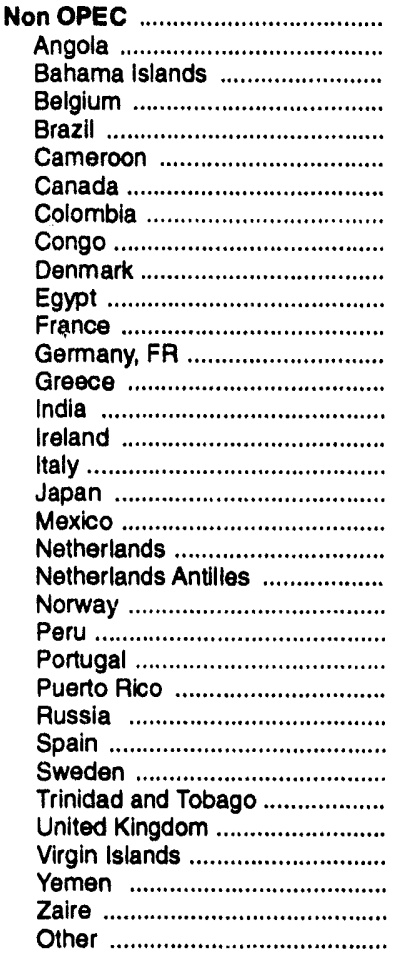 & $\begin{array}{r}16,686 \\
4,009 \\
0 \\
0 \\
0 \\
0 \\
1,605 \\
525 \\
0 \\
0 \\
702 \\
0 \\
0 \\
0 \\
0 \\
0 \\
0 \\
0 \\
1,495 \\
0 \\
0 \\
4,650 \\
0 \\
0 \\
0 \\
0 \\
0 \\
0 \\
0 \\
3,003 \\
0 \\
0 \\
697 \\
0\end{array}$ & $\begin{array}{r}1,335 \\
0 \\
0 \\
0 \\
0 \\
0 \\
411 \\
0 \\
0 \\
0 \\
0 \\
0 \\
0 \\
0 \\
0 \\
0 \\
0 \\
0 \\
0 \\
0 \\
0 \\
573 \\
0 \\
0 \\
0 \\
0 \\
0 \\
0 \\
0 \\
351 \\
0 \\
0 \\
0 \\
0\end{array}$ & $\begin{array}{r}4,794 \\
0 \\
0 \\
344 \\
0 \\
0 \\
0 \\
0 \\
0 \\
0 \\
0 \\
170 \\
326 \\
0 \\
265 \\
0 \\
0 \\
0 \\
0 \\
217 \\
445 \\
191 \\
0 \\
656 \\
0 \\
0 \\
442 \\
0 \\
0 \\
0 \\
1,442 \\
296 \\
0 \\
0\end{array}$ & $\begin{array}{r}189 \\
0 \\
0 \\
0 \\
0 \\
0 \\
0 \\
0 \\
0 \\
0 \\
0 \\
0 \\
0 \\
0 \\
0 \\
0 \\
0 \\
0 \\
0 \\
0 \\
0 \\
0 \\
0 \\
0 \\
0 \\
0 \\
0 \\
0 \\
0 \\
0 \\
0 \\
0 \\
0 \\
0 \\
0 \\
0 \\
0 \\
184 \\
0 \\
0 \\
0\end{array}$ & $\begin{array}{r}6,841 \\
0 \\
0 \\
0 \\
299 \\
0 \\
1,588 \\
0 \\
0 \\
0 \\
0 \\
283 \\
0 \\
335 \\
0 \\
0 \\
968 \\
0 \\
0 \\
0 \\
261 \\
0 \\
0 \\
0 \\
0 \\
0 \\
0 \\
0 \\
0 \\
479 \\
2,370 \\
0 \\
0 \\
258\end{array}$ & $\begin{array}{r}1,570 \\
0 \\
0 \\
0 \\
0 \\
0 \\
75 \\
0 \\
0 \\
0 \\
0 \\
0 \\
0 \\
0 \\
0 \\
0 \\
0 \\
0 \\
0 \\
0 \\
215 \\
0 \\
0 \\
0 \\
0 \\
0 \\
0 \\
0 \\
0 \\
0 \\
1,280 \\
0 \\
0 \\
0\end{array}$ & $\begin{array}{r}5,691 \\
0 \\
0 \\
0 \\
36 \\
0 \\
2,291 \\
0 \\
0 \\
0 \\
0 \\
0 \\
197 \\
0 \\
0 \\
156 \\
0 \\
0 \\
0 \\
0 \\
198 \\
0 \\
0 \\
0 \\
0 \\
379 \\
0 \\
0 \\
0 \\
0 \\
2,434 \\
0 \\
0 \\
0\end{array}$ & $\begin{array}{r}11,813 \\
357 \\
2,207 \\
458 \\
0 \\
143 \\
461 \\
1,217 \\
717 \\
142 \\
0 \\
0 \\
328 \\
0 \\
0 \\
0 \\
0 \\
0 \\
0 \\
433 \\
1,530 \\
156 \\
180 \\
0 \\
0 \\
0 \\
436 \\
192 \\
329 \\
330 \\
2,128 \\
0 \\
0 \\
69\end{array}$ & $\begin{array}{r}52 \\
0 \\
0 \\
0 \\
0 \\
0 \\
27 \\
0 \\
0 \\
0 \\
0 \\
0 \\
0 \\
0 \\
0 \\
25 \\
0 \\
0 \\
0 \\
0 \\
0 \\
0 \\
0 \\
0 \\
0 \\
0 \\
0 \\
0 \\
0 \\
0 \\
0 \\
0 \\
0 \\
0\end{array}$ & $\begin{array}{r}44 \\
0 \\
0 \\
0 \\
0 \\
0 \\
44 \\
0 \\
0 \\
0 \\
0 \\
0 \\
0 \\
0 \\
0 \\
0 \\
0 \\
0 \\
0 \\
0 \\
0 \\
0 \\
0 \\
0 \\
0 \\
0 \\
0 \\
0 \\
0 \\
0 \\
0 \\
0 \\
0 \\
0\end{array}$ \\
\hline Total & 38,463 & 1,533 & 5,115 & 184 & 7,768 & 3,784 & 7,357 & 15,756 & 280 & 44 \\
\hline 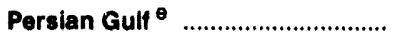 & 4,763 & 0 & 0 & 0 & 0 & 152 & 0 & 0 & 0 & $\mathbf{0}$ \\
\hline
\end{tabular}

See footnotes at end of table. 
Table 36. PAD District $1-$ imports of Crude Oil and Petroleum Products by Country of Origin, ${ }^{a}$ February 1994 (Continued)

(Thousand Barrels)

\begin{tabular}{|c|c|c|c|c|c|c|c|c|c|c|}
\hline \multirow[b]{2}{*}{ Country of Origin } & \multirow[b]{2}{*}{$\begin{array}{c}\text { Naphtha for } \\
\text { Petrochemical } \\
\text { Feedstock } \\
\text { Use }\end{array}$} & \multirow[b]{2}{*}{$\begin{array}{c}\text { Other Oils for } \\
\text { Petrochemical } \\
\text { Feedstock } \\
\text { Use }\end{array}$} & \multirow[b]{2}{*}{ Lubricants } & \multirow[b]{2}{*}{$\begin{array}{c}\text { Asphatt and } \\
\text { Road Oll }\end{array}$} & \multirow[b]{2}{*}{$\begin{array}{c}\text { Other } \\
\text { Products }\end{array}$} & \multirow[b]{2}{*}{$\begin{array}{c}\text { Total } \\
\text { Products }\end{array}$} & \multirow[b]{2}{*}{$\begin{array}{l}\text { Total } \\
\text { Crude Oil } \\
\text { and } \\
\text { Products }\end{array}$} & \multicolumn{3}{|c|}{ Daily Average } \\
\hline & & & & & & & & $\begin{array}{c}\text { Crude } \\
\text { Oil }\end{array}$ & Products & Tota \\
\hline 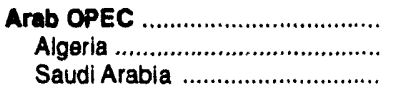 & $\begin{array}{l}0 \\
0 \\
0\end{array}$ & $\begin{array}{l}0 \\
0 \\
0\end{array}$ & $\begin{array}{l}0 \\
0 \\
0\end{array}$ & $\begin{array}{l}0 \\
0 \\
0\end{array}$ & $\begin{array}{r}90 \\
0 \\
90\end{array}$ & $\begin{array}{r}2,241 \\
1,999 \\
242\end{array}$ & $\begin{array}{l}7,004 \\
1,999 \\
5,005\end{array}$ & $\begin{array}{r}170 \\
0 \\
170\end{array}$ & $\begin{array}{r}80 \\
71 \\
9\end{array}$ & $\begin{array}{r}250 \\
71 \\
179\end{array}$ \\
\hline 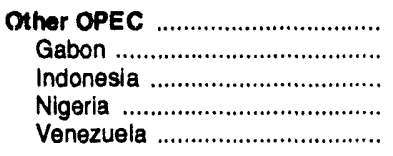 & $\begin{array}{l}0 \\
0 \\
0 \\
0 \\
0\end{array}$ & $\begin{array}{l}0 \\
0 \\
0 \\
0 \\
0\end{array}$ & $\begin{array}{l}0 \\
0 \\
0 \\
0 \\
0\end{array}$ & $\begin{array}{r}243 \\
0 \\
0 \\
0 \\
243\end{array}$ & $\begin{array}{l}0 \\
0 \\
0 \\
0 \\
0\end{array}$ & $\begin{array}{r}7,589 \\
111 \\
1.210 \\
534 \\
5,734\end{array}$ & $\begin{array}{r}25,603 \\
5,003 \\
1,210 \\
9,770 \\
9,620\end{array}$ & $\begin{array}{r}643 \\
175 \\
0 \\
330 \\
139\end{array}$ & $\begin{array}{r}271 \\
4 \\
43 \\
19 \\
205\end{array}$ & $\begin{array}{r}914 \\
179 \\
43 \\
349 \\
344\end{array}$ \\
\hline 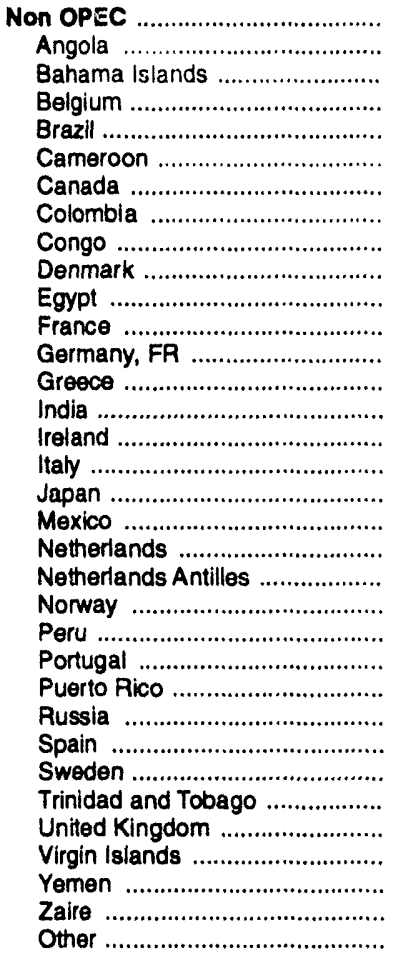 & $\begin{array}{r}195 \\
0 \\
0 \\
0 \\
0 \\
0 \\
7 \\
0 \\
0 \\
0 \\
0 \\
0 \\
0 \\
0 \\
0 \\
0 \\
0 \\
0 \\
0 \\
0 \\
0 \\
0 \\
0 \\
0 \\
188 \\
0 \\
0 \\
0 \\
0 \\
0 \\
0 \\
0 \\
0 \\
0\end{array}$ & $\begin{array}{l}0 \\
0 \\
0 \\
0 \\
0 \\
0 \\
0 \\
0 \\
0 \\
0 \\
0 \\
0 \\
0 \\
0 \\
0 \\
0 \\
0 \\
0 \\
0 \\
0 \\
0 \\
0 \\
0 \\
0 \\
0 \\
0 \\
0 \\
0 \\
0 \\
0 \\
0 \\
0 \\
0 \\
0\end{array}$ & $\begin{array}{r}37 \\
0 \\
0 \\
0 \\
0 \\
0 \\
37 \\
0 \\
0 \\
0 \\
0 \\
0 \\
0 \\
0 \\
0 \\
0 \\
0 \\
0 \\
0 \\
0 \\
0 \\
0 \\
0 \\
0 \\
0 \\
0 \\
0 \\
0 \\
0 \\
0 \\
0 \\
0 \\
0 \\
0\end{array}$ & $\begin{array}{r}216 \\
0 \\
0 \\
0 \\
0 \\
0 \\
216 \\
0 \\
0 \\
0 \\
0 \\
0 \\
0 \\
0 \\
0 \\
0 \\
0 \\
0 \\
0 \\
0 \\
0 \\
0 \\
0 \\
0 \\
0 \\
0 \\
0 \\
0 \\
0 \\
0 \\
0 \\
0 \\
0 \\
0\end{array}$ & $\begin{array}{r}498 \\
0 \\
0 \\
0 \\
0 \\
0 \\
14 \\
0 \\
0 \\
0 \\
0 \\
0 \\
3 \\
0 \\
0 \\
0 \\
0 \\
2 \\
123 \\
353 \\
0 \\
0 \\
0 \\
0 \\
0 \\
0 \\
0 \\
0 \\
0 \\
0 \\
0 \\
0 \\
0 \\
3\end{array}$ & $\begin{array}{r}33,270 \\
357 \\
2,207 \\
802 \\
335 \\
143 \\
5,171 \\
1,217 \\
717 \\
142 \\
0 \\
453 \\
854 \\
335 \\
265 \\
181 \\
968 \\
2 \\
123 \\
1,003 \\
2,649 \\
920 \\
180 \\
656 \\
188 \\
379 \\
878 \\
192 \\
329 \\
1,160 \\
9,838 \\
296 \\
0 \\
330\end{array}$ & $\begin{array}{r}49,956 \\
4,366 \\
2,207 \\
802 \\
335 \\
143 \\
6,776 \\
1,742 \\
717 \\
142 \\
702 \\
453 \\
854 \\
335 \\
265 \\
181 \\
968 \\
2 \\
1,618 \\
1,003 \\
2,649 \\
5,570 \\
180 \\
656 \\
188 \\
379 \\
878 \\
192 \\
329 \\
4,163 \\
9,838 \\
296 \\
697 \\
330\end{array}$ & $\begin{array}{r}596 \\
143 \\
0 \\
0 \\
0 \\
0 \\
57 \\
19 \\
0 \\
0 \\
25 \\
0 \\
0 \\
0 \\
0 \\
0 \\
0 \\
0 \\
53 \\
0 \\
0 \\
166 \\
0 \\
0 \\
0 \\
0 \\
0 \\
0 \\
0 \\
107 \\
0 \\
0 \\
25 \\
0\end{array}$ & $\begin{array}{r}1,188 \\
13 \\
79 \\
29 \\
12 \\
5 \\
185 \\
43 \\
26 \\
5 \\
0 \\
16 \\
31 \\
12 \\
9 \\
6 \\
35 \\
(s) \\
4 \\
36 \\
95 \\
33 \\
6 \\
23 \\
7 \\
14 \\
31 \\
7 \\
12 \\
41 \\
351 \\
11 \\
0 \\
12\end{array}$ & $\begin{array}{r}1,784 \\
156 \\
79 \\
29 \\
12 \\
5 \\
242 \\
62 \\
26 \\
5 \\
25 \\
16 \\
31 \\
12 \\
9 \\
6 \\
35 \\
(\mathrm{~s}) \\
58 \\
36 \\
95 \\
199 \\
6 \\
23 \\
7 \\
14 \\
31 \\
7 \\
12 \\
149 \\
351 \\
11 \\
25 \\
12\end{array}$ \\
\hline Total & 195 & 0 & 37 & 459 & 588 & 43,100 & 82,563 & 1,409 & 1,539 & 2,949 \\
\hline Persian Gulf ${ }^{\circ}$............................... & $\mathbf{0}$ & 0 & 0 & 0 & 90 & 242 & 5,005 & 170 & 9 & 179 \\
\hline
\end{tabular}

\footnotetext{
a Crude oil and unfinished oils are reported by the PAD District in which they are to be processed; all other products are reported by the PAD District of entry.

Includes crude oil imported for storage in the Strategic Petroleum Reserve.

c includes aviation gasoline, aviation gasoline blending components, miscellaneous products, other hydrocarbons and oxygenates, pentanes plus, petroleum coke, and waxes.

On December 31, 1992, Ecuador withdrew as a member of OPEC. As of January 1, 1994, imports of petroleum from Ecuador appear under imports from Non-OPEC Sources.

- Includes Bahrain, Iran, Iraq, Kuwait, Qatar, Saudi Arabia, and United Arab Emirates

(s) = Less than 500 barrels per day.

Note: Totals may not equal sum of components due to independent rounding

Source: Energy Information Administration (EIA) Form EIA-814, "Monthly Imports Report."
} 
Table 37. PAD District II-Imports of Crude Oil and Petroleum Products by Country of Origin, ${ }^{a}$ February 1994

(Thousand Barrels)

\begin{tabular}{|c|c|c|c|c|c|c|c|c|c|c|}
\hline Country of Origin & $\begin{array}{c}\text { Crude } \\
\text { Oill }\end{array}$ & $\begin{array}{c}\text { Liquefied } \\
\text { Petroleum } \\
\text { Gases }\end{array}$ & $\begin{array}{c}\begin{array}{c}\text { Unfinished } \\
\text { Olls }\end{array} \\
\end{array}$ & $\begin{array}{c}\text { Gasoline } \\
\text { Blending } \\
\text { Compo- } \\
\text { nents }\end{array}$ & $\begin{array}{l}\text { Finished } \\
\text { Motor } \\
\text { Gasoline }\end{array}$ & Let Fuel & $\begin{array}{l}\text { Distillate } \\
\text { Fuel Oil }\end{array}$ & $\begin{array}{l}\text { Residual } \\
\text { Fuel Oil }\end{array}$ & Kerosene & $\begin{array}{c}\text { Special } \\
\text { Naphthas }\end{array}$ \\
\hline $\begin{array}{l}\text { Arab OPEC } \\
\text { Kuwait } \\
\text { Saudi Arabia }\end{array}$ & $\begin{array}{l}2,512 \\
1,113 \\
1,399\end{array}$ & $\begin{array}{l}0 \\
0 \\
0\end{array}$ & $\begin{array}{l}0 \\
0 \\
0\end{array}$ & $\begin{array}{l}0 \\
0 \\
0\end{array}$ & $\begin{array}{l}0 \\
0 \\
0\end{array}$ & $\begin{array}{l}0 \\
0 \\
0\end{array}$ & $\begin{array}{l}0 \\
0 \\
0\end{array}$ & $\begin{array}{l}0 \\
0 \\
0\end{array}$ & $\begin{array}{l}0 \\
0 \\
0\end{array}$ & $\begin{array}{l}0 \\
0 \\
0\end{array}$ \\
\hline 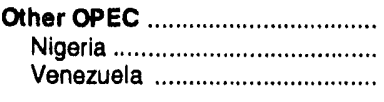 & $\begin{array}{l}\mathbf{5 , 4 7 7} \\
1,854 \\
3,623\end{array}$ & $\begin{array}{l}0 \\
0 \\
0\end{array}$ & $\begin{array}{l}0 \\
0 \\
0\end{array}$ & $\begin{array}{l}0 \\
0 \\
0\end{array}$ & $\begin{array}{l}0 \\
0 \\
0\end{array}$ & $\begin{array}{l}0 \\
0 \\
0\end{array}$ & $\begin{array}{l}0 \\
0 \\
0\end{array}$ & $\begin{array}{l}0 \\
0 \\
0\end{array}$ & $\begin{array}{l}0 \\
0 \\
0\end{array}$ & $\begin{array}{l}0 \\
0 \\
0\end{array}$ \\
\hline $\begin{array}{l}\text { Non OPEC } \\
\text { Canada } \\
\text { Colombia } \\
\text { Ecuador } \\
\text { Germany, FR } \\
\text { Mexico }\end{array}$ & $\begin{array}{r}26,556 \\
20,344 \\
526 \\
373 \\
0 \\
5,313\end{array}$ & $\begin{array}{r}2,849 \\
2,849 \\
0 \\
0 \\
0 \\
0\end{array}$ & $\begin{array}{r}26 \\
26 \\
0 \\
0 \\
0 \\
0\end{array}$ & $\begin{array}{l}1 \\
1 \\
0 \\
0 \\
0 \\
0\end{array}$ & $\begin{array}{r}64 \\
64 \\
0 \\
0 \\
0 \\
0\end{array}$ & $\begin{array}{r}33 \\
33 \\
0 \\
0 \\
0 \\
0\end{array}$ & $\begin{array}{r}244 \\
244 \\
0 \\
0 \\
0 \\
0\end{array}$ & $\begin{array}{l}16 \\
16 \\
0 \\
0 \\
0 \\
0\end{array}$ & $\begin{array}{l}0 \\
0 \\
0 \\
0 \\
0 \\
0\end{array}$ & $\begin{array}{r}68 \\
68 \\
0 \\
0 \\
0 \\
0\end{array}$ \\
\hline 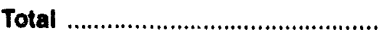 & 34,545 & 2,849 & 26 & 1 & 64 & 33 & 244 & 16 & 0 & 88 \\
\hline Persian Gulf ${ }^{\theta}$ & 2,512 & 0 & 0 & 0 & 0 & 0 & 0 & 0 & 0 & 0 \\
\hline
\end{tabular}

See footnotes at end of table. 
Table 37. PAD District I--Imports of Crude Oil and Petroleum Products by Country of Origin," February 1994 (Continued)

(Thousand Barrels)

\begin{tabular}{|c|c|c|c|c|c|c|c|c|c|c|}
\hline \multirow[b]{2}{*}{ Country of Origin } & \multirow[b]{2}{*}{$\begin{array}{c}\text { Naphtha for } \\
\text { Petrochemical } \\
\text { Feedstock } \\
\text { Use }\end{array}$} & \multirow[b]{2}{*}{$\begin{array}{c}\text { Other Oils for } \\
\text { Petrochemical } \\
\text { Feedstock } \\
\text { Use }\end{array}$} & \multirow[b]{2}{*}{ Lubricants } & \multirow[b]{2}{*}{$\begin{array}{c}\text { Asphatt and } \\
\text { Road Oil }\end{array}$} & \multirow[b]{2}{*}{$\begin{array}{c}\text { Other } \\
\text { Products }\end{array}$} & \multirow[b]{2}{*}{$\begin{array}{c}\text { Total } \\
\text { Products }\end{array}$} & \multirow[b]{2}{*}{$\begin{array}{l}\text { Total } \\
\text { Crude OII } \\
\text { and } \\
\text { Producte }\end{array}$} & \multicolumn{3}{|c|}{ Daily Average } \\
\hline & & & & & & & & $\begin{array}{c}\text { Crude } \\
\text { Oll }\end{array}$ & Products & Total \\
\hline 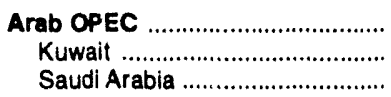 & $\begin{array}{l}0 \\
0 \\
0\end{array}$ & $\begin{array}{l}0 \\
0 \\
0\end{array}$ & $\begin{array}{l}0 \\
0 \\
0\end{array}$ & $\begin{array}{l}0 \\
0 \\
0\end{array}$ & $\begin{array}{l}0 \\
0 \\
0\end{array}$ & $\begin{array}{l}0 \\
0 \\
0\end{array}$ & $\begin{array}{l}2,512 \\
1,113 \\
1,399\end{array}$ & $\begin{array}{l}90 \\
40 \\
50\end{array}$ & $\begin{array}{l}0 \\
0 \\
0\end{array}$ & $\begin{array}{l}90 \\
40 \\
50\end{array}$ \\
\hline 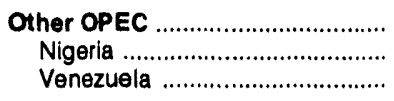 & $\begin{array}{l}0 \\
0 \\
0\end{array}$ & $\begin{array}{l}0 \\
0 \\
0\end{array}$ & $\begin{array}{l}0 \\
0 \\
0\end{array}$ & $\begin{array}{l}0 \\
0 \\
0\end{array}$ & $\begin{array}{l}0 \\
0 \\
0\end{array}$ & $\begin{array}{l}0 \\
0 \\
0\end{array}$ & $\begin{array}{l}\mathbf{5 , 4 7 7} \\
1,854 \\
\mathbf{3 , 6 2 3}\end{array}$ & $\begin{array}{r}196 \\
66 \\
129\end{array}$ & $\begin{array}{l}0 \\
0 \\
0\end{array}$ & $\begin{array}{r}196 \\
66 \\
129\end{array}$ \\
\hline 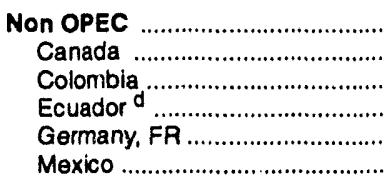 & $\begin{array}{r}19 \\
19 \\
0 \\
0 \\
0 \\
0\end{array}$ & $\begin{array}{l}0 \\
0 \\
0 \\
0 \\
0 \\
0\end{array}$ & $\begin{array}{r}18 \\
18 \\
0 \\
0 \\
0 \\
0\end{array}$ & $\begin{array}{l}0 \\
0 \\
0 \\
0 \\
0 \\
0\end{array}$ & $\begin{array}{r}49 \\
47 \\
0 \\
0 \\
2 \\
0\end{array}$ & $\begin{array}{r}3,387 \\
3,385 \\
0 \\
0 \\
2 \\
0\end{array}$ & $\begin{array}{r}29,943 \\
23,729 \\
526 \\
373 \\
2 \\
5,313\end{array}$ & $\begin{array}{r}948 \\
727 \\
19 \\
13 \\
0 \\
190\end{array}$ & $\begin{array}{r}121 \\
121 \\
0 \\
0 \\
(s) \\
0\end{array}$ & $\begin{array}{r}1,069 \\
847 \\
19 \\
13 \\
(s) \\
190\end{array}$ \\
\hline Total & 19 & 0 & 18 & 0 & 49 & 3,387 & 37,932 & 1,234 & 121 & 1,355 \\
\hline Persian Gulf ${ }^{\ominus}$........................... & 0 & 0 & 0 & 0 & 0 & 0 & 2,512 & 90 & 0 & 90 \\
\hline
\end{tabular}

a Crude oil and unfinished oils are reported by the PAD District in which they are to be processed; all other products are reported by the PAD District of entry

b includes crude oil imported for storage in the Strategic Petroleum Reserve.

c Includes aviation gasoline, aviation gasoline blending components, miscellaneous products, other hydrocarbons and oxygenates, pentanes plus, petroleum coke, and waxes.

¿ On December 31, 1992, Ecuador withdrew as a member of OPEC. As of January 1, 1994, imports of petroleum from Ecuador appear under imports from Non-OPEC Sources.

Includes Bahrain, Iran, Iraq, Kuwait, Qatar, Saudi Arabia, and United Arab Emirates.

(s) = Less than 500 barrels per day.

Note: Totals may not equal surn of components due to independent rounding.

Source: Energy Information Administration (EIA) Form EIA-814, "Monthly Imports Report." 
Table 38. PAD District II-Imports of Crude Oil and Petroleum Products by Country of Origin, ${ }^{a}$ February 1994

(Thousand Barrels)

\begin{tabular}{|c|c|c|c|c|c|c|c|c|c|c|}
\hline Country of Origin & $\begin{array}{c}\text { Crude } \\
\mathbf{O A l}^{\mathbf{b}}\end{array}$ & $\begin{array}{c}\text { Liquefied } \\
\text { Petroleum } \\
\text { Gases }\end{array}$ & $\begin{array}{c}\text { Unfinished } \\
\text { Olls }\end{array}$ & $\begin{array}{c}\text { Gasoline } \\
\text { Blending } \\
\text { Compo- } \\
\text { nents } \\
\end{array}$ & $\begin{array}{l}\text { Finished } \\
\text { Motor } \\
\text { Gasoline }\end{array}$ & Jet Fuel & $\begin{array}{l}\text { Distillate } \\
\text { Fuel Oll }\end{array}$ & $\begin{array}{l}\text { Residual } \\
\text { Fuel OII }\end{array}$ & Kerosene & $\begin{array}{c}\text { Special } \\
\text { Naphthas }\end{array}$ \\
\hline 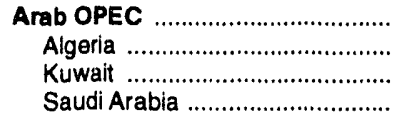 & $\begin{array}{r}31,939 \\
573 \\
8,872 \\
22,494\end{array}$ & $\begin{array}{l}0 \\
0 \\
0 \\
0\end{array}$ & $\begin{array}{r}1,131 \\
149 \\
0 \\
982\end{array}$ & $\begin{array}{l}0 \\
0 \\
0 \\
0\end{array}$ & $\begin{array}{l}0 \\
0 \\
0 \\
0\end{array}$ & $\begin{array}{l}0 \\
0 \\
0 \\
0\end{array}$ & $\begin{array}{l}0 \\
0 \\
0 \\
0\end{array}$ & $\begin{array}{r}43 \\
43 \\
0 \\
0\end{array}$ & $\begin{array}{l}0 \\
0 \\
0 \\
0\end{array}$ & $\begin{array}{l}0 \\
0 \\
0 \\
0\end{array}$ \\
\hline 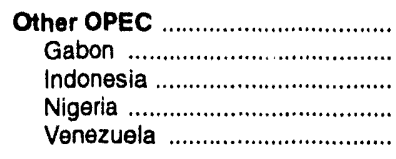 & $\begin{array}{r}24,417 \\
925 \\
0 \\
4,511 \\
18,981\end{array}$ & $\begin{array}{l}0 \\
0 \\
0 \\
0 \\
0\end{array}$ & $\begin{array}{r}889 \\
0 \\
0 \\
0 \\
889\end{array}$ & $\begin{array}{r}46 \\
0 \\
0 \\
0 \\
46\end{array}$ & $\begin{array}{l}0 \\
0 \\
0 \\
0 \\
0\end{array}$ & $\begin{array}{l}0 \\
0 \\
0 \\
0 \\
0\end{array}$ & $\begin{array}{l}0 \\
0 \\
0 \\
0 \\
0\end{array}$ & $\begin{array}{r}316 \\
0 \\
0 \\
0 \\
316\end{array}$ & $\begin{array}{l}0 \\
0 \\
0 \\
0 \\
0\end{array}$ & $\begin{array}{l}0 \\
0 \\
0 \\
0 \\
0\end{array}$ \\
\hline 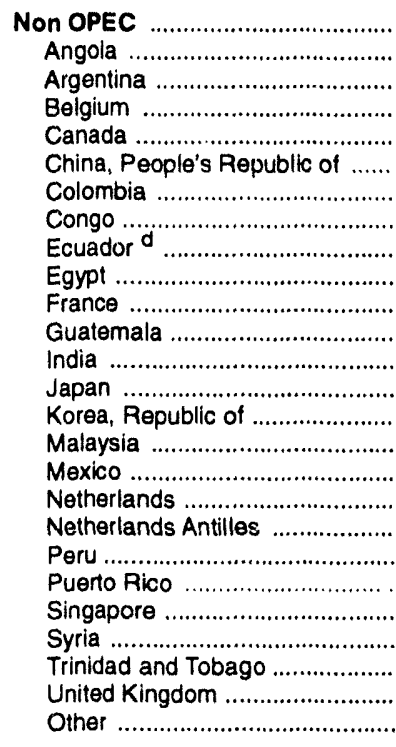 & $\begin{array}{r}36,843 \\
3,881 \\
0 \\
0 \\
832 \\
674 \\
2,621 \\
530 \\
2,324 \\
493 \\
0 \\
222 \\
0 \\
0 \\
0 \\
406 \\
19,111 \\
0 \\
0 \\
0 \\
0 \\
0 \\
0 \\
2,250 \\
3,499 \\
0\end{array}$ & $\begin{array}{r}316 \\
0 \\
0 \\
0 \\
0 \\
0 \\
0 \\
0 \\
0 \\
0 \\
17 \\
0 \\
0 \\
0 \\
0 \\
0 \\
274 \\
0 \\
25 \\
0 \\
0 \\
0 \\
0 \\
0 \\
0 \\
0\end{array}$ & $\begin{array}{r}4,415 \\
0 \\
0 \\
172 \\
36 \\
0 \\
271 \\
0 \\
0 \\
0 \\
691 \\
0 \\
0 \\
0 \\
1,319 \\
0 \\
0 \\
187 \\
662 \\
142 \\
0 \\
241 \\
231 \\
0 \\
463 \\
0\end{array}$ & $\begin{array}{l}0 \\
0 \\
0 \\
0 \\
0\end{array}$ & $\begin{array}{l}0 \\
0 \\
0 \\
0 \\
0 \\
0 \\
0 \\
0 \\
0 \\
0\end{array}$ & $\begin{array}{l}8 \\
0 \\
0 \\
0 \\
0 \\
0\end{array}$ & $\begin{array}{l}0 \\
0 \\
0 \\
0 \\
0 \\
0 \\
0\end{array}$ & $\begin{array}{l}0 \\
0 \\
0 \\
0 \\
0 \\
0 \\
0 \\
0\end{array}$ & $\begin{array}{r}85 \\
0 \\
0 \\
0 \\
0 \\
0 \\
0 \\
0 \\
0 \\
0 \\
0 \\
0 \\
0 \\
0 \\
0 \\
0 \\
85 \\
0 \\
0 \\
0 \\
0 \\
0 \\
0 \\
0 \\
0 \\
0\end{array}$ & $\begin{array}{r}45 \\
0 \\
0 \\
0 \\
45 \\
0 \\
0 \\
0 \\
0 \\
0 \\
0 \\
0 \\
0 \\
0 \\
0 \\
0 \\
0 \\
0 \\
0 \\
0 \\
0 \\
0 \\
0 \\
0 \\
0 \\
0\end{array}$ \\
\hline Total & 93,199 & 316 & 6,435 & 46 & 0 & 8 & 0 & 359 & 85 & 45 \\
\hline Persian Gulf ${ }^{\theta}$ & 31,366 & 0 & 962 & 0 & 0 & 0 & 0 & 0 & 0 & 0 \\
\hline
\end{tabular}


Table 38. PAD District III-Imports of Crude Oil and Petroleum Products by Country of Origin, ${ }^{a}$ February 1994 (Continued) (Thousand Barrels)

\begin{tabular}{|c|c|c|c|c|c|c|c|c|c|c|}
\hline \multirow[b]{2}{*}{ Country of Origin } & \multirow[b]{2}{*}{$\begin{array}{c}\text { Naphtha for } \\
\text { Petrochemical } \\
\text { Feedstock } \\
\text { Use }\end{array}$} & \multirow[b]{2}{*}{$\begin{array}{c}\text { Other Oils for } \\
\text { Petrochemical } \\
\text { Feedstock } \\
\text { Use }\end{array}$} & \multirow[b]{2}{*}{ Lubricants } & \multirow[b]{2}{*}{$\begin{array}{c}\text { Asphat and } \\
\text { Road Oll }\end{array}$} & \multirow[b]{2}{*}{$\begin{array}{c}\text { Other } \\
\text { Products }\end{array}$} & \multirow[b]{2}{*}{$\begin{array}{c}\text { Total } \\
\text { Products }\end{array}$} & \multirow[b]{2}{*}{$\begin{array}{l}\text { Total } \\
\text { Crude OII } \\
\text { and } \\
\text { Products }\end{array}$} & \multicolumn{3}{|c|}{ Dally Average } \\
\hline & & & & & & & & $\begin{array}{c}\text { Crude } \\
\text { Oll }\end{array}$ & Products & Total \\
\hline 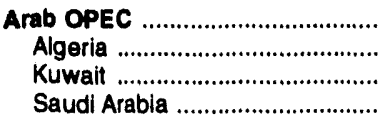 & $\begin{array}{r}95 \\
0 \\
0 \\
95\end{array}$ & $\begin{array}{r}3,038 \\
3,038 \\
0 \\
0\end{array}$ & $\begin{array}{l}0 \\
0 \\
0 \\
0\end{array}$ & $\begin{array}{l}0 \\
0 \\
0 \\
0\end{array}$ & $\begin{array}{r}528 \\
528 \\
0 \\
0\end{array}$ & $\begin{array}{r}4,835 \\
3,758 \\
0 \\
1,077\end{array}$ & $\begin{array}{r}36,774 \\
4,331 \\
8,872 \\
23,571\end{array}$ & $\begin{array}{r}1,141 \\
20 \\
317 \\
803\end{array}$ & $\begin{array}{r}173 \\
134 \\
0 \\
38\end{array}$ & $\begin{array}{r}1,313 \\
155 \\
317 \\
842\end{array}$ \\
\hline 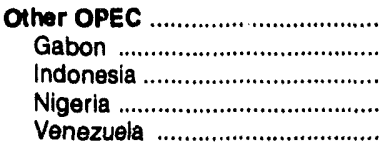 & $\begin{array}{l}0 \\
0 \\
0 \\
0 \\
0\end{array}$ & $\begin{array}{l}0 \\
0 \\
0 \\
0 \\
0\end{array}$ & $\begin{array}{l}0 \\
0 \\
0 \\
0 \\
0\end{array}$ & $\begin{array}{l}0 \\
0 \\
0 \\
0 \\
0\end{array}$ & $\begin{array}{l}9 \\
0 \\
9 \\
0 \\
0\end{array}$ & $\begin{array}{r}1,260 \\
0 \\
9 \\
0 \\
1,251\end{array}$ & $\begin{array}{r}25,677 \\
925 \\
9 \\
4,511 \\
20,232\end{array}$ & $\begin{array}{r}872 \\
33 \\
0 \\
161 \\
678\end{array}$ & $\begin{array}{r}45 \\
0 \\
(s) \\
0 \\
45\end{array}$ & $\begin{array}{r}917 \\
33 \\
(s) \\
161 \\
723\end{array}$ \\
\hline 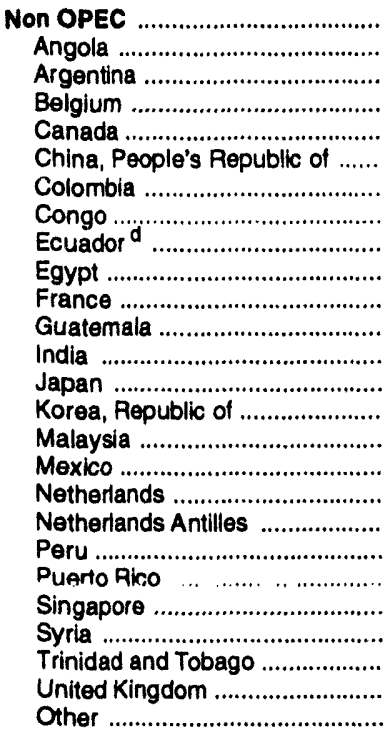 & $\begin{array}{r}798 \\
0 \\
365 \\
0 \\
29 \\
0 \\
0 \\
0 \\
0 \\
0 \\
0 \\
0 \\
242 \\
10 \\
32 \\
0 \\
0 \\
0 \\
0 \\
0 \\
120 \\
0 \\
0 \\
0 \\
0 \\
0\end{array}$ & $\begin{array}{r}260 \\
0 \\
0 \\
0 \\
260 \\
0 \\
0 \\
0 \\
0 \\
0 \\
0 \\
0 \\
0 \\
0 \\
0 \\
0 \\
0 \\
0 \\
0 \\
0 \\
0 \\
0 \\
0 \\
0 \\
0 \\
0\end{array}$ & $\begin{array}{l}0 \\
0 \\
0 \\
0 \\
0 \\
0 \\
0 \\
0 \\
0 \\
0 \\
0 \\
0 \\
0 \\
0 \\
0 \\
0 \\
0 \\
0 \\
0 \\
0 \\
0 \\
0 \\
0 \\
0 \\
0 \\
0\end{array}$ & $\begin{array}{l}0 \\
0 \\
0 \\
0 \\
0 \\
0 \\
0 \\
0 \\
0 \\
0 \\
0 \\
0 \\
0 \\
0 \\
0 \\
0 \\
0 \\
0 \\
0 \\
0 \\
0 \\
0 \\
0 \\
0 \\
0 \\
0\end{array}$ & $\begin{array}{r}460 \\
0 \\
0 \\
0 \\
0 \\
0 \\
0 \\
0 \\
0 \\
0 \\
0 \\
0 \\
0 \\
0 \\
25 \\
0 \\
432 \\
0 \\
0 \\
0 \\
0 \\
0 \\
0 \\
0 \\
0 \\
3\end{array}$ & $\begin{array}{r}6,387 \\
0 \\
365 \\
172 \\
370 \\
0 \\
271 \\
0 \\
0 \\
0 \\
708 \\
0 \\
242 \\
10 \\
1,376 \\
0 \\
799 \\
187 \\
687 \\
142 \\
120 \\
241 \\
231 \\
0 \\
463 \\
3\end{array}$ & $\begin{array}{r}43,230 \\
3,881 \\
365 \\
172 \\
1,202 \\
674 \\
2,892 \\
530 \\
2,324 \\
493 \\
708 \\
222 \\
242 \\
10 \\
1,376 \\
406 \\
19,910 \\
187 \\
687 \\
142 \\
120 \\
241 \\
231 \\
2,250 \\
3,962 \\
3\end{array}$ & $\begin{array}{r}1,316 \\
139 \\
0 \\
0 \\
30 \\
24 \\
94 \\
19 \\
83 \\
18 \\
0 \\
8 \\
0 \\
0 \\
0 \\
15 \\
683 \\
0 \\
0 \\
0 \\
0 \\
0 \\
0 \\
80 \\
125 \\
0\end{array}$ & $\begin{array}{r}228 \\
0 \\
13 \\
6 \\
13 \\
0 \\
10 \\
0 \\
0 \\
0 \\
25 \\
0 \\
9 \\
(\mathrm{~s}) \\
49 \\
0 \\
29 \\
7 \\
25 \\
5 \\
4 \\
9 \\
8 \\
0 \\
17 \\
(\mathrm{~s})\end{array}$ & $\begin{array}{r}1,544 \\
139 \\
13 \\
6 \\
43 \\
24 \\
103 \\
19 \\
83 \\
18 \\
25 \\
8 \\
9 \\
(s) \\
49 \\
15 \\
711 \\
7 \\
25 \\
5 \\
4 \\
9 \\
8 \\
80 \\
142 \\
(\mathrm{~s})\end{array}$ \\
\hline Total & 893 & 3,298 & 0 & 0 & 997 & 12,482 & 105,681 & 3,329 & 446 & 3,774 \\
\hline 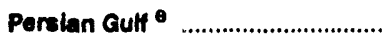 & 95 & $\mathbf{0}$ & 0 & 0 & $\mathbf{0}$ & 1,077 & 32,443 & 1,120 & 38 & 1,159 \\
\hline
\end{tabular}

Crude oil and unfinished oils are reported by the PAD District in which they are to be processed; all other products are reported by the PAD District of entry.

b Includes crude oil imported for storage in the Strategic Petroleum Reserve.

c includes aviation gasoline, aviation gasoline blending components, miscellaneous products, other hydrocarbons and oxygenates, pentanes plus. petroleum coke, and waxes.

d On December 31, 1992, Ecuador withdrew as a member of OPEC. As of January 1, 1994, imports of petroleum from Ecuador appear under imports from Non-C PEC Sources.

- Includes Bahrain, Iran, Iraq, Kuwait, Qatar, Saudl Arabla, and United Arab Emirates.

$(s)=$ Less than 500 barrels per day.

Note: Totals may not equal sum of components due to independent rounding.

Source: Energy Information Administration (EIA) Form EIA-814, "Monthly Imports Report." 
Table 39. PAD Districts IV and V-Imports of Crude Oil and Petroleum Products by Country of Origin, February 1994 (Thousand Barrels)

\begin{tabular}{|c|c|c|c|c|c|c|c|c|c|c|}
\hline Country of Origi: & $\begin{array}{l}\text { Crude } \\
\text { Oilb }^{\mathrm{b}}\end{array}$ & $\begin{array}{l}\text { Liquefied } \\
\text { Petroleum } \\
\text { Gases }\end{array}$ & $\begin{array}{c}\text { Unfinished } \\
\text { Oils }\end{array}$ & $\begin{array}{c}\text { Gasoline } \\
\text { Blending } \\
\text { Compo- } \\
\text { nents }\end{array}$ & $\begin{array}{l}\text { Finished } \\
\text { Motor } \\
\text { Gasolline }\end{array}$ & Jet Fuel & $\begin{array}{l}\text { Distillate } \\
\text { Fuel Oll }\end{array}$ & $\begin{array}{l}\text { Residual } \\
\text { Fuel OII }\end{array}$ & Kerosene & $\begin{array}{l}\text { Special } \\
\text { Naphthas }\end{array}$ \\
\hline & \multicolumn{10}{|c|}{ PAD District IV } \\
\hline $\begin{array}{l}\text { Non OPEC } \\
\text { Canada }\end{array}$ & $\begin{array}{l}2,853 \\
2,853\end{array}$ & $\begin{array}{l}247 \\
247\end{array}$ & $\begin{array}{l}0 \\
0\end{array}$ & $\begin{array}{l}0 \\
0\end{array}$ & $\begin{array}{l}5 \\
5\end{array}$ & $\begin{array}{l}0 \\
0\end{array}$ & $\begin{array}{l}97 \\
97\end{array}$ & $\begin{array}{l}2 \\
2\end{array}$ & $\begin{array}{l}0 \\
0\end{array}$ & $\begin{array}{l}0 \\
0\end{array}$ \\
\hline Total & 2,853 & 247 & 0 & 0 & 5 & 0 & 97 & 2 & 0 & 0 \\
\hline
\end{tabular}

PAD District V

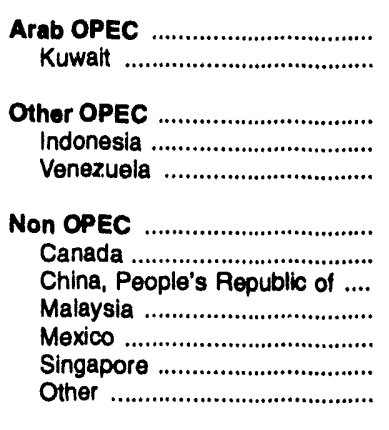

Total .

Persian Gulf ${ }^{\circ}$

$\begin{array}{rrrrrr}1,853 & 0 & 0 & 0 & 0 \\ 1,853 & 0 & 0 & 0 & 0 & \\ 1,850 & 0 & 0 & 0 & 0 \\ 1,650 & 0 & 0 & 0 & 0 & \\ 0 & 0 & 0 & 0 & 0 & \\ 3,211 & 162 & 260 & 0 & 21 & 26 \\ 2,185 & 162 & 41 & 0 & 21 & \\ 569 & 0 & 0 & 0 & 0 & \\ 0 & 0 & 0 & 0 & 0 & 0 \\ 0 & 0 & 0 & 0 & 0 & 24 \\ 0 & 0 & 219 & 0 & 0 & \\ 457 & 0 & 0 & 0 & 0 & \\ 6,714 & 162 & 260 & 0 & 21 & 27 \\ 1,853 & 0 & 0 & 0 & 0 & \end{array}$

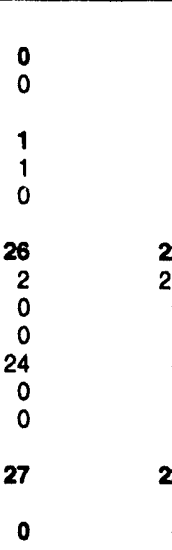

$\begin{array}{rrrl}0 & 0 & 0 & 0 \\ 0 & 0 & 0 & 0 \\ 0 & 0 & 0 & 0 \\ 0 & 0 & 0 & 0 \\ 0 & 0 & 0 & 0 \\ 22 & 267 & 0 & 2 \\ 22 & 45 & 0 & 2 \\ 0 & 0 & 0 & 0 \\ 0 & 0 & 0 & 0 \\ 0 & 222 & 0 & 0 \\ 0 & 0 & 0 & 0 \\ 0 & 0 & 0 & 0 \\ 22 & 267 & 0 & 2 \\ 0 & 0 & 0 & 0\end{array}$


Table 39. PAD Districts IV and V-Imports of Crude Oil and Petroleum Products by Country of Origin, ${ }^{a}$ February 1994 (Continued)

(Thousand Barrels)

\begin{tabular}{|c|c|c|c|c|c|c|c|c|c|c|}
\hline \multirow[b]{2}{*}{ Country of Origin } & \multirow[b]{2}{*}{$\begin{array}{c}\text { Naphtha for } \\
\text { Petrochemical } \\
\text { Feedetock } \\
\text { Use }\end{array}$} & \multirow[b]{2}{*}{$\begin{array}{c}\text { Other Olis for } \\
\text { Petrochemical } \\
\text { Feedstock } \\
\text { Use }\end{array}$} & \multirow[b]{2}{*}{-ubricants } & \multirow[b]{2}{*}{$\begin{array}{c}\text { Asphalt and } \\
\text { Boad OII }\end{array}$} & \multirow[b]{2}{*}{$\begin{array}{c}\text { Other } \\
\text { Producte }\end{array}$} & \multirow[b]{2}{*}{$\begin{array}{c}\text { Total } \\
\text { Products }\end{array}$} & \multirow[b]{2}{*}{$\begin{array}{l}\text { Total } \\
\text { Crude Oll } \\
\text { and } \\
\text { Products }\end{array}$} & \multicolumn{3}{|c|}{ Daily Average } \\
\hline & & & & & & & & $\begin{array}{c}\text { Crude } \\
\text { Oil }\end{array}$ & Products & Total \\
\hline
\end{tabular}

PAD District IV

\begin{tabular}{|c|c|c|c|c|c|c|c|c|c|c|}
\hline \multirow[b]{2}{*}{ 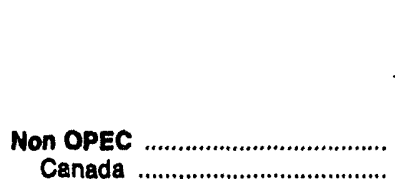 } & \multicolumn{10}{|c|}{ PAD District IV } \\
\hline & $\begin{array}{l}0 \\
0\end{array}$ & $\begin{array}{l}0 \\
0\end{array}$ & $\begin{array}{l}0 \\
0\end{array}$ & $\begin{array}{l}0 \\
0\end{array}$ & $\begin{array}{l}349 \\
349\end{array}$ & $\begin{array}{l}700 \\
700\end{array}$ & $\begin{array}{l}3,553 \\
3,553\end{array}$ & $\begin{array}{l}102 \\
102\end{array}$ & $\begin{array}{l}25 \\
25\end{array}$ & $\begin{array}{l}127 \\
127\end{array}$ \\
\hline 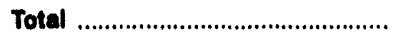 & 0 & 0 & 0 & 0 & 349 & 700 & 3,553 & 102 & 25 & 127 \\
\hline
\end{tabular}

PAD District $V$

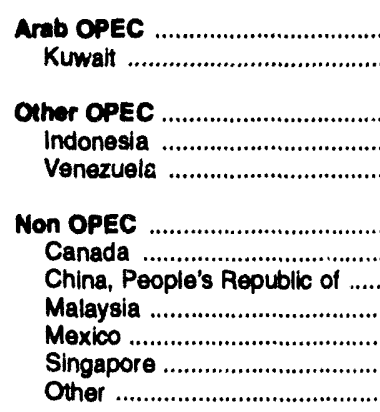

Total

Porsian Culf ${ }^{\ominus}$

.

0
0
0
0
0
0
0
0
0
0
0
0
0
0

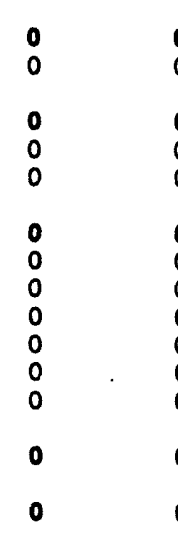

$\begin{array}{ll}0 & \\ 0 & \\ 0 & \\ 0 & \\ 0 & \\ 0 & \\ 0 & \\ 0 & 20 \\ 0 & \\ 0 & \\ 0 & \\ 0 & \\ 0 & \\ 0 & \end{array}$

$\begin{array}{rr}0 & \\ 0 & \\ 0 & \\ 0 & \\ 0 & \\ 20 & \\ 20 & \\ 0 & \\ 0 & \\ 0 & \\ 0 & \\ 0 & \\ 20 & \\ 0 & \end{array}$

$\begin{array}{rrrrrr}0 & 0 & 1,853 & 66 & 0 & 66 \\ 0 & 0 & 1,853 & 66 & 0 & 66 \\ 236 & 237 & 1,887 & 59 & 6 & 67 \\ 0 & 1 & 1,651 & 59 & (8) & 59 \\ 236 & 236 & 236 & 0 & 8 & 8 \\ 563 & 1,343 & 4,554 & 115 & 48 & 163 \\ 428 & 743 & 2,928 & 78 & 27 & 105 \\ 0 & 0 & 569 & 20 & 0 & 20 \\ 133 & 133 & 133 & 0 & 5 & 5 \\ 2 & 248 & 248 & 0 & 9 & 9 \\ 0 & 219 & 219 & 0 & 8 & 8 \\ 0 & 0 & 457 & 16 & 0 & 16 \\ 798 & 1,580 & 8,294 & 240 & 56 & 296 \\ 0 & 0 & 1,853 & 66 & 0 & 66\end{array}$

\footnotetext{
a Crude oll and unfinished oils are reported by the PAD District in which they are to be processed; all other products are reported by the PAD District of entry.

Includes crude oil imported for storage in the Strategic Petroleum Reserve.
c Includes aviation gasoline, aviation gasoline blending components, miscellaneous products, other hydrocarbons and oxygenates, pentanes plus, petroleum coke, and

On December 31, 1992, Ecuador withdrew as a member of OPEC. As of January 1, 1994, imports of petroleum from Ecuador appear under imports from Non-OPEC

- Includes Bahrain, Iran, Iraq, Kuwait, Qatar, Saudl Arabia, and United Arab Emirates.

$(8)=$ Less than 500 barrels per day.

Note: Totals may not equal sum of components due to independent rounding.

Source: Energy Intormation Administration (EIA) Form EIA-814, "Monthly Imports Report."
} waxes. Sources. 
Table 40. Year-to-Date Imports of Crude Oil and Petroleum Products into the United States by Country of Origin," January-February 1994 (Thousand Barrels)

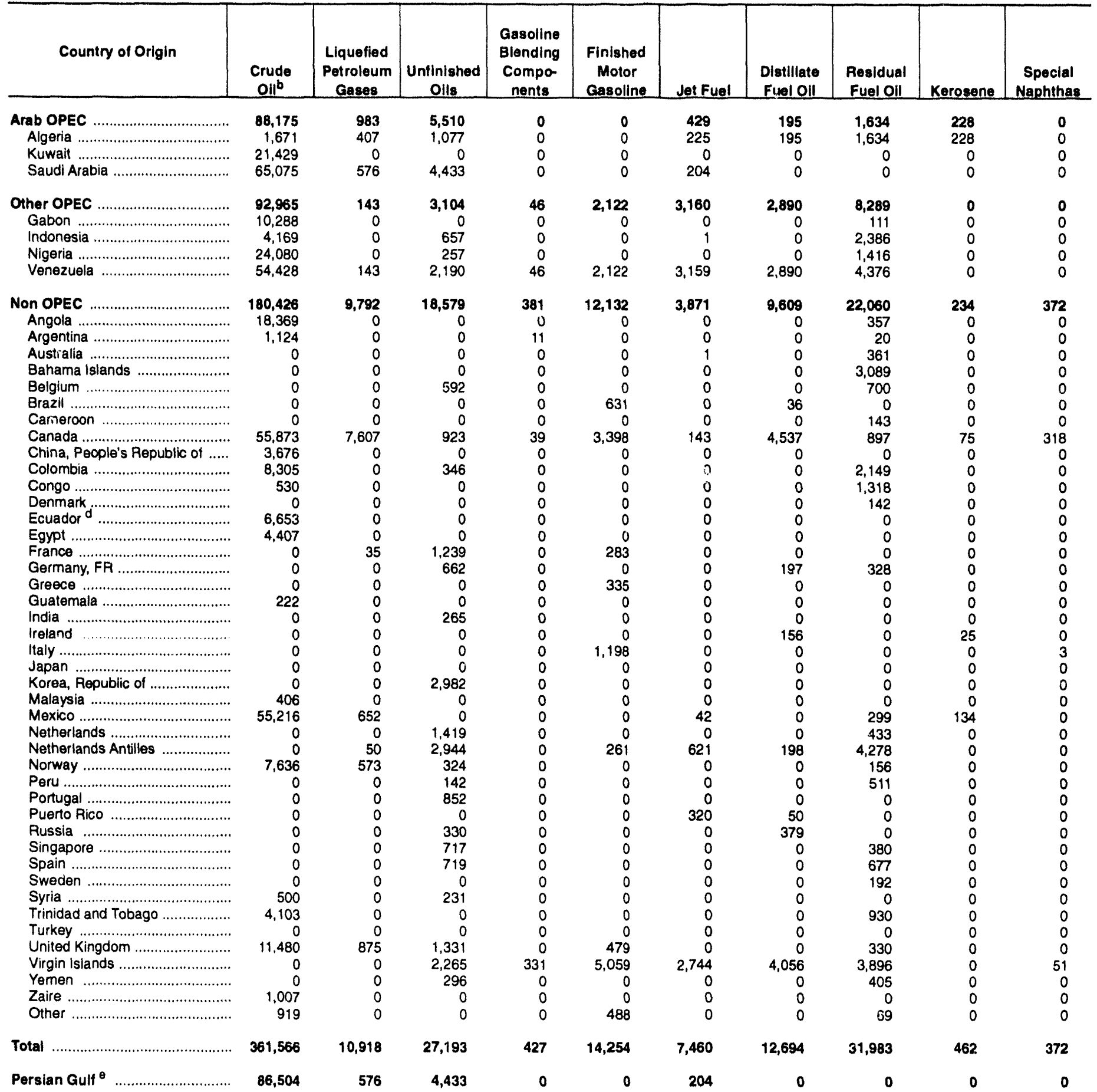


Table 40. Year-to-Date Imports of Crude Oil and Fetroleum Products into the United States by Country of Origin," January-February 1994 (Continued)

(Thousand Barrels)

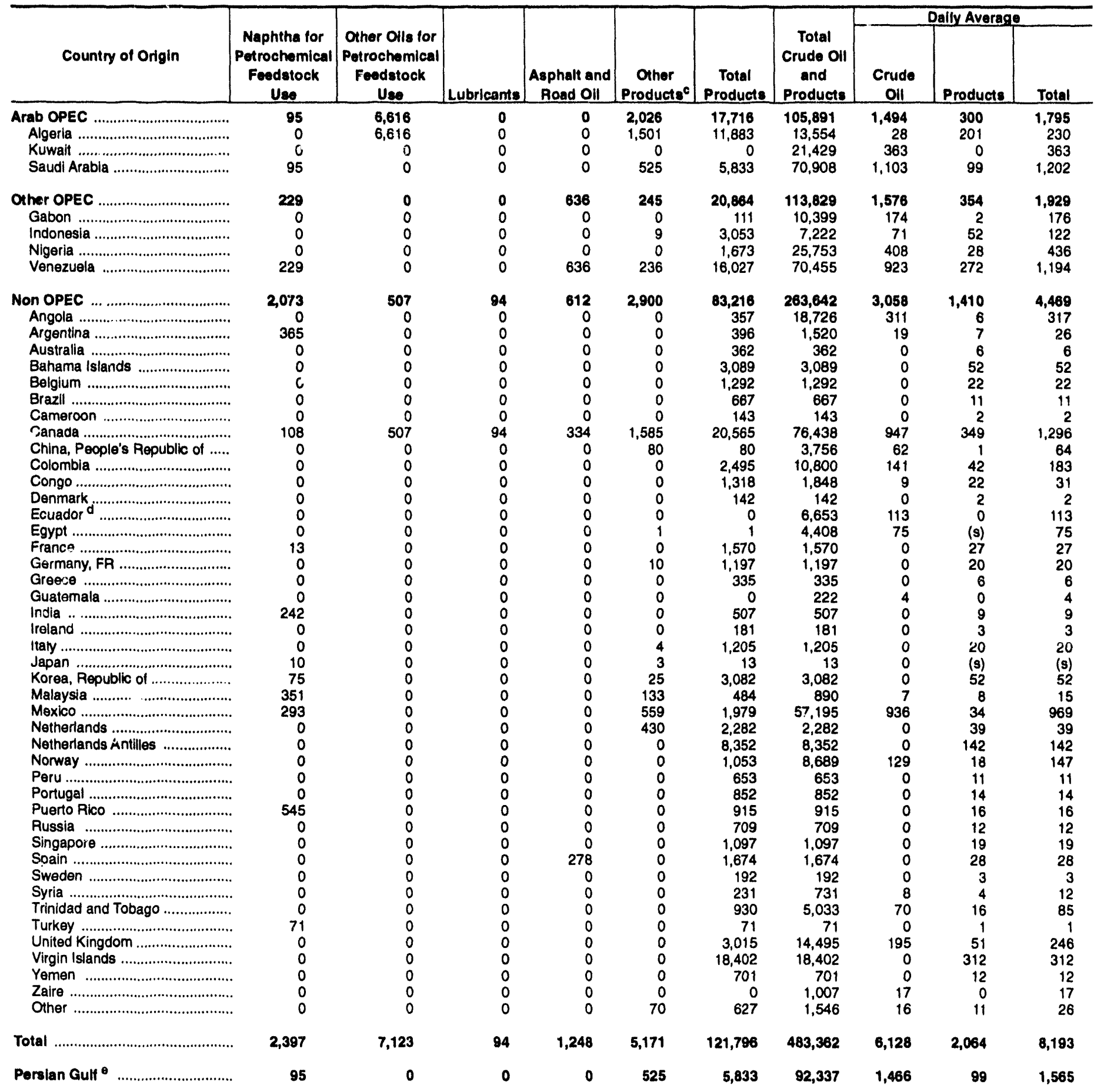

Crude oil and unfinished oils are reported by the PAD District in which they are to be processed; all other products are reported by the PAD District of entry.

b Inciudes crude oil imported for storage in the Strategic Petroleum Reserve.

c Includes aviation gasoline, aviation gasoline blending components, miscellaneous products, other hydrocarbons and oxygenates, pentanes plus, petroleum coke, and waxes.

d On December 31, 1992, Ecuador withdrew as a member of OPEC. As of January 1, 1994, imports of petroleum from Ecuador appear under imports from Non-OPEC Sources.

- Includes Bahrain, Iran, Iraq, Kuwait, Qatar, Saudl Arabla, and United Arab Emirates.

(s) = Less than 500 barrels per day.

Note: Totals may not equal sum of components due to independent rouriding.

Source: Energy Information Administration (EIA) Form EIA-814, "Monthly Imports Report." 
Table 41. PAD District —-Year-to-Date Imports of Crude Oil and Petroleum Products by Country of Origin, ${ }^{a}$ January-February 1994 (Thousand Barrels)

\begin{tabular}{|c|c|c|c|c|c|c|c|c|c|c|}
\hline Country of Origin & $\begin{array}{c}\text { Crude } \\
\text { Oil }\end{array}$ & $\begin{array}{l}\text { Liquefied } \\
\text { Petroleum } \\
\text { Caces } \\
\end{array}$ & $\begin{array}{c}\text { Unfinished } \\
\text { Olls }\end{array}$ & $\begin{array}{l}\text { Gasoline } \\
\text { Blending } \\
\text { Compo- } \\
\text { nonts } \\
\end{array}$ & $\begin{array}{l}\text { Finished } \\
\text { Motor } \\
\text { Gasoline }\end{array}$ & Jet Fuel & $\begin{array}{l}\text { Distillate } \\
\text { Fupl Oll }\end{array}$ & $\begin{array}{l}\text { Residual } \\
\text { Fuel Oll }\end{array}$ & Kerosene & $\begin{array}{c}\text { Special } \\
\text { Naphthas }\end{array}$ \\
\hline 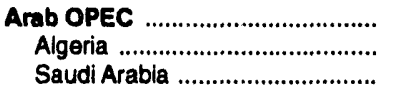 & $\begin{array}{r}7,544 \\
0 \\
7,544\end{array}$ & $\begin{array}{l}590 \\
407 \\
183\end{array}$ & $\begin{array}{r}321 \\
321 \\
0\end{array}$ & $\begin{array}{l}0 \\
0 \\
0\end{array}$ & $\begin{array}{l}0 \\
0 \\
0\end{array}$ & $\begin{array}{l}404 \\
225 \\
179\end{array}$ & $\begin{array}{r}195 \\
195 \\
0\end{array}$ & $\begin{array}{r}1,591 \\
1,591 \\
0\end{array}$ & $\begin{array}{r}228 \\
228 \\
0\end{array}$ & $\begin{array}{l}0 \\
0 \\
0\end{array}$ \\
\hline 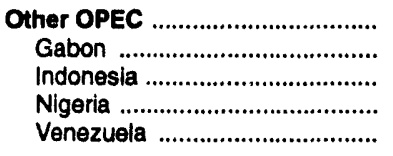 & $\begin{array}{r}32,870 \\
8,438 \\
0 \\
16,706 \\
7,726\end{array}$ & $\begin{array}{l}0 \\
0 \\
0 \\
0 \\
0\end{array}$ & $\begin{array}{r}1,515 \\
0 \\
657 \\
257 \\
601\end{array}$ & $\begin{array}{l}0 \\
0 \\
0 \\
0 \\
0\end{array}$ & $\begin{array}{r}2,122 \\
0 \\
0 \\
0 \\
2,122\end{array}$ & $\begin{array}{r}3,159 \\
0 \\
0 \\
0 \\
3,159\end{array}$ & $\begin{array}{r}2,890 \\
0 \\
0 \\
0 \\
2,890\end{array}$ & $\begin{array}{r}7,192 \\
111 \\
2,225 \\
1,416 \\
3,440\end{array}$ & $\begin{array}{l}0 \\
0 \\
0 \\
0 \\
0\end{array}$ & $\begin{array}{l}0 \\
0 \\
0 \\
0 \\
0\end{array}$ \\
\hline 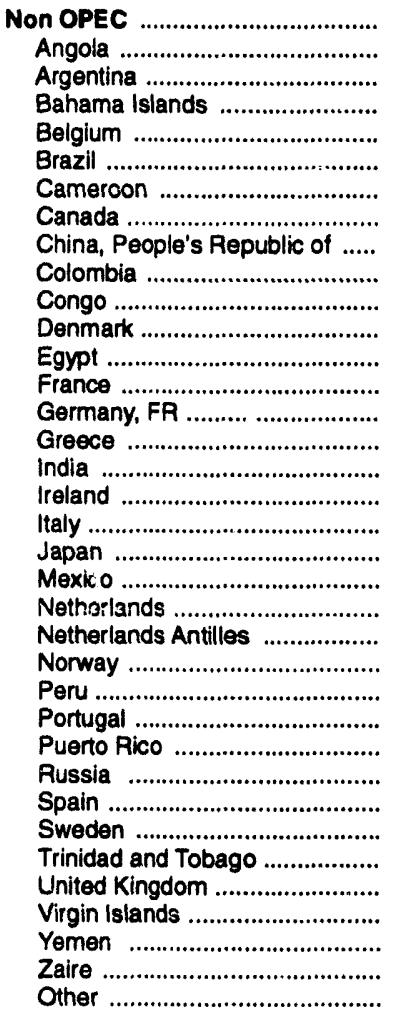 & $\begin{array}{r}31,780 \\
7,273 \\
0 \\
0 \\
0 \\
0 \\
0 \\
3,463 \\
1,291 \\
1,499 \\
0 \\
0 \\
1,408 \\
0 \\
0 \\
0 \\
0 \\
0 \\
0 \\
0 \\
3,129 \\
0 \\
0 \\
7,149 \\
0 \\
0 \\
0 \\
0 \\
0 \\
0 \\
561 \\
5,000 \\
0 \\
0 \\
1,007 \\
0\end{array}$ & $\begin{array}{r}2,375 \\
0 \\
0 \\
0 \\
0 \\
0 \\
0 \\
927 \\
0 \\
0 \\
0 \\
0 \\
0 \\
0 \\
0 \\
0 \\
0 \\
0 \\
0 \\
0 \\
0 \\
0 \\
0 \\
573 \\
0 \\
0 \\
0 \\
0 \\
0 \\
0 \\
0 \\
875 \\
0 \\
0 \\
0 \\
0\end{array}$ & $\begin{array}{r}7,648 \\
0 \\
0 \\
0 \\
344 \\
0 \\
0 \\
313 \\
0 \\
0 \\
0 \\
0 \\
0 \\
548 \\
662 \\
0 \\
265 \\
0 \\
0 \\
0 \\
0 \\
217 \\
652 \\
191 \\
0 \\
852 \\
0 \\
0 \\
719 \\
0 \\
0 \\
324 \\
2,265 \\
296 \\
0 \\
0 \\
\end{array}$ & $\begin{array}{r}331 \\
0 \\
0 \\
0 \\
0 \\
0 \\
0 \\
0 \\
0 \\
0 \\
0 \\
0 \\
0 \\
0 \\
0 \\
0 \\
0 \\
0 \\
0 \\
0 \\
0 \\
0 \\
0 \\
0 \\
0 \\
0 \\
0 \\
0 \\
0 \\
0 \\
0 \\
0 \\
331 \\
0 \\
0 \\
0\end{array}$ & $\begin{array}{r}11,844 \\
0 \\
0 \\
0 \\
0 \\
631 \\
0 \\
3,110 \\
0 \\
0 \\
0 \\
0 \\
0 \\
283 \\
0 \\
335 \\
0 \\
0 \\
1,198 \\
0 \\
0 \\
0 \\
261 \\
0 \\
0 \\
0 \\
0 \\
0 \\
0 \\
5,059 \\
0 \\
0 \\
0 \\
488\end{array}$ & $\begin{array}{r}3,760 \\
0 \\
0 \\
0 \\
0 \\
0 \\
0 \\
75 \\
0 \\
0 \\
0 \\
0 \\
0 \\
0 \\
0 \\
0 \\
0 \\
0 \\
0 \\
0 \\
0 \\
0 \\
621 \\
0 \\
0 \\
0 \\
320 \\
0 \\
0 \\
0 \\
0 \\
0 \\
2,744 \\
0 \\
0 \\
0\end{array}$ & $\begin{array}{r}8,913 \\
0 \\
0 \\
0 \\
0 \\
36 \\
0 \\
3,841 \\
0 \\
0 \\
0 \\
0 \\
0 \\
0 \\
197 \\
0 \\
0 \\
156 \\
0 \\
0 \\
0 \\
0 \\
198 \\
0 \\
0 \\
0 \\
50 \\
379 \\
0 \\
0 \\
0 \\
0 \\
4,056 \\
0 \\
0 \\
0\end{array}$ & $\begin{array}{r}20,550 \\
357 \\
20 \\
3,089 \\
700 \\
0 \\
143 \\
832 \\
0 \\
2,149 \\
1,318 \\
142 \\
0 \\
0 \\
328 \\
0 \\
0 \\
0 \\
0 \\
0 \\
0 \\
433 \\
4,278 \\
156 \\
511 \\
0 \\
0 \\
0 \\
677 \\
192 \\
930 \\
330 \\
3,896 \\
0 \\
0 \\
69\end{array}$ & $\begin{array}{r}100 \\
0 \\
0 \\
0 \\
0 \\
0 \\
0 \\
0 \\
75 \\
0 \\
0 \\
0 \\
0 \\
0 \\
0 \\
0 \\
0 \\
0 \\
0 \\
0 \\
0 \\
25 \\
0 \\
0 \\
0 \\
0 \\
0 \\
0 \\
0 \\
0 \\
0 \\
0 \\
0 \\
0 \\
0 \\
0 \\
0 \\
0 \\
0 \\
0 \\
0 \\
0 \\
0 \\
0 \\
0 \\
0\end{array}$ & $\begin{array}{r}103 \\
0 \\
0 \\
0 \\
0 \\
0 \\
0 \\
0 \\
52 \\
0 \\
0 \\
0 \\
0 \\
0 \\
0 \\
0 \\
0 \\
0 \\
0 \\
0 \\
0 \\
0 \\
0 \\
3 \\
0 \\
0 \\
0 \\
0 \\
0 \\
0 \\
0 \\
0 \\
0 \\
0 \\
0 \\
0 \\
0 \\
0 \\
0 \\
0 \\
0 \\
0 \\
0 \\
51 \\
0 \\
0 \\
0 \\
0\end{array}$ \\
\hline 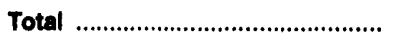 & 72,184 & 2,965 & 9,484 & 331 & 13,966 & 7,323 & 11,998 & 29,333 & 328 & 106 \\
\hline Persian Gulf ${ }^{\theta}$................................. & 7,544 & 183 & $\mathbf{0}$ & $\mathbf{0}$ & 0 & 179 & 0 & 0 & 0 & 0 \\
\hline
\end{tabular}


Table 41. PAD District 1-Year-to-Date Imports of Crude Oil and Petroleum Products by Country of Origin, January-February 1994 (Continued)

(Thousand Barrels)

\begin{tabular}{|c|c|c|c|c|c|c|c|c|c|c|}
\hline \multirow[b]{2}{*}{ Country of Origin } & \multirow[b]{2}{*}{$\begin{array}{c}\text { Naphtha for } \\
\text { Potrochemical } \\
\text { Feedstock } \\
\text { Use }\end{array}$} & \multirow[b]{2}{*}{$\begin{array}{c}\text { Other Olls for } \\
\text { Potrochemical } \\
\text { Feedstock } \\
\text { Use }\end{array}$} & \multirow[b]{2}{*}{ Lubricants } & \multirow[b]{2}{*}{$\begin{array}{c}\text { Asphatt and } \\
\text { Road Oll }\end{array}$} & \multirow[b]{2}{*}{$\begin{array}{c}\text { Other } \\
\text { Productse }\end{array}$} & \multirow[b]{2}{*}{$\begin{array}{c}\text { Total } \\
\text { Products }\end{array}$} & \multirow[b]{2}{*}{$\begin{array}{c}\text { Total } \\
\text { Crude Oil } \\
\text { and } \\
\text { Producte }\end{array}$} & \multicolumn{3}{|c|}{ Dally Average } \\
\hline & & & & & & & & $\begin{array}{c}\text { Crude } \\
\text { Oil }\end{array}$ & Products & Total \\
\hline 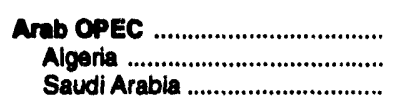 & $\begin{array}{l}0 \\
0 \\
0\end{array}$ & $\begin{array}{l}0 \\
0 \\
0\end{array}$ & $\begin{array}{l}0 \\
0 \\
0\end{array}$ & $\begin{array}{l}0 \\
0 \\
0\end{array}$ & $\begin{array}{r}260 \\
0 \\
260\end{array}$ & $\begin{array}{r}3,589 \\
2,967 \\
622\end{array}$ & $\begin{array}{r}11,133 \\
2,967 \\
8,166\end{array}$ & $\begin{array}{r}128 \\
0 \\
128\end{array}$ & $\begin{array}{l}61 \\
50 \\
11\end{array}$ & $\begin{array}{r}189 \\
50 \\
138\end{array}$ \\
\hline 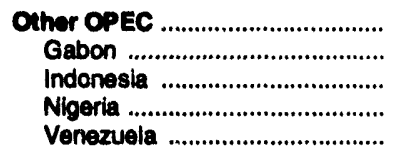 & $\begin{array}{l}0 \\
0 \\
0 \\
0 \\
0\end{array}$ & $\begin{array}{l}0 \\
0 \\
0 \\
0 \\
0\end{array}$ & $\begin{array}{l}0 \\
0 \\
0 \\
0 \\
0\end{array}$ & $\begin{array}{r}583 \\
0 \\
0 \\
0 \\
583\end{array}$ & $\begin{array}{l}0 \\
0 \\
0 \\
0 \\
0\end{array}$ & $\begin{array}{r}17,461 \\
111 \\
2,882 \\
1,673 \\
12,795\end{array}$ & $\begin{array}{r}50,331 \\
8,549 \\
2,882 \\
18,379 \\
20,521\end{array}$ & $\begin{array}{r}557 \\
143 \\
0 \\
283 \\
131\end{array}$ & $\begin{array}{r}296 \\
2 \\
49 \\
28 \\
217\end{array}$ & $\begin{array}{r}853 \\
145 \\
49 \\
312 \\
348\end{array}$ \\
\hline 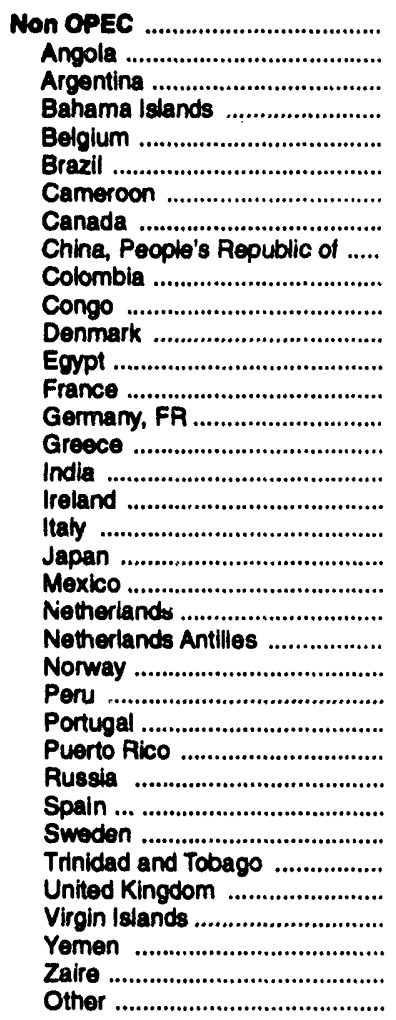 & $\begin{array}{r}452 \\
0 \\
0 \\
0 \\
0 \\
0 \\
0 \\
14 \\
0 \\
0 \\
0 \\
0 \\
0 \\
13 \\
0 \\
0 \\
0 \\
0 \\
0 \\
0 \\
0 \\
0 \\
0 \\
0 \\
0 \\
0 \\
425 \\
0 \\
0 \\
0 \\
0 \\
0 \\
0 \\
0 \\
0 \\
0\end{array}$ & $\begin{array}{l}0 \\
0 \\
0 \\
0 \\
0 \\
0 \\
0 \\
0 \\
0 \\
0 \\
0 \\
0 \\
0 \\
0 \\
0 \\
0 \\
0 \\
0 \\
0 \\
0 \\
0 \\
0 \\
0 \\
0 \\
0 \\
0 \\
0 \\
0 \\
0 \\
0 \\
0 \\
0 \\
0 \\
0 \\
0 \\
0\end{array}$ & $\begin{array}{r}64 \\
0 \\
0 \\
0 \\
0 \\
0 \\
0 \\
64 \\
0 \\
0 \\
0 \\
0 \\
0 \\
0 \\
0 \\
0 \\
0 \\
0 \\
0 \\
0 \\
0 \\
0 \\
0 \\
0 \\
0 \\
0 \\
0 \\
0 \\
0 \\
0 \\
0 \\
0 \\
0 \\
0 \\
0 \\
0\end{array}$ & $\begin{array}{r}523 \\
0 \\
0 \\
0 \\
0 \\
0 \\
0 \\
245 \\
0 \\
0 \\
0 \\
0 \\
0 \\
0 \\
0 \\
0 \\
0 \\
0 \\
0 \\
0 \\
0 \\
0 \\
0 \\
0 \\
0 \\
0 \\
0 \\
0 \\
0 \\
278 \\
0 \\
0 \\
0 \\
0 \\
0 \\
0 \\
0\end{array}$ & $\begin{array}{r}604 \\
0 \\
0 \\
0 \\
0 \\
0 \\
0 \\
31 \\
0 \\
0 \\
0 \\
0 \\
0 \\
0 \\
8 \\
0 \\
0 \\
0 \\
4 \\
3 \\
123 \\
430 \\
0 \\
0 \\
0 \\
0 \\
0 \\
0 \\
0 \\
0 \\
0 \\
0 \\
0 \\
0 \\
0 \\
5\end{array}$ & $\begin{array}{r}57,270 \\
357 \\
20 \\
3,089 \\
1,044 \\
667 \\
143 \\
9,579 \\
0 \\
2,149 \\
1,318 \\
142 \\
0 \\
844 \\
1,195 \\
335 \\
265 \\
181 \\
1,205 \\
3 \\
123 \\
1,080 \\
6,010 \\
920 \\
511 \\
852 \\
795 \\
379 \\
1,674 \\
192 \\
930 \\
2,008 \\
18,402 \\
296 \\
0 \\
562\end{array}$ & $\begin{array}{r}89,050 \\
7,630 \\
20 \\
3,089 \\
1,044 \\
667 \\
143 \\
13,042 \\
1,291 \\
3,648 \\
1,318 \\
142 \\
1,408 \\
844 \\
1,195 \\
335 \\
265 \\
181 \\
1,205 \\
3 \\
3,252 \\
1,080 \\
6,010 \\
8,069 \\
511 \\
852 \\
795 \\
379 \\
1,674 \\
192 \\
1,491 \\
7,008 \\
18,402 \\
296 \\
1,007 \\
562\end{array}$ & $\begin{array}{r}539 \\
123 \\
0 \\
0 \\
0 \\
0 \\
0 \\
59 \\
22 \\
25 \\
0 \\
0 \\
24 \\
0 \\
0 \\
0 \\
0 \\
0 \\
0 \\
0 \\
53 \\
0 \\
0 \\
121 \\
0 \\
0 \\
0 \\
0 \\
0 \\
0 \\
10 \\
85 \\
0 \\
0 \\
17 \\
0\end{array}$ & $\begin{array}{r}971 \\
6 \\
(s) \\
52 \\
18 \\
11 \\
2 \\
162 \\
0 \\
36 \\
22 \\
2 \\
0 \\
14 \\
20 \\
6 \\
4 \\
3 \\
20 \\
(\mathbf{s}) \\
2 \\
18 \\
102 \\
16 \\
9 \\
14 \\
13 \\
6 \\
28 \\
3 \\
16 \\
34 \\
312 \\
5 \\
0 \\
10\end{array}$ & $\begin{array}{r}1,509 \\
129 \\
(\mathrm{~s}) \\
52 \\
18 \\
11 \\
2 \\
221 \\
22 \\
62 \\
22 \\
2 \\
24 \\
14 \\
20 \\
6 \\
4 \\
3 \\
20 \\
(\mathrm{~s}) \\
55 \\
16 \\
102 \\
137 \\
9 \\
14 \\
13 \\
6 \\
28 \\
3 \\
25 \\
119 \\
312 \\
5 \\
17 \\
10\end{array}$ \\
\hline 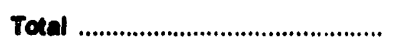 & 452 & 0 & 64 & 1,106 & 864 & 78,320 & 150,514 & 1,224 & 1,327 & 2,551 \\
\hline Porsian Gulf ${ }^{\circ}$.................................. & 0 & 0 & 0 & 0 & 260 & 622 & 8,166 & 128 & 11 & 138 \\
\hline
\end{tabular}

Crude oil and unfinished oils are reported by the PAD District in which they are to be processed; all other products are reported by the PAD District of entry.

- Includes crude oil imported for storage in the Strategic Petroleum Reserve.

c Includes aviation gasoline, aviation gasoline blending components, miscellaneous products, other hydrocarbons and oxygenates, pentanes plus, petroleum coke, and waxes. Sources.

- Includes Bahrain, Iran, iraq, Kuwait, Qatar, Saudi Arabia, and United Arab Emirates.

(8) = Less than 500 barrels per day.

Note: Totals may not equal sum of components due to independent rounding.

Source: Energy Information Administration (EIA) Form EIA-814, "Monthly Imports Report." 
Table 42. PAD District II-Year-to-Date Imports of Crude Oil and Petroleum Products by Country of Origin, January-February 1994 (Thousand Barrels)

\begin{tabular}{|c|c|c|c|c|c|c|c|c|c|c|}
\hline Country of Origin & $\begin{array}{c}\text { Crude } \\
\text { Oil }\end{array}$ & $\begin{array}{l}\text { Liquefied } \\
\text { Petroleum } \\
\text { Coges }\end{array}$ & $\begin{array}{c}\text { Uminished } \\
\text { Olls }\end{array}$ & $\begin{array}{l}\text { Geseline } \\
\text { Blending } \\
\text { Compo: } \\
\text { nente }\end{array}$ & $\begin{array}{l}\text { Finished } \\
\text { Motor } \\
\text { Cnsoline }\end{array}$ & Jet Fuel & $\begin{array}{l}\text { Distillate } \\
\text { Fual Oll }\end{array}$ & $\begin{array}{c}\text { Residual } \\
\text { Fuel Oil } \\
\end{array}$ & Kerosene & $\begin{array}{c}\text { Special } \\
\text { Naphthas }\end{array}$ \\
\hline 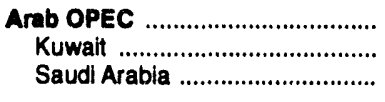 & $\begin{array}{l}5,060 \\
2,112 \\
2,948\end{array}$ & $\begin{array}{l}0 \\
0 \\
0\end{array}$ & $\begin{array}{l}0 \\
0 \\
0\end{array}$ & $\begin{array}{l}0 \\
0 \\
0\end{array}$ & $\begin{array}{l}0 \\
0 \\
0\end{array}$ & $\begin{array}{l}0 \\
0 \\
0\end{array}$ & $\begin{array}{l}0 \\
0 \\
0\end{array}$ & $\begin{array}{l}0 \\
0 \\
0\end{array}$ & $\begin{array}{l}0 \\
0 \\
0\end{array}$ & $\begin{array}{l}0 \\
0 \\
0\end{array}$ \\
\hline 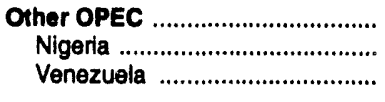 & $\begin{array}{l}9,608 \\
1,854 \\
7,752\end{array}$ & $\begin{array}{l}0 \\
0 \\
0\end{array}$ & $\begin{array}{l}0 \\
0 \\
0\end{array}$ & $\begin{array}{l}0 \\
0 \\
0\end{array}$ & $\begin{array}{l}0 \\
0 \\
0\end{array}$ & $\begin{array}{l}0 \\
0 \\
0\end{array}$ & $\begin{array}{l}0 \\
0 \\
0\end{array}$ & $\begin{array}{l}0 \\
0 \\
0\end{array}$ & $\begin{array}{l}0 \\
0 \\
0\end{array}$ & $\begin{array}{l}0 \\
0 \\
0\end{array}$ \\
\hline 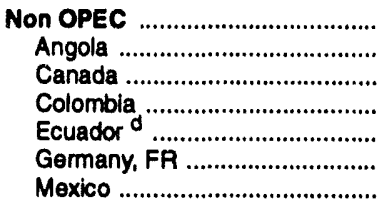 & $\begin{array}{r}52,973 \\
946 \\
40,798 \\
526 \\
1,820 \\
0 \\
8,883\end{array}$ & $\begin{array}{r}5,449 \\
0 \\
5,449 \\
0 \\
0 \\
0 \\
0\end{array}$ & $\begin{array}{r}29 \\
0 \\
29 \\
0 \\
0 \\
0 \\
0\end{array}$ & $\begin{array}{r}39 \\
0 \\
39 \\
0 \\
0 \\
0 \\
0\end{array}$ & $\begin{array}{r}117 \\
0 \\
117 \\
0 \\
0 \\
0 \\
0\end{array}$ & $\begin{array}{r}68 \\
0 \\
66 \\
0 \\
0 \\
0 \\
0\end{array}$ & $\begin{array}{r}501 \\
0 \\
501 \\
0 \\
0 \\
0 \\
0\end{array}$ & $\begin{array}{r}16 \\
0 \\
16 \\
0 \\
0 \\
0 \\
0\end{array}$ & $\begin{array}{l}0 \\
0 \\
0 \\
0 \\
0 \\
0 \\
0\end{array}$ & $\begin{array}{r}139 \\
0 \\
139 \\
0 \\
0 \\
0 \\
0\end{array}$ \\
\hline Total & 67,689 & 5,449 & 20 & 39 & 117 & 68 & 501 & 16 & $\mathbf{0}$ & 139 \\
\hline 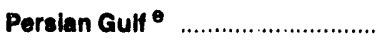 & 5,060 & 0 & 0 & 0 & 0 & 0 & 0 & 0 & 0 & 0 \\
\hline
\end{tabular}


Table 42. PAD District I-Year-to-Date Imports of Crude Oil and Petroleum Products by Country of Origin," January-February 1994 (Continued) (Thousand Barrels)

\begin{tabular}{|c|c|c|c|c|c|c|c|c|c|c|}
\hline \multirow[b]{2}{*}{ Country of Origin } & \multirow[b]{2}{*}{$\begin{array}{c}\text { Naphtha for } \\
\text { Petrochemical } \\
\text { Feedstock } \\
\text { Use }\end{array}$} & \multirow[b]{2}{*}{$\begin{array}{c}\text { Other Oils for } \\
\text { Petrochemical } \\
\text { Feedstock } \\
\text { Uee }\end{array}$} & \multirow[b]{2}{*}{ Lubricante } & \multirow[b]{2}{*}{$\begin{array}{c}\text { Aephatt and } \\
\text { Road OII }\end{array}$} & \multirow[b]{2}{*}{$\begin{array}{c}\text { Other } \\
\text { Productec }\end{array}$} & \multirow[b]{2}{*}{$\begin{array}{c}\text { Total } \\
\text { Products }\end{array}$} & \multirow[b]{2}{*}{$\begin{array}{c}\text { Total } \\
\text { Crude Oil } \\
\text { and } \\
\text { Products }\end{array}$} & \multicolumn{3}{|c|}{ Daily Average } \\
\hline & & & & & & & & $\begin{array}{c}\text { Crude } \\
\text { Oll } \\
\end{array}$ & Products & Total \\
\hline 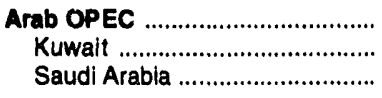 & $\begin{array}{l}0 \\
0 \\
0\end{array}$ & $\begin{array}{l}0 \\
0 \\
0\end{array}$ & $\begin{array}{l}0 \\
0 \\
0\end{array}$ & $\begin{array}{l}0 \\
0 \\
0\end{array}$ & $\begin{array}{l}0 \\
0 \\
0\end{array}$ & $\begin{array}{l}0 \\
0 \\
0\end{array}$ & $\begin{array}{l}5,060 \\
2,112 \\
2,948\end{array}$ & $\begin{array}{l}86 \\
36 \\
50\end{array}$ & $\begin{array}{l}0 \\
0 \\
0\end{array}$ & $\begin{array}{l}86 \\
36 \\
50\end{array}$ \\
\hline 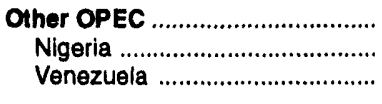 & $\begin{array}{l}0 \\
0 \\
0\end{array}$ & $\begin{array}{l}0 \\
0 \\
0\end{array}$ & $\begin{array}{l}0 \\
0 \\
0\end{array}$ & $\begin{array}{l}0 \\
0 \\
0\end{array}$ & $\begin{array}{l}0 \\
0 \\
0\end{array}$ & $\begin{array}{l}0 \\
0 \\
0\end{array}$ & $\begin{array}{l}9,606 \\
1,854 \\
7,752\end{array}$ & $\begin{array}{r}163 \\
31 \\
131\end{array}$ & $\begin{array}{l}0 \\
0 \\
0\end{array}$ & $\begin{array}{r}163 \\
31 \\
131\end{array}$ \\
\hline 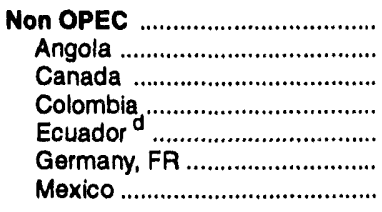 & $\begin{array}{r}35 \\
0 \\
35 \\
0 \\
0 \\
0 \\
0\end{array}$ & $\begin{array}{l}0 \\
0 \\
0 \\
0 \\
0 \\
0 \\
0\end{array}$ & $\begin{array}{r}30 \\
0 \\
30 \\
0 \\
0 \\
0 \\
0\end{array}$ & $\begin{array}{l}0 \\
0 \\
0 \\
0 \\
0 \\
0 \\
0\end{array}$ & $\begin{array}{r}99 \\
0 \\
97 \\
0 \\
0 \\
2 \\
0\end{array}$ & $\begin{array}{r}6,520 \\
0 \\
6,518 \\
0 \\
0 \\
2 \\
0\end{array}$ & $\begin{array}{r}59,493 \\
946 \\
47,316 \\
526 \\
1,820 \\
2 \\
8,883\end{array}$ & $\begin{array}{r}898 \\
16 \\
691 \\
9 \\
31 \\
0 \\
151\end{array}$ & $\begin{array}{r}111 \\
0 \\
110 \\
0 \\
0 \\
(s) \\
0\end{array}$ & $\begin{array}{r}1,008 \\
16 \\
802 \\
9 \\
31 \\
(8) \\
151\end{array}$ \\
\hline 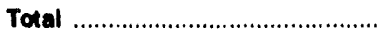 & 35 & 0 & 30 & $\mathbf{0}$ & $\infty$ & 6,520 & 74,159 & 1,146 & 111 & 1,257 \\
\hline 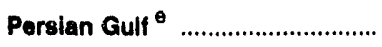 & 0 & 0 & 0 & 0 & 0 & 0 & 5,060 & 86 & 0 & 86 \\
\hline
\end{tabular}

Crude oll and unfinished oils are reported by the PAD District in which they are to be procesed; all other products are reported by the PAD District of entry.

Includes crude oil imported for storage in the Strategic Petroleum Reserve.

c Includes aviation gasoline, aviation gasoline blending components, miscellaneous products, other hydrocarbons and oxygenates, pentanes plus, petroleum coke, and waxes.

On December 31, 1992, Ecuador withdrew as a member of OPEC. As of January 1, 1994, imports of petroleum from Ecuador appear under imports from Non-OPEC Sources.

Includes Bahrain, Iran, Iraq, Kuwait, Qatar, Saudl Arabia, and United Arab Emirates.

(s) : Less than 500 barrels per day.

Note: Totals may not equal sum of components due to independent rounding.

Source: Energy Information Administration (EIA) Form ElA-814, "Monthly Imports Report." 
Table 43. PAD District II-Year-to-Date Imports of Crude Oil and Petroleum Products by Country of Origin, January-February 1994 (Thousand Barrels)

\begin{tabular}{|c|c|c|c|c|c|c|c|c|c|c|}
\hline Country of Origln & $\begin{array}{c}\text { Crude } \\
\text { Oil }\end{array}$ & $\begin{array}{l}\text { Liquofied } \\
\text { Puroloum } \\
\text { Cesees }\end{array}$ & $\begin{array}{c}\text { Unilinished } \\
\text { Olls }\end{array}$ & $\begin{array}{l}\text { Blending } \\
\text { Compo- } \\
\text { nente }\end{array}$ & $\begin{array}{l}\text { FInlohed } \\
\text { Motor } \\
\text { Ceseoline }\end{array}$ & Jet Fuel & $\begin{array}{l}\text { Distillate } \\
\text { Fuel Oil }\end{array}$ & $\begin{array}{c}\text { Residual } \\
\text { Fuel Oll }\end{array}$ & Kerosene & $\begin{array}{c}\text { Special } \\
\text { Naphthes }\end{array}$ \\
\hline 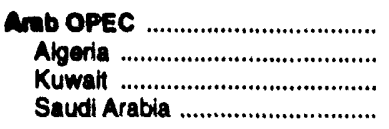 & $\begin{array}{r}73,042 \\
1,671 \\
16,788 \\
54,583\end{array}$ & $\begin{array}{r}393 \\
0 \\
0 \\
393\end{array}$ & $\begin{array}{r}5,189 \\
756 \\
0 \\
4,433\end{array}$ & $\begin{array}{l}0 \\
0 \\
0 \\
0\end{array}$ & $\begin{array}{l}0 \\
0 \\
0 \\
0\end{array}$ & $\begin{array}{l}0 \\
0 \\
0 \\
0\end{array}$ & $\begin{array}{l}0 \\
0 \\
0 \\
0\end{array}$ & $\begin{array}{r}43 \\
43 \\
0 \\
0\end{array}$ & $\begin{array}{l}0 \\
0 \\
0 \\
0\end{array}$ & $\begin{array}{l}0 \\
0 \\
0 \\
0\end{array}$ \\
\hline 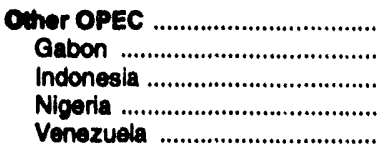 & $\begin{array}{r}45,680 \\
1,850 \\
0 \\
5,520 \\
38,290\end{array}$ & $\begin{array}{r}143 \\
0 \\
0 \\
0 \\
143\end{array}$ & $\begin{array}{r}1,589 \\
0 \\
0 \\
0 \\
1,589\end{array}$ & $\begin{array}{r}46 \\
0 \\
0 \\
0 \\
46\end{array}$ & $\begin{array}{l}0 \\
0 \\
0 \\
0 \\
0\end{array}$ & $\begin{array}{l}0 \\
0 \\
0 \\
0 \\
0\end{array}$ & $\begin{array}{l}0 \\
0 \\
0 \\
0 \\
0\end{array}$ & $\begin{array}{r}936 \\
0 \\
0 \\
0 \\
936\end{array}$ & $\begin{array}{l}0 \\
0 \\
0 \\
0 \\
0\end{array}$ & $\begin{array}{l}0 \\
0 \\
0 \\
0 \\
0\end{array}$ \\
\hline 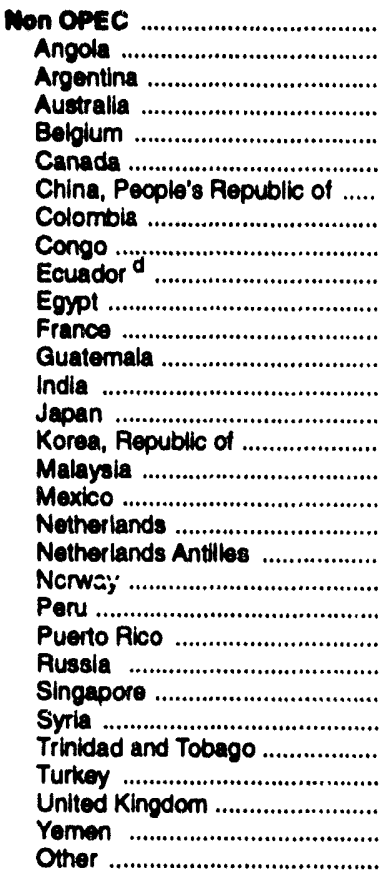 & $\begin{array}{r}81,842 \\
10,150 \\
1,124 \\
0 \\
0 \\
1,083 \\
674 \\
6,280 \\
530 \\
4,161 \\
2,999 \\
0 \\
222 \\
0 \\
0 \\
0 \\
406 \\
43,204 \\
0 \\
0 \\
487 \\
0 \\
0 \\
0 \\
0 \\
500 \\
3,542 \\
0 \\
6,480 \\
0 \\
0\end{array}$ & $\begin{array}{r}1,231 \\
0 \\
0 \\
0 \\
0 \\
494 \\
0 \\
0 \\
0 \\
0 \\
0 \\
35 \\
0 \\
0 \\
0 \\
0 \\
0 \\
652 \\
0 \\
50 \\
0 \\
0 \\
0 \\
0 \\
0 \\
0 \\
0 \\
0 \\
0 \\
0 \\
0\end{array}$ & $\begin{array}{r}10,481 \\
0 \\
0 \\
0 \\
248 \\
480 \\
0 \\
346 \\
0 \\
0 \\
0 \\
691 \\
0 \\
0 \\
0 \\
2,982 \\
0 \\
0 \\
1,202 \\
2,292 \\
132 \\
142 \\
0 \\
330 \\
397 \\
231 \\
0 \\
0 \\
1,007 \\
0 \\
0\end{array}$ & $\begin{array}{r}11 \\
0 \\
11 \\
0 \\
0 \\
0 \\
0 \\
0 \\
0 \\
0 \\
0 \\
0 \\
0 \\
0 \\
0 \\
0 \\
0 \\
0 \\
0 \\
0 \\
0 \\
0 \\
0 \\
0 \\
0 \\
0 \\
0 \\
0 \\
0 \\
0 \\
0\end{array}$ & $\begin{array}{l}0 \\
0 \\
0 \\
0 \\
0 \\
0 \\
0 \\
0 \\
0 \\
0 \\
0 \\
0 \\
0 \\
0 \\
0 \\
0 \\
0 \\
0 \\
0 \\
0 \\
0 \\
0 \\
0 \\
0 \\
0 \\
0 \\
0 \\
0 \\
0 \\
0 \\
0\end{array}$ & $\begin{array}{r}18 \\
0 \\
0 \\
0 \\
0 \\
0 \\
0 \\
0 \\
0 \\
0 \\
0 \\
0 \\
0 \\
0 \\
0 \\
0 \\
0 \\
18 \\
0 \\
0 \\
0 \\
0 \\
0 \\
0 \\
0 \\
0 \\
0 \\
0 \\
0 \\
0 \\
0\end{array}$ & $\begin{array}{l}0 \\
0 \\
0 \\
0 \\
0 \\
0 \\
0 \\
0 \\
0 \\
0 \\
0 \\
0 \\
0 \\
0 \\
0 \\
0 \\
0 \\
0 \\
0 \\
0 \\
0 \\
0 \\
0 \\
0 \\
0 \\
0 \\
0 \\
0 \\
0 \\
0 \\
0\end{array}$ & $\begin{array}{r}1.146 \\
0 \\
0 \\
361 \\
0 \\
0 \\
0 \\
0 \\
0 \\
0 \\
0 \\
0 \\
0 \\
0 \\
0 \\
0 \\
0 \\
0 \\
0 \\
0 \\
0 \\
0 \\
0 \\
0 \\
380 \\
0 \\
0 \\
0 \\
0 \\
405 \\
0\end{array}$ & $\begin{array}{r}134 \\
0 \\
0 \\
0 \\
0 \\
0 \\
0 \\
0 \\
0 \\
0 \\
0 \\
0 \\
0 \\
0 \\
0 \\
0 \\
0 \\
134 \\
0 \\
0 \\
0 \\
0 \\
0 \\
0 \\
0 \\
0 \\
0 \\
0 \\
0 \\
0 \\
0\end{array}$ & $\begin{array}{r}122 \\
0 \\
0 \\
0 \\
0 \\
120 \\
0 \\
0 \\
0 \\
0 \\
0 \\
0 \\
0 \\
0 \\
0 \\
0 \\
0 \\
0 \\
0 \\
0 \\
0 \\
0 \\
0 \\
0 \\
0 \\
0 \\
0 \\
0 \\
0 \\
0 \\
0\end{array}$ \\
\hline 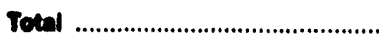 & 200,544 & 1,787 & 17,250 & 57 & 0 & 18 & 0 & 2,125 & 134 & 122 \\
\hline Purslan Gutf ${ }^{\ominus}$............................... & 71,371 & 393 & 4,433 & 0 & $\mathbf{0}$ & $\mathbf{0}$ & $\mathbf{0}$ & 0 & 0 & $\mathbf{0}$ \\
\hline
\end{tabular}


Table 43. PAD District III-Year-to-Date Imports of Crude Oil and Petroleum Products by Country of Origin, ${ }^{a}$ January-February 1994 (Continu-d) (Thousand Barrels)

\begin{tabular}{|c|c|c|c|c|c|c|c|c|c|c|}
\hline \multirow[b]{2}{*}{ Country of Origin } & \multirow[b]{2}{*}{$\begin{array}{c}\text { Naphtha for } \\
\text { Petrochemical } \\
\text { Feedstock } \\
\text { Use }\end{array}$} & \multirow[b]{2}{*}{$\begin{array}{c}\text { Other Olls for } \\
\text { Petrochemical } \\
\text { Feedstock } \\
\text { Use }\end{array}$} & \multirow[b]{2}{*}{ Lubricants } & \multirow[b]{2}{*}{$\begin{array}{c}\text { Asphalt and } \\
\text { Road OII }\end{array}$} & \multirow[b]{2}{*}{$\begin{array}{c}\text { Other } \\
\text { Products }\end{array}$} & \multirow[b]{2}{*}{$\begin{array}{c}\text { Total } \\
\text { Products }\end{array}$} & \multirow[b]{2}{*}{$\begin{array}{l}\text { Total } \\
\text { Crude Oil } \\
\text { and } \\
\text { Products }\end{array}$} & \multicolumn{3}{|c|}{ Daily Average } \\
\hline & & & & & & & & $\begin{array}{c}\text { Crude } \\
\text { Oll }\end{array}$ & Products & Total \\
\hline 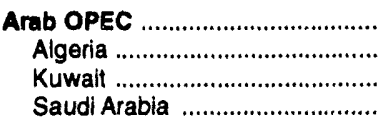 & $\begin{array}{r}95 \\
0 \\
0 \\
95\end{array}$ & $\begin{array}{r}6,616 \\
6,616 \\
0 \\
0\end{array}$ & $\begin{array}{l}0 \\
0 \\
0 \\
0\end{array}$ & $\begin{array}{l}0 \\
0 \\
0 \\
0\end{array}$ & $\begin{array}{r}1,501 \\
1,501 \\
0 \\
0\end{array}$ & $\begin{array}{r}13,837 \\
8,916 \\
0 \\
4,921\end{array}$ & $\begin{array}{l}86,879 \\
10,587 \\
16,788 \\
59,504\end{array}$ & $\begin{array}{r}1,238 \\
28 \\
285 \\
925\end{array}$ & $\begin{array}{r}235 \\
151 \\
0 \\
83\end{array}$ & $\begin{array}{r}1,473 \\
179 \\
285 \\
1,009\end{array}$ \\
\hline 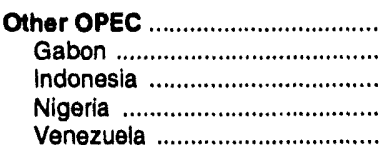 & $\begin{array}{r}229 \\
0 \\
0 \\
0 \\
229\end{array}$ & $\begin{array}{l}0 \\
0 \\
0 \\
0 \\
0\end{array}$ & $\begin{array}{l}0 \\
0 \\
0 \\
0 \\
0\end{array}$ & $\begin{array}{r}53 \\
0 \\
0 \\
0 \\
53\end{array}$ & $\begin{array}{l}9 \\
0 \\
9 \\
0 \\
0\end{array}$ & $\begin{array}{r}3,005 \\
0 \\
9 \\
0 \\
2,996\end{array}$ & $\begin{array}{r}48,665 \\
1,850 \\
9 \\
5,520 \\
41,286\end{array}$ & $\begin{array}{r}774 \\
31 \\
0 \\
94 \\
649\end{array}$ & $\begin{array}{r}51 \\
0 \\
(s) \\
0 \\
51\end{array}$ & $\begin{array}{r}825 \\
31 \\
(s) \\
94 \\
700\end{array}$ \\
\hline 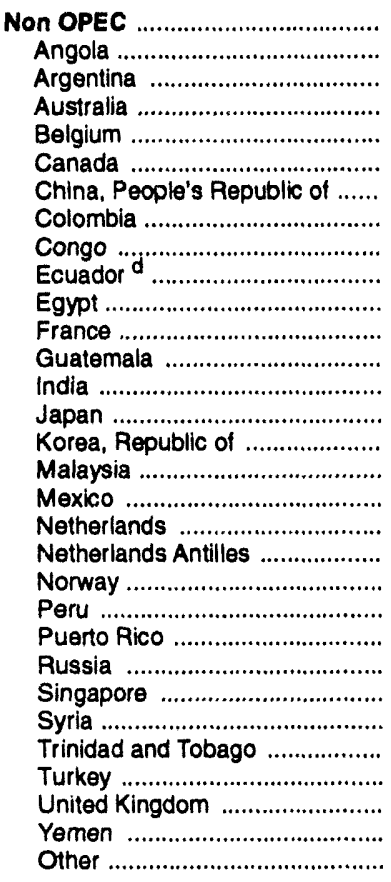 & $\begin{array}{r}1,543 \\
0 \\
365 \\
0 \\
0 \\
59 \\
0 \\
0 \\
0 \\
0 \\
0 \\
0 \\
0 \\
242 \\
10 \\
32 \\
351 \\
293 \\
0 \\
0 \\
0 \\
0 \\
120 \\
0 \\
0 \\
0 \\
0 \\
71 \\
0 \\
0 \\
0\end{array}$ & $\begin{array}{r}507 \\
0 \\
0 \\
0 \\
0 \\
507 \\
0 \\
0 \\
0 \\
0 \\
0 \\
0 \\
0 \\
0 \\
0 \\
0 \\
0 \\
0 \\
0 \\
0 \\
0 \\
0 \\
0 \\
0 \\
0 \\
0 \\
0 \\
0 \\
0 \\
0 \\
0\end{array}$ & $\begin{array}{l}0 \\
0 \\
0 \\
0 \\
0 \\
0 \\
0 \\
0 \\
0 \\
0 \\
0 \\
0 \\
0 \\
0 \\
0 \\
0 \\
0 \\
0 \\
0 \\
0 \\
0 \\
0 \\
0 \\
0 \\
0 \\
0 \\
0 \\
0 \\
0 \\
0 \\
0\end{array}$ & $\begin{array}{l}0 \\
0 \\
0 \\
0 \\
0 \\
0 \\
0 \\
0 \\
0 \\
0 \\
0 \\
0 \\
0 \\
0 \\
0 \\
0 \\
0 \\
0 \\
0 \\
0 \\
0 \\
0 \\
0 \\
0 \\
0 \\
0 \\
0 \\
0 \\
0 \\
0 \\
0\end{array}$ & $\begin{array}{r}543 \\
0 \\
0 \\
0 \\
0 \\
0 \\
80 \\
0 \\
0 \\
0 \\
1 \\
0 \\
0 \\
0 \\
0 \\
25 \\
0 \\
432 \\
0 \\
0 \\
0 \\
0 \\
0 \\
0 \\
0 \\
0 \\
0 \\
0 \\
0 \\
0 \\
5\end{array}$ & $\begin{array}{r}15,736 \\
0 \\
376 \\
361 \\
248 \\
1,662 \\
80 \\
346 \\
0 \\
0 \\
1 \\
726 \\
0 \\
242 \\
10 \\
3,039 \\
351 \\
1,529 \\
1,202 \\
2,342 \\
133 \\
142 \\
120 \\
330 \\
777 \\
231 \\
0 \\
71 \\
1,007 \\
405 \\
5\end{array}$ & $\begin{array}{r}97,578 \\
10,150 \\
1,500 \\
361 \\
248 \\
2,745 \\
754 \\
6,626 \\
530 \\
4,161 \\
3,000 \\
726 \\
222 \\
242 \\
10 \\
3,039 \\
757 \\
44,733 \\
1,202 \\
2,342 \\
620 \\
142 \\
120 \\
330 \\
777 \\
731 \\
3,542 \\
71 \\
7,487 \\
405 \\
5\end{array}$ & $\begin{array}{r}1,387 \\
172 \\
19 \\
0 \\
0 \\
18 \\
11 \\
106 \\
9 \\
71 \\
51 \\
0 \\
4 \\
0 \\
0 \\
0 \\
7 \\
732 \\
0 \\
0 \\
8 \\
0 \\
0 \\
0 \\
0 \\
8 \\
60 \\
0 \\
110 \\
0 \\
0\end{array}$ & $\begin{array}{r}267 \\
0 \\
6 \\
6 \\
4 \\
28 \\
1 \\
6 \\
0 \\
0 \\
(s) \\
12 \\
0 \\
4 \\
(s) \\
52 \\
6 \\
26 \\
20 \\
40 \\
2 \\
2 \\
2 \\
6 \\
13 \\
4 \\
0 \\
1 \\
17 \\
7 \\
(s)\end{array}$ & $\begin{array}{r}1,654 \\
172 \\
25 \\
6 \\
4 \\
47 \\
13 \\
112 \\
9 \\
71 \\
51 \\
12 \\
4 \\
4 \\
(s) \\
52 \\
13 \\
758 \\
20 \\
40 \\
11 \\
2 \\
2 \\
6 \\
13 \\
12 \\
60 \\
1 \\
127 \\
7 \\
(\mathrm{~s})\end{array}$ \\
\hline 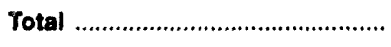 & 1,867 & 7,123 & 0 & 53 & 2,053 & 32,578 & 233,122 & 3,399 & 552 & 3,951 \\
\hline 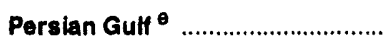 & 95 & 0 & 0 & 0 & 0 & 4,921 & 76,292 & 1,210 & 83 & 1,293 \\
\hline
\end{tabular}

Crude oil and unfinished oils are reported by the PAD District in which they are to be processed; all other products are reported by the PAD District of entry.

b Includes crude oil imported for storage in the Strategic Petroleum Reserve.

c Includes aviation gasoline, aviation gasoline blending components, miscellaneous products, other hydrocarbons and oxygenates, pentanes plus, petroleum coke, and waxes.

d On December 31, 1992, Ecuador withdrew as a member of OPEC. As of January 1, 1994, imports of petroleum from Ecuador appear under imports from Non-OPEC Sources.

- Includes Bahrain, Iran, Iraq, Kuwait, Qatar, Saudi Arabia, and United Arab Emirates

$(s)=$ Less than 500 barrels per day.

Note: Totals may not equal sum of components due to independent rounding

Source: Energy Information Administration (EIA) Form ElA-814, "Monthly Imports Report." 
Table 44. PAD Districts IV and V-Year-to-Date Imports of Crude Oil and Petroleum Products by Country of Origin," January-February 1994

(Thousand Barrels)

\begin{tabular}{|c|c|c|c|c|c|c|c|c|c|c|}
\hline Country of Origin & $\begin{array}{c}\text { Crude } \\
\mathrm{OAl}^{\mathrm{b}}\end{array}$ & $\begin{array}{c}\text { Liquofied } \\
\text { Potroloum } \\
\text { Gases }\end{array}$ & $\begin{array}{c}\text { Unfinished } \\
\text { Olls }\end{array}$ & $\begin{array}{c}\text { Gasoline } \\
\text { Blending } \\
\text { Compo- } \\
\text { nents } \\
\end{array}$ & $\begin{array}{l}\text { Finished } \\
\text { Motor } \\
\text { Gasoline }\end{array}$ & Jet Fuel & $\begin{array}{l}\text { Diatillate } \\
\text { Fuel Oll }\end{array}$ & $\begin{array}{l}\text { Residual } \\
\text { Fuel Oll }\end{array}$ & Kerosene & $\begin{array}{c}\text { Special } \\
\text { Naphthas }\end{array}$ \\
\hline
\end{tabular}

PAD District IV

Non OPEC

Canada

Total

$\begin{array}{lll}5,879 & 556 & 0 \\ 5,879 & 556 \\ 5,879 & 556 & \end{array}$

$\begin{array}{ll}0 & 12 \\ 0 & 12\end{array}$

12
12
12

0
0
0

153
153
153

4
4
4

$\begin{array}{ll}0 & 0 \\ 0 & 0 \\ 0 & 0\end{array}$

PAD District $V$

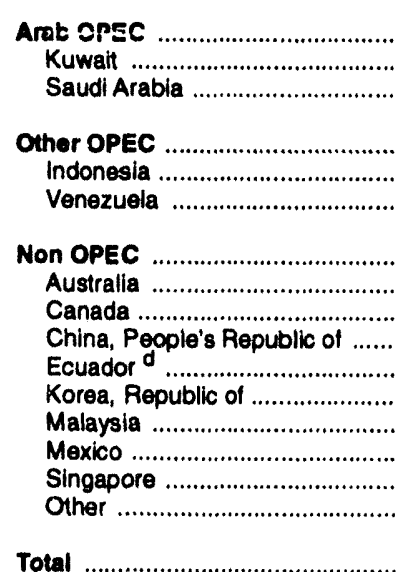

Total

Perslan Gulf ${ }^{\circ}$

\begin{tabular}{|c|c|c|c|c|c|c|c|c|c|}
\hline \multicolumn{10}{|c|}{ PAD District V } \\
\hline $\begin{array}{r}2, E 22 \\
2,529 \\
0\end{array}$ & $\begin{array}{l}0 \\
0 \\
0\end{array}$ & $\begin{array}{l}0 \\
0 \\
0\end{array}$ & $\begin{array}{l}0 \\
0 \\
0\end{array}$ & $\begin{array}{l}0 \\
0 \\
0\end{array}$ & $\begin{array}{r}25 \\
0 \\
25\end{array}$ & $\begin{array}{l}0 \\
0 \\
0\end{array}$ & $\begin{array}{l}0 \\
0 \\
0\end{array}$ & $\begin{array}{l}\mathbf{C} \\
0 \\
0\end{array}$ & $\begin{array}{l}0 \\
0 \\
0\end{array}$ \\
\hline $\begin{array}{r}4,829 \\
4,169 \\
660\end{array}$ & $\begin{array}{l}0 \\
0 \\
0\end{array}$ & $\begin{array}{l}0 \\
0 \\
0\end{array}$ & $\begin{array}{l}0 \\
0 \\
0\end{array}$ & $\begin{array}{l}0 \\
0 \\
0\end{array}$ & $\begin{array}{l}1 \\
1 \\
0\end{array}$ & $\begin{array}{l}0 \\
0 \\
0\end{array}$ & $\begin{array}{r}161 \\
161 \\
0\end{array}$ & $\begin{array}{l}0 \\
0 \\
0\end{array}$ & $\begin{array}{l}0 \\
0 \\
0\end{array}$ \\
\hline $\begin{array}{r}7,952 \\
0 \\
4,650 \\
1,711 \\
672 \\
0 \\
0 \\
0 \\
0 \\
919\end{array}$ & $\begin{array}{r}181 \\
0 \\
181 \\
0 \\
0 \\
0 \\
0 \\
0 \\
0 \\
0\end{array}$ & $\begin{array}{r}421 \\
0 \\
101 \\
0 \\
0 \\
0 \\
0 \\
0 \\
320 \\
0\end{array}$ & $\begin{array}{l}0 \\
0 \\
0 \\
0 \\
0 \\
0 \\
0 \\
0 \\
0 \\
0\end{array}$ & $\begin{array}{r}159 \\
0 \\
159 \\
0 \\
0 \\
0 \\
0 \\
0 \\
0 \\
0\end{array}$ & $\begin{array}{r}27 \\
1 \\
2 \\
0 \\
0 \\
0 \\
0 \\
24 \\
0 \\
0\end{array}$ & $\begin{array}{r}42 \\
0 \\
42 \\
0 \\
0 \\
0 \\
0 \\
0 \\
0 \\
0\end{array}$ & $\begin{array}{r}344 \\
0 \\
45 \\
0 \\
0 \\
0 \\
0 \\
299 \\
0 \\
0\end{array}$ & $\begin{array}{l}0 \\
0 \\
0 \\
0 \\
0 \\
0 \\
0 \\
0 \\
0 \\
0\end{array}$ & $\begin{array}{l}\mathbf{5} \\
0 \\
5 \\
0 \\
0 \\
0 \\
0 \\
0 \\
0 \\
0\end{array}$ \\
\hline 15,310 & 181 & 421 & 0 & 159 & 53 & 42 & 505 & 0 & $\mathbf{5}$ \\
\hline 2,529 & 0 & 0 & 0 & 0 & 25 & 0 & 0 & 0 & 0 \\
\hline
\end{tabular}

See tootnotes at end of table. 
Table 44. PAD Districts IV and V-Year-to-Date Imports of Crude Oil and Petroleum Products by Country of Origin," January-February 1994 (Continued)

(Thousand Barrels)

\begin{tabular}{|c|c|c|c|c|c|c|c|c|c|c|}
\hline \multirow[b]{2}{*}{ Country of Origin } & \multirow[b]{2}{*}{$\begin{array}{c}\text { Naphtha for } \\
\text { Petrochemical } \\
\text { Foedstock } \\
\text { Use }\end{array}$} & \multirow[b]{2}{*}{$\begin{array}{c}\text { Other Olls for } \\
\text { Petrochemical } \\
\text { Feedstock } \\
\text { Use }\end{array}$} & \multirow[b]{2}{*}{ Lubricants } & \multirow[b]{2}{*}{$\begin{array}{c}\text { Asphalt and } \\
\text { Road OII }\end{array}$} & \multirow[b]{2}{*}{$\begin{array}{c}\text { Other } \\
\text { Productse }\end{array}$} & \multirow[b]{2}{*}{$\begin{array}{c}\text { Total } \\
\text { Products }\end{array}$} & \multirow[b]{2}{*}{$\begin{array}{c}\text { Total } \\
\text { Crude OII } \\
\text { and } \\
\text { Products }\end{array}$} & \multicolumn{3}{|c|}{ Dally Average } \\
\hline & & & & & & & & $\begin{array}{c}\text { Crude } \\
\text { Oll }\end{array}$ & Products & Total \\
\hline
\end{tabular}

PAD District IV

\begin{tabular}{|c|c|c|c|c|c|c|c|c|c|c|}
\hline \multirow[b]{2}{*}{$\begin{array}{l}\text { Non OPEC } \\
\text { Canada }\end{array}$} & \multicolumn{10}{|c|}{ PAD District IV } \\
\hline & $\begin{array}{l}0 \\
0\end{array}$ & $\begin{array}{l}0 \\
0\end{array}$ & $\begin{array}{l}0 \\
0\end{array}$ & $\begin{array}{l}1 \\
1\end{array}$ & $\begin{array}{l}729 \\
729\end{array}$ & $\begin{array}{l}1,455 \\
1,455\end{array}$ & $\begin{array}{l}7,334 \\
7,334\end{array}$ & $\begin{array}{l}100 \\
100\end{array}$ & $\begin{array}{l}25 \\
25\end{array}$ & $\begin{array}{l}124 \\
124\end{array}$ \\
\hline 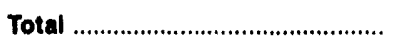 & 0 & 0 & 0 & 1 & 729 & 1,455 & 7,334 & 100 & 25 & 124 \\
\hline
\end{tabular}

PAD District $v$

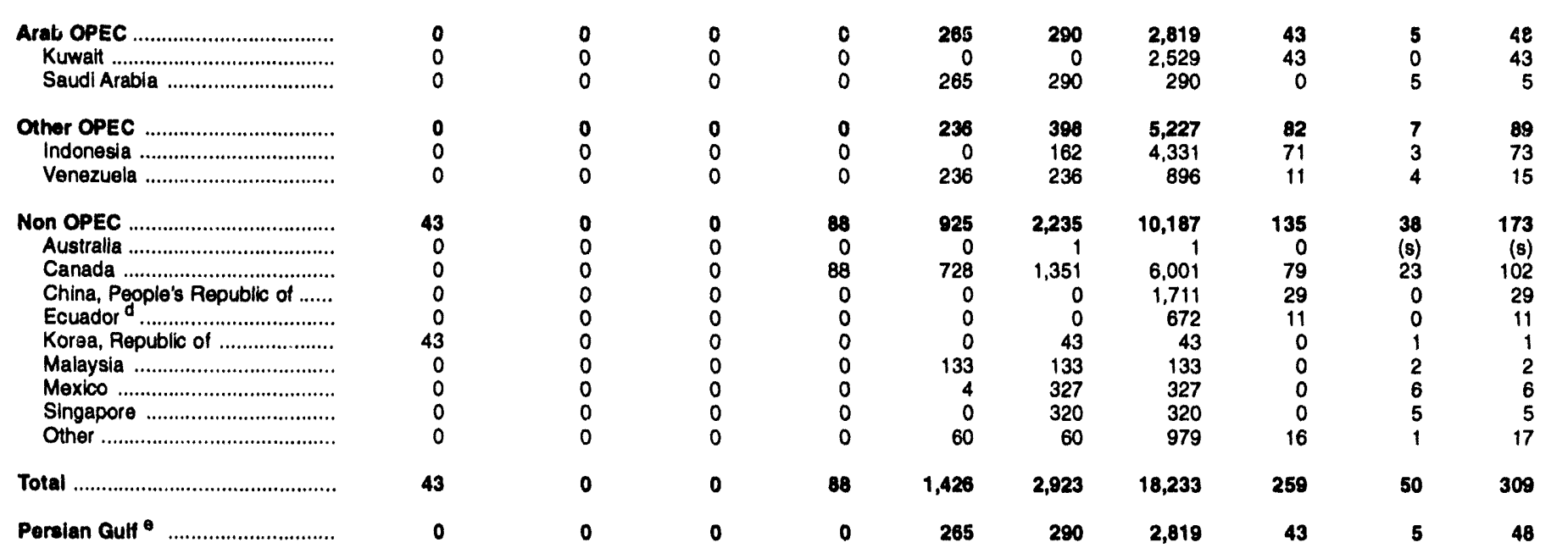

Crude oil and unfinished oils are reported by the PAD District in which they are to be processed; all other products are reported by the PAD District of entry.

includes crude oil imported for storage in the Strategic Petroleum Resene.

c Includes aviation gasoline, aviation gasoline blending components, miscellaneous products, other hydrocarbons and oxygenates, pentanes plus, petroleum coke, and waxes. Sources.

On December 31, 1992, Ecuador withdrew as a member of OPEC. As of January 1, 1994, imports of petroleum from Ecuador appear under imports from Non-OPEC

Includes Bahrain, Iran, Iraq, Kuwait, Qatar, Saudl Arabia, and United Arab Emirates.

(s) = Less than 500 barrels per day.

Note: Totals may not equal sum of components due to independent rounding.

Source: Energy Information Administration (EIA) Form EIA-814, "Monthly Imports Report." 
Table 45. Exports of Crude Oil and Petroleum Products by PAD District, February 1994

(Thousand Barrels)

\begin{tabular}{|c|c|c|c|c|c|c|c|}
\hline \multirow[b]{2}{*}{ Commodity } & \multicolumn{6}{|c|}{ Petroleum Administration for Defense Districts } & \multirow[b]{2}{*}{$\begin{array}{c}\text { Dally } \\
\text { Average }\end{array}$} \\
\hline & 1 & $\|$ & III & IV & $v$ & $\begin{array}{l}\text { U.S. } \\
\text { Total }\end{array}$ & \\
\hline Crude $\mathrm{Oll}^{\mathbf{a}}$ & 2 & 0 & 5 & 0 & 3,237 & 3,244 & 116 \\
\hline 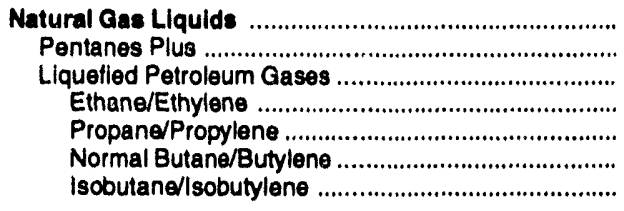 & $\begin{array}{r}27 \\
1 \\
26 \\
0 \\
20 \\
5 \\
0\end{array}$ & $\begin{array}{r}147 \\
17 \\
130 \\
0 \\
63 \\
67 \\
0\end{array}$ & $\begin{array}{r}925 \\
0 \\
925 \\
0 \\
736 \\
189 \\
0\end{array}$ & $\begin{array}{l}3 \\
3 \\
0 \\
0 \\
0 \\
0 \\
0\end{array}$ & $\begin{array}{r}159 \\
0 \\
159 \\
0 \\
21 \\
138 \\
0\end{array}$ & $\begin{array}{r}1,261 \\
22 \\
1,240 \\
0 \\
841 \\
399 \\
0\end{array}$ & $\begin{array}{r}45 \\
1 \\
44 \\
0 \\
30 \\
14 \\
0\end{array}$ \\
\hline $\begin{array}{l}\text { Other Llquids } \\
\text { Other Hydrocarbons/Oxygenates } \\
\text { Motor Gasoline Blend. Comp. }\end{array}$ & $\begin{array}{r}1 \\
(8) \\
(8)\end{array}$ & $\begin{array}{r}(8) \\
(8)\end{array}$ & $\begin{array}{r}119 \\
118 \\
1\end{array}$ & $\begin{array}{l}0 \\
0 \\
0\end{array}$ & $\begin{array}{r}246 \\
0 \\
246\end{array}$ & $\begin{array}{l}366 \\
119 \\
247\end{array}$ & $\begin{array}{r}13 \\
4 \\
9\end{array}$ \\
\hline 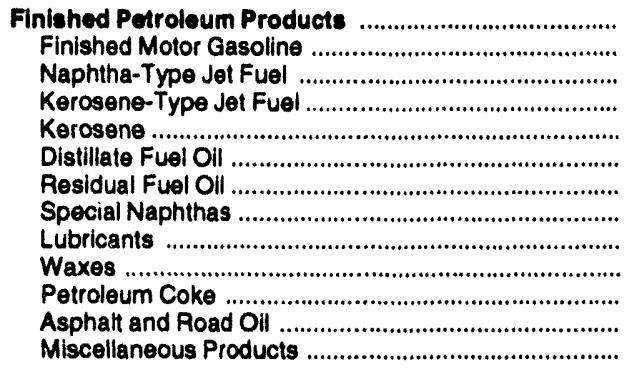 & $\begin{array}{r}676 \\
15 \\
(s) \\
(8) \\
1 \\
63 \\
260 \\
7 \\
94 \\
9 \\
218 \\
3 \\
5\end{array}$ & $\begin{array}{r}288 \\
14 \\
0 \\
21 \\
0 \\
87 \\
40 \\
10 \\
32 \\
3 \\
43 \\
18 \\
1\end{array}$ & $\begin{array}{r}10,083 \\
1,836 \\
0 \\
11 \\
(8) \\
2,705 \\
1,778 \\
17 \\
316 \\
30 \\
3,371 \\
20 \\
(\mathrm{~s})\end{array}$ & $\begin{array}{r}18 \\
10 \\
0 \\
0 \\
0 \\
3 \\
0 \\
(s) \\
4 \\
0 \\
0 \\
1 \\
0\end{array}$ & $\begin{array}{r}8,773 \\
277 \\
265 \\
690 \\
3 \\
3,710 \\
1,488 \\
2 \\
81 \\
10 \\
2,236 \\
9 \\
1\end{array}$ & $\begin{array}{r}19,819 \\
2,152 \\
266 \\
722 \\
4 \\
6,568 \\
3,565 \\
36 \\
527 \\
52 \\
5,868 \\
51 \\
8\end{array}$ & $\begin{array}{r}708 \\
77 \\
9 \\
26 \\
(8) \\
235 \\
127 \\
1 \\
19 \\
2 \\
210 \\
2 \\
(8)\end{array}$ \\
\hline Total & 705 & 415 & 11,133 & 21 & 12,415 & 24,690 & 882 \\
\hline
\end{tabular}

- Crude oll exports are restricted to: (1) crude oll dertved from flelds under the State waters of Alaska's Cook iniet; (2) certain domestically produced crude gil testined for Canada; and (3) shipments to U.S. territories, and Calitornia crude oil to Pacific Rim countries. On December 6, 1991, the U.S Departmant of Commerce approved a license to export 25,000 barrels per day of Callornia heavy crude oil (less than 20 degrees API gravity) to Paciflc Rim countries for one year. (s) = Less than 500 barrels or less than 500 barrels per day.

Note: Totais may not equal sum of components due to independent rounding.

Sources: Energy Information Administration (EIA) Form EIA-810, "Monthly Refinery Report" and the U.S. Bureau of the Census. 
Table 46. Year-to-Date Exports of Crude Oil and Petroleum Products by PAD District, January-February 1994

(Thousand Barrels)

\begin{tabular}{|c|c|c|c|c|c|c|c|}
\hline \multirow{2}{*}{ Commodity } & \multicolumn{6}{|c|}{ Petroleum Administration for Defense Districts } & \multirow[b]{2}{*}{$\begin{array}{c}\text { Dally } \\
\text { Average }\end{array}$} \\
\hline & 1 & $\boldsymbol{H}$ & III & IV & $\mathbf{v}$ & U.S. & \\
\hline Crude OIr & 2 & 0 & 5 & 0 & 6,638 & 6,645 & 113 \\
\hline 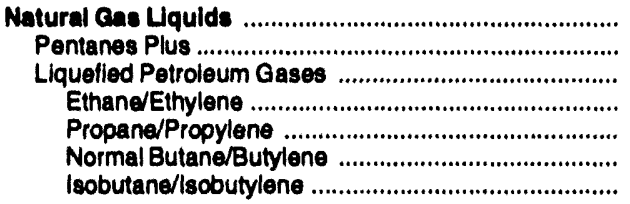 & $\begin{array}{r}48 \\
5 \\
43 \\
0 \\
37 \\
6 \\
0\end{array}$ & $\begin{array}{r}258 \\
30 \\
229 \\
0 \\
94 \\
134 \\
0\end{array}$ & $\begin{array}{r}1,566 \\
0 \\
1,566 \\
0 \\
1,201 \\
365 \\
0\end{array}$ & $\begin{array}{l}9 \\
9 \\
0 \\
0 \\
0 \\
0 \\
0\end{array}$ & $\begin{array}{r}274 \\
(s) \\
274 \\
0 \\
110 \\
163 \\
0\end{array}$ & $\begin{array}{r}2,155 \\
43 \\
2,112 \\
0 \\
1,442 \\
669 \\
0\end{array}$ & $\begin{array}{r}37 \\
1 \\
36 \\
0 \\
24 \\
11 \\
0\end{array}$ \\
\hline 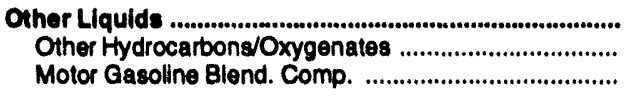 & $\begin{array}{l}1 \\
1 \\
1\end{array}$ & $\begin{array}{l}(\mathbf{s}) \\
(\mathrm{s}) \\
(\mathrm{s})\end{array}$ & $\begin{array}{r}285 \\
284 \\
1\end{array}$ & $\begin{array}{l}0 \\
0 \\
0\end{array}$ & $\begin{array}{r}246 \\
(s) \\
246\end{array}$ & $\begin{array}{l}533 \\
285 \\
248\end{array}$ & $\begin{array}{l}9 \\
5 \\
4\end{array}$ \\
\hline 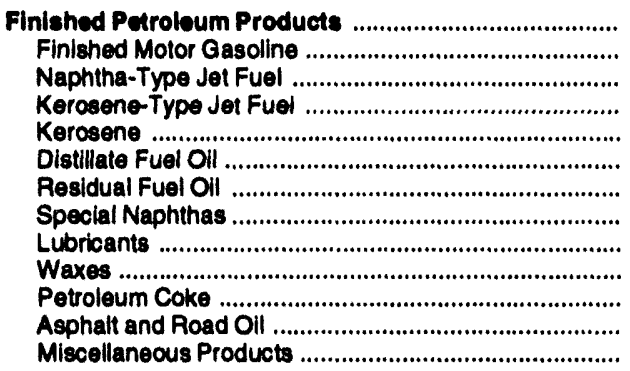 & $\begin{array}{r}2,215 \\
38 \\
1 \\
44 \\
2 \\
1,147 \\
338 \\
13 \\
230 \\
26 \\
359 \\
5 \\
11\end{array}$ & $\begin{array}{r}637 \\
96 \\
1 \\
83 \\
46 \\
90 \\
96 \\
20 \\
68 \\
6 \\
103 \\
27 \\
1\end{array}$ & $\begin{array}{r}23,553 \\
4,229 \\
343 \\
53 \\
(5) \\
8,227 \\
2,517 \\
43 \\
601 \\
56 \\
7,458 \\
25 \\
(s)\end{array}$ & $\begin{array}{r}31 \\
17 \\
0 \\
0 \\
0 \\
5 \\
0 \\
1 \\
7 \\
0 \\
0 \\
2 \\
0\end{array}$ & $\begin{array}{r}17,655 \\
781 \\
603 \\
1,102 \\
3 \\
7,379 \\
2,612 \\
6 \\
162 \\
22 \\
4,959 \\
24 \\
2\end{array}$ & $\begin{array}{r}44,092 \\
5,161 \\
948 \\
1,283 \\
52 \\
16,849 \\
5,564 \\
82 \\
1,067 \\
111 \\
12,879 \\
82 \\
15\end{array}$ & $\begin{array}{r}747 \\
87 \\
16 \\
22 \\
1 \\
286 \\
94 \\
1 \\
18 \\
2 \\
218 \\
1 \\
(8)\end{array}$ \\
\hline (n) & 2,286 & 898 & 25,409 & 40 & 24,814 & $\mathbf{5 3 , 4 2 5}$ & 906 \\
\hline
\end{tabular}

- Crude oll exports are restricted to: (1) crude oll derived from flelds under the State waters of Alaska's Cook Inlet; (2) certain domestically produced crude oil destined for Canade; and (3) shipments to U.S. territories, and California crude oil to Pacific Fim countries. On December 6, 1991, the U.S. Department of Commerce epproved a license to export 25,000 barrels per day of California heavy crude oll (less than 20 degrees API gravity) to Pacific Rim countries for one year.

(8) = Less than 500 barrels or less than 500 barrels per day.

Note: Totals may not equal sum of components due to independent rounding.

Sources; Energy Information Administration (EIA) Form EIA-810, "Monthly Refinery Report" and the U.S. Bureau of the Census. 
Table 47. Exports of Crude Oll and Petroleum Products by Destination, February 1994 (Thousand Barrels)

\begin{tabular}{|c|c|c|c|c|c|c|c|c|}
\hline Destination & $\begin{array}{l}\text { Crude } \\
\text { OII }\end{array}$ & $\begin{array}{c}\text { Pentanes } \\
\text { Plue }\end{array}$ & $\begin{array}{l}\text { Liquolled } \\
\text { Petroloum } \\
\text { Ches }\end{array}$ & $\begin{array}{l}\text { Finiched } \\
\text { Motor } \\
\text { Ceseline }\end{array}$ & det Ful & Kerosene & $\begin{array}{c}\text { Dletillate Fuel } \\
\text { Oll }\end{array}$ & $\begin{array}{l}\text { Pesidual } \\
\text { Fuel Oil }\end{array}$ \\
\hline 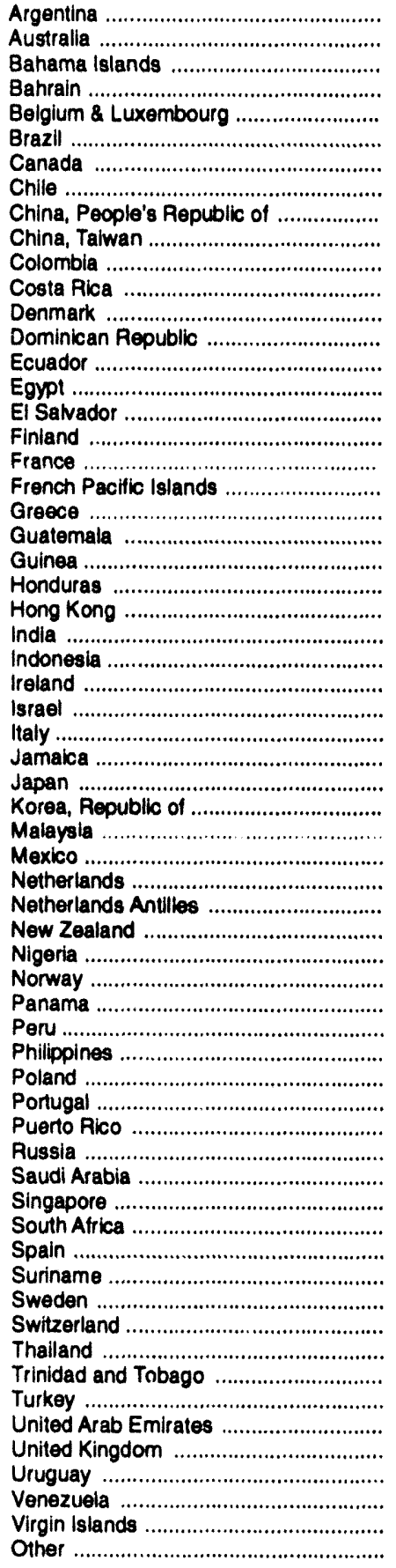 & 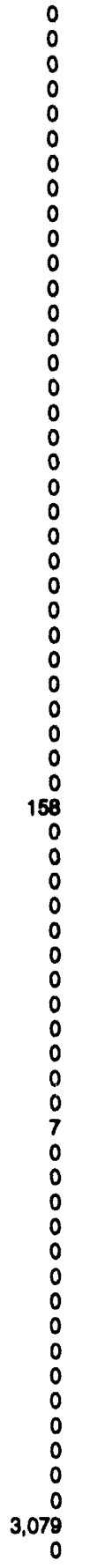 & 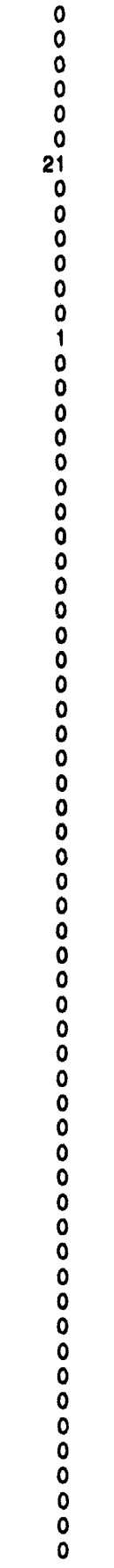 & $\begin{array}{r}0 \\
0 \\
18 \\
0 \\
0 \\
0 \\
168 \\
0 \\
0 \\
0 \\
38 \\
31 \\
18\end{array}$ & 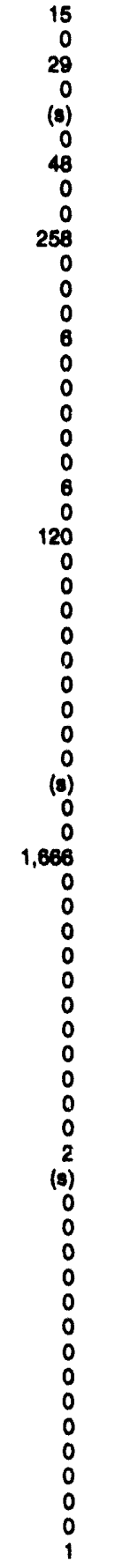 & $\begin{array}{r}0 \\
0 \\
1 \\
0 \\
0 \\
0 \\
0 \\
129 \\
0 \\
0 \\
0 \\
0 \\
03 \\
0 \\
0 \\
0 \\
0 \\
0 \\
0 \\
0 \\
0 \\
0\end{array}$ & 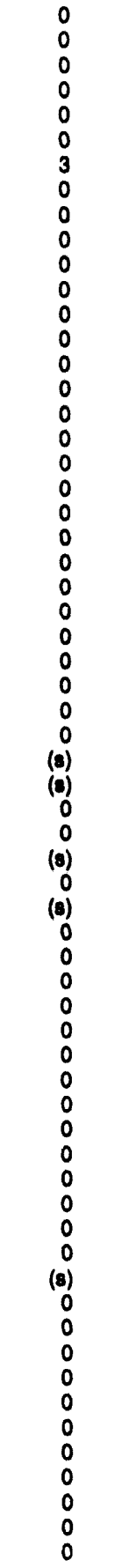 & $\begin{array}{r}0 \\
294 \\
6 \\
(8) \\
0 \\
99 \\
499 \\
0 \\
15 \\
547 \\
(8) \\
0 \\
0 \\
174 \\
0 \\
0 \\
0 \\
0 \\
0 \\
0 \\
0 \\
158 \\
(8) \\
0 \\
(8) \\
9 \\
0 \\
0 \\
255 \\
29 \\
0 \\
786 \\
0 \\
0 \\
(8) \\
14 \\
0 \\
185 \\
175 \\
0 \\
0 \\
0 \\
18) \\
19 \\
2 \\
200 \\
0 \\
0 \\
0 \\
0 \\
0 \\
0 \\
0 \\
0 \\
0 \\
0 \\
0 \\
0 \\
0\end{array}$ & $\begin{array}{r}0 \\
0 \\
316 \\
0 \\
0 \\
0 \\
211 \\
0 \\
0 \\
192 \\
0 \\
0 \\
0 \\
72 \\
0 \\
0 \\
0 \\
0 \\
0 \\
48 \\
0 \\
0 \\
0 \\
0 \\
0 \\
0 \\
0 \\
178 \\
0 \\
0 \\
868 \\
(8) \\
760 \\
0 \\
630 \\
0 \\
0 \\
0 \\
0 \\
0 \\
0 \\
0 \\
0 \\
0 \\
0 \\
0 \\
0 \\
198 \\
0 \\
0 \\
0 \\
0 \\
0 \\
0 \\
0 \\
0 \\
0 \\
0 \\
0 \\
0 \\
0 \\
0 \\
0 \\
0 \\
0 \\
0 \\
0 \\
0 \\
0 \\
0 \\
0 \\
0 \\
0 \\
0 \\
0 \\
0 \\
0\end{array}$ \\
\hline 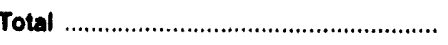 & 3,244 & 22 & 1,240 & 2,152 & $\boldsymbol{9 0 7}$ & 4 & 6,588 & 3,585 \\
\hline
\end{tabular}


Table 47. Exports of Crude Oll and Petroleum Products by Destination, February 1994 (Continued) (Thousand Barrels)

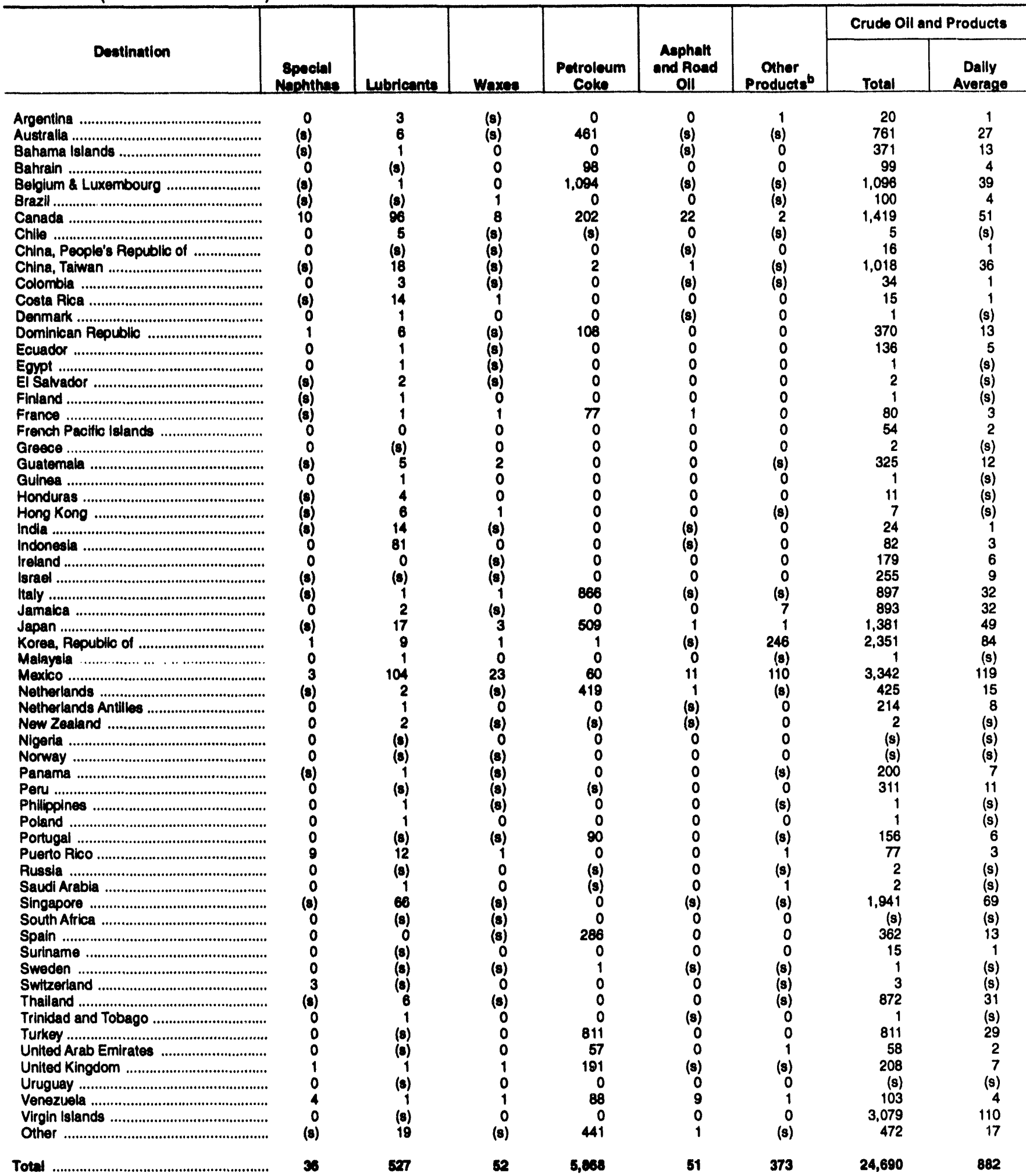

Crude oll exports are restricted to: (1) crude oll derwed from fields under the State waters of Alaska's Cook Inlet; (2) certain domestically produced crude oll destined for Canada; and (3) shipments to U.S. tentiories, and Callornia crude oll to Pacitic Rim countries. On December 6, 1991, the U.S. Department of Commerce approved a license to export 25,000 barrels per day of California heavy crude oll (less than 20 degrees API gravity) to Pacific Rim countries for one year.

b Includes miscellaneous products, molor gasoline blending components, and other hydrocarbons and oxygenates.

(s) = Less than 500 barrels or less than 500 barrels per day.

Note: Totals may not equal sum of components due to independent rounding.

Sources: Energy Information Administration (ELA) Form EIA-810, "Monthy Refinery Report' and the U.S. Bureau of the Census. 
Table 48. Year-to-Date Exports of Crude Oll and Petroleum Products by Destination, January-February 1994 (Thousand Barrels)

\begin{tabular}{|c|c|c|c|c|c|c|c|c|}
\hline Destination & $\begin{array}{c}\text { Crude } \\
\text { oll }^{a}\end{array}$ & $\begin{array}{c}\text { Pentanes } \\
\text { Plus }\end{array}$ & $\begin{array}{c}\text { Liquelied } \\
\text { Petroleum } \\
\text { Cases }\end{array}$ & $\begin{array}{l}\text { Finished } \\
\text { Motor } \\
\text { Casooline }\end{array}$ & Jet Fuel & Kercesene & $\begin{array}{c}\text { Distiliate Fuel } \\
\text { Oil }\end{array}$ & $\begin{array}{l}\text { Residual } \\
\text { Fuel OII }\end{array}$ \\
\hline 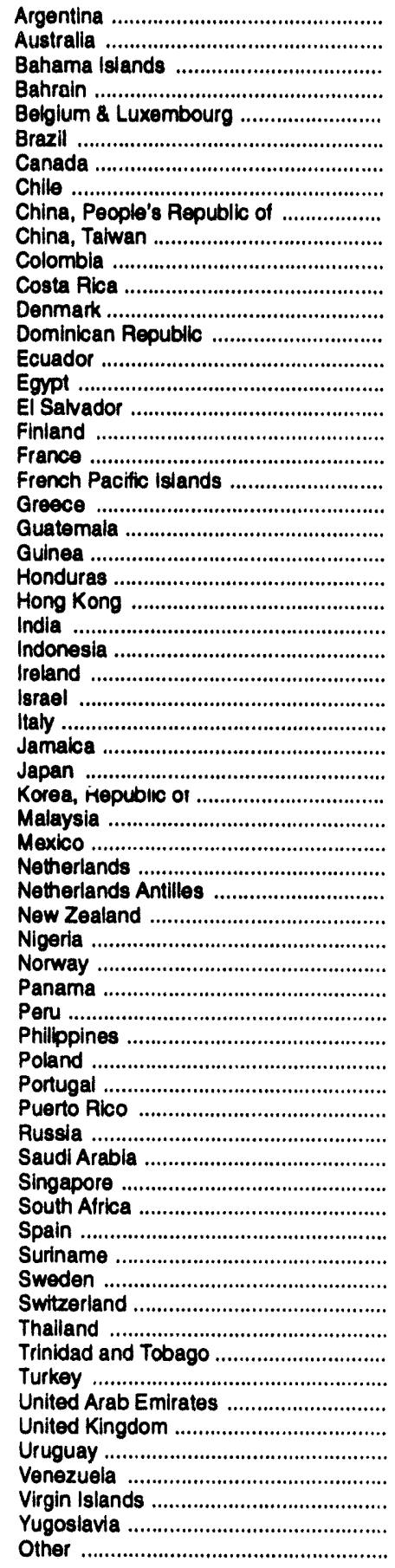 & 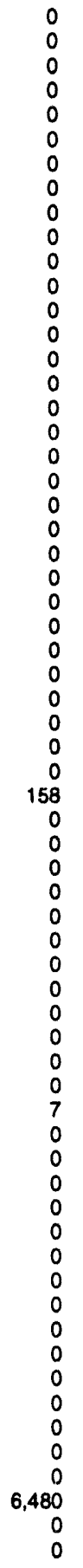 & $\begin{array}{r}0 \\
0 \\
0 \\
0 \\
0 \\
0 \\
0 \\
39 \\
0 \\
03 \\
0 \\
0 \\
0 \\
0 \\
0 \\
3 \\
0 \\
0 \\
0 \\
0 \\
0 \\
0 \\
0 \\
0 \\
0 \\
0 \\
0 \\
0 \\
0 \\
0 \\
0 \\
0 \\
0 \\
0 \\
0 \\
0 \\
0 \\
0 \\
0 \\
0 \\
0 \\
0 \\
0 \\
0 \\
0 \\
0 \\
0 \\
0 \\
0 \\
0 \\
0 \\
0 \\
0 \\
0 \\
0 \\
0 \\
0 \\
0 \\
0 \\
0 \\
0 \\
0 \\
0 \\
0 \\
0 \\
0 \\
0 \\
0 \\
0 \\
0 \\
0 \\
0 \\
0 \\
0 \\
0 \\
0 \\
0 \\
0 \\
0\end{array}$ & 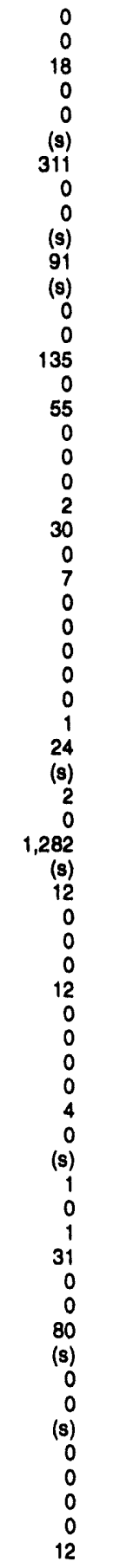 & 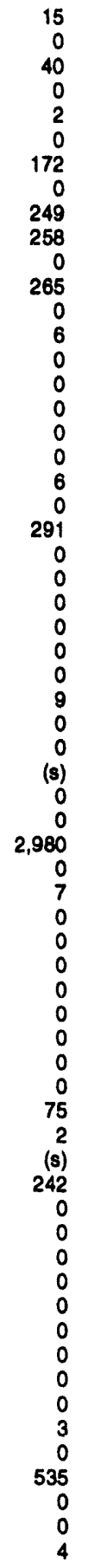 & 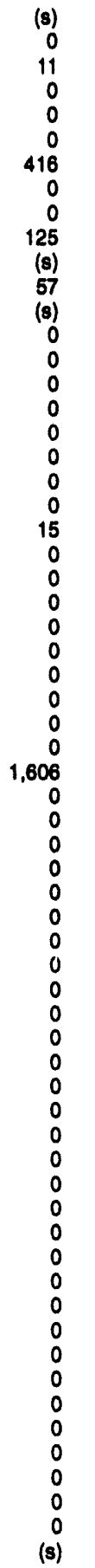 & $\begin{array}{r}0 \\
0 \\
0 \\
0 \\
0 \\
0 \\
0 \\
0 \\
51 \\
0 \\
0 \\
0 \\
0 \\
0 \\
0 \\
0 \\
0 \\
0 \\
0 \\
0 \\
0 \\
0 \\
0 \\
0 \\
0 \\
0 \\
0 \\
0 \\
0 \\
0 \\
0 \\
0 \\
0 \\
0 \\
0 \\
0 \\
0 \\
0 \\
0 \\
0 \\
0 \\
0 \\
0 \\
0 \\
0 \\
0 \\
0 \\
0 \\
0 \\
0 \\
0 \\
0 \\
0 \\
0 \\
0 \\
0 \\
0 \\
0 \\
0 \\
0 \\
0 \\
0 \\
0 \\
0 \\
0 \\
0 \\
0 \\
0 \\
0\end{array}$ & 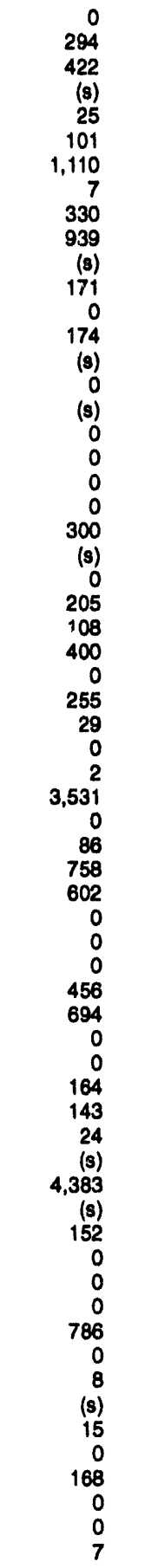 & 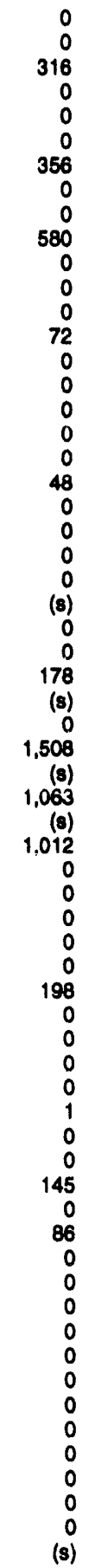 \\
\hline Total & 6,645 & 43 & 2,112 & 5,161 & 2,231 & 52 & 16,849 & 5,564 \\
\hline
\end{tabular}

See footnotes at end of table. 
Table 48. Year-to-Date Exports of Crude Oll and Petroleum Products by Destination, January-February 1994 (Continued) (Thousand Barrels)

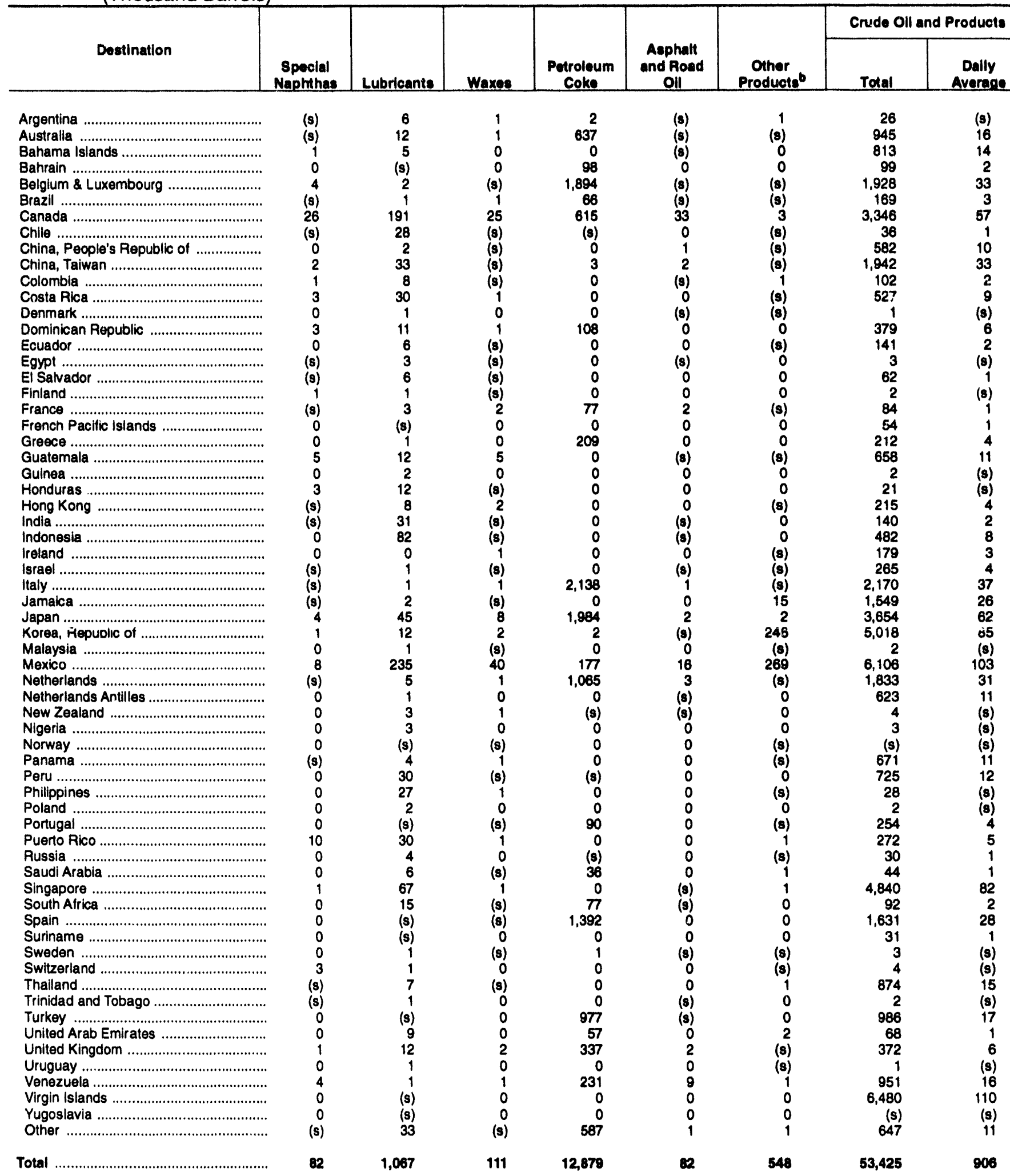

a Crude oll exports are restricted to: (1) crude oll derived from fields under the State waters of Alaska's Cook Inlet; (2) certain domestically produced crude oil destined for Canada; and (3) shipments to U.S. territories, and California crude oil to Pacilic Rim countries. On December 6, 1991, the U.S. Department of Commerce approved a license to export 25,000 barrels per day of California heavy crude oll (less than 20 degrees API gravity) to Pacific Rim countries for one year.

Includes miscellaneous products, motor gasoline blending components, and other hydrocarbons and oxygenates.

(s) = Less than 500 barrels or less than 500 barrels per day.

Note: Totals may not equal sum of components due to independent rounding.

Sources: Energy Information Administration (EIA) Form ElA-810, "Monthly Reflnery Report" and the U.S. Bureau of the Census. 
Table 49. Net Imports of Crude Oil and Petroleum Products into the United States by Country, February 1994

(Thousand Barrels per Day)

\begin{tabular}{|c|c|c|c|c|c|c|c|c|c|c|c|}
\hline Country & $\begin{array}{c}\text { Crude } \\
\text { Oill }\end{array}$ & $\begin{array}{c}\text { Liquefied } \\
\text { Petroleum } \\
\text { Gases }\end{array}$ & $\begin{array}{c}\text { Finished } \\
\text { Motor } \\
\text { Gasoline }\end{array}$ & Jet Fuel & $\begin{array}{c}\text { Distillate } \\
\text { Fuel Oil }\end{array}$ & $\begin{array}{c}\text { Residual } \\
\text { Fuel Oil }\end{array}$ & $\begin{array}{c}\text { Petroleum } \\
\text { Coke }\end{array}$ & Lubricants & $\begin{array}{c}\text { Other } \\
\text { Products }\end{array}$ & $\begin{array}{c}\text { Total } \\
\text { Products }\end{array}$ & $\begin{array}{c}\text { Total } \\
\text { Crude Oil } \\
\text { and Products } \\
\end{array}$ \\
\hline 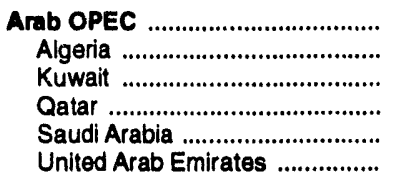 & $\begin{array}{r}1,467 \\
20 \\
423 \\
0 \\
1,023 \\
0\end{array}$ & $\begin{array}{r}7 \\
7 \\
0 \\
0 \\
(s) \\
0\end{array}$ & $\begin{array}{r}\text { (s) } \\
0 \\
0 \\
0 \\
\text { (s) } \\
0\end{array}$ & $\begin{array}{r}13 \\
8 \\
0 \\
0 \\
5 \\
0\end{array}$ & $\begin{array}{r}7 \\
7 \\
0 \\
0 \\
\text { (s) } \\
\text { (s) }\end{array}$ & $\begin{array}{r}31 \\
31 \\
0 \\
0 \\
0 \\
0\end{array}$ & $\begin{array}{r}-2 \\
0 \\
0 \\
0 \\
(s) \\
-2\end{array}$ & $\begin{array}{l}\text { (s) } \\
(\mathrm{s}) \\
(\mathrm{s}) \\
(\mathrm{s}) \\
(\mathrm{s}) \\
(\mathrm{s})\end{array}$ & $\begin{array}{r}194 \\
152 \\
(s) \\
0 \\
42 \\
(\mathbf{s})\end{array}$ & $\begin{array}{r}251 \\
206 \\
(s) \\
(s) \\
47 \\
-2\end{array}$ & $\begin{array}{r}1,717 \\
226 \\
423 \\
(s) \\
1,070 \\
-2\end{array}$ \\
\hline 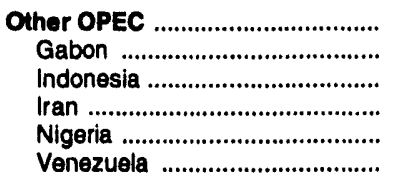 & $\begin{array}{r}1,770 \\
208 \\
59 \\
0 \\
557 \\
946\end{array}$ & $\begin{array}{l}0 \\
0 \\
0 \\
0 \\
0 \\
0\end{array}$ & $\begin{array}{r}33 \\
0 \\
0 \\
0 \\
0 \\
33\end{array}$ & $\begin{array}{r}66 \\
0 \\
(s) \\
0 \\
0 \\
66\end{array}$ & $\begin{array}{r}\mathbf{5 3} \\
0 \\
0 \\
0 \\
0 \\
53\end{array}$ & $\begin{array}{r}122 \\
4 \\
43 \\
0 \\
19 \\
56\end{array}$ & $\begin{array}{c}-3 \\
0 \\
0 \\
0 \\
0 \\
-3\end{array}$ & $\begin{array}{r}-3 \\
0 \\
-3 \\
(s) \\
(s) \\
(s)\end{array}$ & $\begin{array}{r}\mathbf{5 0} \\
0 \\
(\mathbf{s}) \\
0 \\
0 \\
50\end{array}$ & $\begin{array}{r}318 \\
4 \\
41 \\
(s) \\
19 \\
254\end{array}$ & $\begin{array}{r}2,088 \\
212 \\
100 \\
(s) \\
576 \\
1,200\end{array}$ \\
\hline 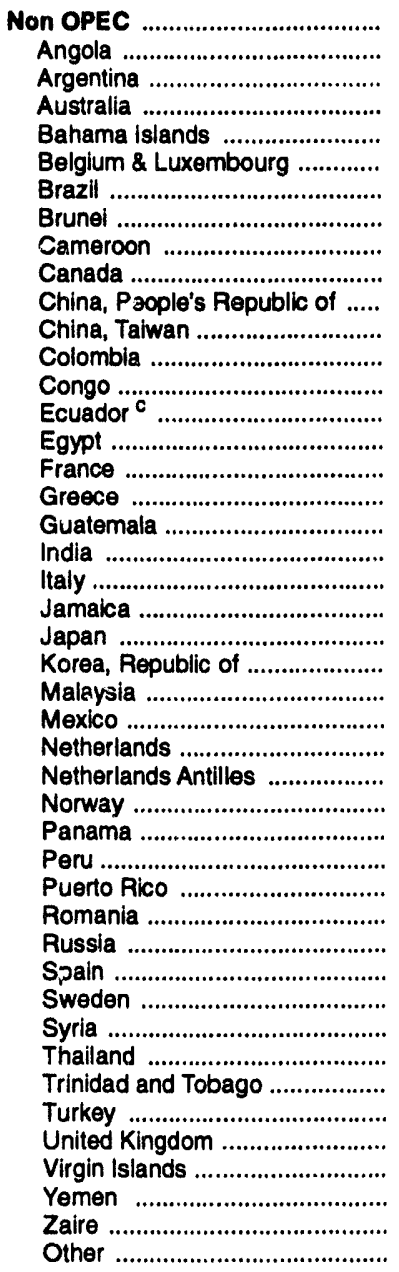 & 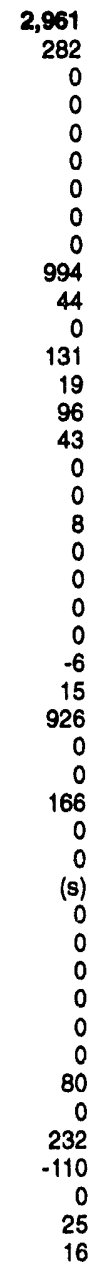 & $\begin{array}{r}131 \\
0 \\
0 \\
0 \\
-1 \\
0 \\
0 \\
0 \\
0 \\
125 \\
0 \\
(\mathbf{s}) \\
-1 \\
0 \\
-5 \\
0 \\
1 \\
(\mathbf{s}) \\
-1 \\
0 \\
(\mathbf{s}) \\
-1 \\
0 \\
0 \\
0 \\
-16 \\
0 \\
(\mathbf{s}) \\
20 \\
(\mathbf{s}) \\
0 \\
(\mathbf{s}) \\
0 \\
0 \\
(\mathbf{s}) \\
0 \\
0 \\
-3 \\
0 \\
0 \\
13 \\
0 \\
0 \\
0 \\
-1\end{array}$ & $\begin{array}{r}171 \\
0 \\
-1 \\
0 \\
-1 \\
(s) \\
11 \\
0 \\
0 \\
58 \\
0 \\
-9 \\
0 \\
0 \\
0 \\
0 \\
10 \\
12 \\
-4 \\
0 \\
35 \\
0 \\
(s) \\
0 \\
0 \\
-60 \\
0 \\
9 \\
0 \\
0 \\
0 \\
0 \\
0 \\
(\mathbf{s}) \\
0 \\
0 \\
0 \\
0 \\
0 \\
0 \\
17 \\
85 \\
0 \\
0 \\
9\end{array}$ & $\begin{array}{r}23 \\
0 \\
0 \\
0 \\
(\mathbf{s}) \\
0 \\
0 \\
0 \\
0 \\
-1 \\
0 \\
0 \\
(\mathbf{s}) \\
0 \\
0 \\
0 \\
0 \\
0 \\
(\mathbf{s}) \\
0 \\
0 \\
0 \\
-30 \\
0 \\
0 \\
1 \\
0 \\
8 \\
0 \\
0 \\
0 \\
0 \\
0 \\
0 \\
0 \\
0 \\
0 \\
0 \\
0 \\
0 \\
0 \\
46 \\
0 \\
0 \\
(\mathbf{s})\end{array}$ & $\begin{array}{r}-18 \\
0 \\
0 \\
-10 \\
(s) \\
0 \\
-2 \\
0 \\
0 \\
77 \\
-1 \\
-20 \\
(s) \\
0 \\
0 \\
0 \\
0 \\
0 \\
-6 \\
(s) \\
-1 \\
0 \\
(s) \\
-42 \\
0 \\
-1 \\
(s) \\
(s) \\
0 \\
0 \\
-11 \\
-2 \\
0 \\
14 \\
-3 \\
0 \\
0 \\
-28 \\
0 \\
0 \\
(s) \\
87 \\
0 \\
0 \\
-69\end{array}$ & $\begin{array}{r}305 \\
13 \\
0 \\
0 \\
68 \\
16 \\
0 \\
0 \\
5 \\
11 \\
0 \\
-7 \\
43 \\
26 \\
0 \\
0 \\
0 \\
0 \\
0 \\
0 \\
0 \\
-31 \\
(s) \\
-27 \\
0 \\
-15 \\
15 \\
55 \\
6 \\
-7 \\
6 \\
(5) \\
0 \\
0 \\
16 \\
7 \\
0 \\
0 \\
12 \\
0 \\
12 \\
76 \\
0 \\
0 \\
5\end{array}$ & $\begin{array}{r}-203 \\
0 \\
0 \\
-16 \\
0 \\
-39 \\
0 \\
0 \\
0 \\
-6 \\
0 \\
(\mathbf{s}) \\
0 \\
0 \\
0 \\
0 \\
-3 \\
0 \\
0 \\
0 \\
0 \\
-31 \\
0 \\
-18 \\
(\mathbf{s}) \\
-2 \\
-2 \\
-15 \\
0 \\
0 \\
0 \\
0 \\
(\mathbf{s}) \\
0 \\
0 \\
(\mathbf{s}) \\
-10 \\
(\mathbf{s}) \\
0 \\
0 \\
0 \\
-29 \\
-7 \\
0 \\
0 \\
0 \\
-26\end{array}$ & $\begin{array}{r}-14 \\
0 \\
(s) \\
(s) \\
(s) \\
(s) \\
(s) \\
(s) \\
0 \\
-1 \\
(s) \\
-1 \\
(s) \\
0 \\
(s) \\
(s) \\
(s) \\
(s) \\
(s) \\
(s) \\
(s) \\
(s) \\
-1 \\
(s) \\
(s) \\
-4 \\
(s) \\
(s) \\
(s) \\
(s) \\
(s) \\
(s) \\
(s) \\
(s) \\
0 \\
(s) \\
0 \\
(s) \\
(s) \\
(s) \\
(s) \\
(s) \\
0 \\
(s) \\
-4\end{array}$ & $\begin{array}{r}459 \\
(s) \\
13 \\
(s) \\
(s) \\
18 \\
(s) \\
0 \\
0 \\
57 \\
(s) \\
(s) \\
10 \\
0 \\
(s) \\
(s) \\
31 \\
0 \\
(s) \\
18 \\
(s) \\
(s) \\
(s) \\
40 \\
5 \\
18 \\
27 \\
40 \\
7 \\
(s) \\
5 \\
11 \\
0 \\
(s) \\
16 \\
(s) \\
8 \\
(s) \\
(s) \\
0 \\
16 \\
58 \\
11 \\
0 \\
52\end{array}$ & $\begin{array}{r}853 \\
13 \\
12 \\
-27 \\
66 \\
-4 \\
8 \\
(\mathrm{~s}) \\
5 \\
320 \\
-1 \\
-36 \\
52 \\
26 \\
-5 \\
(\mathrm{~s}) \\
39 \\
12 \\
-12 \\
17 \\
3 \\
-32 \\
-49 \\
-29 \\
5 \\
-78 \\
27 \\
112 \\
33 \\
-7 \\
(\mathrm{~s}) \\
8 \\
(\mathrm{~s}) \\
13 \\
18 \\
7 \\
8 \\
-31 \\
12 \\
-29 \\
51 \\
351 \\
11 \\
(\mathrm{~s}) \\
-34\end{array}$ & $\begin{array}{r}3,814 \\
295 \\
12 \\
-27 \\
66 \\
-4 \\
8 \\
8 \\
(s) \\
5 \\
1,313 \\
44 \\
-36 \\
183 \\
45 \\
91 \\
43 \\
39 \\
12 \\
-4 \\
17 \\
3 \\
-32 \\
-49 \\
-35 \\
19 \\
848 \\
27 \\
112 \\
199 \\
-7 \\
(s) \\
8 \\
(s) \\
13 \\
18 \\
7 \\
8 \\
-31 \\
92 \\
-29 \\
283 \\
241 \\
11 \\
25 \\
-18\end{array}$ \\
\hline Total & 6,197 & 138 & 204 & 102 & 41 & 458 & -209 & -17 & 703 & 1,422 & 7,619 \\
\hline Persian Gulf ${ }^{d}$ & 1,446 & (s) & (s) & 5 & (s) & 0 & -6 & (s) & 42 & 41 & 1,488 \\
\hline
\end{tabular}

\footnotetext{
a Includes crude oil imported for storage in the Strategic Petroleum Reserve.

b Includes asphalt and road oil, aviation gasoline, aviation gasoline blending components, kerosene, miscellaneous products, motor gasoline blending components, naphtha for petrochemical feedstock use, other hydrocarbons and oxygenates, other oils for petrochemical feedstock use, pentanes plus, special naphthas, unfinished oils, and waxes.

c On December 31, 1992, Ecuador withdrew as a member of OPEC. As of January 1, 1994, imports of petroleum from Ecuador appear under imports from Non-OPEC Sources.

d Includes Bahrain, Iran, Iraq, Kuwait, Qatar, Saudi Arabia, and United Arab Emirates.

(s) = Less than 500 barrels per day.

Note: Totals may not equal sum of components due to independent rounding

Sources: Energy Information Administration (EIA) Forms EIA-810, "Monthly Retinery Report," EIA-814, "Monthly Imports Report" and the U.S. Bureau of the Census.
} 
Table 50. Year-to-Date Net Imports of Crude Oil and Petroleum Products into the United States by Country, January-February 1994

(Thousand Barrels per Day)

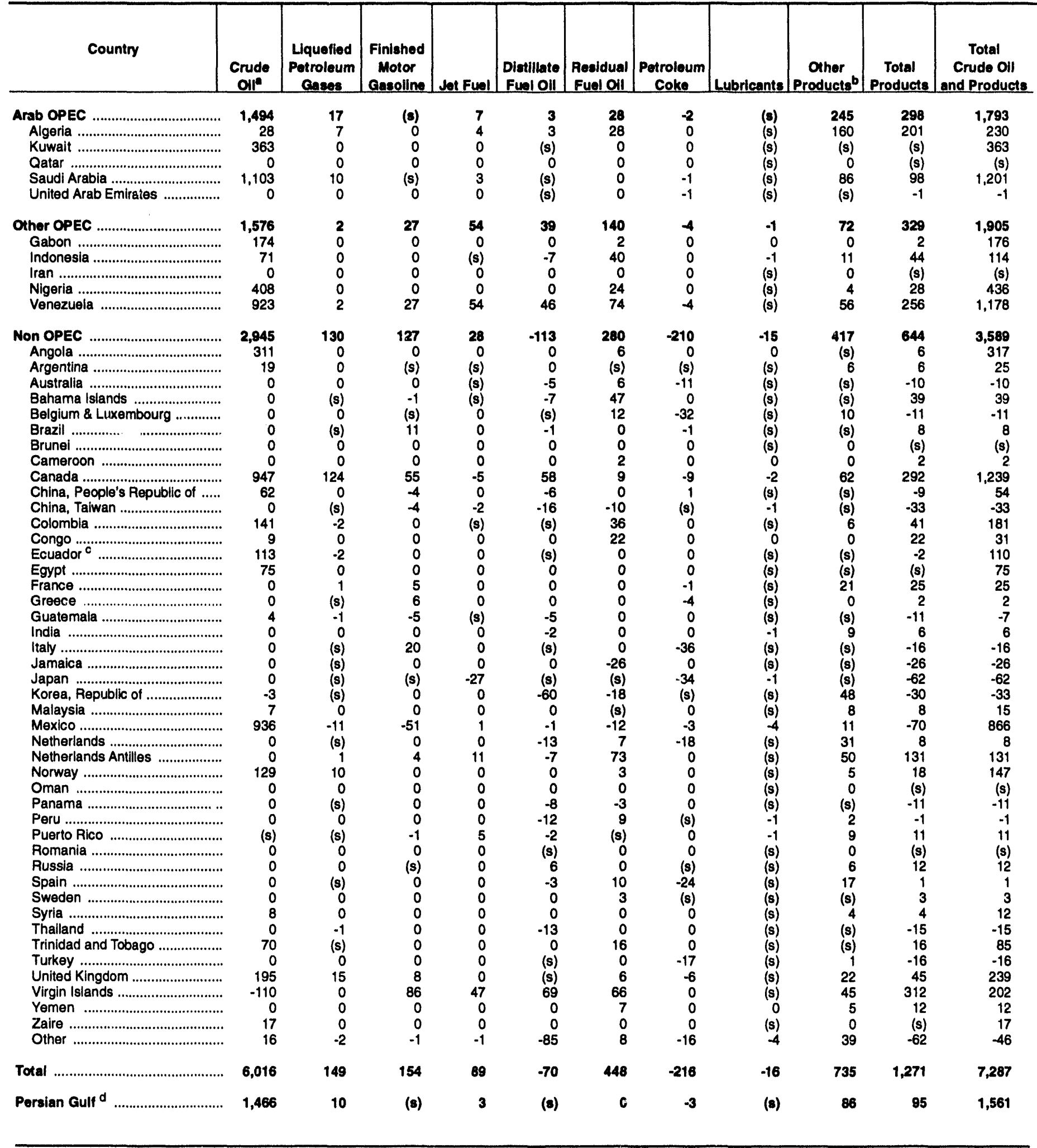

a Includes crude oll imported for storage in the Strategic Petroleum Reserve.

b Includes asphalt and road oil, aviation gasoline, aviation gasoline blending components, kerosene, miscellaneous products, motor gasoline blending components, naphtha for petrochemical feedstock use, other hydrocarbons and oxygenates, other oils for petrochemical feedstock use, pentanes plus, special naphthas, unfinished oils, and waxes.

c On December 31, 1992, Ecuador withdrew as a member of OPEC. As of January 1, 1994, imports of petroleum from Ecuador appear under imports from Non-OPEC Sources.

Includes Bahrain, Iran, Iraq, Kuwait, Qatar, Saudi Arabia, and United Arab Emirates.

(s) = Less than 500 barrels per day.

Note: Totals may not equal sum of components due to independent rounding.

Sources: Energy Information Administration (EIA) Forms EIA-810, "Monthly Refinery Report," EIA-814, "Monthly Imports Report" and the U.S. Bureau of the Census. 
Table 51. Stocks of Crude Oil and Petroleum Products by PAD District, February 1994 (Thousand Barreis)

\begin{tabular}{|c|c|c|c|c|c|c|}
\hline \multirow{2}{*}{ Commodity } & \multicolumn{5}{|c|}{ Petroleum Administration for Defense Districts } & \multirow{2}{*}{ Total } \\
\hline & $\mathbf{I}$ & $\|$ & III & IV & $\mathbf{v}$ & \\
\hline 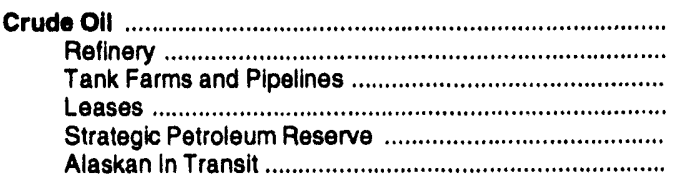 & $\begin{array}{r}15,297 \\
14,353 \\
938 \\
6 \\
0 \\
0\end{array}$ & $\begin{array}{r}75,430 \\
13,547 \\
60,659 \\
1,224 \\
0 \\
0\end{array}$ & $\begin{array}{r}741,913 \\
45,045 \\
94,764 \\
14,911 \\
587,193 \\
0\end{array}$ & $\begin{array}{r}11,066 \\
1,862 \\
8,385 \\
819 \\
0 \\
0\end{array}$ & $\begin{array}{r}73,648 \\
23,002 \\
32,800 \\
1,391 \\
0 \\
16,455\end{array}$ & $\begin{array}{r}917,354 \\
97,809 \\
197,546 \\
18,351 \\
587,193 \\
16,455\end{array}$ \\
\hline 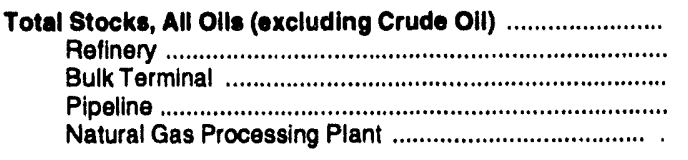 & $\begin{array}{r}148,787 \\
48,994 \\
74,235 \\
25,485 \\
73\end{array}$ & $\begin{array}{r}157,277 \\
63,966 \\
55,673 \\
34,549 \\
3,089\end{array}$ & $\begin{array}{r}240,547 \\
137,005 \\
62,065 \\
38,269 \\
3,208\end{array}$ & $\begin{array}{r}19,634 \\
13,893 \\
3,075 \\
2,400 \\
266\end{array}$ & $\begin{array}{r}97,126 \\
67,137 \\
23,993 \\
5,929 \\
67\end{array}$ & $\begin{array}{r}663,371 \\
330,995 \\
219,041 \\
106,632 \\
6,703\end{array}$ \\
\hline 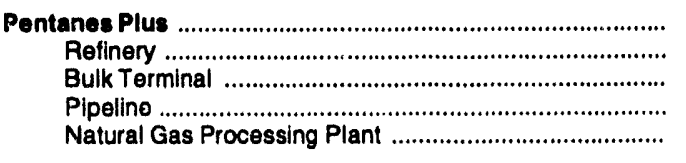 & $\begin{array}{r}165 \\
131 \\
22 \\
0 \\
12\end{array}$ & $\begin{array}{r}3,157 \\
617 \\
1,502 \\
623 \\
415\end{array}$ & $\begin{array}{r}4,738 \\
222 \\
2,643 \\
970 \\
903\end{array}$ & $\begin{array}{r}179 \\
5 \\
1 \\
72 \\
101\end{array}$ & $\begin{array}{r}50 \\
24 \\
12 \\
0 \\
14\end{array}$ & $\begin{array}{r}8,289 \\
999 \\
4,180 \\
1,665 \\
1,445\end{array}$ \\
\hline 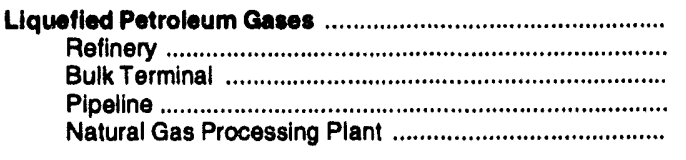 & $\begin{array}{r}3,075 \\
959 \\
1,145 \\
910 \\
61\end{array}$ & $\begin{array}{r}19,174 \\
2,058 \\
7,779 \\
6,663 \\
2,674\end{array}$ & $\begin{array}{r}40,184 \\
6,762 \\
23,755 \\
7,362 \\
2,305\end{array}$ & $\begin{array}{r}1,138 \\
443 \\
71 \\
459 \\
165\end{array}$ & $\begin{array}{r}1,836 \\
1,003 \\
780 \\
0 \\
53\end{array}$ & $\begin{array}{r}\mathbf{6 5 , 4 0 7} \\
11,225 \\
33,530 \\
15,394 \\
5,258\end{array}$ \\
\hline 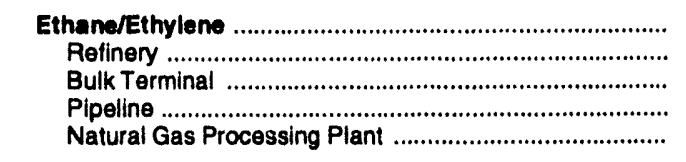 & $\begin{array}{l}0 \\
0 \\
0 \\
0 \\
0\end{array}$ & $\begin{array}{r}4,181 \\
3 \\
1,864 \\
1,590 \\
724\end{array}$ & $\begin{array}{r}12,109 \\
333 \\
8,359 \\
2,937 \\
480\end{array}$ & $\begin{array}{r}185 \\
0 \\
0 \\
183 \\
2\end{array}$ & $\begin{array}{l}0 \\
0 \\
0 \\
0 \\
0\end{array}$ & $\begin{array}{r}16,475 \\
336 \\
10,223 \\
4,710 \\
1,206\end{array}$ \\
\hline 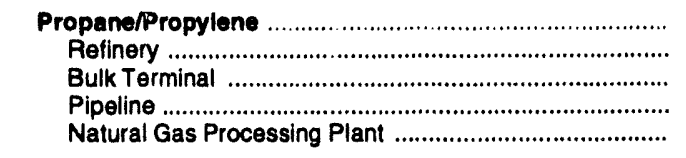 & $\begin{array}{r}2,237 \\
207 \\
1,084 \\
900 \\
46\end{array}$ & $\begin{array}{r}8,692 \\
936 \\
2,746 \\
3,823 \\
1,187\end{array}$ & $\begin{array}{r}13,229 \\
1,814 \\
7,238 \\
3,183 \\
994\end{array}$ & $\begin{array}{r}422 \\
88 \\
69 \\
164 \\
101\end{array}$ & $\begin{array}{r}553 \\
141 \\
376 \\
0 \\
36\end{array}$ & $\begin{array}{r}25,133 \\
3,186 \\
11,513 \\
8,070 \\
2,364\end{array}$ \\
\hline 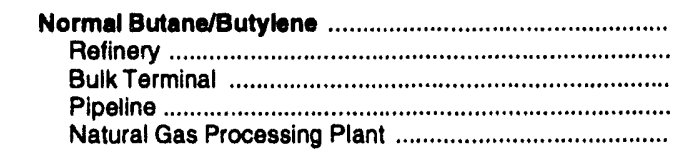 & $\begin{array}{r}700 \\
620 \\
61 \\
10 \\
9\end{array}$ & $\begin{array}{r}3,408 \\
582 \\
1,549 \\
705 \\
572\end{array}$ & $\begin{array}{r}7,914 \\
2,980 \\
3,580 \\
838 \\
516\end{array}$ & $\begin{array}{r}336 \\
233 \\
2 \\
50 \\
51\end{array}$ & $\begin{array}{r}783 \\
529 \\
244 \\
0 \\
10\end{array}$ & $\begin{array}{r}13,141 \\
4,944 \\
5,436 \\
1,603 \\
1,158\end{array}$ \\
\hline 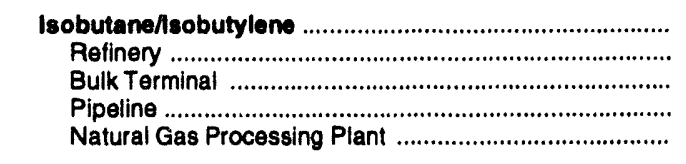 & $\begin{array}{r}138 \\
132 \\
0 \\
0 \\
6\end{array}$ & $\begin{array}{r}2,693 \\
537 \\
1,620 \\
545 \\
191\end{array}$ & $\begin{array}{r}6,932 \\
1,635 \\
4,578 \\
404 \\
315\end{array}$ & $\begin{array}{r}195 \\
122 \\
0 \\
62 \\
11\end{array}$ & $\begin{array}{r}500 \\
333 \\
160 \\
0 \\
7\end{array}$ & $\begin{array}{r}10,658 \\
2,759 \\
6,358 \\
1,011 \\
530\end{array}$ \\
\hline 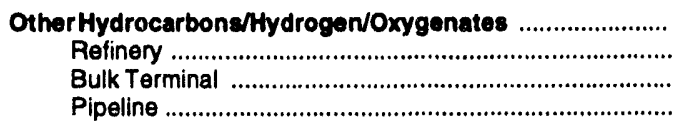 & $\begin{array}{r}1,288 \\
1,160 \\
128 \\
0\end{array}$ & $\begin{array}{r}1,072 \\
406 \\
666 \\
0\end{array}$ & $\begin{array}{r}5,463 \\
2,105 \\
2,952 \\
406\end{array}$ & $\begin{array}{r}270 \\
122 \\
148 \\
0\end{array}$ & $\begin{array}{r}2,900 \\
2,305 \\
428 \\
167\end{array}$ & $\begin{array}{r}10,993 \\
6,098 \\
4,322 \\
573\end{array}$ \\
\hline $\begin{array}{l}\text { Other Hydrocarbona/Hydrogen } \\
\text { Refinery }\end{array}$ & 4 & $\begin{array}{l}23 \\
23\end{array}$ & $\begin{array}{l}1 \\
1\end{array}$ & $\begin{array}{l}0 \\
0\end{array}$ & $\begin{array}{l}6 \\
6\end{array}$ & $\begin{array}{l}34 \\
34\end{array}$ \\
\hline 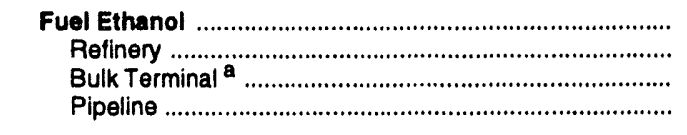 & $\begin{array}{l}79 \\
W \\
W \\
W\end{array}$ & $\begin{array}{r}786 \\
160 \\
W \\
W\end{array}$ & $\begin{array}{r}452 \\
W \\
W \\
W\end{array}$ & $\begin{array}{l}80 \\
W \\
W \\
W\end{array}$ & $\begin{array}{r}311 \\
W \\
W \\
W\end{array}$ & $\begin{array}{r}1,708 \\
298 \\
W \\
W\end{array}$ \\
\hline $\begin{array}{l}\text { ETBE } \\
\text { Refinery } \\
\text { Bulk Terminal } \\
\text { Pipeline }\end{array}$ & $\begin{array}{l}W \\
W \\
W \\
W\end{array}$ & $\begin{array}{l}W \\
W \\
W \\
W\end{array}$ & $\begin{array}{l}W \\
W \\
W \\
W\end{array}$ & $\begin{array}{l}W \\
W \\
W \\
W\end{array}$ & $\begin{array}{l}W \\
W \\
W \\
W\end{array}$ & $\begin{array}{l}\mathbf{w} \\
W \\
W \\
W\end{array}$ \\
\hline Methanol $\quad$ Refinery & $\begin{array}{l}\mathbf{w} \\
\mathbf{W}\end{array}$ & $\mathbf{W}$ & $\mathbf{W}$ & $\begin{array}{l}\mathbf{W} \\
\mathbf{W}\end{array}$ & $\begin{array}{l}w \\
W\end{array}$ & $\begin{array}{l}324 \\
324\end{array}$ \\
\hline
\end{tabular}

See footnotes at end of table. 
Table 51. Stocks of Crude Oil and Petroleum Products by PAD District, February 1994 (Continued)

(Thousand Barrels)

\begin{tabular}{|c|c|c|c|c|c|c|}
\hline \multirow{2}{*}{ Commodity } & \multicolumn{5}{|c|}{ Potroleum Administration for Dofonse Districts } & \multirow{2}{*}{ T. 8.} \\
\hline & $\mathbf{I}$ & $\|$ & III & $\mathbf{N}$ & $\mathbf{v}$ & \\
\hline 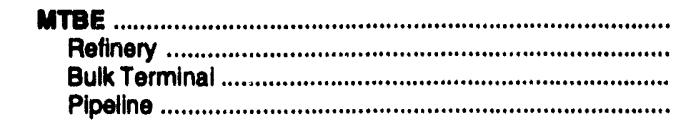 & $\begin{array}{r}1,080 \\
971 \\
W \\
W\end{array}$ & $\begin{array}{l}w \\
w \\
w \\
w\end{array}$ & $\begin{array}{r}4,528 \\
1,853 \\
2,327 \\
406\end{array}$ & $\begin{array}{l}W \\
W \\
W \\
W\end{array}$ & $\begin{array}{r}2,503 \\
2,291 \\
127 \\
165\end{array}$ & $\begin{array}{r}8,676 \\
5,388 \\
2,717 \\
571\end{array}$ \\
\hline 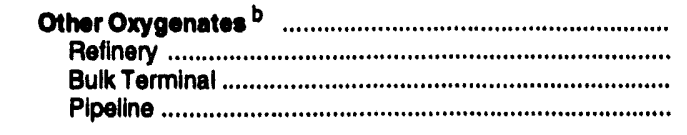 & $\begin{array}{l}w \\
w \\
w \\
W\end{array}$ & $\begin{array}{l}W \\
W \\
W \\
W\end{array}$ & $\begin{array}{l}W \\
W \\
W \\
W\end{array}$ & $\begin{array}{l}W \\
W \\
W \\
W\end{array}$ & $\begin{array}{l}W \\
W \\
W \\
W\end{array}$ & $\begin{array}{l}w \\
w \\
w \\
w\end{array}$ \\
\hline 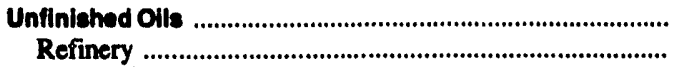 & 9,550 & 15,014 & 40,915 & 2,545 & 25,510 & 103,134 \\
\hline 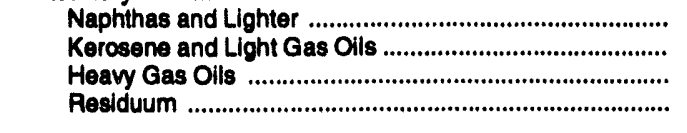 & $\begin{array}{l}2,727 \\
1,614 \\
4,196 \\
1,013\end{array}$ & $\begin{array}{l}4,099 \\
2,485 \\
5,311 \\
3,719\end{array}$ & $\begin{array}{r}13,348 \\
8,731 \\
19,359 \\
8,477\end{array}$ & $\begin{array}{l}521 \\
830 \\
876 \\
318\end{array}$ & $\begin{array}{r}4,190 \\
5,292 \\
12,292 \\
3,736\end{array}$ & $\begin{array}{l}24,885 \\
18,952 \\
42,034 \\
17,263\end{array}$ \\
\hline 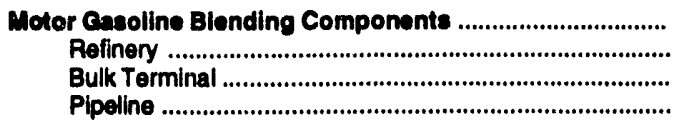 & $\begin{array}{r}5,125 \\
4,986 \\
139 \\
0\end{array}$ & $\begin{array}{r}9,139 \\
8,061 \\
400 \\
678\end{array}$ & $\begin{array}{r}15,338 \\
14,131 \\
775 \\
432\end{array}$ & $\begin{array}{r}2,581 \\
2,581 \\
0 \\
0\end{array}$ & $\begin{array}{r}8,509 \\
7,352 \\
49 \\
1,188\end{array}$ & $\begin{array}{r}40,772 \\
37,111 \\
1,363 \\
2,298\end{array}$ \\
\hline 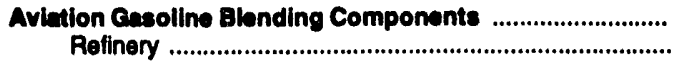 & $\begin{array}{l}16 \\
16\end{array}$ & $\begin{array}{l}\mathbf{0} \\
\mathbf{0}\end{array}$ & 42 & $\begin{array}{l}0 \\
0\end{array}$ & $\begin{array}{l}12 \\
12\end{array}$ & $\begin{array}{l}70 \\
70\end{array}$ \\
\hline 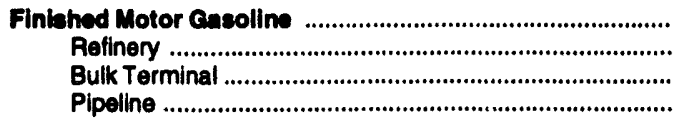 & $\begin{array}{l}56,902 \\
15,029 \\
29,918 \\
12,045\end{array}$ & $\begin{array}{l}\mathbf{5 0 , 1 6 7} \\
11,272 \\
23,043 \\
15,852\end{array}$ & $\begin{array}{r}47,857 \\
19,579 \\
11,336 \\
16,942\end{array}$ & $\begin{array}{l}5,672 \\
2,865 \\
1,660 \\
1,147\end{array}$ & $\begin{array}{r}25,915 \\
11,726 \\
12,208 \\
1,981\end{array}$ & $\begin{array}{r}186,603 \\
60,471 \\
78,165 \\
47,967\end{array}$ \\
\hline 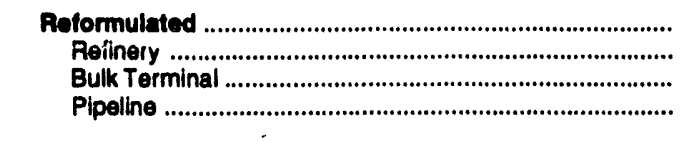 & $\begin{array}{l}0 \\
0 \\
0 \\
0\end{array}$ & $\begin{array}{l}0 \\
0 \\
0 \\
0\end{array}$ & $\begin{array}{l}0 \\
0 \\
0 \\
0\end{array}$ & $\begin{array}{l}0 \\
0 \\
0 \\
0\end{array}$ & $\begin{array}{l}0 \\
0 \\
0 \\
0\end{array}$ & $\begin{array}{l}0 \\
\vdots \\
0 \\
0\end{array}$ \\
\hline 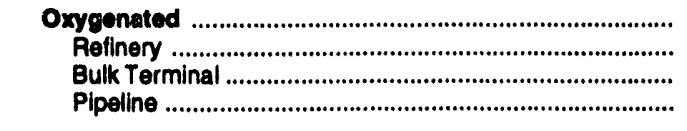 & $\begin{array}{l}9,502 \\
1,886 \\
5,573 \\
2,043\end{array}$ & $\begin{array}{r}1,168 \\
783 \\
251 \\
134\end{array}$ & $\begin{array}{r}4,206 \\
1,878 \\
184 \\
2,164\end{array}$ & $\begin{array}{r}381 \\
214 \\
126 \\
41\end{array}$ & $\begin{array}{r}3,390 \\
1,826 \\
1,400 \\
173\end{array}$ & $\begin{array}{r}18,678 \\
6,587 \\
7,534 \\
4,555\end{array}$ \\
\hline 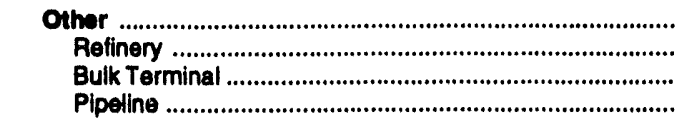 & $\begin{array}{l}47,490 \\
13,143 \\
24,345 \\
10,002\end{array}$ & $\begin{array}{l}48,999 \\
10,489 \\
22,792 \\
15,718\end{array}$ & $\begin{array}{l}\mathbf{4 3 , 6 8 1} \\
17,701 \\
11,152 \\
14,778\end{array}$ & $\begin{array}{l}5,291 \\
2,651 \\
1,534 \\
1,106\end{array}$ & $\begin{array}{r}22,516 \\
9,900 \\
10,808 \\
1,808\end{array}$ & $\begin{array}{r}167,927 \\
53,884 \\
70,631 \\
43,412\end{array}$ \\
\hline 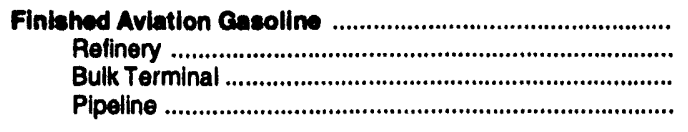 & $\begin{array}{r}420 \\
64 \\
356 \\
0\end{array}$ & $\begin{array}{r}386 \\
97 \\
197 \\
72\end{array}$ & $\begin{array}{r}411 \\
368 \\
43 \\
0\end{array}$ & $\begin{array}{r}49 \\
41 \\
8 \\
0\end{array}$ & $\begin{array}{r}441 \\
145 \\
296 \\
0\end{array}$ & $\begin{array}{r}1,687 \\
715 \\
900 \\
72\end{array}$ \\
\hline 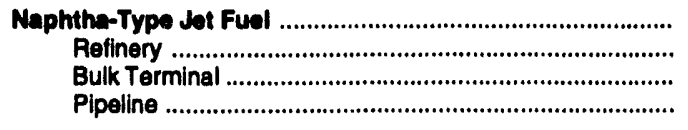 & $\begin{array}{r}225 \\
13 \\
163 \\
49\end{array}$ & $\begin{array}{l}729 \\
327 \\
247 \\
155\end{array}$ & $\begin{array}{r}758 \\
532 \\
0 \\
226\end{array}$ & $\begin{array}{r}195 \\
137 \\
0 \\
58\end{array}$ & $\begin{array}{r}338 \\
24 \\
0 \\
312\end{array}$ & $\begin{array}{r}2,243 \\
1,033 \\
410 \\
800\end{array}$ \\
\hline 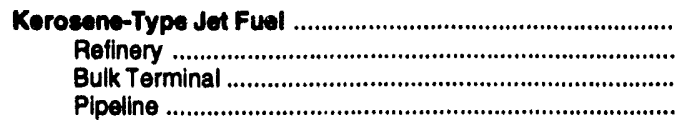 & $\begin{array}{l}9,818 \\
1,337 \\
3,174 \\
5,307\end{array}$ & $\begin{array}{l}7,328 \\
2,741 \\
2,153 \\
2,434\end{array}$ & $\begin{array}{r}12,715 \\
6,499 \\
1,806 \\
4,410\end{array}$ & $\begin{array}{l}655 \\
229 \\
280 \\
146\end{array}$ & $\begin{array}{l}7,398 \\
3,513 \\
2,855 \\
1,028\end{array}$ & $\begin{array}{l}37,912 \\
14,319 \\
10,268 \\
13,325\end{array}$ \\
\hline
\end{tabular}

See footnotes at end of table. 
Table 51. Stocks of Crude Oil and Petroleum Products by PAD District, February 1994 (Continued)

(Thousand Barrels)

\begin{tabular}{|c|c|c|c|c|c|c|}
\hline \multirow{2}{*}{ Commodity } & \multicolumn{5}{|c|}{ Potroleum Adminiatration for Defense Districts } & \multirow[b]{2}{*}{ U.S. } \\
\hline & $\mathbf{I}$ & N & III & IV & $\mathbf{v}$ & \\
\hline 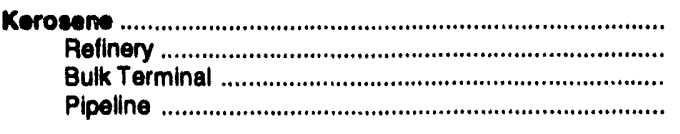 & $\begin{array}{r}1,802 \\
108 \\
1,454 \\
300\end{array}$ & $\begin{array}{r}1,352 \\
664 \\
433 \\
255\end{array}$ & $\begin{array}{r}1,201 \\
825 \\
80 \\
376\end{array}$ & $\begin{array}{r}113 \\
83 \\
7 \\
23\end{array}$ & $\begin{array}{r}67 \\
46 \\
15 \\
6\end{array}$ & $\begin{array}{r}4,675 \\
1,726 \\
1,989 \\
960\end{array}$ \\
\hline 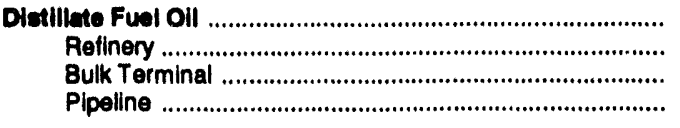 & $\begin{array}{r}35,955 \\
6,201 \\
22,880 \\
6,874\end{array}$ & $\begin{array}{r}28,800 \\
8,472 \\
12,545 \\
7,783\end{array}$ & $\begin{array}{r}25,603 \\
12,878 \\
5,631 \\
7,094\end{array}$ & $\begin{array}{r}3,059 \\
1,723 \\
847 \\
489\end{array}$ & $\begin{array}{r}10,568 \\
4,625 \\
4,806 \\
1,137\end{array}$ & $\begin{array}{r}103,985 \\
33,899 \\
46,709 \\
23,377\end{array}$ \\
\hline 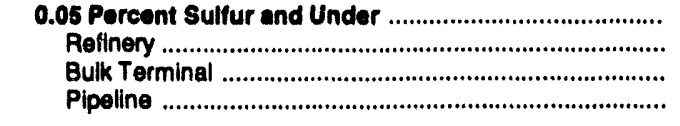 & $\begin{array}{r}11,008 \\
1,913 \\
6,988 \\
2,125\end{array}$ & $\begin{array}{r}17,125 \\
3,302 \\
8,127 \\
5,696\end{array}$ & $\begin{array}{r}11,408 \\
4,653 \\
3,062 \\
3,691\end{array}$ & $\begin{array}{r}1,979 \\
939 \\
597 \\
443\end{array}$ & $\begin{array}{r}7,166 \\
2,977 \\
3,470 \\
719\end{array}$ & $\begin{array}{l}48,702 \\
13,784 \\
22,244 \\
12,674\end{array}$ \\
\hline 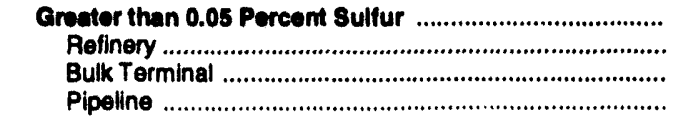 & $\begin{array}{r}24,829 \\
4,288 \\
15,892 \\
4,749\end{array}$ & $\begin{array}{r}11,675 \\
5,170 \\
4,418 \\
2,087\end{array}$ & $\begin{array}{r}14,197 \\
8,225 \\
2,569 \\
3,403\end{array}$ & $\begin{array}{r}1,080 \\
784 \\
250 \\
46\end{array}$ & $\begin{array}{r}3,402 \\
1,648 \\
1,336 \\
418\end{array}$ & $\begin{array}{l}55,283 \\
20,115 \\
24,465 \\
10,703\end{array}$ \\
\hline 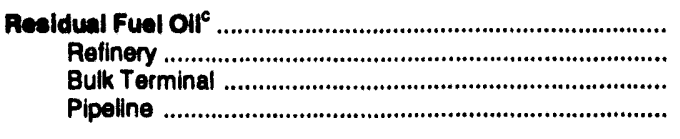 & $\begin{array}{r}14,075 \\
4,112 \\
9,963 \\
0\end{array}$ & $\begin{array}{r}2,877 \\
1,984 \\
913 \\
0\end{array}$ & $\begin{array}{r}16,805 \\
7,018 \\
9,787 \\
0\end{array}$ & $\begin{array}{r}321 \\
321 \\
0 \\
0\end{array}$ & $\begin{array}{r}5,362 \\
3,721 \\
1,531 \\
110\end{array}$ & $\begin{array}{r}39,440 \\
17,136 \\
22,194 \\
110\end{array}$ \\
\hline 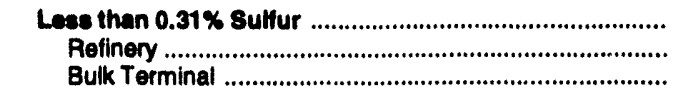 & $\begin{array}{l}3,309 \\
1,274 \\
2,035\end{array}$ & $\begin{array}{r}13 \\
13 \\
0\end{array}$ & $\begin{array}{r}1,011 \\
915 \\
96\end{array}$ & $\begin{array}{r}46 \\
46 \\
0\end{array}$ & $\begin{array}{r}315 \\
315 \\
0\end{array}$ & $\begin{array}{l}4,694 \\
2,563 \\
2,131\end{array}$ \\
\hline 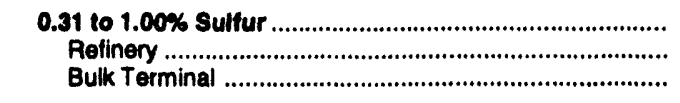 & $\begin{array}{l}4,090 \\
1,698 \\
2,392\end{array}$ & $\begin{array}{l}587 \\
291 \\
296\end{array}$ & $\begin{array}{r}5,213 \\
790 \\
4,423\end{array}$ & $\begin{array}{r}146 \\
146 \\
0\end{array}$ & $\begin{array}{l}904 \\
515 \\
389\end{array}$ & $\begin{array}{r}10,940 \\
3,440 \\
7,500\end{array}$ \\
\hline 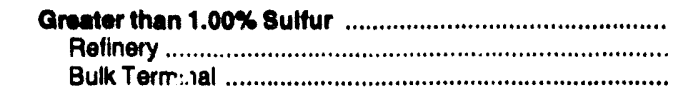 & $\begin{array}{l}6,676 \\
1,140 \\
5,536\end{array}$ & $\begin{array}{r}2,277 \\
1,660 \\
617\end{array}$ & $\begin{array}{r}10,581 \\
5,313 \\
5,268\end{array}$ & $\begin{array}{r}129 \\
129 \\
0\end{array}$ & $\begin{array}{l}4,033 \\
2,891 \\
1,142\end{array}$ & $\begin{array}{l}23,696 \\
11,133 \\
12,563\end{array}$ \\
\hline 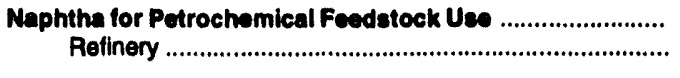 & $\begin{array}{l}243 \\
243\end{array}$ & $\begin{array}{l}204 \\
204\end{array}$ & $\begin{array}{l}1,551 \\
1,551\end{array}$ & $\begin{array}{l}0 \\
0\end{array}$ & $\begin{array}{l}76 \\
76\end{array}$ & $\begin{array}{l}2,074 \\
2,074\end{array}$ \\
\hline 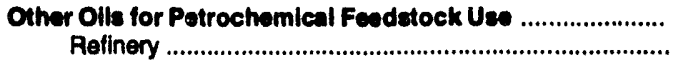 & 6 & $\begin{array}{l}3 \\
3\end{array}$ & $\begin{array}{l}1,620 \\
1,620\end{array}$ & $\begin{array}{l}0 \\
0\end{array}$ & $\begin{array}{l}103 \\
103\end{array}$ & $\begin{array}{l}1,732 \\
1,732\end{array}$ \\
\hline 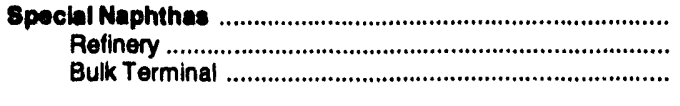 & $\begin{array}{r}130 \\
47 \\
83\end{array}$ & $\begin{array}{r}363 \\
346 \\
17\end{array}$ & $\begin{array}{r}1,727 \\
1,299 \\
428\end{array}$ & $\begin{array}{l}1 \\
1 \\
0\end{array}$ & $\begin{array}{r}41 \\
41 \\
0\end{array}$ & $\begin{array}{r}2,262 \\
1,734 \\
528\end{array}$ \\
\hline 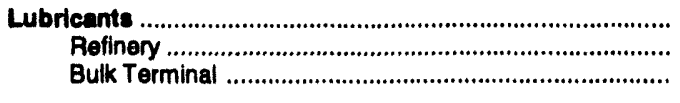 & $\begin{array}{r}2,729 \\
886 \\
1,843\end{array}$ & $\begin{array}{r}1,630 \\
761 \\
869\end{array}$ & $\begin{array}{r}5,537 \\
4,692 \\
845\end{array}$ & $\begin{array}{l}0 \\
0 \\
0\end{array}$ & $\begin{array}{r}1,705 \\
1,033 \\
672\end{array}$ & $\begin{array}{r}11,601 \\
7,372 \\
4,229\end{array}$ \\
\hline 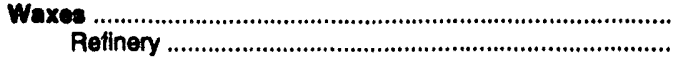 & $\begin{array}{l}158 \\
158\end{array}$ & $\begin{array}{l}107 \\
107\end{array}$ & $\begin{array}{l}438 \\
438\end{array}$ & $\begin{array}{l}28 \\
28\end{array}$ & $\begin{array}{l}70 \\
70\end{array}$ & $\begin{array}{l}801 \\
801\end{array}$ \\
\hline Petroloum Coke & $\begin{array}{l}1,061 \\
1,061\end{array}$ & $\begin{array}{l}2,247 \\
2,247\end{array}$ & $\begin{array}{l}2,699 \\
2,699\end{array}$ & $\begin{array}{l}142 \\
142\end{array}$ & $\begin{array}{l}3,820 \\
3,820\end{array}$ & $\begin{array}{l}9,969 \\
9,969\end{array}$ \\
\hline $\begin{array}{l}\text { Aaphat and Roud Oll } \\
\text { Refinery } \\
\text { Bulk Terminal }\end{array}$ & $\begin{array}{l}5,389 \\
2,869 \\
2,500\end{array}$ & $\begin{array}{r}12,608 \\
7,876 \\
4,822\end{array}$ & $\begin{array}{r}4,231 \\
3,462 \\
769\end{array}$ & $\begin{array}{r}2,666 \\
2,613 \\
53\end{array}$ & $\begin{array}{r}2,092 \\
1,895 \\
197\end{array}$ & $\begin{array}{r}27,056 \\
18,715 \\
8,341\end{array}$ \\
\hline 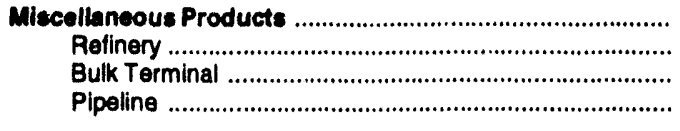 & $\begin{array}{r}525 \\
58 \\
467 \\
0\end{array}$ & $\begin{array}{r}250 \\
129 \\
87 \\
34\end{array}$ & $\begin{array}{r}1,634 \\
368 \\
1,215 \\
51\end{array}$ & $\begin{array}{r}20 \\
14 \\
0 \\
6\end{array}$ & $\begin{array}{r}237 \\
93 \\
144 \\
0\end{array}$ & $\begin{array}{r}2,666 \\
662 \\
1,913 \\
91\end{array}$ \\
\hline 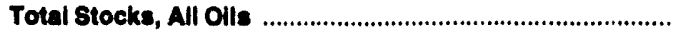 & 164,084 & 232,707 & 982,460 & 30,700 & 170,774 & $1,580,72 E$ \\
\hline
\end{tabular}

Includes stocks held by producers.

b Includes tertiary amyl methyl ether (TAME), tertiary butyl acohol (TBA), and other alphatic alcohols and ethers Intended for motor gasoline blending (e.g., isopropyl ether (IPE) or n-propanol).

C Sultur content not available for stocks held by pipelines.

$W=$ Withheld to avoid disclosure of indwidual company data.

Note: Stocks are reported as of the last day of the month.

Sources: Energy Information Administration (EIA) Forms EIA-810, "Monthly Refinery Report," EIA-811, "Monthly Bulk Terminal Report, EIA-812, "Monthly Product Pipeline Report," EIA-813, "Monthly Crude Oil Report," and EIA-816, "Monthly Natural Gas Liquids Report." 
Table 52. Refinery, Bulk Terminal, and Natural Gas Plant Stocks of Selected Petroleum Products by PAD District and State, February 1994 (Thousand Barrels)

\begin{tabular}{|c|c|c|c|c|c|c|c|c|c|}
\hline \multirow[b]{2}{*}{ PAD District and State } & \multicolumn{3}{|c|}{ Motor Gasoline } & \multirow[b]{2}{*}{ Kerosene } & \multicolumn{3}{|c|}{ Distillate Fuel Oll } & \multirow[b]{2}{*}{$\begin{array}{c}\text { Aesidual } \\
\text { Fuel }\end{array}$} & \multirow[b]{2}{*}{$\begin{array}{l}\text { Propanel } \\
\text { Propyiene }\end{array}$} \\
\hline & Reformulated & Oxygenated & Other & & Total & $\begin{array}{l}0.05 \% \text { Sulfur } \\
\text { and Under }\end{array}$ & \begin{tabular}{l|} 
Greater than \\
$0.05 \%$ Sulfur
\end{tabular} & & \\
\hline 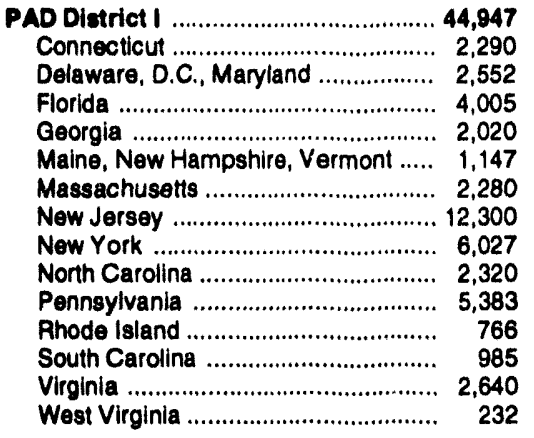 & $\begin{array}{l}0 \\
0 \\
0 \\
0 \\
0 \\
0 \\
0 \\
0 \\
0 \\
0 \\
0 \\
0 \\
0 \\
0 \\
0\end{array}$ & $\begin{array}{r}7,459 \\
642 \\
719 \\
0 \\
0 \\
0 \\
60 \\
3,350 \\
1,218 \\
309 \\
832 \\
0 \\
0 \\
329 \\
0\end{array}$ & $\begin{array}{r}37,488 \\
1,648 \\
1,833 \\
4,005 \\
2,020 \\
1,147 \\
2,220 \\
8,950 \\
4,809 \\
2,011 \\
4,551 \\
766 \\
985 \\
2,311 \\
232\end{array}$ & $\begin{array}{r}1,562 \\
4 \\
54 \\
115 \\
33 \\
196 \\
145 \\
41 \\
302 \\
78 \\
393 \\
W \\
97 \\
81 \\
W\end{array}$ & $\begin{array}{r}29,081 \\
1,650 \\
1,834 \\
1,320 \\
776 \\
1,265 \\
1,833 \\
6,131 \\
4,351 \\
1,161 \\
5,076 \\
1,172 \\
591 \\
1,796 \\
125\end{array}$ & $\begin{array}{r}8,901 \\
404 \\
496 \\
710 \\
337 \\
271 \\
515 \\
1,609 \\
1,170 \\
444 \\
1,493 \\
202 \\
300 \\
837 \\
113\end{array}$ & $\begin{array}{r}20,180 \\
1,246 \\
1,338 \\
610 \\
439 \\
994 \\
1,318 \\
4,522 \\
3,181 \\
717 \\
3,583 \\
970 \\
291 \\
959 \\
12\end{array}$ & $\begin{array}{r}14,075 \\
59 \\
1,772 \\
1,247 \\
300 \\
425 \\
725 \\
4,707 \\
2,160 \\
367 \\
1,101 \\
W \\
W \\
777 \\
W\end{array}$ & $\begin{array}{r}1,337 \\
W \\
W \\
144 \\
W \\
W \\
W \\
W \\
W \\
W \\
W \\
W \\
W \\
W \\
W\end{array}$ \\
\hline 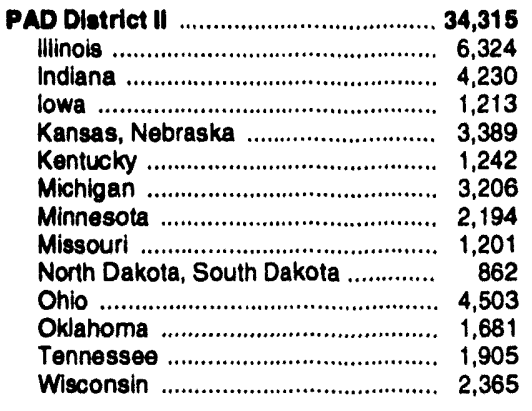 & $\begin{array}{l}0 \\
0 \\
0 \\
0 \\
0 \\
0 \\
0 \\
0 \\
0 \\
0 \\
0 \\
0 \\
0 \\
0\end{array}$ & $\begin{array}{r}1,034 \\
118 \\
57 \\
0 \\
0 \\
182 \\
33 \\
280 \\
0 \\
1 \\
55 \\
222 \\
86 \\
0\end{array}$ & $\begin{array}{r}33,281 \\
6,206 \\
4,173 \\
1,213 \\
3,389 \\
1,060 \\
3,173 \\
1,914 \\
1,201 \\
861 \\
4,448 \\
1,459 \\
1,819 \\
2,365\end{array}$ & $\begin{array}{r}1,097 \\
132 \\
139 \\
W \\
7 \\
10 \\
152 \\
W \\
W \\
W \\
209 \\
W \\
75 \\
W\end{array}$ & $\begin{array}{r}21,017 \\
3,712 \\
2,795 \\
1,461 \\
2,081 \\
860 \\
1,658 \\
1,500 \\
377 \\
879 \\
1,884 \\
1,418 \\
720 \\
1,672\end{array}$ & $\begin{array}{r}11,429 \\
1,891 \\
1,017 \\
1,182 \\
1,402 \\
179 \\
971 \\
1,098 \\
311 \\
442 \\
950 \\
472 \\
495 \\
1,019\end{array}$ & $\begin{array}{r}9,588 \\
1,821 \\
1,778 \\
279 \\
679 \\
681 \\
687 \\
402 \\
66 \\
437 \\
934 \\
946 \\
225 \\
653\end{array}$ & $\begin{array}{r}2,877 \\
1,067 \\
297 \\
W \\
10 \\
W \\
104 \\
174 \\
W \\
W \\
213 \\
336 \\
347 \\
61\end{array}$ & $\begin{array}{r}4,869 \\
587 \\
W \\
W \\
1,903 \\
W \\
541 \\
W \\
W \\
W \\
W \\
771 \\
W \\
W\end{array}$ \\
\hline 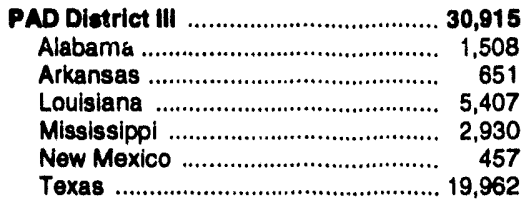 & $\begin{array}{l}0 \\
0 \\
0 \\
0 \\
0 \\
0 \\
0\end{array}$ & $\begin{array}{r}2,062 \\
0 \\
0 \\
504 \\
184 \\
0 \\
1,374\end{array}$ & $\begin{array}{r}28,853 \\
1,508 \\
651 \\
4,903 \\
2,746 \\
457 \\
18,588\end{array}$ & $\begin{array}{r}905 \\
47 \\
W \\
307 \\
7 \\
W \\
542\end{array}$ & $\begin{array}{r}18,509 \\
560 \\
358 \\
4,128 \\
1,620 \\
301 \\
11,542\end{array}$ & $\begin{array}{r}7,715 \\
380 \\
242 \\
1,226 \\
402 \\
233 \\
5,232 \\
\end{array}$ & $\begin{array}{r}10,794 \\
180 \\
116 \\
2,902 \\
1,218 \\
68 \\
6,310\end{array}$ & $\begin{array}{r}16,605 \\
213 \\
W \\
7,121 \\
W \\
21 \\
9,102\end{array}$ & $\begin{array}{r}10,040 \\
31 \\
W \\
1,670 \\
771 \\
W \\
7,382\end{array}$ \\
\hline 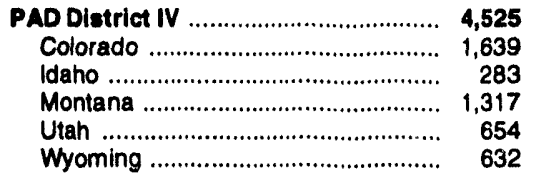 & $\begin{array}{l}0 \\
0 \\
0 \\
0 \\
0 \\
0\end{array}$ & $\begin{array}{r}340 \\
340 \\
0 \\
0 \\
0 \\
0\end{array}$ & $\begin{array}{r}4,185 \\
1,299 \\
283 \\
1,317 \\
654 \\
632\end{array}$ & $\begin{array}{l}90 \\
W \\
W \\
W \\
W \\
W\end{array}$ & $\begin{array}{r}2,570 \\
485 \\
236 \\
655 \\
655 \\
539\end{array}$ & $\begin{array}{r}1,536 \\
187 \\
182 \\
439 \\
328 \\
400\end{array}$ & $\begin{array}{r}1,034 \\
298 \\
54 \\
216 \\
327 \\
139\end{array}$ & $\begin{array}{r}321 \\
W \\
W \\
57 \\
126 \\
W\end{array}$ & $\begin{array}{r}258 \\
W \\
W \\
17 \\
124 \\
60\end{array}$ \\
\hline 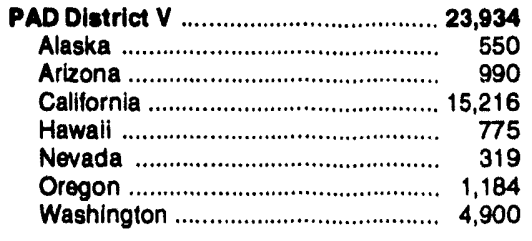 & $\begin{array}{l}0 \\
0 \\
0 \\
0 \\
0 \\
0 \\
0 \\
0\end{array}$ & $\begin{array}{r}3,226 \\
0 \\
99 \\
3,112 \\
0 \\
15 \\
0 \\
0\end{array}$ & $\begin{array}{r}20,708 \\
550 \\
891 \\
12,104 \\
775 \\
304 \\
1,184 \\
4,900\end{array}$ & $\begin{array}{l}61 \\
W \\
W \\
47 \\
W \\
W \\
W \\
W\end{array}$ & $\begin{array}{r}9,431 \\
884 \\
216 \\
4,825 \\
405 \\
166 \\
867 \\
2,068\end{array}$ & $\begin{array}{r}8,447 \\
256 \\
161 \\
4,156 \\
102 \\
137 \\
517 \\
1,118\end{array}$ & $\begin{array}{r}2,984 \\
628 \\
55 \\
669 \\
303 \\
29 \\
350 \\
950\end{array}$ & $\begin{array}{r}5,252 \\
W \\
W \\
3,047 \\
W \\
W \\
177 \\
1,045\end{array}$ & $\begin{array}{r}553 \\
W \\
W \\
157 \\
W \\
W \\
W \\
29\end{array}$ \\
\hline U.8. Total .......................................138,636 & $\mathbf{0}$ & 14,121 & 124,515 & 3,715 & 80,608 & 36,028 & 44,580 & 39,330 & 17,063 \\
\hline
\end{tabular}

$W=$ Withheld to avoid disclosure of individual company data.

Notes: - Stocks are reported as of the last day of the month. - Totals may not equal sum of components due to independent rounding.

Sources: Energy Intormation Administration (EIA) Forms EIA-810, "Monthly Retinery Report," ElA-811, "Monthly Bulk Terminal Repont," and EIA-816, "Monthly Natural Gas Liquids Report." 
Table 53. Movements of Crude Oll and Petroleum Products by Pipeline, Tanker, and Barge Between PAD Districts, February 1994

(Thousand Barrels)

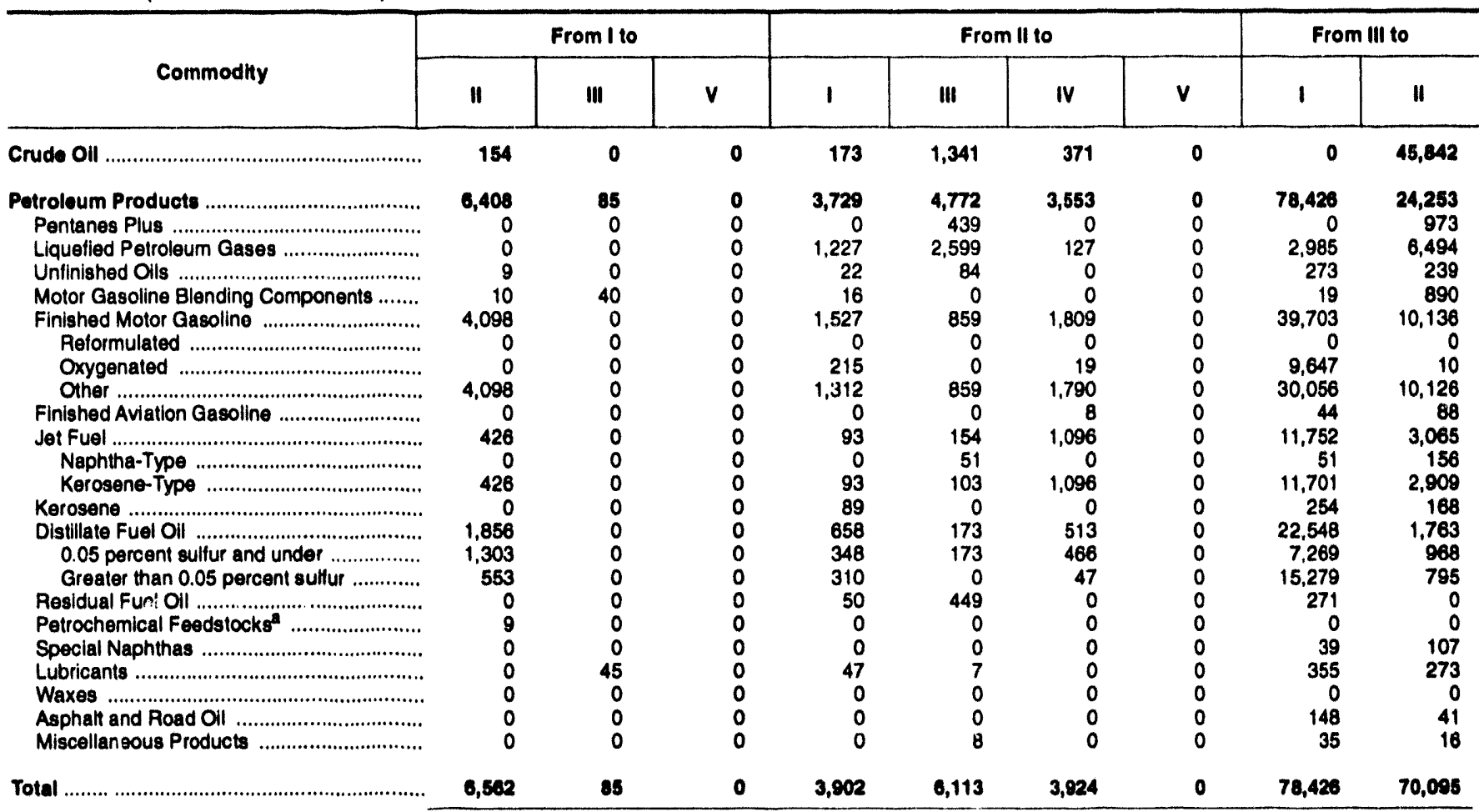

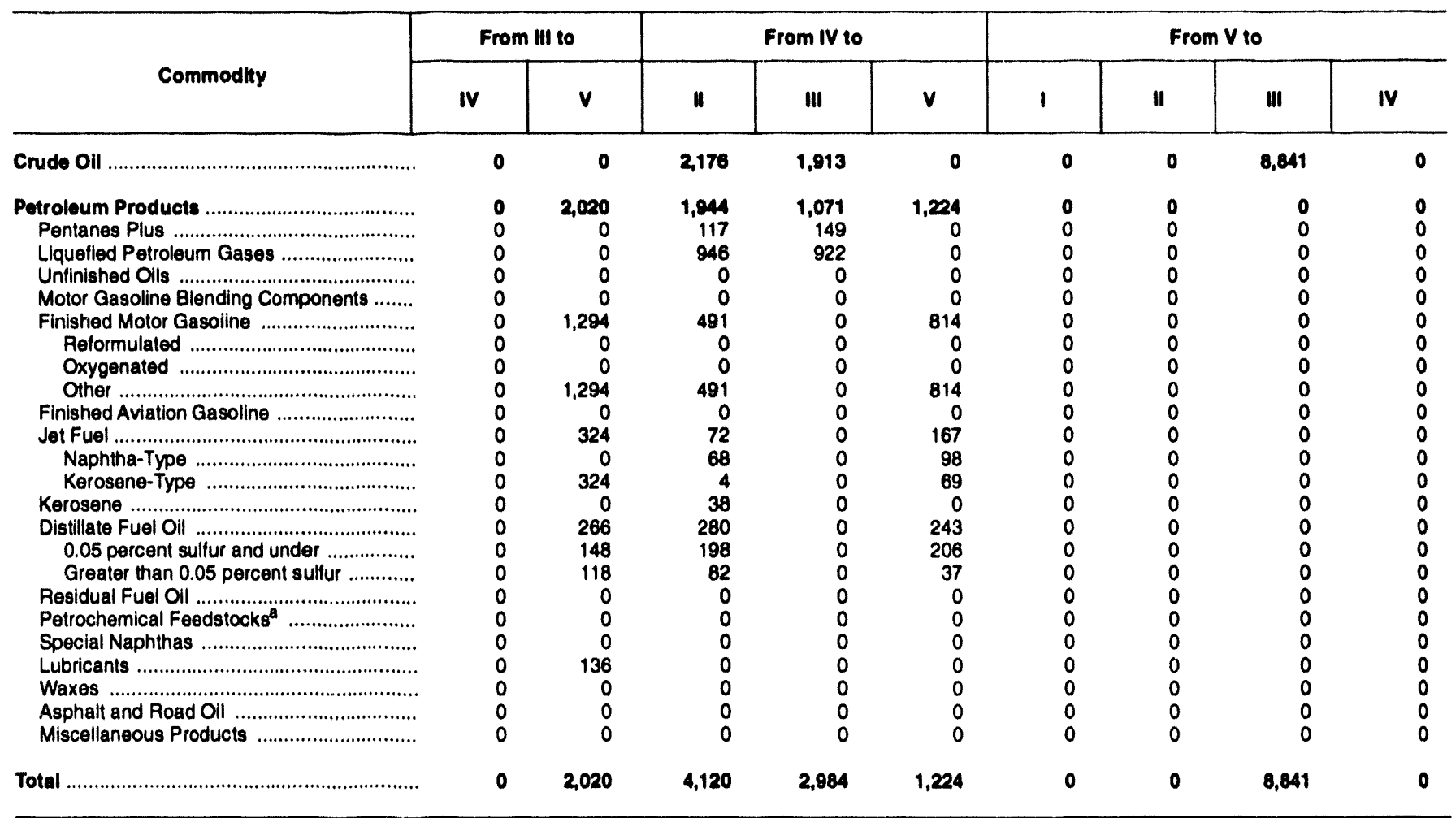

a Includes naphtha less than $401^{\circ} \mathrm{F}$ endpoint and other oils equal to or greater than $401^{\circ} \mathrm{F}$ endpoint.

Sources: Energy Information Administration (EIA) Forms EIA-812, "Monthly Product Pipeline Report," EIA-813, "Monthly Crude Oil Report," and EIA-817, "Monthly Tanker and Barge Movement Report." 
Table 54. Movements of Crude Oll and Petroleum Products by Pipeline Between PAD Districts, February 1994

(Thousand Barrels)

\begin{tabular}{|c|c|c|c|c|c|c|c|}
\hline \multirow{2}{*}{ Commodity } & \multicolumn{2}{|c|}{ From I to } & \multicolumn{3}{|c|}{ From II to } & \multicolumn{2}{|c|}{ From III to } \\
\hline & $\|$ & III & $\mathbf{1}$ & III & IV & 1 & $\|$ \\
\hline 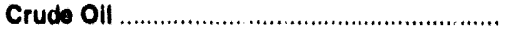 & 100 & 0 & $\mathbf{0}$ & 1,341 & 371 & 0 & 45,842 \\
\hline 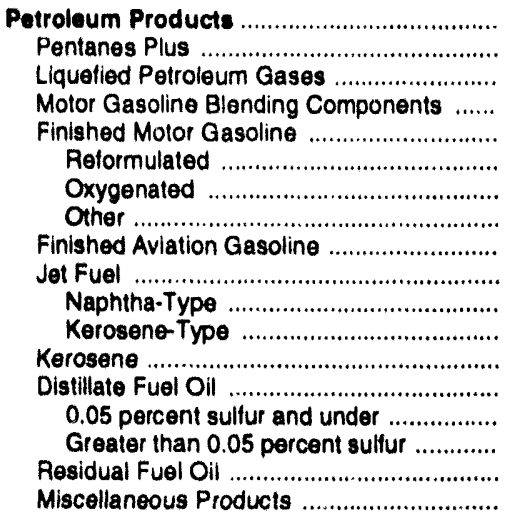 & $\begin{array}{r}6,380 \\
0 \\
0 \\
0 \\
4,098 \\
0 \\
0 \\
4,098 \\
0 \\
426 \\
0 \\
426 \\
0 \\
1,856 \\
1,303 \\
553 \\
0 \\
0\end{array}$ & $\begin{array}{l}0 \\
0 \\
0 \\
0 \\
0 \\
0 \\
0 \\
0 \\
0 \\
0 \\
0 \\
0 \\
0 \\
0 \\
0 \\
0 \\
0 \\
0\end{array}$ & $\begin{array}{r}2,146 \\
0 \\
1,227 \\
16 \\
704 \\
0 \\
0 \\
704 \\
0 \\
69 \\
0 \\
89 \\
0 \\
130 \\
80 \\
50 \\
0 \\
0\end{array}$ & $\begin{array}{r}3,944 \\
439 \\
2,599 \\
0 \\
683 \\
0 \\
0 \\
683 \\
0 \\
139 \\
51 \\
88 \\
0 \\
76 \\
76 \\
0 \\
0 \\
8\end{array}$ & $\begin{array}{r}3,553 \\
0 \\
127 \\
0 \\
1,809 \\
0 \\
19 \\
1,790 \\
8 \\
1,096 \\
0 \\
1,096 \\
0 \\
513 \\
466 \\
47 \\
0 \\
0\end{array}$ & $\begin{array}{r}44,258 \\
0 \\
2,688 \\
0 \\
31,160 \\
0 \\
9,100 \\
22,060 \\
0 \\
9,990 \\
51 \\
9,939 \\
254 \\
20,163 \\
6,624 \\
13,539 \\
0 \\
0\end{array}$ & $\begin{array}{r}21,057 \\
973 \\
6,494 \\
840 \\
8,973 \\
0 \\
0 \\
8,973 \\
88 \\
2,787 \\
156 \\
2,631 \\
129 \\
1,373 \\
818 \\
555 \\
0 \\
0\end{array}$ \\
\hline Total & 6,480 & $\mathbf{0}$ & 2,148 & $\mathbf{5 , 2 8 5}$ & 3,924 & e4,285 & 67,490 \\
\hline
\end{tabular}

\begin{tabular}{|c|c|c|c|c|c|c|c|}
\hline \multirow[b]{2}{*}{ Commodity } & \multicolumn{2}{|c|}{ From Ill to } & \multicolumn{3}{|c|}{ From IV to } & \multicolumn{2}{|c|}{ From V to } \\
\hline & IV & $\mathbf{v}$ & $\|$ & III & $\mathbf{v}$ & III & IV \\
\hline 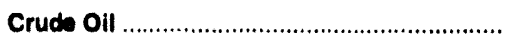 & 0 & 0 & 2,176 & 1,913 & $\mathbf{0}$ & 4,200 & $\mathbf{0}$ \\
\hline 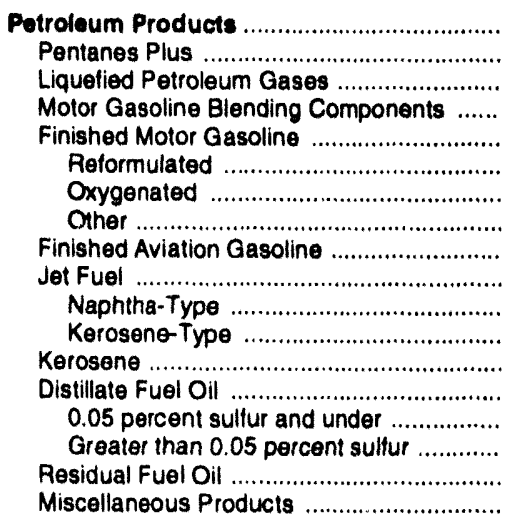 & $\begin{array}{l}0 \\
0 \\
0 \\
0 \\
0 \\
0 \\
0 \\
0 \\
0 \\
0 \\
0 \\
0 \\
0 \\
0 \\
0 \\
0 \\
0 \\
0\end{array}$ & $\begin{array}{r}1,884 \\
0 \\
0 \\
0 \\
1,294 \\
0 \\
0 \\
1,294 \\
0 \\
324 \\
0 \\
324 \\
0 \\
266 \\
148 \\
118 \\
0 \\
0\end{array}$ & $\begin{array}{r}1,944 \\
117 \\
946 \\
0 \\
491 \\
0 \\
0 \\
491 \\
0 \\
72 \\
68 \\
4 \\
38 \\
280 \\
198 \\
82 \\
0 \\
0\end{array}$ & $\begin{array}{r}1,071 \\
149 \\
922 \\
0 \\
0 \\
0 \\
0 \\
0 \\
0 \\
0 \\
0 \\
0 \\
0 \\
0 \\
0 \\
0 \\
0 \\
0\end{array}$ & $\begin{array}{r}1,224 \\
0 \\
0 \\
0 \\
814 \\
0 \\
0 \\
814 \\
0 \\
167 \\
98 \\
69 \\
0 \\
243 \\
206 \\
37 \\
0 \\
0\end{array}$ & $\begin{array}{l}0 \\
0 \\
0 \\
0 \\
0 \\
0 \\
0 \\
0 \\
0 \\
0 \\
0 \\
0 \\
0 \\
0 \\
0 \\
0 \\
0 \\
0\end{array}$ & $\begin{array}{l}0 \\
0 \\
0 \\
0 \\
0 \\
0 \\
0 \\
0 \\
0 \\
0 \\
0 \\
0 \\
0 \\
0 \\
0 \\
0 \\
0 \\
0\end{array}$ \\
\hline Total & $\mathbf{0}$ & 1,884 & 4,120 & $\mathbf{2 , 9 8 4}$ & 1,224 & 4,200 & $\mathbf{0}$ \\
\hline
\end{tabular}

Sources: Energy Information Administration (EIA) Forms ElA-812, "Monthly Product Pipellne Report," and EIA-813, Monthly Crude Oll Repont." 
Table 55. Movements of Crude Oll and Petroleum Products by Tanker and Barge Between PAD Districts, Fobruary 1994

(Thousand Barrels)

\begin{tabular}{|c|c|c|c|c|c|c|c|c|}
\hline \multirow[b]{2}{*}{ Commodity } & \multicolumn{3}{|c|}{ From I to } & \multicolumn{3}{|c|}{ From $\|$ to } & \multicolumn{2}{|c|}{ From III to } \\
\hline & $\mathbf{n}$ & III & $\mathbf{v}$ & $\mathbf{I}$ & III & $\mathbf{v}$ & 1 & $\begin{array}{l}\text { Now } \\
\text { England }\end{array}$ \\
\hline 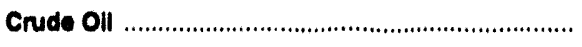 & $\mathbf{s 4}$ & 0 & 0 & 173 & $\mathbf{0}$ & $\mathbf{0}$ & 0 & $\mathbf{0}$ \\
\hline 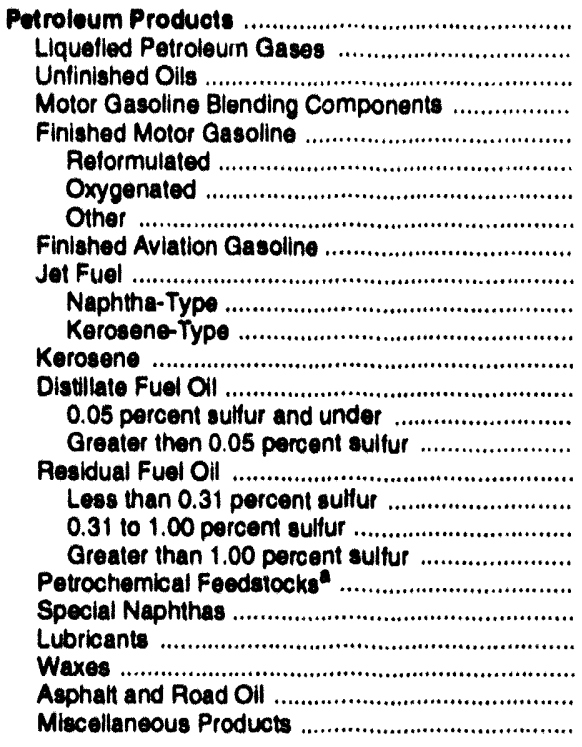 & $\begin{array}{r}28 \\
0 \\
9 \\
10 \\
0 \\
0 \\
0 \\
0 \\
0 \\
0 \\
0 \\
0 \\
0 \\
0 \\
0 \\
0 \\
0 \\
0 \\
0 \\
0 \\
9 \\
0 \\
0 \\
0 \\
0 \\
0\end{array}$ & $\begin{array}{r}85 \\
0 \\
0 \\
40 \\
0 \\
0 \\
0 \\
0 \\
0 \\
0 \\
0 \\
0 \\
0 \\
0 \\
0 \\
0 \\
0 \\
0 \\
0 \\
0 \\
0 \\
0 \\
45 \\
0 \\
0 \\
0\end{array}$ & $\begin{array}{l}0 \\
0 \\
0 \\
0 \\
0 \\
0 \\
0 \\
0 \\
0 \\
0 \\
0 \\
0 \\
0 \\
0 \\
0 \\
0 \\
0 \\
0 \\
0 \\
0 \\
0 \\
0 \\
0 \\
0 \\
0 \\
0\end{array}$ & $\begin{array}{r}1,863 \\
0 \\
22 \\
0 \\
823 \\
0 \\
215 \\
608 \\
0 \\
24 \\
0 \\
24 \\
89 \\
528 \\
268 \\
260 \\
50 \\
0 \\
0 \\
50 \\
0 \\
0 \\
47 \\
0 \\
0 \\
0\end{array}$ & $\begin{array}{r}828 \\
0 \\
84 \\
0 \\
176 \\
0 \\
0 \\
176 \\
0 \\
15 \\
0 \\
15 \\
0 \\
97 \\
97 \\
0 \\
449 \\
0 \\
0 \\
449 \\
0 \\
0 \\
7 \\
0 \\
0 \\
0\end{array}$ & $\begin{array}{l}0 \\
0 \\
0 \\
0 \\
0 \\
0 \\
0 \\
0 \\
0 \\
0 \\
0 \\
0 \\
0 \\
0 \\
0 \\
0 \\
0 \\
0 \\
0 \\
0 \\
0 \\
0 \\
0 \\
0 \\
0 \\
0\end{array}$ & $\begin{array}{r}14,171 \\
297 \\
273 \\
19 \\
8,543 \\
0 \\
547 \\
7,996 \\
44 \\
1,762 \\
0 \\
1,762 \\
0 \\
2,385 \\
645 \\
1,740 \\
271 \\
0 \\
271 \\
0 \\
0 \\
39 \\
355 \\
0 \\
148 \\
35\end{array}$ & $\begin{array}{r}484 \\
0 \\
0 \\
0 \\
0 \\
0 \\
0 \\
0 \\
0 \\
0 \\
0 \\
0 \\
0 \\
494 \\
0 \\
494 \\
0 \\
0 \\
0 \\
0 \\
0 \\
0 \\
0 \\
0 \\
0 \\
0\end{array}$ \\
\hline Total & 82 & 85 & $\mathbf{0}$ & 1,786 & 828 & $\mathbf{0}$ & 14,171 & 494 \\
\hline
\end{tabular}

\begin{tabular}{|c|c|c|c|c|c|c|c|}
\hline \multirow[b]{2}{*}{ Commodity } & \multicolumn{4}{|c|}{ From III to } & \multicolumn{3}{|c|}{ From V to } \\
\hline & $\begin{array}{l}\text { Contral } \\
\text { Allantic }\end{array}$ & $\begin{array}{l}\text { Lower } \\
\text { Atlantle }\end{array}$ & 11 & $\mathbf{v}$ & 1 & $\|$ & III \\
\hline 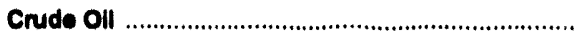 & 0 & $\mathbf{0}$ & $\mathbf{0}$ & $\mathbf{0}$ & 0 & $\mathbf{0}$ & 4,041 \\
\hline 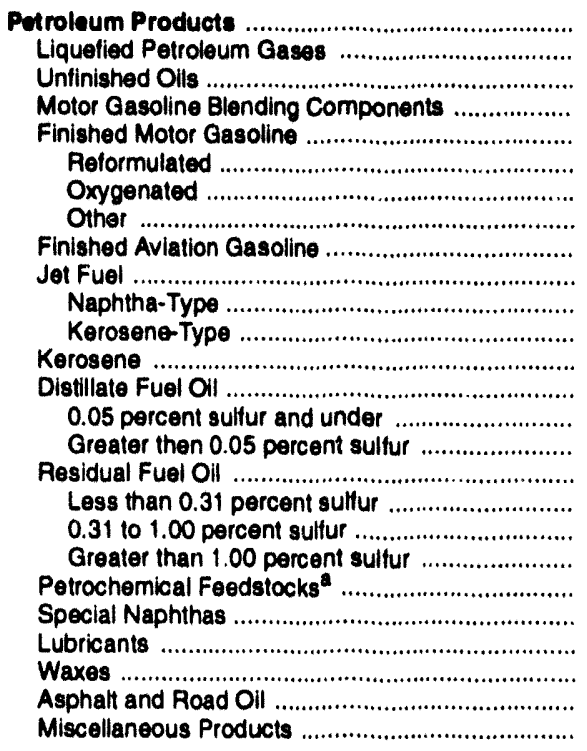 & $\begin{array}{r}862 \\
0 \\
9 \\
0 \\
76 \\
0 \\
0 \\
76 \\
0 \\
105 \\
0 \\
105 \\
0 \\
178 \\
0 \\
178 \\
271 \\
0 \\
271 \\
0 \\
0 \\
0 \\
223 \\
0 \\
0 \\
0\end{array}$ & $\begin{array}{r}12,815 \\
297 \\
264 \\
19 \\
8,467 \\
0 \\
547 \\
7,920 \\
44 \\
1,657 \\
0 \\
1,657 \\
0 \\
1,713 \\
645 \\
1,068 \\
0 \\
0 \\
0 \\
0 \\
0 \\
39 \\
132 \\
0 \\
148 \\
35\end{array}$ & $\begin{array}{r}2,596 \\
0 \\
239 \\
50 \\
1,163 \\
0 \\
10 \\
1,153 \\
0 \\
278 \\
0 \\
278 \\
39 \\
390 \\
150 \\
240 \\
0 \\
0 \\
0 \\
0 \\
0 \\
107 \\
273 \\
0 \\
41 \\
16\end{array}$ & $\begin{array}{r}138 \\
0 \\
0 \\
0 \\
0 \\
0 \\
0 \\
0 \\
0 \\
0 \\
0 \\
0 \\
0 \\
0 \\
0 \\
0 \\
0 \\
0 \\
0 \\
0 \\
0 \\
0 \\
136 \\
0 \\
0 \\
0\end{array}$ & $\begin{array}{l}0 \\
0 \\
0 \\
0 \\
0 \\
0 \\
0 \\
0 \\
0 \\
0 \\
0 \\
0 \\
0 \\
0 \\
0 \\
0 \\
0 \\
0 \\
0 \\
0 \\
0 \\
0 \\
0 \\
0 \\
0 \\
0\end{array}$ & $\begin{array}{l}0 \\
0 \\
0 \\
0 \\
0 \\
0 \\
0 \\
0 \\
0 \\
0 \\
0 \\
0 \\
0 \\
0 \\
0 \\
0 \\
0 \\
0 \\
0 \\
0 \\
0 \\
0 \\
0 \\
0 \\
0 \\
0\end{array}$ & $\begin{array}{l}0 \\
0 \\
0 \\
0 \\
0 \\
0 \\
0 \\
0 \\
0 \\
0 \\
0 \\
0 \\
0 \\
0 \\
0 \\
0 \\
0 \\
0 \\
0 \\
0 \\
0 \\
0 \\
0 \\
0 \\
0 \\
0\end{array}$ \\
\hline Total & 882 & 12,815 & 2,593 & 136 & $\mathbf{0}$ & $\mathbf{0}$ & 4,641 \\
\hline
\end{tabular}

Includes naphtha less than $401^{\circ} \mathrm{F}$ endpoint and other oils equal to or greater than $401^{\circ} \mathrm{F}$ endpoint.

Sources: Energy Information Administration (EIA) Forms EIA-812, "Monthly Product Pipeline Report" and EIA-817, "Monthly Tanker and Barge Movement Report." 
Table 56. Net Movements of Crude Oll and Petroleum Products by Pipeline, Tanker, and Barge Between PAD Districts, February 1994

(Thousand Barrels)

\begin{tabular}{|c|c|c|c|c|c|c|}
\hline \multirow{2}{*}{ Commodity } & \multicolumn{3}{|c|}{ PAD Distriof I } & \multicolumn{3}{|c|}{ PAD Dlatriet II } \\
\hline & Recelpts & shipments & Not Recolpte & Rocelpte & shlpments & Not Rocolpte \\
\hline Crude Oll & 173 & 154 & 19 & 48,172 & 1,885 & 40,287 \\
\hline 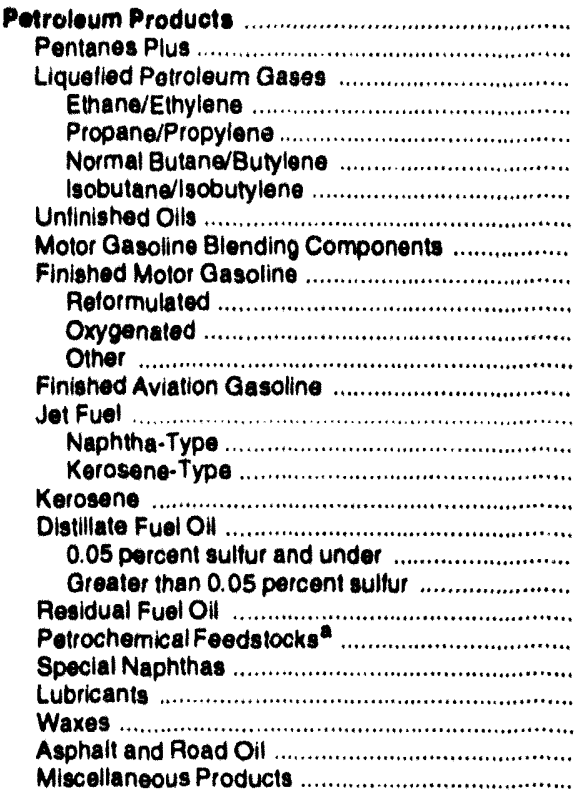 & $\begin{array}{r}r 2,158 \\
0 \\
4,212 \\
0 \\
4,212 \\
0 \\
0 \\
295 \\
35 \\
41,230 \\
0 \\
9,802 \\
31,368 \\
44 \\
11,845 \\
51 \\
11,794 \\
343 \\
23,206 \\
7,617 \\
15,589 \\
321 \\
0 \\
39 \\
402 \\
0 \\
148 \\
35\end{array}$ & $\begin{array}{r}0,493 \\
0 \\
0 \\
0 \\
0 \\
0 \\
0 \\
9 \\
50 \\
4,098 \\
0 \\
0 \\
4,098 \\
0 \\
426 \\
0 \\
428 \\
0 \\
1,856 \\
1,303 \\
553 \\
0 \\
9 \\
0 \\
45 \\
0 \\
0 \\
0\end{array}$ & $\begin{array}{r}75,002 \\
0 \\
4,212 \\
0 \\
4,212 \\
0 \\
0 \\
286 \\
-15 \\
37,132 \\
0 \\
9,862 \\
27,270 \\
44 \\
11,419 \\
51 \\
11,368 \\
343 \\
21,350 \\
6,314 \\
15,036 \\
321 \\
-9 \\
39 \\
367 \\
0 \\
148 \\
35\end{array}$ & $\begin{array}{r}32,008 \\
1,090 \\
7,440 \\
943 \\
5,008 \\
833 \\
656 \\
248 \\
900 \\
14,725 \\
0 \\
10 \\
14,715 \\
88 \\
3,563 \\
224 \\
3,339 \\
206 \\
3,899 \\
2,469 \\
1,430 \\
0 \\
9 \\
109 \\
273 \\
0 \\
41 \\
16\end{array}$ & $\begin{array}{r}12,054 \\
439 \\
3,953 \\
1,226 \\
2,188 \\
453 \\
86 \\
106 \\
16 \\
4,195 \\
0 \\
234 \\
3,961 \\
8 \\
1,343 \\
51 \\
1,292 \\
89 \\
1,344 \\
987 \\
357 \\
499 \\
0 \\
0 \\
54 \\
0 \\
0 \\
8\end{array}$ & $\begin{array}{r}20,551 \\
651 \\
3,487 \\
-283 \\
2,820 \\
380 \\
570 \\
142 \\
884 \\
10,530 \\
0 \\
-224 \\
10,754 \\
80 \\
2,220 \\
173 \\
2,047 \\
117 \\
2,555 \\
1,482 \\
1,073 \\
-499 \\
9 \\
107 \\
219 \\
0 \\
41 \\
8\end{array}$ \\
\hline 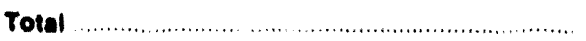 & 82,328 & 6,647 & 75,681 & 80,777 & 13,930 & 68.836 \\
\hline
\end{tabular}

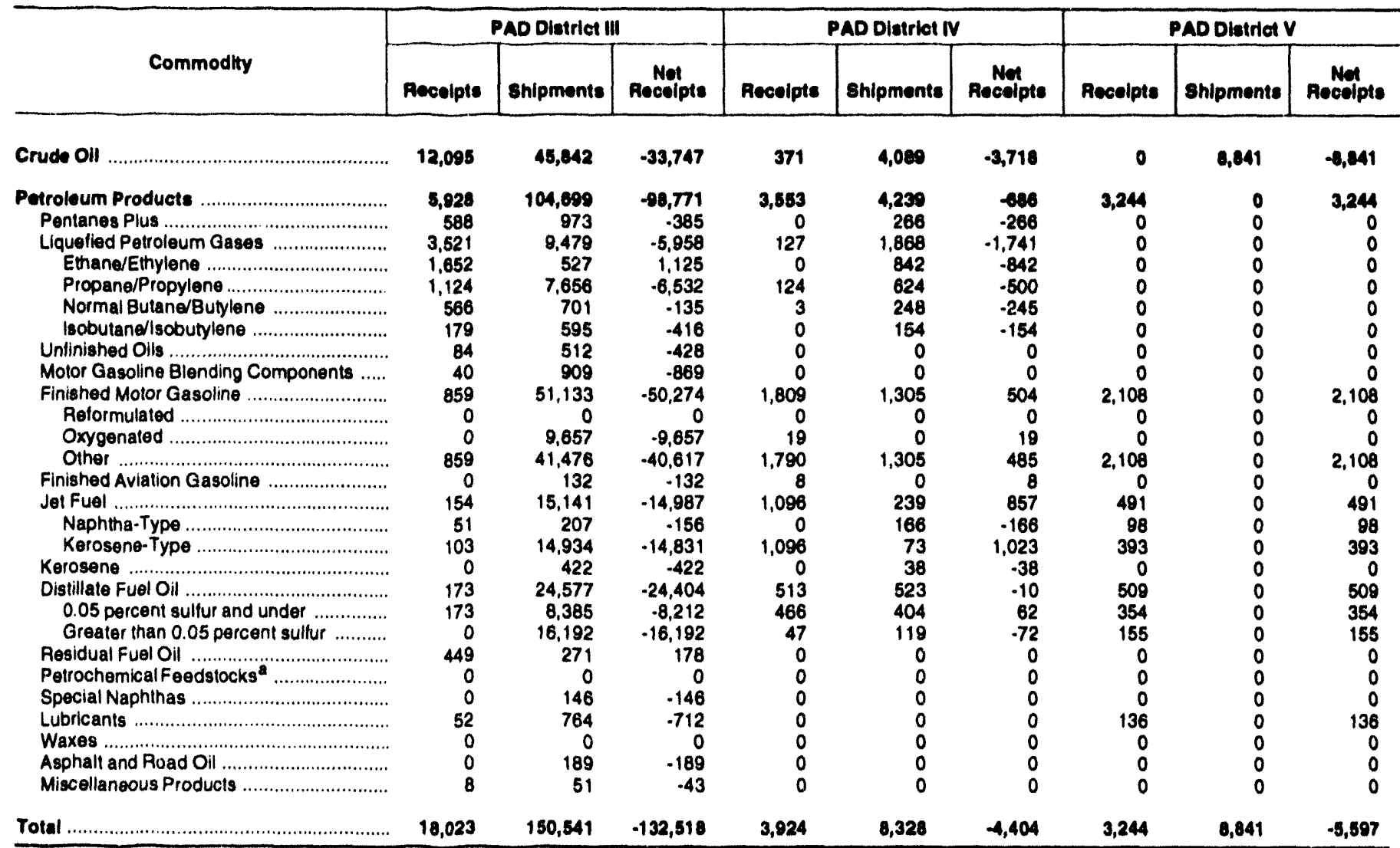

- Includes naphtha less than $401^{\circ} \mathrm{F}$ endpoint and other olls equal to or greater than $401^{\circ} \mathrm{F}$ endpoint.

Sources: Energy Intormation Administration (EIA) Forms EIA-812, "Monthly Product Pipeline Report," EIA-813, "Monthly Crude Oil Repor," and ElA-817, "Monthly Tanker and Barge Movement Report." 


\title{
Appendix A
}

\author{
District \\ Descriptions \\ and Maps
}

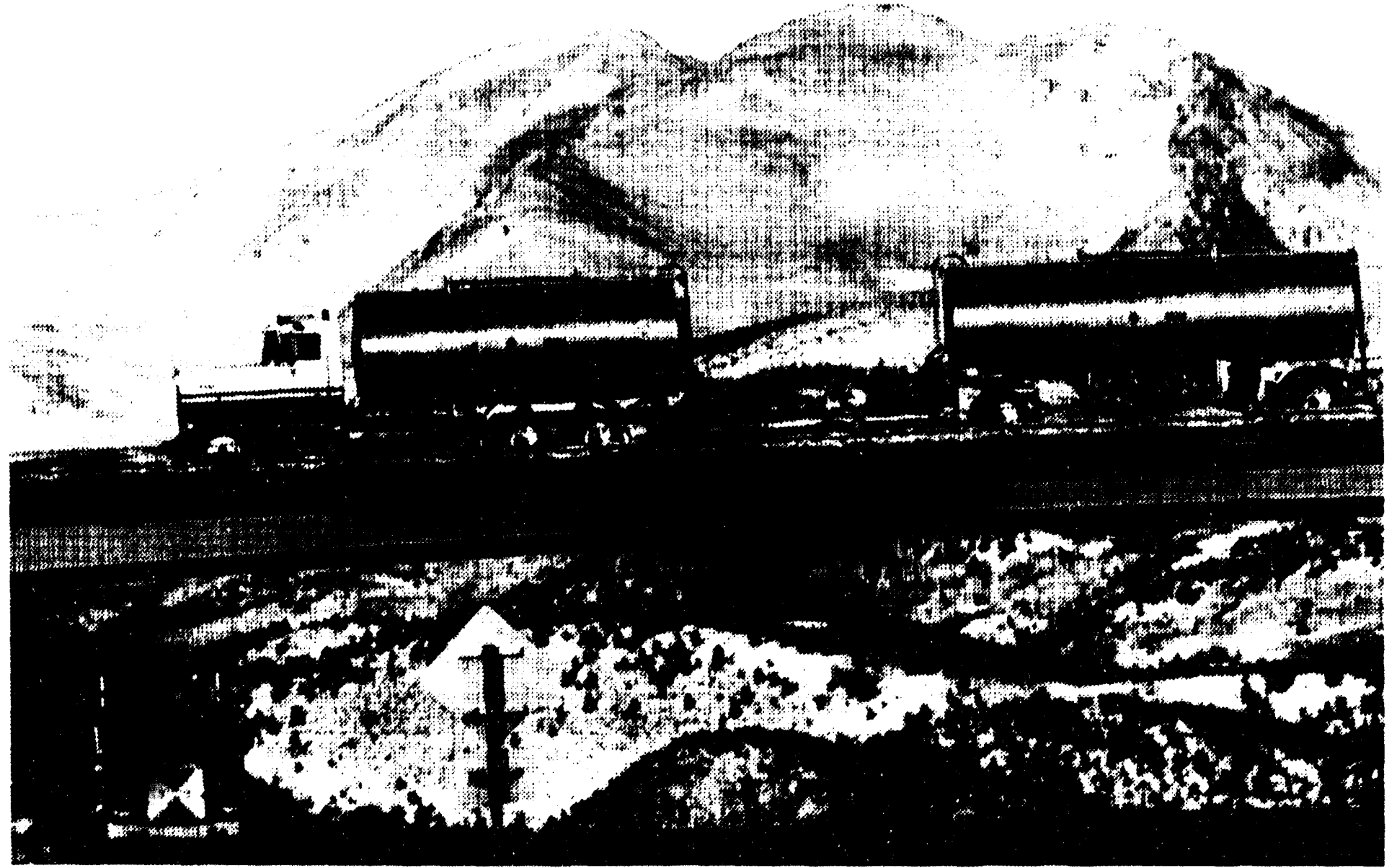




\section{District Descriptions and Maps}

The following are the Refining Districts which make up the Petroleum Administration for Defense (PAD) Districts.

\section{PAD District I}

East Coast: District of Columbia and the States of Maine, New Hampshire, Vermont, Massachusetts, Rhode Island, Connecticut, New Jersey, Delaware, Maryland, Virginia, North Carolina, South Carolina, Georgia, Florida, and the following counties of the State of New York: Cayuga, Tompkins, Chemung, and all counties east and north thereof. Also the following counties in the State of Pennsylvania: Bradford, Sullivan, Columbia, Montour, Northumberland, Dauphin, York, and all counties east thereof.

Appalachian No. 1: The State of West Virginia and those parts of the States of Pennsylvania and New York not included in the East Coast District.

\section{Sub-PAD District I}

New England: The States of Connecticut, Maine, Massachusetts, New Hampshire, Rhode Island and Vermont.

Central Atlantic: The District of Columbia and the States of Delaware, Maryland, New Jersey, New York, and Pennsylvania.

Lower Allantic: The States of Florida, Georgia, North Carolina, South Carolina, Virginia and West Virginia.

\section{PAD District II}

Indiana-Illinois-Kentucky: The States of Indiana, IIlinois, Kentucky, Tennessee, Michigan, and Ohio.

Minnesota-Wisconsin-North and South Dakota: The States of Minnesota, Wisconsin, North Dakota, and South Dakota.

Oklahoma-Kansas-Missouri: The States of Oklahoma, Kansas, Missouri, Nebraska, and Iowa.

\section{PAD District III}

Texas Inland: The State of Texas except the Texas Gulf Coast District.

Texas Gulf Coast: The following counties of the State of Texas: Newton, Orange, Jefferson. Jasper, Tyler, Hardin, Liberty, Chambers, Polk, San Jacinto, Montgomery, Harris, Galveston, Waller, Fort Bend, Brazoria, Wharton, Matagorda, Jackson, Victoria, Calhoun, Refugio, Aransas, San Patricio, Nueces, Kleberg, Kenedy, Willacy, and Cameron.

Louisiana Gulf Coast: The following parishes of the State of Louisiana: Vernon, Rapides, Avoyelles, Pointe Coupee, West Feliciana, East Feliciana, Saint Helena, Tangipahoa, Washington, and all parishes south thereof. Also the following counties of the State of Mississippi: Pearl River, Stone, George, Hancock, Harrison, and Jackson. Also the following counties of the State of Alabama: Mobile and Baldwin.

North Louisiana-Arkansas: The State of Arkansas and those parts of the States of Louisiana, Mississippi, and Alabama not included in the Louisiana Gulf Coast District.

New Mexico: The State of New Mexico.

\section{PAD District IV}

Rocky Mountain: The States of Montana, Idaho, Wyoming, Utah, and Colorado.

\section{PAD District V}

West Coast: The States of Washington, Oregon, California, Nevada, Arizona, Alaska, and Hawaii. 


\section{Petroleum Administration for Defense (PAD) Districts}
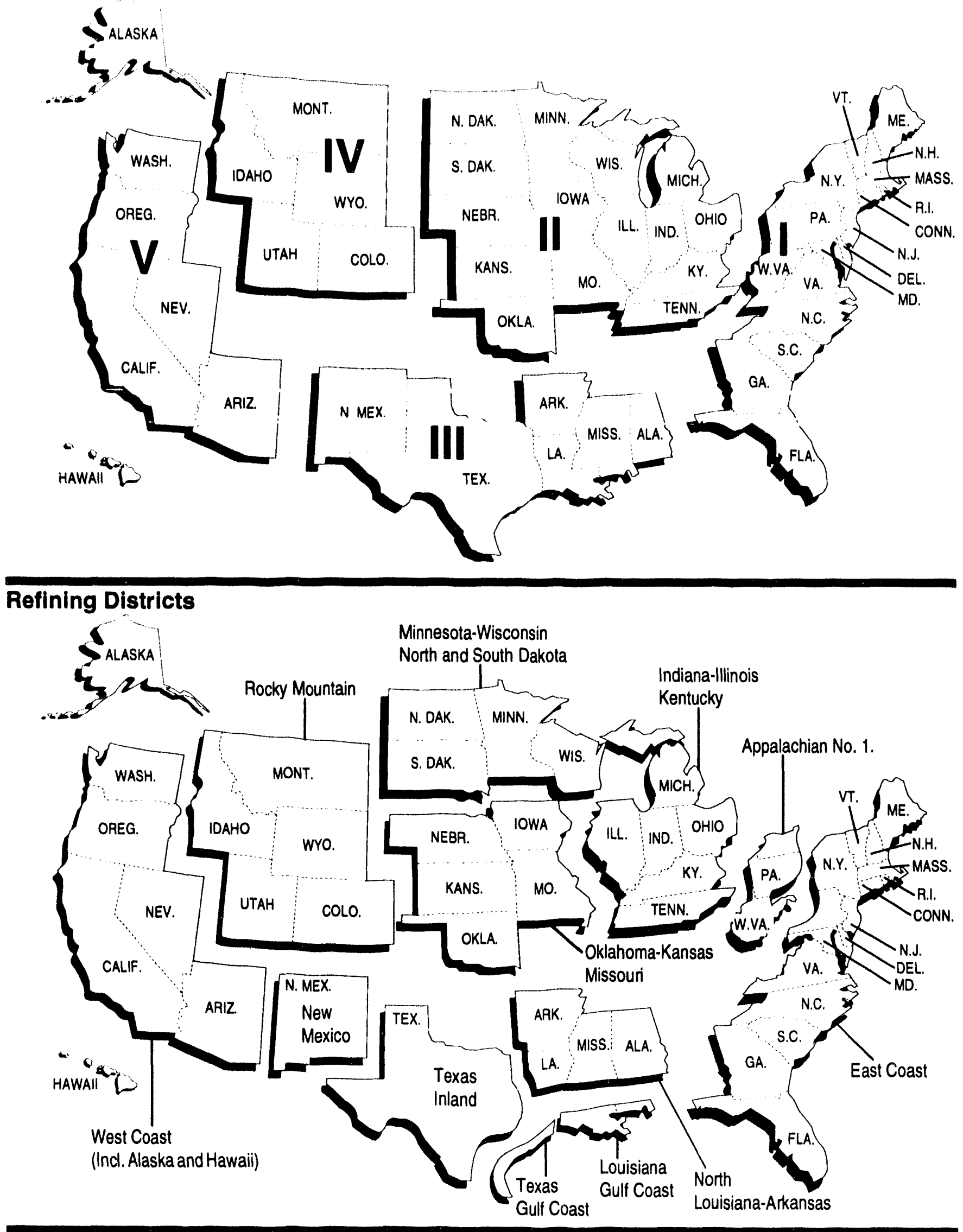


\section{Appendix B}

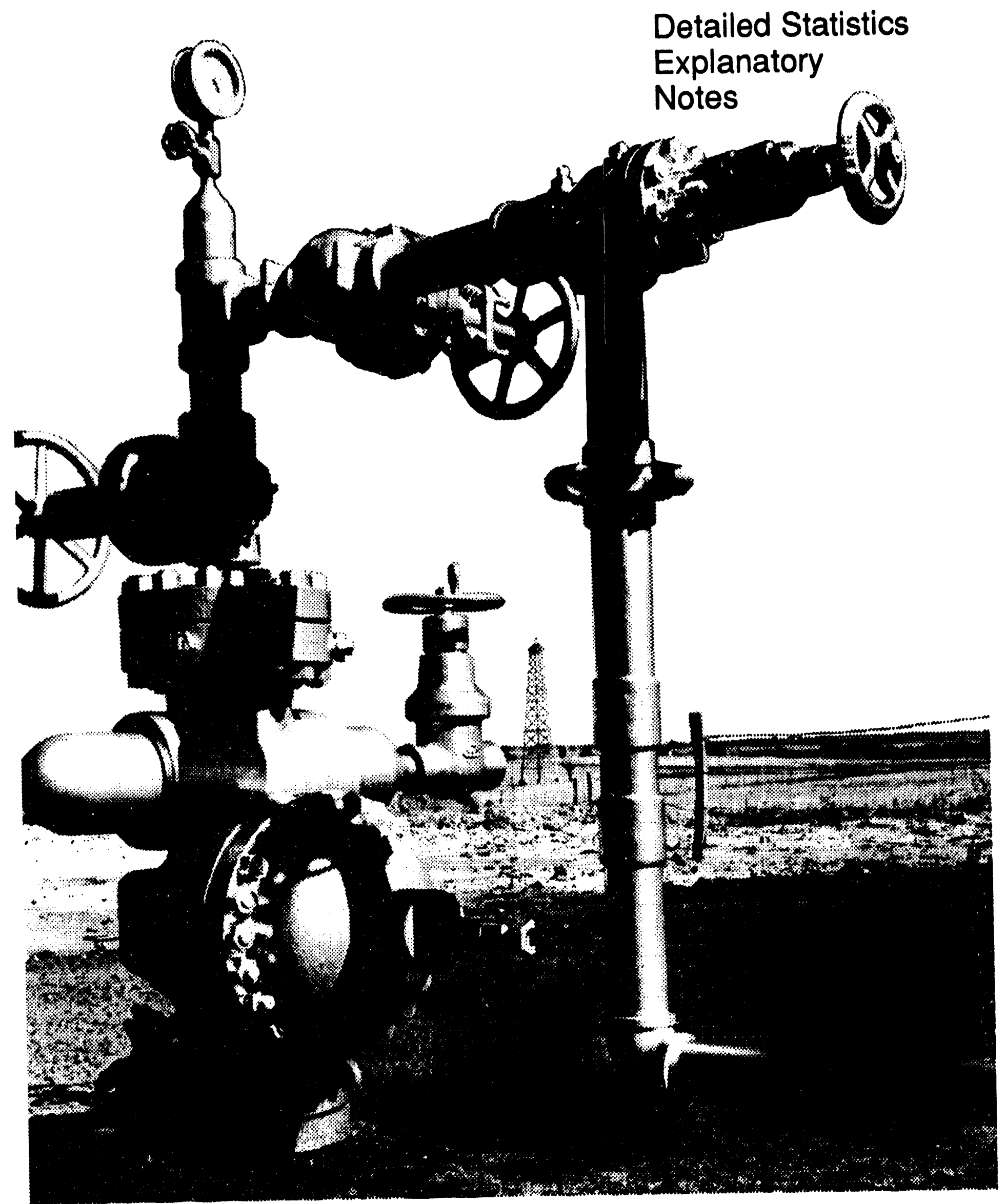

The cluster of pipes and valves that control the flow of oil at the mouth of an oil well is what oilmen call a "Christmas Tree." 


\section{Appendix B}

\section{Explanatory Notes}

The following Explanatory Notes are provided to assist in understanding and interpreting the data presented in the Detailed Statistics section of this publication.

- Note 1. Petroleum Supply Reporting System

- Note 2. Monthly Petroleum Supply Reporting System

- Note 3. Technical Notes for Detailed Statistics Tables

- Note 4. Domestic Crude Oil Production

- Note 5. Export Data

- Note 6. Quality Control and Data Revision

- Note 7. Frames Maintenance

- Note 8. Practical Limitations of Data Collection Efforts

- Note 9. 1994 Changes in the Petroleum Supply Monthly

\section{Note 1. Petroleum Supply Reporting System}

The Petroleum Supply Reporting System (PSRS) represents a family of data collection survey forms, data processing systems, and publication systems that have been consolidated to achieve comparability and consistency throughout. The survey forms that comprise the PSRS are:

\begin{tabular}{|c|c|}
\hline $\begin{array}{l}\text { Form } \\
\text { Number }\end{array}$ & Name \\
\hline EIA-800 & "Weekly Refinery Report" \\
\hline EIA-801 & "Weekly Bulk Terminal Report" \\
\hline EIA-802 & "Weekly Product Pipeline Report" \\
\hline EIA-803 & "Weekly Crude Oil Stocks Report" \\
\hline EIA-804 & "Weekly Imports Report" \\
\hline EIA-807 & "Propane Telephone Survey" \\
\hline EIA-810 & "Monthly Refinery Report" \\
\hline EIA-811 & "Monthly Bulk Terminal Report" \\
\hline EIA-812 & "Monthly Product Pipeline Report" \\
\hline EIA-813 & "Monthly Crude Oil Report" \\
\hline EIA-814 & "Monthly Imports Report" \\
\hline EIA-816 & "Monthly Natural Gas Liquids Report" \\
\hline EIA-817 & $\begin{array}{l}\text { "Monthly Tanker and Barge Movement } \\
\text { Report" }\end{array}$ \\
\hline EIA-819M & "Monthly Oxygenate Telephone Report" \\
\hline EIA-819A & "Annual Oxygenate Capacity Report" \\
\hline EIA-820 & "Annual Refinery Report" \\
\hline
\end{tabular}

Forms EIA-800 through 804 comprise the Weekly Petroleum Supply Reporting System (WPSRS). A sample of all petroleum companies report weekly data to the Energy Information Administration (EIA) on crude oil and petroleum product stocks, refinery inputs and production, and crude oil and petroleum product imports. The sample of companies that report weekly is selected from the universe of companies that report on the comparable monthly surveys. Data collected from the WPSRS are used to develop estimates of the most current monthly quantities in the Summary Statistics section of the Petroleum Supply Monthly (PSM) and which appear in the Weekly Petroleum Status Report (WPSR).

The Form EIA-807, "Propane Telephone Survey" is used to collect data on production, stocks, and imports of propane. These data are used to monitor the supply of propane and to report to the Congress and others on supplies when requested. Data are collected from a sample of respondents reporting on the Monthly Petroleum Supply Reporting System (MPSRS) surveys. Data are collected on a weekly basis during the heating season (October through March) and published in the Winter Fuels Report. During the non-heating season (April through September) data are collected on end-of-month stocks only. These data are published in the WPSR.

Forms EIA-810 through 814,816 , and 817 comprise the MPSRS. These surveys are used to collect detailed refinery/blender and natural gas plant operations data; refinery/blender, bulk terminal, natural gas plant, and pipeline stocks data; crude oil and petroleum product imports data; and data on movements of petroleum products and crude oil between Petroleum Administration for Defense (PAD) Districts. A description of the MPSRS forms follows in Explanatory Note 2.

Data from these surveys are published in preliminary form in the PSM. They are published in final form in the Petroleum Supply Annual (PSA), Volumes 1 and 2.

Summary information on the revision error between preliminary and final data is published once a year in the PSM feature article entitled, "Timeliness and Accuracy of Petroleum Supply Data." The last article was published in the August 1993 issue and evaluated the accuracy of the data for 1992 compared with previous years.

The Form EIA-819M, "Monthly Oxygenate Telephone Report," is used to collect preliminary data on production, imports, and stocks of oxygenates by PAD District. These 
data are used to monitor the supply of oxygenates. Data are collected from a sample of respondents reporting on the MPSRS surveys and from the universe of oxygenate producers. Data are published in Appendix D of this publication and in the WPSR.

The Form EIA-819A, "Annual Oxygenate Capacity Report," is used to collect data on current and projected production capacity of oxygenates and annual production and end-of-year inventories of fuel ethanol. The results of this survey are published in the Oxygenate Capacity section of the PSA, Volume 1.

The Form EIA-820, "Annual Refinery Report," is used to collect data on refinery fuel use and consumption of steam and electricity, refinery receipts of crude oil by method of transportation, operable capacity for atmospheric crude oil distillation units and downstream units, as well as production capacity and storage capacity for petroleum products. This survey is the primary source of data in the Refinery Capacity section of the PSA Volume 1.

\section{Note 2. Monthly Petroleum Supply Reporting System}

The Monthly Petroleum Supply Reporting System (MPSRS) was implemented in January 1983 as the result of an extensive effort by the Energy Information Administration (EIA) to integrate the collection and processing of petroleum supply data that had been collected on other survey forms for many years. The collection of monthly petroleum supply statistics began as early as 1918 when the U.S. Bureau of Mines began collecting data on refinery operations, crude oil stocks and movements. The collection systems were further expanded in 1925 to include natural gas plant liquids production and storage, imports of crude oil and petroleum products and storage and movement of petroleum products in 1959, and tanker and barge movements of crude oil and petroleum products in 1964. Since their inception, each survey has undergone numerous changes, but the MPSRS was the first effort to make them all consistent and comparable. The forms that comprise the MPSRS are:

\begin{tabular}{|ll|}
\hline Form & \\
Number & Name \\
EIA-810 & "Monthly Refinery Report" \\
EIA-811 & "Monthly Bulk Terminal Report" \\
EIA-812 & "Monthly Product Pipeline Report" \\
EIA-813 & "Monthly Crude Oil Report" \\
EIA-814 & "Monthly Imports Report" \\
EIA-816 & "Monthly Natural Gas Liquids Report" \\
EIA-817 & "Monthly Tanker and Barge Movement \\
EIA-819M & "Meport" \\
\hline
\end{tabular}

\section{Respondent Frame}

Form EIA-810, "Monthly Refinery Report" - Operators of all operating and idle petroleum refineries and blending plants located in the 50 States, the District of Columbia, Puerto Rico, the Virgin Islands, Guam and other U.S. possessions. Approximately 240 respondents report on the Form EIA-810.

Form EIA-811, "Monthly Bulk Terminal Report" - Every bulk terminal operating company located in the 50 States, the District of Columbia, Puerto Rico, the Virgin Islands, and other U.S. possessions. A bulk terminal is primarily used for storage and/or marketing of petroleum products and has a total bulk storage capacity of 50,000 barrels or more, and/or receives petroleum products by tanker, barge, or pipeline. Bulk terminal facilities associated with a product pipeline are included. In addition, the Form EIA-811 must be completed by merchant oxygenate plants that produce oxygenates. Approximately 330 respondents report on the Form EIA-811.

Form EIA-812, "Monthly Product Pipeline Report" - All product pipeline companies that carry petroleum products (including interstate, intrastate, and intracompany pipelines) in the 50 States and the District of Columbia. Approximately 80 respondents report on the Form EIA812.

Form EIA-813, "Monthly Crude Oil Report" - All companies which carry or store 1,000 barrels or more of crucie oil. Included in this survey are gathering and trunk pipeline companies (including interstate, intrastate, and intracompany pipelines), crude oil producers, terminal operators, storers of crude oil (except refineries), and companies transporting Alaskan crude oil by water in the 50 States and the District of Columbia. Approximately 160 respondents report on the Form EIA-813.

Form EIA-814, "Monthly Imports Report" - All companies, including subsidiary or affiliated companies, that import crude oil or petroleum products (1) into the 50 States and the District of Columbia, (2) into Puerto Rico, the Virgin Islands and other U.S. possessions (Guam, Midway Islands, Wake Island, American Samoa, and Northern Mariana Islands), and (3) from Puerto Rico, the Virgin Islands and other U.S. possessions into the 50 States and the District of Columbia. Imports into Foreign Trade Zones located in the 50 States and the District of Columbia are considered imports into the 50 States and the District of Columbia and must be reported. A report is required only if there has been an import during the month unless the importer has been selected as part of a sample to report every month regardless of activity. Approximately 220 respondents report on the Form EIA-814.

Form EIA-816, "Monthly Natural Gas Liquids Report" Operators of all facilities that extract liquid hydrocarbons from a natural gas stream (natural gas processing plant) and/or separate a liquid hydrocarbon stream into its com- 
ponent products (fractionator). Approximately 720 respondents report on the Form EIA-816.

Form EIA-817, "Monthly Tanker and Barge Movement Report" - All companies that have custody of crude oil or petroleum products transported by tanker or barge between Petroleum Administration for Defense (PAD) Districts or between the Panama Canal and the United States. For purposes of this report, custody is defined as physical possession of crude oil or petroleum products on a company-owned tanker or barge. Also, companies which lease vessels or contract for the movement of crude oil or petroleum products on a tanker or barge between PAD Districts or between the Panama Canal and the United States are considered to have custody. Approximately 40 respondents report on the Form EIA-817.

Form EIA-819M, "Monthly Oxygenate Telephone Report" - The sample of companies that report on the EIA-819M are selected from the universe of companies that report on the MPSRS surveys and from the universe of oxygenate producers. The universe consists of (1) operators of facilities that produce (manufacture or distill) oxygenates (including MTBE plants, petrochemical plants, and refineries that produce oxygenates as part of their operations); (2) operators of petroleum refineries; (3) operators of bulk terminals, bulk stations, blending plants, and other nonrefinery facilities that store and/or blend oxygenates; and (4) importers of oxygenates (importer of record) located in or importing oxygenates into the 50 States and the District of Columbia. Approximately 100 respondents report on the Form EIA-819M.

\section{Sampling}

The sampling procedure used for the survey Form EIA$819 \mathrm{M}$ is the cut-off method and is performed using software developed by EIA's Office of Statistical Standards. In the cut-off method, companies are ranked from largest to smallest on the basis of quantities reported (oxygenate production, oxygenate stocks, and oxygenate imports) during 1992. Companies are chosen for the sample beginning with the largest and adding companies until the total sample covers approximately 90 percent of the total for each oxygenate item and supply type by geographic region (PAD Districts I through V) for which data may be published.

\section{Description of Survey Forms}

The Form EIA-810, "Monthly Refinery Report," is used to collect data on refinery input and capacity, sulfur content and API gravity of crude oil, and data on supply (beginning stocks, receipts, and production) and disposition (inputs, shipments, fuel use and losses, and ending stocks) of crude oil and refined products.

The Form EIA-811, "Monthly Bulk Terminal Report," is used to collect data on end-of-month stock levels of finished petroleum products by State in the custody of the bulk terminal company or merchant oxygenate plant regardless of ownership. Leased tankage at other facilities is excluded. All domestic and foreign stocks held at bulk terminals and in-transit thereto, except those in-transit by pipeline are included. Petroleum products in-transit by pipeline are reported by pipeline operators on Form EIA812, "Monthly Product Pipeline Report."

The Form EIA-812, "Monthly Product Pipeline Report," is used to collect data on end-of-month stock levels and movements of petroleum products transported by pipeline. Intermediate movements for pipeline systems operating in more than two PAD Districts are included.

The Form EIA-813, "Monthly Crude Oil Report," is used to collect data on end-of-month stocks of crude oil held at pipeline and tank farms (associated with the pipelines) and terminals operated by the reporting company. Also, crude oil consumed by pipelines and on leases as pump fuel, boiler fuel, etc., is reported. Data are reported on a PAD District basis.

Total Alaskan crude oil stocks in-transit by water (including stocks held at transshipment terminals between Alaska and the continental United States) to the 50 States, the District of Columbia, Puerto Rico, and the Virgin Islands are also reported by the transporting company having custody of the stocks.

Inter-PAD District movements of crude oil by pipeline are collected by the shipping and receiving PAD District. Intermediate movements for pipeline systems operating in more than two PAD Districts are not included.

The Form EIA-814, "Monthly Imports Report," is used to collect data on imports of crude oil and petroleum products (1) into the 50 States and the District of Columbia, (2) into Puerto Rico, the Virgin Islands, and other U.S. possessions (Guam, Midway Islands, Wake Island, American Samoa, and Northern Mariana Islands), and (3) from Puerto Rico, the Virgin Islands, and other U.S. possessions into the 50 States and the District of Columbia. Imports into Foreign Trade Zones located in the 50 States and the District of Columbia are considered imports into the 50 States and the District of Columbia.

The type of commodity, port of entry, country of origin, quantity (thousand barrels), sulfur percent by weight, API gravity, and name and location of the processing or storage facility are reported. Sulfur percent by weight is requested for crude oil, crude oil burned as fuel, and residual fuel oil only. API gravity is requested for crude oil only. The name and location of the processing or storage facility is requested for crude oil, unfinished oils, other hydrocarbons/hydrogen/oxygenates and blending components only.

The Form EIA-816, "Monthly Natural Gas Liquids Report," is used to collect data on the operations of natural gas processing plants and fractionators. Beginning and end-of-month stocks, receipts, inputs, production, ship- 
ments, and plant fuel use and losses during the month are collected from operators of natural gas processing plants. End-of-month stocks are collected from fractionators.

The Form EIA-817, "Monthly Tanker and Barge Movement Report," is used to collect data on the movements of crude oil and petroleum products between PAD Districts. Data are reported by shipping and receiving PAD District and sub-PAD District. Shipments to and from the Panama Canal are also included if the shipment was delivered to the Canal.

The Form EIA-819M, "Monthly Oxygenate Telephone Report," is used to collect data on production, stocks, and imports of oxygenates. Data on end-of-month stocks are reported on a custody basis regardless of ownership. Data are reported on a PAD District basis.

\section{Collection Nothods}

Except for the EIA-819M, survey forms for the MPSRS can be submitted by mail, facsimile, or electronic transmission. Completed forms are required to be postmarked by the 20th calendar day following the end of the report month. Data collection for the $819 \mathrm{M}$ begins on the seventh working day of each month. Data are solicited by telephone or transmitted to the EIA by facsimile. Receipt of the reports are monitored using an automated respondent mailing list. Telephone follow-up calls are made to nonrespondents prior to the publication deadline.

\section{Response Rate}

The response rate is generally 98 to 100 percent. Chronic nonrespondents and late filing respondents are contacted in writing and reminded of their requirement to report. Companies that file late or fail to file are subject to criminal fines, civil penalties, and other sanctions as provided by Section 13(i) of the Federal Energy Administration (FEA) Act.

\section{Data Imputation}

Imputation is performed for companies that fail to file Forms EIA-810 through 813,816 , and $819 \mathrm{M}$. For such companies, previous monthly values are used for current values.

On the EIA-819M, data are aggregated for each geographic region. Estimation factors, which are derived from 1993 reported data, are then applied to each cell to generate published estimates.

Data for nonrespondents on the Forms EIA-814 and 817 are not imputed because these data series, by respondent, are highly variable.

\section{Confidentiality}

The Office of Legal Counsel of the Department of Justice concluded on March 20, 1991, that the Federal Energy Administration Act requires the EIA to provide companyspecific data to the Department of Justice, or to any Federal agency when requested for official use, which may include enforcement of Federal law. The information contained on this form may also be made available, upon request, to another component of the Department of Energy (DOE), to any Committee of Congress, the General Accounting Office, or other Congressional agencies authorized by law to receive such information. A court of competent jurisdiction may obtain this information in response to an order.

The information contained on Forms EIA-810 through $813,816,817$, and $819 \mathrm{M}$ are kept confidential and not disclosed to the public to the extent that they satisfy the criteria for exemption under the Freedom of Information Act (FOIA), 5 U.S.C. 552, the Department of Energy (DOE) regulations, 10 C.F.R. 1004.11, implementing the FOIA, and the Trade Secrets Act, 18 U.S.C. 1905. The information contained on Form ElA-814 are not considered confidential and historically has not been treated as such.

Upon receipt of a request for this information under the FOIA, the DOE shall make a final determination whether the information is exempt from disclosure in accordance with the procedures and criteria provided in the regulations. To assist us in this determination, respondents should demonstrate to the DOE that, for example, their information contains trade secrets or commercial or financial information whose release would be likely to cause substantial harm to their company's competitive position. A letter accompanying the submission that explains (on an element-by-element basis) the reasons why the information would be likely to cause the respondent substantial competitive harm if released to the public would aid in this determination. A new justification does not need to be provided each time information is submitted on the form, if the company has previously submitted a justification for that information and the justification has not changed. Company specific data are also provided to other DOE offices for the purpose of examining operations in the context of emergency response planning and actual emergencies.

The data collected on Forms EIA-810 through 814, 816, and 817 appear in EIA publications such as Petroleum Supply Monthly (PSM), Monthly Energy Review, Petroleum Supply Annual (PSA), and the Annual Energy Review.

Data on the breakdown between liquefied refinery gases and olefins, and lubricants is suppressed on PSM Table 29, "Refinery Net Production of Finished Petroleum Products by PAD and Refining Districts" and the corresponding 
PSA table to avoid disclosure of company identifiable data.

Statistics representing data aggregated from less than three companies or aggregated data representing 60 percent or more of a single company's data are suppressed on the PSM and corresponding PSA tables listed below. In addition, complementary suppression is performed to avoid any residual disclosure.

- Table 28, "Refinery Input of Crude Oil and Petroleum Products by PAD and Refining Districts," (inputs of oxygenates)

- Table 30, "Refinery Stocks of Crude Oil and Petroleum Products by PAD and Refining Districts," (stocks of oxygenates)

- Table 51, "Stocks of Crude Oil and Petroleum Products by PAD District," (stocks of oxygenates)

- Table 52, "Refinery, Bulk Terminal, and Natural Gas Plant Stocks of Selected Petroleum Products," (all products)

- Table D2, "Monthly Fuel Ethanol Production and Stocks by PAD Districts," and

- Table D3, "Monthly MTBE Production and Stocks by PAD Districts."

With the exception of the tables listed above, the tables in the PSM (and corresponding PSA tables) are not subject to statistical nondisclosure procedures. Thus, there may be some table cells which are based on data from only one or two respondents, or which are dominated by data from one or two large respondents. In these cases, it may be possible for a knowledgeable user of the data to make inferences about the data reported by a specific respondent.

\section{Note 3. Technical Notes for Detailed Statistics Tables}

The detailed statistics tables in the Petroleum Supply Monthly (PSM) provide complete supply and demand information for the current year. The tables are organized to locate National and Petroleum Administration for Defense (PAD) District summary data at the front followed by tables on crude oil and petroleum product production, import/export data, stocks information, and lastly, data on crude oil and petroleum product movements. To assist in the interpretation of these tables, the following technical notes are provided. Column and row headings are defined in the Glossary.

\section{Supply}

Field Production - Field production is the sum of crude oil production, natural gas plant liquids production, other liquids production, and finished petroleum products production.
Crude oil production is an estimate based on data received from State conservation agencies and the Mineral Management Service of the U.S. Department of the Interior. Refer to Explanatory Note 4 for further details.

Field production of natural gas plant liquids is reported on Form EIA-816 and published on a net basis (i.e., production minus inputs) in this column.

Other liquids field production is calculated by forcing the product supplied to be zero; thereby backing into field production.

Field production of finished petroleum products is calculated by (1) adding the amount of fuel ethanol that has been blended into finished motor gasoline, and (2) plus $(+)$ or minus $(-)$ the field production of motor gasoline blending components. Refer to Explanatory Note 8 for a further discussion of this calculation.

Negative field production of motor gasoline blending components represents an understatement for finished motor gasoline.

Negative field production of other finished motor gasoline represents an overstatement of other finished motor gasoline and an understatement of oxygenated motor gasoline.

Refinery Production - Published production of these products equal refinery production minus refinery input. Refinery production of other hydrocarbons, hydrogen and oxygenates, unfinished oils, and motor and aviation gasoline blending components appear on a net basis under refinery input. Negative refinery production will occur when the amount of a product produced during the month is less than the amount of that same product that is reprocessed (input) or reclassified to become another product during the same month.

Unaccounted for Crude Oil - This column is a balancing item for crude oil. This data element represents the difference between crude oil supply and disposition. Crude oil supply is the sum of field production and imports. Crude oil disposition is the sum of stock change, losses, refinery inputs, exports, and products supplied. A positive result indicates that refiners and exporters reported use of more crude oil than was reported to have been available to them. (This occurs, for example, when imports are undercounted due to late reporting or other problems). A negative result indicates that more crude oil was reported to have been supplied to refiners and exporters than they reported to have used.

\section{Disposition}

Stock Change - This column is calculated as the difference between the Ending Stocks column of this table and the Ending Stocks column of this table in the prior month's publication. A negative number indicates a 
decrease in stocks and a positive number indicates an increase in stocks.

Crude Losses - The volume of crude oil reported by petroleum refineries as being lost in their operations. These losses are due to spills, contamination, fires, etc., as opposed to refining processing losses or gains.

Refinery Inputs - Refinery inputs of crude oil and intermediate materials (unfinished oils, gasoline blending components, other hydrocarbons and oxygenates, liquefied petroleum gases, and pentanes plus) that are processed at refineries to produce finished petroleum products.

Crude oil inputs represents total crude oil (domestic and foreign) input to atmospheric crude oil distillation units and other refinery processing units (i.e., catalytic cracking units, cokers).

Inputs of natural gas liquids are natural gas liquids received from natural gas plants for blending and processing. Published inputs of natural gas liquids are reported on a gross basis.

Inputs of unfinished oils, motor and aviation gasoline blending components, and other hydrocarbons and oxygenates are published on a net basis (i.e., refinery input minus refinery production).

Inputs of finished petroleum products are published on a net basis (i.e., refinery production minus refinery inputs) and displayed under the refinery production column.

Exports - Exports include crude oil shipments from the 50 States to Puerto Rico, and the Virgin Islands.

Products Supplied - Products supplied is equal to field production, plus refinery production, plus imports, plus unaccounted for crude oil, (plus net receipts on a PAD District basis), minus stock change, minus crude losses, minus refinery inputs, minus exports.

Products supplied indicates those quantities of petroleum products supplied for domestic consumption. Occasionally, the result for a product is negative because total disposition of the product exceeds total supply. Negative product supplied may occur for a number of reasons: (1) product reclassification has not been reported; (2) data were misreported or reported late; (3) in the case of calculations on a PAD District basis, the figure for net receipts was inaccurate because the coverage of interdistrict movements was incomplete; and (4) products such as gasoline blending components and unfinished oils have entered the primary supply channels with their production not having been reported, e.g., streams returned to refineries from petrochemical plants.

Product supplied for crude oil is the sum of crude oil burned on leases and by pipelines as fuel. Prior to January 1983, crude oil burned on leases and by pipelines as fuel were reported as either distillate or residual fuel oil and were included in product supplied for these products.

Yields

The refinery yield of finished motor gasoline is calculated by subtracting the inputs of pentanes plus, liquefied petroleum gases, other hydrocarbons/oxygenates and motor gasoline blending components from the production of finished motor gasoline before dividing by the sum of crude oil input and unfinished oils input (net).

The refinery yield of finished aviation gasoline is calculated by subtracting the inputs of aviation gasoline blending components from the production of finished aviation gasoline before dividing by the sum of crude oil input and unfinished oils input (net).

Refinery yields for all products (except finished motor gasoline and finished aviation gasoline) are calculated by dividing the production for each product by the sum of crude oil input and unfinished oils input (net) reported in the U.S. total.

\section{Stocks}

Primary stocks of petroleum products do not include either secondary stocks held by dealers and jobbers or tertiary stocks held by consumers.

\section{Movements}

Movements of crude oil by pipeline between PAD Districts include trunk pipeline companies (interstate, intrastate, and intracompany pipelines). Intermediate movements for crude oil pipeline systems operating in more than two PAD Districts are not included.

Movements of petroleum products by pipeline between PAD Districts include trunk pipeline companies (interstate, intrastate and intracompany pipelines). Intermediate movements for product pipeline systems operating in more than two PAD Districts are included. For example, a shipment originating in PAD District 3, passing through PAD District 2 to PAD District 1 , is reported as a movement from PAD District 3 to PAD District 2 and also from PAD District 2 to PAD District 1.

Waterborne movements of crude oil and petroleum products between PAD Districts include all shipments of crude oil or petroleum products for which the transporter has custody at the time of shipment. Custody is defined as physical possession of crude oil or petroleum products on a company-owned tanker and barge.

\section{Note 4. Domestic Crude Oil Production}

The Energy Information Administration (EIA) collects monthly crude oil production data on an ongoing basis. Data on crude oil production for States are reported to the 
ElA by State government agencies. Data on crude oil production for Federal offshore areas are reported to the EIA by the Minerals Management Service of the U.S. Department of the Interior and the Conservation Committee of California Oil Producers.

Currently, all except four crude oil producing States (Michigan, New York, Ohio, and Pennsylvania) report production on a monthly basis. These four States report crude oil production on an annual basis. Estimates of monthly crude oil production for these four States are made by the EIA using data reported on Form EIA-182, "Domestic Crude Oil First Purchase Report." After the end of each calendar year, the monthly crude oil production estimates are updated using annual reports from various State agencies, the Minerals Management Service, and the Conservation Committee of California Oil Producers. The final estimate is published in the Petroleum Supply Annual (PSA).

Table 26 of this publication provides estimates of crude oil production in the latest month for which most State production data are available. There is a time lag of approximately 4 months between the end of the production month and the time when most monthly State crude oil production data become available.

In order to present more timely crude oil production estimates, the EIA prepares a weekly crude oil production estimate, which is used in the Weekly Petroleum Status Report. At the end of the production month, these weekly estimates are aggregated into an original estimate of monthly crude oil production. Approximately 45 days later, this original estimate is replaced by State-level interim estimates. The State-level interim estimates are based on: (a) data reported by the States (e.g., production data for Alaska are typically reported to the EIA before the interim estimate is made); (b) first purchase data reported on Form EIA-182, "Domestic Crude Oil First Purchase Report;" (c) exponential or hyperbolic curve fitted projections based on recent State data; or (d) constant level projections based on the average production rate during a recent time period.

Table $B 1$ is intended to provide further insight into the EIA's estimates of monthly U.S. crude oil production. It shows: (a) how the aggregate of reported State data evolves over a period of 18 months; (b) the number of producing States that have not leported production for a given month within that period; and (c) various EIA estimates of monthly crude oil production within that period:

- The original estimate is a monthly aggregate of the weekly crude oil production estimates published in the Weekly Petroleum Status Report. This original monthly estimate is used in the Petroleum Supply Monthly (PSM) Tables $\mathrm{S} 1$ and $\mathrm{S} 2$ until replaced by the interim estimate.
- The interim estimate is used in the PSM Tables 1 through 25 , and in Tables $S 1$ and $S 2$ until replaced by the final estimate.

- The initial estimate based upon first purchase data collected on the Form EIA-182 is used as an estimation tool in generating the interim estimate. The initial volume represents the best estimate available 40 days after the end of the production month and includes imputation for nonresponse and possible reporting errors. The revised volume is the best estimate available about 70 days after the production month and includes imputation as needed. A final revision is published concurrent with publication of Form EIA-182 price data in the Petroleum Marketing Annual.

- The final estimate is published in the PSA.

\section{Note 5. Export Data}

Each month the Energy Information Administration (EIA) receives magnetic tapes of aggregated export statistics from the U.S. Bureau of the Census (EM-522 and EM594).

Census export statistics used in the Petroleum Supply Monthly reflect both govemment and nongovernment exports of domestic and foreign merchandise from the United States (the 50 States and the District of Columbir) to foreign countries and U.S. possessions, without regard to whether or not the exportation involves a commercial transaction. The following types of transactions are excluded from the statistics:

(1) Merchandise shipped in transit through the United States from one foreign country to another, when documented as such with U.S. Customs.

(2) Bunker fuels and other supplies and equipment for use on departing vessels, planes, or other carriers engaged in foreign trade.

\section{Source of Export Information}

The official U.S. export statistics are compiled by the U.S. Bureau of the Census. Exporters are required to file export documents with U.S. Customs officials (Customs Form 7525).

\section{Country and Area of Destination}

The country of destination is defined as the country of ultimate destination or the country where the goods are to be consumed, further processed, or manufactured, as known to the shipper at the time of exportation. If the shipper does not know the country of ultimate destination, the shipment is credited to the last country to which the 
Table B1. U.S. Crude OilP Production Estimates and Reported States' Data by Month (Thousand Barrels per Day)

\begin{tabular}{|c|c|c|c|c|c|c|c|c|c|c|c|c|c|c|c|c|}
\hline \multirow{2}{*}{$\begin{array}{l}\text { Date of Data } \\
\text { Avallabllity }\end{array}$} & \multicolumn{16}{|c|}{ Month of Production } \\
\hline & $10-92$ & 11.92 & 12.92 & 1.93 & $2 \cdot 93$ & $3-83$ & $4 \cdot 93$ & 5.93 & $6-93$ & 7.93 & 8.93 & $9.93 \quad 10-93 \quad 11.93$ & 12.93 & 1.94 & 2.94 & 3.94 \\
\hline & \multicolumn{16}{|c|}{ Foported state Data" } \\
\hline
\end{tabular}

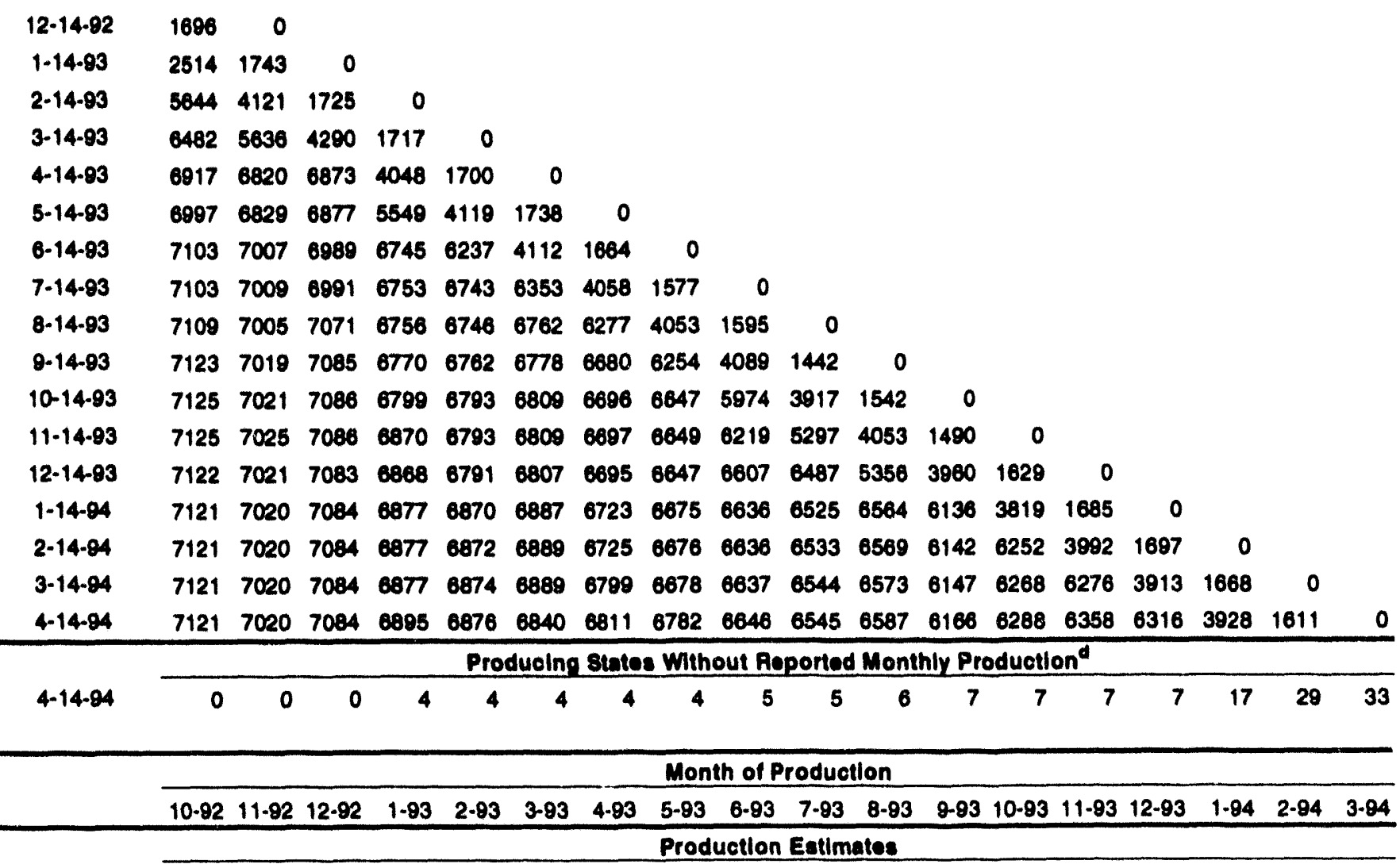

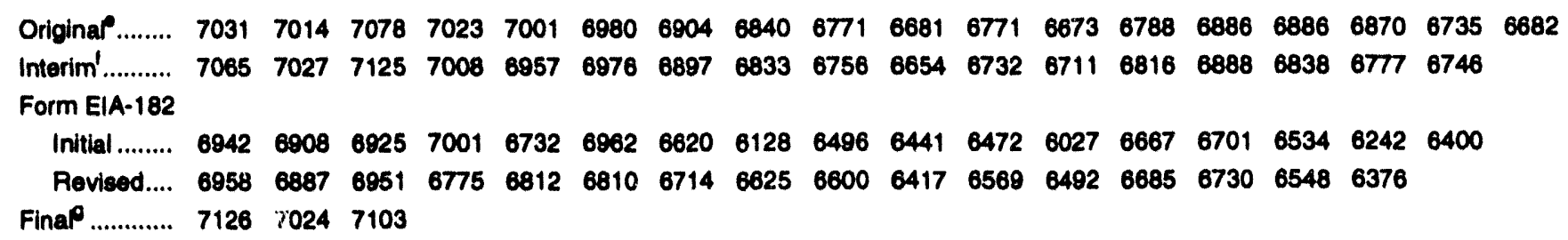

\footnotetext{
- Includes lease condensate.

- Includes Federal offshore areas, Gulf of Mexico (PADD III) and Pacific (PADD V), as two separate reporting entities.

c Includes ElA prorated monthly production in 1992 (annual average of 75 thousand barrels per day) for four States (Michigan, New York, Ohio, and Pennsytvania) for which only annual State data are available.

Michigan, New York. Ohio, and Pennsytvania are counted as having monthly reported data in 1992 after their annual reports were received. These data are first reported as of 6-14-93.

- Original estimates are weighted averages based on the weekly estimates published in the Weekly Petroleum Status Report.

1 Interim estimates were made 44 days after the end of the production month.

- Published in the Petroleum Supply Annual 1992, DOE/EIA 0340(92)/2.
} 
shipper knows that the merchandise will be shipped in the same form as it was when exported.

\section{Note 6. Quality Control and Data Revision}

\section{Quality Control}

The Energy Information Administration (EIA) monitors the supply and disposition of crude oil, petroleum products, and natural gas liquids in the United States. Through a tracking system, the EIA provides insight into the activities of primary operators and distributors in the petroleum industry. The tracking system, known as the Petroleum Supply Reporting System (PSRS), consists of production, inputs, imports, inventories, movements, and other petroleum-related data collected on weekly, monthly, and annual surveys.

Survey forms are periodically reviewed for completeness, meaningfulness, and clarity. Modifications are made, when needed, to maintain efficient measure of the intended data items and to track product movement accurately throughout the industry. Through this process, the EIA can maintain consistency among forms, minimize respondent burden, and eliminate ambiguity.

\section{Sampling and Nonsampling Errors}

There are two types of errors usually associated with data produced from a survey -- nonsampling errors and sampling errors. Because the estimates for the monthly surveys 810 through 813,816 , and 817 are based on a complete census of the frame, there is no sampling error in the data presented. The data, however, are subject to nonsampling errors. Nonsampling errors, sometimes referred to as biases, are those which can arise from a number of sources: (1) the inability to obtain data from all companies in the frame or sample (nonresponse and the method used to account for nonresponses, (2) definitional difficulties and/or improperly worded questions which lead to different interpretations. (3) mistakes in recording or coding the data obtained from respondents, and (4) other errors of collection, response, coverage, and estimation.

Response rates on the monthly surveys are very high. In general, response rates average above 95 percent for the weekly survey and above 98 percent for monthly surveys. Whenever survey responses are not received in time to be included in published statistics, the data are imputed. Although imputing for missing data may not eliminate the total error associated with nonresponse, it can serve to reduce the error. The data reported in the previous month are used as imputed values for missing data for all surveys except the Forms EIA-814, "Monthly Imports Report," and EIA-817, "Monthly Tanker and Barge Movement Report." There is no imputation procedure for these sur- veys because these data series, by respondent, are highly variable.

Response error is the major factor affecting the accuracy of PSRS data. Response, or reporting error, is the difference between the true value and the value reported on a survey form. Response error can occur for any number of reasons. For example, figures may be entered incorrectly when written on forms by the respondent, or errors may result from the misunderstanding of survey form instructions or definitions. Response error can also occur from the use of preliminary data when final data are not available. This can result in differences between published preliminary and final data. To help detect and minimize probable reporting errors, automated editing procedures are used to check current data for consistency with past data, as well as for internal consistency (e.g., totals equal to the sums of the parts), and to flag those data elements that fail edit criteria.

Errors can also be introduced during data processing. For example, while creating computer data files, key errors can occur in transcribing or coding the data; or information can be entered into the wrong cell. Using well designed edit criteria which examine orders of magnitude, cell position, and historical reporting patterns, many of these errors can be identified and corrected.

Monthly data are compared to weekly data on a regular basis. Discrepancies betweenly weekly and monthly data are documented and respondents are called when dis. crepancies are either large (usually over 300 thousand barrels) or consistent (e.g., weekly data are always lower than monthly data). In addition, a comparison of the data collected on the PSRS with other similar data series from sources outside of the Petroleum Supply Division is performed each year. The results of this data comparison are published once a year in the Petroleum Supply Monthly (PSM) feature article, "Comparison of Independent Statistics on Petroleum Supply."

Sampling errors are those errors that occur when survey estimates are based on a sample rather than being derived from a complete census of the frame. The $819 \mathrm{M}$ data, which are based on sample estimates, serve as leading indicators of the PSRS monthly data for oxygenates. To assess the accuracy of the $819 \mathrm{M}$ statistics, data are compared with the monthly aggregate data for the EIA-810, 811 , and 812 surveys. Although monthly data are still subject to error, they have been thoroughly reviewed and edited, and are considered to be the most accurate data available.

\section{Data Revision}

Resubmissions are any changes to the originally submitted data that were either requested by the EIA or initiated by the respondent. Resubmissions are compared with the original submission and processed at the time of receipt. For Forms EIA-810 through 813, 816, and 817 the 
Resubmission Tracking System (RTS) is run after resubmissions have been processed for the month. The RTS enables the user to study major products and data series to see how company resubmissions impact published data on a month by month basis. During the processing year, a summary of the effect of these resubmissions to major series is provided in Appendix C.

For the EIA-819M data, a determination is made on whether to process the resubmissions based on the mag. nitude of the revision. Cell entries on publication tables are marked with an "R" for revised.

\section{Late Response}

Respondents who fail to respond within the prescribed time limit (25th day following the end of the report month) become nonrespondents for that particular report period and are contacted by phone to obtain the current month's data. Respondents who are chronically late (i.e.. 3 consecutive months) are notified by EIA either by letter or telephone.

\section{Nonresponse}

Follow-up action is taken when a company fails to respond adequately to data requests from the EIA. Preliminary attempts to gather delinquent reports are made by phone. Noncompliance form letters are sent to those companies that have not submitted reports and have not responded to data requests by phone.

\section{Note 7. Frames Maintenance}

The Petroleum Supply Division (PSD) maintains complete lists of respondents to its monthly surveys. Each survey has a list of companies and facilities required to submit petroleum activity data. This list is known as the survey frame. Frame maintenance procedures are used to monitor the status of petroleum companies and facilities currently contained in each survey frame as well as to identify new members to be added to the frame. As a result, all known petroleum supply organizations falling within the definition of "Who Must Submit" participate in the survey.

The activities for frames maintenance are conducted on a monthly and annual basis. Monthly frames maintenance procedures focus on examining several frequently published industry periodicals that report changes in status (births, deaths, sales, and acquisitions) of petroleum facilities producing, transporting, importing, and/or storing crude oil and petroleum products. These sources are augmented by articles in newspapers, letters from respondents indicating changes in status, and information received from survey systems operated by other offices. Survey managers review these sources regularly to monitor changes in company operations and to develop lists of potential respondents. These activities assure coverage of the reporting universe and maintain accurate facility informution on addresses and ownership.

Annual frames maintenance focuses on re-evaluating the "must submit" companies filing the Form EIA-814 and reviewing the sample frame for the Form EIA-819M, "Monthly Oxygenate Telephone Report."

To supplement monthly and annual frames maintenance activities and to provide more thorough coverage, the PSD periodically conducts a comprehensive frames investigation. These investigations result in the reassessment and recompilation of the complete frame for each survey. The effort also includes the evaluation of the impact of potential frame changes on the historical time series data published from these respondents. The results of this frame study are usually implemented in January to provide a full year under the same frame.

\section{Note 8. Practical Limitations of Data Collection Efforts}

\section{Cruds OII Lease Stock Adjustment}

End-of-month crude oil stocks held on leases are reported on the EIA-813, "Monthly Crude Oil Report." However, only those companies that store 1,000 barrels or more of crude oil are required to submit a report. Previous frames analysis has shown that crude oil stocks held on leases reported to the EIA are consistently lower than the lease stocks reported to individual states.

Up until 1983, monthly state government data on lease stocks were substituted for ElA data wherever possible in order to rectify the understatement of lease crude oil stocks. State data were available from three states -. Texas, New Mexico, and Montana. To calculate the "lease adjustment," a comparison between EIA reported data and the state government data was made and the difference added to the EIA data for the respective states.

In 1983, the EIA modified the Form EIA-813 to eliminate state data on crude oil stocks and began collecting crude oil stock data by Petroleum Administration for Defense (PAD) District. With this change, the "lease adjustment" could no longer be calculated on a state basis and was changed to a PAD District level.

\section{Trans Alaskan Pipeline System Adjustment}

Beginning with the January 1989 data, adjustments are made to refinery inputs and product supplied of natural gas liquids (NGLs) and refinery inputs of crude oil to account for refiner misreporting. Substantial volumes of NGLs are produced at natural gas processing plants in Alaska and injected into the crude oil moving in the Trans Alaska Pipeline System (TAPS). Refiners receiving any crude oil commingled with NGLs are instructed to report the NGL portion of that stream separately from the crude oil portion. This has not been done for Alaskan crude oil 
because refiners are unable to identify these volumes for accounting purposes. As a result, the NGL production in Alaska has been credited directly toward product supplied and also toward product supplied from refinery production when the refiner processes the crude oil-NGL mixture. In addition, the reporting of the commingled stream as crude oil by the refiner has overstated crude oil inputs and resulted in an increase in unaccounted for crude oil equal to the volume of NGL in the crude oil.

To offset this reporting error, an adjustment is made to refinery input in all PAD Districts receiving Alaskan crude oil. The adjustment reduces the crude oil inputs and increases the NGL inputs by an equal amount. Each PAD District adjustment is a portion of the known AlaskanNGL production that is proportional to the PAD District's share of Alaskan crude oil received at all refineries in the United States. The greatest impact occurs in PAD District $V$ for butane and pentanes plus.

The reporting problem which began in 1987 grew as injections on NGLs into the TAPS increased. Data for 1988 was revised in the Petroleum Supply Annual to account for the adjustment.

\section{Finished Motor Gasoline Product Supplied Adjuatment}

Beginning with the reporting of January 1993 data, adjustments were made to the product supplied series for finished motor gasoline. It was recognized that motor gasoline statistics published by the EIA through 1992 were underreported because the reporting system was not collecting all fuel ethanol and motor gasoline blending components being blended downstream from the refinery. The EIA was able to quantify these volumes and make corrective adjustments for 1992 in 1993 (refer to Table B2).

\section{Fual Ethanol Adjustment}

Prior to 1993, an estimated 60 to 70 thousand barrels per day of fuel ethanol were added to motor gasoline to produce gasohol but were not included in the EIA finished motor gasoline production data. In 1992, the EIA attempted to collect these data from downstream fuel ethanol motor gasoline blenders but found that this effort was impractical and the results were inaccurate.

Beginning in January 1993, an estimate for the missing fuel ethanol blended into motor gasoline was calculated. This estimate was calculated as production (from the EIA819M, "Monthly Oxygenate Telephone Report"), plus imports (from the EIA-814, "Monthly Imports Report"), minus inputs at refineries (from the EIA-810, "Monthly Refinery Report"), plus or minus stock change (from the ElA-819M survey). This estimate for the amount of fuel ethanol blended into motor gasoline was added to Table 1 for Natural Gas Liquids Field Production (line 14) and in the Field Production column for finished motor gasoline in Tables 2 through 25 published in the PSM.
An estimate for the total amount of gasohol produced with the ethanol is given as 10 times the estimated fuel ethanol blended (this assumes a 10 percent ethanol blend). This amount is added to the column labeled field production of "oxygenated gasoline" and subtracted from the field production of "other" finished gasoline. The PAD District level detail was obtained by allocating the national level estimates according to the percent of gasohol sales from the U.S. Department of Transportation, Federal Highway Administration, Monthly Motor Fuel Reported by States, 1991.

\section{Motor Gasoline Blending Component Adjustment}

Prior to 1993, the EIA published a "product supplied" for motor gasoline blending components. Since these components are to be blended into finished motor gasoline, there is no actual demand for this intermediate product. The ElA corrected this series by including the quantity of "product supplied" for motor gasoline blending components with "other" finished motor gasoline. This change was accomplished in Tables 2 through 25 by adding product supplied for motor gasoline blending components to the column labeled field production of "other" motor gasoline, and subtracting it from the field production column for "motor gasoline blending components."

\section{Fuel Ethanol Stock Adjustment}

Total end-of-month stocks of fuel ethanol are underreported in the PSRS because of the inability to collect data from downstream fuel ethanol motor gasoline blenders. Total stocks of fuel ethanol are assumed to be those reported by ethanol producers on the Form EIA819M, "Monthly Oxygenate Telephone Report." The difference between the stocks reported on the EIA-819M and the stocks reported in the PSRS (from refiners, bulk terminal and pipeline operators) is added to the stocks shown for bulk terminals. If the stocks for the PSRS are higher than those reported on the EIA-819M, no adjustment is made.

\section{Note 9. 1994 Changes in the Petroleum Supply Monthly}

Effective with January 1994 data, several enhancements were made to the tables in the Petroleum Supply Monthly to reflect changes in the petroleum industry and to provide more meaningful petroleum statistics. These changes primarily affect data reported for imports, exports, and product supplied.

- On December 31, 1992, Ecuador withdrew as a member of the Organization of Petroleum Exporting Countries (OPEC). As of January 1994, imports of petroleum from Ecuador now appear under imports from NonOPEC sources. No revision was made to 1993 data. Countries have been realphabetized accordingly. This 
Table B2. Finlshed Motor Gasoline Product Supplied Adjustment, 1992

(Thousand Barrels por Day)

\begin{tabular}{|c|c|c|c|c|c|}
\hline Yoar/Month & $\begin{array}{l}\text { Produot 8upplied } \\
1092 \text { Babls }\end{array}$ & $\begin{array}{l}\text { Fual Ethanol } \\
\text { Adjustment }\end{array}$ & $\begin{array}{l}\text { Motor Gasoline Blending } \\
\text { Component Adjustment }\end{array}$ & $\begin{array}{l}\text { Product Supplied } \\
1903 \text { Basis }\end{array}$ & Difforence \\
\hline January ..................... & 6,869 & 68 & -8 & 6,929 & 60 \\
\hline Fobruary.................... & 6,963 & 68 & -6 & 7,025 & 62 \\
\hline March ........................ & 7,137 & 62 & 59 & 7,258 & 121 \\
\hline Aprill........................... & 7,238 & 68 & 49 & 7,355 & 117 \\
\hline May ............................. & 7,328 & 55 & 36 & 7,419 & 91 \\
\hline June ........................... & 7,460 & 64 & 11 & 7,535 & 75 \\
\hline July................................ & 7,639 & 62 & 75 & 7,766 & 127 \\
\hline Auguat...................... & 7,380 & 66 & 91 & 7,537 & 157 \\
\hline September ............... & 7,344 & 54 & 43 & 7,441 & 97 \\
\hline 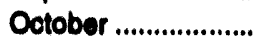 & 7,338 & 76 & -14 & 7,400 & 62 \\
\hline November ................ & 7,102 & 91 & 68 & 7,261 & 159 \\
\hline December ................ & 7,386 & 100 & 66 & 7,662 & 168 \\
\hline Average ................... & 7,268 & 69 & 39 & 7,378 & 108 \\
\hline
\end{tabular}

Note: Totals may not equal sum of componente due to independent rounding

Souree: - Full Ethand Adjustment - 1002, Energy Intormation Administration (ElA), Petroleum Supply Monthly, Appendix D. - Motor Gasoline Blending Component Adjustment - 1992, EIA, Petroloum Supply Annual, Volumes I and II.

change is evident in Tables S3 and 35 through 44,49 and 50.

- Exports data are now published for oxygenates and the sub-categories of finished motor gasoline (reformulated, oxygenated, and other) and distillate fuel oil
$(0.05 \%$ sulfur and under, and greater than $0.05 \%$ sulfur).

- Product supplied is now calculated for reformulated, oxygenated, and other finished motor gasoline as well as the sulfur categories of distillate fuel oil $(0.05 \%$ sulfur and under, and greater than $0.05 \%$ sulfur). 


\section{Appendix C}

This table contains information on revisions to published statistics caused by resubmisslon of respondent survey forms. The table shows the published value in the Petroleum Supply Monthly (PSM) and the cumulative difference resulting from resubmissions for the major product serles. The official published petroleum supply statistics are not changed to reflect revisions until publication of the Petroleum Supply Annual (PSA), except in cases of catastrophic error.

This table is provided as a service to analysts who need to know the latest available statistics. It should be used with caution because resubmissions are received on an irregular bacis and the impact on published data can change from month to month. In some cases, the pattem of revision caused by resubmissions during the year is a poor incicator of final statistics that will be published in the PSA.
Impact of

Resubmissions

on Major

Series, 1993

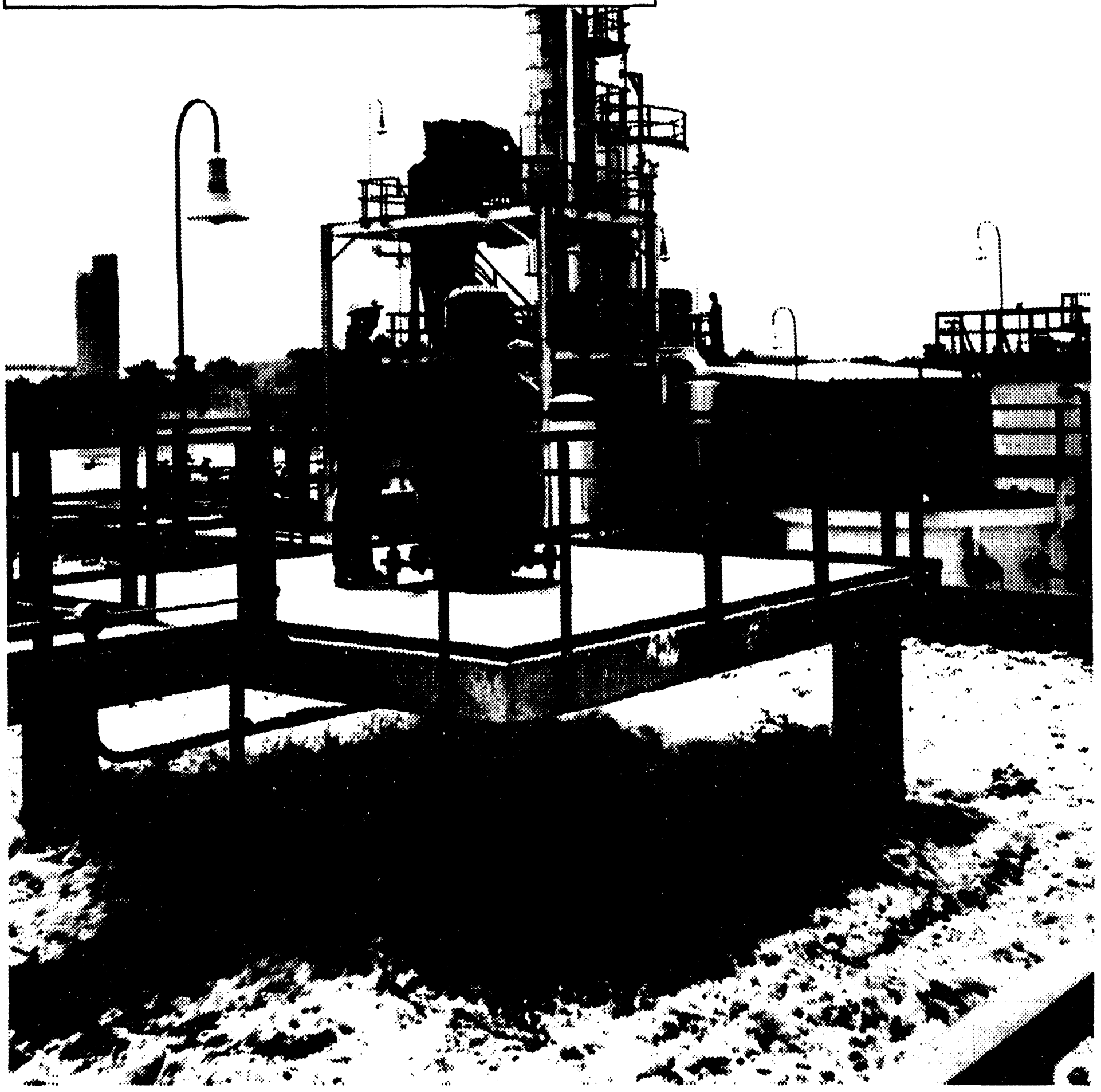

Sufface aerators are used at U.S. petroleum refineries to help prevent water pollution. These aerators speed up the

oxidation process by beating air into water. 
Table C1. Impact of Resubmissions on Major Series, 1993

(Thousand Barrels per Day, Except Where Noted)

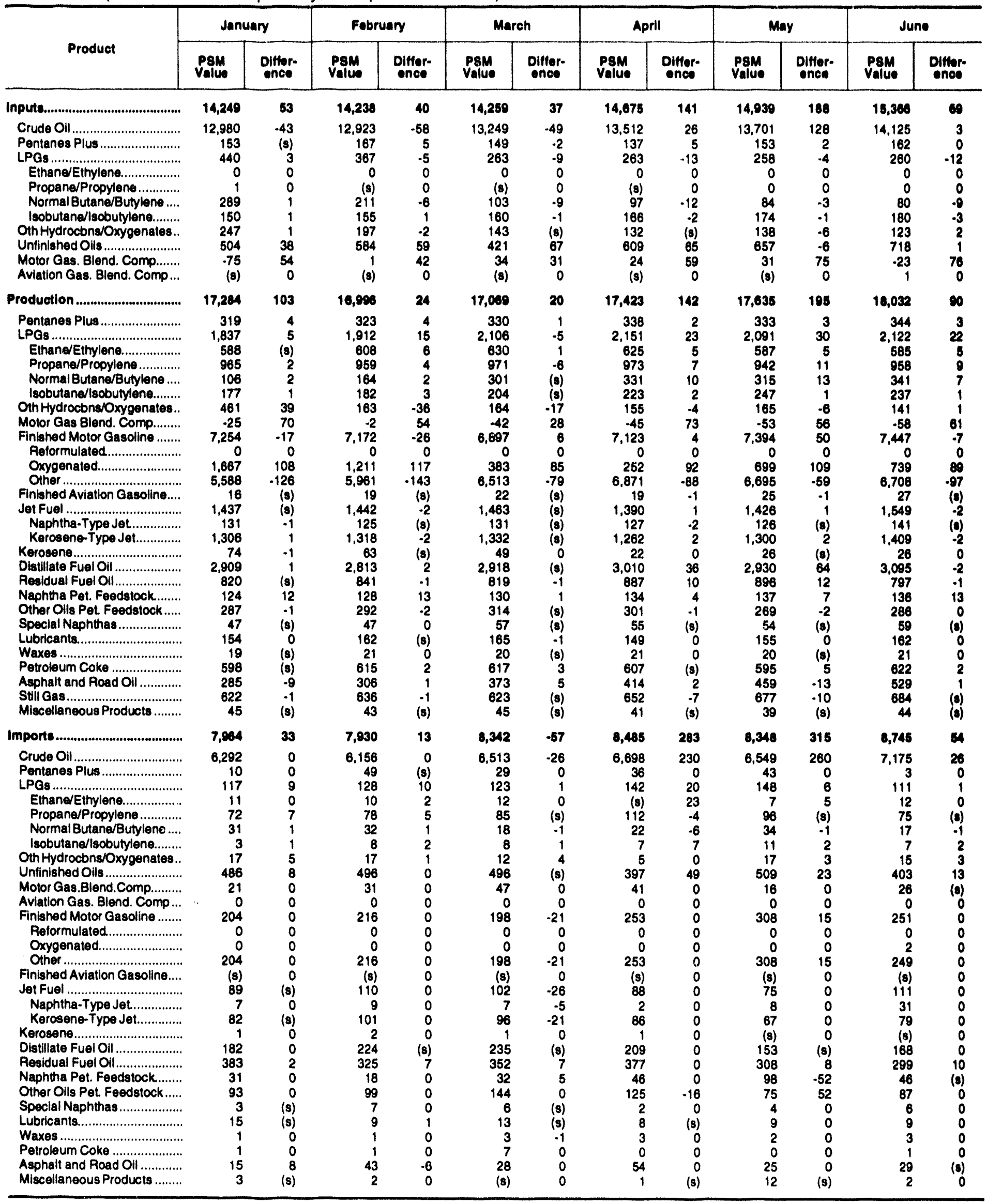

(s) = Less than 500 barrels per day.

Note: Volumes indicate cumulative changes resulting from resubmissions received for that month as of the date of this publication. 
Table C1. Impact of Resubmissions on Major Series, 1993 (Continued) (Thousand Barrels per Day, Except Where Noted)

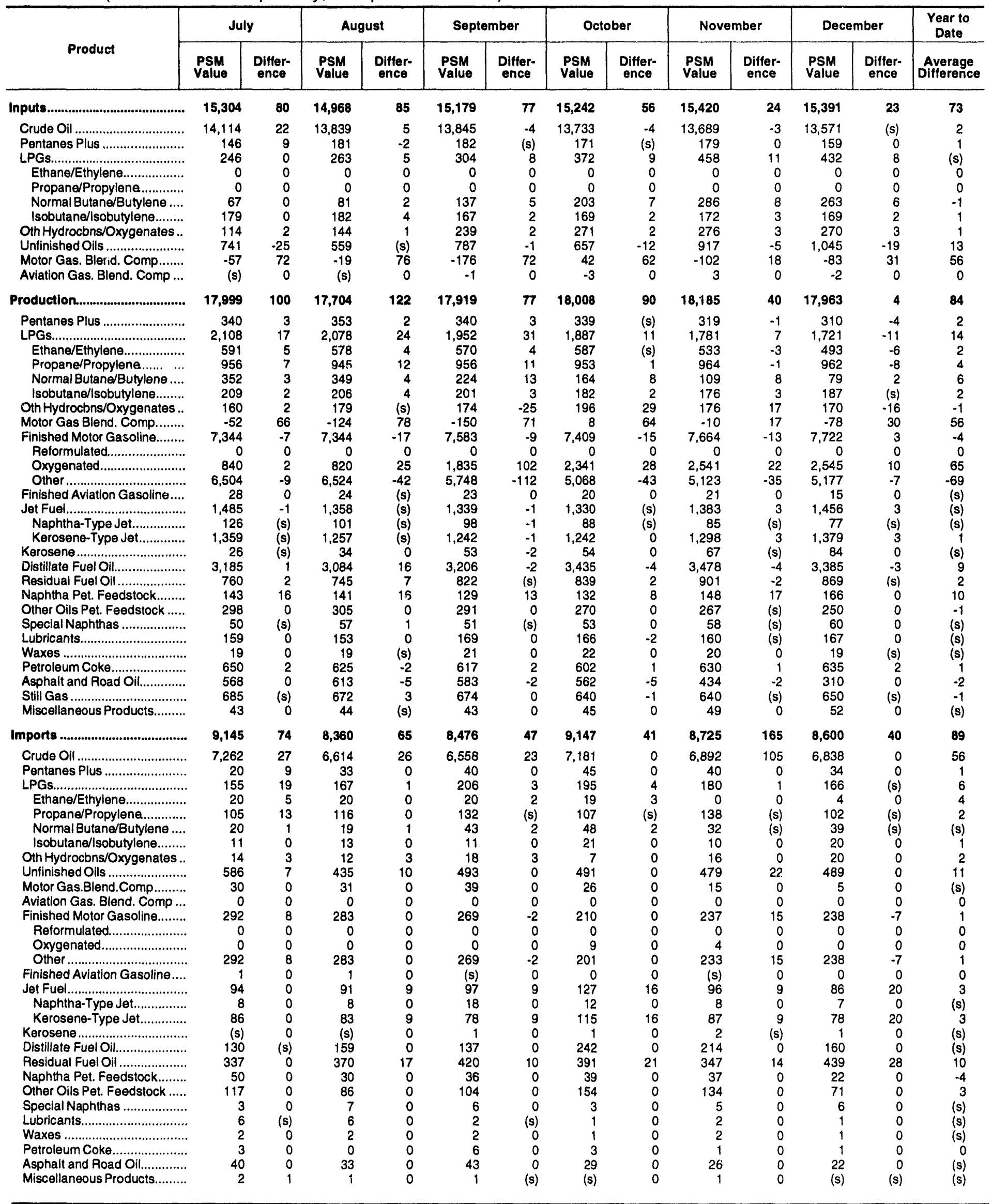

$(s)=$ Less than 500 barrels per day.

Note: Volumes indicate cumulative changes resulting from resubmissions received for that month as of the date of this publication. 
Table C1. Impact of Resubmissions on Major Series, 1993 (Continued)

(Thousand Barrels per Day, Except Where Noted)

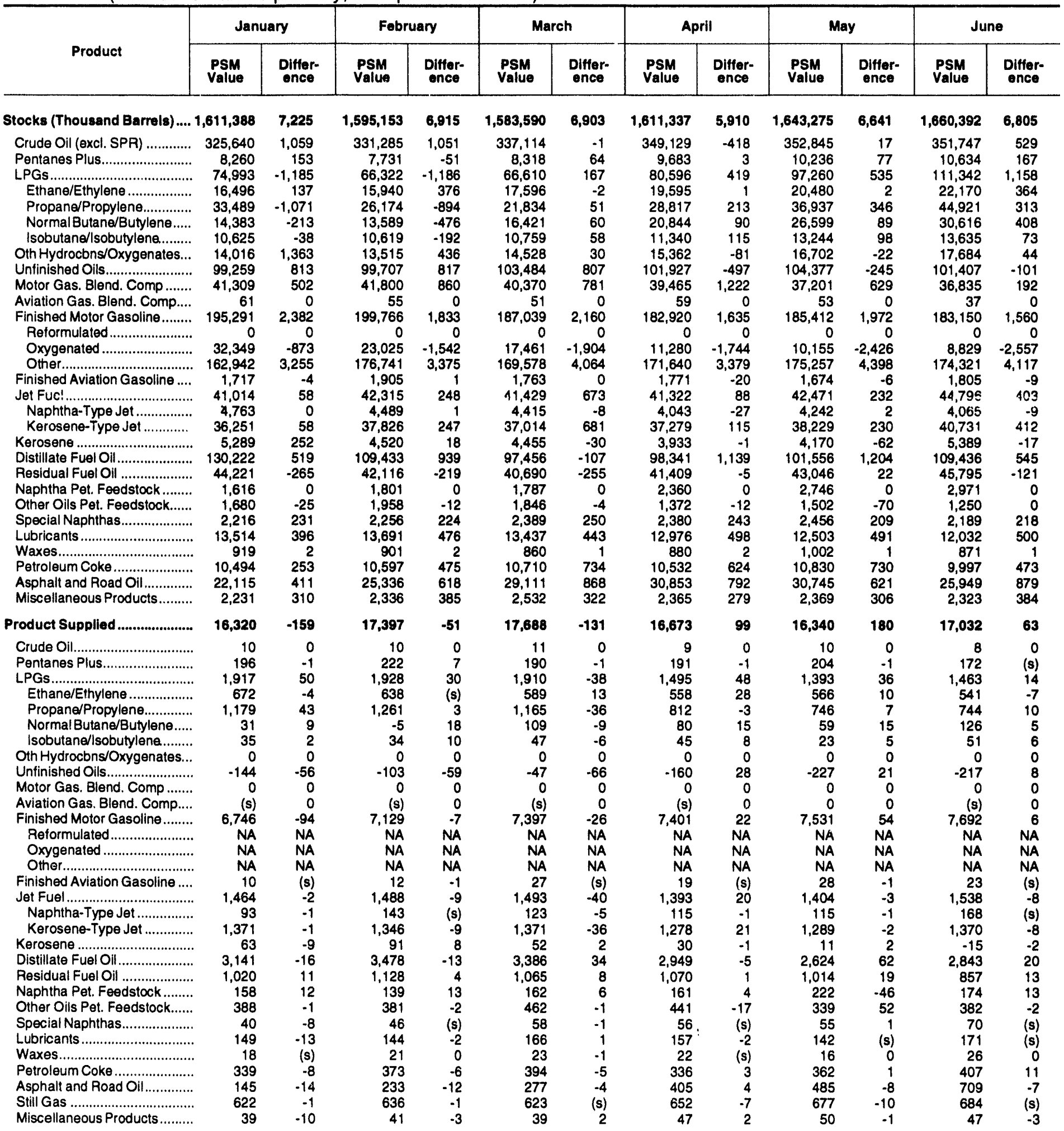

$(s)=$ Less than 500 barrels per day.

$\mathrm{NA}=$ Not Available.

Note: Volumes indicate cumulative changes resulting from resubmissions received for that month as of the date of this publication. 
Table C1. Impact of Resubmissions on Major Series, 1993 (Continued) (Thousand Barrels per Day, Except Where Noted)

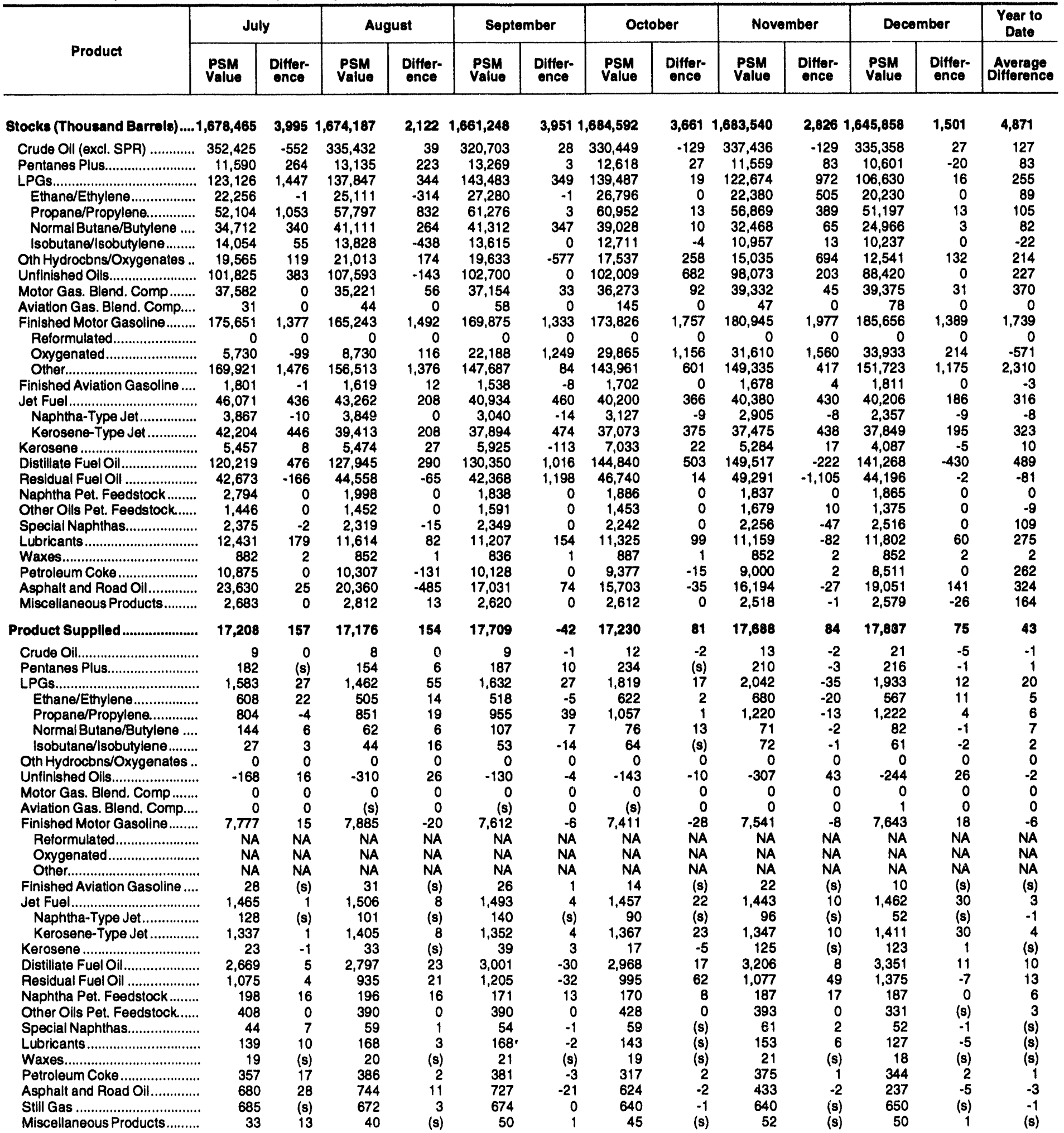

(s) = Less than 500 barrels per day.

NA=Not Available.

Note: Volumes indicate cumulative changes resulting from resubmissions received for that month as of the date of this publication. 


\section{Appendix D}

\section{EIA 819M Monthly Oxygenate Telephone Report}

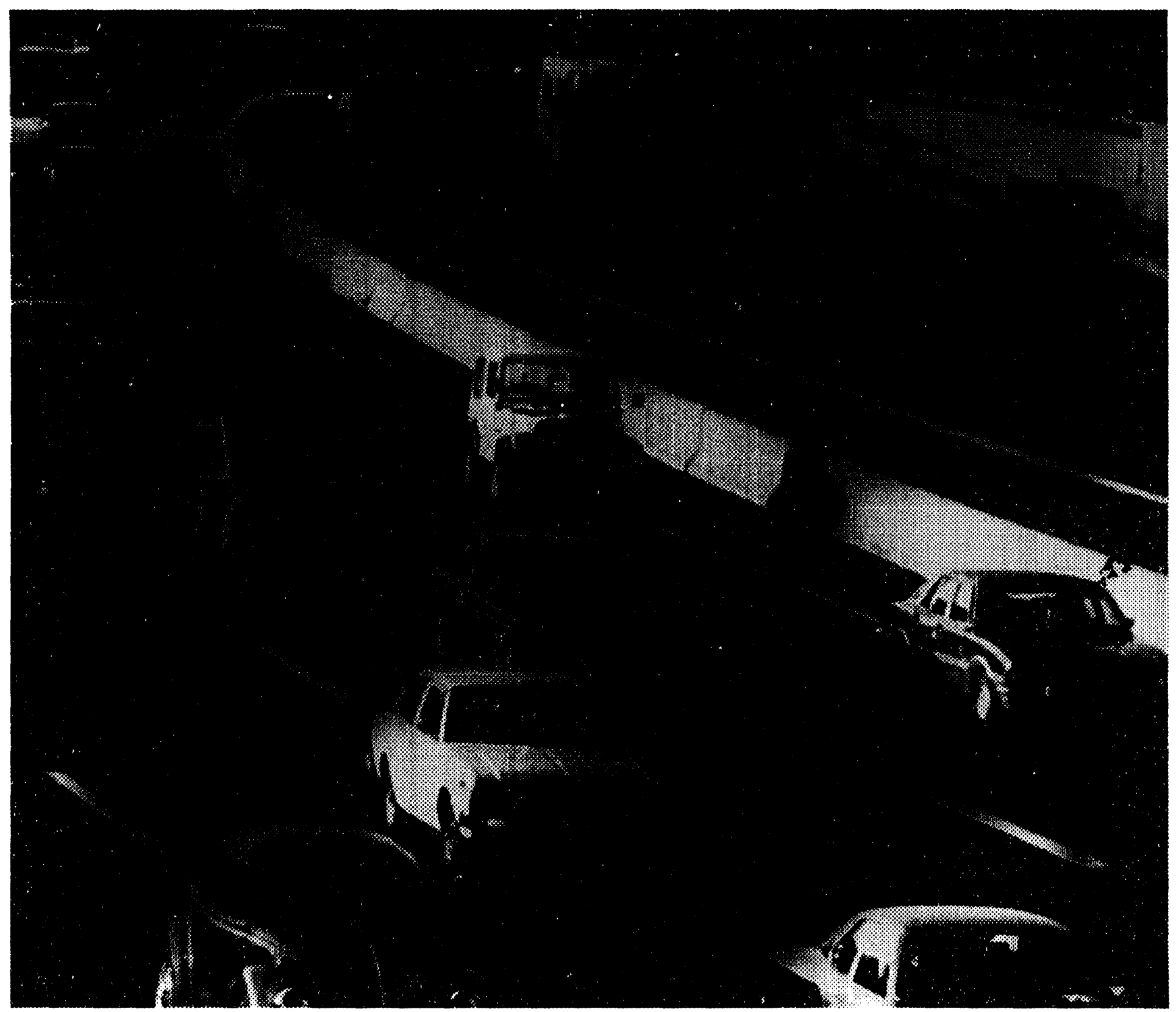




\section{EIA-819M \\ Monthly Oxygenate Telephone Report}

The EIA-819M, "Monthly Oxygenate Telephone Report," provides production data and preliminary stock data for fuel ethanol and methyl tertiary butyl ether (MTBE) in the United States and major U.S. geographic regions. These data have been published in the Weekly Petroleum Status Report (WPSR) and the Petroleum Supply Monthly since March 1992.

Data are collected from a sample of respondents reporting on the Monthly Petroleum Supply Reporting System surveys. Final data on production and stocks of fuel ethanol and MTBE are presented in the Detailed Statistics section beginning with the March 1993 issue. The quantity of oxygenates blended into motor gasoline previously published in this appendix is now presented in the Highlights section.

Table D1. U.S. Summary Table, March 1994

\begin{tabular}{|c|c|c|c|c|c|c|}
\hline \multirow[b]{2}{*}{ Products } & \multicolumn{2}{|c|}{ March 1994} & \multicolumn{2}{|c|}{ February 1994} & \multicolumn{2}{|c|}{ Year-to-Date } \\
\hline & $\begin{array}{c}\text { Thousand } \\
\text { Barrels }\end{array}$ & $\begin{array}{c}\text { Thousand } \\
\text { Barrels per Day }\end{array}$ & $\begin{array}{c}\text { Thousand } \\
\text { Barrels }\end{array}$ & \begin{tabular}{|c|} 
Thousand \\
Barrels per Day
\end{tabular} & $\begin{array}{c}\text { Thousand } \\
\text { Barrels }\end{array}$ & $\begin{array}{c}\text { Thousand } \\
\text { Barrels per Day }\end{array}$ \\
\hline \multicolumn{7}{|l|}{ Fuel Ethanol } \\
\hline $\begin{array}{l}\text { Production } \\
\text { Stocks }\end{array}$ & $\begin{array}{l}2,592 \\
1,650\end{array}$ & $\begin{array}{r}84 \\
--\end{array}$ & $\begin{array}{l}2,285 \\
1,689\end{array}$ & $\begin{array}{r}82 \\
--\end{array}$ & $\begin{array}{l}7,426 \\
1,650\end{array}$ & $\begin{array}{r}83 \\
--\end{array}$ \\
\hline \multicolumn{7}{|l|}{ MTBE } \\
\hline $\begin{array}{l}\text { Production } \\
\text { Stocks }\end{array}$ & $\begin{array}{r}4,001 \\
10619\end{array}$ & 129 & 3,929 & 140 & $\begin{array}{l}11,739 \\
10619\end{array}$ & 130 \\
\hline
\end{tabular}

Source: Energy Information Administration (EIA) Form EIA-81 9M, "Monthly Oxygenate Telephone Report." 
Table D2. Monthly Fuel Ethanol Production and Stocks by Petroleum Administration for Defense Districts (PADD)

(Thousand Barrels per Day, Except Where Noted)

\begin{tabular}{|c|c|c|c|c|c|c|c|c|c|c|c|c|}
\hline DistrictYear & Jan & Fob & Mar & Apr & May & Jun & Jul & Aug & Sep & Oct & Nov & Dec \\
\hline \multicolumn{13}{|l|}{$\begin{array}{l}\text { Total U.S. } \\
\text { Production }\end{array}$} \\
\hline 1993 & 76 & 73 & 77 & 76 & 74 & 76 & 69 & 66 & 72 & 76 & 85 & 85 \\
\hline 1994 & 82 & 82 & 84 & & & & & & & & & \\
\hline \multicolumn{13}{|c|}{ Stocks (thous. bbls.) } \\
\hline 1993 & 2,036 & 1,929 & 1,878 & 2,069 & 2,314 & 2,499 & 2,459 & 2,768 & 2,633 & 2,640 & 2,275 & 2,105 \\
\hline 1994 & 1,740 & 1,689 & 1,650 & & & & & & & & & \\
\hline
\end{tabular}

\begin{tabular}{|c|c|c|c|c|c|c|c|c|c|c|c|c|}
\hline \multicolumn{13}{|c|}{ East Cosat (PADD I) } \\
\hline \multicolumn{13}{|c|}{ Production } \\
\hline 1993 & $\mathbf{w}$ & $w$ & w & $w$ & $w$ & w & W & w & w & $w$ & $w$ & $w$ \\
\hline 1994 & $\mathbf{w}$ & $w$ & $w$ & & & & & & & & & \\
\hline \multicolumn{13}{|c|}{ Stocks (thous. bbls.) } \\
\hline 1993 & 117 & 64 & 62 & 41 & 136 & 112 & 37 & 157 & 135 & 82 & 241 & 162 \\
\hline 1994 & 54 & 60 & 68 & & & & & & & & & \\
\hline
\end{tabular}

\begin{tabular}{|c|c|c|c|c|c|c|c|c|c|c|c|c|}
\hline \multicolumn{13}{|c|}{ Midwest (PADD II) } \\
\hline \multicolumn{13}{|c|}{ Production } \\
\hline 1993 & 74 & 71 & 75 & 74 & 73 & 74 & 67 & 64 & 70 & 74 & 83 & 83 \\
\hline 1994 & 80 & 80 & 82 & & & & & & & & & \\
\hline \multicolumn{13}{|c|}{ Stocks (thous. bbls.) } \\
\hline 1993 & 1,094 & 1,124 & 1,143 & 1,310 & 1,322 & 1,413 & 1,570 & 1,408 & 1,314 & 1,269 & 981 & 779 \\
\hline 1994 & 750 & 786 & 833 & & & & & & & & & \\
\hline
\end{tabular}

\begin{tabular}{|c|c|c|c|c|c|c|c|c|c|c|c|c|}
\hline \multicolumn{13}{|c|}{ Gulf Coast (PADD IiI) } \\
\hline \multicolumn{13}{|c|}{ Production } \\
\hline 1993 & $w$ & $w$ & $w$ & W & w & w & W & W & W & $w$ & $w$ & w \\
\hline 1994 & w & w & $w$ & & & & & & & & & \\
\hline \multicolumn{13}{|c|}{ Stocks (thous. bbls.) } \\
\hline 1993 & 203 & 244 & 216 & 294 & 312 & 333 & 358 & 616 & 530 & 468 & 366 & 554 \\
\hline 1994 & 431 & 452 & 488 & & & & & & & & & \\
\hline
\end{tabular}

\begin{tabular}{|c|c|c|c|c|c|c|c|c|c|c|c|c|}
\hline \multicolumn{13}{|c|}{ Rocky Mountain (PADD IV) } \\
\hline \multicolumn{13}{|c|}{ Production } \\
\hline 1993 & w & $w$ & $W$ & $w$ & $W$ & w & w & $w$ & W & $w$ & w & $\mathbf{w}$ \\
\hline 1994 & $w$ & $w$ & $w$ & & & & & & & & & \\
\hline \multicolumn{13}{|c|}{ Stocks (thous. bbls.) } \\
\hline 1993 & 61 & 44 & 45 & 41 & 42 & 45 & 47 & 47 & 50 & 85 & 70 & 88 \\
\hline 1994 & 99 & 80 & 68 & & & & & & & & & \\
\hline
\end{tabular}

\begin{tabular}{|c|c|c|c|c|c|c|c|c|c|c|c|c|}
\hline \multicolumn{13}{|c|}{ West Coast (PADD V) } \\
\hline \multicolumn{13}{|c|}{ Production } \\
\hline 1993 & $w$ & $w$ & w & w & w & W & w & w & $w$ & $w$ & $w$ & $w$ \\
\hline 1994 & W & $w$ & $w$ & & & & & & & & & \\
\hline \multicolumn{13}{|c|}{ Stocks (thous. bbls.) } \\
\hline 1993 & 561 & 453 & 412 & 383 & 502 & 596 & 447 & 540 & 604 & 736 & 617 & 522 \\
\hline 1994 & 406 & 311 & 193 & & & & & & & & & \\
\hline
\end{tabular}

$W=$ Withheld to avoid disclosure of individual company data.

Note: - Geographic coverage is the 50 States and the District of Columbia. - Totals may not equal sum of components due to independent rounding. Source: Energy Information Administration (EIA) Form EIA-819M, "Monthiy Oxygenate Telephone Report. " 
Table D3. Monthly Mothyl Tertiary Butyl Ether (MTBE) Production and Stocks by Potroleum Administration for Defense Districts (PADD)

(Thousand Barrels per Day, Except Where Noted)

\begin{tabular}{|c|c|c|c|c|c|c|c|c|c|c|c|c|}
\hline DistrictMonth & Jan & Fob & Mar & Apr & May & Jun & Jul & Aug & Sep & Oct & Nov & Dec \\
\hline \multicolumn{13}{|l|}{$\begin{array}{l}\text { Total U.S. } \\
\text { Production }\end{array}$} \\
\hline 1993 & 115 & 114 & 112 & 138 & 132 & 126 & 155 & 142 & 157 & 146 & 148 & 144 \\
\hline 1994 & 123 & 140 & 129 & & & & & & & & & \\
\hline \multicolumn{13}{|c|}{ Stocks (thous. bbls.) } \\
\hline 1993 & 10,648 & 10,148 & 10,550 & 11,953 & 13,476 & 14,544 & 16,044 & 17,047 & 15,510 & 13,139 & 11,468 & 9,744 \\
\hline 1994 & 8,226 & 8,444 & 10,619 & & & & & & & & & \\
\hline
\end{tabular}

\begin{tabular}{|c|c|c|c|c|c|c|c|c|c|c|c|c|}
\hline \multicolumn{13}{|c|}{ East Coast (PADD D) } \\
\hline \multicolumn{13}{|c|}{ Production } \\
\hline 1993 & $w$ & $w$ & $w$ & W & $w$ & $w$ & $\mathbf{w}$ & $w$ & w & $w$ & $w$ & $w$ \\
\hline 1994 & $w$ & w & $\mathbf{w}$ & & & & & & & & & \\
\hline \multicolumn{13}{|c|}{ Stocks (thous. bbls.) } \\
\hline 1993 & 1,881 & 1,833 & 1,492 & 1,598 & 2,201 & 2,578 & 2,429 & 3,062 & 2,604 & 2,402 & 2,141 & 1,339 \\
\hline 1994 & 836 & 1,048 & 1,356 & & & & & & & & & \\
\hline
\end{tabular}

\begin{tabular}{|c|c|c|c|c|c|c|c|c|c|c|c|c|}
\hline \multicolumn{13}{|c|}{ Mldweat (PADD II) } \\
\hline \multicolumn{13}{|c|}{ Production } \\
\hline 1993 & $w$ & $w$ & w & $w$ & $w$ & $w$ & $w$ & w & $w$ & W & W & $w$ \\
\hline 1994 & $\mathbf{w}$ & $\mathbf{w}$ & $w$ & & & & & & & & & \\
\hline \multicolumn{13}{|c|}{ Stocks (thous. bbls.) } \\
\hline 1993 & $w$ & $w$ & w & $w$ & $w$ & $w$ & $w$ & $w$ & $w$ & $w$ & $w$ & $w$ \\
\hline 1994 & $w$ & $w$ & $w$ & & & & & & & & & \\
\hline
\end{tabular}

\begin{tabular}{|c|c|c|c|c|c|c|c|c|c|c|c|c|}
\hline \multicolumn{13}{|c|}{ Gulf Coast (PADD III) } \\
\hline \multicolumn{13}{|c|}{ Productlon } \\
\hline 1993 & 102 & 101 & 99 & 124 & 117 & 111 & 139 & 125 & 139 & 130 & 129 & 126 \\
\hline 1994 & 108 & 122 & 115 & & & & & & & & & \\
\hline \multicolumn{13}{|c|}{ Stocks (thous. bbls.) } \\
\hline 1993 & 4,987 & 4,707 & 5,304 & 6,152 & 6,553 & 6,890 & 7,834 & 8,040 & 7,664 & 6,440 & 5,828 & 4,752 \\
\hline 1994 & 4,057 & 4,756 & 5,375 & & & & & & & & & \\
\hline
\end{tabular}

\begin{tabular}{|c|c|c|c|c|c|c|c|c|c|c|c|c|}
\hline \multicolumn{13}{|c|}{ Rocky Mountaln (PADD IV) } \\
\hline \multicolumn{13}{|c|}{ Production } \\
\hline 1993 & $\mathbf{w}$ & $w$ & w & $\mathbf{w}$ & $w$ & $w$ & $w$ & $w$ & $w$ & $w$ & $w$ & $W$ \\
\hline 1994 & W & $\mathbf{w}$ & $\mathbf{w}$ & & & & & & & & & \\
\hline \multicolumn{13}{|c|}{ Stocks (thous. bbls.) } \\
\hline 1993 & $w$ & w & w & $w$ & $\mathbf{w}$ & $w$ & w & $\mathbf{w}$ & w & W & $w$ & $w$ \\
\hline 1994 & w & $w$ & W & & & & & & & & & \\
\hline
\end{tabular}

\begin{tabular}{|c|c|c|c|c|c|c|c|c|c|c|c|c|}
\hline \multicolumn{13}{|c|}{ West Cosst (PADD V) } \\
\hline \multicolumn{13}{|c|}{ Production } \\
\hline 1993 & $w$ & $w$ & $\mathbf{w}$ & $w$ & $w$ & $w$ & $w$ & $w$ & $w$ & $w$ & W & W \\
\hline 1994 & $w$ & $w$ & $w$ & & & & & & & & & \\
\hline \multicolumn{13}{|c|}{ Stocks (thous. bbls.) } \\
\hline 1993 & 3,536 & 3,333 & 3,516 & 3,921 & 4,427 & 4,774 & 5,452 & 5,481 & 4,782 & 3,883 & 3,134 & 3,302 \\
\hline 1994 & 2,909 & 2,186 & 3,405 & & & & & & & & & \\
\hline
\end{tabular}

$W=$ Withheld to avoid disclosure of individual company data.

Note: - Geographic coverage is the 50 States and the District of Columbia. - Totals may not equal sum of components due to independent rounding.

Source: Energy Information Administration (EIA) Form ElA-819M, "Monthly Oxygenate Telephone Report. " 


\section{Glossary}

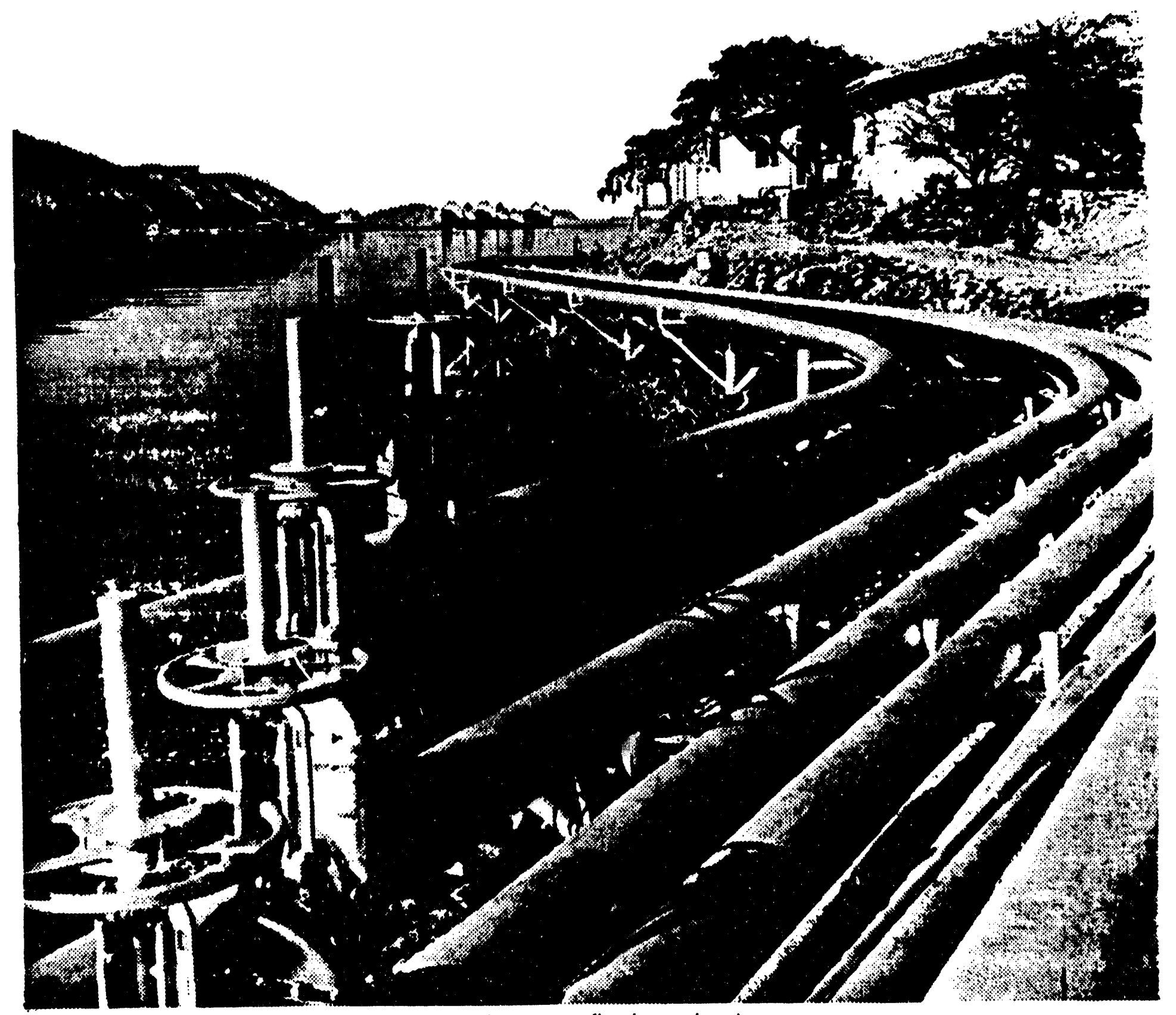

Pipelines carry crude oil and petroleum products between refineries and ports. 


\section{Definitions of Petroleum Products and Other Terms}

Alcohol. The family name of a group of organic chemical compounds composed of carbon, hydrogen, and oxygen. The series of molecules vary in chain length and are composed of a hydrocarbon plus a hydroxyl group; $\mathrm{CH}_{3}-\left(\mathrm{CH}_{2}\right) \mathrm{n}-\mathrm{OH}$ (e.g., methanol, ethanol, and tertiary butyl alcohol).

Alkylate. The product of an alkylation reaction. It usually refers to the high octane product from alkylation units. This alkylate is used in blending high octane gasoline.

Alkylation. A refining process for chemically combining isobutane with olefin hydrocarbons (e.g., propylene, butylene) through the control of temperature and pressure in the presence of an acid catalyst, usually sulfuric acid or hydrofluoric acid. The product, alkylate, an isoparaffin, has high octane value and is blended with motor and aviation gasoline to improve the antiknock value of the fuel.

API Gravity. An arbitrary scale expressing the gravity or density of liquid petroleum products. The measuring scale is calibrated in terms of degrees API; it is calculated as follows:

$$
\text { Degrees API }=\frac{141.5}{\text { sp.gr.60'F/60 F }} \cdot 131.5
$$

Aromatics. Hydrocarbons characterized by unsaturated ring structures of carbon atoms. Commercial petroleum aromatics are benzene, toluene, and xylene (BTX).

Asphalt. A dark-brown-to-black cement-like material containing bitumens as the predominant constituent obtained by petroleum processing. The definition includes crude asphalt as well as the following finished products: cements, fluxes, the asphalt content of emulsions (exclusive of water), and petroleum distillates blended with asphalt to make cutback asphalts. The conversion factor for asphalt is 5.5 barrels per short ton.

ASTM. The acronym for the American Society for Testing and Materials.

Atmospheric Crude Oil Distillation. The refining process of separating crude oil components at atmospheric pressure by heating to temperatures of about $600^{\circ}$ to $750^{\circ} \mathrm{F}$ (depending on the nature of the crude oil and desired products) and subsequent condensing of the fractions by cooling.
Aviation Gasoline (Finished). All special grades of gasoline for use in aviation reciprocating engines, as given in ASTM Specification D910 and Military Specification MIL-G-5572. Excludes blending components which will be used in blending or compounding into finished aviation gasoline.

Aviation Gasoline Blending Components. Naphthas which will be used for blending or compounding into finished aviation gasoline (e.g., straight-run gasoline, alkylate, reformate, benzene, toluene, and xylene). Excludes oxygenates (alcohols, ethers), butane, and pentanes plus. Oxygenates are reported as other hydrocarbons, hydrogen, and oxygenates.

Barrel. A volumetric unit of measure for crude oil and petroleum products equivalent to 42 U.S. gallons. This measure is used in most statistical reports. Factors for converting petroleum coke, asphalt, still gas and wax to barrels are given in the definitions of these products.

Barrels Per Calendar Day. The maximum number of barrels of input that can be processed during a 24-hour period after making allowances for the following limitations:

the capability of downstream facilities to absorb the output of crude oil processing facilities of a given refinery. No reduction is made when a planned distribution of intermediate streams through other than downstream facilities is part of a refinery's normal operation;

the types and grades of inputs to be processed;

the types and grades of products expected to be manufactured;

the environmental constraints associated with refinery operations;

the reduction of capacity for scheduled downtime such as routine inspection, mechanical problems, maintenance, repairs, and turnaround; and

the reduction of capacity for unscheduled downtime such as mechanical problems, repairs, and slowdowns.

Barrels Per Stream Day. The amount a unit can process running at full capacity under optimal crude oil and product slate conditions.

Shaded areas in the definitions represent changes introduced in January 1994. 
Benzene $\left(\mathrm{C}_{6} \mathrm{H}_{6}\right)$. An aromatic hydrocarbon present in small proportion in some crude oils and made commercially from petroleum by the catalytic reforming of naphthenes in petroleum naphtha. Also made from coal in the manufacture of coke. Used as a solvent, in manufacturing detergents, synthetic fibers, and petrochemicals and as a component of high-octane gasoline.

Blending Components. See Motor or Aviation Gasoline Blending Components.

Blending Plant. A facility which has no refining capability but is either capable of producing finished motor gasoline through mechanical blending or blends oxygenates with motor gasoline.

Bonded Petroleum Imports. Petroleum imported and entered into Customs bonded storage. These imports are not included in the import statistics until they are: (1) withdrawn from storage free of duty for use as fuel for vessels and aircraft engaged in international trade; or (2) withdrawn from storage with duty paid for domestic use.

BTX. The acronym for the commercial petroleum aromatics benzene, toluene, and xylene. See individual categories for definitions.

Bulk Station. A facility used primarily for the storage and/or marketing of petroleum products which has a total bulk storage capacity of less than 50,000 barrels and receives its petroleum products by tank car or truck.

Bulk Terminal. A facility used primarily for the storage and/or marketing of petroleum products which has a total bulk storage capacity of 50,000 barrels or more and/or receives petroleum products by tanker, barge, or pipeline.

Butane ( $\left.\mathrm{C}_{4} \mathrm{H}_{10}\right)$. A normally gaseous straight-chain or branch-chain hydrocarbon extracted from natural gas or refinery gas streams. It includes isobutane and normal butane and is designated in ASTM Specification D1835 and Gas Processors Association Specifications for commercial butane.

Isobutane (CAH10). A normally gaseous branch-chain hydrocarbon. It is a colorless paraffinic gas that boils at a temperature of $10.9^{\circ} \mathrm{F}$. It is extracted from natural gas or refinery gas streams.

Normal Butane ( $\left.C_{4} H_{10}\right)$. A normally gaseous straight-chain hydrocarbon. It is a colorless paraffinic gas that boils at a temperature of $31.1^{\circ} \mathrm{F}$. It is extracted from natural gas or refinery gas streams.

Butylene $\left(\mathrm{C}_{4} \mathrm{H}_{8}\right)$. An olefinic hydrocarbon recovered from refinery processes.
Captive Refinery Oxygenate Plants. Oxygenate production facilities located within or adjacent to a refinery complex.

Catalytic Cracking. The refining process of breaking down the larger, heavier, and more complex hydrocarbon molecules into simpler and lighter molecules. Catalytic cracking is accomplished by the use of a catalytic agent and is an effective process for increasing the yield of gasoline from crude oil. Catalytic cracking processes fresh feeds and recycled feeds.

Fresh Feeds. Crude oil or petroleum distillates which are being fed to processing units for the first time.

Recycled Feeds. Feeds that are continuously fed back for additional processing.

Catalytic Hydrocracking. A refining process that uses hydrogen and catalysts with relatively low temperatures and high pressures for converting middle boiling or residual material to high-octane gasoline, reformer charge stock, jet fuel, and/or high grade fuel oil. The process uses one or more catalysts, depending upon product output, and can handle high sulfur feedstocks without prior desulfurization.

Catalytic Hydrotreating. A refining process for treating petroleum fractions from atmospheric or vacuum distillation units (e.g., naphthas, midille distillates, reformer feeds, residual fuel oil, and heavy gas oil) and other petroleum (e.g., cat cracked naphtha, coker naphtha, gas oil, etc.) in the presence of catalysts and substantial quantities of hydrogen. Hydrotreating includes desulfurization, removal of substances (e.g., nitrogen compounds) that deactivate catalysts, conversion of olefins to paraffins to reduce gum formation in gasoline, and other processes to upgrade the quality of the fractions.

Catalytic Reforming. A refining process using controlled heat and pressure with catalysts to rearrange certain hydrocarbon molecules, thereby converting paraffinic and naphthenic type hydrocarbons (e.g., low-octane gasoline boiling range fractions) into petrochemical feedstocks and higher octane stocks suitable for blending into finished gasoline. Catalytic reforming is reported in two categories. They are:

Low Pressure. A processing unit operating at less than 225 pounds per square inch gauge (PSIG) measured at the outlet separator.

High Pressure. A processing unit operating at either equal to or greater than 225 pounds per square inch gauge (PSIG) measured at the outlet separator. 
Charge Capacity. The input (feed) capacity of the refinery processing facilities.

Coal. A black or brownish-black solid combustible substance formed by the partial decomposition of vegetable matter without access to air. The rank of coal, which includes anthracite, bituminous coal, subbituminous coal, and lignite, is based on fixed carbon, volatile matter, and heating value. Coal rank indicates the progressive alteration, or coalification, from lignite to anthracite. Lignite contains approximately 9 to 17 million BTU per ton. The heat contents of subbituminous and bituminous coal range from 16 to 24 million BTU per ton, and from 19 to 30 million BTU per ton, respectively. Anthracite contains approximately 22 to 28 million BTU per ton.

Commercial Kerosene-Type Jet Fuel. See Kerosene-Type Jet Fuel.

Crude Oil (Including Lease Condensate). A mixture of hydrocarbons that exists in liquid phase in underground reservoirs and remains liquid at atmospheric pressure after passing through surface-separating facilities. Included are lease condensate and liquid hydrocarbons produced from tar sands, gilsonite, and oil shale. Drip gases are also included, but topped crude oil (residual oil) and other unfinished oils are excluded. Liquids produced at natural gas processin: plants and mixed with crude oil are likewise excluded where identifiable. Crude oil is considered as either domestic or foreign, according to the following:

Domestic. Crude oil produced in the United States or from its "outer continental shelf" as defined in 43 USC 1331.

Foreign. Crude oil produced outside the United States. Imported Athabasca hydrocarbons are included.

Crude Oil, Refinery Receipts. Receipts of domestic and foreign crude oil at a refinery. Includes all crude oil in transit except crude oil in transit by pipeline. Foreign crude oil is reported as a receipt only after entry through customs. Crude oil of foreign origin held in bonded storage is excluded.

Crude Oil Losses. Represents the volume of crude oil reported by petroleum refineries as being lost in their operations. These losses are due to spills, contamination, fires, etc. as opposed to refinery processing losses.

Crude Oil Production. The volume of crude oil produced from oil reservoirs during given periods of time. The amount of such production for a given period is measured as volumes delivered from lease storage tanks (i.e., the point of custody transfer) to pipelines, trucks, or other media for transport to refineries or terminals with adjustments for (1) net differences between opening and closing lease inventories, and (2) basic sediment and water (BS\&W).

Crude Oil Qualities. Refers to two properties of crude oil, the sulfur content and API gravity, which affect processing complexity and product characteristics.

Delayed Coking. A process by which heavier crude oil fractions can be thermally decomposed under conditions of elevated temperatures and pressure to produce a mixture of lighter oils and petroleum coke. The light oils can be processed further in other refinery units to meet product specifications. The coke can be used either as a fuel or in other applications such as the manufacturing of steel or aluminum.

Disposition. The components of petroleum disposition are stock change, crude oil losses, refinery inputs, exports, and products supplied for domestic consumption.

Distillate Fuel Oil. A general classification for one of the petroleum fractions produced in conventional distillation operations. It is used primarily for space heating, on-and-off-highway diesel engine fuel (including railroad engine fuel and fuel for agricultural machinery), and electric power generation. Included are products known as No. 1, No. 2, and No. 4 fuel oils; No. 1, No. 2, and No. 4 diesel fuels. Distillate fuel oil is reported in the following sulfur categories: $0.05 \%$ sulfur and under and Greater than $0.05 \%$ sulfur.

No. 1 Distillate. A petroleum distillate which meets the specifications for No. 1 heating or fuel oil as defined in ASTM D 396 and/or the specifications for No. 1 diesel fuel as defined in ASTM Specification D 975 with distillation temperatures of $420^{\circ} \mathrm{F}$ at the 10-percent recovery point and $550^{\circ} \mathrm{F}$ at the 90-percent recovery point, and kinematic viscosities between 1.4 and 2.2 centistokes at $100^{\circ} \mathrm{F}$.

No. 2 Distillate. A petroleum distillate which meets the specifications for No. 2 heating or fuel oil as defined in ASTM D 396 and/or the specifications for No. 2 diesel fuel as defined in ASTM Specification D 975 with distillation temperatures of $540^{\circ}$ and $640^{\circ} \mathrm{F}$ at the 90-percent recovery point, and kinematic viscosities between 2.0 and 4.3 centistokes at $100^{\circ} \mathrm{F}$.

No. 4 Fuel Oil. A fuel oil for commercial burner installations not equipped with preheating facilities. It is used extensively in industrial plants. This grade is a blend of distillate fuel oil and residual fuel oil stocks that conforms to ASTM Specification D396 or Federal Specification VV-F-815C; with minimum and maximum kinematic viscosities between 5.8 and 26.4 centistokes at 
$100^{\circ} \mathrm{F}$. Also included is No. 4-D, a fuel oil for low and medium-speed diesel engines that conforms to ASTM Specification D975.

Electricity (Purchased). Electricity purchased for refinery operations that is not produced within the refinery complex.

Ending Stocks. Primary stocks of crude oil and petroleum products held in storage as of 12 midnight on the last day of the month. Primary stocks include crude oil or petroleum products held in storage at (or in) leases, refineries, natural gas processing plants, pipelines, tank farms, and bulk terminals that can store at least 50,000 barrels of petroleum products or that can receive petroleum products by tanker, barge, or pipeline. Crude oil that is in-transit by water from Alaska, or that is stored on Federal leases or in the Strategic Petroleum Reserve is included. Primary Stocks exclude stocks of foreign origin that are held in bonded warehouse storage.

ETBE (Ethyl tertiary butyl ether) $\left(\mathrm{CH}_{3}\right)_{3} \mathrm{COC}_{2} \mathrm{H}_{5}$. An oxygenate blend stock formed by the catalytic etherification of isobutylene with ethanol.

Ethane $\left(\mathrm{C}_{2} \mathrm{H}_{6}\right)$. A normally gaseous straight-chain hydrocarbon. It is a colorless paraffinic gas that boils at a temperature of $-127.48^{\circ} \mathrm{F}$. It is extracted from natural gas and refinery gas streams.

Ether. A generic term applied to a group of organic chemical compounds composed of carbon, hydrogen, and oxygen, characterized by an oxygen atom attached to two carbon atoms (e.g., methyl tertiary butyl ether).

Ethylene $\left(\mathrm{C}_{2} \mathrm{H}_{4}\right)$. An olefinic hydrocarbon recovered from refinery processes or petrochemical processes.

Exports. Shipments of goods from the 50 States and the District of Columbia to foreign countries, Puerto Rico, the Virgin Islands, and other U.S. possessions and territories.

Field Production. Represents crude oil production on leases, natural gas liquids production at natural gas processing plants, new supply of other hydrocarbons/ oxygenates and motor gasoline blending components, and fuel ethanol blended into finished motor gasoline.

Flexicoking. A thermal cracking process which converts heavy hydrocarbons such as crude oil, tar sands bitumen, and distillation residues into light hydrocarbons. Feedstocks can be any pumpable hydrocarbons including those containing high concentrations of sulfur and metals.

Fluid Coking. A thermal cracking process utilizing the fluidized-solids technique to remove carbon (coke) for continuous conversion of heavy, low-grade oils into lighter products.

Fresh Feed Input. Represents input of material (crude oil, unfinished oils, natural gas liquids, other hydrocarbons and oxygenates or finished products) to processing units at a refinery that is being processed (input) into a particular unit for the first time.

\section{Examples:}

(1) Unfinished oils coming out of a crude oil distillation unit which are input into a catalytic cracking unit are considered fresh feed to the catalytic cracking unit.

(2) Unfinished oils coming out of a catalytic cracking unit being looped back into the same catalytic cracking unit to be reprocessed are not considered fresh feed.

Fuel Ethanol ( $\left.\mathrm{C}_{2} \mathrm{H}_{5} \mathrm{OH}\right)$. An anhydrous denatured aliphatic alcohol intended for gasoline blending as described in Oxygenates definition.

Fuels Solvent Deasphalting. A refining process for removing asphalt compounds from petroleum fractions, such as reduced crude oil. The recovered stream from this process is used to produce fuel products.

Gas Oil. A liquid petroleum distillate having a viscosity intermediate between that of kerosene and lubricating oil. It derives its name from having originally been used in the manufacture of illuminating gas. It is now used to produce distillate fuel oils and gasoline.

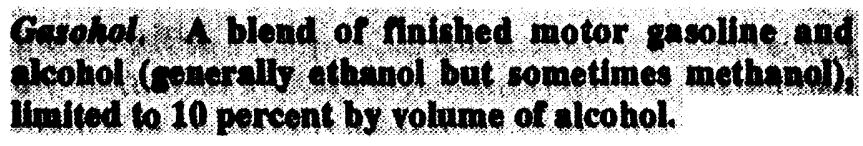

Gasoline Blending Components. Naphthas which will be used for blending or compounding into finished aviation or motor gasoline (e.g., straight-run gasoline, alkylate, reformate, benzene, toluene, and xylene). Excludes oxygenates (alcohols, ethers), butane, and pentanes plus.

Gross Input to Atmospheric Crude Oil Distillation Units. Total input to atmospheric crude oil distillation units. Includes all crude oil, lease condensate, natural gas plant liquids, unfinished oils, liquefied refinery gases, slop oils, and other liquid hydrocarbons produced from tar sands, gilsonite, and oil shale.

Heavy Gas Oil. Petroleum distillates with an approximate boiling range from $651^{\circ}$ to $1000^{\circ} \mathrm{F}$. 
Hydrogen. The lightest of all gases, occurring chiefly in combination with oxyget in water; exists also in acids, bases, alcohols, petroleum, and other hydrocarbons.

Idle Capacity. The component of operable capacity that is not in operation and not under active repair, but capable of being placed in operation within $\mathbf{3 0}$ days; and capacity not in operation but under active repair that can be completed within 90 days.

Imported Crude Oil Burned As Fuel. The amount of foreign crude oil burned as a fuel oil, usually as residual fuel oil, without being processed as such. Imported crude oil burned as fuel includes lease condensate and liquid hydrocarbons produced from tar sands, gilsonite, and oil shale.

Imports. Receipts of goods into the 50 States and the District of Columbia from foreign countries, Puerto Rico, the Virgin Islands, and other U.S. possessions and territories.

Isobutane. See Butane.

Isobutylene $\left(\mathrm{C}_{4} \mathrm{Hg}\right)$. An olefinic hydrocarbon recovered from refinery processes or petrochemical processes.

Isohexane $\left(\mathrm{C}_{6} \mathrm{H}_{14}\right)$. A saturated branch-chain hydrocarbon. It is a colorless liquid that boils at a temperature of $156.2^{\circ} \mathrm{F}$.

Isomerization. A refining process which alters the fundamental arrangement of atoms in the molecule without adding or removing anything from the original material. Used to convert normal butane into isobutane $\left(\mathrm{C}_{4}\right)$, an alkylation process feedstock, and normal pentane and hexane into isopentane $\left(\mathrm{C}_{5}\right)$ and isohexane $\left(\mathrm{C}_{6}\right)$, high-octane gasoline components.

\section{Isopentane. See Natural Gasoline and Isopentane.}

Kerosene. A petroleum distillate that has a maximum distillation temperature of $401^{\circ} \mathrm{F}$ at the 10-percent recovery point, a final boiling point of $572^{\circ} \mathrm{F}$, and a minimum flash point of $100^{\circ} \mathrm{F}$. Included are the two grades designated in ASTM D3699: No. 1-K and No. 2-K, and all grades of kerosene called range or stove oil. Kerosene is used in space heaters, cook stoves, and water heaters and is suitable for use as an illuminant when burned in wick lamps.

Kerosene-Type Jet Fuel. A quality kerosene product with a maximum distillation temperature of $400^{\circ} \mathrm{F}$ at the 10-percent recovery point and a final maximum boiling point of $572^{\circ} \mathrm{F}$. The fuel is designated in ASTM Specification D1655 and Military Specification MIL-T-5624L (Grades JP-5 and JP-8). A relatively low-freezing point distillate of the kerosene type used primarily for turbojet and turboprop aircraft engines.

Commercial. Kerosene-type jet fuel intended for commercial use.

Military. Kerosene-type jet fuel intended for military use.

Lease Condensate. A natural gas liquid recovered from gas well gas (associated and non-associated) in lease separators or natural gas field facilities. Lease condensate consists primarily of pentanes and heavier hydrocarbons.

Light Gas Oils. Liquid petroleum distillates heavier than naphtha, with an approximate boiling range from $401^{\circ} \mathrm{F}$ to $650^{\circ} \mathrm{F}$.

Liquefied Petroleum Gases (LPG). Ethane, ethylene, propane, propylene, normal butane, butylene, isobutane, and isobutylene produced at refineries or natural gas processing plants, including plants that fractionate raw natural gas plant liquids.

Liquefied Refinery Gases (LRG). Liquefied petroleum gases fractionated from refinery or still gases. Through compression and/or refrigeration, they are retained in the liquid state. The reported categories are ethane/ethylene, propane/propylene, normal butane/butylene, and isobutane/isobutylene. Excludes still gas.

Lubricants. A substance used to reduce friction between bearing surfaces or as process materials either incorporated into other materials used as processing aids in the manufacturing of other products, or as carriers of other materials. Petroleum lubricants may be produced either from distillates or residues. Other substances may be added to impart or improve certain required properties. Do not include byproducts of lubricating oil refining such as aromatic extracts derived from solvent extraction or tars derived from deasphalting. "Lubricants" includes all grades of lubricating oils from spindle oil to cylinder oil and those used in greases. Reporting categories include:

Paraffinic. Includes all grades of bright stock and neutrals with a Viscosity Index $>75$.

Naphthenic. Includes all lubricating oil base stocks with a Viscosity Index $<75$.

Note: The criterion for categorizing the lubricants is based solely on the Viscosity Index of the stocks and is independent of crude sources and type of processing used to produce the oils. 
Exceptions: Lubricating oil base stocks that have been historically classified as naphthenic or paraffinic by a refiner may continue to be so categorized irrespective of the Viscosity Index criterion.

Example:

(1) Unextracted paraffinic oils that would not meet the Viscosity Index test.

Merchant Oxygenate Plants. Oxygenate production facilities that are not associated with a petroleum refinery. Production from these facilities is sold under contract or on the spot market to refiners or other gasoline blenders.

Methanol $\left(\mathrm{CH}_{3} \mathrm{OH}\right)$. A light, volatile alcohol eligible for gasoline blending as described in Oxygenate definition.

Middle Distillates. A general classification of refined petroleum products that includes distillate fuel oil and kerosene.

Military Kerosene-Type Jet Fuel. See Kerosene-Type Jet Fuel.

Miscellaneous Products. Includes all finished products not classified elsewhere (e.g., petrolatum, lube refining byproducts (aromatic extracts and tars), absorption oils, ram-jet fuel, petroleum rocket fuels, synthetic natural gas feedstocks, and specialty oils).

Motor Gasoline (Finished). A complex mixture of relatively volatile hydrocarbons, with or without small quantities of additives, that has been blended to form a fuel suitable for use in spark-ignition engines. Motor gasoline, as given in ASTM Specification D439 or Federal Specification VV-G-1690B, includes a range in distillation temperatures from $122^{\circ}$ to $158^{\circ} \mathrm{F}$ at the 10-percent recovery point and from $365^{\circ}$ to $374^{\circ} \mathrm{F}$ at the 90-percent recovery point. "Motor gasoline" includes reformulated gasoline, oxygenated gasoline, and other finished gasoline. Blendstock is excluded until blending has been completed.

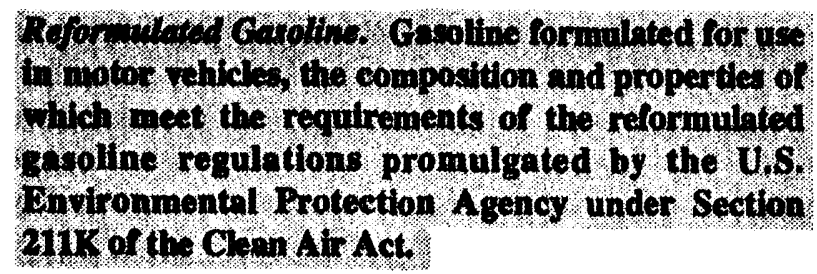

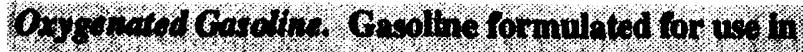

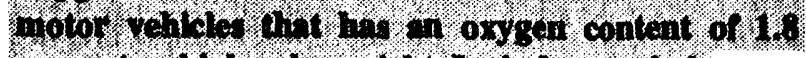
percint on higher, by wejht. Thchdes gasohol.

Wher Finited. Yotor gesoline not lnchuded th the orvenated or we or mulated gasoline categarles.
Motor Gasoline Blending. Mechanical mixing of motor gasoline blending components and oxygenates to produce finished motor gasoline (see definition of Motor Gasoline).

Motor Gasoline Blending Components. Naphthas which will be used for blending or compounding into finished motor gasoline (e.g. straight-run gasoline, alkylate, reformate, benzene, toluene, and xylene). Excludes oxygenates (alcohols, ethers), butane, and pentanes plus. Oxygenates are reported as individual components and included in the total for other hydrocarbons, hydrogens, and oxygenates.

MTBE (Methyl tertiary butyl ether) ( $\left.\mathrm{CH}_{3}\right)_{3} \mathrm{COCH}_{3}$. An ether intended for gasoline blending as described in Oxygenate definition.

Nameplate Capacity. The maximum design production capacity specified by the manufacturer of a processing unit or the maximum amount of a product that can be produced running the manufacturing unit at full capacity.

Naphtha. A generic term applied to a petroleum fraction with an approximate boiling range between $122^{\circ}$ and $400^{\circ}$ F.

\section{Naphtha Less Than $401^{\circ} F$. See Petrochemical Feedstocks.}

Naphtha-Type Jet Fuel. A fuel in the heavy naphtha boiling range. ASTM Specification D1655 specifies for this fuel maximum distillation temperatures of $290^{\circ} \mathrm{F}$ at the 20-percent recovery point and $470^{\circ} \mathrm{F}$ at the 90 -percent point, meeting Military Specification MIL-T-5624L (Grade JP-4). JP-4 is used for turbojet and turboprop aircraft engines, primarily by the military. Excludes ram-jet and petroleum rocket fuels.

Natural Gas. A mixture of hydrocarbons and small quantities of various nonhydrocarbons existing in the gaseous phase or in solution with crude oil in underground reservoirs.

Natural Gas Field Facility. A field facility designed to process natural gas produced from more than one lease for the purpose of recovering condensate from a stream of natural gas; however, some field facilities are designed to recover propane, normal butane, pentanes plus, etc., and to control the quality of natural gas to be marketed.

Natural Gas Plant Liquids. Natural gas liquids recovered from natural gas in gas processing plants, and in some situations, from natural gas field facilities. Natural gas liquids extracted by fractionators are also included. These liquids are defined according to the published specifications of the Gas Processors 
Association and the American Society for Testing and Materials and are classified as follows: ethane, propane, normal butane, isobutane, and pentanes plus.

Natural Gas Processing Plant. A facility designed (1) to achieve the recovery of natural gas liquids from the stream of natural gas which may or may not have been processed through lease separators and field facilities, and (2) to control the quality of the natural gas to be marketed. Cycling plants are classified as gas processing plants.

Natural Gasoline and Isopentane. A mixture of hydrocarbons, mostly pentanes and heavier, extracted from natural gas, that meets vapor pressure, end-point, and other specifications for natural gasoline set by the Gas Processors Association. Includes isopentane which is a saturated branch-chain hydrocarbon, $\left(\mathrm{C}_{5} \mathrm{H}_{12}\right)$, obtained by fractionation of natural gasoline or isomerization of normal pentane.

Net Receipts. The difference between total movements into and total movements out of each PAD District by pipeline, tanker, and barge.

\section{Normal Butane. See Butane.}

OPEC. The acronym for the Organization of Petroleum Exporting Countries, that have organized for the purpose of negotiating with oil companies on matters of oil production, prices and future concession rights. Current members are Algeria, Gabon, Indonesia, Iran, Iraq, Kuwait, Libya, Nigeria, Qatar, Saudi Arabia, United Arab Emirates, and Venezuela. The Neutral Zone between Kuwait and Saudi Arabia is considered part of OPEC.

Operable Capacity. The amount of capacity that, at the beginning of the period, is in operation; not in operation and not under active repair, but capable of being placed in operation within $\mathbf{3 0}$ days; or not in operation but under active repair that can be completed within 90 days. Operable capacity is the sum of the operating and idle capacity and is measured in barrels per calendar day or barrels per stream day.

Operating Capacity. The component of operable capacity that is in operation at the beginning of the period.

Operable Utilization Rate. Represents the utilization of the atmospheric crude oil distillation units. The rate is calculated by dividing the gross input to these units by the operable refining capacity of the units.

Operating Utilization Rate. Represents the utilization of the atmospheric crude oil distillation units. The rate is calculated by dividing the gross input to these units by the operating refining capacity of the units.
Other Finished. See Motor Gasoline (Finished).

Other Hydrocarbons. Materials received by a refinery and consumed as a raw material. Includes hydrogen, coal tar derivatives, gilsonite, and natural gas received by the refinery for reforming into hydrogen. Natural gas to be used as fuel is excluded.

Other Oils Equal To or Greater Than $401^{\circ} \mathrm{F}$. See Petrochemical Feedstocks.

Other Oxygenates. Other aliphatic alcohols and aliphatic ethers intended for motor gasoline blending (e.g., isopropyl ether (IPE) or n-propanol).

Oxygenated Gasoline. See Motor Gasoline (Finished).

Oxygenates. Any substance which, when added to gasoline, increases the amount of oxygen in that gasoline blend. Through a series of waivers and interpretive rules, the Environmental Protection Agency (EPA) has determined the allowable limits for oxygenates in unleaded gasoline. The "Substantially Similar" Interpretive Rules (56 FR (February 11, 1991)) allows blends of aliphatic alcohols other than methanol and aliphatic ethers, provided the oxygen content does not exceed 2.7 percent by weight. The "Substantially Similar" Interpretive Rules also provides for blends of methanol up to 0.3 percent by volume exclusive of other oxygenates, and butanol or alcohols of a higher molecular weight up to 2.75 percent by weight. Individual waivers pertaining to the use of oxygenates in unleaded gasoline have been issued by the EPA. They include:

Fuel Ethanol. Blends of up to 10 percent by volume anhydrous ethanol (200 proof) (commonly referred to as the "gasohol waiver").

Methanol. Blends of methanol and gasoline-grade tertiary butyl alcohol (GTBA) such that the total oxygen content does not exceed 3.5 percent by weight and the ratio of methanol to GTBA is less than or equal to 1 . It is also specified that this blended fuel must meet ASTM volatility specifications (commonly referred to as the "ARCO" waiver).

Blends of up to 5.0 percent by volume methanol with a minimum of 2.5 percent by volume cosolvent alcohols having a carbon number of 4 or less (i.e., ethanol, propanol, butanol, and/or GTBA). The total oxygen must not exceed 3.7 percent by weight, and the blend must meet ASTM volatility specifications as well as phase separation and alcohol purity specifications (commonly referred to as the "DuPont" waiver).

MTBE (Methyl tertiary butyl ether). Blends up to 15.0 percent by volume MTBE which must meet the ASTM 
D4814 specifications. Blenders must take precautions that the blends are not used as base gasolines for other oxygenated blends (commonly referred to as the "Sun" waiver).

Pentanes Plus. A mixture of hydrocarbons, mostly pentanes and heavier, extracted from natural gas. Includes isopentane, natural gasoline, and plant condensate.

Persian Gulf. The countries that comprise the Persian Gulf are: Bahrain, Iran, Iraq, Kuwait, Qatar, Saudi Arabia, and the United Arab Emirates.

Petrochemical Feedstocks. Chemical feedstocks derived from petroleum principally for the manufacture of chemicals, synthetic rubber, and a variety of plastics. The categories reported are "Naphtha Less Than $401^{\circ} \mathrm{F}$ " and "Other Oils Equal To or Greater Than 401 F."

Naphtha Less Than $401^{\circ} \mathrm{F}$. A naphtha with a boiling range of less than $401^{\circ} \mathrm{F}$ that is intended for use as a petroctemical feedstock.

Other Oils Equal To or Greater Than $401^{\circ} \mathrm{F}$. Oils with a boiling range equal to or greater than $401^{\circ} \mathrm{F}$ that are intended for use as a petrochemical feedstock.

Petroleum Administration for Defense (PAD) Districts. Geographic aggregations of the 50 States and the District of Columbia into five districts by the Petroleum Administration for Defense in 1950. These districts were

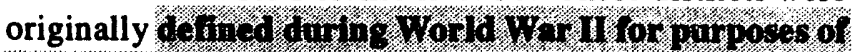
dininistonte oll Mostion.

Petroleum Coke. A residue, the final product of the condensation process in cracking. This product is reported as marketable coke or catalyst coke. The conversion factor is 5 barrels per short ton.

Marketable Coke. Those grades of coke produced in delayed or fluid cokers which may be recovered as relatively pure carbon. This "green" coke may be sold as is or further purified by calcining.

Catalyst Coke. In many catalytic operations (e.g., catalytic cracking) carbon is deposited on the catalyst, thus deactivating the catalyst. The catalyst is reactivated by burning off the carbon, which is used as a fuel in the refining process. This carbon or coke is not recoverable in a concentrated form.

Petroleum Products. Petroleum products are obtained from the processing of crude oil (including lease condensate), natural gas, and other hydrocarbon compounds. Petroleum products include unfinished oils, liquefied petroleum gases, pentanes plus, aviation gasoline, motor gasoline, naphtha-type jet fuel, kerosene-type jet fuel, kerosene, distillate fuel oil, residual fuel oil, petrochemical feedstocks, special naphthas, lubricants, waxes, petroleum coke, asphalt, road oil, still gas, and miscellaneous products.

Pipeline (Petroleum). Crude oil and product pipelines used to transport crude oil and petroleum products respectively, (including interstate, intrastate, and intracompany pipelines) within the 50 States and the District of Columbia.

Plant Condensate. One of the natural gas liquids, mostly pentanes and heavier hydrocarbons, recovered and separated as liquids at gas inlet separators or scrubbers in processing plants.

Processing Gain. The volumetric amount by which total output is greater than input for a given period of time. This difference is due to the processing of crude oil into products which, in total, have a lower specific gravity than the crude oil processed.

Processing Loss. The volumetric amount by which total refinery output is less than input for a given period of time. This difference is due to the processing of crude oil into products which, in total, have a higher specific gravity than the crude oil processed.

Product Supplied, Crude Oil. Crude oil burned on leases and by pipelines as fuel.

Production Capacity. The amount of product that can be produced from processing facilities.

Products Supplied. Approximately represents consumption of petroleum products because it measures the disappearance of these products from primary sources, i.e., refineries, natural gas processing plants, blending plants, pipelines, and bulk terminals. In general, product supplied of each product in any given period is computed as follows: field production, plus refinery production, plus imports, plus unaccounted for crude oil, (plus net receipts when calculated on a PAD District basis), minus stock change, minus crude oil losses, minus refinery inputs, minus exports.

Propane $\left(\mathrm{C}_{3} \mathrm{H}_{8}\right)$. A normally gaseous straight-chain hydrocarbon. It is a colorless paraffinic gas that boils at a temperature of $-43.67^{\circ} \mathrm{F}$. It is extracted from natural gas or refinery gas streams. It includes all products designated in ASTM Specification D1835 and Gas Processors Association Specifications for commercial propane and HD-5 propane.

Propylene $\left(\mathrm{C}_{3} \mathrm{H}_{6}\right)$. An olefinic hydrocarbon recovered from refinery processes or petrochemical processes. 
Refinery. An installation that manufactures finished petroleum products from crude oil, unfinished oils, natural gas liquids, other hydrocarbons, and oxygenates.

Refinery Input, Crude Oil. Total crude oil (domestic plus foreign) input to crude oil distillation units and other refinery processing units (cokers, etc.).

Refinery Input, Total. The raw materials and intermediate materials processed at refineries to produce finished petroleum products. They include crude oil, products of natural gas processing plants, unfinished oils, other hydrocarbons and oxygenates, motor gasoline and aviation gasoline blending components and finished petroleum products.

Refinery Production. Petroleum products produced at a refinery or blending plant. Published production of these products equals refinery production minus refinery input. Negative production will occur when the amount of a product produced during the month is less than the amount of that same product that is reprocessed (input) or reclassified to become another product during the same month. Refinery production of unfinished oils, and motor and aviation gasoline blending components appear on a net basis under refinery input.

Refinery Yield. Refinery yield (expressed as a percentage) represents the percent of finished product produced from input of crude oil and net input of unfinished oils. It is calculated by dividing the sum of crude oil and net unfinished input into the individual net production of finished products. Before calculating the yield for finished motor gasoline, the input of natural gas liquids, other hydrocarbons and oxygenates, and net input of motor gasoline blending components must be subtracted from the net production of finished motor gasoline. Before calculating the yield for finished aviation gasoline, input of aviation gasoline blending components must be subtracted from the net production of finished aviation gasoline.

\section{Reformulated Gasoline. See Motor Gasoline (Finished).}

Residual Fuel Oil. The heavier oils that remain after the distillate fuel oils and lighter hydrocarbons are distilled away in refinery operations and that conform to ASTM Specifications D396 and 975 . Included are No. 5, a residual fuel oil of medium viscosity; Navy Special, for use in steam-powered vessels in government service and in shore power plants; No. 6, which includes Bunker C fuel oil, and is used for commercial and industrial heating, electricity generation and to power ships. Imports of residual fuel oil include imported crude oil burned as fuel.
Residuum. Residue from crude oil after distilling off all but the heaviest components, with a boiling range greater than $1000^{\circ} \mathrm{F}$.

Road Oil. Any heavy petroleum oil, including residual asphaltic oil used as a dust pallative and surface treatment on roads and highways. It is generally produced in six grades from 0 , the most liquid, to 5 , the most viscous.

Shell Storage Capacity. The design capacity of a petroleum storage tank which is always greater than or equal to working storage capacity.

Special Naphthas. All finished products within the naphtha boiling range that are used as paint thinners, cleaners, or solvents. These products are refined to a specified flash point. Special naphthas include all commercial hexane and cleaning solvents conforming to ASTM Specification D1836 and D484, respectively. Naphthas to be blended or marketed as motor gasoline or aviation gasoline, or that are to be used as petrochemical and synthetic natural gas (SNG) feedstocks are excluded.

Steam (Purchased). Steam, purchased for use by a refinery, that was not generated from within the refinery complex.

Still Gas (Refinery Gas). Any form or mixture of gases produced in refineries by distillation, cracking, reforming, and other processes. The principal constituents are methane, ethane, ethylene, normal butane, butylene, propane, propylene, etc. Still gas is used as a refinery fuel and a petrochemical feedstock. The conversion factor is 6 million BTU's per fuel oil equivalent barrel.

Stock Change. The difference between stocks at the beginning of the month and stocks at the end of the month. A negative number indicates a decrease in stocks and a positive number indicates an increase in stocks.

Strategic Petroleum Reserve (SPR). Petroleum stocks maintained by the Federal Government for use during periods of major supply interruption.

Sulfur. A nonmetallic element of lemon-yellow color, sometimes known as "brimstone".

Supply. The components of petroleum supply are field production, refinery production, imports, and net receipts when calculated on a PAD District basis.

TAME (Tertiary amyl methyl ether) $\left(\mathrm{CH}_{3}\right)_{2}\left(\mathrm{C}_{2} \mathrm{H}_{5}\right)_{\mathrm{COCH}}$. An oxygenate blend stock formed by the catalytic etherification of isoamylene with methanol. 
Tank Farm. An installation used by gathering and trunk pipeline companies, crude oil producers, and terminal operators (except refineries) to store crude oil.

Tanker and Barge. Vessels that transport crude oil or petroleum products. Data are reported for movements between PAD Districts; from a PAD District to the Panama Canal; or from the Panama Canal to a PAD District.

TBA (Tertiary butyl alcohol) $\left(\mathrm{CH}_{3}\right)_{3} \mathrm{COH}$. An alcohol primarily used as a chemical feedstock, a solvent or feedstock for isobutylene production for MTBE; produced as a co-product of propylene oxide production or by direct hydration of isobuiylene.

Thermal Cracking. A refining process in which heat and pressure are used to break down, rearrange, or combine hydrocarbon molecules. Thermal cracking includes gas oil, visbreaking, fluid coking, delayed coking, and other thermal cracking processes (e.g., flexicoking). See individual categories for definition.

Toluene $\left(\mathrm{C}_{6} \mathrm{H}_{5} \mathrm{CH}_{3}\right)$. Colorless liquid of the aromatic group of petroleum hydrocarbons, made by the catalytic reforming of petroleum naphthas containing methyl cyclohexane. A high-octane gasoline-blending agent, solvent, and chemical intermediate, base for TNT.

Unaccounted for Crude Oil. Represents the arithmetic difference between the calculated supply and the calculated disposition of crude oil. The calculated supply is the sum of crude oil production plus imports minus changes in crude oil stocks. The calculated disposition of crude oil is the sum of crude oil input to refineries, crude oil exports, crude oil burned as fuel, and crude oil losses.

Unfinished Oils. Includes all oils requiring further processing, except those requiring only mechanical blending. Includes naphthas and lighter oils, kerosene and light gas oils, heavy gas oils, and residuum. See individual categories for definition.

Unfractionated Streams. Mixtures of unsegregated natural gas liquid components excluding those in plant condensate. This product is extracted from natural gas.

United States. The United States is defined as the $\mathbf{5 0}$ States and the District of Columbia.

Vacuum Distillation. Distillation under reduced pressure (less the atmospheric) which lowers the boiling temperature of the liquid being distilled. This technique with its relatively low temperatures prevents cracking or decomposition of the charge stock.

Visbreaking. A thermal cracking process in which heavy atmospheric or vacuum-still bottoms are cracked at moderate temperatures to increase production of distillate products and reduce viscosity of the distillation residues.

Wax. A solid or semi-solid material derived from petroleum distillates or residues by such treatments as chilling, precipitating with a solvent, or de-oiling. It is light-colored, more-or-less translucent crystalline mass, slightly greasy to the touch, consisting of a mixture of solid hydrocarbons in which the paraffin series predominates. Includes all marketable wax whether crude scale or fully refined. The three grades included are microcrystalline, crystalline-fully refined, and crystalline-other. The conversion factor is 280 pounds per 42 U.S. gallons per barrel.

Microcrystalline Wax. Wax extracted from certain petroleum residues having a finer and less apparent crystalline structure than paraffin wax and having the following physical characteristics: penetration at $77^{\circ} \mathrm{F}$ (D1321)-60 maximum; viscosity at $210^{\circ} \mathrm{F}$ in Saybolt Universal Seconds (SUS); (D88)-60 SUS (10.22 centistokes) minimum to 150 SUS (31.8 centistokes) maximum; oil content (D721)-5 percent minimum.

Crystalline-Fully Refined Wax. A light-colored paraffin wax having the following characteristics: viscosity at $210^{\circ} \mathrm{F}$ (D88)-59.9 SUS (10.13 centistokes) maximum; oil content (D721)-0.5 percent maximum; other +20 color, Saybolt minimum.

Crystalline-Other Wax. A paraffin wax having the following characteristics: viscosity at $210^{\circ} \mathrm{F}$ (D88)-59.9 SUS (10.18 centistokes) maximum; oil content (D721)-0.51 percent minimum to 15 percent maximum.

Working Storage Capacity. The difference in volume between the maximum safe fill capacity and the quantity below which pump suction is ineffective (bottoms).

Xylene $\left(\mathrm{C}_{6} \mathrm{H}_{4}\left(\mathrm{CH}_{3}\right)_{2}\right)$. Colorless liquid of the aromatic group of hydrocarbons made the catalytic reforming of certain naphthenic petroleum fractions. Used as high-octane motor and aviation gasoline blending agents, solvents, chemical intermediates. Isomers are metaxylene, orthoxylene, paraxylene. 

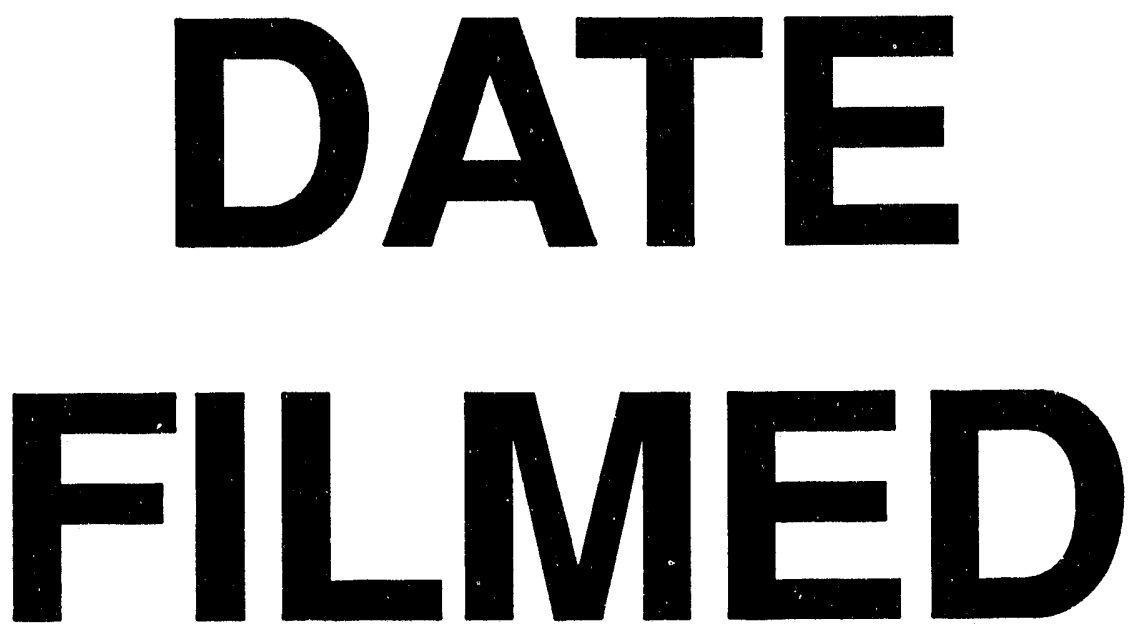

$6 / 10 / 94$
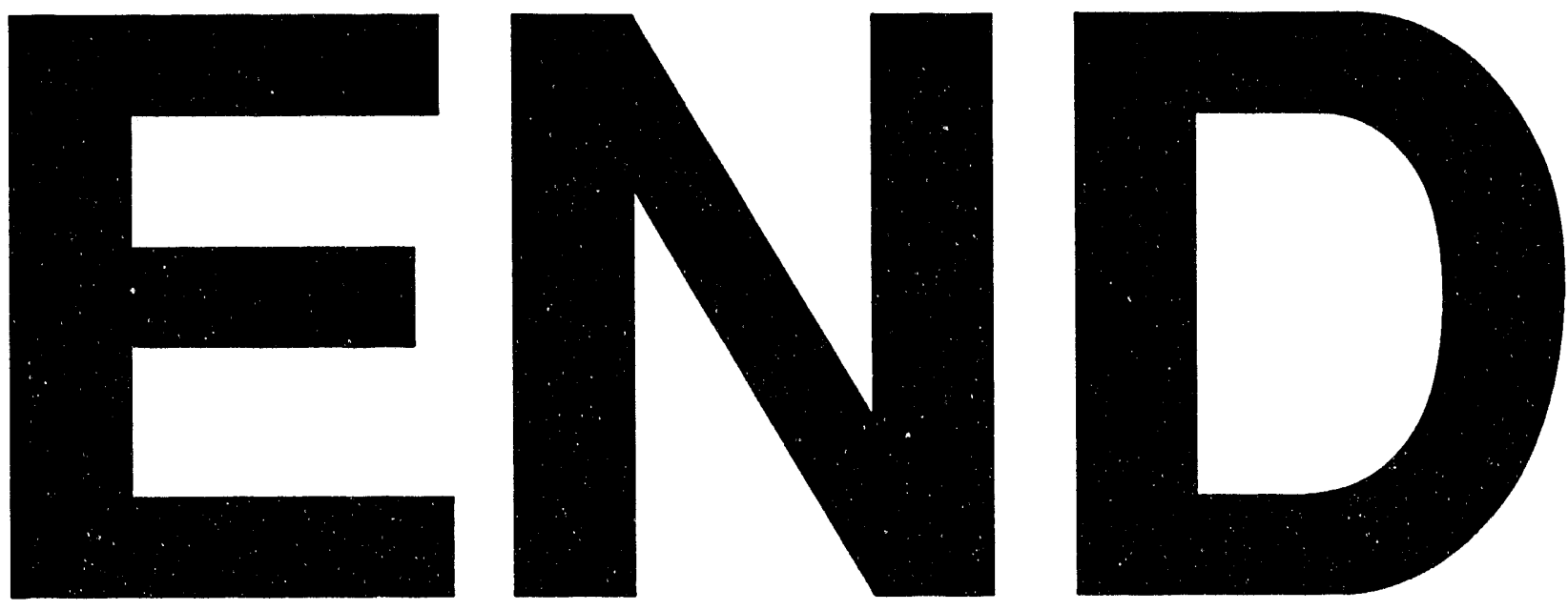
